\author{
UNIVERSIDADE DE SÃO PAULO \\ ESCOLA DE COMUNICAÇÕES E ARTES \\ PROGRAMA DE PÓS-GRADUAÇÃO EM CIÊNCIAS DA COMUNICAÇÃO
}

\title{
Animação e quadrinhos Disney: \\ Produção cultural no início do século XXI
}

CELBI VAGNER MELO PEGORARO

SÃO PAULO

2016 



\section{CELBI VAGNER MELO PEGORARO}

\section{Animação e quadrinhos Disney: Produção cultural no início do século XXI}

Tese apresentada ao Programa de PósGraduação em Ciências da Comunicação da Escola de Comunicações e Artes da Universidade de São Paulo, como exigência parcial para obtenção do título de Doutor em Ciências da Comunicação. Versão Corrigida.

Área de Concentração: Interfaces Sociais da Comunicação

Orientador: Prof. Dr. Waldomiro de Castro Santos Vergueiro

SÃO PAULO 
Autorizo a reprodução e divulgação total ou parcial deste trabalho, por qualquer meio convencional ou eletrônico, para fins de estudo e pesquisa, desde que citada a fonte.

Versão Corrigida. A versão original encontra-se disponível na Biblioteca da ECA/USP e Biblioteca Digital de Teses e Dissertações da USP (BDTD).

\section{Catalogação na Publicação}

Serviço de Biblioteca e Documentação

Escola de Comunicações e Artes da Universidade de São Paulo

Dados fornecidos pelo(a) autor(a)

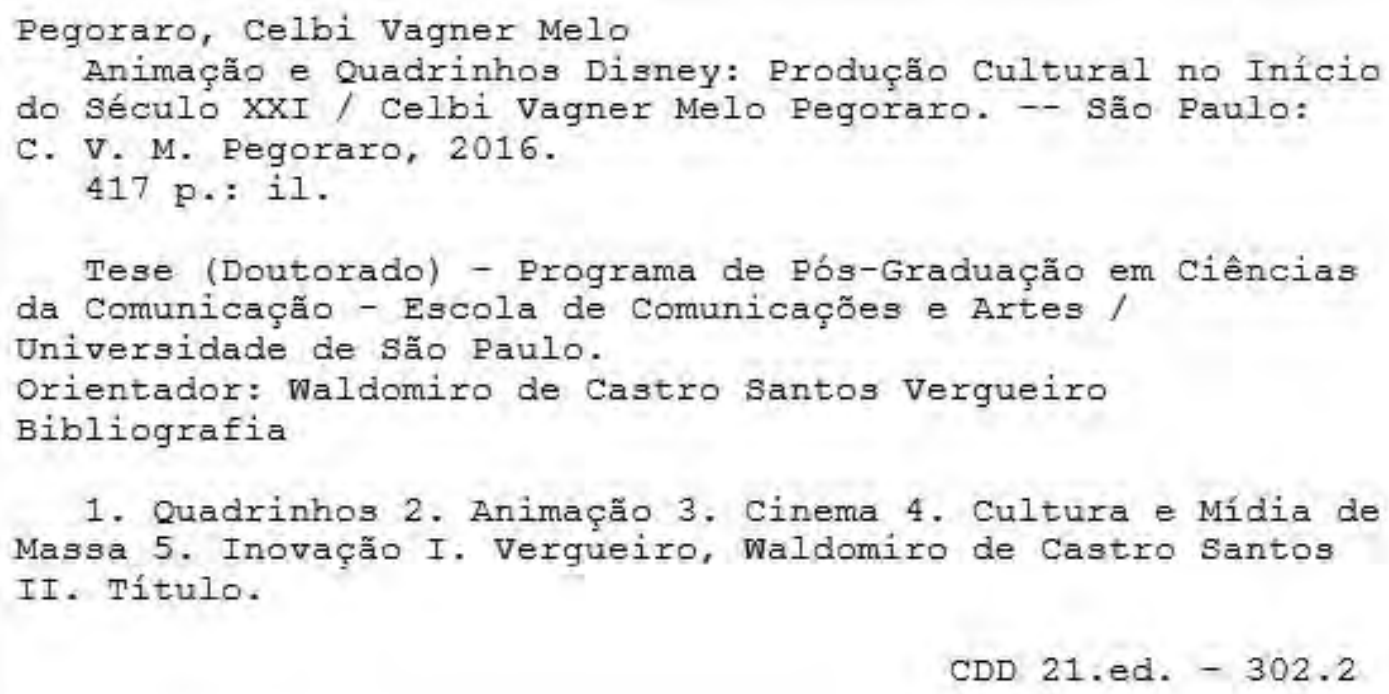




\section{Universidade de São Paulo}

\section{ATA DE DEFESA}

Aluno: 27154 - 6320294 - 1/ Página 1 de 1

Ata de defesa pública de Tese do(a) Senhor(a) Celbi Vagner Melo Pegoraro no Programa: Ciências da Comunicação, do(a) Escola de Comunicações e Artes da Universidade de São Paulo.

Aos 15 dias do mês de abril de 2016, no(a) Auditório Lupe Cotrim realizou-se a Defesa da Tese do(a) Senhor(a) Celbi Vagner Melo Pegoraro, apresentada para a obtenção do título de Doutor intitulada:

"Animação e quadrinhos Disney: produção cultural no início do século XXI"

Após declarada aberta a sessão, o(a) Sr(a) Presidente passa a palavra ao candidato para exposição e a seguir aos examinadores para as devidas arguições que se desenvolvem nos termos regimentais. Em seguida, a Comissão Julgadora proclama o resultado:

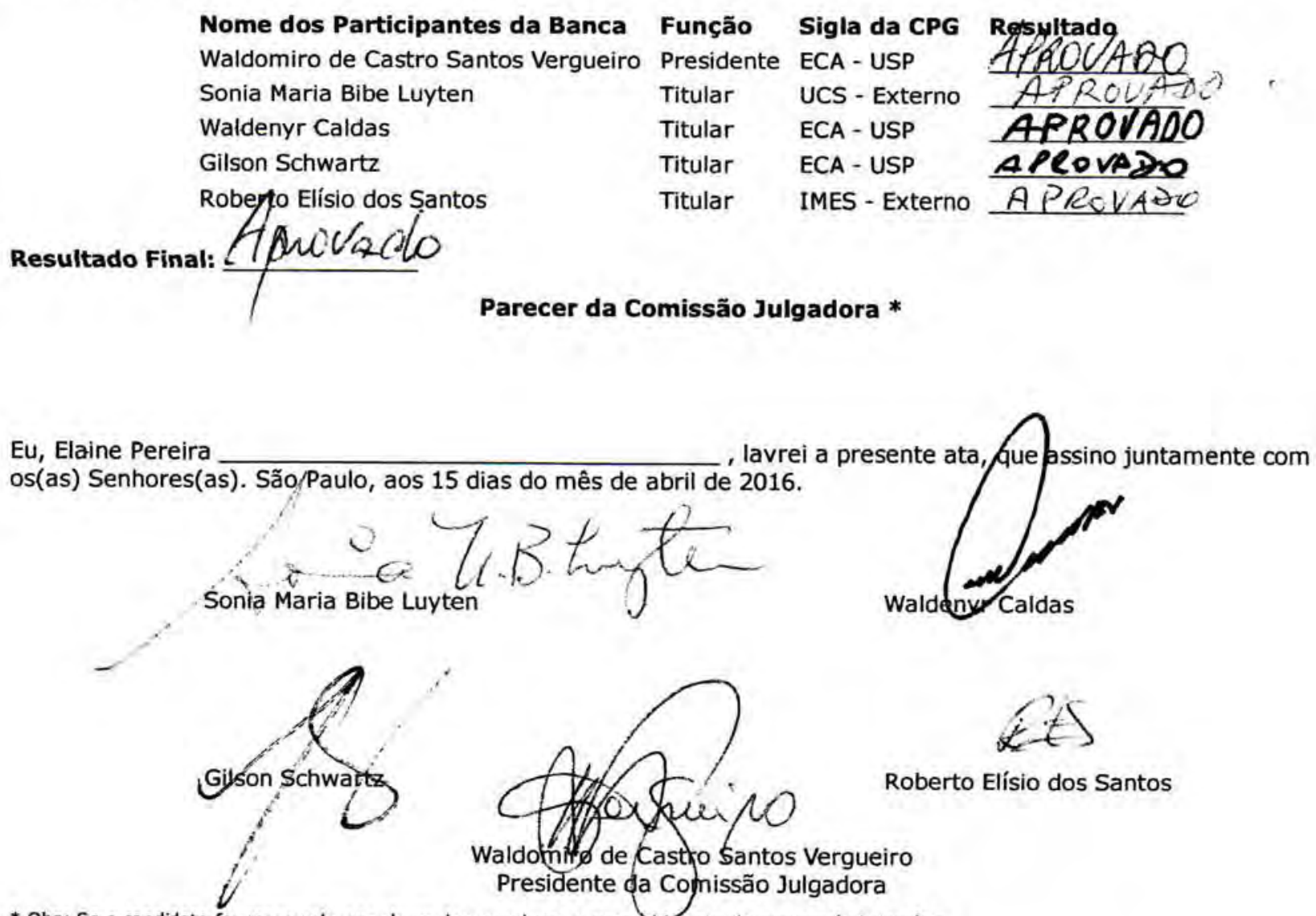

* Obs: Se o candidato for reprovado por algum dos membros, o preenchimento do parecer é obrigatório.

A defesa foi homologada pela Comissão de Pós-Graduação em $/ / \cdot \ell 5$. $/ l_{t}$, e, portanto, o(a) aluno(a) faz jus ao título de Doutor em Ciências obtido no Programa Ciências da Comunicação - Área de concentração: Interfaces Sociais da Comunicação.

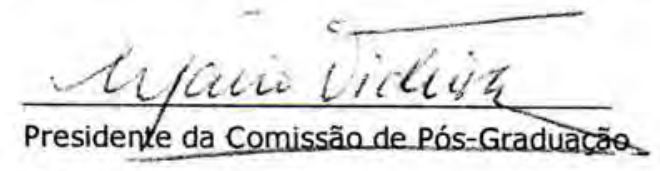

Prot. Dr. Mario Rodrigues Videlra Junior 



\section{AGRADECIMENTOS}

À Fundação de Amparo à Pesquisa do Estado de São Paulo (Fapesp), processo n. 2013/041039, pelo apoio financeiro.

À minha mãe Celina, por todo o apoio e compreensão durante a jornada desta tese; e ao meu pai João Carlos, por periodicamente ter discutido os temas da tese comigo

Aos meus primos Marcos e Christina por todo o seu apoio e companheirismo nas viagens aos Estados Unidos, pelas dicas de livrarias e atividades culturais.

Ao Prof. Dr. Waldomiro Vergueiro por seu apoio incondicional e por promover um ambiente rico de pesquisa em quadrinhos na USP. Suas sugestões e críticas foram bem recebidas e só enriquecem a tese. Sinto-me honrado em ter sido seu orientando.

Ao animador Floyd Norman, quem colaborou em sua gentileza e disposição ao nos guiar pelos estúdios Disney na Califórnia.

Ao Fernando Ventura, caríssimo amigo, incentivador e um avaliador implacável de minhas pesquisas.

Ao amigo Gerson Levy da Silva Mendes pelo apoio e por apostar, ainda em 2007, que eu faria um doutorado direto.

Aos colegas de Observatório de Histórias em Quadrinhos da ECA/USP e das Jornadas Internacionais de Histórias em Quadrinhos pela amizade, apoio e troca de ideias.

Aos professores Dr. Waldenyr Caldas e Dr. Roberto Elísio dos Santos pelas ricas contribuições nos exames de qualificação e pela confiança ao terem promovido esta pesquisa ao nível de doutoramento direto.

Aos professores doutores da ECA, Cristian da Silva Borges, Eugênio Bucci, Paulo Eduardo Ramos, Eduardo Morettin, Mary Anne Junqueira, Celso Frederico e Gilson Schwartz pelas novas descobertas nas disciplinas cursadas no programa de pós-graduação.

Aos colegas e amigos da USP e da vida que dividiram suas experiências comigo.

Aos animadores e quadrinistas da Disney cujos trabalhos me encantam desde a infância e continuam a estimular novas descobertas e experiências. 



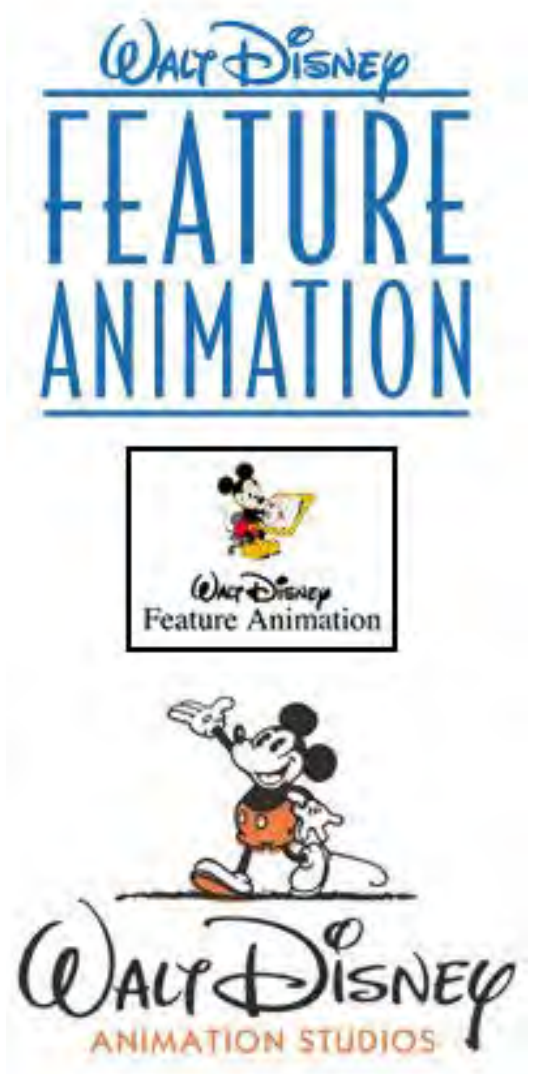

"Any sufficiently advanced technology is indistinguishable from magic"

Arthur C. Clarke

"It's kind of fun to do the impossible"

Walt Disney 



\section{RESUMO}

PEGORARO, Celbi V. M. Animação e Quadrinhos Disney: Produção Cultural no Início do Século XXI. 2016. 416 f. Tese (Doutorado) - Escola de Comunicações e Artes, Universidade de São Paulo, São Paulo, 2016.

Analisa as influências e as transformações promovidas pelas produções cinematográficas Disney, a partir das mudanças da estrutura corporativa, resultando numa descentralização do processo de produção e a criação de uma nova dinâmica na indústria cultural. Para seu desenvolvimento, utilizou-se o método funcionalista com pesquisa bibliográfica e visita técnica de campo. Com um viés tecnológico, a pesquisa transdisciplinar teve como objetivos analisar o atual processo de produção nas histórias em quadrinhos e animação Disney, com ênfase a partir da década de 1990. O trabalho baseia-se em duas hipóteses: 1) a produção cultural Disney passa por um momento de transição criativa, levando em consideração que o processo é cíclico quando compreendemos o processo histórico Disney e a expansão do universo de personagens; 2) em segundo plano, lançamentos da indústria cultural no início desta década apontam para uma nova dinâmica na produção. Há uma sinergia econômica, tecnológica e cultural na construção do universo Disney, em que as histórias em quadrinhos se colocam em posição privilegiada como matéria-prima em relação as produções audiovisuais. A tese é iniciada com um panorama histórico de diversas perspectivas sobre a produção Disney discutidas por autores como Adorno, Benjamin, Dorfman, Mattelart, Eco, Baudrillard, Swingewood e Watts. A pesquisa apresenta as origens e convergências dos quadrinhos e animação Disney, seguido de um levantamento de dados de produção histórica. Há uma discussão sobre "o que é arte" na indústria cultural no contexto da inovação e sua relação com os estúdios de Hollywood. Para compreender a dinâmica dos universos expandidos, analisamos os quadrinhos de Don Rosa e Casty. Duas gestões da Disney (Michael Eisner e Bob Iger) são analisadas em suas diferentes filosofias e estratégias de produção. A análise comprovou a existência do que chamamos de saturação e estagnação da produção do estúdio durante os períodos de transição ocorridos entre os anos 1990 e 2010, e o resultante efeito de "meltdown" (colapso) do mercado dos produtores culturais. Na década de 2010, os efeitos da cultura digital e da cultura de fã foram fundamentais para compreender os fenômenos culturais dos super-herois da Marvel e da saga "Star Wars". Constatou-se que o storytelling transmídia e os universos expandidos tornaram-se fundamentais para o negócio do entretenimento.

Palavras-Chave: Quadrinhos; Animação; Cinema; Cultura e Mídia de Massa; Inovação. 



\begin{abstract}
PEGORARO, Celbi V.M. Disney Animation and Comics: Cultural Production in the beginning of XXI Century. 2016. 416 f. Tese (Doutorado) - Escola de Comunicações e Artes, Universidade de São Paulo, São Paulo, 2016

Analyzes the influences and the transformation promoted by the Disney film productions, beginning with the changes of corporate structure, resulting in decentralization of the production process and creating a new dynamic in the cultural industry. For its development, we used the functional method with bibliographic research and field trip. Using a technological approach, the transdisciplinary research aimed at analyzing the current production process in comic books and Disney animation, with emphasis from the 1990s. This thesis is based on two assumptions: 1) the Disney cultural production is suffering a moment of creative transition, taking into account that the process is cyclical when we understand the historical process and the expansion of Disney characters universe; 2) beginning in the 2010's the cultural industry points to a new dynamic in production. There is an economic, technological and cultural synergy in building the Disney universe, where the comics are placed in a privileged position as a raw material for audiovisual productions. The thesis begins with a historical overview of different perspectives on the Disney production discussed by authors such as Adorno, Benjamin, Dorfman, Mattelart, Eco, Baudrillard, Swingewood and Watts. The research presents the origins and similarities of Disney comics and animation, followed by a survey of historical production data. There is a discussion about "what is art" in the cultural industry in the context of innovation and its relationship with the Hollywood studios. To understand the dynamics of the expanded universe, we analyze the comic stories by Don Rosa and Casty. Two terms of Disney management (Michael Eisner and Bob Iger) are analyzed in their different philosophies and production strategies. The analysis confirmed the existence of what we call saturation and production stagnation during the transitional periods that occurred between 1990 and 2010, and the resulting effect of a market "meltdown" for cultural producers. In the 2010s, the effects of digital culture and fan culture were fundamental to understanding the cultural phenomena of Marvel superheroes and the "Star Wars" saga. It was found that transmedia storytelling and expanded universes have become central to the entertainment business.
\end{abstract}

Keywords: Comics; Animation; Cinema; Mass Media and Culture; Innovation. 



\section{LISTA DE FIGURAS}

*Fonte das imagens: Divulgação da Disney, a não ser quando outra origem é informada.

Figura 1 - Carl Barks, o maior mestre dos quadrinhos Disney 30

Figura 2 - Os estúdios Walt Disney em Burbank - Califórnia, incluindo a rota da visita técnica (foto: Google Earth) .47

Figura 3 -Floyd Norman e Celbi Pegoraro durante a visita aos estúdios Disney em Burbank, Califórnia. (Fonte: Celbi Pegoraro) 48

Figura 4 - O edifício sede dos estúdios de animação Disney em Burbank, Califórnia (Fonte: Celbi Pegoraro) 52

Figura 5 - Celbi Pegoraro (o autor desta tese) na Legends Plaza

Figura 6 - A sede administrativa da Disney - Michael D. Eisner Building, conhecido anteriormente como Team Disney Building. .53

Figura 7 - Walt Disney ao lado de um zoetrope, primeiro equipamento de animação.........62

Figura 8 - Walt Disney supervisionando as histórias em quadrinhos nos anos 1930...........91

Figura 9 - Walt Disney supervisionando as histórias em quadrinhos nos anos 1930...........91

Figura 10 - Levantamento de criação de personagens por universo...................................104

Figura 11 - Criação de Personagens por produtora/editora/território .................................105

Figura 12 - Animações Disney (montagem Disney Wikia) ............................................117

Figura 13 - Gráfico de comparação da produção de animação Disney .............................119

Figura 14 - Gráfico de comparação ilustra a intensificação na produção nas últimas décadas

Figura 15 - Logomarcas das novas produtoras de Disney.

Figura 16 - Logomarcas das novas produtoras de Disney

Figura 17 - Logomarcas da Miramax e Hollywood Pictures. 
Figura 18 - Logomarcas da Miramax e Hollywood Pictures

Figura 19 - "Steamboat Willie" (1928), o primeiro curta-metragem sonoro 130

Figura 20 - "The Band Concert" (1934) o primeiro curta-metragem do Mickey em cores 130

Figura 21 - "Fantasia" (1940) - Para muitos críticos o auge do Mickey foi em "O Aprendiz de Feiticeiro" 130

Figura 22 - "Mickey and the Seal" (1948), um dos melhores exemplos do Mickey "urbano".

Figura 23 - Mickey como mestre de cerimônia em "O Clube do Mickey", sucesso na televisão na década de 1950.

Figura 24 - "House of Mouse" (anos 2000)

Figura 25 - o “novo Mickey” em seus desenhos na década de 2010

Figura 26 - “The Skeleton Dance” (1929)

Figura 27 - "Flowers and Trees" (1932)

Figura 28 - Câmera Multiplana

Figura 29 - O curta-metragem "O Velho Moinho"

Figura 30 - o longa "Branca de Neve e os Sete Anões (1937)

Figura 31 - "A Bela Adormecida" (1959) - primeiro longa-metragem em Super Technirama $70 \mathrm{~mm}$, atendendo ao formato Cinemascope, popular na década de 1950 135

Figura 32 -“101 Dálmatas” (1961) - Necessidades econômicas levaram ao uso da Xerografia para eliminar o processo de transferência dos esboços para a célula de animação 135 Figura 33 - "Fantasia" de 1940 trouxe duas inovações. O primeiro uso do sistema estereofônico em larga escala. No seu relançamento em 1982, apresentou regravação da trilha em formato digital.

Figura 34 - "O Ratinho Detetive" (1986), o primeiro uso efetivo da animação computadorizada em uma sequência (clímax no relógio Big Ben) 136

Figura 35 - "Bernardo e Bianca na Terra dos Cangurus" (1990) - frame do filme......136 
Figura 36 - "Bernardo e Bianca na Terra dos Cangurus" (1990) - Tecnologia CAPS introduziu a colorização digital nos filmes de animação

Figura 37 - Gráfico de futuros lançamentos da Disney - muitos filmes das marcas Pixar, Marvel e Star Wars (Lucasfilm)

Figura 38 - Ed Catmull, Steve Jobs e John Lasseter - os principais líderes na Pixar.....149

Figura 39 - Keno Don Rosa

Figura 40 - Exemplos de páginas com os traços de Robert Crumb (Wierdo no. 4, Robert

Crumb, 1981) 153

Figura 41 - Don Rosa (Walt Disney's Comics and Stories 614, Don Rosa, 1997) ......153

Figura 42 - "O Ouro e o Repolho" (Barks, 1954) 155

Figura 43 - "Fortuna Deslizante" (Don Rosa, 1987). 155

Figura 44 - "Paraíso Perdido" (Barks, 1954) 155

Figura 45 - "De Volta à Xanadu” (Don Rosa, 1991) 155

Figura 46 - Pôster ilustra exemplos do traço de Don Rosa, diferente de Carl Barks.....156 Figura 47 - "O Retorno dos Três Cavalheiros" (Don Rosa, 2000) demonstra a quantidade paineis e texto.

Figura 48 - O detalhismo cronológico de Don Rosa resulta em "buracos" na árvore genealógica da família Pato. 159

Figura 49 - O detalhismo cronológico de Don Rosa resulta em "buracos" na árvore genealógica da família Pato

Figura 50 - Em ilustração autônoma para publicação alemã, Don Rosa reforça sua visão de que o Tio Patinhas "morre" em 1967 com a aposentadoria de Carl Barks, o mestre dos patos. (Der Hamburger Donaldist, $\left.\mathrm{n}^{\circ} 77,1991\right)$ 160

Figura 51 - Andrea Castellan ou simplesmente Casty. 161

Figura 52 - Desenho de Casty feito em sua infância. 162

Figura 53 - Cattivik (Créditos Mck/Silver) 163

Figura 54 - "Ilha de Quandomai". 165 
Figura 55 - "Ilha de Quandomai". 165

Figura 56 - Mancha das Trevas 167

Figura 57 - Cenas de ação exibem hibridismo nos quadrinhos Disney..... 168

Figura 58 - "Mickey e o Mundo do Amanhã" - trabalho de Casty também publicado nos EUA 169

Figura 59 - O retorno de Atomino em "Os Sombronautas" 170

Figura 60 - Walker e Miller foram os líderes da Disney após os irmãos Disney. 175

Figura 61 - Michael Eisner e Frank Wells - a dupla que fez renascer a Disney 177

Figura 62 - Pôster de "Dick Tracy". 184

Figura 63 - Batman foi o grande sucesso da Warner em 1989 185

Figura 64 - A sinergia Disney em 1957 - o núcleo central era a produção de filmes..193 Figura 65 - Walt Disney e seu irmão Roy Oliver Disney (1965). 197

Figura 66 - John Pomeroy, Don Bluth e Gary Goldman, os primeiros do êxodo de animadores 200

Figura 67 - Peter Schneider, Roy Edward Disney e Jeffrey Katzenberg, responsáveis pelas produções no estúdio .203

Figura 68 - Os compositores Howard Ashman e Alan Menken .205

Figura 69 - Clímax do filme com a transformação da Fera (A Bela e a Fera, 1991)................208

Figura 70 - Clímax do filme com a transformação da Fera (A Bela e a Fera, 1991) ................208

Figura 71 - Clímax do filme com a transformação da Fera (A Bela e a Fera, 1991) ...............208

Figura 72 - Clímax do filme com a transformação da Fera (A Bela e a Fera, 1991) .............209

Figura 73 - Clímax do filme com a transformação da Fera (A Bela e a Fera, 1991) ...............209

Figura 74 - Clímax do filme com a transformação da Fera (A Bela e a Fera, 1991) ...............209

Figura 75 - John Pomeroy 210

Figura 76 - Penny (“Bernardo e Bianca”, 1977) 210

Figura 77 - Tigrão ("Winnie the Pooh and Tigger Too", 1974). 210 
Figura 78 - Capitão John Smith (“Pocahontas, 1995).

Figura 79 - Cartógrafo e linguista Milo Thatch (“Atlantis: O Reino Perdido”, 2001)...........211

Figura 80 - Capitão Nathaniel Flint ("Planeta do Tesouro", 2002)........................................211

Figura 81 - Pássaro de Fogo (“Fantasia 2000”, 1999)............................................................211

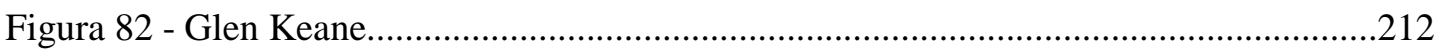

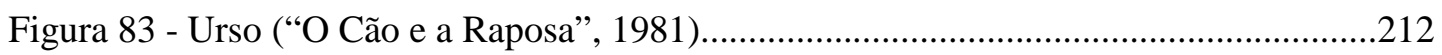

Figura 84 - Prof. Ratagão (“O Ratinho Detetive”, 1986). ..................................................212

Figura 85 - Georgette (“Oliver e sua Turma”, 1988).......................................................212

Figura 86 - Ariel (“A Pequena Sereia”, 1989)....................................................................213

Figura 87 - Águia Marahute (“Bernardo e Bianca na Terra dos Cangurus”, 1990).............213

Figura 88 - Esboço da Fera (“A Bela e a Fera”, 1991)...........................................................213

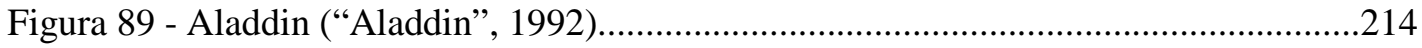

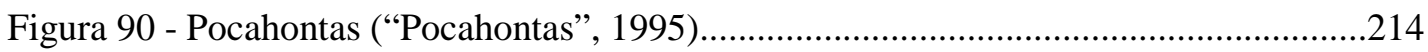

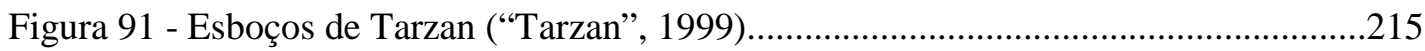

Figura 92 - Pirara John Silver, personagem combinando elementos tradicionais e digitais ("Planeta do

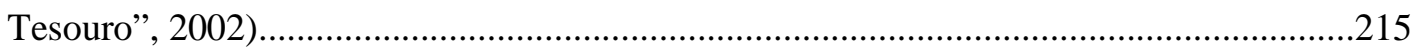

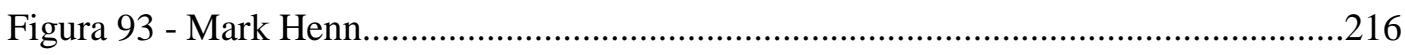

Figura 94 - Mickey Mouse no curta-metragem “O Natal de Mickey Mouse” (1983).......216

Figura 95 - Detetive Basil e Watson (“O Ratinho Detetive”, 1986)..................................216

Figura 96 - Jenny e Oliver (“'Oliver e sua Turma”, 1988)................................................217

Figura 97 - Ariel na cena do jantar (“A Pequena Sereia”, 1989)......................................217

Figura 98 - Bernardo (“Bernardo e Bianca na Terra dos Cangurus”, 1990). ...................217

Figura 99 - Tiana (“A Princesa e o Sapo”, 2009)..............................................................217

Figura 100 - Bela na sequência "Something There” (“A Bela e a Fera”, 1991)...............217

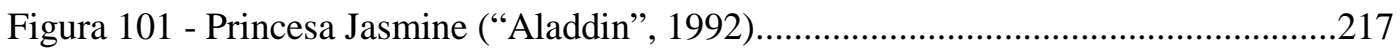

Figura 102 - O jovem leão Simba (“"O Rei Leão”, 1994)...................................................218 
Figura 103 - Fa Zhou e sua filha Mulan (“Mulan”, 1998)......................................................218

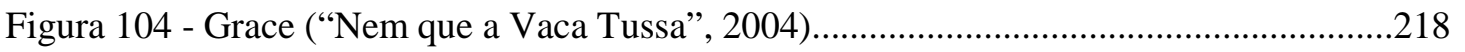

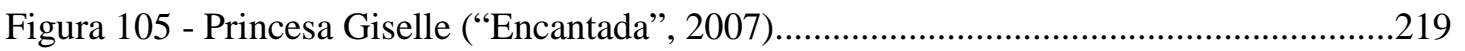

Figura 106 - Direção do curta-metragem “John Henry” (2000)..............................................219

Figura 107 - Winnie the Pooh e Christopher Robin (“Ursinho Pooh”, 2011).................219

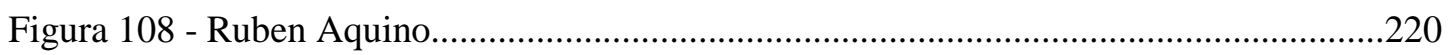

Figura 109 - Buldogue Francis (“Oliver e sua Turma”, 1988)...............................................220

Figura 110 - Úrsula (“A Pequena Sereia”, 1989).............................................................220

Figura 111 - Jake, o canguru (“Bernardo e Bianca na Terra dos Cangurus”, 1990)...............221

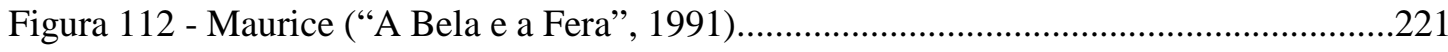

Figura 113 - Simba adulto (“O Rei Leão”, 1994)..................................................................221

Figura 114 - Chefe Powhatan ("Pocahontas", 1995)...........................................................222

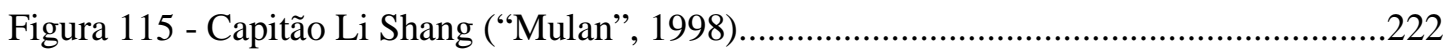

Figura 116 - Pleakley ("Lilo \& Stitch”, 2002) ....................................................................222

Figura 117 - David Kawena (“Lilo \& Stithc”, 2002).............................................................222

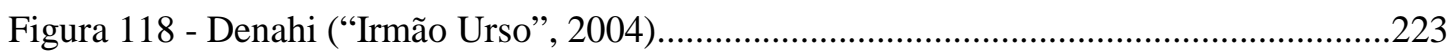

Figura 119 - Mildred (“A Família do Futuro”, 2007).............................................................223

Figura 120 - James e Eudora (“A Princesa e o Sapo”, 2009)...................................................223

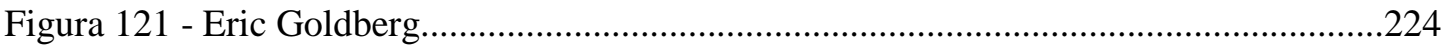

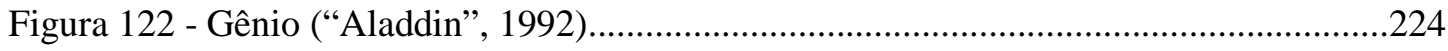

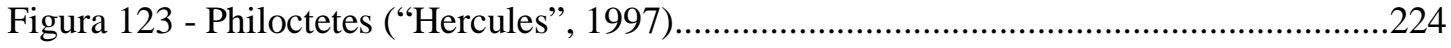

Figura 124 - O que um flamingo faria com um ioiô ("Fantasia 2000”, 1999)........................225

Figura 125 - Segmento "Carnaval dos Animais" (“Fantasia 2000”, 1999)_...........................225

Figura 126 - Teste para um novo filme com Roger Rabbit computadorizado (1999)..............225

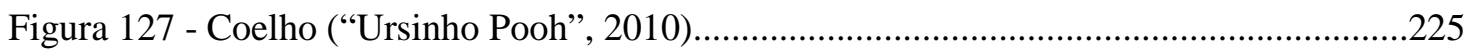

Figura 128 - Amargo Bill e Rei Doce (“Detona Ralph”, 2012).............................................225 
Figura 129 - Inspirado nos traços do caricaturista Al Hirschfeld, segmento "Rhapsody in Blue"

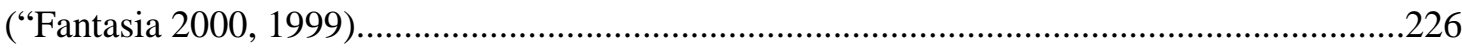

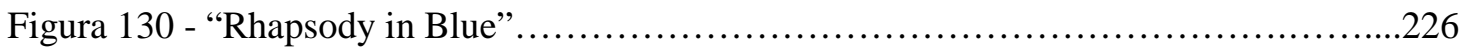

Figura 131 - George Gershwin (“Fantasia 2000”, 1999)..............................226

Figura 132 - Sequência do Monstro Voltogo (“Ursinho Pooh”, 2010)......................................226

Figura 133 - Crocodilo Louis (“A Princesa e o Sapo”, 2009)....................................................227

Figura 134 - Sequência “Almost there”, inspirado nas pinturas do afro-americano Aaron Douglas. (“A

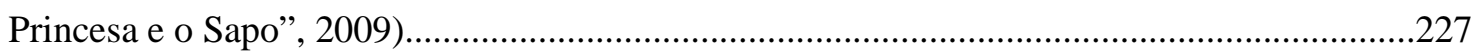

Figura 135 - João Bafo de Onça no curta-metragem "Hora de Viajar" (2014)..........................227

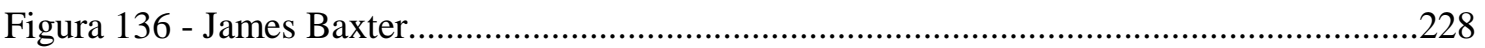

Figura 137 - Doninhas (“Uma Cilada para Roger Rabbit”, 1988)..........................................228

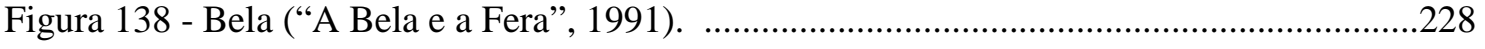

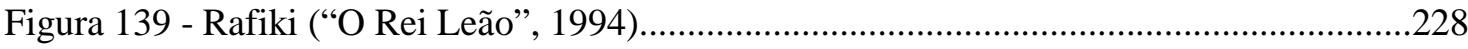

Figura 140 - Quasímodo (“O Corcunda de Notre Dame”, 1996).................................................229

Figura 141 - Model Sheet (o guia-modelo) do personagem Quasímodo....................................229

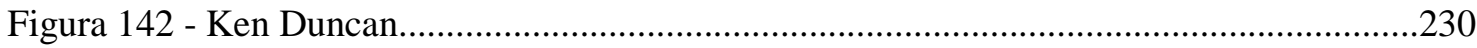

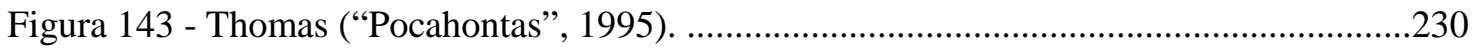

Figura 144 - O vilão Scroop ("Planeta do Tesouro” 2002). .........................................................230

Figura 145 - Modelo-guia da personagem Mégara ("Hercules”, 1997)_..................................230

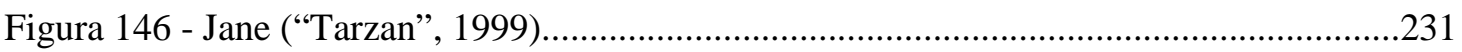

Figura 147 - Capitã Amelia ("Planeta do Tesouro", 2002)......................................................231

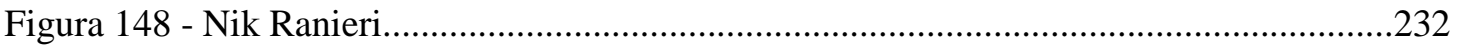

Figura 149 - O castiçal Lumière (“A Bela e a Fera”, 1991).....................................................232

Figura 150 - O albatroz Wilbur (“Bernardo e Bianca na Terra dos Cangurus”, 1990)...........232

Figura 151 - O gaxinim Meeko ("Pocahontas”, 1995)..........................................................232

Figura 152 - O peru Redfeather, descartado quando optou-se por uma história mais séria e sem bichos falantes em "Pocahontas" (1995) 
Figura 153 - O vilão Hades (“Hercules”, 1997).

Figura 154 - Imperador Kuzco (“A Nova Onda do Imperador”, 2000)..................................233

Figura 155 - Pedro Galo (“O Galinho Chicken Little”, 2005).............................................234

Figura 156 - Charlotte La Bouff (“A Princesa e o Sapo”, 2009). ..........................................234

Figura 157 - Lewis (“A Família do Futuro”, 2007)................................................................234

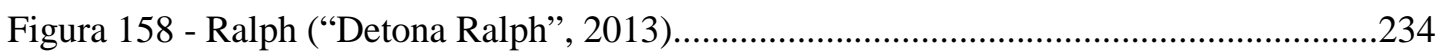

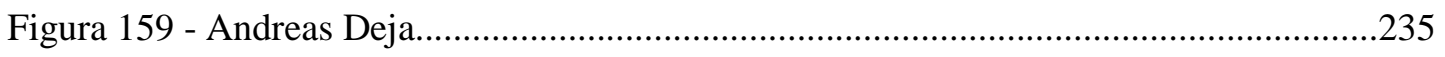

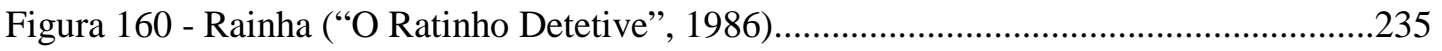

Figura 161 - Roger Rabbit, gorila Bongo e Mickey Mouse em "Uma Cilada Para Roger Rabbit"

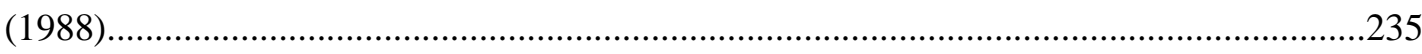

Figura 162 - Rei Tritão (“A Pequena Sereia”, 1989)............................................................235

Figura 163 - Mickey Mouse em “O Príncipe e o Mendigo” (1990)....................................235

Figura 164 - O vilão Gaston (“A Bela e a Fera”, 1991)......................................................236

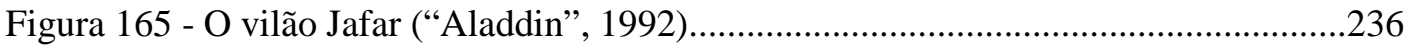

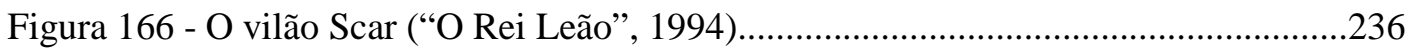

Figura 167 - Mickey Mouse no curta-metragem “Cérebro Fugitivo” (1995)....................237

Figura 168 - A primeira versão da vilã Yzma em “Kingdom of the Sun”.........................237

Figura 169 - Modelo-guia do protagonista Hercules ("Hercules", 1997).........................237

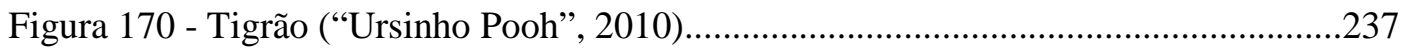

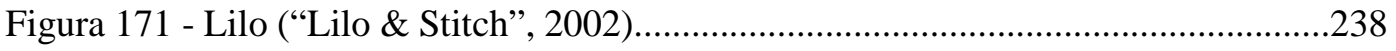

Figura 172 - A vilã rainha Narissa (“Encantada”, 2007)...................................................238

Figura 173 - A feiticeira Mama Odie (“A Princesa e o Sapo”, 2009).................................238

Figura 174 - Complexa cena do salão de bailes em “A Bela e a Fera” (1991)...................244

Figura 175 - Cavernas das Maravilhas - uso de CGI em “Aladdin” (1992)......................244

Figura 176 - Multidão digital em "O Corcunda de Notre Dame” (1996)............................244

Figura 177 - Estouro da manada em “O Rei Leão” (1994)...............................................245 
Figura 178 - "Tron” revolucionou o uso da animação computadorizada em 1982.

Figura 179 - John Lasseter e Glen Keane produzindo "Where the Wild Things Are".....246

Figura 180 - John Lasseter e Glen Keane produzindo "Where the Wild Things Are"........246

Figura 181 - John Lasseter e Glen Keane produzindo "Where the Wild Things Are".........246

Figura 182 - John Lasseter e Glen Keane produzindo "Where the Wild Things Are”........246

Figura 183 - "Luxo Jr.”, animação CGI podia mostrar emoção.............................................251

Figura 184 - “Toy Story” (1995), o primeiro longa-metragem de animação CGI..................254

Figura 185 - Jim Henson e suas criações, os Muppets............................................................262

Figura 186 - Os sócios da DreamWorks SKG: Katzenberg, Spielberg e Geffen....................264

Figura 187 - A batalha das formigas foi destaque na imprensa (Revista Time - MASTERS, 1998)..265

Figura 188 - Segmento "Pinheiros de Roma” ("Fantasia 2000") .269

Figura 189 - Segmento "O Soldadinho de Chumbo" (Fantasia 2000") .269

Figura 190 - O sucesso de Steve Jobs na Apple e na Pixar é destaque na imprensa....... .273

Figura 191 - "Shrek” da DreamWorks desbancou a Disney em 2001 .278

Figura 192 - "Avatar" (2010 - Fox). .281

Figura 193 - "Alice no País das Maravilhas" (2010 - Disney). .281

Figura 194 - Cartoon de Floyd Norman: Michael Eisner quer saber de Steve Jobs e John Lasseter o segredo para fazer filmes de sucesso. NORMAN, Floyd. Son of Faster Cheaper: A Sharp Look Inside the Animation Business. Theme Park Press, 2015c. .284

Figura 195 - Cartoon de Floyd Norman descrevendo o clima de crise nos estúdios Disney - Eisner diz: "Relaxe, Roy! Eu estou fazendo alguns ajustes!". NORMAN, Floyd. Son of Faster Cheaper: A Sharp Look Inside the Animation Business. Theme Park Press, 2015c. .288

Figura 196 - Bob Iger, atual CEO da The Walt Disney Company.... .291

Figura 197 - Logomarca da Disney Interactive 298

Figura 198 - Sheryl Sandberg 299

Figura 199 - Jack Dorsey

Figura 200 - Kevin Mayer .299 
Figura 201 - O robô BB-8 da saga "Star Wars", criado em parceria com empresa start-up

Sphero 300

Figura 202 - As pulseiras mágicas do projeto Disney NexGen 302

Figura 203 - Gráfico da Cauda Longa. 306

Figura 204 - Gráfico demonstra que custos maiores de produção e marketing resultam em retorno financeiro maior no caso de blockbusters (ELBERSE, 2013, p.19)

Figura 205 - "John Carter: Entre Dois Mundos". 312

Figura 206 - Logomarca da Pixar Animation Studios .313

Figura 207 - Imagem do website da Pixar com a frase de Lasseter. 313

Figura 208 - Ed Catmull, Steve Jobs, Bob Iger e John Lasseter no anúncio da compra da Pixar pela Disney 318

Figura 209 - "Carros" (2006), um sucesso comercial, mas nem tanto de crítica. 329

Figura 210 - "O Bom Dinossauro" (2015), a animação com a repercussão mais fria. 329

Figura 211 - Valente" (2012), filme com troca de direção 329

Figura 212 - Pôster de "Procurando Nemo" (2003) 330

Figura 213 - Pôster de "Divertidamente" (2015). 330

Figura 214 - Pôster de "Toy Story 3" (2010). 330

Figura 215 - "Os Incríveis" (2004), animação de ação com situações de violência.. .331

Figura 216 - "Monstros S.A" (2010) .331

Figura 217 - "Up: Altas Aventuras" (2009). 331

Figura 218 - "Ratatouille" (2007), um dos filmes mais sofisticados da Pixar. .331

Figura 219 - "Vida de Inseto" (1998), sucesso na inércia do primeiro "Toy Story". 332

Figura 220 - "Wall-E”, sucesso de crítica com seu tema ligado a sustentabilidade. 332

Figura 221 - A influência da Pixar altera "Bolt: Supercão" (2008) da Disney.... 332

Figura 222 - "A Família do Futuro" (2009) 332

Figura 223 - "Enrolados" (2011) com a historia da Rapunzel é a primeira animação da nova gestão com resultado acima do esperado 333 
Figura 224 - "Zootopia: Essa Cidade é o Bicho" (2016)

Figura 225 - "Frozen: Uma Aventura Congelante" (2014), o maior sucesso da animação......333

Figura 226 - "Moana" (2016), animação com tema polinésio. .334

Figura 227 - "O Espetacular Homem-Aranha” - personagem licenciado para a Sony .346

Figura 228 - "Buffy, a Caça Vampiros", editora Dark Horse 347

Figura 229 - "Jessica Jones". 351

Figura 230 - "O Demolidor" 351

Figura 231 - "Os Vingadores", sucesso do universo compartilhado Marvel 353

Figura 232 - Gráfico mostrando as conexões do Universo Cinematográfico Marvel .354

Figura 233 - "Vingadores: Era de Ultron" (2015) explorou narrativa compartilhada. .355

Figura 234 - As culturas digital e participativa inverteram os parâmetros de consumo 369

Figura 235 - Hierarquização da indústria do entretenimento até os anos 1990 370

Figura 236 - Hierarquização da indústria do entretenimento a partir dos anos 2000 .370

Figura 237 - Gráfico ilustra o desdobramento possível de uma criação original .372

Figura 238 - Bob Iger e George Lucas na divulgação da aquisição da Lucasfilm. .375

Figura 239 - O retorno de Chewbacca e Han Solo. Ligação afetiva com os fãs foi o elemento essencial para atrair os fãs em "Star Wars - Episódio VII: O Despertar da Força” (2015). .376

Figura 240 - O CEO Bob Iger promoveu "Star Wars" ao discutir sua doutrina tecnológica com a revista Fortune 376

Figura 241 - Cadeia de valor (em dólares) da saga "Star Wars" até janeiro de 2015 (http://www.statisticbrain.com/star-wars-total-franchise-revenue/) 377

Figura 242 - O hype e as discussões entre fãs ajudaram na divulgação do filme. 379

Figura 243 - Capa da graphic novel "Epic Mickey 2 - Poder em Dobro" 384

Figura 244 - Gibi com história em quadrinhos inédita do Osvaldo em 2015 384

Figura 245 - Personagens de "Rogue One", filme autônomo na saga "Star Wars".....393

Figura 246 - Bob Iger e o presidente chinês Xi Jinping no Grande Salão do Povo em Pequim em 5 de maio de 2016. (Getty Images) 395 


\section{LISTA DE TABELAS}

Tabela 1 - Levantamento numérico da criação de personagens por território.........106

Tabela 2 - Produção de Histórias em Quadrinhos Disney na década de 1950........107

Tabela 3 - Produção de Histórias em Quadrinhos Disney na década de 1960........108

Tabela 4 - Produção de Histórias em Quadrinhos Disney na década de 1970........109

Tabela 5 - Produção de Histórias em Quadrinhos Disney na década de 1980........109

Tabela 6 - Produção de Histórias em Quadrinhos Disney na década de 1990........110

Tabela 7 - Produção audiovisual Disney em suas diferentes divisões ....................122

Tabela 8 - Divisões da The Walt Disney Company. ...............................................123

Tabela 9 - Valores de produção e faturamento na Pixar.......................................252

Tabela 10 - Recepção da crítica especializada compilada em websites da área......253

Tabela 11 - Orçamentos, Faturamento e Recepção Crítica das animações Disney..267

Tabela 12 - Levantamento das produções derivadas da Disney (AMID, 2015)......271

Tabela 13- Evolução do “meltdown” Disney no início dos anos 2000...................285

Tabela 14 - Novos modelos de negócios atrelados a cultura digital........................338

Tabela 15 - Lista com as maiores bilheterias da Disney, incluindo animações e as produções de recentes aquisições, caso da Marvel e Lucasfilm. 


\section{SUMÁRIO}

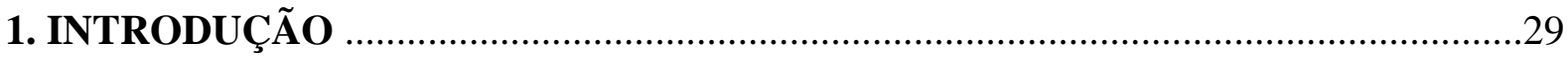

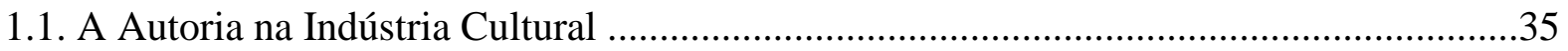

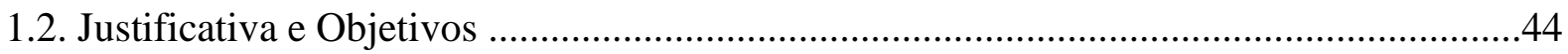

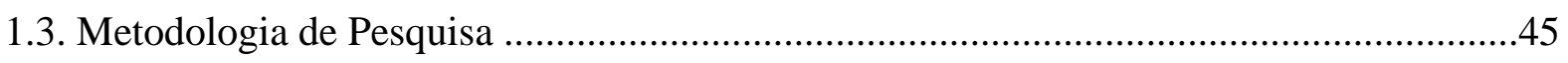

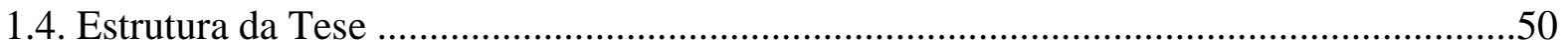

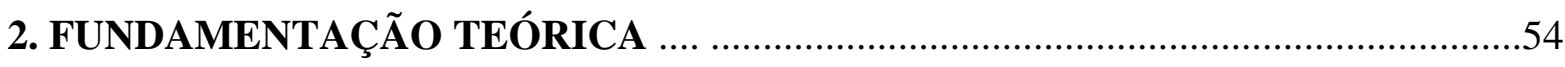

2.1. Perspectiva Alemã: Mickey Mouse nas reflexões de Adorno e Benjamin .....................55

2.2. Perspectiva Sul-Americana: Ideologia e a produção Disney .......................................64

2.3. Perspectiva do Hiper-realismo: O Universo Disney de Umberto Eco e Jean

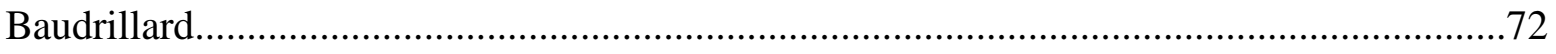

2.4. Perspectiva Britânica/Norte-Americana: Alan Swingewood, Robert Feild, Robin Allan,

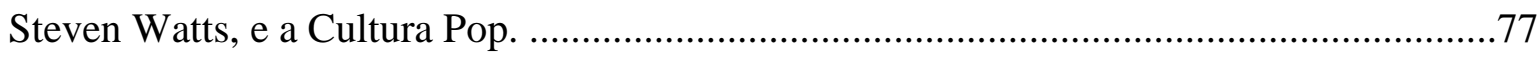

\section{HISTÓRIAS EM QUADRINHOS E ANIMAÇÃO DSNEY: ORIGENS E}

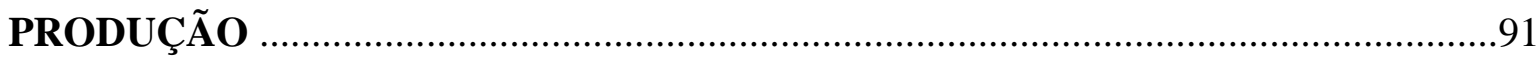

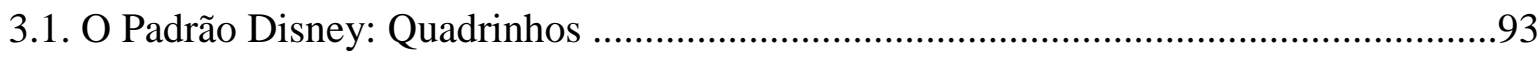

3.2. História e Importância da Indexação de produção ..........................................................96

3.3. Coleta e Análise de Dados sobre os Quadrinhos Disney ........................................103

3.4. Coleta e Análise de Dados sobre a Animação Disney ...............................................112

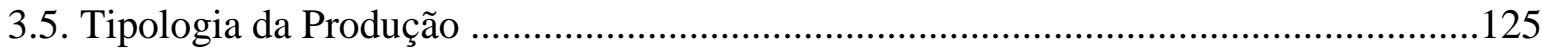




\section{A PRODUÇÃO: A INOVAÇÃ̃ DA INDÚSTRIA, TECNOLOGIA E}

CRIAÇÃ̃o

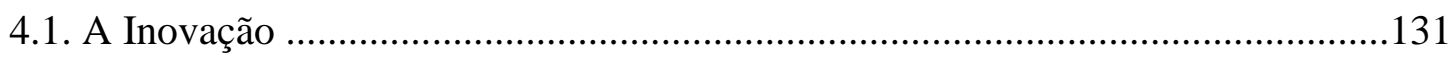

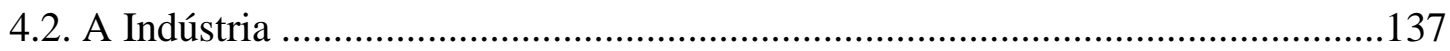

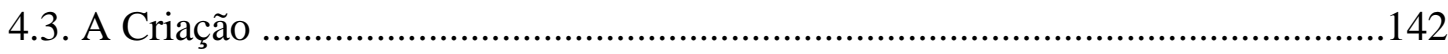

5. OS QUADRINISTAS E A CRIAÇÃO DO “UNIVERSO”.............................151

5.1. Keno Don Rosa e a "renovação" dos Patos .........................................................151

5.2. Casty e o "novo mundo" do Mickey .................................................................161

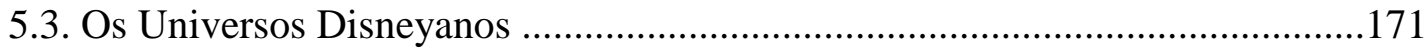

6. A ERA DAS CORPORAÇÕES DE MÍDIA (1984-2005) ............................174

6.1. Início da gestão Michael Eisner ......................................................................174

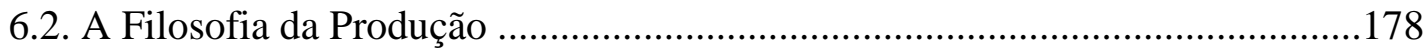

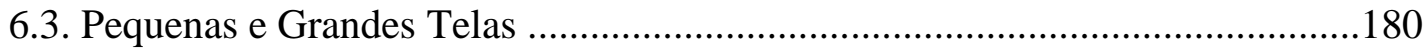

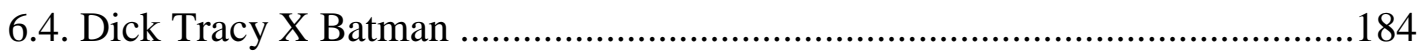

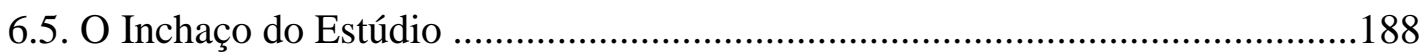

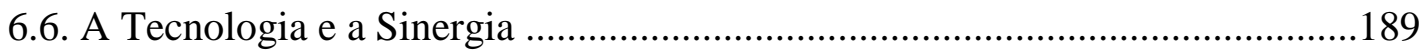

7. ANIMAÇÃO DISNEY E A “NOVA GERAÇÃO” (1980-2000)...................197

7.1. Exemplos Gráficos da Animação Disney ......................................................207

7.2. Novas Tecnologias na Animação................................................................239

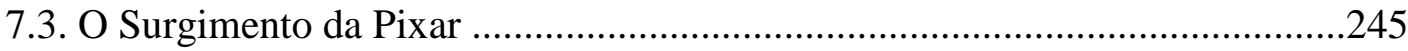

7.4. A Parceria Disney e Pixar.................................................................................250

7.5. O Home-Vídeo e a Saturação da Produção........................................................255 
7.6. Verticalização e Crise

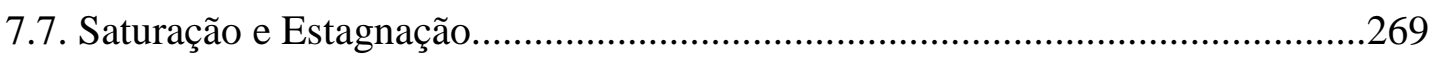

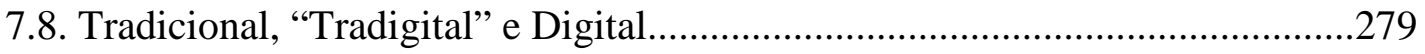

8. A ERA DO IMPÉRIO DA TECNOLOGIA..............................................291

8.1. A gestão Bob Iger e o foco em Tecnologia...................................................292

8.2. Estratégias: A Cauda Longa e o Blockbuster....................................................304

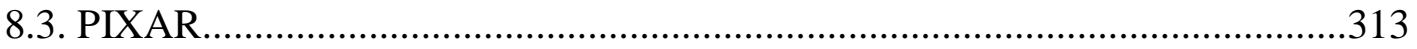

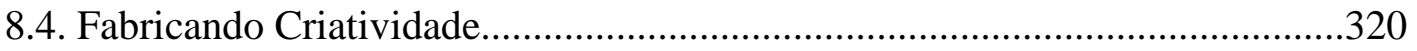

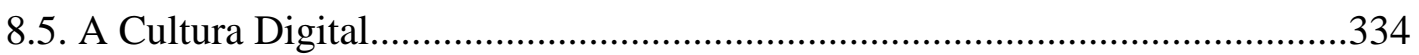

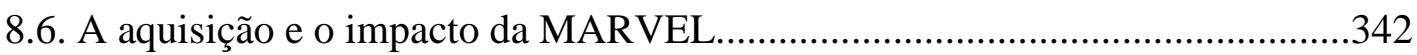

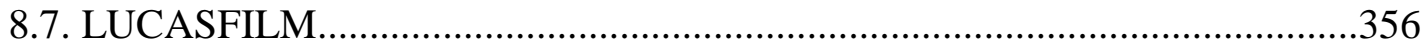

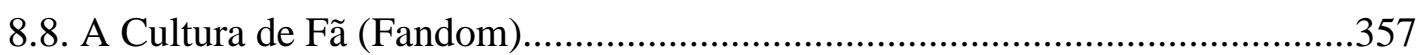

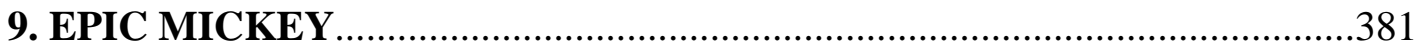

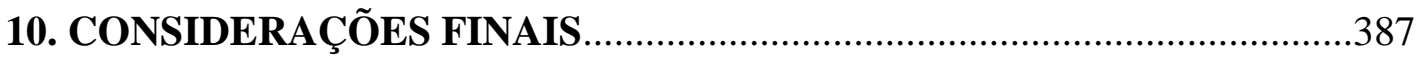

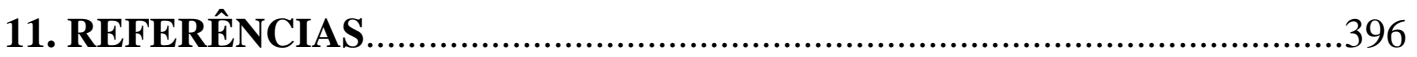




\section{INTRODUÇÃO}

Ao longo do século XX, as histórias em quadrinhos e a animação Disney apresentaram diversos ciclos de criação e popularidade com diferentes consequências artísticas e econômicas. Dentre as dezenas de artistas que contribuíram nas histórias em quadrinhos ao longo dos anos, alguns tiveram participação especial no desenvolvimento e na expansão do universo dos personagens Disney. A partir dos anos 1930 Floyd Gottfredson desenvolveu o universo do Mickey, nos anos 1940 e 1950 Carl Barks fez o mesmo pelo Pato Donald, criando o Tio Patinhas e a cidade de Patópolis, expandindo o universo dos patos. Os anos 1960 e 1970 tiveram novos desenvolvimentos, com as criações italianas de Romano Scarpa e o universo do Zé Carioca no Brasil, com Renato Canini.

Entretanto, a produção de histórias em quadrinhos Disney chega ao século XXI ainda sem um direcionamento e com muitas tentativas bem intencionadas de renovação do interesse de seu público leitor. Muitas dessas tentativas, atualmente, tendem a trabalhar elementos da produção Disney em esquema de sinergia, de modo que um lançamento contribua para o desenvolvimento de produtos em outro setor de consumo dentro da corporação. Deste modo, uma série de televisão ou um videogame podem contribuir para a criação de uma história em quadrinhos e vice-versa.

O universo dos quadrinhos tem seu início próximo das origens do cinema de animação Disney. Os estúdios tiveram suas origens em 1923, com destaque para o lançamento de Mickey Mouse, em novembro de 1928. A produção de quadrinhos Disney começou em 13 de janeiro de 1930 com a primeira tira da King Features Syndicate (uma associação que agenciava os artistas, distribuindo seus trabalhos nos mais diversos jornais), tendo Ub Iwerks e logo em seguida Win Smith como responsáveis pelas aventuras impressas de Mickey Mouse. É preciso ter em mente que a produção Disney seguiu caminhos diferentes, ainda que paralelos, no cinema de animação e nas tiras/histórias em quadrinhos. Enquanto que a animação e, por muito tempo, as tiras, eram produzidas ou supervisionadas pelo próprio estúdio Disney, a produção quadrinística era terceirizada por meio de licenciamento a editoras.

Essa produção paralela é muito mais importante do ponto de vista profissional do que da criação em quadrinhos. Afinal, a história dos quadrinhos Disney demonstra que seus 
personagens seguiram um processo de evolução/transformação muitas vezes diferente de seus correlatos nos cinemas. Mas muitos dos mestres dos quadrinhos Disney, caso de Al Taliaferro e Carl Barks, foram empregados do estúdio de animação, carregando atitudes e um pouco da cultura própria estabelecida por Walt Disney.

Floyd Gottfredson, também oriundo do estúdio de animação, assumiu as tiras de Mickey Mouse em maio de 1930, estabelecendo inicialmente um casamento com o traço natural (ou dito, clássico) do personagem nos cinemas. Mas, aos poucos, teve oportunidade de expandir o universo do personagem criando novos personagens como o Esquálidus (o homem do futuro) e o Coronel Cintra. Em setembro de 1934, o colega artista Al Taliaferro produziu a adaptação do curta-metragem “A Galinha Sábia” (a estréia do Pato Donald) e convenceu a King Features a lançar as tiras do Donald em 1937. Do mesmo modo que Gottfredson, Taliaferro teve a oportunidade de usar muito de sua experiência na animação (bastando observar muitas de suas histórias com planos típicos do cinema) e da criação de novos personagens como a Vovó Donalda, Gansolino e os três sobrinhos Huguinho, Zezinho e Luisinho, que apenas estreariam no cinema em 1938.

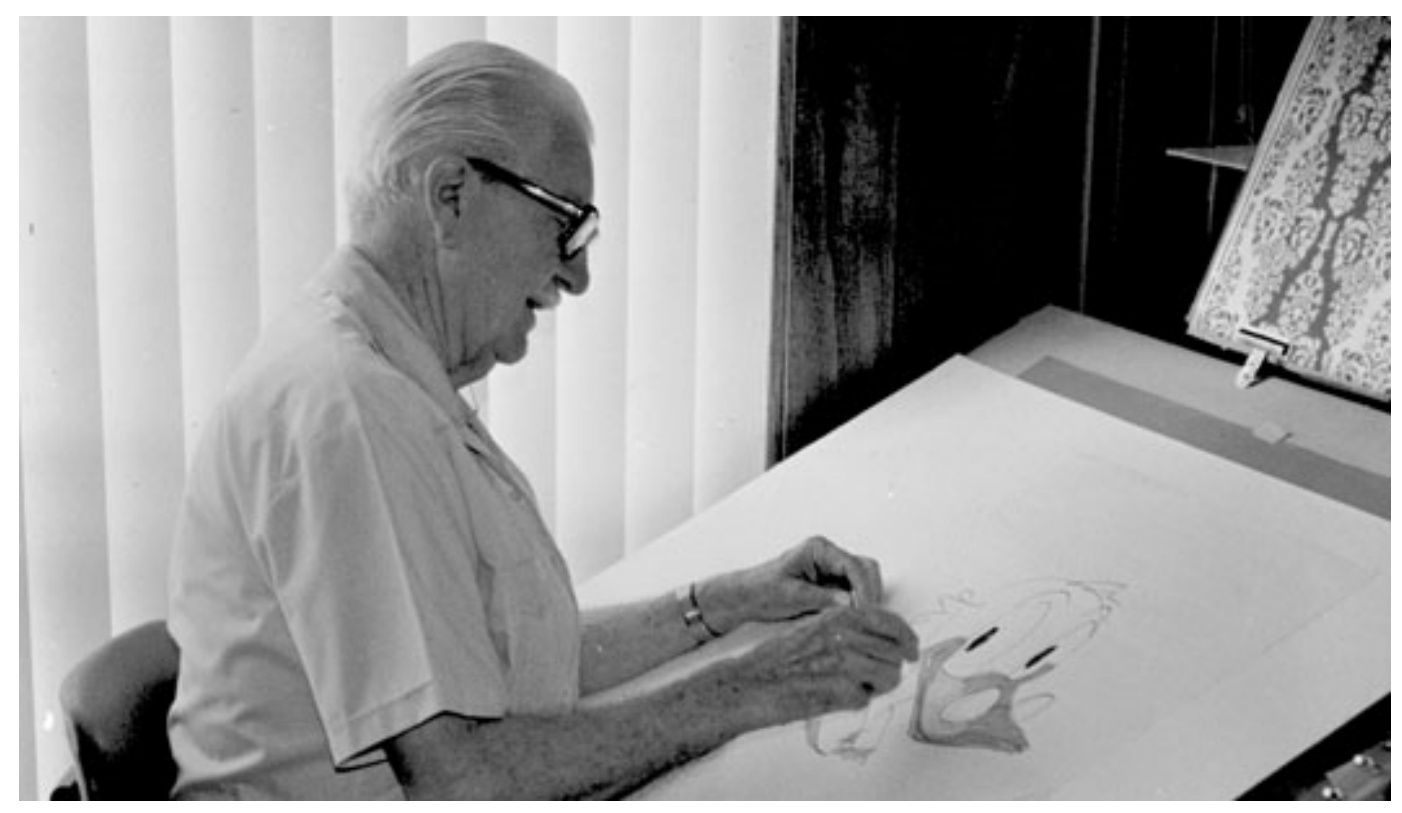

Figura. 1 . Carl Barks, o maior mestre dos quadrinhos Disney

A produção em quadrinhos prossegue até que Carl Barks a revoluciona na década de 1940, ampliando a personalidade do Pato Donald e dos demais personagens do universo dos patos, criando o Tio Patinhas e a cidade de Patópolis, levando os leitores para aventuras em 
diversos locais do mundo (e fora dele); o autor abusa de cenários inspirados em fotos da revista National Geographic e introduz uma série de novidades que torna a leitura dos quadrinhos atrativa para todas as idades. Temas como aventuras surreais, mulheres, política, novidades tecnológicas, o American way of life (modo de vida americano) e uma linguagem com humor mais irônico, sarcástico, por vezes crítico à natureza humana (ANDRAE, 2006, p. 19) atrelados a um traço simples, porém elegante, transformariam Barks no maior mestre dos quadrinhos Disney. Seu colega Paul Murry, numa proporção menor, mas não menos importante, também irá revolucionar os quadrinhos do Mickey Mouse, apostando em histórias como Dick Tracy, Agente Secreto X-9, Sherlock Holmes, Sam Spade, Philip Marlowe, entre outros, indo ao encontro de um dos gêneros dos quadrinhos que fazia mais sucesso na década de 1950 .

É preciso ter mente que, entre o final da década de 1940 e a década seguinte, os personagens clássicos Disney (Mickey, Donald, Pateta, etc) estão sofrendo um processo gradual e custoso de estagnação ou esgotamento temático nos cinemas. Não somente porque o retorno comercial dos curtas era cada vez mais baixo, mas porque os artistas do estúdio não sabiam mais o que fazer com os personagens, tendo em vista que suas características haviam se fixado no imaginário popular após duas décadas de grande sucesso. Daí, temos o esgotamento. Paul Murry (criador de diversas histórias de aventura em co-autoria com Carl Falberg) e Carl Barks são os responsáveis por darem sobrevida aos personagens nos quadrinhos, ampliando seus universos e trazendo maior densidade as suas características psicológicas - algo complexo de se fazer em animação na época.

A produção em quadrinhos Disney ganha o mundo por meio de licenças para editoras de diversos países, tendo uma produção local italiana já no final da década de 1930, mas retomada apenas após a Segunda Guerra Mundial. A Itália terá um importante artista que podemos considerar como fundamental para a expansão do universo Disney, tendo em vista também as peculiaridades locais. Romano Scarpa não apenas criaria novos personagens (Tudinha, Pata Lee, Brigite, etc), como abriria espaço com seu traço para outros artistas continuarem ou dialogarem com seu trabalho; outro grande talento foi Giorgio Cavazzano, cujo estilo do traço seria copiado por muitos colegas. No Brasil, o artista gaúcho Renato Canini foi responsável pela adaptação e evolução do personagem Zé Carioca, aproximando suas aventuras da realidade brasileira, colocando o personagem vivendo num morro carioca. 
Por mais de cinco décadas, começando nos anos 1930, as histórias em quadrinhos Disney, com seus processos cíclicos de esgotamento temático e adaptação, tiveram sucesso sem grandes oscilações, tendo como primeiro "inimigo" as próprias limitações naturais do mercado de quadrinhos em todo o mundo. Neste mesmo período, os quadrinhos Disney, com suas renovações e expansões dos universos de personagens, não fugiram de uma série de procedimentos ou diretrizes que formalizam o senso natural da criação, levando-se em conta as particularidades de acordo com o país onde foi produzido. Roberto Elísio dos Santos (2002, p. 218-230) lista cinco temas a partir dos quais os diversos enredos são estruturados: 1) o maniqueísmo, 2) a contraposição entre a modernidade e a tradição, 3) a defesa dos ideais americanos, 4) a relação com os “povos primitivos” e 5) a contestação da arte culta.

A animação Disney, por sua vez, teria períodos cíclicos de sucesso a partir dos anos 1950, quando os personagens dos curtas-metragens ganharam nova visibilidade nos quadrinhos. Nos cinemas, ganhou novas influências de origem europeia com os lançamentos dos filmes "Cinderela", "Alice no País das Maravilhas", "Peter Pan" e "A Bela Adormecida". Na televisão, buscou experimentações tendo em vista o novo modelo "modernista" de animação que pregava um estilo anti-realista, contraponto do que até então se conhecia como padrão de estilo Disney (MALTIN, 1980).

Após o período áureo dos grandes clássicos como "Branca de Neve e os Sete Anões" (1937), "Pinóquio" (1940), "Fantasia" (1940), "Dumbo" (1941) e "Bambi” (1942), há historiadores (BARRIER, 1999) que consideram os anos 1940 como período que representa o início do esgotamento da inovação artística Disney, antes de sucumbir às limitações do processo de produção que viriam nos anos posteriores.

Diferente da produção em quadrinhos, os momentos de esgotamento no cinema são muito bem documentados, ainda que nem todos tenham sido analisados. Mais difundido na imprensa, o renascimento criativo do fim dos anos 1980, com os lançamentos de campeões de crítica e público como “A Pequena Sereia” (1989), “A Bela e a Fera” (1991), “Aladdin”(1992) e "O Rei Leão" (1994), representaram um forte estímulo para o mercado, em que as principais majors (Warner, Universal, Fox) passaram a investir pesadamente na produção de filmes e seriados de animação, nem sempre com o mesmo esmero e know-how (SITO, 2006, pp. 293$317)$. 
Outros períodos de estagnação são praticamente desconhecidos como, por exemplo, o dos anos 1960, quando Walt Disney pensou seriamente em abandonar a produção de animação para cinema, quase sucumbindo aos apelos dos executivos que julgavam ser mais lucrativo apenas relançar periodicamente os filmes já produzidos. Michael Barrier (2012) cita entrevista conduzida em 1976 com Eric Larson, em que o animador descreve a ação retratada em foto publicada em um livro de $1958^{1}$. Na situação, Walt Disney observa os storyboards e comenta ao animador Eric Larson "Não acho que podemos continuar. É muito caro!".

Um dos motivos seriam o alto custo e longo tempo utilizados na produção de "A Bela Adormecida" (1959), que não deu o retorno financeiro esperado nos cinemas. Ironicamente, a produção foi salva graças ao grande sucesso inesperado de "101 Dálmatas" (1961), filme produzido já em um esquema tecnicamente mais econômico comparado aos filmes da década de 1950. Há também exemplos de esgotamento nos anos 1970, quando há inclusive maior reaproveitamento de cenas produzidas no passado como suporte para novas cenas (CANEMAKER, 2001, p. 161).

É importante ressaltar que as mesmas diretrizes sofreram nuances no decorrer das décadas. Tendo em vista esta questão, os quadrinhos Disney chegam à década de 1990 com o início latente de um processo de estagnação ou esgotamento criativo. A animação sofrerá o mesmo processo novamente um pouco mais tarde, nos anos 2000. Como se não bastassem as problemáticas do mercado, como a queda de vendas e a maior variedade no entretenimento (mangás, videogame, internet, etc), os obstáculos de produção fora dos Estados Unidos, além da própria indiferença da Disney americana com os quadrinhos, fizeram com que fosse iminente certa decadência das histórias em quadrinhos Disney.

Porém, cabe a ressalva de que mesmo com a produção quadrinística da Disney em diversos países, especialmente na Europa, a Itália talvez seja ainda o único caso em que as revistas em quadrinhos são suficientemente populares para que o escritório local da Disney ainda gerencie, de modo direto e competente, o processo de criação - mesmo que isso também signifique um certo comodismo dos artistas italianos, que tendem, nos últimos anos a ser mais auto-referenciais do que propriamente "revolucionários". Tendo em vista a formação da maioria dos artistas italianos em Belas Artes, Roberto Elísio dos Santos afirma que eles "consideram a história em quadrinhos como manifestação artística [...], em consequência, o quadrinhista

\footnotetext{
${ }^{1}$ THOMAS, Bob. Walt Disney: The Art of Animation. New York. Golden Press, 1958, p. 178.
} 
italiano orgulha-se de seu trabalho, tornando-o uma obra que se inspira no original americano sem contudo, limitar-se a imitá-lo" (2002, p. 250). E para complementar, Disney atualmente possui dois elementos agregados que oferecem novas possibilidades criativas e de produção os quadrinhos da Marvel e os estúdios Pixar.

A Pixar é um estúdio de animação computadorizada norte-americano criado em 1979, ainda parte da divisão da Lucasfilm (do cineasta George Lucas). O estúdio, até então produzindo hardwares e efeitos visuais para filmes, foi comprado por Steve Jobs em 1986 (PRICE, 2008, p. 83). Com o auxílio de um animador oriundo da Disney, John Lasseter, a Pixar produziu uma série de curtas e longas-metragens de sucesso como "Toy Story" (1995), "Vida de Inseto" (1998), "Montros S.A." (2001), "Procurando Nemo" (2003), "Os Incríveis" (2004), "Ratatouille" (2007) e "WALL-E" (2008). A Pixar se beneficiava de um acordo de parceria com a Disney (que distribuía e ganhava boa parte dos lucros), A Disney passava por uma safra tão ruim de animações com resultados fracos nos cinemas, que não hesitou em tentar adquirir a Pixar. Steve Jobs, por sua vez, queria retormar todos os direitos sobre os filmes e os personagens frutos da parceria antiga. O resultado foi a compra da Pixar pela Disney por US\$ 7,4 bilhões em 2006, tornando Jobs o maior acionista individual da Disney e fazendo de John Lasseter e do cientista da computação Ed Catmull os novos chefes da divisão de animação Disney (ISAACSON, 2011, pp. 458-461).

A Marvel Entertainment é uma companhia americana que inclui a Marvel Comics, responsável pela publicação de diversos sucessos das histórias em quadrinhos. Inicialmente conhecida como Timely Publications em 1939 (fundada por Martin Goodman) e como Atlas Comics no início dos anos 1950, a Marvel obteve seu status em 1961 quando lançou o "Quarteto Fantástico" e títulos do gênero super-heróis criados por Steve Ditko, Jack Kirby e Stan Lee. Dentre os títulos constam Homem-Aranha, Wolverine, Homem de Ferro, Capitão América, XMen, entre outros (WOLK, 2007). Após escapar de um processo de falência no início dos anos 2000, a Marvel passou a diversificar seus produtos, não apenas na linha editorial, mas licenciando seus personagens para grandes produções de cinema de Hollywood. Visando atrair para si um capital criativo e lucrativo, a Disney comprou a proprietária da Marvel Comics, a Marvel Entertainment, por US\$ 4 bilhões em agosto de 2009. Em 2012, a Disney ainda estudava como aproveitar o acervo Marvel. 
A Lucasfilm é uma companhia produtora de cinema e televisão. Foi fundada pelo cineasta George Lucas em 1971 e é mais conhecida pela criação das franquias "Indiana Jones" e "Star Wars", cujo primeiro filme estreou nos cinemas em 1977. O grupo mantém uma série de empresas, com destaque para a Industrial Light \& Magic (efeitos visuais), a Skywalker Sound (efeitos sonoros, mixagem e gravação musical) e a LucasArts (desenvolvedora de games). O grupo foi adquirido pela Disney em outubro de 2012 por US\$ 4 bilhões. O lançamento do filme "Star Wars - Episódio VII: O Despertar da Força" em dezembro de 2015 se tornou um dos filmes mais vistos na história do cinema (LANG, 2015).

\subsection{A Autoria na Indústria Cultural}

Na questão da produção, há dois pontos importantes a se considerar. Em primeiro lugar, a identidade e a importância do autor no processo de produção. E, em segundo lugar, as diferentes variáveis relacionando a produção ao marketing, a sinergia entre diferentes suportes midiáticos e as novas formas de recepção que, nos últimos anos, começam a alterar algumas características da "indústria cultural".

O autor ou "criador" na indústria cultural tem origem no artista do século XIX, como afirma Edgar Morin (1997, p. 29) "ele se afirma precisamente no momento em que se começa a era industrial. Tende a se desagregar com a introdução das técnicas industriais na cultura. A criação tende a se tornar produção". Em síntese, as novas artes neste novo sistema industrial resgatam, de certo modo, o antigo coletivismo do trabalho artístico. Morin cita, por exemplo, como os personagens dos quadrinhos Tarzan e Flash Gordon foram passando por diferentes mãos com o passar dos anos: "Pela primeira na história, é a divisão industrial do trabalho que faz surgir a unidade da criação artística, como a manufatura fazer surgir o trabalho artesanal" (1997, p. 30).

Um dos exemplos da grande arte industrial, o cinema, está estruturado em uma divisão de trabalho rigorosa, semelhante a qualquer outra indústria, segue um processo desde sua matéria-prima (o script), passando por todos os profissionais e áreas que realizarão o filme (roteiristas, produtores, diretores, cenógrafos, figurinistas, músicos, maquiadores, técnicos de som, etc). Apesar de haver um realizador inicial, geralmente creditado, o resultado é fruto de um trabalho coletivo. 
A divisão do trabalho transformado em coletivo é um aspecto de uma racionalização do sistema industrial que tem origem na fabricação dos produtos, segue nos planejamentos de produção, de distribuição e divulgação, e termina nos estudos do mercado cultural. Morin (1997, p.30) afirma que esta "racionalização corresponde a padronização: a padronização impõe ao produto cultural verdadeiros modos espaço-temporais: o filme deve ter, aproximadamente, $2.500 \mathrm{~m}$ de película, isto é, cobrir uma hora e meia [...]". Entretanto, a divisão do trabalho não é incompatível com a individualização da obra. Há uma variedade de obras-primas no cinema que, segundo Morin, em condições ideais o realizador está à frente ou precisa assumir diferentes funções no processo industrial, ou seja,

\begin{abstract}
A padronização em si mesma não ocasiona, necessariamente, a desindividualização; ela pode ser o equivalente industrial das "regras" clássicas da arte, como as três unidades que impunham as formas e os temas. Os constrangimentos objetivos ou sufocam, ou, ao contrário, aumentam a obra de arte" (MORIN, 1997, p. 31).
\end{abstract}

O cinema e os quadrinhos, portanto, dividem várias semelhanças em seu processo de produção. Segundo McLuhan (1974, p. 323, "O cinema não é um meio simples [...] mas uma forma de arte coletiva [...]. A imprensa, o rádio, a TV e as histórias em quadrinhos também são formas de arte que dependem de equipes completas e de hierarquias de capacidade empenhadas em ação corporada".

Muito mais do que no cinema, os quadrinhos ainda mantêm uma relação dialética entre dois processos de produção distintos. Duncan (2007, p. 88) descreve os dois, sendo o primeiro o industrial, que se refere aos quadrinhos criados de forma coletiva, com divisões claras no processo, com a participação em tarefas específicas do roteirista, do artista, do colorista, artefinalistas, letristas, todos supervisionado por um editor. Este processo também é conhecido como "assembly line", em que o produto é estruturado a serviço das prioridades comerciais do que propriamente criativas.

O segundo processo é o artesanal, em que os quadrinhos são criados por um único artista que tipicamente é o responsável por grande parte do trabalho criativo. Esse processo é mais visto em pequenas editoras independentes, menos interessadas na venda do personagem de capa em revistas mensais, e mais no nome dos criadores que possuem mais liberdade e tempo para produzir um número menor de histórias com resultados estéticos normalmente mais interessantes (DUNCAN e SMITH, 2009, p. 88, tradução nossa). Há também os artistas 
freelancers (work-for-hire) que são contratados mesmo pelas grandes editoras mainstream ${ }^{2}$ especificamente para desenhar histórias ou uma coleção singular (DUNCAN, 2009, p. 91).

O processo de produção também ganha uma dinâmica diferente quando levamos em conta o aspecto da empresa controladora. Os quadrinhos foram publicados por diversas editoras ao longo das últimas oito décadas, assim como ao longo do século $\mathrm{XX}$ muitos estúdios de animação produziram seriados, curtas e longas-metragens. No entanto, o mercado caminhou para uma concentração midiática em termos de propriedade e produção. No caso dos quadrinhos nos Estados Unidos, "a produção é caracterizada como um oligopólio" (DUNCAN, 2007, p. 90), condição em que poucas empresas competidoras controlam boa parte do mercado. Duas editoras norte-americanas, a Marvel Comics e a DC Comics, controlam 70\% do mercado, deixando os $30 \%$ restantes pulverizados entre editoras pequenas e independentes.

É necessário apontar que tanto a Marvel Comics e DC Comics são, por sua vez, subsidiárias de grandes conglomerados de mídia (respectivamente Disney e Time Warner), que também produzem conteúdo para outros suportes. Apesar das editoras se preocuparem basicamente na produção de quadrinhos (os mais populares do mainstream), elas licenciam seus personagens e histórias para uso em outras mídias, geralmente com lucro muito maior que a fonte original. Não é surpresa, portanto, que propriedades da DC Comics como Superman e Batman alcancem tamanha visibilidade por via de seriados e filmes derivados dos estúdios Warner Bros. e dos canais de televisão $\mathrm{CW}^{3}$ e Cartoon Network.

Igualmente temos a Marvel, que nos anos 1990 passou por um período de crise financeira, se transformando numa gigante do licenciamento, tendo agora seus personagens (Homem Aranha, Capitão América, Hulk, entre outros) uma enorme plataforma midiática na Disney. Os estúdios de animação Disney fazem também parte do conglomerado chamado The Walt Disney Company. As produções cinematográficas funcionam da mesma forma, utilizando seu conteúdo para sinergia em outras divisões (internet, consumo, TV, etc).

\footnotetext{
${ }^{2}$ Mainstream ("corrente principal"): "Palavra de origem americana: para o grande público, dominante, popular. Cultura mainstream: pode ter conotação positiva, no sentido de "cultura para todos", ou negativa, no sentido de "cultura hegemônica". Filme mainstream: direcionado para o grande público. Mídia mainstream: veículo de comunicação de massa. "Ele quer ser mainstream": quer agradar a todo mundo". (MARTEL, 2012)

${ }^{3}$ Rede de TV americana, joint-venture entre a CBS Corporation e a Warner Entertainment. A CW foi inaugurada em 2006 com a fusão dos canais concorrentes Warner e UPN e tem como foco o público jovem e adulto.
} 
Apesar dos efeitos nos conglomerados de mídia terem se intensificado ferozmente desde meados dos anos 1990, a sinergia neste campo é um fenômeno mais antigo. Fernando Mascarello (2006, p. 347) descreve que relatos historiográficos recentes apontam que se trata de um mito a rivalidade existente entre cinema e TV, sendo que "um primeiro aspecto ressaltado é o redirecionamento na década de 1950 de boa parte dos recursos de pessoal e equipamento das majors (antes empregados na produção de filmes $\mathrm{B}$, documentários e cinejornais) para a realização de séries televisivas". E a TV, por sua vez, descobriria o filme hollywoodiano como um efetivo produto comercial.

A sinergia faz parte do processo pela qual a indústria cultural buscou estratificar ainda mais seus produtos. Se os quadrinhos alçaram sua popularidade, em grande parte pela exploração de um nicho antes não explorado de crianças e jovens (PUSTZ, 1999), o cinema também superou suas limitações pela estratificação de sua produção. Com a concorrência da TV e a decadência do cinema ainda calcado em musicais, comédias e filme experimentais, foi preciso se reinventar para atrair um outro tipo de público. Há autores que apontam que a trilogia de blockbusters-catástrofes "O Destino do Poseidon" (Ronald Neame, 1972), "Terremoto" (Mark Robson, 1974) e "Tubarão" (Steven Spielberg, 1975) "demarcam o início da era do blockbuster high concept e do reencontro com a estabilidade financeira" (MASCARELLO, 2006, p. 346). "Tubarão" inaugura uma fórmula poderosa de lançamento e publicidade por saturação (a TV transformou o filme em um evento nacional).

É graças aos recursos dos disaster movie (filme-catástrofe) que muitos dos filmes do cinema progressista hollywoodiano ainda se mantinham viáveis comercialmente. Outros dois filmes (ambos lançados em 1977) sacramentariam a sinergia midiática. O primeiro, "Os Embalos de Sábado à Noite" (John Badham), "revela as imensas possibilidades de aproximação mercadológica entre as indústrias do cinema e da música, até ali pouco exploradas - além de romper, com John Travolta, a barreira histórica entre os mercados de atuação para cinema e TV" (MASCARELLO, 2006, p. 346). O segundo filme, "Guerra nas Estrelas" (George Lucas) se apresentou como o primeiro e maior exemplo do "filme-franquia", iniciando o florescimento da indústria de negócios conexos, como cita Mascarello, intimamente associada à prática (deflagrada pelo filme) das reprises e sequências.

O processo de concentração nas corporações de mídia teve seu auge na década de 1990. "Nas indústrias culturais e mediáticas, a concentração é um fenômeno antigo: a história de todas 
as indústrias culturais e de todas as grandes mídias é feita de absorções, de fusões, de participações, de tomada de controle e de tentativas brutais de resgates. Geralmente os efeitos nefastos dessas operações sobre a criação cultural e sobre a qualidade da informação são regularmente denunciados e até combatidos”. (MIÈGE, 2007, p. 52). Podemos destacar a autonomia dessas concentrações e lógicas financeiras com as fusões da AOL e Time Warner, Viacom e CBS, Seagram e Universal (depois com o grupo francês Vivendi) e finalmente Disney e a Capital Cities/ABC (em fusão realizada em 1996 por mais de US\$ 19 bilhões).

No caso da Disney, os efeitos da concentração podem ser medidos, de modo prático, com o crescimento abundante da corporação, dificultando inclusive o gerenciamento das bases fundadoras da empresa - o estúdio de animação. Em outras frentes, terceirizaram-se diversos setores que ficaram sob supervisões pífias e investiu-se no conceito de branding (gestão de marcas) que resultou na diluição de personagens consagrados, ou pelo menos da atenção dada a eles. Em 1993, antes mesmo do sucesso de "O Rei Leão" e da fusão com a ABC, a Disney já era digna de respeito. Parece pertinente que, em 1993, o maior ganhador do pacote de bônus de fim de ano para os executivos foi Michael Eisner, presidente da The Walt Disney Company “o bônus de Eisner de US\$203,1 milhões equivalia a 68\% dos lucros totais da companhia: de US\$ 299,8 milhões naquele ano - sem dúvida, grande o bastante para que ele próprio criasse algumas ilusões pessoais" (KORTEN, 1995, p. 133).

A importância da imagem pode ser vista quando, no Natal do ano 2000, Andy Mooney, executivo contratado pela Disney vindo da Nike para revigorar a marca, fez um seminário expressando a importância da "marca Disney". O sobrinho de Walt Disney, o executivo Roy E. Disney, imediatamente o contradisse afirmando que "marca é para gado", argumentando que o importante era a Disney criar histórias e os produtos que elas geravam (STEWART, 2005, p. 354-355). Mooney sugeriu a ideia da criação de uma montanha de brinquedos de pelúcia nas lojas Disney, e isso incluiria uma versão totalmente "branca" da pelúcia do Mickey Mouse, o que era considerado uma heresia por todos os gerentes do departamento. "Mickey é preto, ponto!" (STEWART, 2005, p. 355). Mooney argumentou que seria bom para a marca e acabou tendo seu plano levado adiante.

Outras questões incluiriam a ampliação do impacto dos produtos relacionados às “princesas Disney”. O pensamento tradicional da empresa era tratá-las como personagens que habitavam universos completamente diferentes, cada qual em sua história. O novo paradigma 
de estratificação pedia a criação da marca "Princesas" em que todas povoassem o mesmo universo. Novamente, um sobressalto sobre uma tradição que imperava há décadas, em nome do mercado. Da mesma forma, o Disney Channel deixou de ser um canal para toda a família e se focou no segmento tween (pré-adolescentes entre 10 e 14 anos), tendo em vista que pesquisas de mercado apontavam que esse era o público que estava sendo negligenciado e era potencialmente positivo e lucrativo para a audiência do canal. Outros canais foram igualmente estratificados, sendo o DisneyXD (anteriormente conhecido como Jetix) relacionado aos garotos que assistem desenhos de ação e animes (animações japonesas) e o Disney Junior (específico para o público pré-escolar, mas que transmite filmes para toda a família). O foco passou a ser a promoção global de forma mais eficiente (GRASER, 2013).

A relação de produção entre indústrias, incluindo a cultural, resultará no que Guy Debord (1997) chamou de a sociedade do espetáculo. A sociedade capitalista se apresenta como sociedade do espetáculo, importando mais do que tudo a imagem, a aparência e a exibição. A ostentação do consumo vale mais do que o próprio consumo. Esta característica da aparência possuir uma supremacia sobre a própria existência está presente na relação existente entre realidade e aparência, à qual Debord chamará de materialidade. Em sua dinâmica, o espetáculo é um estágio do capital onde toda a produção é mediada por imagens.

$\mathrm{Na}$ era do espetáculo, ele se apropria de qualquer representação, pois a lógica é a do mercado. A indústria do imaginário passa a ser regida pela economia:

A sociedade que se baseia na indústria moderna não é fortuita ou superficialmente espetacular, ela é fundamentalmente espetaculoísta. No espetáculo, imagem da economia reinante, o fim não é nada, o desenrolar é tudo. O espetáculo não deseja chegar a nada que não seja ele mesmo (DEBORD, 1997, p. 17).

No universo Disney, a questão da imagem e do significante da marca sofreram mudanças drásticas após a era das grandes fusões das empresas de mídia nos Estados Unidos na década de 1990.

O cinema passa por mais um período crítico, se levarmos em consideração a nova concorrência com os mais diferentes aparatos tecnológicos e as consequências da era da convergência. A convergência, por sua vez, não ocorre por meio de aparelhos, por mais sofisticados que venham a ser: 
A convergência ocorre dentro dos cérebros de consumidores individuais e em sua interações sociais com outros. Cada um de nós constroi a própria mitologia pessoal, a partir de pedaços e fragmentos de informações extraídos do fluxo midiático e transformados em recursos através dos quais compreendemos nossa vida cotidiana. Por haver mais informações sobre determinado assunto do que alguém possa aguardar na cabeça, há um incentivo extra para que conversemos entre nós sobre a mídia que consumimos. Essas conversas geram um burburinho cada vez mais valorizado pelo mercado das mídias. O consumo tornou-se um processo coletivo [...]. Nenhum de nós pode saber tudo; cada um de nós sabe alguma coisa; e podemos juntar as peças, se associarmos nossos recursos e unirmos nossas habilidades (JENKINS, 2009, p. 30).

Zygmunt Bauman (2008), por sua vez, encara o consumo como o grande herói do capital, porque a única forma do capital se manter é através do consumo. Entretanto, o consumidor seria o grande vilão da sociedade. Haveria uma relação dialética entre o cidadão consumidor e o cidadão vilipendiado pelo que consome, e os próprios produtores são vítimas disso.

Não pretendemos ampliar a discussão em torno das teorias do consumo, mas os dados servem como base para tentar compreender como o mercado funciona no início do século XXI. O chefe técnico da Walt Disney Animation Studios, Andy Hendrickson, revelou o pensamento por trás da estratégia de lançamentos cinematográficos e que, de certo modo, podemos estender aos concorrentes. $\mathrm{O}$ executivo afirma que o número de espectadores por lançamento está caindo, e os estúdios precisam lutar contra isso usando tentpoles ${ }^{4}$. Hendrickson cita que a venda de ingressos de cinema está estável desde 2005 (com exceção de uma pequena queda durante a crise financeira de 2008), mas o número de filmes lançados cresceu consideravelmente (apud COHEN, 2011).

O executivo confirma que o mercado de home-video não encolheu, e que o faturamento das compras realizadas na internet via streaming ${ }^{5}$ é o mesmo dos alugueis do VHS, ou seja, a era altamente lucrativa das vendas de DVDs ocorrida entre o VHS e o streaming hoje parece

\footnotetext{
${ }^{4}$ Tentpole - na indústria do cinema e da TV norte-americana, o termo se refere a uma produção que sirva para manter e equilibrar o desempenho financeiro de um estúdio ou de uma rede de televisão. Na TV, por exemplo, é comum uma emissora usar um seriado ou programa de alta audiência (um tentpole, portanto) para tentar impulsionar outro programa novo ou não, que tenha menos público.

${ }^{5}$ Streaming é uma forma de distribuição de dados, geralmente em multimídia por uma rede pelo uso de pacotes. É mais utilizado para distribuir conteúdo multimídia pela Internet, sendo que as informações não são armazenadas no computador do usuário. Ele só recebe o "stream" (transmissão de dados) que é arquivada temporariamente em seu Disco Rígido (HD). A tecnologia permite que a reprodução proteja direitos autorais de forma similar a TV e o rádio.
} 
uma aberração. A equação dos estúdios, segundo Hendrickson, é: declínio do lucro somado a necessidade de mais espectadores resulta no foco nos tentpole films. É possível semear o desejo de ver o filme para qualquer um em todos os canais de distribuição. Seria o único meio do estúdio investir US\$ 100 milhões em marketing.

Ao contrário da lógica propagada por John Lasseter, atual chefe dos estúdios de animação Disney e Pixar, o executivo Andy Hendrickson, parafraseando Walt Disney de que a história é o ingrediente mais importante de um filme, diz que este mantra não se encaixa em tentpole films. Listando os 12 filmes de maior bilheteria de todos os tempos, afirma que todos são filmes espetaculares, e que em todos o visual (a imagem, os efeitos especiais ou os atores destacados) foi o requisito básico de seu sucesso. Confirmando Paul Virilio (1996), que analisa a velocidade e afirma que o tempo está mais rápido do que antes, Hendrickson conclui sua análise com a afirmação de que o espetáculo visual guia os espectadores nos primeiros fins-desemana (parte da semana mais lucrativa) de um filme nos cinemas. Nesse sentido, "Diferente do passado quando um filme como "O Rei Leão" (1994) podia ficar em cartaz tanto quanto um ano, quase todos os filmes saem de cartaz rapidamente nos dias de hoje. Uma vez fora dos cinemas, seu potencial máximo de lucro terminou" (apud COHEN, 2011).

Podemos citar uma discussão levantada por Yochai Benkler (2006), cujo livro desenvolve como a produção social transforma mercados e a liberdade, de que a produção cultural passa por mudanças profundas no tocante ao custo estrutural da produção da música e dos filmes, possibilitando a criação de novas estratificações na sociedade. A música não começou com o fonógrafo e nem terminará com a troca de arquivos na internet, do mesmo modo que não depende dos direitos autorais. Toda a informação, conhecimento e cultura na nossa sociedade são apoiadas por uma rede diversa de fluxos de faturamento e modelos de negócio. Muito da música clássica e jazz que conhecemos é baseada na combinação de performances públicas e da aceitação pública. Os direitos autorais estão relacionados exclusivamente ao controle das cópias. E quando você a retira do contexto isso cria problemas para certos modelos de negócio.

Benkler diz que estamos longe da morte da produção cultural, tomando em consideração que diferentes formas de arte e formas de expressão têm diferentes construtores e diferentes formas práticas sociais de consumo e apreciação. A produção cultural da música, em voga com a decadência das gravadoras, tem um custo cada vez mais baixo de produção e gravação, e a 
rede de distribuição não precisa ser gigantesca com enormes quantidades de discos físicos. $\mathrm{O}$ compositor/artista não obtém seu sustento dos direitos autorais e sim de suas performances. Quando retiramos a cópia física (CD), restam apenas os direitos autorais da obra criada. As gravadoras inventaram uma forma de extrair valor dos CDs para si próprias, externalizando os riscos de custo aos artistas. Então, quando retiramos a mídia física, o artista perde pouco, mas a empresa perde muito. A internet e as novas mídias estão criando um novo modelo de negócio da música.

O cinema, por sua vez, tem custos de produção elevados. Porém, possui sistemas concorrentes equilibrados ao redor do mundo, com indústrias cinematográficas custeadas por Estados, além de Hollywood. Para Benkler, Hollywood tem retido controle sobre uma porção significativa do faturamento das performances públicas, ou seja, a prática social de ir ao cinema ver filmes é importante para a indústria cinematográfica (rendendo dezenas de bilhões de dólares anualmente) ao contrário da musical. Basta lembrar que o ato da pessoa possuir uma cópia física de um filme em casa tem pouco mais de 20 anos - antes o negócio era totalmente calcado na sala de cinema ou na atenção focada na televisão.

Benkler acredita que é possível uma contração da criação cinematográfica ou um deslocamento dos altos valores de produção dos filmes blockbusters que podem ser replicados em diferentes mídias, para uma apropriação de produção de vídeos de menor escala/amador em que os espectadores gastariam mais tempo assistindo. Não seria o fim do cinema, mas uma contração do modelo hollywoodiano e poderia aumentar a eficiência do modelo de apoio popular. Benkler conclui que, a longo prazo, a disponibilidade de aparelhos baratos de gravação com relativa alta qualidade, de mecanismos baratos de distribuição e de oportunidades para as pessoas verem, responderem e se importarem com que veem abre um novo domínio estratificado de filmes não-comerciais ou de filmes comerciais menores, de modo que dezenas de milhares de novas pessoas participem do processo de produção.

Outro ponto de reflexão, a curto prazo, seria o fato das pessoas, ao ganharem o hábito de assistirem vídeos mais curtos (principalmente na internet), começarem a se preocupar mais com o conteúdo narrativo do que propriamente com os valores de produção, de modo a propiciar novas oportunidades para outras pessoas criativas produzirem novas experiências inovadoras de filmes nos suportes midiáticos. Como podemos ver, há diversos elementos para pensar a produção cultural no início do século XXI. 
As consequências da sinergia entre esses produtos podem subsidiar esta análise sobre os processos de esgotamento e indicações de um novo "renascimento" nos quadrinhos e na animação Disney.

\subsection{Justificativa e Objetivos}

Esta pesquisa justifica-se, inicialmente, por sua atualidade - é um tema novo e pouco explorado, especialmente tendo em vista o papel dos meios de comunicação de massa e suas contribuições para a difusão da produção cultural. Estudos referentes aos efeitos globalizantes das indústrias culturais e suas relações sócio-econômica e cultural só começaram a surgir no fim dos anos 1970 e, na maioria dos casos, oriundos dos cursos de economia e com base na crítica da economia política na comunicação (MIÈGE, 2007). Um dos principais aspectos era o processo de reorganização da produção, inclusão de novas tecnologias e novos fluxos de comunicação e de base corporativa, como descritos mais recentemente por Yochai Benkler (2006).

Esta relação pode ser vista nas mais diversas esferas culturais. Debatendo os parâmetros da globalização na economia política internacional, é possível perceber o quanto as corporações de mídia - proprietárias de grande parte da produção cultural (estúdios de cinema, redes de TV, editoras, etc) - não só mudaram seu esquema de gestão como também influem no processo decisório das políticas nacionais.

Em outro exemplo, mais focado nos produtos culturais analisados neste trabalho, pesquisadores como Benkler (2006), Denis (2010), Grover (1997) e Korten (1995), viram o quão decisivo é o papel da economia, modelos de negócios e a própria "moda" cultural (videogame, seriado de TV que é promovida no momento de determinado lançamento. É um processo cíclico que transforma a própria mídia a partir dos parâmetros já citados anteriormente, sendo uma análise que merece um estudo mais aprofundado para melhor compreensão do funcionamento do aspecto criativo, neste caso da produção Disney. Como pode ser analisado no quadro teórico de referência, Disney foi objeto de análise em diversas correntes das teorias da comunicação, tomando aqui o destaque os estudos referentes à produção e seus efeitos comunicacionais. Espera-se, portanto, que esta pesquisa contribua para a compreensão dos objetos estudados na área da comunicação. 
Esta tese tem como objetivos analisar o atual processo de produção nos quadrinhos e animação Disney, com ênfase nos efeitos a partir da década de 1990, levando em consideração os contextos econômicos e culturais. Pretende-se analisar a existência do que chamamos de saturação e estagnação durante os períodos de transição ocorrido entre os anos 1990 e 2000, a partir do impacto tecnológico, econômico e cultural que resultaria em riscos de um colapso (meltdown) do mercado e dos produtores culturais. Embora analisemos casos específicos em meio aos diversos capítulos, a última parte é destinada a análise do game "Epic Mickey" e sua relação com as mídias cinema e quadrinhos.

Esta pesquisa parte de duas hipóteses: A produção cultural Disney passa por um momento de transição criativa, levando em consideração que o processo é cíclico quando compreendemos o processo histórico Disney e a expansão do universo de personagens. Em segundo plano, lançamentos no início desta década apontam para uma nova dinâmica na produção. Há uma sinergia econômica, tecnológica e cultural na construção do universo Disney, em que as histórias em quadrinhos se colocam em posição privilegiada como matéria-prima em relação as produções audiovisuais.

\subsection{Metodologia de Pesquisa}

A metodologia de abordagem necessária para a pesquisa é a funcionalista, pois esta se baseia mais em uma interpretação dos objetos isolados do que propriamente em uma coleta de dados para investigação. Segundo esta metodologia, a função da atividade humana é decorrência de seu papel na sociedade, é uma sustentação para a estrutura social, relacionando aspectos como: a sociedade como uma estrutura complexa de grupos sociais, numa constante interação entre ações e reações; e a sociedade como um sistema integrado de instituições, agindo e reagindo umas em relações as outras. O método funcionalista estuda a sociedade do ponto de vista da função de suas unidades, isto é, como um sistema organizado de atividades (CERVO, 1983). A pesquisa também tem um viés exploratório, devido a proporcionar dados elementares para dar suporte à realização de estudos mais aprofundados sobre o tema, visando maior familiaridade com o problema, tornando-o explícito ou construindo hipóteses sobre ele.

Houve a necessidade primordial de pesquisa bibliográfica, em grande parte em obras estrangeiras, onde foram encontradas as informações básicas dos temas e períodos que são 
abordados no estudo, através da literatura de referência. Tem como finalidade fundamental promover a produção, coleta, utilização e comunicação das informações coletadas para o desempenho da pesquisa. Além disso, a pesquisa documental se faz necessária no momento em que serão cobrados levantamentos históricos não só nos livros e periódicos como também em fotos, artigos, filmes e outros documentos. Nesse sentido, considerou-se documento qualquer informação sob a forma de textos, imagens, sons, gravações, pintura, etc, além de documentos oficiais (CERVO et al, 2007). Sua utilização compreende também as técnicas e os métodos que facilitam a sua busca e sua identificação. Foi possível também a interação com pesquisadores e especialistas, além do uso de suportes que auxiliaram na complementação da pesquisa. Para contextualizar a análise, foi necessária a elaboração de tabelas mostrando a evolução da produção audiovisual e das histórias em quadrinhos.

No caso das histórias em quadrinhos, foi utilizada como fonte a base de dados Inducks ${ }^{6}$. Trata-se de uma base de dados que tem por objetivo catalogar todas as publicações e histórias em quadrinhos do mundo todo. A partir desta base online, foi possível descobrir rapidamente quais histórias fazem parte de qualquer publicação, assim como o artista responsável pelo roteiro, colorização, tradução, etc.

O projeto Inducks é atualizado todos os dias, sendo um sistema colaborativo (semelhante ao sistema da Wikipedia) - centenas de artistas e editores Disney do mundo todo contribuem com informações sobre os créditos. Seus resultados incompletos e em constante revisão não são apropriados como fonte única, entretanto consideramos os dados relevantes para apontamento de tendências de produção, como veremos durante o andamento da pesquisa.

Por sugestão de parecer da Fapesp, agência financiadora desta pesquisa, foram feitas viagens de pesquisa ao exterior. A mais importante delas, realizada no final de 2015, pois foram incluídas visitas ao Museu da Família Disney em San Francisco e aos estúdios de Hollywood, em Los Angeles, ambas as cidades na Califórnia, EUA. Apresentamos a seguir o roteiro da viagem:

\section{9/11 a 02/12 - San Francisco:}

Pesquisa no Walt Disney Family Museum

03/12 - Los Angeles/Glendale/Burbank:

\footnotetext{
${ }^{6}$ Inducks - < http://coa.inducks.org/index.php>
} 
Visita ao Creative Campus da Disney em Glendale (áreas de licenciamento de publicações, brinquedos e vestuário). Visita aos estúdios Walt Disney (sedes administrativas, estúdio de animação, rede $\mathrm{ABC}$ e prédios históricos.

\section{4/12 - Los Angeles}

Visita aos estúdios Paramount

\section{5/12 - Los Angeles/Burbank}

Visita aos estúdios Warner Bros.

Visita ao Dolby Theater (sede da cerimônia do Oscar da Academia de Artes e Ciências Cinematográficas.

Visita ao Grauman's Chinese Theatre.

Visita ao Larry Edmunds Bookshop (livraria especializada em entretenimento) e The Last Bookstore (livraria com amplo acervo de cinema e quadrinhos).

Visita a University of Southern California (USC)

\section{6/12 - Los Angeles}

Visita a Universal Studios Hollywood

\section{8-12/12 - Los Angeles/Anaheim}

Disneyland Resort (Disneyland e Disney California Adventure) - história, tecnologia, recepção, eficiência, livrarias.

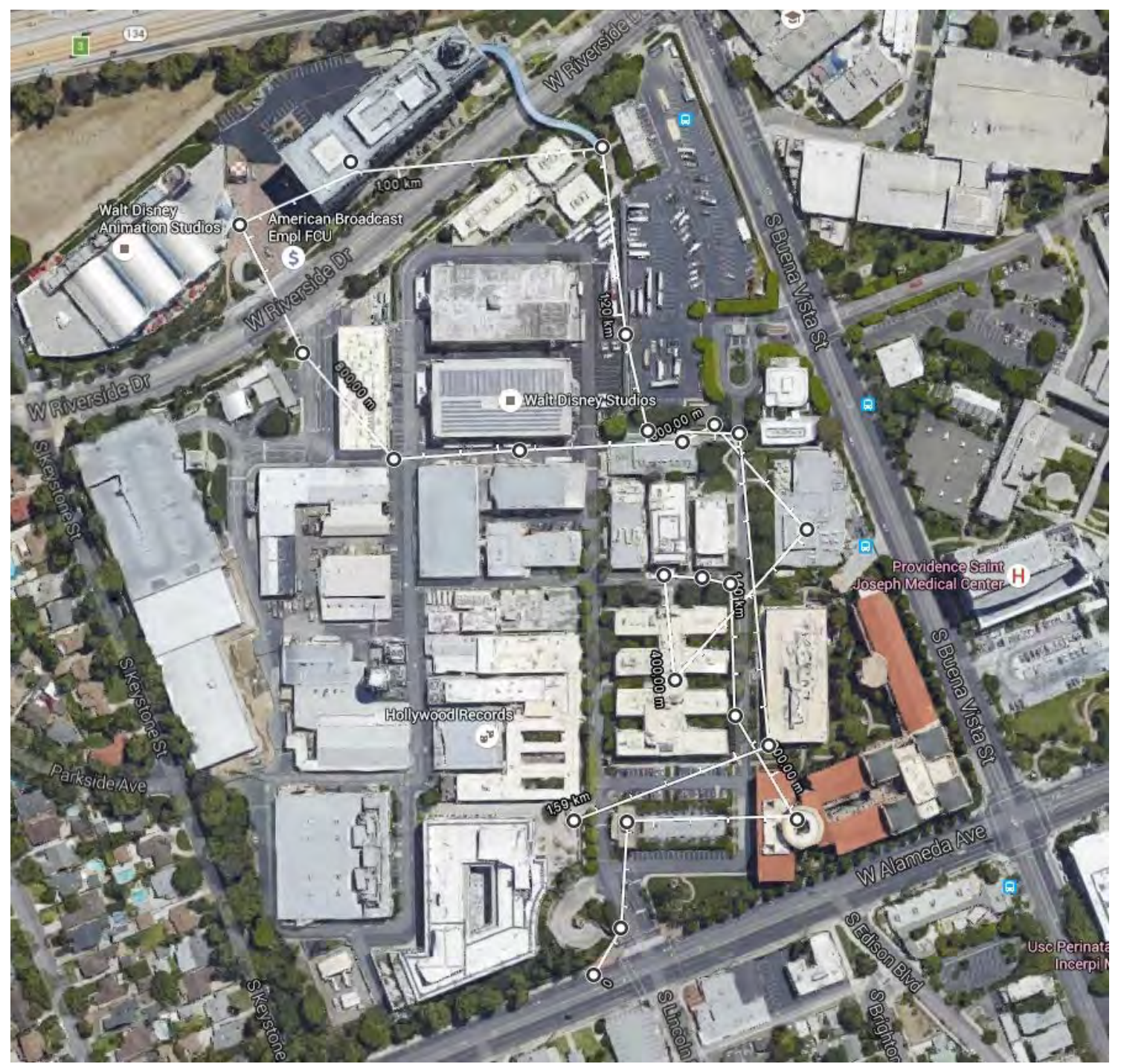

Figura. 2 - Os estúdios Walt Disney em Burbank - Califórnia, incluindo a rota da visita técnica (foto: Google Earth) 
As visitas aos estúdios de Hollywood foram particularmente esclarecedoras. O ambiente é verdadeiramente industrioso e são impressionantes pelo tamanho e pela eficiência e segurança em todas as fases da produção. Dois pontos são destacáveis. Primeiro é o fato dos personagens de histórias em quadrinhos serem destaque em todos os estúdios, o que comprova a importância destes como matéria-prima para o cinema. O segundo fato é justamente a eficiência de certas fases da produção. Os estúdios combinam esforços e se utilizam das estruturas alheias não só para filmar em seus backlots ${ }^{7}$ com cenários gigantes. Por exemplo, a Disney pode produzir cenas internas em um de seus soundstages ${ }^{8}$ as cenas externas podem ser gravadas na Fox, a trilha musical pode ser gravada no famoso estúdio de som da Sony (ex-MGM), sendo que um musical pode utilizar o estúdio de som da Warner para gravar as vozes, e finalmente pode fazer a edição final no prédio da Technicolor, que fica no complexo Paramount.

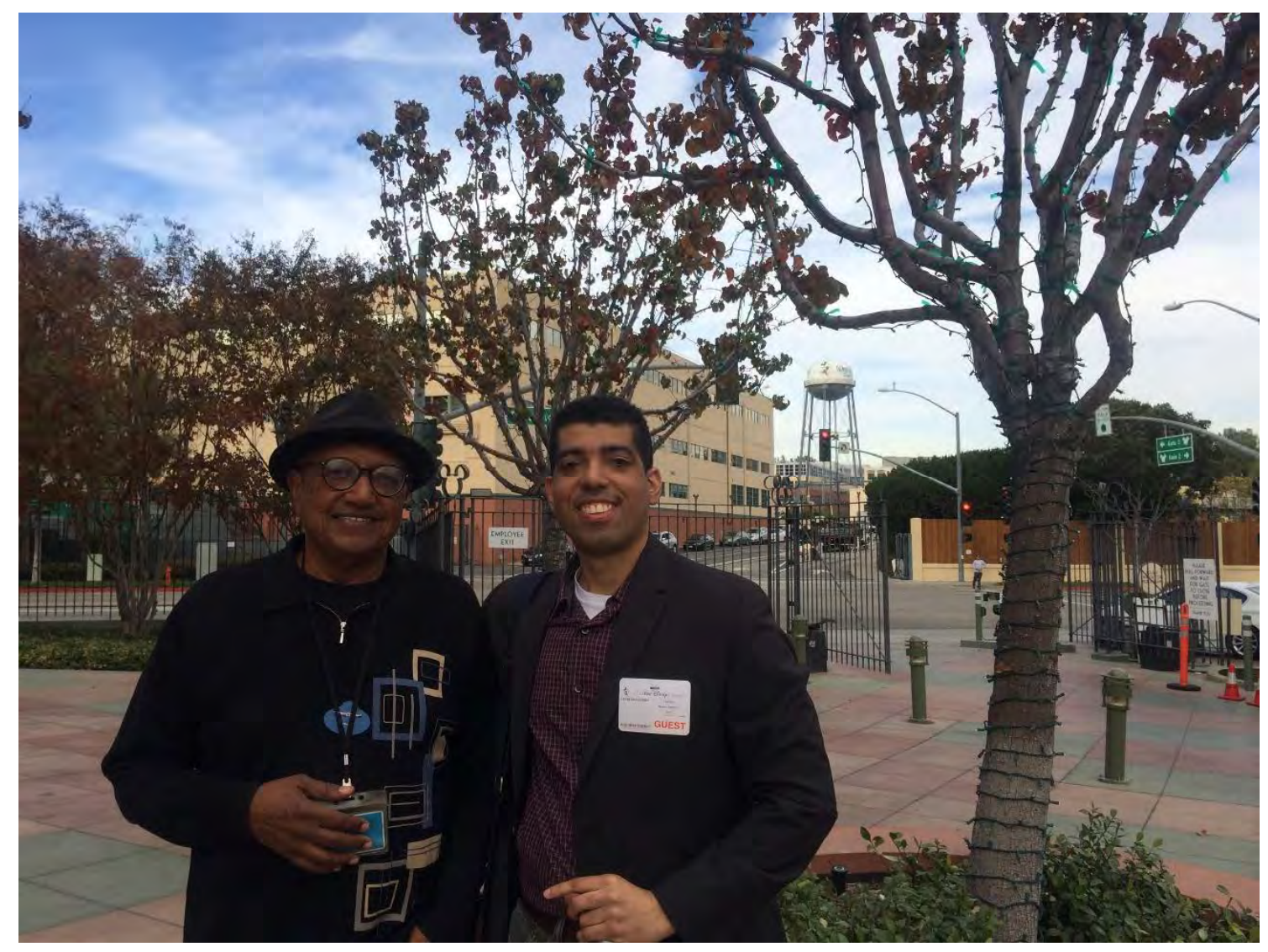

Figura. 3 - Floyd Norman e Celbi Pegoraro durante a visita aos estúdios Disney em Burbank, Califórnia.

\footnotetext{
${ }^{7}$ Área externa a um estúdio de cinema ou TV.

${ }^{8}$ Edifício usado em filmagens, parecido com um hangar a prova de som, geralmente localizado dentro do perímetro dos estúdios.
} 
A principal parte da visita, no entanto, foi nos estúdios Disney. O anfitrião foi o octogenário Floyd Norman Animador e argumentista, começou na Disney em 1956 trabalhando em clássicos como “A Bela Adormecida” (1959), “101 Dálmatas” (1961), “A Espada era a Lei” (1963), "Mogli: O Menino Lobo" (1966). Com ampla experiência em diversos estúdios, retornou à Pixar onde trabalhou em "Toy Story 2" (1999) e "Monstros S.A.” (2001) além de outros filmes na Disney. Ele também produziu tiras em quadrinhos do Mickey Mouse na década de 1980. Aposentado, permanece colaborando nos estúdios Disney e Pixar e no setor de publicações do Creative Campus de Glendale. O discreto campus foi meu ponto de partida. Lá ficam as sedes da Walt Disney Imaginering (onde são desenvolvidas as atrações dos parques temáticos), as gigantescas bibliotecas de pesquisa, e a área de licenciamento com as áreas de publicação, brinquedos e vestuário.

Com intensa disposição, Floyd Norman nos levou de carro até os estúdios Walt Disney em Burbank, inaugurado em 1940. O tour de 3 horas de duração incluiu a praça onde ficam as placas das Lendas Disney, o Team Disney Building (agora conhecido como Michael D Eisner Building) - a sede administrativa da corporação, o Roy O. Disney Building (a imensa sede do departamento jurídico), Pluto's Corner (a famosa placa do filme “O Dragão Relutante” de 1941), o antigo teatro onde as orquestras gravavam as trilhas, o cinema onde até hoje promovem exibições especiais, e o antigo estúdio de animação onde os clássicos supervisionados por Walt Disney foram feitos (atualmente abriga produtores parceiros do estúdio).

Após uma pausa para o almoço no restaurante Comissary (o mesmo dos tempos de Walt Disney, só que renovado), visitamos o Hyperion Bungalow - atualmente usado para conferências mas que é conhecido como um dos poucos prédios originais do mais antigo estúdio que Walt Disney ocupou (no início ele era a sede do departamento de tiras em quadrinhos); passamos pelo prédio de Edição, caminhamos entre os enormes soundstages que estavam sendo usados em filmagens e pela área de um estacionamento onde nos velhos tempos estava montado os cenários do seriado "Zorro" estrelado por Guy Williams nos anos 1950. Além de detalhes sobre a história dos estúdios, Floyd contribuiu com ideias enquanto discutimos brevemente a tese, especialmente na indicação do uso do termo meltdown.

A visita de três horas foi concluída do outro lado da Riverside Dr. com uma passagem pelo Roy E. Disney Building (sede atual da produção de animação), a sede da rede de televisão ABC e, já de volta ao campus principal, uma passagem próxima ao Frank G. Wells Building 
(sede dos Arquivos Disney). A área externa é cheia de surpresas. Ruas como a Keystone St. e outras tiveram muitas de suas residências adquiridas pela Disney, e são usadas como cenários de filmes e seriados. Houve a oportunidade de flagrar uma equipe preparando uma das casas na região para filmagem. Faço um agradecimento público ao sr. Floyd Norman, por sua disposição e gentileza, e pelo rico conhecimento compartilhado, incluindo os quadrinhos Disney europeus e brasileiros.

\subsection{Estrutura da Tese}

É importante frisar que o arcabouço teórico utilizado para a metodologia da pesquisa funcionalista, com origem nas idéias de Émile Durkheim, ou mesmo os autores dos Estudos Culturais, não corroboram estritamente os autores focados e discutidos na fundamentação teórica. Desta forma, os autores discutidos na fundamentação teórica (Capítulo 2) representam uma reflexão histórica de correntes da área da comunicação que estão relacionadas aos mais diferentes estudos, focando direta ou indiretamente o universo Disney. Espera-se, portanto, que contribuam para a construção de uma análise atual da comunicação, tendo em vista os objetivos e as hipóteses da pesquisa. Conforme sugestão de parecer da Fapesp, a pesquisa foi estruturada mais próxima do formato de livro, o que justifica o desenvolvimento mais longo de alguns tópicos.

O capítulo 3 é dedicado a um detalhado levantamento da produção em histórias em quadrinhos e animação Disney, cada qual contextualizado dentro de suas áreas. A intenção foi constatar o volume e a evolução da produção dentro de territórios e estruturas específicas. $\mathrm{O}$ capítulo 4 é uma tentativa de relacionar a complexa relação entre indústria, tecnologia e arte. Há dois propósitos principais: o primeiro é o debate polêmico sobre a arte na indústria cultural. Não raramente os criadores de histórias em quadrinhos e os animadores, além de parte dos profissionais no meio audiovisual serem chamados de "artistas". Embora a tese aplique o uso de termos como "criador" ou "produtor criativo", espera-se a compreensão do entendimento dado como "arte" neste estudo. O segundo propósito é justificar porque a tese utilizou uma abordagem transdisciplinar em sua análise. Se no início esperava-se fazer uma análise do ponto de vista puramente tecnológico, a visita técnica realizada aos estúdios em Hollywood comprovou que a inovação tecnológica, as estratégias corporativas e a evolução do processo criativo funcionaram simultaneamente, sempre com uma dessas esferas pressionando mudanças sobre as demais. Pela extensão do trabalho, não foi possível analisar profundamente aspectos 
criativos de animadores específicos da chamada "nova geração", porém optou-se pela manutenção do viés tecnológico permeando a base das discussões em todas as esferas, especialmente nos capítulos 5, 6, 7, 8 e 9 .

O capítulo 5 é uma exploração do aspecto criativo e de um importante ingrediente que tem sido usado de formas mais ambiciosas por Hollywood - "a criação de universos narrativos. Descrevendo e analisando o trabalho de dois dos maiores quadrinistas da Disney, o norteamericano Don Rosa e o italiano Casty traçamos um panorama sobre as origens de seus pensamentos, seus métodos de criação e como trabalham suas ideias de universo ou "mundo construído". A escolha dos dois quadrinistas está no fato de serem artistas completos, roteiristas e desenhistas. Consideramos uma forma prática de compreender o conceito, pois uma análise, por exemplo, dos universos dos quadrinhos da Marvel demandaria uma tese completa por si só.

O capítulo 6 se despreende totalmente da criação e aborda o lado corporativo da Disney. É uma descrição e uma análise da gestão Michael Eisner (1984-2005) elencando como muitas estratégias de produção são conduzidas, desde a filosofia, a entrada de novas tecnologias e a briga de egos de seus executivos. Quando se conhece o processo de inchaço do estúdio, começamos a entender a ideia de saturação e estagnação da produção. O capítulo 7 analisa o caminho paralelo, mostrando como evoluiu a animação Disney, a evolução da animação computadorizada e o impacto da Pixar Animation Studios e os efeitos da crise e meltdown causados pelas transformações no período de transição.

O capítulo 8 aborda a gestão Bob Iger na Disney e como a tecnologia tornou-se fundamentalmente o centro das abordagens estratégicas de produção. Não somente isso, aos poucos conhecemos como a cultura digital e a cultura de fã alteraram a lógica de produção, especialmente no caso das franquias e na exploração de marcas como "Marvel" e "Star Wars". Algum leitor poderia questionar o que Marvel e Star Wars têm a ver com a criação Disney e Pixar. A resposta foi obtida na visita técnica aos estúdios Disney: “Tudo isso agora é Disney!". Os resultados dessas marcas e sua exploração em novos suportes midiáticos afetam a indústria cultural em geral. O capítulo 9 apresenta um estudo de caso, um projeto de videogame que envolveu elementos da animação e dos quadrinhos. O tema é novo, complexo, repleto de desvios, e sem muitas certezas quanto ao futuro. Em que pese a análise do aspecto sinérgico da produção, em sua estrutura complexa nos últimos quinze anos, optamos pelo uso de uma revista em quadrinhos (no caso a auto-intitulada graphic novel em volume único) lançada pela Editora 
Abril, "Disney Epic Mickey" (2011), que apresenta em seu conteúdo uma interessante combinação de valores e imagens referentes a diferentes esferas da corporação Disney (quadrinhos, cinema, parques temáticos e videogame). Temos, portanto, em uma única obra, potencial fonte de análise no momento em que nos debruçamos sobre a questão da produção cultural na parte final da tese.

A intenção é mergulhar nos aspectos positivos e negativos do rápido avanço tecnológico e suas tendências nas primeiras décadas do século XXI.

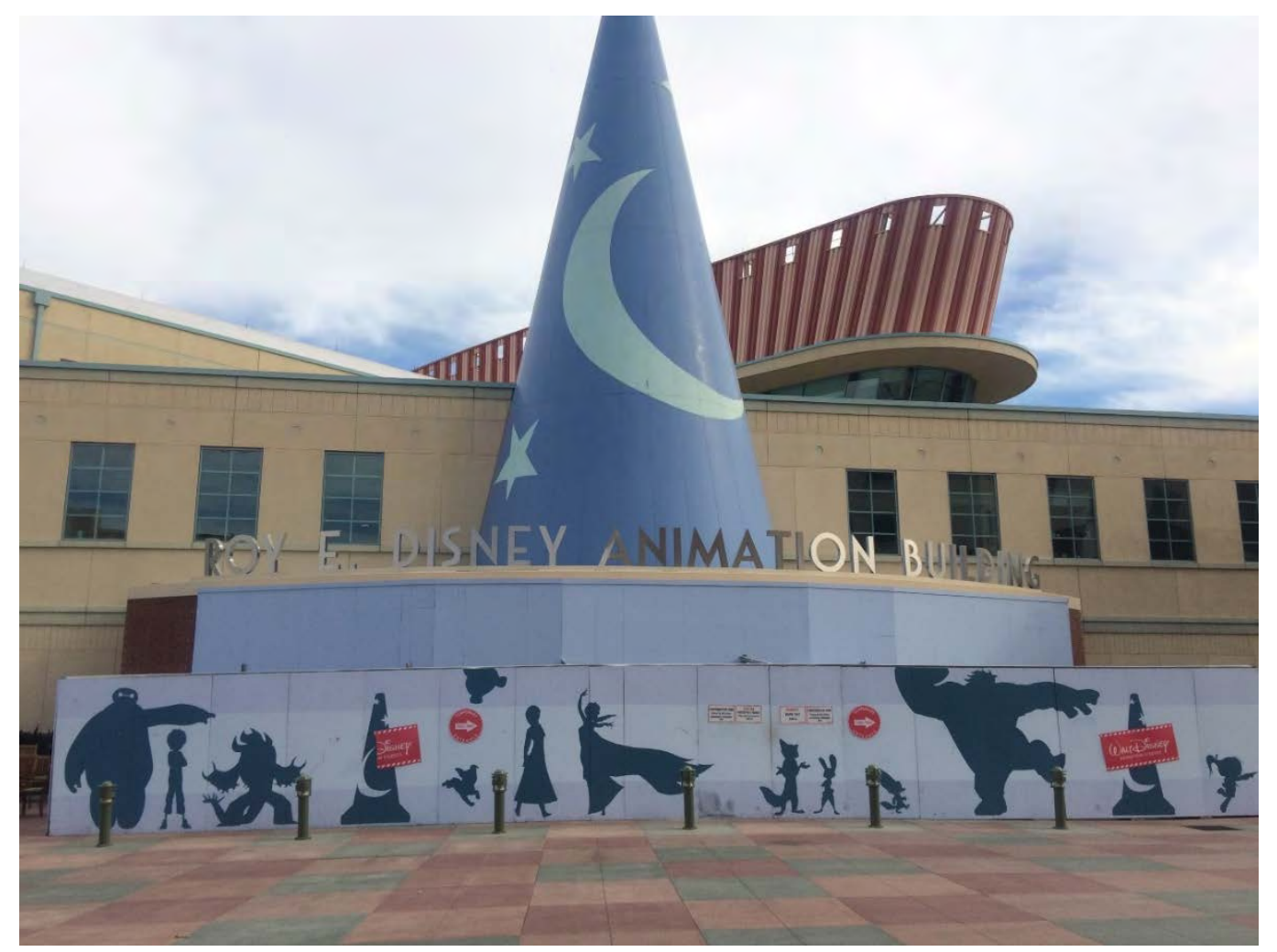

Figura. 4 - O edifício sede dos estúdios de animação Disney com arquitetura pós-moderna de Robert A.M. Stern, em Burbank, Califórnia. 


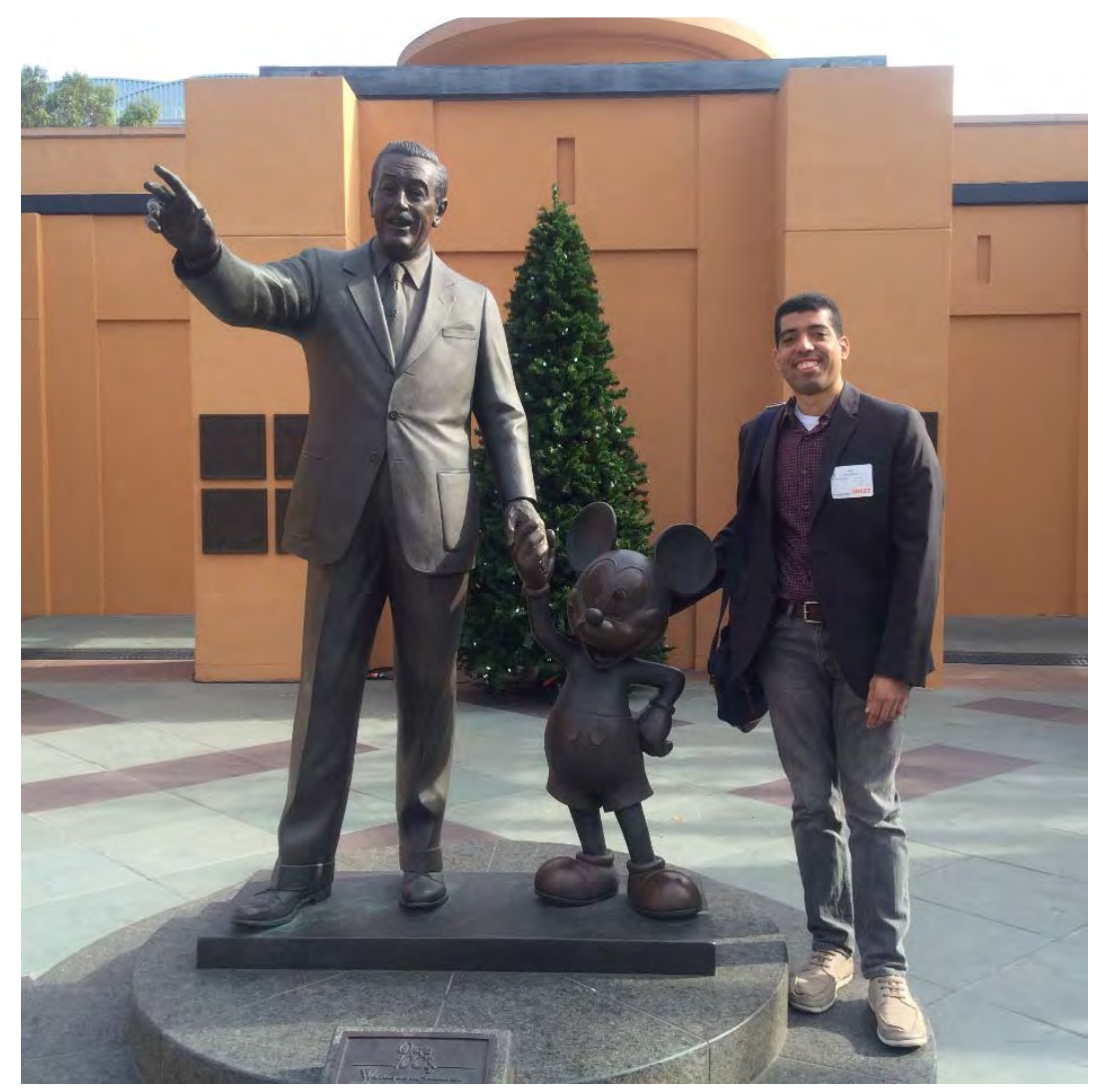

Figura. 5 - Celbi Pegoraro (o autor desta tese) na Legends Plaza com a estátua "Partners", esculpida por Blaine Gibson.

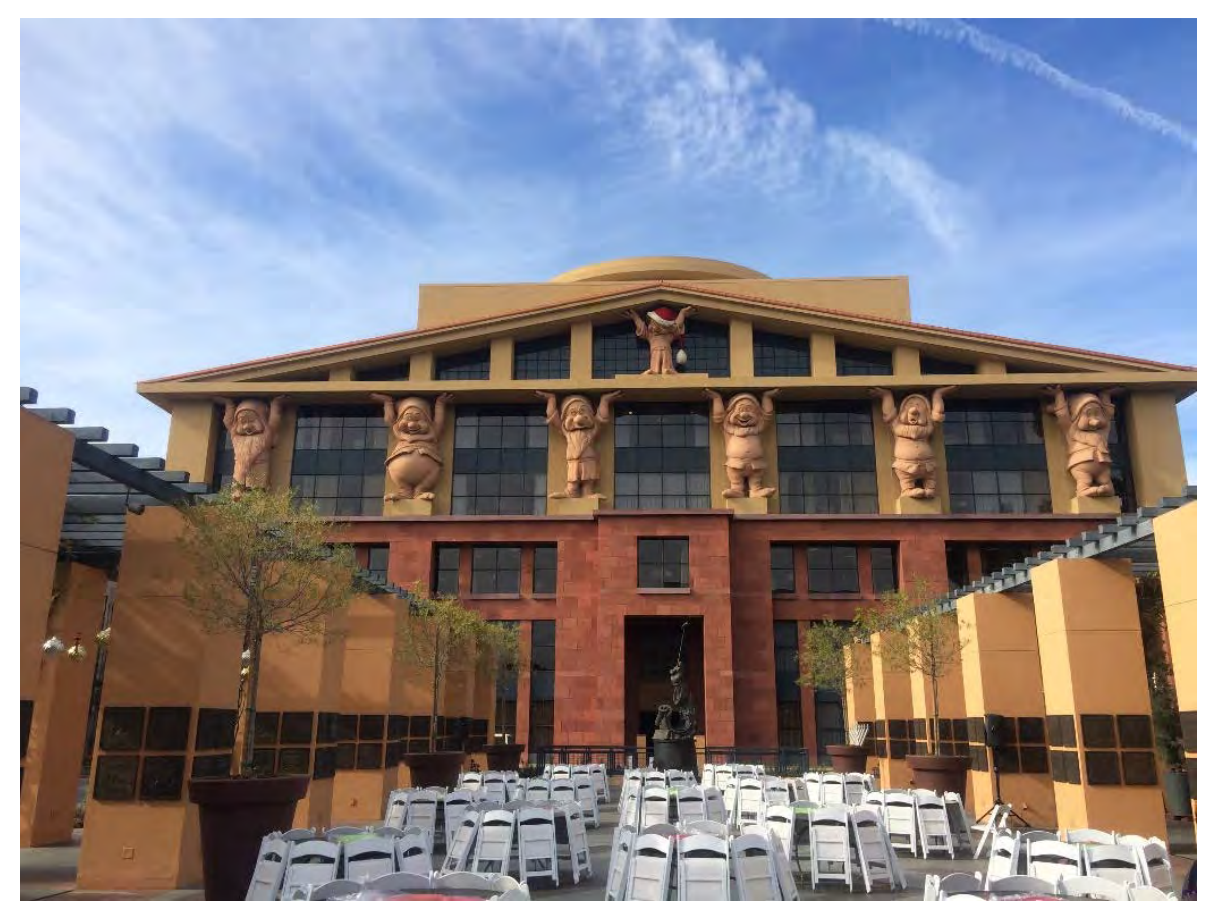

Figura. 6 - A sede administrativa da Disney - Michael D. Eisner Building, conhecido anteriormente como Team Disney Building. 


\section{FUNDAMENTAÇÃO TEÓRICA}

Os trabalhos acadêmicos realizados ao longo do século XX e início do século XXI representam uma variação complexa de reflexões, análises e conclusões no que diz respeito à produção cultural e sua relação direta e/ou indireta com a política e a sociedade. Enquanto os acadêmicos brasileiros estão mais familiarizados com a obra Para Ler o Pato Donald (DORFMAN, MATTELART, 1980) por sua natureza crítica, analisando as histórias em quadrinhos sob o viés marxista, há uma série de outras obras publicadas mundialmente que trabalham a produção Disney como objeto de análise. O que apresentamos a seguir é um levantamento das principais obras e autores que pontuam a evolução do estudo deste tema.

Inicialmente, é importante formular o que consideramos "cultura" e mais especificamente "produção cultural", porque esta última, dentro da lógica da indústria cultural, se refere aos "atores" que produzem a mensagem midiática. Randy Duncan (2009, p. 87) afirma que a indústria da mídia é composta por três esferas que interagem entre si: a produção, a distribuição e a exibição (ponto de venda, no caso dos quadrinhos). Interessa-nos aqui, portanto, os processos de produção.

Clifford Geertz (1989) faz uma análise da cultura com base antropológica, em que o homem está ligado a uma rede de significados que ele mesmo construiu, deste modo a cultura estaria ligada à interpretação desses significados. O sociólogo húngaro Karl Mannheim (2008, p. 141-208) discutiu a questão da democratização da cultura em ensaio em 1933. O brasileiro Muniz Sodré (1983) produziu um livro específico sobre a comunicação de massa e o grotesco. O britânico Richard Hoggart (1973) produziu um estudo da cultura partindo do estilo de vida das classes populares na Inglaterra, partindo do contexto do período entre os anos 1930 e 1950 em que os operários britânicos foram escolarizados e passam a consumir jornais, revistas, livros e, posteriormente, o rádio passa a fazer parte da rotina cotidiana da classe operária.

Tal como Hoggart, outros autores dos Estudos Culturais questionavam a classificação e os valores da "alta cultura", resultando nas tensões sociais originadas dessa dimensão, e criticavam a questão do paradoxo existente entre civilização e cultura. Assim como Raymond Williams (2011) reforça o novo entendimento entre cultura e sociedade, criticando a visão conservadora humanista da cultura como resultado dos valores, dos costumes, dos modos de vida. Pelo contrário, irá afirmar que a cultura é um campo privilegiado para a compreensão 
crítica da sociedade, incluindo o questionamento sobre o papel da alta cultura, de quem a produz, e nesse caminho vai nos propor uma cultura em comum:

Um entendimento que mais do que valorizar a produção do homem traz à tona a diferenciação hierárquica presente no interior do modo de produção capitalista expondo uma concepção materialista da cultura nos dizendo que a definição de cultura passa por [um] entendimento histórico do modo de produção" (SILVA, 2008, p. 322).

Tendo em vista a complexidade do conceito, buscamos utilizar sua descrição mais genérica, e mais próxima da formulada na obra "Primitive Culture" de 1871, pelo antropólogo britânico Edward B. Tylor, de que a cultura é "tudo aquilo que o homem pode produzir voluntariamente ou involuntariamente, consciente ou inconscientemente, incluindo o conhecimento, os mitos, hábitos, aptidões, artes, crenças, leis e costumes" (TYLOR, 1871 apud LARAIA, 1986, p. 25). Sintetizava, portanto, os antigos significados mais relacionados as ditas "altas formas de manifestação artística" (música erudita, por exemplo) ou ao passado etimológico do termo relacionado à agricultura. A produção cultural, portanto, não trata apenas a produção oficial ou referendada pela universidade, mas o que é produzido em forma de literatura, cinema, música, televisão, rádio, manifestações artísticas, moda, etc.

\subsection{Perspectiva Alemã: Mickey Mouse nas reflexões de Adorno e Benjamin}

Theodor Adorno criou o que chamamos de uma teoria da comunicação, que resultou nos grupos de estudos da comunicação. Foi o primeiro teórico a se preocupar com a presença dos veículos de comunicação de massa. Os veículos, segundo essa corrente da Escola de Frankfurt, agiam até mais forte do que o Estado. Adorno afirmou que os veículos não estão à disposição para o desenvolvimento dos potenciais humanos, mas foram cooptados pelo sistema capitalista, por quem tem dinheiro, e se tornaram grandes empresas. Os veículos, portanto, perderam sua condição inicial para a produção de lucros (ADORNO, 1989).

Há certa confusão entre os termos Indústria Cultural e Cultura de Massa, que era confundida com Cultura Popular. A Cultura de Massa é uma cultura para se ganhar dinheiro, difundida na massa. E não uma cultura produzida por esta massa. A Cultura Popular, para Adorno, é uma cultura espontânea que nasce das relações sociais, entre as pessoas, em seus respectivos grupos, categorias e segmentos de massa. 
Mas há uma diferença na relação entre os conceitos de Massa e Popular. A Cultura de Massa é fabricada industrialmente. Se existe uma indústria que produz a cultura, então existe a indústria da cultura. O resultado foi a criação do termo Indústria Cultural, que no fundo significa a mesma coisa. Por exemplo: as histórias em quadrinhos - as editoras contratam desenhistas, usam a gráfica de Gutenberg e imprimem em larga escala. O processo é diferente, digamos, de uma literatura de cordel, etc. Portanto, o conceito de Massa difere de Popular, ao mesmo tempo em que a Indústria Cultural se equivale a Cultura de Massa.

Adorno faz uma análise ideológica dos media, mas cujo conteúdo da época sobre a indústria cultural ou cultura de massa não tem o mesmo significado no contexto atual. Ressaltemos que Adorno e seus contemporâneos - Benjamin, Marcuse, Horkheimer, entre outros, eram judeus que sofreram os efeitos da Segunda Guerra Mundial, e seus textos resultaram em análises pessimistas. Adorno enxergava a comunicação alemã sendo manipulada pelo governo nazista (SWINGEWOOD, 1978, p. 14). Portanto, não poderia ter uma visão positiva da comunicação, e por isso o texto está defasado. Ainda assim, seu conteúdo continua válido para regimes autoritários, embora nem tanto para os democráticos.

Os desenhos animados foram alvos da análise dos intelectuais nos anos 1930. Para Benjamin e Adorno (que trocaram cartas discutindo o tema), as produções Disney (pelo menos as pioneiras até o início dos anos 1930) apresentavam reflexões anti-burguesas e da cultura de massa interessantes como a junção entre o natural e o técnico, a representação das classes menos favorecidas, temas polêmicos e inversões nas hierarquias de poder e cultura. Podemos observar reflexões modernistas em produções pioneiras, como em um curta-metragem da série Alice Comedies (1924-27), onde há o tema da disputa trabalhista e dos meios de produção na indústria, algo que some em animações posteriores. Além disso, as produções lidavam com o absurdo e o "barbarismo", elogiado por Walter Benjamin, que ilustrava um certo desafio à mortalidade (GADASSIK, 2010). Adorno, por sua vez, encarava a animação como uma forma de revelar e acostumar, pelo uso da violência e do absurdo, os trabalhadores para a violência imposta em seus ambientes. O importante é ressaltar como o universo Disney já se apresentava como tema importante na esfera intelectual (ROLLASON, 2012). Mas iniciemos com Walter Benjamin.

Em seu clássico ensaio “A Obra de Arte na Era de sua Reprodutibilidade Técnica”, de 1936, Walter Benjamin (1994) é influenciado principalmente pela arte russa pré-1934 e irá 
construir uma teria da destruição da "aura", ou mais especificamente, da autenticidade na obra de arte por via da reprodutibilidade técnica. A reprodução em série transforma o culto da obra de arte em uma forma de exibição legitimada por novos interesses capitalistas. Do mesmo modo que uma reprodução fonográfica torna a obra diferente de uma audição ao vivo e in loco, o cinema também modifica a experiência do teatro. A própria ideia de arte autêntica somente existe quando a autenticidade é ameaçada como espécie de obra de arte. As formas de reprodução fazem com que o ato de experimentar uma obra ganhe uma nova face, não tendo mais limitações de tempo e espaço, construindo novos valores pela exibição em massa com ajuda da publicidade.

A "aura" é concebida como uma experiência da natureza que é transformada pela reprodução técnica, resultando na perda do sentido do inalcançável. Apesar da aparente perfeição das imagens e sons produzidos pelas reproduções, está ausente a presença do objeto. A reprodução fotográfica de uma pintura impede a percepção verdadeira de se estar fisicamente em sua presença, assim como o cinema provoca a ausência física dos atores, se consideramos o palco de um teatro. A percepção de uma obra é sensivelmente alterada, resultando agora em reações coletivas e não mais individuais do que é experimentado ou consumido. A maior participação da massa também altera os modos de participação e produção. "A massa se torna retrógrada diante de Picasso, ela se torna progressista diante de Chaplin" (BENJAMIN, 1994, p. 187).

Benjamin observa ainda como o público participa ou se torna parte da obra de arte. Isso é explicado utilizando o trabalho produzido nos novos suportes midiáticos consumidos pela massa. Desse modo, quando o espectador observa um objeto, seja qual for seu suporte, ele o faz a partir da perspectiva do modo de produção, ou seja, se torna parte do processo de produção. Se o espectador assiste a um filme, ele está vendo o que acontece na tela, ao mesmo tempo em que o seu olhar se encontra ao da câmera. O espectador é, de certo modo, um crítico, em que Benjamin compara o "olho da câmera" a um "teste". Do mesmo jeito que numa entrevista de emprego, a câmera (em sua função no processo de produção) também edita o que é bom ou ruim. O espectador emprega o mesmo papel na forma de um crítico.

Isso não significa que o espectador seja um bom crítico. $\mathrm{Na}$ verdade, Benjamin corrobora a percepção de pessoas que afirmam ir ao cinema quando estão cansados ou desejam apenas se distrair - e o ponto é exatamente esse - o público está distraído. No papel de críticos, 
os espectadores não estão prestando atenção mesmo quando experimentam algo pelo olho da câmera ou nos demais suportes midiáticos, e isso porque a tecnologia é capaz de nos mostrar mais detalhes da realidade que de outra maneira não seriam percebidos, pelo uso de efeitos como o slow motion, as ampliações, as acelerações, enquadramentos específicos, etc.

A câmera nos apresenta ao inconsciente ótico, ou seja, a câmera é uma perspectiva privilegiada para criar um "sonho coletivo". Ela nos mostra as coisas como elas são (ou achamos que são), ou talvez nos mostre coisas que observamos na rua com nossos olhos, mas que não são necessariamente reais, tendo em vista que a câmera também é suspeita. A câmera pode alterar a percepção por uso dos mais diferentes efeitos visuais. O ponto-chave para Benjamin é a relação dialética entre a distração e o choque (o efeito de sucessão das imagens em movimento na tela interrompe a associação de ideias). Porém, o distraído pode habituar-se:

A recepção através da distração, que se observa crescentemente em todos os domínios da arte e constitui o sintoma de transformações profundas nas estruturas perceptivas, tem no cinema o seu cenário privilegiado. E aqui, onde a coletividade procura a distração, não falta de modo algum a dominante tátil, que rege a reestruturação do sistema perceptivo. É na arquitetura que ela está em seu elemento, de forma mais originária. Mas nada revela mais claramente as violentas tensões de nosso tempo que o fato de que essa dominante tátil prevalece no próprio universo da ótica. É justamente o que acontece no cinema, através do efeito de choque de suas sequiências de imagens. O cinema se revela assim, também desse ponto de vista, o objeto atualmente mais importante daquela ciência da percepção que os gregos chamavam de estética. (BENJAMIN, 1994, p. 194)

E aqui chegamos ao momento em que o personagem Mickey Mouse é citado. A criação de Walt Disney e Ub Iwerks de 1928 (IWERKS, 2001) já havia sido foco de diversas cartas entre Benjamin e Adorno (e outros intelectuais) antes de 1936, como podemos observar nos escritos de uma carta datada de 1931: 
Mickey Mouse por Walter Benjamin

De uma conversa com [Gustav] Glück e [Kurt] Weill. - Relações de propriedade nos filmes de Mickey Mouse: aqui aparece pela primeira vez que alguém pode ser roubado de seu próprio braço, sim, de seu próprio corpo. $\mathrm{O}$ percurso de um documento em uma repartição tem mais semelhança com um dos que Mickey Mouse percorre do que com o dos maratonistas.

Nestes filmes a humanidade prepara-se para sobreviver à civilização.

Mickey Mouse demonstra que a criatura ainda pode subsistir mesmo quando toda semelhança com o homem lhe foi retirada. Ele rompe com a hierarquia das criaturas concebida com fundamento no humano.

Estes filmes desautorizam, da maneira mais radical, a experiência. Não é compensador em um tal mundo ter experiências.

Semelhança com os contos de fada. Nunca desde esses contos os fenômenos mais vitais e importantes foram vividos de forma tão não simbólica e sem atmosfera. O incomensurável contraste com Maeterlink e com Mary Wigman. Todos os filmes de Mickey Mouse têm como motivo sair para aprender o medo.

Portanto, não a "mecanização", não a "fórmula", não um "mal-entendido" são a base do tremendo sucesso destes filmes, e sim o fato de que o público neles reconhece sua própria vida. (BENJAMIN, 1931)

Benjamin considera o personagem Mickey Mouse uma manifestação da síntese entre a arte e a ciência. O camundongo ganha a vida por conta de processos técnicos que lhe dão movimento, resultando em uma personalidade que combina atributos do animal, do ser humano (orgânico por meio da antropomorfização) e da máquina (não-orgânico). Utilizando especialmente a produção em animação dos anos 1920 e 1930, Mickey está constantemente tentando sobreviver em um ambiente híbrido em que objetos ganham vida e interagem, e animais podem ter seus dentes tocados como teclas de piano. Mickey seria um dos exemplos da relação massiva entre distração e choque: Benjamin analisa que a câmera é uma ferramenta do processo que induz a um aprofundamento da massa em relação ao híbrido dos desenhos animados, deste modo:

Os procedimentos da câmera correspondem aos procedimentos graças aos quais a percepção coletiva do público se apropria dos modos de percepção individual do psicótico ou do sonhador. O cinema introduziu uma brecha na velha verdade de Heráclito segundo a qual o mundo dos homens acordados é comum, o dos que dormem é privado. E o fez menos pela descrição do mundo onírico que pela criação de personagens do sonho coletivo, como o camundongo Mickey, que hoje percorre o mundo inteiro. Se levarmos em conta as perigosas tensões que a tecnização (...) engendrou nas massas tensões que em estágios críticos assumem um caráter psicótico -, percebemos que essa mesma tecnização abriu a possibilidade de uma imunização contra tais psicoses de massa através de certos filmes, capazes de impedir, pelo 
desenvolvimento artificial de fantasias sadomasoquistas, seu amadurecimento natural e perigoso. A hilaridade coletiva representa a eclosão precoce e saudável dessa psicose em massa." (BENJAMIN, 1994, p. 190)

As muitas situações sádicas, hilárias ou grotescas constituem, segundo Benjamin (1994, p. 190), uma explosão terapêutica do inconsciente: "Seu precursor foi o excêntrico. Nos novos espaços de liberdade abertos pelo filme, ele foi o primeiro a sentir-se em casa. É aqui que se situa o Chaplin, como figura histórica".

Após intensa troca de cartas sobre o tema, Adorno produz uma resposta definitiva à reflexão de Benjamin pelo ensaio “O Fetichismo na Música e a Regressão da Audição” (1983), produzido em 1938. Trata-se de um trabalho menos ligado à experiência de ouvir e mais sobre a condição social afetando a audição, e o impacto dessa "condição de audição" na percepção. Benjamin trabalha com fotografia e cinema buscando construir uma teoria sobre a arte na cultura de massa. Adorno trabalha com a música, abrindo uma constatação sobre a consciência e obediência da massa. Ambos tratam dos problemas de produção e consumo, mas suas ênfases diferem. Benjamin está mais preocupado com a questão do consumo de audiência e como a platéia recebe a arte em massa. Adorno está mais focado na produção e sobre o quê é dado para o consumo, usando exemplos populares e clássicos - para ele padronizados - criticando a redução da arte em produto.

Em seu ensaio, Adorno descreve o que ele chama de fetichização da música, focando sua atenção na música clássica - especificamente criticando o então famoso maestro Toscanini, uma estrela cult que se reverteria em fetiche, alterando a espontaneidade das apresentações, resultando em espetáculos padronizados que aparentavam ser um produto gravado. Adorno utiliza o termo "barbarismo da perfeição" para descrever a forma de disciplina fetichistatecnocrática e pureza musical empregada sob o controle do maestro.

Na segunda metade de seu ensaio, de mais interesse a esta pesquisa, Adorno analisa o que chama de regressão da audição produzida pela fetichização da música. Ele reconhece que a partir da tecnologia de comunicação de massa, milhões de pessoas terão mais acesso à música. Sua preocupação, entretanto, é que esta audição está "presa a um estágio infantil", uma afirmação que vai contra o que Adorno considera a sugestão de Benjamin de que o público de cinema se torna crítico ou "expert" do que está vendo. Adorno questiona como isso acontece, 
especialmente quando o que é consumido, de sua perspectiva aparente, merece uma dura avaliação.

Usando a música em contrapartida ao cinema, Adorno questiona a noção do consumo distraído de Benjamin, refletindo que se um indivíduo não presta atenção (seja pelo preço pago do evento, pela padronização ou pela natureza modificada do produto, de modo que a música é menos importante do que o maestro), ele não ouve a música, ou a escuta atomicamente, considerando que a audição desconcentrada torna impossível uma percepção coerente e crítica. O indivíduo teria uma impressão superficial sem qualquer desenvolvimento narrativo do que está consumindo, da mesma forma como assimila canais de televisão enquanto os troca usando o controle remoto.

Dois extremos são estabelecidos. Benjamin constrói um argumento para a dessacralização e para a força emancipatória da arte em massa. Adorno considera a negação fundamental de sua realidade, mantendo sua fé na arte avant-garde $^{9}$ cujo acesso essencialmente tinha pouco público. Adorno também confronta a questão da tendência progressista da arte de massa política - com uma tendência do produto regredir para a propaganda, com o resultado sendo um pouco melhor do que as formas de arte massiva que rejeitava. (LEPPERT, 2002).

O universo dos primeiros curtas de animação de Mickey Mouse sugere uma visão utópica da união entre natureza e tecnologia, assim como Charles Chaplin fez em "Tempos Modernos" (Modern Times, 1936) Em contraposição, Adorno encontra poucas qualidades na animação Disney. Ele não considera Mickey Mouse uma figura revolucionária criticando a modernidade, mas uma figura "regressiva", típica do "pseudo-individual" criado pela cultura de massa, figura cuja singularidade foi determinada por sua excentricidade, determinada por padrões de não-conformidade que lhe foi atribuído pela indústria cultural. As atividades frenéticas do Mickey Mouse deste período não representam a luta social, mas as necessidades "pseudo-individualistas" que aprovavam as ações externadas do personagem.

\footnotetext{
${ }^{9}$ Refere-se a vanguarda, movimentos de pioneirismo e rompimento de modelos preestabelecidos e tradicionais em movimentos sociais, políticos e artísticos. Envolve exploração e novas técnicas a frente de seu tempo.
} 


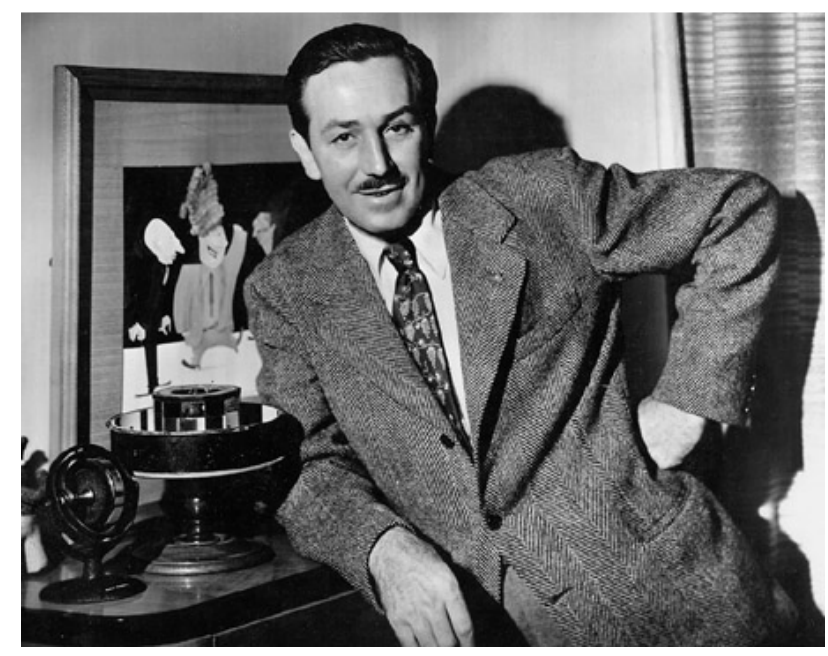

Figura. 7 - Walt Disney ao lado de um zoetrope, primeiro equipamento de animação.

Concluindo, Benjamin argumenta que o espectador ria com o Mickey Mouse em sua luta moderna por via do "riso coletivo" e de uma explosão terapêutica de psicose em massa. Adorno acredita que o espectador ri das palhaçadas do Mickey, mas este riso não é revolucionário, sendo resultado do pior sadismo "burguês". Adorno tinha um problema com o crescente desprezo de Disney pelas excentricidades (suas produções estavam cada vez mais formulaicas e moralmente corretas), sendo que o prazer cinematográfico usava o excêntrico como arma para a falta da liberdade própria (GREENE, 2004).

A acadêmica britânica Esther Leslie (2002), faz um excelente trabalho de análise focando as observações de Walter Benjamin e Theodor Adorno sobre Mickey Mouse, descrevendo não apenas como o personagem se tornou objeto de análise como também reconstrói os debates na década de 1920, envolvendo questões como a abstração da arte, a cultura de massa e a reprodução técnica. A autora contextualiza como intelectuais como Benjamin e Kracauer acreditavam na importância da "rua" para o pensamento utópico e como ficaram consternados com a tomada de controle da esfera pública pelos nazistas:

Nos últimos dias da República de Weimar o dia-a-dia é um campo de batalha, e os revolucionários estão no lado dos perdedores. Foi um pouco diferente em Moscou. Benjamin encontrou uma nova figura de utopia. Não era um novo regime, mas veio na forma de um guardião (de quatro dedos) do sonho coletivo e tinha o formato de um camundongo (LESLIE, 2002, p. 79, tradução nossa). 
Leslie descreve parte da história dos desenhos animados do ponto de vista da teoria crítica, especialmente dos textos e das diferentes versões do artigo de Benjamin (1994) "A Obra de Arte na Era de sua Reprodutibilidade Técnica". Nesse sentido, ela ilustra como ocorre um deslocamento da significação de Mickey Mouse. Em 1931, Mickey Mouse foi denunciado por um jornal nazista publicado na Pomerânia, chamado The Dictatorship. Sob o título The Mickey Mouse Scandal, o articulista descreve uma série de características negativas do personagem:

Loura, juventude alemã de livre pensamento urbana presa as cordas do avental dos financistas Judeus. Juventude, onde está o seu orgulho? Juventude, onde está sua auto-consciência? Mickey Mouse é o ideal mais desprezível, mais miserável já inventado. Mickey Mouse é um dispositivo de embrutecimento enviado com o capital do Young-Plan [plano de reestruturação da dívida da Primeira Guerra Mundial]. Instinto saudável informa todas as garotas decentes e garotos corretos que os vermes vis e sujos, que importam bactérias ao reino animal, não podem ser transformados em um tipo de animal ideal. Não temos nada melhor a fazer do que decorar nossas vestes sujas com animais sujos porque o comércio americano Judeu querem lucrar? Abaixo a fraude judaica do povo, expulsem os vermes, abaixo com o Mickey Mouse, ergam as suásticas! (The Dictactorship, 1931 apud LESLIE, 2002, p. 80, tradução nossa).

Sem dúvida, uma representação negativa. "Para este nazista, Mickey Mouse representa a antítese do jovem Ariano. Seu Americanismo era sinônimo de (qualidades) judaicas, e o Judaísmo era prova de lixo e degeneração" (LESLIE, 2002, p. 80). No mesmo ano, críticos dessa opinião afirmavam que Mickey deveria ser usado como símbolo da razão, contra a "suástica" e a perseguição. Ao invés de usar o emblema "suástica", defensores da Disney seguiram a sugestão de comprar nos cinemas pequenos broches de Mickey Mouse para tomar uma posição anti-nazista. Esse ataque nazista tem relação com a explosão da mania Mickey que estava tomando a Alemanha, após uma estréia retumbante dos primeiros curtas-metragens em fevereiro de 1930 em Berlim. E vale lembrar que, apesar da predominância judaica em Hollywood, Walt Disney possui origem cristã.

No mesmo ano do ataque do jornal da Pomerânia, Walter Benjamin escreveu o fragmento chamado "Zu Micky-Maus" (1931). As poucas anotações fornecem uma defesa do 
desmascaramento de Mickey das negatividades sociais. Benjamin teria percebido nos desenhos animados uma rejeição do tema da burguesia "civilizada" (LESLIE, 2002, p. 81). Mickey, em seus primeiros filmes, é enfadonho, travesso, tem um padrão de vida baixo, entregando-se ao vaudeville $^{10}$. Como citado no Film-Kurier de fevereiro de 1930, Mickey seria uma fera vivendo no ritmo do jazz. - cada passo um movimento de dança, cada movimento sincopado. Leslie cita que Mickey, por esta linha de pensamento, "seria um animal espirituoso e insubordinado em um mundo de coisas vivas. Queira Judeu ou Negro, ele era o coração imigrante da América" (2002, p. 81 .

\subsection{Perspectiva Sul-Americana: Ideologia e a produção Disney}

Há também trabalhos importantes da comunicação e da sociologia, especificamente no que se refere ao campo da ideologia. A ideologia se refere a um conjunto de ideias comuns tomadas sobre como o mundo funciona. A ideologia não é algo oculto, a menos que seja considerado como tal em plena vista, considerando que é composto de concepções tidas como corretas sobre como o mundo social aparentemente funciona (DUNCAN, 2009, p. 247).

Por este entendimento, as pessoas constroem ideias próprias sobre uma série de temas de gênero, política, origens sociais e étnicas, etc, que informam como percebemos e interagimos entre si: "As ideologias emergem quando grupos de pessoas desenvolvem meios de pensar sobre seus relacionamentos entre si e outros no mundo. Este conjunto de ideias - a ideologia - os ajudam a gerenciar o mundo e se torna uma ferramenta para a vida" (DUNCAN e SMITH, 2009, p.247). Quanto mais tempo as ideologias são levadas em consideração, muito menos provável será que alguém questione suas premissas. Por um lado, uma ideologia é considerada como "senso comum" dentro da cultura que a agrega; de outro, podem surgir críticas de grupos fora da zona de influência desta ideologia. Como Duncan (2009) afirma, a ideologia é uma questão importante a ser compreendida porque envolve questões de poder - aqueles que se beneficiam de uma idéia frequentemente exercem o poder numa sociedade.

O cinema é repleto de questões que envolvem ideologia e o exercício do poder utilizando os meios de comunicação de massa. As técnicas de animação hiper-realistas permitem que a

\footnotetext{
${ }^{10}$ Vaudeville é um gênero de entretenimento de variedades predominante nos Estados Unidos e Canadá do início dos anos 1880 ao início dos anos 1930, incluindo espetáculos baratos como apresentações burlescas, imitações, comediantes, "circos de horror", museus baratos, acrobatas e dançarinas, etc.
} 
publicidade atinja um público-alvo mais jovem, tendo em vista que é possível apresentar produtos de uma forma muito diferente do real. Essa qualidade pode ser descrita como sendo uma qualidade agregada, uma vez que,

a mais-valia é de extrema importância, dado que a imagem animada traz mais do que efeitos especiais a uma publicidade de automóvel tradicional; ela cria um novo imaginário irreverente para este veículo, tornado atrativo na vida real pelas façanhas maravilhosas que lhe vimos no anúncio. (DENIS, 2010, p. 100)

Podemos, assim, destacar a história da força da animação na publicidade quando os curtas-metragens do personagem Popeye (estúdios Fleischer) se tornaram mais populares que os do Mickey Mouse durante os anos 1930 - de início o personagem comia poucos espinafres, mas logo interessou à indústria, que considerou atrativo o fato do personagem obter uma força descomunal graças ao consumo deles. Da mesma forma, existe a importância do caráter pedagógico da animação via documentários, seriados e projetos especiais para difundir conhecimento - produções deste tipo foram feitas em muitos países.

Há outra face da propaganda, não a ligada à publicidade como forma de propaganda econômica e ideológica (a difusão maciça de um modo de vida ocidental globalizado), mas ao termo "propaganda" relacionado à acepção política de difusão de uma mensagem com vista a apoiar um político, um governo, um movimento ou uma ideologia (DENIS, 2010: 108). Desde a Primeira Guerra Mundial, a animação é usada pelos governos, com exemplos na Inglaterra, na ex-União Soviética, Alemanha, França e Argentina, enquanto "(...) Países pouco conhecidos pela sua animação também apostam na diatribe antialemã, como o Brasil com o curta-metragem “O Kaiser"11 em 1917" (DENIS, 2010, p. 108-109).

Durante a Segunda Guerra Mundial, a animação se torna importante instrumento para a propaganda ideológica. Nos EUA, os estúdios Disney, Warner, MGM, entre outros, iniciam a produção de diversos filmes e curtas-metragens com conteúdo ideológico contra as nações do eixo (especialmente contra a Alemanha nazista), incluindo projetos de instrução militar e pedagógico, ensinando os americanos e os Aliados em como contribuir para o esforço de guerra (MALTIN, 1980). Seguindo o caráter pedagógico, outras animações foram produzidas tendo como alvo os países latino-americanos, seguindo a Política de Boa-Vizinhança de Franklin

\footnotetext{
${ }^{11}$ Considerado o primeiro desenho animado brasileiro, realizado por Álvaro Marins. (BENDAZZI, 2015, p. 86).
} 
Roosevelt, que visava estreitar os laços culturais entre os países e afastar a influência alemã do continente americano (BARRIER, 2007, p.187). Deste período temos a criação do personagem Zé Carioca, que estrelou os filmes Alô Amigos (1942) e Você já foi a Bahia? (1944).

Fora dos Estados Unidos, há diversos filmes de propaganda ideológica. Na Alemanha, a partir de 1933, qualquer forma de arte abstrata é proibida e julgada "degenerada". Uma vez que a maioria dos artistas que trabalhavam com abstração vinha da Alemanha, a animação experimental desaparece, dando lugar a um simples desenho animado de circunstância, num contexto de concorrência com os filmes de Disney ou Fleischer (DENIS, 2010, p.110-111). Um exemplo alemão que tentará uma visão não diretamente propagandística será Hans Fischerkoesen, com mensagens dúbias do regime alemão. Na União Soviética, a animação foi utilizada também para denunciar o mundo capitalista - em Black and White (Ivan Ivanov-Vano, 1932), há uma história sobre a escravidão moderna representada pelas plantações em Cuba. O pós-guerra abre passagem para a propaganda de Guerra Fria, essencialmente ideológica entre "Ocidente" e "Leste". O anticomunismo responde à extensão do comunismo no mundo, em que o autor exemplifica com “A Revolução dos Bichos”, animação de John Halas e Joy Batchelor de 1951, baseada no livro de George Orwell (2007), sendo o primeiro longa-metragem de animação britânico com caráter bastante anticomunista. Ainda que contenha um grafismo próximo ao de Disney, seu tom é mais sombrio (DENIS, 2010, p. 113). Muito mais recentes, em South Park - O Filme (1998) e Team America (2004), os criadores Matt Stone e Trey Parker não hesitam em revelar a sua oposição às duas guerras do Golfo Pérsico ocorridas em 1990-91 e 2003-04.

Com as histórias em quadrinhos não foi diferente. Primeiramente, temos a própria natureza do suporte, que pode transmitir mensagens em pouco espaço, combinando textos e imagens, e num formato cujos valores e intenções podem ser interpretados de forma singular ou múltipla (WOLK, 2007, p. 60). A outra razão seria sua importância como forma social de comunicação. Se considerados genericamente como infantis, os quadrinhos podem ser vistos como leitura de fácil ritual para crianças e adultos, especialmente se focarmos nos jornais. Os quadrinhos seriam, portanto, um meio perfeito para mecanismos de manipulação ou de transmissão de ideologias em massa. Uma das obras mais difundidas sobre esse enfoque é o livro do psiquiatra alemão Fredric Wertham, "A Sedução dos Inocentes" (1954), considerado o catalizador de uma campanha anti-quadrinhos que se espalhou pelo mundo, com suas críticas as mensagens negativas (violência e conteúdo sexual) transmitidas pelos quadrinhos aos jovens 
que os liam nos anos 1950 (VERGUEIRO, 2010, p. 12). Mas assim como os quadrinhos sempre transmitem uma intenção, o livro de Wertham é também ideológico, certamente influenciado por teóricos da cultura de massa como Theodor Adorno.

Diversos livros com estudos acadêmicos analisam as histórias em quadrinhos sem o foco específico em ideologia. Isso não significa, entretanto, que não haja um viés ideológico nas obras. Logicamente, o assunto não se esgota aqui, tendo em vista que há muitas nuances quando tratamos de ideologia nos quadrinhos. Porém, dado o tema desta pesquisa, é importante citar aspectos históricos e conflitantes do livro "Para Ler o Pato Donald: Comunicação de Massa e Colonialismo" (DORFMAN e MATTELART, 1980), obra bastante difundida nos cursos de sociologia e comunicação nas universidades brasileiras, e que trata do universo Disney. Há exemplos de trabalhos brasileiros, caso de "Tio Patinhas e os Mitos da Comunicação" (MIRANDA, 1978) e o artigo "Tio Patinhas e o Centro do Universo" (MARTINS, 1975), ambos de acadêmicos da área da sociologia. Os autores trabalham com a propaganda, a manifestação prática da ideologia. A propaganda tenta alcançar uma grande audiência pelo uso dos meios de comunicação de massa para criar uma uniformidade de interpretação utilizando o que consideram técnicas de manipulação (DUNCAN e SMITH, 2009, p. 248) Os quadrinhos, portanto, seriam um suporte ideal para a propaganda, especialmente do público infanto-juvenil.

Dorfman e Mattelart tiveram seu livro publicado em 1971, servindo como ferramenta para o governo socialista chileno. Com a derrubada do governo Salvador Allende e a implantação da ditadura militar em 1973, foram obrigados a se exilar. A ideia geral do livro é tentar revelar uma visão imperialista contida no que é considerado inocente - no caso, os quadrinhos Disney. As histórias em quadrinhos Disney seriam uma ferramenta poderosa do imperialismo norte-americano porque elas pretendem ser inofensivas, produto de entretenimento para crianças. Os autores argumentam que os quadrinhos Disney são formas de propaganda capitalista e ferramenta de divulgação da própria Disney e do império norteamericano. Em prefácio da edição brasileira, o tradutor Álvaro de Moya alerta que "este livro tem que ser, portanto, encarado como um panfleto, uma obra sectária, política, parcial, radical, esquerdista, antiimperialista e anticolonialista em seu bom e seu mau sentido" (DORFMAN, MATTELART, 1980, p. 5).

Os autores iniciam sua análise criticando a estrutura familiar nos quadrinhos, descrevendo a ausência da relação entre pais e filhos, a falta de união estável (casamento), a 
dominação paternalista e a horizontalização do mundo. Segundo os autores, há uma tentativa de enganar as crianças dentro das redes de poder paternalista. O Pato Donald sempre aparece como sujeito irresponsável, incompetente, um adulto infantilizado, representando uma inversão de valores. Quando os três sobrinhos se rebelam contra os "crimes" de Donald, eles o fazem em nome dos valores adultos. As crianças ao se identificarem com os sobrinhos, reagem adotando esses valores, abandonando sua natural progressão para a espontaneidade, imaginação e subversão da autoridade adulta. A mulher, por sua vez, é mostrada em seus extremos (Branca de Neve ou uma bruxa), com empregos banais do universo feminino (secretária, modista, decoradora, criada, etc). A horizontalização se dá numa sociedade sem hierarquia, exceto a quantidade de riqueza e dinheiro possuídos, onde não há solidariedade, restando apenas uma competição cruel (DORFMAN, MATTELART, 1980, p. 36).

Dorfman e Mattelart também fazem uma análise relacionando crianças e os cidadãos do Terceiro Mundo. Estes últimos seriam como as crianças - nobres selvagens e amigáveis, felizes, ingênuas, despreocupadas, confiáveis, etc. Diferente das crianças urbanas de Patópolis, que estão sempre corrigindo os adultos - às do Terceiro Mundo faltam inteligência, astúcia, disciplina e habilidades técnicas (DORFMAN, MATTELART, 1980, p. 52). Por internalizar a imagem de si mesma como primitiva, os quadrinhos Disney reforçam a relação de dependência entre a América e o mundo subdesenvolvido que legitima "a pilhagem imperialista ocidental". Os países subdesenvolvidos seriam, de acordo com os autores, como as crianças devem ser tratadas - com severa disciplina.

O que os aventureiros procuram nas histórias? O ouro. Para os autores, há sempre um excesso de referências a uma antiguidade nos tesouros (pirâmides, navios antigos, cavernas), numa alusão ao término dessas civilizações. Serviria como conveniência para os inocentes desses locais. Basta qualquer um chegar (o Tio Patinhas e seus sobrinhos) e coletar o tesouro, tendo em vista que esses povos primitivos não produziram as riquezas, sendo em geral guerreiros, conquistadores, exploradores, etc. Não há processo de produção. O problema é localizar seu centro geográfico e não recolher o ouro. A divisão do trabalho não pode ser questionada (DORFMAN, MATTELART, 1980, p. 62).

Quando se trata de analisar o trabalho nos quadrinhos Disney, os autores questionam o motivo do trabalho para o Pato Donald, especulando que seria para férias ou comprar produtos supérfluos. A fome foi superada, a sociedade emana bens, representada por um setor de serviços 
e não a indústria. Do mesmo modo, os trabalhos sempre existem, proliferam. E há um paradoxo na situação constante do Donald perder o emprego em várias histórias: "Donald representa bastardamente todos os trabalhadores que devem imitar sua submissão, porque eles tampouco teriam colaborado na edificação deste mundo material" (DORFMAN, MATTELART, 1980, p. 101). O personagem é desajeitado e descuidado, eternamente demitido.

Em outro trecho, os autores destacam a neutralização dos polos antagônicos nas histórias em quadrinhos Disney. A diversão, tal como entende a cultura de massas, trata de conciliar o trabalho com o ócio, o cotidiano com o imaginário, o social com o extra-social, o corpo com a alma, a produção com o consumo, a cidade com o campo, esquecendo as contradições que subsistem dentro dos primeiros termos. Cada um desses antagonismos, pontos nevrálgicos da sociedade burguesa, fica absorvido no mundo do entretenimento sempre que passe antes pela purificação da fantasia, afirmam Dorfman e Mattelart (1980, p. 107).

Podemos exemplificar esta passagem dando como exemplo o primo sortudo do Donald, Gastão, que consegue tudo o que deseja desde que seja material, ou a repetição da evolução da riqueza do Tio Patinhas, revisada a cada aventura. Não há superioridade baseado no dinheiro porque ele nunca o utiliza. Assim, "(...) O mito básico da mobilidade social no sistema capitalista é o self made man. Igualdade de oportunidade, democracia absoluta, cada criança parte do zero e acumula o que merece" (DORFMAN, MATTELART, p. 112). A pobreza e o desemprego foram abolidos na utopia Disney.

Em relação à História, os autores afirmam que tudo é colorido e no tempo presente sem qualquer alteração histórica, como a eterna permanência dos mesmos gorros e roupas. O interesse pelo consumo das novidades tecnológicas pode ser aferido pelos produtos das ciências - as invenções do professor Pardal são objetos de consumo imediato, perecíveis, fugazes e substituíveis. O enclausuramento deste mundo estaria disfarçado pela mobilidade física dos personagens geograficamente. Todos falam o mesmo idioma.

Os quadrinhos Disney teriam uma grande ênfase na "Glória" e na "Aparência". Segundo os autores, na maioria das histórias em quadrinhos Disney a corrida é sempre para chegar a algum lugar ou objeto. Isso não significa apenas a luta pelo dinheiro, mas a fama e a glória, como prova de destreza por ultrapassar obstáculos. Seria o fim do caminho do sofrimento, o término do trabalho que desemboca no seguro porto da fama. A fama seria obter todos os 
benefícios. Não importa a verdade e sim aparência dos fatos. O bom nome do protagonista depende exclusivamente da história como fofoca. Há uma obsessão da difusão da própria imagem de forma positiva para o registro dos grandes feitos dos personagens:

\begin{abstract}
Um dos modos mais habituais de iniciar um episódio é por meio de um álbum fotográfico. Se não há evidência, não existe o fenômeno. Cada aventura está vista por seu protagonista como enquadrada já no álbum, como turista de si mesmo. A câmera é uma maneira de enlatar o passado. Quando a foto é falha, perde-se a memória, perde-se a imortalidade, perdeu-se a garantia de reprodução de si mesmo (nos meios de comunicação) e, portanto, perdeu-se a documentação histórica: o desenho é a fala do personagem, é sua existência para além de si mesmo. (DORFMAN, MATTELART, 1980, p. 120)
\end{abstract}

A competência faria do indivíduo um produto, uma coisa terminada, sem possibilidade de outro processo de produção, estando sempre pronto para consumir-se ou para consumir. Os autores fazem uma comparação entre os dominantes (Patópolis) e os dominados (selvagens bonzinhos ou delinquentes). Seria uma metáfora dos gêneros bom e mau (DORFMAN, MATTELART, 1980, p. 132). Nos dominantes, há variações de ricos e pobres, sortudos e desafortunados, inteligentes e burros. Os bandidos irmãos Metralhas são punidos quando se disfarçam de bandidos. Tio Patinhas e Mickey são enganados e o Donald sempre perde e ganha. Nos dominados, é impossível a maldade se você apenas se conforma. Sair do mundo selvagem é cair na criminalidade. A história sucede à margem desses seres, sejam eles malignos ou passivamente bondosos. O fato de não existir uma liberdade de personalidade seria prova de que se trata de mundo fechado e asfixiante: "A burguesia, no auge da cultura e da civilização, sente-se no direito de reinterpretar a história e sua própria chegada ao poder de seu ponto de vista. A classe dominante vê toda a sua ascensão como um fenômeno natural e nunca social" (DORFMAN, MATTELART, 1980, p. 134).

O corpus teórico da obra de Dorfman e Mattelart conclui que a Disney é um mundo que desejaria ser imaterial, onde desaparece a produção em todas as suas formas (indústrias, sexo, trabalho, cotidiano), e onde o acontecimento nunca é social (competência entre o bem e o mal, competência mais ou menos afortunada, tontos e inteligentes). Portanto, a base material que existe em cada ação em nosso mundo cotidiano concretamente situado não está presente para os personagens Disney (DORFMAN, MATTELART, 1980, p. 142).

Cabe fazer uma reflexão sobre as problemáticas envolvidas em sua discussão. O primeiro deles, além do ideológico, é que se trata de uma perspectiva latino-americana dentro 
do contexto da expansão de regimes políticos militares na região. A própria ideia da suposta manipulação com o uso dos personagens não impediu que os chilenos elegessem o socialista Salvador Allende como presidente em 1966. Há uma fraca contextualização do ponto de vista norte-americano, observando que Carl Barks, artista responsável por uma renovação importante nos quadrinhos Disney, nunca é citado. Tratava-se de um período em que Disney dava um pouco mais de autonomia aos artistas produtores de quadrinhos, e o próprio Barks fora responsável por inserir mais cinismo, sátiras e um pouco de crítica política e da sociedade em suas criações. As histórias analisadas por Dorfman e Mattelart são dos anos 1960, período em que o American way of life era relacionado ao fortalecimento do setor de serviços:

O conceito de classe de Dorfman e Mattelart é dirigido aos leitores no Terceiro Mundo. Entretanto, para interpretar as histórias de Barks é necessário levar em consideração o contexto social do público norte-americano. Enquanto trabalhadores industriais predominam em cidades subdesenvolvidas, quatro quintos dos empregados norte-americanos estavam no setor de serviços nos anos 1950. Portando, a representação de trabalho em Patópolis feita por Barks é precisa, em vez de uma mistificação ideológica das realidades de classe. Além disso, é arrogante argumentar que só porque prestação de serviços não é industrial, que não se trata de trabalho. A alienação, opressão e falta de controle no trabalho do Pato Donald são elementos-chave de sua personalidade no universo criado por Barks (ANDRAE, 2006, p. 14).

Os autores, que mais tarde reconheceriam os exageros em sua obra, também se esquecem de citar ou analisar verdadeiros exemplos de propaganda oficial. Nos anos 1940, a Disney produziu diversos filmes como parte da Política de Boa Vizinhança para expandir os laços de amizade entre os EUA e os países da América Latina, como vimos anteriormente.

Para uma abordagem não materialista cabe citar a obra de 1954, "Bandeirantes e Pioneiros - Paralelo entre duas culturas" de Vianna Moog (2011), primeira tentativa de interpretação comparativa entre a cultura norte-americana e a brasileira. Em determinado momento, considera o Pluto o representante típico das frustrações e no crédito dos aspectos morais da vida. O cão bondoso seria o resultado de uma leitura sem ajuda de intérpretes da Bíblia, "O Contrato Social" e as doutrinas de Rousseau e Jefferson. O pato Donald estereotipa a América das frustrações resultantes na crença da competição, na livre empresa, concorrência, publicidade e no êxito. Mickey Mouse, para o autor, não é simbolicamente uma tipologia norteamericana. Suas ações teriam origem no heroísmo à maneira antiga. Seus vários empregos e aventuras remetem ao grego Ulisses e El Cid e menos ao americano típico, que se enxerga mais em Pluto e Donald. Sem dúvida uma reflexão instigante se comparado a outros autores. 


\subsection{Perspectiva do Hiper-realismo: O Universo Disney de Umberto Eco e Jean Baudrillard}

Há diferentes vertentes nos estudos da comunicação que utilizam o universo Disney como objeto de estudo a partir dos anos 1970. O sociólogo francês Jean Baudrillard foi um dos teóricos que construiu sua análise sobre o simulacro dando como um de seus exemplos os parques temáticos Disney, representação concreta dos quadrinhos e animações. Em suas primeiras obras, Baudrillard está mais interessado numa análise sociológica com base no consumo, afirmando que isto e não a produção seria o motor da sociedade capitalista. Haveria, portanto, uma dupla análise com a função social distinta dos objetos e a da função política de ideologia a ela ligada (BAUDRILLARD, 1995, p. 9), ou seja, além da função das necessidades, os objetos também ganham o seu sentido na relação econômica do homem com o ambiente circundante.

Quando analisa o consumo ostentatório, o autor fala sobre as funções (além da essencial) dos objetos, como podemos observar neste trecho quando analisa Veblen:

\footnotetext{
Segundo Veblen, um dos maiores expoentes de prestígio, além da riqueza e da dilapidação (wasteful expenditure), é a ociosidade (waste of time) exercida diretamente ou por procuração (vicarious leisure). O mundo dos objetos não escapa a esta regra, a este constrangimento de superfluidade: efetivamente é sempre naquilo que têm de inútil, de fútil, de supérfluo, de decorativo, de não funcional, que se constituem categorias inteiras de objetos (bibelots, gadgets, acessórios) ou, em cada objeto, todas as conotações e o metabolismo das formas, o jogo da moda, etc; em suma, os objetos nunca se esgotam naquilo que servem, e é neste excesso de presença que ganham a sua significação de prestígio, que "designam" não já o mundo, mas o ser e a categoria social do seu possuidor. (BAUDRILLARD, 1995, p.12)
}

O autor descreve a utilidade (ou inutilidade) dos objetos, quais suas funções sociológicas - levando-se em conta que vários objetos têm acessórios mais importantes do que sua função principal (caso do telefone celular), o que resulta na construção do conceito de simulacro funcional, em que os objetos (e não somente eles) continuariam a desempenhar o seu papel de discriminantes sociais.

Criticando o conceito de "valor de uso" de Marx, Baudrillard (2009) descreve as quatro diferentes formas pela qual o objeto obtém valor: a primeira é o seu valor funcional instrumental 
(sua função básica); a segunda o valor de troca (valor econômico) do objeto; a terceira o valor simbólico do objeto onde há uma relação casual ou factual; e a quarta o valor do signo ou seu valor no sistema dos objetos, em que um objeto enquanto igual a seu similar possui um prestígio maior, resultando em valores sociais discriminantes, o que envolve o gosto ou a classe de quem o consome. Baudrillard argumenta que as duas principais formas de valor são afetadas pela terceira e, principalmente pela quarta forma (valor do signo).

Não nos interessa descrever esta teoria de Baudrillard, bastante complexa e paradoxal, mas este percurso resultou num aprofundamento dos conceitos de simulacro e simulação nos anos 1980. O autor deixou de lado o marxismo e o viés econômico para considerar a mediação e a comunicação de massa, especialmente influenciado pela semiótica de Saussure e pelo comunicólogo Marshall McLuhan, analisando como a natureza das relações sociais é determinada pelas formas de comunicação empregadas pela sociedade. Em resumo, o conceito de simulacro envolveria a negação do conceito da realidade como normalmente compreendemos.

Afirmando que atualmente não existe o que chamamos de realidade, Baudrillard (1991) descreve que a simulação é o estágio atual do simulacro. O resultado seria a hiper-realidade, em que tudo é composto por referências sem referentes. É como a bomba nuclear usada como poder dissuasório, que é reproduzida e compreendida apenas em seu senso hiper-real, porque a idéia é nunca utilizá-la. Para Baudrillard, já assumimos a reprodutibilidade de tudo, levando-se em consideração que não é a realidade dessas simulações que imaginamos, mas sua reprodução. Mais complexo ainda, não compreendemos essas idéias e objetos como reproduções, posto que a imagem original é ela própria uma reprodução. Percebemos, portanto, uma simulação.

A hiper-realidade, portanto, se torna instrumento da filosofia e da semiótica pósmoderna para descrever esta incapacidade do consciente em diferenciar a realidade da simulação. Outro teórico que também se interessa pelo tema é o escritor e semiólogo italiano Umberto Eco, que contribuiu com importantes textos usando as histórias em quadrinhos como objetos de análise da cultura de massa. Na obra "Apocalípticos e Integrados" (1964), Eco propõe uma defesa de uma nova orientação nos estudos dos fenômenos da cultura de massa: 
Expoente da teoria da comunicação na Europa, Umberto Eco, em seu livro Apocalípticos e Integrados, critica os teóricos "integrados" (funcionalistas) por passividade diante das questões relativas à CULTURA DE MASSA e, principalmente, os "apocalípticos" (membros da Escola de Frankfurt) por seu pessimismo diante da sociedade de massa por negar a cultura de massa sem realmente analisá-la. Para Eco, ambos (integrados e apocalípticos) utilizam "conceitos-fetiche" (massa, indústria cultural) para tratar de maneira genérica um fenômeno complexo como a cultura de massa. (SANTOS, 1992, p. 17)

A obra contém análises envolvendo histórias em quadrinhos como Steve Canyon, Peanuts e o Superman, cuja análise sobre o mito do Superman levantou interessantes questões sobre símbolos, mitologia (o Superman como mito moderno), política e sociedade. Porém, em 1973 publica a obra "Viagem na Irrealidade Cotidiana" (ECO, 1984), em que se aproxima do pensamento de Baudrillard sobre o tema da simulação e da hiper-realidade. Mais do que isso, ambos irão considerar a Disneylândia como um exemplo de hiper-realidade.

Após viagem pelos Estados Unidos, Eco descreve diversos locais que se encaixam em seu exemplo, desde museus e parques até cidades como Las Vegas - concentrada no jogo e no espetáculo, sua arquitetura é totalmente artificial, tornando-se um fato urbanístico novo, uma cidade "mensagem". Mas ainda assim, a hiper-real Las Vegas é uma cidade "verdadeira". Procurando o que descreve como o "falso absoluto", Eco se concentra na Disneylândia (Califórnia) e no Walt Disney World (Flórida), os exemplos máximos disso, mas não exceções, tendo o autor destacado que nos Estados Unidos há diversas cidades que imitam uma cidade da mesma forma que os museus de cera imitam a pintura e os palácios venezianos ou as vilas de Pompéia imitam a arquitetura (ECO, 1984, p. 51).

Observa que os edifícios da Disneylândia, em especial os da rua principal Main Street, foram construídos em escala um por um no que diz respeito ao andar térreo e em escala dois terços no que se refere ao andar superior, de modo que dão a impressão de serem habitáveis, e o são, e de pertencer a um passado fantástico que podemos dominar com a fantasia. Mais do que isso, o autor cita que dentro dos edifícios encontramos sempre um supermercado travestido, em que se compra obsessivamente, acreditando que se continua a brincar: 
Nesse sentido a Disneylândia é mais hiper-realista que o museu de cera, justamente porque este ainda tenta fazer acreditar que o que se vê reproduz absolutamente a realidade, enquanto a Disneylândia deixa claro que no seu recinto mágico se reproduz absolutamente a fantasia. $\mathrm{O}$ museu de arte tridimensional vende como quase verdadeira a sua "Vênus de Milo", enquanto a Disneylândia pode se permitir a venda de suas reconstruções como obrasprimas de falsificação, visto que aquilo que ela vende efetivamente, as mercadorias, não são reproduções mas mercadorias autênticas. O que é falsificada é a nossa vontade de comprar, que tomamos por verdadeira, e nesse sentido, Disneylândia é realmente quintessência da ideologia consumista. (ECO, 1984, p. 55).

Eco, no entanto, afirma que uma vez o "todo falso" sendo admitido, é necessário que para ser desfrutado pareça verdadeiro. Por isso, explica a incrível atenção aos detalhes dispensada nas instalações. E quando testemunhamos algo "fora da realidade", caso dos crocodilos ou dinossauros, isso está presente para estimular um desejo. É possível, por exemplo, ver um crocodilo no zoológico, mas certamente as chances são grandes dele estar cochilando ou escondido. Na Disneylândia, no entanto, e graças à técnica, o crocodilo animatrônico estará sempre em ação, respondendo às exigências do público. Desta forma, "A Disneylândia nos diz que a técnica pode nos dar mais realidade que a natureza" (ECO, 1984, p. 56).

Considerando a Disneylândia, em essência, uma alegoria do consumo, Eco descreve que o parque também é o lugar da passividade total, onde os visitantes devem aceitar viver ali como os seus autômatos, percorrendo as atrações por corredores de corrimões e barreiras metálicas, seguindo instruções de segurança e conduta, em labirinto, desencorajando qualquer iniciativa individual. A quantidade de visitantes também impõe por todo o parque um ritmo de fila e os funcionários (cast-members) estão sempre dando instruções de direção em tom gentil, impessoal, imperioso.

Paradoxalmente, Eco encerra esta parte da análise questionando que se a América (EUA) é a mesma do Museu Guggenheim ou dos novos arranha-céus de Manhattan, então a Disneyândia é uma exceção curiosa e, faria bem mesmo que os intelectuais norte-americanos não a visitassem. Entretanto, "se a América é aquela que vimos no curso de nossa viagem, então a Disneylândia é a sua Capela Sistina e os hiper-realistas das galerias são apenas tímidos voyers de um imenso e contínuo "objeto trouvé"" (ECO, 1984, p. 60).

Baudrillard também descreve a Disneylândia em "Simulacros e Simulações" (1991), afirmando que o parque é um modelo perfeito de todos os tipos de simulacros confundidos, um 
grande jogo de ilusões, que atrairia multidões muito mais pelo microcosmos social, o gozo religioso, miniaturizado da América real, dos seus constrangimentos e das suas alegrias. $\mathrm{O}$ mundo exterior, o pretenso real, permanece no exterior, ora esquecido pelas horas de diversão dispensadas em seu interior inspirado pela "miniatura" da América (e o American way of life) e pelos filmes de animação. Para o autor, entretanto, isso ocultaria uma trama ideológica, a de servir como cobertura a uma simulação de terceira categoria. A Disneylândia serviria, portanto, para esconder que é o país "real", toda a América "real" que é a Disneylândia:

\begin{abstract}
A Disneylândia é colocada como imaginário a fim de fazer crer que o resto é real, quando toda Los Angeles e a América que a rodeia já não são mais reais, mas do domínio do hiper-real e da simulação. Já não se trata de uma representação falsa da realidade (a ideologia), trata-se de esconder que o real já não é o real e portanto de salvaguardar o princípio da realidade.

O imaginário da Disneylândia não é verdadeiro nem falso, é uma máquina de dissuasão encenada para regenerar no plano oposto a ficção do real. Daí a debilidade deste imaginário, a sua degenerescência infantil. O mundo quer-se infantil para fazer crer que os adultos estão noutra parte, no mundo "real", e para esconder que a verdadeira infantilidade está em toda a parte, é a dos próprios adultos que vêm aqui fingir que são crianças para iludir sua infantilidade real. (BAUDRILLARD, 1991, p. 21).
\end{abstract}

A Disneylândia não é o caso único em que isso acontece. Há exemplos de hiperrealidade em locais muito mais banais no mundo "real", seja num McDonalds ou assistindo a um filme de Hollywood. Toda grande cidade, a exemplo de Los Angeles, está repleta de centrais imaginárias que alimentam com o real um mundo cujo mistério consiste em não ser mais do que uma rede de circulação incessante do irreal.

Em artigo publicado em 1997, Baudrillard afirmara que a Nova Ordem mundial é disneyca:

O virtual compra o real a preço baixo e o expele tal qual, em forma de prêt-aporter (...). A própria realidade, o próprio mundo, com toda a sua atividade frenética de clones, já se transformou em performance interativa, em uma espécie de Luna Park das ideologias, das técnicas, do saber e até mesmo da destruição - tudo isso para ser clonado e ressuscitado num museu infantil da imaginação, num museu virtual da imaginação. (BAUDRILLARD, 1997)

Em 2001, ao criticar o sucesso dos reality-shows na televisão, reafirmou a questão do real simulado: 
O equivalente a um ready-made - transposição exata da vida de todo dia, ela mesma já falsificada por todos os modelos dominantes. Banalidade sintética, fabricada em circuito fechado e sob tela de controle. Nisso o microcosmo artificial do loft é parecido com a Disneylândia, que dá a ilusão de um mundo real, de um mundo exterior, enquanto os dois são exatamente idênticos. Todos os Estados Unidos são uma Disneylândia, e estamos todos no loft. Não é preciso entrar no duplo virtual da realidade, já estamos nele - o universo televisual é apenas um detalhe holográfico da realidade global. Até em nossa existência mais cotidiana já estamos numa situação de realidade experimental. E é aí que surge o fascínio por imersão e por interatividade espontânea (BAUDRILLARD, 2001).

Desta forma, conclui-se que a distinção entre o que é realidade corpórea e o que é virtual deixa de ser relevante. Ambas se alternam e há uma sistemática troca e perda de sentidos na percepção do que nos cerca.

2.4. Perspectiva Britânica/Norte-Americana: Alan Swingewood, Robert Feild, Robin Allan, Steven Watts, e a Cultura Pop

O texto do norte-americano Alan Swingewood (1980) diverge de Adorno. O material faz parte de um livro, cujo material é um ciclo de conferências do autor na universidade norteamericana de Princeton na década de 1970. Swingewood ficou muito conhecido nos Estados Unidos por instigar outros intelectuais que ficavam neutros em relação a Adorno. Deste modo, surgiu o pensamento organizado e sistemático contra a Escola de Frankfurt, a Escola Evolucionista-Progressista. - com membros mais ligados ao centro-direita do espectro político - estudando a sociedade contemporânea.

Swingewood, apesar de ser um autor de direita, não é um extremista. Discute os media e a sociedade de massa com respaldo empírico. Quando ele afirma que a cultura de massa é democrática e pluralista, podemos encarar a afirmação como um grande choque com a posição de Adorno (informação verbal) ${ }^{12}$. Se observarmos com a perspectiva contemporânea, a cultura continua cooptando via instrumentos publicitários, de marketing, e de pseudo-inovações, nos sensibilizando a comprar os produtos da cultura de massa. De todo modo, para aplicar um problema, a democracia é algo que deve ter acesso a todos, e o produto cultural é estratificado (os mais pobres na periferia não podem comprar de tudo), como podemos ver nesta passagem:

\footnotetext{
${ }^{12}$ Fornecida por Waldenyr Caldas em aula sobre o tema "Cultura de Massa ou Democratização da Cultura?" na disciplina "O Consumo Estratificado da Produção Cultural" - PPGCOM/ECA/USP - 14 abr. 2011.
} 
Conforme argumentamos no capítulo um, críticos culturais como T.S. Eliot e F.R. Leavis, se bem que mais preocupados com os aspectos literários da cultura, argumentaram também que a tecnologia era a causa direta do colapso dos valores e do nivelamento do gosto cultural. Em todas as versões da tese da cultura de massa, a crise dos valores e os problemas de legitimidade estão mecanicamente relacionados com a ação cega de um determinismo tecnológico pelo qual a própria democracia acaba sendo ameaçada. (...) [exploramos] a relação entre as instituições democráticas do capitalismo e a inevitabilidade de uma cultura de massa uniforme. (SWINGEWOOD, 1980, p. 79)

De imediato, o autor reconhece a cultura de massa como fenômeno do capitalismo. Há um confronto de ideias entre Dwight McDonald e Swingewood, especialmente sobre o que é cultura de massa, onde lemos um parágrafo do pensamento adorniano. McDonald afirma que a cultura de massa é simplesmente uma cultura "fabricada por técnicos contratados por homens de empresa, sua audiência são os consumidores passivos, cuja participação se limita a escolha entre comprar e não comprar". (SWINGEWOOD, 1980, p. 79). Por outro lado, vemos uma posição oposta aos intelectuais da Escola de Frankfurt, nas opiniões de Leavis e Horkheimer, afirmando que "em sua pior manifestação a cultura de massa não só ameaça tornar imbecil nosso gosto, mas também brutalizar nossos sentidos enquanto prepara o terreno para o totalitarismo" (SWINGEWOOD, 1980, p. 79-80). Por esta linha, a cultura de massa reforçaria atitudes emocionais que parecem inseparáveis da existência na sociedade moderna - a passividade e o tédio.

Analisando o conceito pelo viés desta escola de pensamento, o conceito progressistaevolucionista de cultura popular "rejeita a idealização do passado e aponta na direção de uma participação cada vez maior de todos os estratos sociais nas decisões políticas e sociais" (SWINGEWOOD, 1980, p. 80). O rápido desenvolvimento tecnológico e o crescimento da instrução e das comunicações resultariam na democratização, e não na brutalização das massas:

As teorias da cultura de massa baseadas na distinção entre níveis culturais altos e baixos tendem a romantizar e a descaracterizar historicamente $o$ passado, criando mitos de sociedades mal letradas com culturas "altas" que unificavam a estrutura social, pois os "padrões de apreciação da alta literatura e arte estavam suficientemente associados aos padrões... uma elite social". Contrastando com isso, as sociedades de massa modernas, preferindo a igualdade à excelência, não têm lugar para as elites criadoras. Surge, em seu lugar, uma cultura criada pelos profissionais para o mercado, uma cultura de massa que absorve todos em seu "mundo sem padrões", atingindo todas as áreas da sociedade. (SWINGEWOOD, 1980, p. 81) 
A questão chave é: a tecnologia e o avanço da comunicação são elementos suficientes para democratizar a cultura como pretende Swingewood? Adorno faz comparações mostrando que a indústria cultural gostaria de fazer crer que o cidadão é o seu sujeito, mas não pensamos sua ideologia. Embora muitas vezes a indústria cultural não pudesse existir sem sua ideologia, sem o que nós almejamos, significa dizer que o consumidor tem certa autonomia. Swingewood diz que a tecnologia e o avanço da comunicação tornam a cultura democrática.

Para Swingewood, o avanço tecnológico é de amplo espectro. A nossa comunicação é cara, mas não por causa dos avanços tecnológicos, mas por conta dos privilégios. A tecnologia é um elemento que veio democratizar a cultura e o avanço da comunicação vem corroborar para termos uma cultura democrática. Mas como esta tecnologia ajuda? Não é possível afirmar que a tecnologia tornou mais barato o acesso à comunicação e democratizou a cultura. Mas para democratizar a partir da tecnologia da imagem, da audição, do e-mail, etc, é preciso que as pessoas tenham esse material para se comunicar com o mundo. Essa tecnologia é positiva desde que seja possível ter acesso a ela para obter algum benefício. Um exemplo disso são os lugares ermos do Brasil que não são pobres, mas atrasados. Swingewood também aponta a dependência em relação aos grandes grupos de mídia:

Em muitas sociedades capitalistas modernas, monopólios gigantescos e empresas multinacionais controlam hoje a radiodifusão e a televisão, a produção cinematográfica e a distribuição e edições em todos os níveis. (...). [Isso não é produzido] por prestarem uma contribuição importante à educação e a cultura, mas, antes, porque são os meios de atração de receita da propaganda. (SWINGEWOOD, 1980, p. 92)

Há uma democratização, mas não tão integral quanto enfatiza o texto. Há um atraso nos locais em que as pessoas desconhecem a tecnologia. Nesse aspecto, podemos tentar avaliar se Adorno repensaria sua teoria com todas as tecnologias dos últimos 20 anos. É muito difícil dizer que o avanço tecnológico nos traz mais instrução, que conduz ao saber. A tecnologia é, de fato, um dos elementos que nos leva ao saber. A velocidade rompeu os limites da comunicação. Tirando o aspecto político-ideológico, o avanço tecnológico é importante para a democratização.

Swingewood também afirma que a cultura de massa é democrática e pluralista. O reino da cultura estava aberto, mais do que nunca, para uma parte muito maior da sociedade, tornando-se, assim, um desafio ao status privilegiado da cultura aristocrática e tradicional, mas 
longe de constituir uma alta cultura distinta ou uma cultura genuinamente democrática (SWINGEWOOD, 1980, p. 83). O autor sintetiza o modo como a baixa cultura colabora para a implantação de uma cultura de melhor formação do seguinte modo: A sociedade é uma estrutura complexa de controles e equilíbrios em que
nenhum grupo galga a um poder dominante. A estrutura intermediária da
sociedade pluralista ajuda a manter o acesso às elites em virtude de sua
independência das elites. Na sociedade pluralista, a vida social é fortalecida,
e não empobrecida, pois a vasta massa da população, pela primeira vez na
história humana, se integra numa cultura de massa democrática.
(SWINGEWOOD, 1980, p. 19)

A ênfase da escola evolucionista-progressista não está na definição estrita, literárioartística, de cultura, mas no conceito que ressalta suas dimensões práticas, sociais e políticas. $\mathrm{O}$ autor não fala em cultura formal, mas do dia-a-dia. O aumento dos padrões de educação, e também do lazer e da riqueza, cria condições do alto consumo de massa. Um número cada vez maior de pessoas se "qualifica" na arte de consumir os produtos da "alta cultura", como vimos anteriormente na questão da diluição de valores. Como Swingewood afirma, a cultura é estratificada, e seu consumo é diferenciado.

Ele se contrapõe a análise feita por Dorfman e Mattelart, em que pese a afirmação dos autores de que Mickey Mouse e o Pato Donald são personagens cujos atos disfarçam as "forças repressivas" da produção e da ordem social capitalista, em que as histórias em quadrinhos são simplesmente instrumentos culturais que ajudam a dominação capitalista. Swingewood afirma que uma análise detida, intrínseca, da ficção popular tenderá a revelar sua natureza antidemocrática, ideológica (SWINGEWOOD, 1980, p. 93) quando estas refletem as forças de mercado capitalistas. Deste ponto de vista da cultura de produção capitalista, "a cultura não é democrática, comercializada em massa e periodicamente avaliada pelas últimas técnicas de pesquisa de mercado, ela é o eco de ideologias antidemocráticas e da preocupação com o status quo" (SWINGEWOOD, 1980, p. 92). Para provar sua afirmação, Swingewood cita uma clássica análise das histórias em quadrinhos americanas e inglesas feitas por George Orwell

Observou que em Gem e Magnet a ação quase sempre girava em torno de cricket, piadas práticas, rivalidade escolar, enquanto que nas novas revistas americanas, a atenção se tinha voltado para o culto da violência e para uma ênfase na "adoração do excelente", de modo que o personagem principal era quase uma figura de um super-homem, "uma espécie de gorila humano". $\mathrm{O}$ principal ponto abordado por Orwell era que estas histórias em quadrinhos, como um todo, rejeitavam os fatos da vida da classe operária, concentrando- 
se conscientemente nos heróis e nas situações de vida fora do sistema industrial - vaqueiros, aventureiros e jogadores profissionais". (ORWELL apud SWEINGEWOOD, 1980, p. 92-93)

Swingewood afirma que, de modo geral, as histórias em quadrinhos mais recentes repercutem a mesma problemática quando pintam a guerra com imagens de violência gratuita e sem sentido, hierarquias rígidas de poder e estereótipos simples em termos de preto e branco, especialmente quando apresentam a figura dos alemães (na Segunda Guerra Mundial) e dos negros.

Observamos até este ponto que as análises partem do uso de elementos do universo Disney como objeto de análise para a construção de teorias relacionadas diretamente à comunicação e à cultura de massa. Porém, oriundas dos Estados Unidos e da Inglaterra, há pesquisas, muitas delas recentes e realizadas por acadêmicos, que desenvolvem análises sobre Disney por viés diferente.

Podemos iniciar por uma análise de uma obra publicada em 1942 nos Estados Unidos. O autor, Robert D. Feild, foi professor assistente de Artes na Universidade Harvard na década de 1930. Bastante popular entre os alunos e considerado à frente de seu tempo, Feild teve a ousadia de tentar equiparar as qualidades artísticas da produção Disney com as criações das chamadas artes nobres (KELLER, 2001, p. 70).

Segundo Steven Watts (1997, p. 101, tradução nossa),

Feild acreditava que os filmes Disney foram pioneiros em um novo tipo de expressão criativa, superando a noção de que somente a música, pintura, escultura e arquitetura fossem artes. Combinando muitas dessa velhas formas e as transportando para um domínio atemporal e espacialmente ilimitado teríamos a forma mais potente de expressão artística já inventada.

As consequências não foram nada boas para o autor. Em uma revisão do corpo docente, Feild não teve seu contrato renovado, sendo demitido em 1939.Seu desligamento do corpo docente de Harvard não lhe impediu de lançar um livro em 1942, The Art of Walt Disney, com uma análise técnica e artística baseada em visitas ao estúdio realizadas por ele entre junho de 1939 e maio de 1940 (FEILD, 1940: XIV). Não tinha a preocupação das Artes com o passado e sim com o impacto presente da produção Disney. O período do lançamento, por si, representou muitas transformações: era o auge da "Era de Ouro" da animação, cujos filmes eram bem 
apreciados pelos intelectuais, os Estados Unidos entrariam na Segunda Guerra após os ataques em Pearl Harbor, o estúdio Disney enfrentara uma greve que culminou em profundas mudanças nas relações trabalhistas e o próprio Walt Disney retornara da América Latina e filmes sobre a região estavam em produção.

Feild inicia sua obra com uma introdução histórica das narrativas gráficas, partindo das pinturas nas cavernas, passando por desenhos no Egito, Grécia e nas igrejas. Destaca o processo que levou à inserção do humor e da sátira (especialmente na Grécia, China e Japão), até o desenvolvimento das caricaturas e das histórias em quadrinhos:

Os personagens dos quadrinhos rapidamente alcançaram maior autenticidade do que poderiam requerer seus contemporâneos vivos. Padrões de comportamento foram criados e pontos de vista incutidos por protagonistas de desenho que irão permanecer vivos após algumas de nossas emergências nacionais serem esquecidas (FEILD, 1947, p. 11, tradução nossa).

Quando fala sobre a popularidade dos quadrinhos e do sucesso dos funnies $^{13}$ Feild (1947, p. 11, tradução nossa) afirma que "precisamos lembrar que eles não tentam responder a necessidades cuja sofisticação demanda um toque sutil. Seu apelo é para o homem comum. (...) Gostemos ou não, as histórias em quadrinhos se tornaram parte de nossa vida".

Do mesmo modo que os quadrinhos galgavam seu espaço a partir da primeira década do século XX, Feild afirma que outra força estava emergindo em influência na mente do povo norte-americano. Era o cinema, cujo poder de ascensão seria relacionado ao desejo natural do homem comum por entretenimento direto: "Suas necessidades de recreação não são apenas para escape (um modo de contraponto a dureza e aos conflitos do dia-a-dia); é uma parte essencial do desenvolvimento cultural das pessoas" (FEILD, 1947, p. 12, tradução nossa). Em essência, desde que o trabalho se tornou um mal necessário para a maioria das pessoas, não tendo qualquer relação com a felicidade de se estar vivo, Feild afirma que é a forma que nós atuamos ao invés de como trabalhamos que se torna um fator determinante em nossas aspirações sociais. Isso explicaria, em boa parte, o apelo dos filmes.

\footnotetext{
${ }^{13}$ Forma como os quadrinhos de jornais eram referidos em seu início, além de caracterizar os animais antropomorfizados
} 
O desenho animado (animação) teve experimentações por gerações muito antes da criação da câmera, e se tornou uma forma de entretenimento graças a sua interação com a fotografia. Mas, como Feild conclui, o desenho animado a mão nunca foi levado a sério como arte. Era considerado como uma série de artifícios usados para entreter mentes infantis com situações cômicas absurdas. Mas a técnica evoluiu, o processo se tornou mais complexo e os desenhos animados passaram a fazer parte do repertório dos cinemas, geralmente antecedendo (junto aos cinejornais) as grandes produções.

Feild afirma que a própria existência do desenho animado poderia ter sido extinta, mas analisa que a integração de outra força na vida da comunidade foi importante:

Foram os quadrinhos que garantiram a sobrevivência dos desenhos animados. Eles ajudaram de vários modos. Em primeiro lugar, a própria natureza dos quadrinhos se emprestou à técnica de animação. Tudo o que se propôs a fazer era contar uma história ridícula, por meio de uma série de desenhos simples que retratam uma sequiência rápida de eventos. Praticamente tudo o que restava a ser feito para torná-lo um desenho animado foi elaborar a ação por uma nova série de desenhos entre as cenas originais, o que permitiria seu movimento ininterrupto aparecer quando projetadas sobre a tela. A essa altura, muitos dos personagens em quadrinhos tornaram-se tão conhecidos que no momento em que apareceram diante da plateia foram recebidos com gritos íntimos de reconhecimento. Mesmo se eles não fossem tão engraçados como poderiam ter sido, a mera existência deles era uma garantia de tolerância bemhumorada. (FEILD, 1947, p. 17, tradução nossa)

Logicamente, essa coincidência de astros dos quadrinhos nos cinemas tem relação com os interesses de mercado. Muitas das histórias em quadrinhos eram propriedades das redes de distribuição (syndicates) dos jornais. Não era uma desvantagem negociar o uso de personagens já testados e apreciados para a indústria do cinema. Ainda que nem sempre, como relembra Feild, os personagens se sustentem em animação, como foi o caso de "Krazy Kat", cuja ação nos quadrinhos funcionava melhor com o texto impresso do que no cinema.

O autor, portanto, reconhece que os desenhos animados (animação) estão nas mãos dos homens de negócios. Mas destaca que os artistas não são inteiramente limitados por esta condição na hora de explorar e aperfeiçoar suas técnicas. Os artistas se aproveitavam das contradições da própria indústria para melhorar sua produção - o importante era tentar agradar ao público. Não tendo uma tradição a manter, não há entraves pela idéia de que a arte precisa ser "toda feita pelas mãos". Graças aos recursos da ciência, oferecendo novas técnicas, e com 
uma clara idéia do que era esperado dele, o artista ia em frente para dar vida às suas idéias (FEILD, 1947, p. 19).

Outro ponto importante é que Feild também reconhece as diferenças de linguagem entre quadrinhos e animação. No momento em que a nova mídia (animação) se estabeleceu e foi aceita como parte do entretenimento cinematográfico, as coisas começaram a evoluir com rapidez. E apesar do crédito dado aos quadrinhos por estimular o ímpeto inicial da animação, ela foi apenas um modo de introdução:

A história em quadrinhos tinha técnica própria, exclusivo para o propósito de colocar uma gag efetivamente dentro das limitações de seu meio. Em seis ou oito pequenos quadros toda uma história tinha que ser contada, a seqüência não requer inteligência por parte do leitor para compreender, foi concebido para manter sua atenção por apenas um momento ou dois.

Mas a técnica da animação teve que evoluir para enfrentar um situação inteiramente diferente. Uma plateia de todas as idades e todos os graus de inteligência estava sentada no escuro aguardando para ser entretida. [A plateia] tem pouca alternativa a não ser olhar para a tela e assistir o curso dos eventos embora possa estar ressentida ou cética sobre o que está acontecendo. Cinco minutos de entretenimento na tela é um longo tempo, particularmente se o interesse pela narrativa não pode ser atraída para manter a atenção do público nos episódios menos excitantes. O desenho animado tem apenas uma responsabilidade - fazer a plateia rir e para mantê-la rindo; não podia se dar ao luxo de perder tempo. Uma gag ou uma piadinha ou uma surpresa do ridicularmente inesperado depende de táticas de choque. Quanto menos antecipação, melhor. $\mathrm{O}$ riso precisa ser evocado antes que a plateia tenha tempo de pensar. E uma vez o clímax tendo sido alcançado, prender a atenção por uma fração de segundo mais tarde irá estragar o efeito. No momento que uma [plateia] se torna consciente de qualquer tentativa de provocar o riso, ela se protege e imediatamente se torna desconfiada e crítica (FEILD, 1947, p. 18-19, tradução nossa)

O autor passa a analisar a estrutura de produção e a evolução técnica e artística dos estúdios Disney no início dos anos 1940. Alguns desses pontos são retomados de forma ainda mais densa no estudo de Steven Watts (1997). Feild afirma que os artistas não são inteiramente limitados pelo business do cinema, podendo explorar diversas possibilidades criativas.

Merece breve menção um estudo mais profundo sobre influências artísticas externas que levaria décadas para ser defendida no âmbito acadêmico. O responsável pelo estudo em questão é o inglês Robin Allan. Entusiasta de Disney, levou 35 anos para realizar o seu sonho de defender uma tese acadêmica sobre o tema. Robin Allan não encontrara espaço porque Disney não era levado a sério para um estudo acadêmico. Por conta de um seminário numa faculdade 
de Manchester, outros acadêmicos se interessaram pelo tema e um deles sugeriu a produção de uma tese de doutorado. Defendida na Universidade de Exeter, foi posteriormente publicada como "Walt Disney and Europe" (ALLAN, 1999).

A pesquisa examina um aspecto de um tema gigantesco: as raízes criativas do império Disney. Mais especificamente, os filmes de animação, que desde o início eram feitos por um norte-americano que desenhava baseado na herança da arte da literatura, grafismo e ilustração européia, incluindo também música e design. Focando nas produções lançadas enquanto Walt Disney era vivo (1901-1966), Allan examinou que praticamente todas elas tiveram forte influência de origem européia, e teve acesso aos artistas que puderam comprovar sua tese incluindo os artistas europeus que fizeram grandes contribuições para os filmes, mas que acabaram submetidos à "máquina" do estúdio.

Em meados dos anos 1930, Walt Disney coletou toda informação que podia sobre artistas europeus, cujos estilos pudessem ser interessantes aos seus projetos. E quando não podia utilizá-los por falta de técnica, contratava quem conhecida o material. Por esse motivo, podemos relacionar que muitos dos artistas do estúdio, imigrantes da Europa, foram treinados em academias européias, e não só levaram consigo a arte e técnica das pinturas, ilustrações e esculturas, como também a tradição de seus países.

Como cita Bruno Girveau ${ }^{14}$, curador da mostra Il Était Une Fois... Walt Disney (Era uma vez... Walt Disney), é possível traçar um paralelo com a arte que inspirou profundamente o estilo Disney, "como o estilo gótico da Idade Média, o surrealismo, a arte de Gustave Doré, Daumier, os pintores do Romantismo alemão, simbolistas, pré-Raphaelistas ingleses e expressionistas" (GIRVEAU apud PEGORARO, 2007, p. 121, tradução do autor).

No entanto, o historiador Michael Barrier (1999) analisa o fato de que na Califórnia dos anos 1930 e 1940, quando os filmes de Disney estavam no auge durante Era de Ouro, "não havia muitos museus com obras dos grandes mestres da pintura. A menos que os artistas tivessem nascido na costa leste americana (ou na Europa) e visitado museus, os artistas Disney eram dependentes de reproduções para ter conhecimento de arte".

\footnotetext{
${ }^{14}$ A exposição Il Était Une Fois... Walt Disney, relacionando Disney e arte européia, foi realizada entre setembro de 2006 e 15 de janeiro de 2007 no Grand Palais em Paris. A exposição também passou por Montreal, entre março e junho de 2007 (GIRVEAU, 2007).
} 
Barrier ainda tem uma teoria sobre a fonte dessas inspirações:

Talvez por esta razão, algumas de suas maiores influências sejam de artistas cujos trabalhos foram espalhados por meio de litografias, gravuras e outros meios de reprodução. Heinrich Kley me vem à mente, mas há outros como Doré, Grandville, Rackham, N. C. Wyeth, e ilustradores alemães (BARRIER, 2007b apud PEGORARO, 2007, p. 121, tradução nossa).

De todo modo, o livro de Robin Allan contribui para entender as influências e o diálogo entre as diferentes linguagens das artes nobres e a criação Disney, incluindo suas nuances como nas experimentações dos anos 1940 envolvendo abstração na produção de "Fantasia" (1940) e as cores quentes e vivas da América Latina em "Você já foi a Bahia?" (1944).

Já Steven Watts, professor da Universidade do Missouri, publicou uma das principais obras sobre a produção Disney, relacionando a cultura norte-americana, o American way of life e o contexto social para explicar a história de Walt Disney. Alguns pontos são relevantes para o contexto histórico da produção.

Na segunda parte do livro, Watts analisa as facetas básicas que tornaram os estúdios Disney uma potência em Hollywood. Elas são três, sendo as duas primeiras relacionadas diretamente ao período da Depressão (pós-crise de 1929). A primeira é o "populismo sentimental". Um dos motivos para o estúdio Disney assegurar e manter tantos talentos artísticos nos anos 1930 seria basicamente a "pobreza". Com a alta do desemprego, os artistas tinham sorte de encontrar abrigo, e o próprio Walt Disney admitia que os tempos difíceis foram responsáveis pelo seu sucesso inicial (WATTS, 1997, p. 63). Não estranhamente, muitos curtasmetragens e quadrinhos continham temas influenciados pelo desastre econômico da década de 1930, como orfanatos, personagens vendendo pertences e atrasos no pagamento de aluguel.

Ironicamente, as massas frequentavam os cinemas em busca de entretenimento. E Mickey Mouse e seus amigos representavam uma espécie de resistência aos tempos difíceis. O curta-metragem vencedor do Oscar "Os Três Porquinhos" (1933) teve sua canção tema "Quem tem medo do Lobo Mau?" transformada em instrumento de apaziguamento social, um verdadeiro fenômeno cultural. Seu estrondoso sucesso dividiu a opinião de intelectuais que não compreendiam como tal desenho animado alcançara tamanho status. Ao mesmo tempo, os 
estúdios Disney faturaram o suficiente para modernizar sua técnica, incluindo gravação sonora, a inserção de cores e o multiplano nos cenários.

A segunda faceta durante a Depressão seriam as "parábolas populistas". O autor descreve que os filmes de animação de 1937 a 1942 (Branca de Neve, Pinóquio, Fantasia, Dumbo e Bambi) não apenas se tornaram centrais e amados pelo legado Disney, mas estabeleceram uma elevada marca criativa, apresentando uma integração complexa de entretenimento variado e de elementos artísticos (WATTS, 1997, p. 83). Além disso, dividem uma confiança comum ideológica. Em vários níveis, destacam os aspectos políticos da Disney no período da Depressão, e o processo que transformou o próprio Walt Disney num herói popular para todos os norte-americanos.

Por muitos anos, segundo Watts, críticos observaram implicações políticas no trabalho de Disney e o tornaram um ícone do populismo cultural. Seus filmes, quase sempre, respondem à filosofia capitalista de Walt Disney, promovendo a excelência e o humanismo. Incontáveis críticos corroboraram o impacto social do cineasta. Disney foi elogiado como alguém que "satiriza a ideia da sobrevivência do mais apto" (WATTS, 1997, tradução nossa), uma tradição econômica do laissez faire que persiste até os dias de hoje. Outros o denunciaram como o líder de um grupo de populistas desproporcionados. Mickey Mouse tornara-se um herói internacional para o homem comum, tendo capturado as massas:

Um fato permanece. A Disney da década de 1930 não era uma divulgadora sincera de dogmas políticos, mas sim era autoconsciente, e provavelmente mais influente e poderosa para isso. $\mathrm{O}$ apelo de seu populismo sentimental era visceral. Para uma audiência de massa de americanos que sofrem privação social e econômica, durante a Depressão, mas anseiam por um ressurgimento da esperança, do riso, e da fé em si mesmos, a visão social do Mickey Mouse, dos Três Porquinhos e Dumbo, provou ser tanto uma catarse e uma reafirmação. Nestes filmes, assim como muitos outros, Walt Disney exerceu uma influência política que a maioria dos políticos só podiam sonhar. (WATTS, 1997, p. 100, tradução nossa)

A terceira face, mais relacionada a uma evolução do estúdio, é o "modernismo sentimental". Nas décadas de 1930 e 1940, intelectuais no mundo todo debatiam a validade artística das produções Disney. Watts reafirma que Disney não era evitado pela intelligentsia, e que nos anos 1930 era chique argumentar que a América havia produzido duas novas formas de arte próprias - o jazz e Walt Disney. No Brasil, intelectuais dedicavam amplo espaço para 
discutir Disney. A edição no 5 da revista Clima, de outubro de 1941, é quase totalmente dedicada ao estudo e à crítica de "Fantasia" (1940), com trabalhos de Rui Coelho, Sergio Milliet, Oswald de Andrade, Paulo Emílio de Sales Gomes, Francisco Luis de Almeida Sales, Flavio de Carvalho e Plínio Sussekind Rocha (PEGORARO, 2012).

Walt Disney, por sua vez, molda a estética de seus filmes de um modo vago, não intencional e ambíguo. Ao mesmo tempo que se interessava por risos, inovações e vendas, ele tropeçou na arena da arte modernista dos anos 1930 e começou a experimentar suas formas e técnicas. Seu coração, entretanto, continuou a bater no ritmo do realismo sentimental do século XIX (WATTS, 1997, p. 102). O resultado é um híbrido estético e cultural, que, dentre outros aspectos de seu legado, juntou elementos de inovação com tradição. Isso contribuiu para que seu público conhecesse uma nova época cultural.

Quem assiste a uma animação Disney a partir do fim dos anos 1930, percebe uma preocupação com o realismo gráfico dos personagens e de suas ações. Ao mesmo tempo, temos situações fantásticas que se contrapõem a esse realismo sentimental. Watts analisa que Disney tentou ao longo dos anos equilibrar elementos da "alta" e da "baixa" arte, mas não conseguiu impedir uma transformação estética oriunda do movimento modernista americano, resultando mesmo assim num híbrido atraente. A isso, o autor descreve como "modernismo sentimental":

\footnotetext{
O "modernismo sentimental" tem várias características-chave. A primeira é que mistura o real e o irreal, o naturalismo e fantasia, de modo a manipular cada um numa tentativa de iluminar o outro. O segundo, garantiu explorações modernistas não-lineares, irracionais, quase abstratas confortavelmente no mapa cultural através da utilização de certas alegorias do passado Vitoriano o sentimentalismo exagerado, o moralismo claramente definido, uma fofura inocente - como sinalizações artísticas familiares. Terceiro, de boa vontade cavou através das camadas de consciência para envolver a fluidez da experiência e da ação, mas sempre voltou a abraçar a racionalidade. Quarto, ele animou o mundo - literalmente - por atribuir intenção, consciência, emoção e vida a objetos inanimados, mas o fez de tal forma a minimizar a presença do mal e da tragédia. Quinto e finalmente, há um bom humor satirizando as pretensões da alta cultura e procurou revigorá-lo com a vitalidade de expressão da cultura popular. (WATTS, 1997, p. 104-105, tradução nossa)
}

Do mesmo modo em que buscava a espontaneidade, Disney promoveu cursos de especialização a todos os seus artistas para que alcançassem um traço mais realista e perfeito. Os filmes ganharam cenários detalhados, perspectiva mais acentuada, o uso da rotoscopia e do multiplano e diferentes fusões artísticas, desde que dentro dos padrões estabelecidos. No campo 
da produção, lembrando Feild (1947), uma das grandes realizações de Disney foi recuperar a grande tradição das oficinas, em que o artista como trabalhador é dedicado ao cumprimento de um propósito, e se contenta em permanecer anônimo.

Entretanto, os artistas se tornaram infelizes com o anonimato e com a política de Walt Disney de creditar a si mesmo pelo trabalho produzido por vários artistas. Os longas-metragens passaram a ter créditos, mas a reivindicação continuou para que os créditos fossem dados aos artistas em todas as produções. O argumento, verdadeiro, é que poucos artistas (normalmente os creditados) ganhavam salários muito maiores que os dos outros, alguns até com mais anos de trabalho no estúdio. Não havia organização trabalhista e o ganho, sem uma meritocracia definida, incomodava. Isso contribuiu para o início da famosa greve de 1941, que paralisou os estúdios Disney.

Em relação à indústria, Walt Disney se tornou grande representante do novo consumismo dos anos 1950, quando houve uma intensa comercialização do lazer. Foi o início da era das interações intensas das estruturas dos estúdios de Hollywood, redes de rádio e televisão, agências de publicidade, gravadoras e das cadeias de jornais e revistas. Segundo Watts (1997, p. 362) a "indústria cultural" lentamente dominou toda a informação e entretenimento nos Estados Unidos pós-guerra, em que grandes corporações produzem em massa commodities culturais por técnicas industriais para, então, promovê-las, divulgá-las e vendê-las para uma enorme audiência nacional. Na década de 1950 o cinema sofre com um declínio na venda de ingressos, o que leva os estúdios de Hollywood a investirem em grandes produções épicas no formato Cinemascope, exibições em 3D e todo tipo de novo atrativo para manterem seu público. A evolução e a popularização da televisão criaram uma nova opção de entretenimento que os estúdios demoraram para assimilar.

Walt Disney foi bastante hábil em se aproveitar das novidades tecnológicas. Enquanto os estúdios de cinema temiam a concorrência da televisão, Disney afirmava que não tinha receio e a usou para promover suas produções e mais tarde fez com que o parque Disneylândia se tornasse conhecido mundialmente. Isso representou uma sinergia perfeita não apenas para divulgação e consumo, mas empregou novos meios de produção para se aproveitar os benefícios da integração. Tanto os quadrinhos e a animação tiveram seus temas alterados para incorporar progressivamente as novidades urbanas e o novo American way of life. As aventuras rurais e as buscas por tesouro em terras distantes dão mais espaço aos conflitos urbanos e as relações de 
consumo. Mais tarde, Walt Disney desenvolveria uma nova faceta de "populismo tecnocrático" (WATTS, 1997, p. 442), que teria implicações políticas e sociais, com seus interesses voltados para novidades industriais e reforma urbana que culminaria em seu projeto EPCOT que iam contra o pensamento vigente do liberalismo dos anos 1960, que pregava o afastamento do Estado e dos programas governamentais para combater problemas sociais. EPCOT, acrônimo para Experimental Prototype Community of Tomorrow (Protótipo Experimental Comunidade do Amanhã), foi um conceito desenvolvido por Walt Disney perto do fim de sua vida. Trata-se de uma "comunidade do futuro" que foi projetada para estimular corporações americanas a terem novas ideias para a vida urbana (THOMAS, 1994). O conceito evoluiu para se tornar o parque temático Epcot aberto em 1982 em Orlando, Flórida.

No que diz respeito a este processo híbrido, a partir da década de 1960 outros teóricos norte-americanos irão classificar este fenômeno dentro do conceito de "Cultura Pop" (Pop Culture). Segundo Roberto Elísio dos Santos (2002, p. 45), os "produtos culturais industrializados e difundidos pelos meios de comunicação de massa absorvem e dão novas formas e sentidos a elementos característicos de outras instâncias culturais (eruditas, populares, regionais, modernas, tradicionais, etc)". Este processo é feito de modo a simplificar e universalizar o produto, tornando-o mais complexo e aberto a novas leituras e interpretações. Uma das vantagens é justamente sua disseminação rápida sem grandes prejuízos à cultura local e tradicional. 


\section{HISTÓRIAS EM QUADRINHOS E ANIMAÇÃO: ORIGENS E PRODUÇÃO}
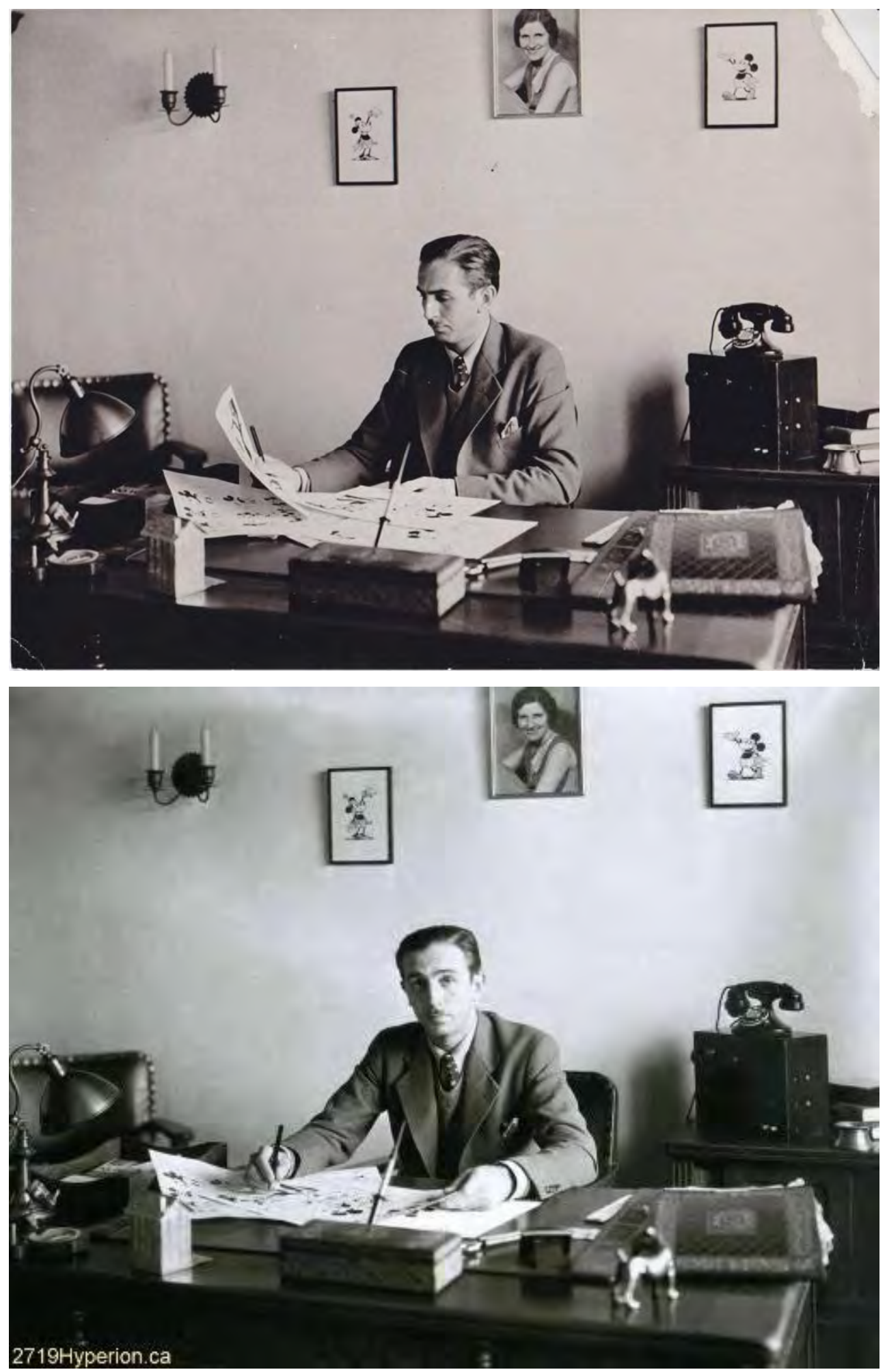

Figura. 8 e Figura. 9 - Walt Disney supervisionando as histórias em quadrinhos nos anos 1930. 
A história do cinema e a do cinema de animação estão amplamente ligadas, "não apenas pelo princípio da recomposição do movimento ser o mesmo em filmagem real e na animação (ainda que a prática seja diferente), mas também porque a descoberta do cinema se fez em grande parte com a ajuda de descobertas científicas que empregavam técnicas gráficas, mesmo depois da fotografia" (DENIS, 2010, p. 41-42).

Outro aspecto curioso e interdisciplinar é quando se discute a relação da animação com os quadrinhos e o humor gráfico na imprensa. Os animadores pioneiros se interessavam pela animação a partir da caricatura - caso de artistas como Blackton, Méliès, McCay, Cohl, Barré, Hurd, Messmer, Terry, O’Galop, e também os animadores do Leste Europeu têm como origem o desenho de imprensa. A diversão viria do meio mecânico de expressão e difusão:

O traço do lápis dos desenhistas tem um papel importante na leitura do jornal. Esta imagética (desenhos que caricaturam políticos, atores, homens do mundo ou trazem pequenas histórias cômicas), detém o papel que mais tarde será atribuído ao desenho animado na composição da sessão de cinema (DENIS, 2010, p. 45).

Além das caricaturas, as tiras e histórias em quadrinhos serviram de base para uma convergência das linguagens. As tiras representaram uma influência central para a animação, com muitas trocas representativas do desenvolvimento de uma sociedade midiática em plena revolução, com imprensa e o cinema. Sébastien Denis (2010, p. 49) afirma que "num primeiro tempo é nos Estados Unidos que as conexões entre os cartoons, as comic strips e os desenhos animados vão ser mais fortes. Os nomes são, aliás, intermutáveis, e primeiro falar-se-á de animated cartoon". Portanto, grande parte dos desenhos animados pioneiros teve origem nas histórias em quadrinhos como fonte de inspiração, podendo citar "Litttle Nemo" de Winsor McCay, "Krazy Kat" de George Herriman, "Hans and Fritz" de Rudolph Dirks e "Mutt and Jeff” de Harry "Bud" Fisher.

A facilidade econômica da produção de curtas-metragens de animação baseados em quadrinhos fez com que se tornassem sucessos imediatos, ao longo do século XX, por exemplo, Popeye criado em 1929 por Elzie Segar (produzido pelo estúdio Fleischer em 1933), Snoopy (1952) de Charles Shultz, que se tornou animação na década de 1960, e pelo mundo afora outras adaptações ocorreram, como o francês Pieds Nickelés de Forton (adaptado depois por Cohl), 
Mafalda em 1982 (a obra de Quino foi adaptada pelo animador cubano Juan Padrón, 1964), Titeuf em 2001 (adaptado por Zep, 1992).

A relação quadrinhos - animação também é nítida (DENIS, 2010, p. 50) quando analisamos que as adaptações de maior sucesso foram baseadas nos quadrinhos de super-heróis da Marvel e DC Comics (Superman, Batman, Capitão América, Homem Aranha, etc). Ao mesmo tempo observamos a relação também envolvendo os quadrinhos underground durante o período da contracultura nos anos 1960 e 1970, tendo como exemplo Fritz the Cat de Robert Crumb (animação de Ralph Bakshi). No Japão, temos a relação quadrinhos (mangá) e a animação (anime) desde Osamu Tezuka, o “inventor” do mangá moderno, produtor do seriado para televisão Astro Boy (1963) inspirado no mangá de 1951. Na Europa, a escola franco-belga dos quadrinhos também fomentou diversas animações inspiradas nas obras de Tintin (Hergé), Os Smurfs (Schtroumpfs) de Peyo que se tornaram populares nos Estados Unidos graças à animação dos estúdios Hanna-Barbera; e Asterix (Uderzo e Goscinny), que resultou em uma série de longas de animação.

\subsection{O Padrão Disney: Quadrinhos}

Tendo descrito muitas características do padrão Disney de animação, torna-se necessário uma breve conceituação do padrão dos quadrinhos Disney. A principal fonte para isso é a tese de doutorado de Roberto Elísio dos Santos (2002) na Universidade de São Paulo, que não apenas é um bom contraponto as críticas ideológicas, mas também adiciona um marco teórico quanto a análise da produção em quadrinhos Disney. Pretendemos aproveitar este estudo para um desdobramento da análise do período posterior. O próprio autor destaca a problemática da relação quadrinhos-animação:

Mesmo tendo como protagonistas os mesmos personagens, trata-se de produtos culturais distintos, que até possuem pontos de contato, mas que também diferem em vários aspectos (de linguagem à temática, ao ritmo, à maneira como os personagens são mostrados, etc). Fica aqui, então, aberta a possibilidade para uma análise específica dos desenhos animados Disney e da relação destes com os quadrinhos, o que pode render outros trabalhos de pesquisa (SANTOS, 2002, p. 18).

A história em quadrinhos, portanto, pode ser descrita como uma forma de comunicação visual impressa (ainda que exemplos de narrativas gráficas sequenciais possam ser lidas na 
internet). Os quadrinhos possuem elementos verbais e visuais, dois códigos de signos gráficos (o primeiro, digital e o segundo, analógico) - em uma seqüência, narrando uma história: “A grande maioria das mensagens dos quadrinhos, no entanto, é percebida pelos leitores por intermédio da interação entre os dois códigos" (VERGUEIRO, 2010, p. 31). Diferentes elementos (muitos deles criados dentro do ambiente próprio dos quadrinhos) foram criados para atingir o objetivo dos autores, ao longo dos anos, permitindo maior rapidez na comunicação exigida por uma mídia de massa por excelência. Além disso, trata-se de um produto cultural e comercial, o que implica grande reprodutibilidade e periodicidade constante" (SANTOS, 2002: 21).

Vergueiro (2010, p. 51-52) também destaca que a maioria das histórias em quadrinhos produzidas pela grande indústria costuma ter um protagonista fixo, constituindo o que se costuma chamar de série. O protagonista é graficamente distinto dos demais em suas características sociais, intelectuais e físicas, com uma presença destacada (normalmente o mesmo tipo de roupa) para fácil identificação do leitor. Em alguns gêneros, como o dos superheróis, apresentam maior uso de personagens estereotipados (especialmente os secundários), e a representação gráfica dos personagens respeita o estilo dos quadrinhos - caricata é uma tendência para personagens cômicos, e mais realista para histórias de aventuras.

Quanto ao gênero, os quadrinhos Disney são classificados como funny-animals. Apresentam personagens, em sua maioria, na forma de bichos (ratos, cachorros, patos, gansos etc.) falantes e inteligentes representando o ser humano por meio de paródias e imitações de suas atitudes e reproduzindo suas idéias (SANTOS, 2002, p. 80). Por esta razão, artistas de diferentes locais e períodos conseguem incorporar elementos próprios de sua época e cultura nas narrativas.

Santos (2002, p. 76-78) explica que as histórias com animais falantes ou antropomorfizados fazem parte da cultura e do imaginário Ocidental há milhares de anos, com exemplos nas religiões zoomórficas primitivas, nas fábulas e nos ensinamentos de moral. No Japão, há exemplos de narrativas iconográficas com os mesmos elementos. Levando-se em conta a caricatura e o absurdo, o leitor consegue ter empatia e legitima uma verossimilhança por meio dos mecanismos simples da fantasia e do humor (ou ironia). Dando ao autor maior liberdade ante as limitações da sociedade humana, pode com isso distorcê-los ou reestruturálos impunemente para parodiar ou satirizar (incluindo a crítica social e a sátira política), isso 
sem retirar o aspecto agradavelmente fantástico da arte gráfica ao leitor. No que diz respeito ao universo dos personagens nos quadrinhos, é possível fazer uma divisão em três grupos:

Com o tempo, o universo iniciado por Disney foi se expandindo, arregimentando novos personagens (criados para os desenhos animados ou diretamente para os quadrinhos). Personagens secundários que ganhavam a simpatia dos leitores ou espectadores dos desenhos animados passavam a protagonizar suas próprias histórias (ainda chegaram a ter suas publicações). De maneira geral, é possível distinguir três grupos de personagens - embora os componentes de cada grupo possam se relacionar com os de outros, se assim o argumento exigir. Os dois principais grupos, "A Turma do Mickey" e "A Família Pato", são típicos do gênero funny-animals, e suas histórias são encontradas em maior quantidade nos quadrinhos; o terceiro grupo, aqui denominado "Terra da Fantasia", reúne os tipos provenientes das animações". (SANTOS, 2002, p. 97)

Estas divisões em grupos serão utilizadas na presente pesquisa de modo a organizar a coleta de dados de produção, com destaque para a produção dos últimos quinze anos, para posterior análise.

A proposta de sequência na pesquisa envolve a organização e a coleta de dados da produção Disney, em resposta à primeira hipótese [a produção cultural Disney passa por um momento de transição criativa, levando em consideração que o processo aparentemente é cíclico quando compreendemos o processo histórico Disney e a expansão do universo de personagens]. Em um primeiro momento, os dados incluem a produção em quadrinhos e animação desde o seu início. A organização em tabelas é feita, em parte, inspirada pela divisão proposta por Roberto Elísio dos Santos (2002) em sua tese.

O levantamento da produção cinematográfica é feito igualmente por via de tabelas, com o uso de livros e documentos com informações relativas aos lançamentos. No caso específico dos filmes, há uma série de divisões nesta área, que serão analisadas no momento adequado, que serão ainda alvo de avaliação devido à polêmica que cerca a classificação de alguns filmes pela própria Disney. É o caso, por exemplo, dos filmes ditos "clássicos", produzidos pelo estúdio principal (denominado atualmente Walt Disney Animation Studios). Alguns filmes, produzidos por divisões "menores" dentro da própria Disney foram incorporados na lista de produções "clássicas". E há uma complexa divisão que envolve os departamentos de produção para televisão e os estúdios "satélites" que a Disney opera fora dos EUA. 


\subsection{História e a importância da indexação da produção}

O registro mais antigo (até o presente momento) de produções Disney no Brasil data de 3 de janeiro de 1930. Neste dia, os cinemas cariocas Primor (centro) e Mascote (Méier) anunciaram no Jornal do Brasil a exibição de dois desenhos animados de Mickey, respectivamente, "O Camondongo Farrista" (Mickey's Follies, 1929) e "Camondongo Machinista" (Mickey's Choo-Choo, 1929). Este último com o seguinte destaque: "fallado, cantado e syncronizado" (1930).

Dez dias depois (13 de janeiro de 1930), estreia nos jornais americanos a tira de Mickey, distribuída pelo King Features Syndicate, com roteiro do próprio Walt Disney, desenhos de Ub Iwerks e arte-final de Win Smith (MOYA, 1996; VERGUEIRO, 2005). Iwerks, então principal animador e colaborador de Disney, desenharia apenas as primeiras dezoito tiras. Em 21 de janeiro, em viagem a New York, Walt descobre que seu distribuidor, Pat Powers, havia assinado contrato com Iwerks, que deixaria Disney para abrir seu próprio estúdio de animação. A tira já estava sendo publicada há 11 dias quando Walt aproveita a viagem para assinar com a King seu primeiro contrato de licenciamento (BARRIER, 2007).

Iwerks seria substituído temporariamente nas tiras por Win Smith e posteriormente por Floyd Gottfredson. Ainda assim, em 11 de março, Mickey estreia nos jornais finlandeses e Iwerks é citado em nota publicitária como o artista responsável pelas tiras. Dias depois, na edição 1226, de 26 de março, a revista "O Tico-Tico" lança as tiras de Mickey no Brasil sob o título "O camondongo curioso" com "exclusividade para o território nacional" (VERGUEIRO, 2005).

Se, já em 1931, Gugliemo Guastaveglia desenha na Itália, para o jornal "Il Popolo di Roma", as primeiras histórias Disney extraoficiais, era questão de tempo para que a demanda por personagens Disney fizesse surgir polos locais de produção desses quadrinhos, inclusive no Brasil.

Em 1932, Disney lança duas tiras dominicais: uma de Mickey e outra das Sinfonias Tolas (Silly Simphonies), inspirada na série de desenhos animados homônima - sem personagens fixos - de 1929. As Sinfonias começam com as 
aventuras do bichinho Bucky - primeiro personagem Disney a estrear nos quadrinhos. Pato Donald ganha tira própria em 7 de fevereiro de 1938. Além do Tico-Tico e dos seus almanaques anuais, essas tiras são publicadas no Brasil em vários suplementos e revistas infantis no decorrer dos anos $1930 \mathrm{e}$ 1940, como "Mirim” (1937-45), “Globo Juvenil” (1937-52), “Gibi” (193950), “O Lobinho" (1940-54), “Guri” (1940-54), "Suplemento Infantil/Juvenil” e "Gazetinha" (SANTOS, 2011'a , tradução nossa).

Explica Roberto Elísio dos Santos (2011b): "Nesses periódicos, as tiras com os personagens Disney dividiam o espaço com histórias de outros personagens distribuídos por syndicates americanos e com histórias feitas por artistas brasileiros." Alguns desses artistas, como J. Carlos, Walter Maia e Oswaldo Storni, ilustram, extraoficialmente, os personagens Disney em capas, ilustrações e anúncios, inclusive assinando esses desenhos.

Além dos suplementos, havia também mini-livrinhos, os chamados "tijolinhos", que adaptavam as tirinhas de jornal em forma de contos ilustrados. Essas coleções foram inicialmente lançadas no Brasil pela EBAL (Editora Brasil-América Limitada), do editor Adolfo Aizen. A mesma editora publicou, em 1946, 17 números da revista Seleções Coloridas (13 traziam histórias Disney), em conjunto com a Editorial Abril da Argentina. Essa editora, que já editava em seu país "El Pato Donald” desde 1944, publica em 1948 três séries de livros ilustrados com títulos Disney: "Pequenos Grandes Livros", "Eu sou...” e "Contos de Abril”.

A Editorial Abril tinha como desenhistas Susana Hochstimm (também secretária editorial), Salvador Schiffer e Luis Destuet (falecido em 2002). Destuet desenhou a capa do primeiro $O$ Pato Donald brasileiro, lançado em 1950 pela Editora Abril brasileira, de Victor Civita, e veio ao Brasil ensinar sua técnica aos brasileiros. Com a Abril, as revistas Disney passaram a ser publicadas regularmente no país (SCARZANELLA, 2009).

Além das capas, os brasileiros começaram a criar histórias ilustradas, charges, caricaturas e, eventualmente, anúncios, para preencher o editorial do Pato Donald e da revista Mickey, lançada em 1952. Até que, em dezembro de 1959, foi publicada a primeira história em quadrinhos brasileira propriamente dita: "Papai Noel por Acaso", desenhada por Jorge Kato. 
Com o lançamento da revista Zé Carioca, em 1961, a produção brasileira começa a se tornar regular. No mesmo ano, Waldyr Igayara torna-se assistente de Kato. A demanda, porém, era maior que a capacidade de produção e a dupla adapta histórias estrangeiras, substituindo Mickey e Pato Donald pelo Zé Carioca, no período conhecido como Zé Fraude (1962-63). A revista “Tio Patinhas” é lançada na mesma época (1963).

Após breve ausência, Igayara retorna à Abril, criando muitas gags do Zé Carioca, enquanto Kato se dedica às capas. Com o lançamento da revista infantil "Recreio" (1969), do qual Igayara era co-criador e diretor, Izomar Camargo Guilherme e Carlos Edgard Herrero ilustram o Zé Carioca, até que, no início dos anos 1970, o papagaio é "adotado" por Renato Canini, que em parceria com outros roteiristas (especialmente Ivan Saidenberg), desenvolve o personagem no seu traço pessoal e diferenciado.

Os anos 1970 foram a década da "profissionalização" dos estúdios de quadrinhos da Abril. Claudio de Souza, responsável pelo setor, tinha grandes planos para as revistas infantis. O primeiro passo foi a participação da Abril na produção de histórias para o Studio Program. Os estúdios Disney enviavam argumentos para as editoras licenciadas para serem desenhadas, que então eram publicadas e exportadas pelo estúdio para outras editoras.

O segundo passo nessa ampliação foi a contratação de Primaggio Mantovi, que havia lançado pela Editora Rio Gráfica o palhaço Sacarrolha, única revista em quadrinhos, fora da Abril, que vendia mais de cem mil exemplares. Primaggio ${ }^{15}$ não somente criou novas histórias Disney, mas também organizou a "Escolinha Disney", projeto em que escritores e artistas promissores eram empregados para aprender a trabalhar no padrão Disney. O lançamento do Almanaque Disney, em 1972, trouxe pela primeira vez no expediente das revistas Disney, o nome de todos os funcionários e colaboradores.

Ocasionalmente, durante os anos 1970, 80 e 90 os nomes de alguns artistas por trás das histórias Disney nacionais foram revelados ao público. Assim como Carl Barks, criador do Tio Patinhas, que teve seu nome tornado público pela primeira vez em uma nota de seu jornal local, o nome de Renato Canini também se tornou público ao ser pauta de matéria do jornal

${ }^{15}$ MANTOVI, Primaggio. Conversa informal com o autor, ca. 2012 
Zero Hora, de Porto Alegre, cidade onde o artista voltou a morar depois de um período em São Paulo, trazendo na mala a incumbência de desenhar o Zé Carioca.

Mas as primeiras histórias brasileiras efetivamente creditadas foram uma série de seis narrativas promocionais sobre a Marinha, Exército e Aeronáutica, escritas por Ivan Saidenberg e desenhadas por Ignácio Justo, publicadas entre 1973 e 1976 no "Almanaque Disney". Da segunda história em diante, Zé Carioca e seus sobrinhos narram as histórias, desenhados por Carlos Edgard Herrero, enquanto Justo faz os cenários, mas Herrero não aparecia nos créditos (comunicação pessoal) ${ }^{16}$.

A partir de 1976, os quadrinistas da editora são agraciados com o "Prêmio Abril de Jornalismo". Revistas, destacando os indicados e premiados, são distribuídas para os funcionários. Em 1977, a Abril lança a coleção "Grande Almanaque Disney”, vendida em fascículos. Cada número é dedicado a um personagem e apresenta, entre outros conteúdos, a história do personagem ilustrada por um desenho de um artista da Abril, com seu nome e características destacadas nas legendas.

Essas iniciativas são reflexo do posicionamento da Editora Abril em tornar claro aos seus leitores que boa parte do material que estavam comprando tinha sido criada no Brasil. Um exemplo é o artigo sem autor publicado em outubro de 1981, no suplemento “A Patada" número 4 (encartado na edição 195 de "Tio Patinhas"), que afirma: "Desde 1960 o Brasil participa da 'criação' de histórias em quadrinhos Disney, sendo atualmente um dos maiores produtores (cerca de 2.500 páginas por ano, com uma qualidade invejável). Para isso temos os nossos próprios 'cobras', autores brasileiros que têm se igualado aos melhores de outros países" (A PATADA, 1981, p. 4).

No decorrer da década de 1980, a Abril desenvolve sua própria base de dados, em conjunto com a USP, que pretendia, principalmente, organizar as histórias disponíveis para republicação. Waldyr Igayara (comunicação pessoal) ${ }^{17}$ comentou informalmente a este autor: "Disney Especial era feito por um programa de computador". Uma vez escolhido o tema, o

\footnotetext{
${ }^{16}$ HERRERO, Carlos. Edgar.Conversa informal com o autor, ca. 2012

${ }^{17}$ IGAYARA, Waldir. Conversa informal com o autor, ca. 2000.
} 
próprio programa montava a programação da revista, que tinha mais de 200 páginas. O roteirista Ivan Saidenberg participou dessa catalogação, antes de sair da Abril, em 1984.

No editorial da revista "Edição Extra" número 4 (17 de março de 1986), dedicada à série "Patrulha Estelar", o diretor de redação Júlio de Andrade toma a liberdade de identificar os autores, inclusive ele próprio: Gérson Teixeira, Júlio de Andrade (roteiros) e Moacir Rodrigues Soares (desenhos). Segundo Primaggio Mantovi (comunicação pessoal) ${ }^{18}$ aquilo foi um "abuso de poder" de Júlio, que pelo contrato com a Disney, não poderia ter tomado essa liberdade. Nesse mesmo ano, a editora Gladstone, de Bruce Hamilton, adquire a licença para publicar quadrinhos Disney nos Estados Unidos, mas somente depois da Disney ter aceitado a imposição de Hamilton em creditar os artistas (1994).

Em 1989, a Abril lança a coleção "Anos de Ouro do Zé Carioca”, série de quatro edições de 224 páginas cada uma, compilando fac-símiles das primeiras 52 revistas do "Zé Carioca" e textos explicativos. No terceiro volume uma série de tiras inéditas, com créditos impressos, apresenta aos leitores o trabalho e os nomes de alguns dos principais autores brasileiros do "Zé Carioca": Carlos Rangel, Jorge Kato, Renato Canini, Arthur Faria Jr., Euclides Miyaura, Gérson Teixeira, Eli Leon, Kaled Kalil Kambour e Moacir Rodrigues Soares. Uma notável ausência foi a de Waldyr Igayara, que havia se aposentado da Editora Abril e abriria sua própria escola de arte.

No ano seguinte é lançada "Graphic Disney”, revista especial inspirada em projeto similar, uma graphic novel dos Trapalhões, em produção na redação vizinha. Júlio de Andrade tentou, sem sucesso, convencer a Disney a permitir a publicação dos nomes dos autores na revista. Os créditos foram revelados na reportagem "Tio Patinhas e sobrinhos perdidos no Espaço" no jornal O Estado de S. Paulo, escrita por Marcelo Alencar (1991), na época editor na Abril.

Nos anos 1970 e 1980, surgiram as primeiras catalogações impressas de histórias em quadrinhos Disney que abordavam, principalmente, dados sobre revistas, histórias e criadores americanos e europeus. E em 1992 o programador sueco Per Starbäck criou na internet a lista de discussão Disney Comics Mailing List. Ele escreve, no dia 4 de agosto:

${ }^{18}$ MANTOVI, Primaggio. Comnversa informal com o autor,ca. 2006. 
Tenho trocado algumas mensagens eletrônicas sobre quadrinhos Disney nos últimos anos, e sei que há muitas perguntas e respostas rodando por aí. Existem também índices, checklists e outros materiais que beneficiaria a todos se distribuídos de forma mais ampla"19.

Em breve os membros começam a trocar listagens de histórias, personagens e autores, cruzando informações com os antigos catálogos impressos. Em maio de 1994, o holandês Harry Fluks cria uma base de dados para organizar essas listagens (até então disponíveis em um site FTP).

Enquanto isso, na Editora Abril, Primaggio Mantovi estava à frente da redação Disney novamente e fechou acordo com os estúdios Disney para a produção de "prequels", histórias em quadrinhos com os personagens dos novos filmes animados Disney. As primeiras histórias, baseadas em "O Corcunda de Notre Dame" foram publicadas nas edições de linha em 1997, com um editorial destacando a produção e seus autores.

Em 1999, Arthur Faria Jr., roteirista Disney, começou a colaborar com o Inducks, adaptando sua própria base de dados ao sistema desenvolvido por Harry Fluks.

Nos primeiros índices, Arthur lista todas as histórias brasileiras de sua coleção, seus respectivos personagens, número de página, layout, em que revista foram publicadas e identifica, além de seus próprios roteiros, grande parte dos desenhistas. Isso só foi possível porque, diferentemente de outras histórias brasileiras produzidas por "fantasmas", os artistas Disney puderam com o tempo desenvolver estilo próprio, ainda que dentro do padrão disneyano.

Fernando Ventura começou a colaborar em 1999 no índice brasileiro. Fernando era aluno da escola de arte de Waldyr Igayara e há pouco havia começado a criar quadrinhos para a Disney. Correções sobre a listagem de Igayara e a inclusão de créditos de centenas de histórias arte-finalizadas por José Wilson Magalhães, também professor da escola de Igayara, são suas primeiras adições ao projeto (comunicação pessoal) ${ }^{20}$.

\footnotetext{
${ }^{19}$ Texto registrado no arquivo online da DCML (The Disney Comics mailing list) http://stp.lingfil.uu.se/ starback/dcml/list.html

${ }^{20}$ VENTURA, Fernando. Conversa informal com o autor, ca. 2012.
} 
Em 2001, autores de histórias em quadrinhos Disney começam a tomar conhecimento do Inducks e enviam dados sobre suas histórias (Marcelo Milani, Xalberto). Procurados por Fernando, outros artistas listam as narrativas que produziram ao longo dos anos: Oscar Kern, Gérson Teixeira, Ivan Saidenberg, Rosana Rios, Marcelo Aragão, Joerly Nascimento Santos, Rafles Magalhães Ramos, Gustavo Machado e Alexandre Silva.

Outros autores, que não haviam compilado suas obras, como Álvaro de Moya, Renato Canini, Primaggio Mantovi, Euclides Miyaura, Marcelo Verde e Denise Ortega corrigem dados e créditos de suas histórias (e de outros autores). Para fazer esse levantamento foi necessária uma intensa troca de e-mails, cartas, fotocópias e scans de histórias. A lista das que foram escritas por Júlio de Andrade, perdida em uma enchente, começa a ser reconstruída e créditos escritos nos originais de algumas histórias também são incorporados ao Inducks.

Em 2003, Roberto Elísio dos Santos publica um artigo no site Omelete, criticando o maltrato da Abril com as publicações Disney. Ele afirma:

\begin{abstract}
A Editora Abril tem colocado nas bancas essas revistas de maneira burocrática, desapontando os fãs e impedindo uma aderência maior dos leitores eventuais que poderiam se tornar compradores regulares destes títulos. (...) Outro desleixo das edições nacionais refere-se à falta de créditos nas histórias. E não é por impedimento da empresa Disney, uma vez que o próprio gerente de publicações no Brasil, André Bogsan, afirma não ter nada contra isso. (SANTOS, 2003)
\end{abstract}

A matéria causa impacto e em pouco tempo os créditos começam a ser publicados regularmente, inicialmente apenas nos quadrinhos estrangeiros. Após uma consulta jurídica, os créditos das histórias nacionais também passam a ser vistos nas republicações. As fontes destes nomes eram o Inducks e os antigos registros de produção da editora Mônica Alves. Em paralelo às pesquisas de créditos, Arthur e Fernando receberam auxílio de outros colecionadores na catalogação das revistas (hoje são trinta pessoas, apenas na parte brasileira). Graças a esse esforço conjunto são disponibilizadas, entre 2006 e 2010, catalogações completas das principais revistas da linha Disney: “Almanaque Disney”, "Edição Extra”, "Tio Patinhas”, "Zé Carioca”, "Mickey" e "O Pato Donald", com correções e adições sendo adicionadas diariamente (comunicação pessoal) $)^{21}$.

${ }^{21}$ VENTURA, Fernando. Entrevista com o autor, ca. 2012 
Após uma década de pesquisas, o Inducks revela números impressionantes sobre a produção nacional de quadrinhos Disney: em quatro décadas, a Abril produziu, pelo menos, 7.790 histórias em quadrinhos Disney. Destas, aproximadamente 77\% são de desenhistas conhecidos e $47 \%$ de roteiristas conhecidos. O projeto revela também que a Abril publicou até 2014 pelo menos 7.570 revistas e 39.232 histórias em quadrinhos Disney (20,3\% de todas as histórias em quadrinhos Disney conhecidas). Se incluída sua participação nos mercados argentino e português, a Abril também é a editora que mais publicou quadrinhos Disney no mundo todo, com 7.693 edições registradas (PEGORARO e VENTURA, 2013).

A catalogação de revistas em quadrinhos Disney brasileiras no Inducks parece caminhar para o final. Em algum tempo, apenas edições novas precisarão ser incorporadas, mas ainda existem desafios: os raros suplementos dos anos 1930 e 1940 ainda não foram listados ou indexados. Revistas como "Disney Especial", "Superalmanaque" e "Família Dinossauros" ainda não foram completamente catalogadas ou ainda não fazem parte do banco de dados. $\mathrm{O}$ maior desafio, porém, parecem ser as revistas de atividades publicadas nos anos 1970 e 1980, que, eventualmente, também traziam quadrinhos, ignoradas pela maior parte dos colecionadores.

Em relação aos créditos, novas informações têm surgido esporadicamente. Espera-se que artistas entrevistados revelem dados ainda não indexados ou que novas informações confiáveis surjam em arquivos e acervos. O Inducks também tem sido importante fonte de pesquisa para a edição de quadrinhos (escolha de material e consulta histórica), de incontáveis artigos e textos jornalísticos sobre quadrinhos no Brasil e no exterior nos últimos anos, a despeito de raramente ser citado como tal.

\subsection{Coleta e Análise de Dados sobre os Quadrinhos Disney}

As variáveis são múltiplas quando se usa o Inducks no tópico criação/produção, porém, no propósito específico desta análise optamos por trabalhar com somente duas variáveis. A primeira delas é a de criação dos personagens por universos. No levantamento a data de "criação de personagens" se refere a primeira aparição e não propriamente o ano de sua criação (em muitos casos, como em personagens oriundos do cinema de animação). A segunda, a produção de histórias em quadrinhos por território (país com alguma editora produzindo o material). Uma 
terceira variável possível seria o de produção referente ao número de páginas, levantamento que seria muito complexo e que não traz elementos que alterem a análise das demais variáveis pesquisadas. Inspirado pela divisão feita por Santos (2002), buscamos separar três universos principais: o de Mickey Mouse, o do Pato Donald, e o da "Floresta". Santos (2002) classifica a “Terra da Fantasia” com personagens originários de filmes. Para esclarecimento, não há um levantamento consolidado por considerarmos que há diversos personagens criados ou não originalmente nos filmes que poderiam fazer parte deste universo.

Foram escolhidos também mais dois universos específicos, por darem ênfase à produção brasileira: Zé Carioca e Pata Lee. Cada qual ganhou diversos personagens ao longo de décadas e os dados procuram revelar o período e o local em que essa produção ocorreu. Ressalta-se que a produção de quadrinhos não se limita a esses cinco universos e nem, tampouco, a classificação apontada seja inabalável. Há diversos casos de personagens existentes em mais de um universo. Muitos deles aparecem em somente uma história em quadrinhos. Portanto, o recorte é fundamental para compreendermos o processo de produção.

A segunda variável é a criação de personagens de acordo com o território/país envolvendo a editora licenciada para a produção de histórias em quadrinhos Disney. Portanto, tomamos em consideração apenas o país em que a(s) editora(s) se localiza(m).

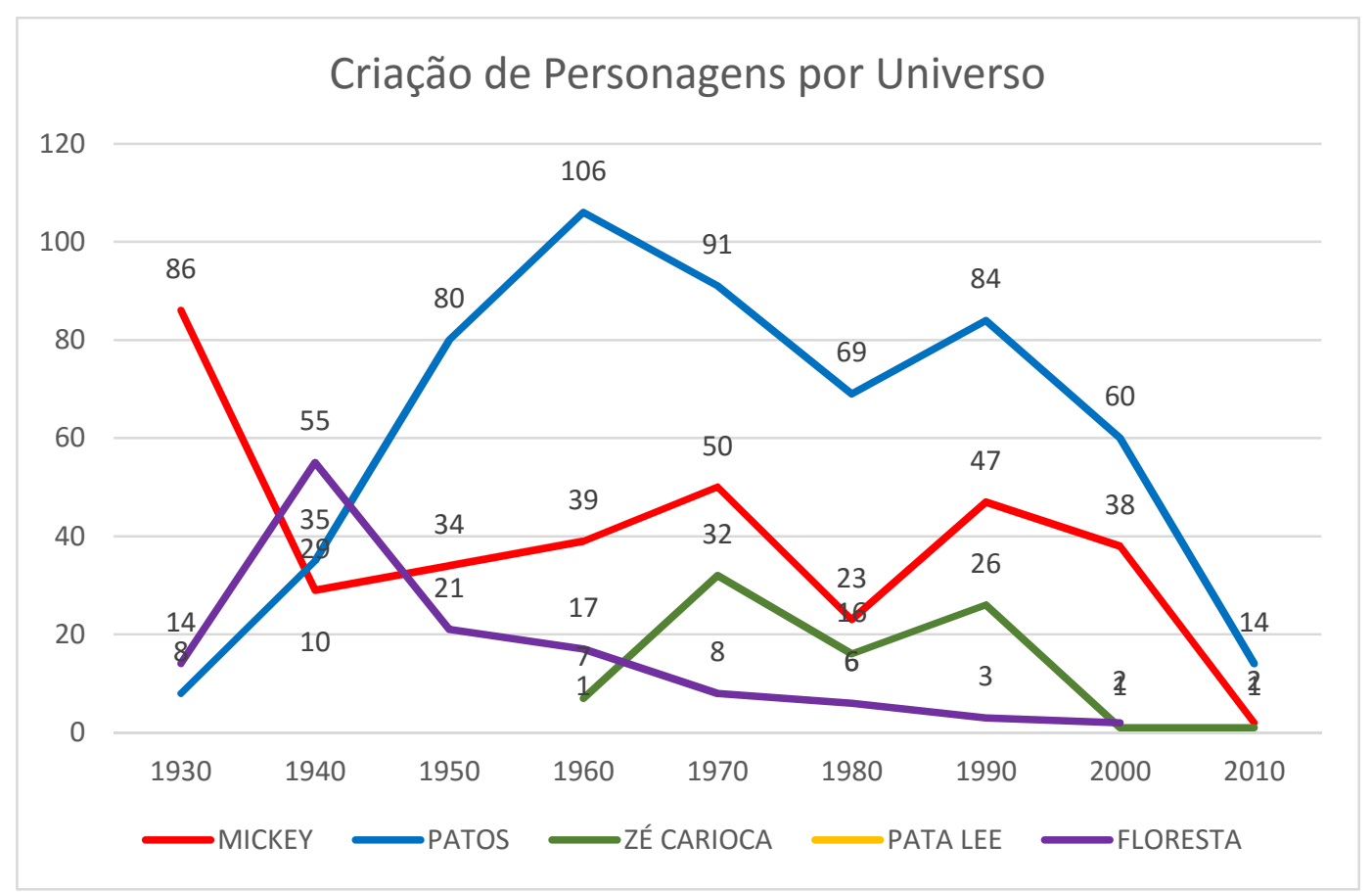

Figura. 10 - Levantamento de criação de personagens por universo. (Fonte: Inducks) 
Como podemos observar no gráfico (Figura 11), os movimentos de produção coincidem com a narrativa histórica da literatura existente sobre os quadrinhos Disney. Os anos 1930 são o período mais fértil para o universo "Mickey Mouse", envolto em sua aura de sucesso nos cinemas. O universo "Floresta" ganha destaque nos anos 1940, com o surgimento de muitas histórias inspiradas ou diretamente quadrinizadas dos filmes clássicos de animação como "Branca de Neve e os Sete Anões" (1937), "Pinóquio" (1940), "Bambi” (1942) e "Canção do Sul" (1946). As décadas de 1950 à 1970 representam o auge criativo do universo "Pato Donald", encabeçado pela produção de Carl Barks e, posteriormente, pelos italianos. Os brasileiros contribuem com 32 personagens no universo "Zé Carioca" somente na década de 1970. E há uma queda geral na criação de personagens nos anos 1980, período em que há uma crise no mercado de quadrinhos e a própria Disney passa por um período de transição em sua administração, que implicará no início da diversificação de suas produções.

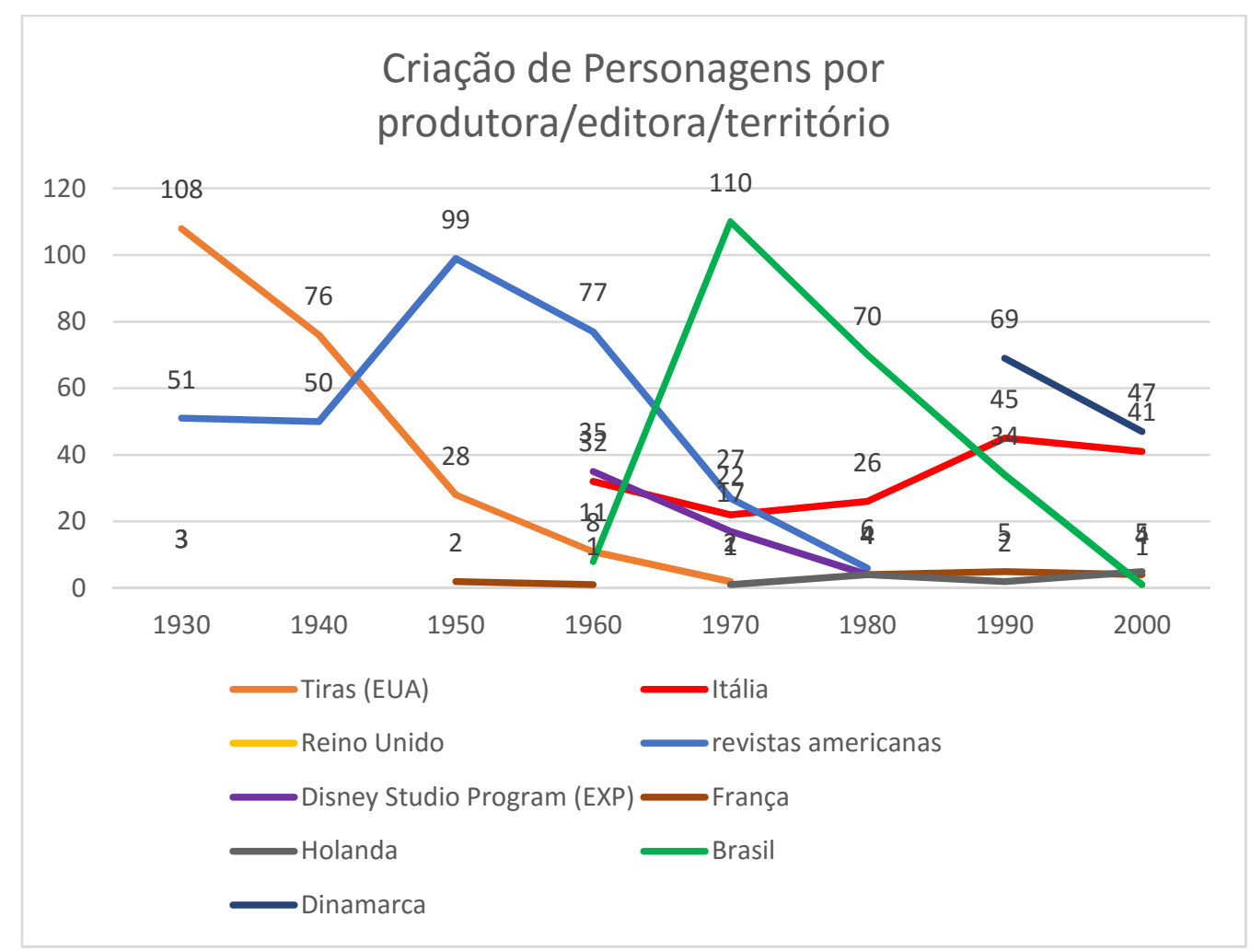

Figura. 11 - Criação de Personagens por produtora/editora/território (Fonte: Inducks) 


\begin{tabular}{|c|c|c|c|c|c|c|c|c|}
\hline Produtora/Território & 1930 & 1940 & 1950 & 1960 & 1970 & 1980 & 1990 & 2000 \\
\hline Alemanha & & & & & & 1 & & \\
\hline Another Rainbow (Gladstone) & & & & & & 3 & & \\
\hline Argentina & & 1 & & & & & & \\
\hline Brasil & & & & 8 & 110 & 70 & 34 & 1 \\
\hline Dinamarca & & & & & 1 & & 69 & 47 \\
\hline $\begin{array}{l}\text { Disney Comics } \\
\text { Disney Studio Program } \\
\text { (EXP) }\end{array}$ & & & & 35 & 17 & 4 & & 3 \\
\hline Egito & & & & 4 & & & & \\
\hline EUA (revistas americanas) & 51 & 50 & 99 & 77 & 27 & 6 & & \\
\hline EUA (Tiras /daily strips) & 108 & 76 & 28 & 11 & 2 & & & \\
\hline França & & & 2 & 1 & & 4 & 5 & 4 \\
\hline Holanda & & & & & 1 & 4 & 2 & 5 \\
\hline Itália & 3 & & & 32 & 22 & 26 & 45 & 41 \\
\hline Reino Unido & 3 & & & & & & & \\
\hline
\end{tabular}

Tabela 1: Levantamento numérico da criação de personagens por território. (Fonte: Inducks)

Por esta segunda variável, observamos que a produção de tiras de jornal com os personagens Disney dominam a década de 1930 e 1940. Os gibis ou comic-books surgiram durante a década de 1930, mas ganharam notoriedade mesmo a partir de 1938, com a publicação de Action Comics e o surgimento dos super-heróis (Tabela 1). Nos anos 1950, a produção para as revistas americanas sofre um aumento, catapultada pelas histórias inspiradas em filmes, telefilmes e seriados de TV. Na década de 1960, a Itália e o Brasil aparecem como maiores fontes criadoras de personagens. Ao mesmo tempo, nos EUA, surge o Disney Studio Program com a intenção de abastecer o mercado internacional com histórias em quadrinhos made in USA. Na década de 1970, há uma hegemonia brasileira na criação de personagens, no mesmo período em que a produção americana de tiras, revistas americanas e Studio Program entram em decadência. A partir dos anos 1980 e 1990, podemos apontar o crescimento da produção italiana e, posteriormente, dinamarquesa - esta última editando histórias em quadrinhos produzidas pelo norte-americano Keno Don Rosa.

Após analisar as duas variáveis sobre a criação de personagens (por universo e por território), faremos uma segunda análise comparativa, utilizando os dados sobre a produção de Histórias em Quadrinhos. Deste modo, podemos verificar concretamente os índices de 
produção por território, para fins de comparação com os dados anteriores de criação de personagens. Vejamos a produção de histórias em quadrinhos Disney nos principais territórios/editoras, por décadas. Foram feitos levantamentos de todas as décadas - de 1930 aos 2000. Entretanto, foram selecionados para discussão somente os dos anos 1950 à 1990.

As décadas de 1930 e 1940, cujos dados não constam em tabelas no corpo desta tese, apresentam uma predominância da produção de tiras de quadrinhos nos jornais nos EUA, porém há uma importante produção no Reino Unido, primeiro território internacional a ganhar o licenciamento para a produção local de histórias e revistas em quadrinhos Disney. A produção britânica, nesta fase, funciona até 1941, paralisada durante a Segunda Guerra Mundial. Nos anos 1940, há uma expansão das histórias em quadrinhos nas revistas em quadrinhos americanas, especialmente após 1945.

\begin{tabular}{|l|r|r|r|r|r|r|r|r|r|r|}
\hline País/Produtora & $\mathbf{1 9 5 0}$ & $\mathbf{1 9 5 1}$ & $\mathbf{1 9 5 2}$ & $\mathbf{1 9 5 3}$ & $\mathbf{1 9 5 4}$ & $\mathbf{1 9 5 5}$ & $\mathbf{1 9 5 6}$ & $\mathbf{1 9 5 7}$ & $\mathbf{1 9 5 8}$ & $\mathbf{1 9 5 9}$ \\
\hline & & & & & & & & & & \\
\hline Argentina & & 1 & & 7 & 1 & 7 & 6 & 6 & 6 & 2 \\
\hline Bélgica & 2 & & & & & & 2 & 1 & 2 & 1 \\
\hline Brasil & & & 1 & 6 & & 7 & & & & 2 \\
\hline EUA (daily strips) & 627 & 630 & 631 & 629 & 629 & 961 & 1455 & 1565 & 1670 & 1878 \\
\hline EUA (páginas dominicais) & 160 & 157 & 157 & 159 & 159 & 158 & 204 & 212 & 211 & 211 \\
\hline $\begin{array}{l}\text { EUA (revistas em } \\
\text { quadrinhos) }\end{array}$ & 125 & 158 & 165 & 224 & 278 & 258 & 287 & 317 & 359 & 326 \\
\hline França & & & 13 & 10 & & 12 & 12 & 8 & 20 & 9 \\
\hline Holanda & & & & & 3 & 7 & 5 & 9 & 5 & \\
\hline Itália & 2 & & 7 & 14 & 24 & 27 & 38 & 43 & 36 & 26 \\
\hline Iugoslávia & & 1 & & & & & & & & \\
\hline Reino Unido & 208 & 248 & 62 & 33 & 77 & 5 & 4 & 6 & 148 & 28 \\
\hline Suécia & 11 & & & & & & & & 2 & 3 \\
\hline Turquia & & & & & & & 4 & & & \\
\hline Vários & & & & & & & & & 1 & \\
\hline
\end{tabular}

Tabela 2 - Produção de Histórias em Quadrinhos Disney na década de 1950. (Fonte: Inducks)

Os dados dos anos 1950 (Tabela 2) ainda comprovam a hegemonia da produção de quadrinhos em tiras de jornais (diárias e páginas dominicais). A produção em revistas americanas ganha força, além do retorno da produção britânica - esta última muito baseada nas quadrinizações de filmes e séries de TV feitas pela Disney. Nesta mesma década, começa a diversificação nos territórios de produção, com criações na França, Holanda e na Itália. 


\begin{tabular}{|l|r|r|r|r|r|r|r|r|r|r|}
\hline País/Produtora & $\mathbf{1 9 6 0}$ & $\mathbf{1 9 6 1}$ & $\mathbf{1 9 6 2}$ & $\mathbf{1 9 6 3}$ & $\mathbf{1 9 6 4}$ & $\mathbf{1 9 6 5}$ & $\mathbf{1 9 6 6}$ & $\mathbf{1 9 6 7}$ & $\mathbf{1 9 6 8}$ & $\mathbf{1 9 6 9}$ \\
\hline & & & & & & & & & & \\
\hline Alemanha & & & & & & & 1 & & & \\
\hline Brasil & 4 & 26 & 40 & 56 & 25 & 13 & 8 & 40 & 65 & 54 \\
\hline Chile & & & & & & 8 & 1 & 16 & 35 & 4 \\
\hline Dinamarca & & & 3 & 18 & 20 & 89 & 85 & 26 & 23 & 36 \\
\hline Disney Studio Program & & & & 20 & 133 & 186 & 153 & 118 & 204 & 156 \\
\hline Egito & & & & & & & 2 & 1 & 1 & \\
\hline EUA (daily strips) & 1886 & 1873 & 1385 & 1253 & 1257 & 1253 & 1253 & 1249 & 1257 & 1253 \\
\hline EUA (páginas domincais) & 212 & 216 & 212 & 212 & 212 & 212 & 213 & 216 & 212 & 213 \\
\hline $\begin{array}{l}\text { EUA (revistas em } \\
\text { quadrinhos) }\end{array}$ & 335 & 359 & 271 & 212 & 148 & 119 & 155 & 124 & 170 & 177 \\
\hline França & 8 & 8 & 7 & 2 & 7 & 4 & 7 & 4 & 6 & 7 \\
\hline Holanda & 1 & & & 2 & 26 & 27 & 52 & 52 & 49 & 39 \\
\hline Itália & 45 & 84 & 110 & 157 & 160 & 149 & 154 & 133 & 141 & 161 \\
\hline Japão & & 1 & 5 & & & & & & & \\
\hline Reino Unido & & 12 & 1 & & & & & & & \\
\hline Vários & 1 & & & & & & & & & \\
\hline
\end{tabular}

Tabela 3 - Produção de Histórias em Quadrinhos Disney na década de 1960.

Os anos 1960 (Tabela 3) mostram uma queda nas revistas em quadrinhos americanas, um ligeiro declínio da produção de tiras diárias, uma estagnação na produção de páginas dominicais, porém os dados apresentam provas da emergência de novas forças de produção. $\mathrm{O}$ Brasil, a Dinamarca, a Holanda e, numa escala maior, a Itália, apresentam números substanciais. A Disney está ciente da popularidade no mercado internacional e inicia, em 1963, o Studio Program para exportar histórias em quadrinhos para as editoras licenciadas. A França mantém uma tímida produção.

A década de 1970 (Tabela 4) poderia ser chamada de "década brasileira" de acordo com os dados de produção. Somente em 1974, o Brasil produziu o recorde de 305 histórias em quadrinhos. Em volume de produção, o Studio Program norte-americano vem em seguida. Outros mercados produtores se mantêm ativos, como Dinamarca, França (em menor volume), Holanda e Itália. Há uma ligeira queda na produção de tiras diárias e páginas dominicais em relação à década de 1960. 


\begin{tabular}{|c|c|c|c|c|c|c|c|c|c|c|}
\hline País/Produtora & 1970 & 1971 & 1972 & 1973 & 1974 & 1975 & 1976 & 1977 & 1978 & 1979 \\
\hline Alemanha & & & & & & & & & 2 & 16 \\
\hline Brasil & 33 & 35 & 95 & 253 & 305 & 232 & 239 & 252 & 254 & 264 \\
\hline Chile & 14 & 5 & & & 3 & & & & & \\
\hline Dinamarca & 44 & 70 & 145 & 192 & 181 & 172 & 144 & 208 & 250 & 272 \\
\hline $\begin{array}{l}\text { Disney Studio (Foreign } \\
\text { market stories) }\end{array}$ & 194 & 218 & 239 & 294 & 243 & 220 & 189 & 133 & 140 & 140 \\
\hline Egito & & & 1 & & & & & & 1 & \\
\hline EUA (daily strips) & 1253 & 1253 & 1253 & 1030 & 940 & 940 & 943 & 940 & 1105 & 1263 \\
\hline EUA (páginas dominicais) & 211 & 212 & 216 & 160 & 160 & 161 & 160 & 160 & 191 & 211 \\
\hline $\begin{array}{l}\text { EUA (revistas em } \\
\text { quadrinhos) }\end{array}$ & 143 & 125 & 126 & 120 & 117 & 197 & 190 & 177 & 183 & 174 \\
\hline Finlândia & & & & & & & & & & 1 \\
\hline França & 21 & 19 & 15 & 9 & 15 & 18 & 12 & 13 & 22 & 10 \\
\hline Holanda & 30 & 49 & 50 & 80 & 108 & 24 & 30 & 28 & 23 & 33 \\
\hline Itália & 142 & 137 & 132 & 146 & 146 & 116 & 133 & 135 & 139 & 125 \\
\hline Iugoslávia & & & 1 & & & & & & & \\
\hline Reino Unido & & & 5 & & & & & & 4 & 1 \\
\hline Vários & & & & & 1 & & 2 & 1 & & \\
\hline
\end{tabular}

Tabela 4 - Produção de Histórias em Quadrinhos Disney na década de 1970. (Fonte: Inducks)

\begin{tabular}{|l|r|r|r|r|r|r|r|r|r|r|}
\hline País/Produtora & $\mathbf{1 9 8 0}$ & $\mathbf{1 9 8 1}$ & $\mathbf{1 9 8 2}$ & $\mathbf{1 9 8 3}$ & $\mathbf{1 9 8 4}$ & $\mathbf{1 9 8 5}$ & $\mathbf{1 9 8 6}$ & $\mathbf{1 9 8 7}$ & $\mathbf{1 9 8 8}$ & $\mathbf{1 9 8 9}$ \\
\hline & & & & & & & & & & \\
\hline Alemanha & 50 & 58 & 22 & 2 & 8 & 12 & 25 & 15 & 10 & 4 \\
\hline Another Rainbow (Gladstone) & & & & & & & 1 & 8 & 25 & 20 \\
\hline Brasil & 201 & 219 & 286 & 271 & 231 & 243 & 214 & 204 & 164 & 157 \\
\hline Dinamarca & 245 & 258 & 265 & 343 & 352 & 272 & 302 & 342 & 330 & 319 \\
\hline Disney Comics & & & & & & & & & 3 & 4 \\
\hline Disney Studio Program & 189 & 171 & 179 & 163 & 195 & 204 & 222 & 198 & 177 & 138 \\
\hline EUA (daily strips) & 1246 & 1253 & 1253 & 1253 & 1253 & 1253 & 1358 & 1566 & 1174 & 702 \\
\hline EUA (páginas dominicais) & 212 & 210 & 211 & 212 & 216 & 212 & 229 & 260 & 260 & 225 \\
\hline $\begin{array}{l}\text { EUA (revistas em } \\
\text { quadrinhos) }\end{array}$ & 132 & 105 & 198 & 1 & 39 & 1 & & & & \\
\hline Finlândia & & & & & & & 1 & 5 & 5 & 1 \\
\hline França & 21 & 4 & 36 & 37 & 42 & 130 & 213 & 266 & 237 & 253 \\
\hline Holanda & 43 & 41 & 76 & 79 & 145 & 169 & 171 & 118 & 172 & 121 \\
\hline Itália & 102 & 111 & 115 & 123 & 132 & 152 & 137 & 190 & 172 & 234 \\
\hline Marvel & & & & & & & & & & 2 \\
\hline Suécia & 1 & & & & & & & & & \\
\hline Vários & & 5 & 2 & 1 & 2 & 2 & & & 1 & \\
\hline
\end{tabular}

Tabela 5 - Produção de Histórias em Quadrinhos Disney na década de 1980. (Fonte: Inducks) 
O fim dos anos 1980 (Tabela 5) ilustra o início da decadência na produção de tiras diárias, embora as páginas dominicais permaneçam estáveis. A produção dinamarquesa mostrou sua força nesta década, superando o Brasil, que manteve uma produção alta por quase todo o decênio. Houve um aumento significativo da produção francesa e holandesa, levando em consideração de que ambas produziram muitas histórias em quadrinhos com somente uma página. Os anos 1980 também mostram o fim da produção para as revistas em quadrinhos americanas, a presença tímida da produção alemã e a manutenção do volume de produção do Studio Program norte-americano.

\begin{tabular}{|l|r|r|r|r|r|r|r|r|r|r|}
\hline País/Produtora & $\mathbf{1 9 9 0}$ & $\mathbf{1 9 9 1}$ & $\mathbf{1 9 9 2}$ & $\mathbf{1 9 9 3}$ & $\mathbf{1 9 9 4}$ & $\mathbf{1 9 9 5}$ & $\mathbf{1 9 9 6}$ & $\mathbf{1 9 9 7}$ & $\mathbf{1 9 9 8}$ & $\mathbf{1 9 9 9}$ \\
\hline & & & & & & & & & & \\
\hline Alemanha & 5 & 9 & 20 & 20 & 15 & 20 & 4 & 3 & 2 & \\
\hline Another Raibow (Gladstone) & 3 & & & & 5 & 9 & 7 & 6 & & \\
\hline Brasil & 157 & 215 & 280 & 219 & 162 & 242 & 227 & 269 & 97 & 84 \\
\hline Dinamarca & 288 & 301 & 339 & 326 & 352 & 408 & 392 & 479 & 424 & 367 \\
\hline Disney Comics & 72 & 152 & 72 & 43 & 37 & 32 & 36 & 28 & 17 & 30 \\
\hline Disney Europe & 1 & 3 & 2 & 3 & 3 & 4 & 4 & 4 & 4 & 1 \\
\hline Disney Studio Program & 66 & 26 & 6 & & 1 & & & 1 & & \\
\hline EUA (daily strips) & 155 & 135 & 128 & 20 & 37 & 4 & 1 & 1 & & \\
\hline EUA (páginas dominicais) & 420 & 55 & 52 & 52 & 52 & 53 & 52 & 52 & 52 & \\
\hline França & 260 & 290 & 251 & 310 & 298 & 329 & 357 & 369 & 365 & 325 \\
\hline Holanda & 180 & 192 & 134 & 189 & 193 & 210 & 302 & 278 & 263 & 249 \\
\hline Itália & 200 & 229 & 284 & 335 & 400 & 508 & 458 & 1201 & 1073 & 827 \\
\hline Iugoslávia & & & & & & & & & & 1 \\
\hline Marvel & & & & & 20 & 65 & 19 & 1 & & \\
\hline Reino Unido & & & & & & & & & & 6 \\
\hline Vários & 8 & 1 & 1 & 3 & 5 & 1 & & 17 & & 2 \\
\hline
\end{tabular}

Tabela 6 - Produção de Histórias em Quadrinhos Disney na década de 1990. (Fonte: Inducks)

A década de 1990 (Tabela 6) apresenta uma considerável produção brasileira, cuja decadência é apontada em 1998. Há uma queda generalizada na produção de tiras diárias e páginas dominicais dos jornais, igualmente no Studio Program; e uma considerável diversificação pela criação de dezenas de universos (não analisadas aqui, porém com início nos anos 1980) e pelo surgimento de diversos espaços de produção - como as editoras Disney Comics, Gladstone, etc. Dinamarca, França e Holanda mantêm uma alta produtividade, porém a hegemonia da produção é transferida para a Itália, produzindo mais de mil histórias em quadrinhos anuais ao fim da década. 
A estratificação e a diversificação de polos de produção e na criação de universos de personagens (a maioria baseada em marcas e seriados de TV) são estratégias permanentes na década de 2000. Os dados apresentam a continuidade da hegemonia italiana na produção de quadrinhos. A Dinamarca é outro forte polo de produção, seguida da Holanda (que produz muitas piadas de uma página). Dentre os principais players do mercado, a França ainda mantém presença, porém com uma ligeira queda no volume de produção. O Brasil deixou de produzir, aguardando uma retomada que só ocorreria na década seguinte.

Os dados levantados apresentam provas concretas que refletem e adicionam contexto à narrativa da literatura existente sobre a história dos quadrinhos Disney, e descrita na introdução desta tese. Embora a base de dados INDUCKS não seja exata, pela própria natureza colaborativa de informações estar em constante atualização, os números utilizados foram suficientes para apontar as tendências esperadas. Até 2015, o INDUCKS informava a existência de 4.241 personagens, sendo que 2.900 são aqueles que aparecem somente em uma única história. 1.341 aparecem em várias histórias, e é deste universo que tentamos listar os personagens mais significativos dos cinco universos pesquisados e analisados (no total existem 122 universos listados no INDUCKS).

Dentre as influências mais fortes escolhidas para análise na tese estão a sinergia (entre quadrinhos e produtos audiovisuais), a produção internacional e a convergência de mídias. Os dados de criação de personagens em seus principais universos principais mostram uma queda em meados dos anos 1980. Este período, pós-instabilidade na administração Disney (a partir de 1985), também é marcado pela diversificação e criação de diversas marcas e seriados de TV, que ganharam seus próprios universos. Deste modo, podemos afirmar que a utilização de personagens externos pelos quadrinhos foi acentuada.

Os números gerais sobre a produção de histórias em quadrinhos Disney no mundo demonstra a diversificação e alternância na hegemonia - EUA (1930 a 1950), Brasil (1970), Dinamarca (1980) e Itália (1990). Atualmente, o mercado de produção é mais fragmentado e equilibrado, tendo o Brasil reiniciado a produção nacional (ainda que timidamente) em 2013. Consideramos que as informações descrevem concretamente a evolução histórica do mercado de histórias em quadrinhos, e serão de utilidade (em um recorte maior) no desafio de explicar os rumos da produção cultural de quadrinhos Disney no início do século XXI. 
Podemos comprovar que a diversidade dos universos de personagens (cada universo em sua própria revista, ou própria marca) é diversificada, se compararmos a lista dos seriados produzidos pela Walt Disney Television Animation a partir dos anos 1980 em relação a lista de universos diversos surgidos a partir do mesmo período, conforme elencado no Inducks.

\subsection{Coleta e Análise de Dados sobre a Animação Disney}

A animação Disney sempre fez parte do núcleo central da The Walt Disney Company. Desde 1923, representa a aura e a origem para os mais diversos negócios, passando por diversas fases artísticas e técnicas, e por diversas reações críticas. Além dos 55 longasmetragens produzidos entre 1937 e 2015 e centenas de curtas-metragens para cinema, considerados "clássicos" pelo cânone disneyano houve um aumento expressivo da produção live-action (não-animada) a partir de 1950 e uma explosão de produção televisiva, de homevídeo e filmes terceirizados ou em co-parcerias a partir dos anos 1980.

Para efeitos de análise nesta pesquisa, não é possível trabalhar somente com o levantamento dos títulos canônicos - observando o universo total de produção, podemos enxergar melhor a evolução da segmentação e da concentração no número de produções. Isto posto, um levantamento de produção aparentemente simples se torna um desafio porque a lista de produções Disney é extensa, tem origem em várias subsidiárias e muitas vezes se confundem. Por exemplo: um filme lançado por um selo adulto (Touchstone Pictures) como "O Estranho Mundo de Jack" (Henry Selick, 1993) foi relançada sob o selo Disney anos mais tarde. Outro exemplo: A própria Disney, por vezes, publica listas de filmes, inserindo no cânone disneyano (ou clássico) produções que tecnicamente não fariam parte dele, por não terem sido criados no mesmo local. E para complicar o trabalho, as listas disponíveis na Internet são ainda menos confiáveis.

Enquanto a produção de quadrinhos foi em boa parte baseada no sistema online INDUCKS, a produção fílmica foi inicialmente compilada com base em listas fornecidas online pela própria Disney e fontes diversas, indo desde a inconsistente Wikipedia ao IMDB (Internet Movie Data Base - especialista em dados de produção cinematográfica ${ }^{22}$. A inconsistência nos

${ }^{22}$ Wikipedia: http://www.wikipedia.com e IMDB: http://www.imdb.com 
dados foi reduzida a partir de duas obras de caráter enciclopédico que listam, à sua maneira (por meio de verbetes e não propriamente listas), todas as produções até suas datas de publicação: “The Wonderful World of Disney Television" de Bill Cotter (1997) e a $3^{\text {a }}$ edição do "The Official Encyclopedia Disney A to Z" do arquivista da Disney, David Smith (2006).

Comecemos pela definição do que consideramos produção fílmica Disney e as diferenciações entre as produções animadas e live-action. O primeiro grupo de filmes de animação é popularmente conhecido como "clássicos". Trata-se dos filmes de animação mais conhecidos e mais importantes da filmografia Disney e dos lançamentos em home-vídeo no auge da era do videocassete - os VHS dos filmes traziam a inscrição "Walt Disney Classics". Esses pouco mais de 50 filmes fazem parte do cânone clássico disneyano. Emprestando a definição de clássico (da literatura) de Ítalo Calvino (2002), temos que:

\begin{abstract}
"Os clássicos são aqueles livros dos quais, em geral, se ouve dizer: "Estou relendo..." e nunca "Estou lendo..." (...) Dizem-se clássicos aqueles livros que constituem uma riqueza para quem os tenha lido e amado; mas constituem uma riqueza não menor para quem se reserva a sorte de lê-los pela primeira vez nas melhores condições para apreciá-los. (...) Os clássicos são livros que exercem uma influência particular quando se impõem como inesquecíveis e também quando se ocultam nas dobras da memória, mimetizando-se como inconsciente coletivo ou individual. (...) Toda releitura de um clássico é uma literatura de descoberta como a primeira. (...) Os clássicos são aqueles livros que chegam até nós trazendo consigo as marcas das leituras que precederam a nossa e atrás de si os traços que deixaram na cultura ou nas culturas que atravessaram (ou mais simplesmente na linguagem ou nos costumes) (...) Um clássico é uma obra que provoca incessantemente uma nuvem de discursos sobre si, mas continuamente a repele para longe. (...) É clássico aquilo que tende a relegar as atualidades à posição de barulho de fundo, mas ao mesmo tempo não pode prescindir desse barulho de fundo. (...) É clássico aquilo que persiste com o rumor mesmo onde predomina a atualidade mais incompatível". (Calvino 2002, p. 9-15)
\end{abstract}

Calvino está analisando o clássico na literatura, porém podemos utilizar suas definições no caso das animações do cânone Disney. Foram alvo de críticas e elogios de mentes tão variadas como Theodor Adorno, Sergei Eisenstein (LESLIE, 2002) e Orson Welles ${ }^{23}$. São os filmes mais relançados na história do cinema hollywoodiano. Públicos de diferentes gerações têm acesso a produções animadas como "Branca de Neve e os Sete Anões" (1937) e "Pinóquio" (1940) - somente poucos filmes live-action obtiveram propagação e sucesso semelhante - como certamente os títulos concorrentes “O Mágico de Oz" (1939) e "E o Vento Levou” (1939) são

\footnotetext{
${ }^{23}$ Orson Welles faz a sua declaração de princípios. Diretrizes - 12/03/41 - p. 12-13, 20.
} 
bons exemplos. Os relançamentos das animações "clássicas” Disney nos cinemas, e posteriormente em home-vídeo, se tornaram tão comuns que fizeram parte de uma estratégia comercial - relançamento a cada 7 anos garantia exposição a uma nova geração. Foi entre o final dos anos 1970 e meados dos anos 1980 que a Disney viu o poder que os antigos filmes possuíam - diversos títulos resultavam em maior retorno de bilheteria se comparados aos filmes recém-produzidos. Como exemplo, podemos ver o ocorrido em 1985 quando um relançamento de "101 Dálmatas" (1961) obteve US\$ 33 milhões nas bilheterias em comparação ao novo "O Caldeirão Mágico" (1985) rendeu US\$ 21,2 milhões - com orçamento de US\$ 24 milhões (GROVER, 1997). O próprio Walt Disney recebia sugestões de que o estúdio poderia sobreviver somente com os relançamentos, tamanho sucesso dos clássicos comparado aos orçamentos crescentes das novas produções (THOMAS, 1958, p. 178).

Todas as produções do chamado cânone "clássico" (1937 até os dias de hoje) foram criadas pelo grupo de elite com os melhores artistas do estúdio sob um selo genérico chamado "Walt Disney Productions". Foi somente no início dos anos 1980 que as produções foram reunidas sob o selo "Walt Disney Feature Animation” (atual Walt Disney Animation Studios) para diferenciar seus filmes dos projetos oriundos de outra divisão, a Walt Disney Television Animation. Os "clássicos" foram em sua maioria produzidos nos estúdios localizados em Burbank, na Califórnia, construídos no início dos anos 1940. Uma nova sede seria aberta no Studio Lot no final de 1994. Uma divisão da então “Walt Disney Feature Animation" funcionou dentro do parque temático Disney-MGM Studios (atual Disney’s Hollywood Studios) de 1989 a 2004 - além de servir de espaço para que os visitantes observassem os artistas trabalhando, a equipe servia para produzir curtas-metragens e apoiar na criação de algumas cenas de longasmetragens. Somente três filmes foram produzidos integralmente na Flórida ("Mulan” em 1998, “Lilo \& Stitch” em 2001 e "Irmão Urso" em 2003).

Em 1994, a Disney adquiriu a Brizzi Films, produtora francesa que colaborava com Disney em projetos televisivos desde 1989 e a transformou em mais uma divisão da "Walt Disney Feature Animation", também servindo de apoio ao estúdio de Burbank até fechar em 2003. Outra divisão em Tóquio, no Japão, ficou responsável por projetos relacionados principalmente a televisão e home-vídeo, de 1989 a 2004 (SMITH, 2006, p. 243). Atentamos para a coincidência no fechamento dos estúdios-satélites (todos entre 2003 e 2004), encerrando uma fase de grande segmentação e terceirização. 
Em volume de produção, a Disney produziu desde o início centenas de curtasmetragens que são elencados neste levantamento desde as "Alice Comedies" (1923) e os “Oswald the Lucky Rabbit” (1927) (projetos anteriores à criação do Mickey, em 1928) até os clássicos do Mickey, Donald, Pluto, etc, as "Silly Symphonies" e os curtas-metragens de propaganda e treinamento da Segunda Guerra Mundial, além dos educacionais. Os longasmetragens do cânone "clássico" são 53 entre 1937 e 2014. A lista revisada da Disney e divulgada em seu site oficial inclui um 54 filme - "Dinossauro" (2000), filme híbrido que mistura animação computadorizada e cenários reais - esta produção não consta em listas oficiais antigas por uma razão fundamental: "Dinossauro" foi produzido por uma equipe autônoma em um estúdio chamado "The Secret Lab" (de propriedade Disney), que desenvolvia produções envolvendo animação computadorizada. Deste modo, nossa lista do cânone clássico é a seguinte, incluindo os títulos nacionais das primeiras exibições:

\section{Lista dos clássicos da animação Disney}

01 - Branca de Neve e os Sete Anões (Snow White and the Seven Dwarfs - 1937)

02 - Pinóquio (Pinocchio -1940)

03 - Fantasia (1940)

04 - Dumbo (1941)

05 - Bambi (1942)

06 - Alô, Amigos (Saludos Amigos -1943)

07 - Você Já Foi à Bahia? (The Three

Caballeros - 1945)

08 - Música, Maestro (Make Mine Music 1946)

09 - Alegre e Folgazão/Como É Bom se

Divertir (Fun and Fancy Free - 1947)

10 - Cante com Disney / Tempo de Melodia

(Melody Time -1948)

11 - Dois Sujeitos Fabulosos / As Aventuras de Ichabod e Sr. Sapo (The Adventures of Ichabod and Mr. Toad -1949)

12 - A Gata Borralheira/Cinderela (Cinderella $-1950)$

13 - Alice no País das Maravilhas (Alice in

Wonderland -1951)

14 - As Aventuras de Peter Pan/Peter Pan

(Peter Pan - 1953)

15 - A Dama e o Vagabundo (Lady and the

Tramp -1955)

16 - A Bela Adormecida (Sleeping Beauty 1959)
17 - A Guerra dos Dálmatas/101 Dálmatas (101 Dalmatians -1961)

18 - A Espada Era a Lei (The Sword in the Stone -1963)

19 - Mogli, o Menino Lobo (The Jungle Book $-1967)$

20 - Aristogatas (The Aristocats -1970)

21 - Robin Hood (1973)

22 - Puff - O Ursinho Guloso (The Many

Adventures of Winnie the Pooh -1977)

23 - Bernardo e Bianca (The Rescuers -1977)

24 - O Cão e a Raposa (The Fox and the

Hound -1981)

25 - O Caldeirão Mágico (The Black

Cauldron - 1985)

26 - As Peripécias de um Ratinho Detetive/O

Ratinho Detetive (The Great Mouse Detective -1986)

27 - Oliver e seus Companheiros (Oliver \& Company -1988)

28 - A Pequena Sereia (The Little Mermaid 1989)

29 - Bernardo e Bianca na Terra dos

Cangurus (The Rescuers Down Under - 1990)

30 - A Bela e a Fera (Beauty and the Beast 1991)

31 - Aladdin (1992)

32 - O Rei Leão (The Lion King -1994) 
33 - Pocahontas - O Encontro de Dois

Mundos (Pocahontas - 1995)

34 - O Corcunda de Notre Dame (The

Hunchback of Notre Dame - 1996)

35 - Hércules (Hercules - 1997)

36 - Mulan (1998)

37 - Tarzan (1999)

38 - Fantasia 2000 (1999-2000)

39 - A Nova Onda do Imperador (The

Emperor's New Groove - 2000)

40 - Atlantis - O Reino Perdido (Atlantis: The

Lost Empire - 2001)

41 - Lilo \& Stitch (2002)

42 - Planeta do Tesouro (Treasure Planet -

2002)

43 - Irmão Urso (Brother Bear - 2003)

44 - Nem que a Vaca Tussa (Home on the

Range - 2004)

45 - O Galinho Chicken Little (Chicken Little

- 2005) - produção em CGI

46 - A Família do Futuro (Meet the

Robinsons - 2007) - produção em CGI

47 - Bolt - Supercão (Bolt - 2008) - produção

em CGI

48 - A Princesa e o Sapo (The Princess and

the Frog - 2009)

49 - Enrolados (Tangled - 2010) - produção

em CGI (*antes "Rapunzel")

50 - Ursinho Pooh (Winnie the Pooh - 2011)

51- Detona Ralph (Wreck-It Ralph - 2012)

52- Frozen: Uma Aventura Congelante

(Frozen - 2013)

53 - Operação Big Hero (Big Hero 6 - 2014) 


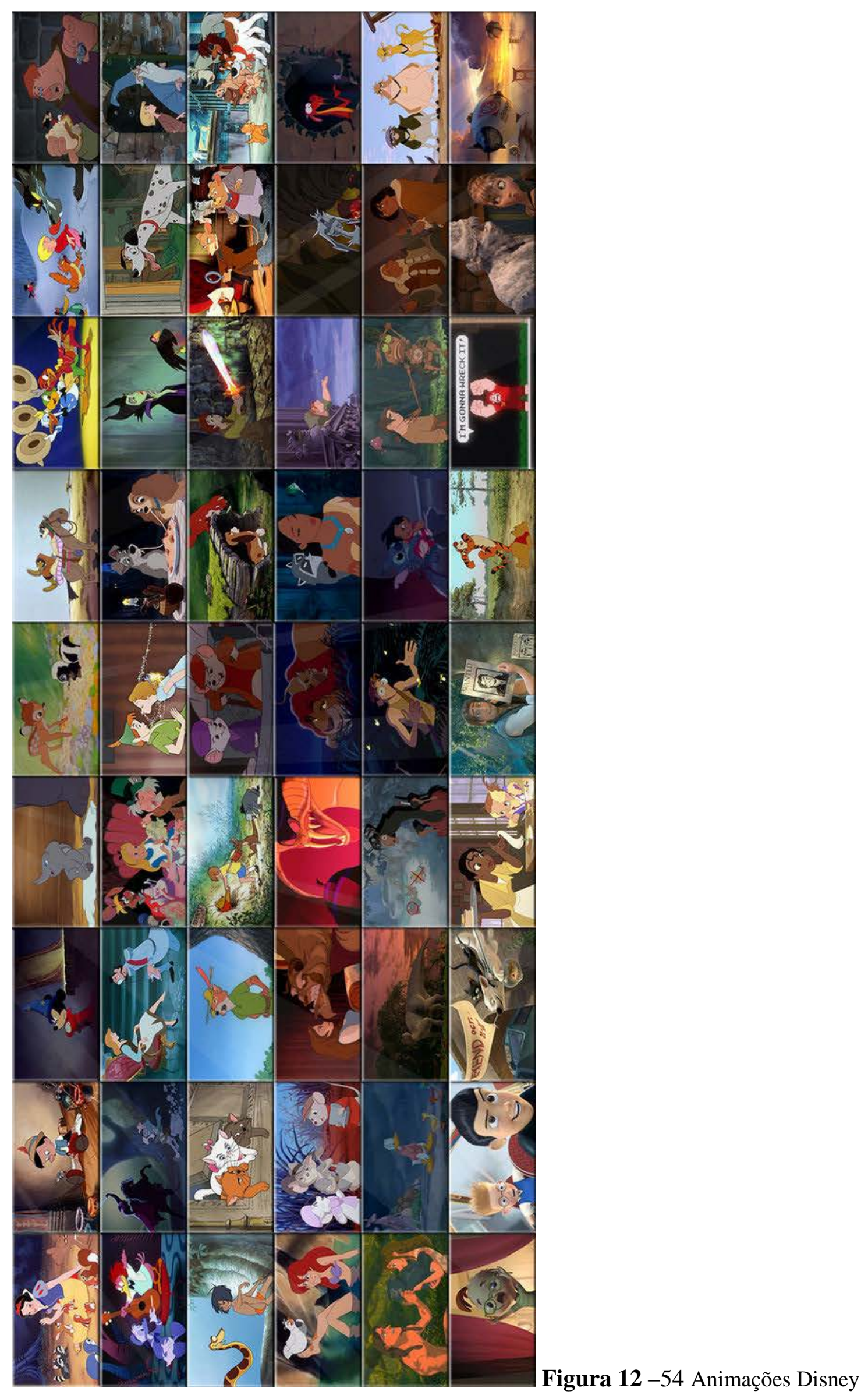


Outras produções em animação são encontradas na televisão. Entre os anos 1950 e 1970 a Disney produzia somente especiais e pequenos trechos animados para os programas existentes, como o "Disneylândia" e "Clube do Mickey". E aproveitava o seu vasto acervo de curtas-metragens para rechear os programas. Foi somente em 1985, com a entrada de uma nova administração, que Disney teve um olhar mais ambicioso para a televisão, cujo espaço estava dominado pelas concorrentes Hanna-Barbera, Filmation, e, num menor grau, pela Warner Bros. A decisão foi investir na produção de seriados animados, usando estúdios terceirizados (no Japão e na Coréia do Sul, principalmente) para vender às grandes redes de TV e emissoras independentes (COTTER, 1997, p. 235). Alguns dos seriados se tornaram tão populares que se transformaram em novas marcas - caso de "Duck Tales Os Caçadores de Aventuras” (1987), “As Novas Aventuras do Ursinho Puff” (1985) e “Os Ursinhos Gummi” (1985). Todas estas novas produções foram reunidas sob o selo Walt Disney Television Animation.

Outras duas variáveis importantes no levantamento de produção são os projetos derivados da TV e os filmes da Pixar. As animações computadorizadas da Pixar formam um importante elo de sucesso com a Disney e as tumultuadas negociações entre ambas influenciaram também as formas e culturas de produção (PRICE, 2008). Já os chamados “derivados de TV”, de difícil compilação, são projetos que partem da esfera de influência da TV. São os telefilmes criados para vender os seriados de animação (espécie de "piloto") - geralmente juntam um grupo de 4 ou 5 episódios em forma de longa-metragem), ou produções originais baseadas nos seriados, e até filmes que tiveram lançamento nos cinemas - por exemplo, os três longas-metragens do universo do Ursinho Pooh (SMITH, 2006).

Uma última variável é o levantamento da Disney Home Entertainment - produções para o mercado de home-video e DVD, em sua maioria filmes que se aproveitavam do sucesso dos “clássicos" - as chamadas continuações - "O Rei Leão 2", "Cinderela 2", "Pocahontas 2", e assim por diante. Os filmes, com qualidades variáveis, foram produzidos em estúdios-satélites no Japão, Canadá e Austrália, por exemplo.

Para demonstrar os efeitos da segmentação e da expansão da produção exclusivamente em animação, o gráfico (Figura 13) apresenta a evolução das variáveis elencadas até o momento ${ }^{24}$.

\footnotetext{
${ }^{24}$ Todos os dados referentes a década "2010" são limitados a produções lançadas até o ano 2014.
} 


\section{Levantamento de Produção - Animação}

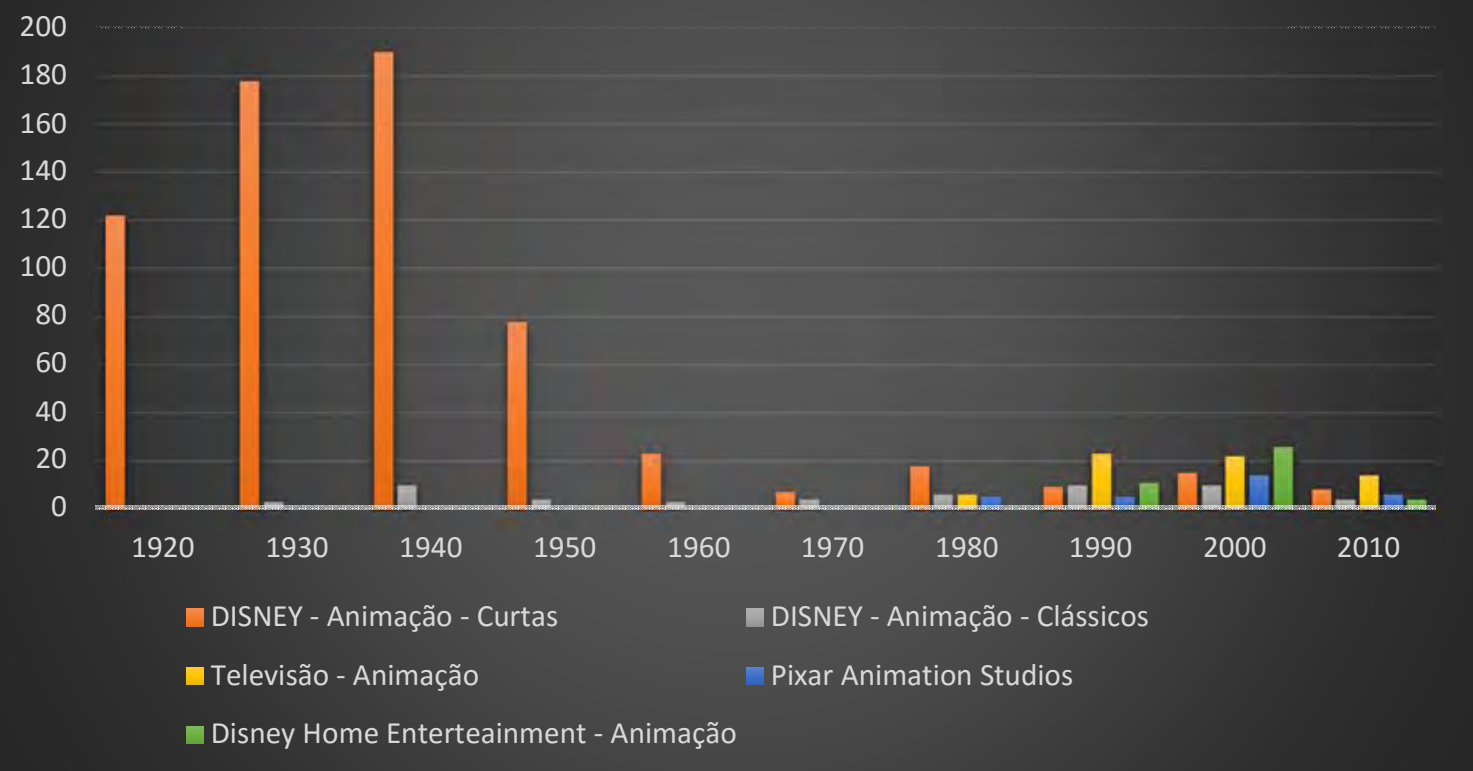

Figura. 13 - Gráfico de comparação da produção de animação Disney.

Como a produção de curtas-metragens foi abundante entre os anos 1920 e 1950, consideremos também o gráfico (Figura 14) que retira esta variável para observarmos a evolução da produção em animação.

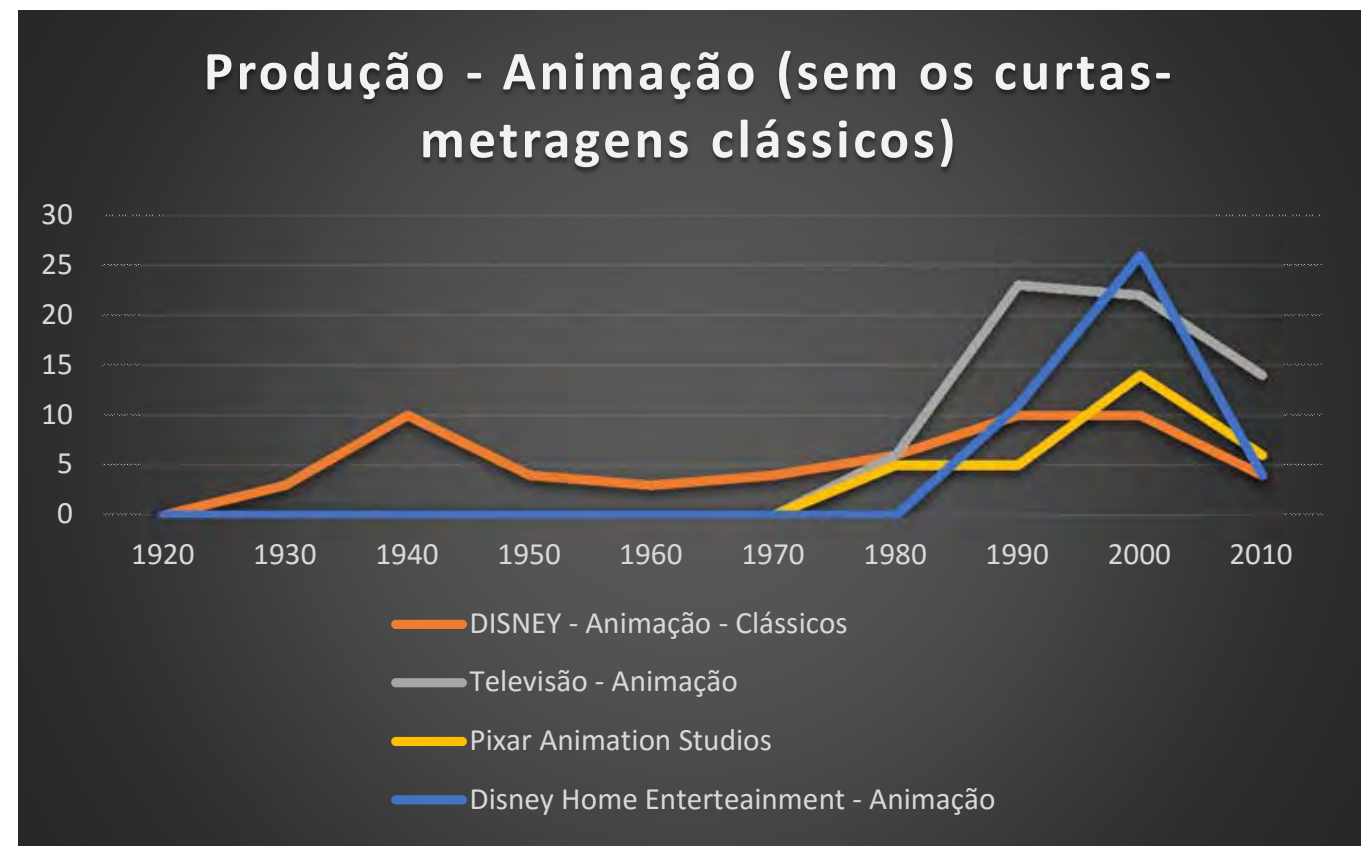

Figura 14 - Gráfico de comparação ilustra a intensificação na produção nas últimas décadas. 
A produção live-action Disney surgiu por pura necessidade - com o dinheiro da bilheteria preso no mercado europeu devido ao bloqueio da Segunda Guerra Mundial, a solução encontrada foi reinvestir em produções rodadas na Europa, sendo “A Ilha do Tesouro" (1950) o primeiro filme desta safra. Desde então, o estúdio passou a investir em filmes típicos para toda a família, em geral comédias leves ou fantasias com efeitos especiais e orçamentos variáveis. A maioria dos filmes não é lembrada como o cânone das animações clássicas, porém alguns títulos se destacam como o musical "Mary Poppins" (1964).

Neste levantamento incluímos toda a produção live-action familiar puramente Disney, de modo a incluir também as produções híbridas (que misturem animação - caso de "Mary Poppins" (1964) e "Se Minha Cama Voasse" (1971) e "extras" - animações e documentários não produzidos nas mesmas instalações onde os "clássicos" são produzidos (caso de animações como "James e o Pêssego Gigante" (1996) e dos documentários).

A armadilha do rótulo "familiar" e das comédias banais limitou as opções da Disney no início dos anos 1980. Dos oito estúdios hollywoodianos, o estúdio Disney era sempre visto como o último em potencial - geralmente apostando em projetos mais econômicos e sem risco (TAYLOR, 1987). Os poucos projetos arriscados e ambiciosos como "Tron: Uma Odisseia Eletrônica" (1982) eram recebidos friamente pelo público e crítica. E qualquer tentativa de inclusão de conteúdo mais sexual ou violento (até mesmo os "palavrões" hoje banais como "hell" ou "damn it") eram mal recebidos pela audiência.

A solução veio de Ron Miller, genro de Walt Disney, e presidente da Disney no começo dos anos 1980 - a criação de um novo selo chamado Touchstone Pictures que carregaria todo filme que não fosse considerado Disney. Deste modo, o filme "Splash" (1984) tornou-se o primeiro liveaction Disney a ser lançado pelo selo adulto (SMITH, 2006, p. 686). Posteriormente, a Touchstone ganhou seus próprios executivos e estrutura para a produção de filmes exclusivos, separando-se em definitivo da mesma equipe que cuidava das produções familiares. A Touchstone lançaria desde então comédias mais ousadas, suspenses, thrillers e até mesmo filmes híbridos com animação ("Uma Cilada para Roger Rabbit - 1988).

A produção da Touchstone cresceu o suficiente para que a Disney criasse um segundo selo adulto com estrutura autônoma. Foi a Hollywood Pictures, criada em fevereiro de 1989, tendo o filme "Aracnofobia" (produção de Steven Spielberg) como estreia. Em 1996, a produtora foi 
encerrada transformando-se em distribuidora de filmes até 2001 - quando foi brevemente reativada como produtora de filmes mais econômicos de gênero por um breve período entre 2007 e 2008, quando foi encerrada.

Houve também acordos de co-produção. Foi o caso da criação, em 1993, da Caravan Pictures, produtora criada por Joe Roth e Roger Birnbaum, que assinaram contrato para entregar no mínimo 25 filmes a serem distribuídos pela Buena Vista Distribution (o braço de distribuição da Disney). Em 1999, a Caravan foi encerrada com Birnbaum e Gary Barber criando outra produtora independente chamada Spyglass Entertainment (SMITH, 2006, p. 109).

Outro caso de sucesso foi a aquisição da Miramax Films no mesmo ano de 1993. Fundada em 1979 pelos irmãos Harvey e Bob Weinstein, a Disney ganhou o direito de explorar seus mais de 200 filmes. A Miramax tinha um portfólio composto em sua maior parte de filmes com orçamentos modestos. Porém, havia uma seleção de títulos com grande sucesso de crítica - muitos vencedores do Oscar como "Shakespeare Apaixonado" (1998), “O Paciente Inglês” (1996) e "Chicago" (2002). A estratégia era clara: adquirir uma produtora que carregava prestígio. E a negociação era positiva para os envolvidos. A Disney financiou futuras produções e os Weinstein continuaram a supervisioná-las (SMITH, 2006, p. 458). Dentro deste esquema, a Miramax abriu uma divisão chamada Dimension Films, que produziu dezenas de filmes de gênero (a maioria de terror) como "Pânico" (1996), cobrindo uma demanda não oferecida antes pela Disney. Os Weinstein deixaram a Miramax em 30 de setembro de 2005 para criar uma nova produtora própria (The Weinstein Company). A Disney continuou a gerenciar o acervo e as novas produções até 2010, quando vendeu a Miramax para a Filmyard Holdings, encerrando seu envolvimento de 17 anos com a produtora.
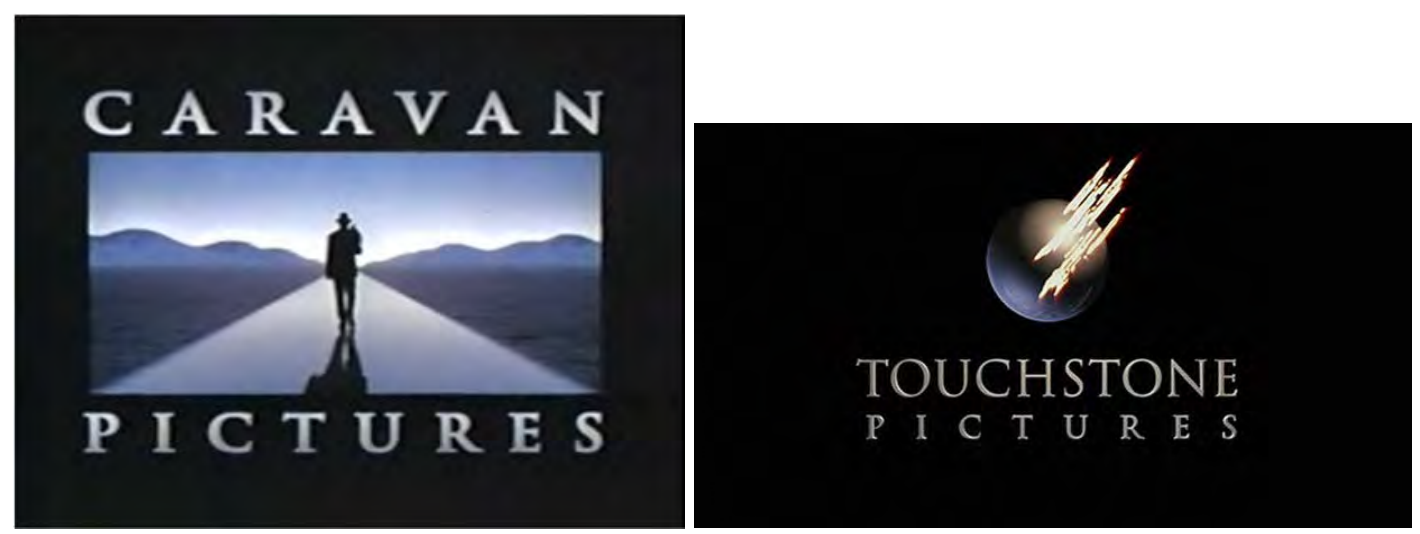

Figura. 15 e Figura. 16 - Logomarcas das novas produtoras de Disney. 

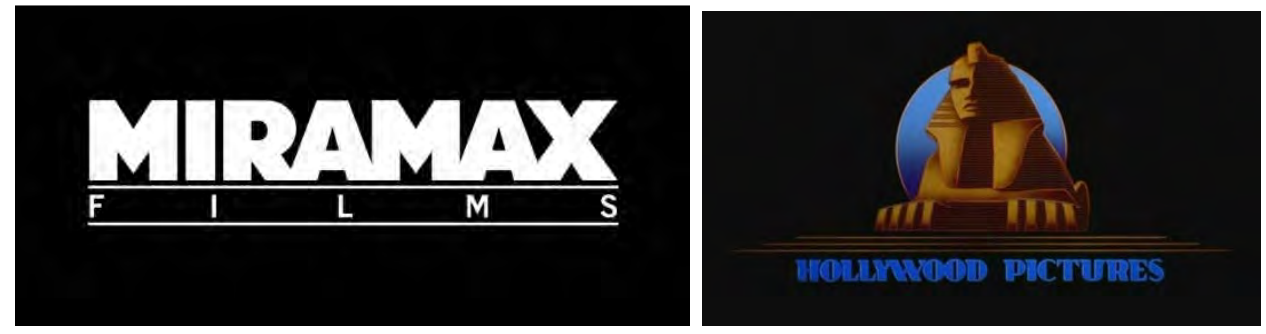

Figura. 17 e Figura. 18 - Logomarcas da Miramax e Hollywood Pictures.

As últimas duas variáveis do levantamento de produção live-action são os filmes da Marvel, que merecerão uma análise aprofundada e os filmes da Home Entertainment - geralmente produções com baixo orçamento inspirados em sucessos do cinema e da TV. Ficaram de fora deste levantamento somente as produções originais feitas para o Disney Channel - filmes familiares para os canais Disney. Nos dados do levantamento geral de produção Disney apresentados a seguir (Tabela 7), incluímos animações, filmes live-action, seriados de TV e co-parcerias (ex: os da Miramax). O importante é verificar como ocorreu uma expansão da produção entre os anos 1980 e 2000, não só por conta do crescimento da corporação Disney, mas de estratégias de expansão do mercado, das marcas e dos universos de personagens.

Vejamos os dados da tabela 7:

\section{Levantamento de Dados da Produção Fílmica Disney}

\begin{tabular}{|c|c|c|c|c|c|c|c|c|c|c|}
\hline & 1920 & 1930 & 1940 & 1950 & 1960 & 1970 & 1980 & 1990 & 2000 & 2010 \\
\hline DISNEY - Animação - Curtas & 122 & 178 & 190 & 78 & 23 & 7 & 18 & 9 & 15 & 8 \\
\hline DISNEY - Animação - Clássicos & 0 & 3 & 10 & 4 & 3 & 4 & 6 & 10 & 10 & 4 \\
\hline Live Actions - incluindo hibridos e extras & 0 & 0 & 1 & 23 & 45 & 45 & 18 & 55 & 56 & 22 \\
\hline True-Life Adventures - Disney Nature (França) & 0 & 0 & 2 & 12 & 0 & 0 & 0 & 0 & 3 & 5 \\
\hline Televisão - Animação & 0 & 0 & 0 & 0 & 0 & 0 & 6 & 23 & 22 & 14 \\
\hline Televisão - Live-action Disney & 0 & 0 & 0 & 4 & 1 & 2 & 15 & 24 & 28 & 18 \\
\hline Televisão - Touchstone & 0 & 0 & 0 & 0 & 0 & 0 & 18 & 51 & 69 & 26 \\
\hline Derivados da TV & 0 & 0 & 0 & 0 & 0 & 0 & 6 & 6 & 13 & 1 \\
\hline Touchstone Pictures & 0 & 0 & 0 & 0 & 0 & 0 & 47 & 99 & 67 & 13 \\
\hline Hollywood Pictures & 0 & 0 & 0 & 0 & 0 & 0 & 2 & 78 & 4 & 0 \\
\hline Caravan Pictures & 0 & 0 & 0 & 0 & 0 & 0 & 0 & 28 & 0 & 0 \\
\hline Miramax Films & 0 & 0 & 0 & 0 & 0 & 0 & 0 & 206 & 128 & 0 \\
\hline Dimension Films & 0 & 0 & 0 & 0 & 0 & 0 & 0 & 64 & 57 & 0 \\
\hline Pixar Animation Studios & 0 & 0 & 0 & 0 & 0 & 0 & 5 & 5 & 14 & 6 \\
\hline Marvel & 0 & 0 & 0 & 0 & 0 & 0 & 0 & 0 & 0 & 9 \\
\hline Disney Home Enterteainment - Animação & 0 & 0 & 0 & 0 & 0 & 0 & 0 & 11 & 26 & 4 \\
\hline Disney Home Enterteainment - Live action & 0 & 0 & 0 & 0 & 0 & 0 & 0 & 3 & 11 & 7 \\
\hline
\end{tabular}

*Dados da década de 2010 incluem títulos lançados até o final de 2014. True-Life Adventures/Disney Nature incluem os documentários sobre a vida selvagem realizados nas décadas de 1940 a 1950 e os filmes mais recentes produzidos na França. O programa "Disneyland/Walt Disney Presents/The Wonderful of Color/The Wonderful World of Disney/The Disney Sunday Movie" basicamente variações do mesmo programa de antologias conhecido no Brasil como "Disneylândia/Cine Disney/O Maravilhoso Mundo de Disney" é incluído no levantamento no grupo "Televisão - Live-action Disney" contabilizado 1 por década a partir dos anos 1940, apesar dos mais variados programas, séries, especiais e animações produzidos especificamente para o programa de TV.

** A década leva em consideração o início no ano "1", ou seja, os anos 1940 compreendem o período entre 1941 e 1950

Tabela 7 - Produção audiovisual Disney em suas diferentes divisões. 
Os resultados refletem as informações disponíveis e o que importa é comprovar a expansão e a segmentação, cujo ápice foi atingido na década de 1990.

A partir dos anos 2000, apesar dos números permanecerem altos, inicia-se uma estratégia de encolhimento e concentração, com o fechamento de departamentos, estúdios-satélites e encerramento de acordos de co-produção. Esta redução será compensada com uma nova estratégia de franquias, o fortalecimento de marcas de personagens e o surgimento de uma nova forma de produção baseada no conceito de tentpole.

Entendemos que o conteúdo discutido até o momento responde a primeira hipótese apresentada, no que ratifica os processos de transição e esgotamento da produção Disney, que são cíclicos e, como observamos, vive mais um desses momentos de transição na última década. Podemos, então, dar um enfoque maior, a partir de agora, na segunda hipótese.

A análise não é simples, necessitando englobar uma série de fatores que ultrapassam os limites do que chamamos da produção em si (o fazer do produto cultural, seja ele um filme ou uma história em quadrinhos). Esses dois objetos são muito interessantes por representarem, dentro de uma grande corporação como a Disney, os únicos polos de pura criação. Os filmes de animação (e podemos incluir algumas produções para televisão) representam as commodities (matérias-primas) que serão exploradas por todas as demais divisões da empresa. A The Walt Disney Company possui cinco grandes divisões, sendo os filmes parte de uma delas - a The Walt Disney Studios. As demais divisões se aproveitam desses lançamentos para alimentar os negócios em outras frentes. Até mesmo a própria divisão dos estúdios se retroalimenta de suas criações.

Vejamos como a corporação é organizada em suas cinco grandes divisões:

The Walt Disney Studios: divisão que inclui o selo "Disney", incluindo a Walt Disney Animation Studios, a Pixar Animation Studios, Disneynature, Marvel Studios, Lucasfilm, Touchstone Pictures - que agora distribui os filmes live-action dos estúdios DreamWorks; The Disney Music Group, que engloba as gravadoras Walt Disney Records e Hollywood Records, e a Disney Music Publishing; The Disney Theatrical Group, que produz e licencia eventos ao vivo como os shows da Broadway, Disney on Ice e Disney Live!.

Media Networks: compreende uma série de negócios de transmissão de cabo, rádio, publicações e negócios digitais dos grupos Disney/ABC Television Group e da esportiva ESPN Inc. Também fornece apoio na comunicação, mídia digital, distribuição, marketing, pesquisa e 
grupos de venda. A Disney/ABC controla não somente a rede de TV-ABC e produz conteúdo, mas variados negócios internacionais como canais afiliados, Disney Channel, Jetix, Disney Junior, ABC Family, produções locais em diversos países, além das participações da A\&E Television Networkd, Hulu e Fusion.

Parks and Resorts: O que começou com a Disneylândia em 17 de julho de 1955 transformouse em uma divisão que abrange 11 parques temáticos (Califórnia, Flórida, Tóquio, Paris e Hong Kong) e 44 hoteis-resort na América do Norte, Europa e Ásia, com uma sexta destinação em construção em Xangai, China. A divisão inclui uma linha de cruzeiros com quatro navios (Disney Magic, Disney Wonder, Disney Dream e Disney Fantasy); o Disney Vacation Club com 12 propriedades e mais de 200 mil membros.

Disney Interactive: Um dos maiores departamentos de criação de entretenimento interativo para todas as atuais e futuras plataformas de mídia digital. Produtos lançados por esta divisão incluem games para celular e consoles, mundos virtuais online, e a administração dos portais na internet das grandes marcas como "Disney.com". entre outras.

Disney Consumer Products: É a divisão que administra todos os lançamentos de diversas linhas de produtos em milhares de categorias que vão de brinquedos e roupas até objetos de arte. É considerado pela própria Disney o maior licenciador do mundo e compreende três subdivisões: Licensing (licenças), Publishing (publicações) e Disney Store (as 350 lojas Disney). A divisão de Licenças está alinhada em cinco marcas consideradas estratégicas: 1 Disney Media, Classics \& Entertainment, 2 - Disney \& Pixar Animation Studios (as animações), 3 - Disney Princess \& Disney Fairies (a linha feminina de princesas e fadas), 4 Lucasfilm (Star Wars e Indiana Jones) e 5 - Marvel (propriedade em histórias em quadrinhos).

Tabela 8 - Divisões da The Walt Disney Company.

Nosso segundo objeto de análise (quadrinhos Disney) está nesta última divisão, a Consumer Products, tratando-se, portanto, de um produto licenciado a diversas editoras ao redor do mundo com razoável liberdade de produção. Em certos territórios, especialmente em parte da Europa e no Brasil, os quadrinhos foram presença importante na divulgação dos personagens, colaborando no esquema sinérgico de produção em outros setores da indústria. Chamamos a atenção, ao mesmo tempo, ao fato de que, ainda que os quadrinhos propriamente Disney (considerando-se aqui os tradicionais e antigos estrelados por personagens como Mickey, Pato Donald e Tio Patinhas ou quadrinhos baseados em seriados e videogames mais recentes) não estejam em alta, a Disney considera a Marvel prioritária para os negócios da corporação. O negócio de licenciamento é alinhado ao redor das cinco marcas prioritárias: Disney Media, Classics \& Entertainment, Disney \& Pixar Animation Studios, Disney Princess \& Disney Fairies, Lucasfilm e Marvel. Esta última, como vimos anteriormente possui vasto acervo de histórias em quadrinhos de super-heróis, e tem sido nos últimos anos responsável por grandes sucessos cinematográficos e pelo faturamento de bilhões de dólares em produtos. Transforma-se, portanto, em um dos elementos-chave para que entendamos a nova lógica de produção Disney. 


\subsection{Tipologia da Produção}

Para entendermos essa nova dinâmica de produção, é necessário separarmos em partes quais os tipos serão analisados, porque elas se complementam. Temos a produção do conteúdo propriamente dito, a parte criativa, artística, que resulta nos personagens e seus universos. Porém, essa parte criativa não está separada da estrutura industrial. Como citado no início do trabalho, Raymond Williams (2011) é um dos acadêmicos que afirma que a cultura é um campo privilegiado para a compreensão crítica da sociedade, incluindo o questionamento sobre o papel da alta cultura, de quem a produz, e nesse caminho vai nos propor uma cultura em comum. A própria arte é material - o papel, a tinta, o petróleo, o quadro - tudo é material. Por ser material, temos uma força produtiva. O capitalismo não produz só mercadoria, mas outros produtos, resultando numa junção cada vez maior entre cultura e economia. Outro pensador que figurará nas tendências culturalistas é Fredric Jameson, que vê a cultura como centro de tudo. Segundo Jameson (1996), o capital se apropriou da cultura e a economia se apropriou da arte. $\mathrm{O}$ mercado especulativo atingiu o mercado da arte, as revistas de cultura, etc, resultando, portanto, numa culturalização da economia.

Jameson baseia sua teoria na obra "O Capitalismo Tardio" de E. Mandel, porém o autor não fala em arte. Ele classificará os anos pós-1940 de período pós-moderno, porém o movimento que ele analisa inicia-se mesmo nos anos 1970 com o advento do capitalismo pós-industrial, os motores eletrônicos e nucleares, a informática, a microeletrônica e o capitalismo multinacional. Por sua teoria, o pós-modernismo é um novo momento, uma ruptura/esgotamento em relação ao modernismo, acabando o caráter singular da obra de arte, do "eu" singular dos artistas, o fim dos estilos e dos manifestos. Faz uma crítica, portanto, ao caráter inovador e provocador do modernismo, que foi cooptado pelo sistema - onde um quadro de Picasso torna-se caro e objeto de status. O movimento pós-modernista junta tudo e acabam-se as diferenças.

Essa discussão é interessante ao nosso tema, porque a corporação Disney iniciou, a partir dos anos 1980, uma série de programas que visava uniformizar toda a produção em escala mundial. Isso não significa que não existissem fórmulas e prosseguimentos anteriores ao período, mas com todas as facilidades de tecnologia e comunicação, buscava-se maior qualidade em relação à dublagem de filmes, ao estilo e tipo de traço, ao que um personagem podia fazer ou não, além de uma padronização visando o mercado globalizado - teríamos assim, por exemplo, o ursinho Puff (como 
era conhecido no Brasil) transformado em Pooh, ou a Fada Sininho transformada em Tinkerbell para satisfazer e facilitar os processos de licenciamento.

A partir dos anos 1990 temos esse processo de uniformização da qualidade de forma muito forte. Um dos resultados foi a repetição de certas fórmulas, como no caso das animações musicais que se proliferaram nos cinemas. Podemos dizer que a produção Disney sofreu razoavelmente duas das características discutidas por Jameson (1998, p.15-44) quando descreve a condição pós-moderna. Temos, de um lado, o pastiche, onde tudo já foi criado e os modelos estão esgotados, restando apenas a cópia e a montagem da arte morta. Faz-se a arte sobre a arte de forma retrô, olhando para trás. Na animação vemos isso de diversas formas. Nos quadrinhos, Don Rosa e Andrea Casty tentam criam o "novo" se aproveitando de todas as características antigas dos universos dos patos e do Mickey. Essa volta ao passado nem sempre significa ter uma posição crítica. O pós-modernismo quer quebrar as fronteiras entre passado e presente, mas não é fidedigno e sim uma reconstrução imaginária. Há uma transformação da realidade em simulacro - sucessão de imagens, sobreposição de imagens, etc (BAUDRILLARD, 1991). Isso resulta na quebra do sentido da História, não havendo a sucessão do novo. Estamos em um presente congelado, estancados - sem futuro.

De outro lado, outra característica que podemos aproveitar do Jameson é o caráter esquizofrênico da produção cultural. Não se trata, propriamente, de dizer que os pós-modernos são esquizofrênicos, e, sim, (o autor utiliza como referência as obras de Lacan) que apresentam uma desorganização de linguagem, sendo um distúrbio do relacionamento entre significantes. Mas a ideia que nos interessa é essa problemática da junção entre economia e cultura, que influi na produção cultural.

Há também a produção técnica, que definimos como o processo de "fabricação" e toda a problemática da indústria e do trabalho. Seguindo a linha de transformações causadas no período do capitalismo pós-industrial, temos todas as modificações causadas pela flexibilização do trabalho subcontratação, emprego temporário, atividades autônomas - e pela redução do espaço-tempo (HARVEY, 1992, p. 178). Há um exemplo ilustrativo: na segunda metade dos anos 1980, a Disney já subcontratava estúdios menores para produção de seriados em animação, e já possuía estúdios satélites na França e na Flórida. Outra problemática: em 1995, chegava aos cinemas o primeiro filme totalmente computadorizado - "Toy Story". Nos anos seguintes, em que novas produções computadorizadas foram surgindo com sucessivas quebras de recorde de bilheteria, as animações tradicionais (feitas com papel e lápis) foram perdendo gradativamente seu espaço. Culpou-se a técnica 
- e não o conteúdo -, pelos insucessos consecutivos como “A Nova Onda do Imperador” (2000), "Atlantis: O Reino Perdido" (2001), "Planeta do Tesouro" (2002), "Irmão Urso" (2003) e "Nem que a Vaca Tussa" (2004). Somente "Lilo \& Stitch" (2002) obteve um resultado de bilheteria considerado razoável pela Disney, mas distante das cifras da década anterior (STEWART, 2005).

Além disso, a nova técnica computadorizada seria, diziam os executivos dos estúdios, uma forma de economizar no processo de produção. A verdade viria anos depois e confirmaria que as produções não se tornaram mais econômicas. Ficaram tão ou mais caras que os filmes ditos tradicionais. E foram copiadas pela concorrência. A DreamWorks lançou "Shrek" em 2001, massacrando o tradicional "Atlantis - O Reino Perdido" da Disney. Poucos viam que isso era um sinal de crise. Não crise do mercado de filmes, que ia muito bem, mas, sim, crise da produção como todos a conheciam. A animação tradicional virou o velho gadget de Baudrillard (1995), que precisava ser jogado fora, substituído pelo novo. O sucesso da indústria da animação como um todo mascarou o que acontecia nos bastidores. Tornou-se a imagem de um espetáculo baseado em números de bilheteria. Poderíamos aqui fazer uma correlação com Debord (1997) quando discute que o espetáculo é o capital em tal grau de acumulação que se torna imagem, não havendo distinção. Os modos de produção do capitalismo são modos de produção de imagem. E a indústria cultural se alinha do mesmo modo à indústria bélica, à indústria automotiva, à farmacêutica, à química e à de entretenimento. Temos, portanto, uma desmaterialização do produto cultural "animação tradicional" em prol do novo. Os quadrinhos não passaram incólumes - cada vez mais, etapas têm sido executadas no computador e o artista não pode ficar defasado em relação à tecnologia.

Temos adicionalmente, desta forma, o problema da desmaterialização do trabalho, citando aqui o artista como o operário que se vê de fronte a novas tecnologias e uma nova realidade de trabalho. Trata-se de um problema dos anos 2000, quando a Disney fez a opção estratégica de abandonar a produção massiva das animações tradicionais em prol das computadorizadas (mais rentáveis e bem recebidas). Os artistas tiveram três opções: deixar diversos postos da animação em si, levando seus lápis e pinceis para departamentos que cuidavam de fases de pré-produção dos filmes (como desenvolvimento visual); aprender a como lidar com as ferramentas computadorizadas e a animar personagens usando vetores; ou abandonar o estúdio (quando não eram demitidos antes). Esse processo de crise do trabalho ocorreu durante uma aparente bonança de bilheterias das animações computadorizadas. E a situação torna-se mais complexa quando incluímos na equação as terceirizações para estúdios em países com o custo de trabalho mais baixo. André Gorz (2003), Maurízio Lazzarato e Antonio Negri (2001) falam na hegemonia do trabalho imaterial, em que a 
riqueza dependerá cada vez menos do tempo humano, passando-se a primazia da ciência (trabalho intelectual) e da tecnologia. Se antes a riqueza dependia do sistema de máquinas, hoje depende ainda mais do conhecimento, como previra Toffler (1971).

Além da produção cultural em si e da produção técnica, ainda temos uma produção do capital, que podemos representar em análise do ponto de vista da estratificação, mas não do produto - tendo em vista que o ingresso do cinema, o preço de um DVD ou o preço de um streaming para baixar um filme são os mesmos em cada suporte de mídia, - mas, sim, da produção. É o processo inverso do que Richard Sennett (2006, p. 134) examina sobre a "laminagem de ouro" quando uma empresa como a Volkswagen vende produtos diferenciados para diferentes classes. No exemplo da produção Disney, temos uma estratificação do processo de produção, onde o preço do produto final não difere muito, mas que pode ser alterado em sua feitura. Um espectador paga o mesmo preço de ingresso para um filme produzido por US\$ 40 milhões ou US\$ 200 milhões. A Disney empreendeu uma estratégia nestas últimas três décadas de lançar produtos baratos visando a maximização dos lucros (GROVER, 1997). Porém, isso, se não controlado, resulta em uma desmaterialização do produto do ponto de vista da perda de qualidade - o que podemos observar com as dezenas de continuações, para o mercado de vídeo e DVD, dos clássicos Disney. Nas décadas de 1990 e 2000, a Disney investiu maciçamente em filmes para o mercado de vídeo (e DVD) com orçamentos baixos e produzidos em estúdios satélites como do Canadá, Japão e Austrália. Em sua maioria, eram continuações dos clássicos como "O Rei Leão 2: O Orgulho de Simba" (1998), "Pocahontas 2" (1998), “A Pequena Sereia 2" (2000), “101 Dálmatas 2" (2002), “Mulan 2" (2005), “Tarzan 2" (2005), “Bambi 2” (2006), “Cinderella 3” (2007), entre outros, com qualidade e valores de produção muito mais baixos em relação aos antigos filmes. 


\section{A PRODUÇÃO: A INOVAÇÃO DA INDÚSTRIA, TECNOLOGIA E CRIAÇÃO}

A produção da animação Disney se baseia nas premissas do cinema hollywoodiano. Há diversas formas de estruturá-lo com o intuito de analisar suas particularidades, porém procuramos primeiramente definir qual seria a ideal para esta análise, tendo em vista as polêmicas naturais que permeiam um conteúdo que mistura elementos de arte e indústria. É o caso do uso da palavra "artista" nomear os animadores, argumentistas e designers; ou o uso nesta pesquisa de "animação computadorizada" e não “animação digital” ou “3D”, porque a partir de 1990 até mesmo a animação tradicional Disney passou a ser colorizada digitalmente. Mesmo se nos atermos ao viés tecnológico, veremos que no caso da animação isso influi diretamente nos aspectos estéticos e mercadológicos.

Se usarmos o Mickey Mouse como exemplo, veremos como a evolução do personagem ilustra as mudanças nos campos estéticos e técnicos, além dos culturais. O primeiro Mickey, o de 1928, é fruto da Era da Depressão (crash de 1929). Preto e branco, sonoro e com um conteúdo mais violento, cínico e sexual. Como citado anteriormente nesta tese, um Mickey revolucionário que atraiu elogios de acadêmicos como Benjamin e Adorno, além de outros intelectuais mundialmente respeitados. Na década de 1930, temos o Mickey Mouse clássico ou da era do Jazz, repleto de narrativas heroicas e sofisticadas (como no "Aprendiz de Feiticeiro" de "Fantasia") ou aventuras rurais e imaginativas. Nos anos 1940, em meio à Segunda Guerra Mundial, Mickey Mouse encarna o americano otimista. Seus parceiros Donald e Pateta são ainda mais efetivos em representar o American way of life. Na era da televisão dos anos 1950, Mickey Mouse já é mais urbano, tecnicamente possui animação mais simples e esteticamente angular. Sua popularidade acabou reforçando fórmulas que tornaram Mickey um personagem antiquado e sem graça. Não surpreendentemente, outros personagens superaram sua popularidade. Nesta mesma época, Disney perdeu boa parte do apoio no meio intelectual ao mesmo tempo em que seus personagens e filmes se fortaleciam mundialmente por meio da televisão e dos produtos licenciados - o Clube do Mickey e a Disneylândia foram o auge do processo de sinergia entre a produção audiovisual, os parques temáticos e os demais produtos como as tiras em quadrinhos (COTTER, 1997).

Somente nos anos 1970, no fluxo de contracultura, Mickey Mouse é redescoberto e o personagem ganha sua era icônica, com toda sua felicidade, inocência infantil e uma representação do emblema dos Estados Unidos. Não somente seus desenhos animados, quadrinhos e produtos se tornaram ainda mais populares, como houve um aproveitamento de uma geração de artistas numa onda para interpretá-lo - caso de Andy Warhol e dezenas de nomes cujos trabalhos foram compilados 
no livro “The Art of Mickey Mouse” de Craig Yoe e Janet Morra-Yoe (1991). Após uma breve, porém poderosa, campanha de aniversário do Mickey Mouse em 1988, devido à comemoração de seus 60 anos, o personagem estrelou poucas produções inéditas. Transformado basicamente em um símbolo corporativo, o estúdio encontraria dificuldades para usar o personagem por conta de sua imagem no imaginário do público e das limitações em moldá-lo em novas situações. A saída, encontrada apenas em 1999 e na década seguinte, seria limitar o Mickey a uma espécie de mestre-de-cerimônia ou "ator" de suas aventuras em seriados como "OK Mundongo do Mickey" (Mickey Mouse Works, 1999) e “(O Point do Mickey” (House of Mouse, 2001). A última década (anos 2010) apresenta uma nova mudança estética e de narrativa, pós-moderna, em que o personagem vive novas aventuras, mais curtas, rápidas, frenéticas, num tom semelhante ao de seus primeiros curtas-metragens dos anos 1920 e 1930. Vejamos nas imagens abaixo os principais marcos da evolução de Mickey Mouse:
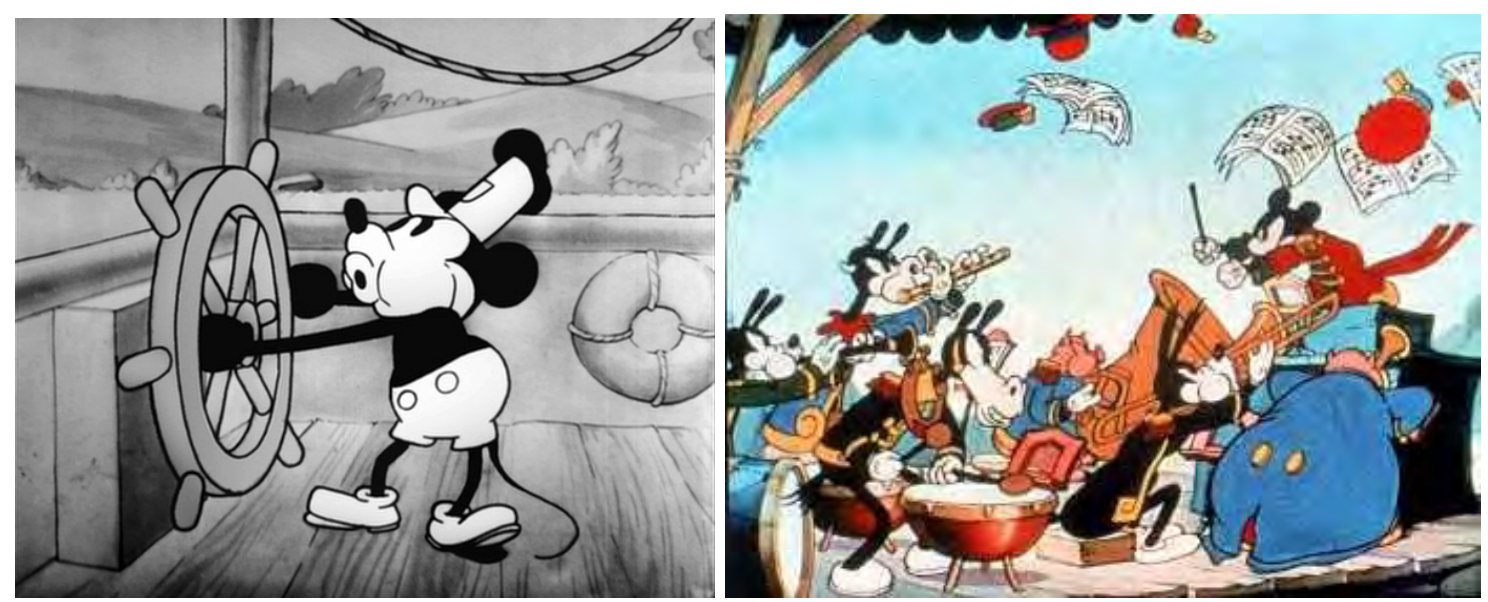

Figura. 19 e Figura. 20 "Steamboat Willie" (1928), o primeiro curta-metragem sonoro. "The Band Concert" (1934) o primeiro curta-metragem do Mickey em cores.

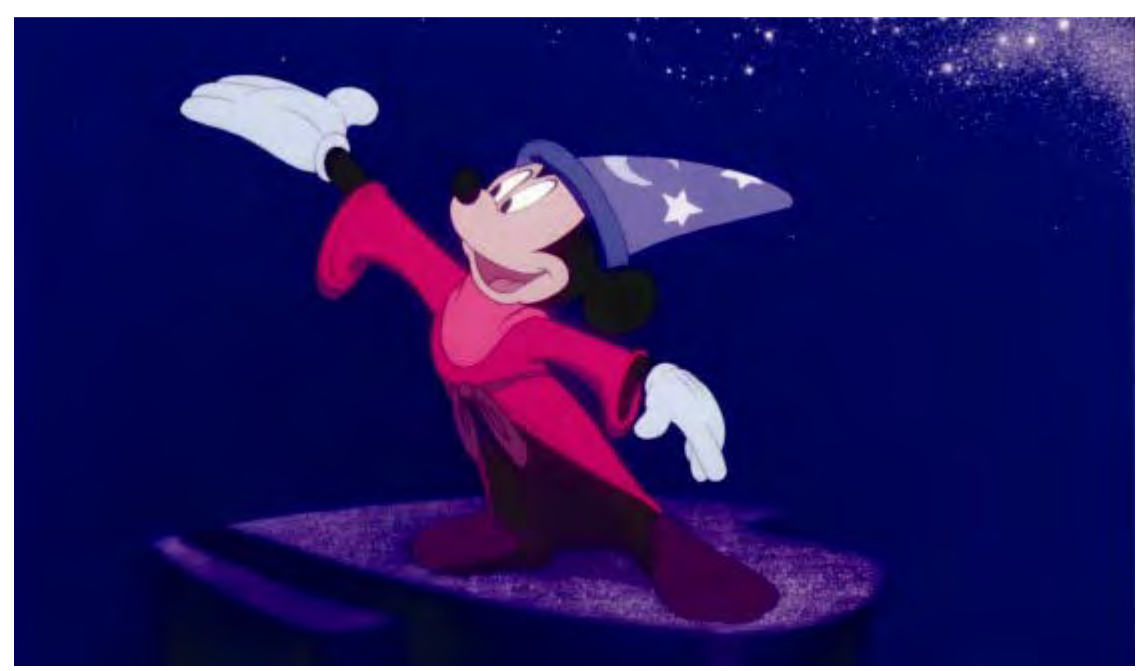

Figura. 21 - "Fantasia" (1940) - Para muitos críticos o auge do Mickey foi em "O Aprendiz de Feiticeiro". 

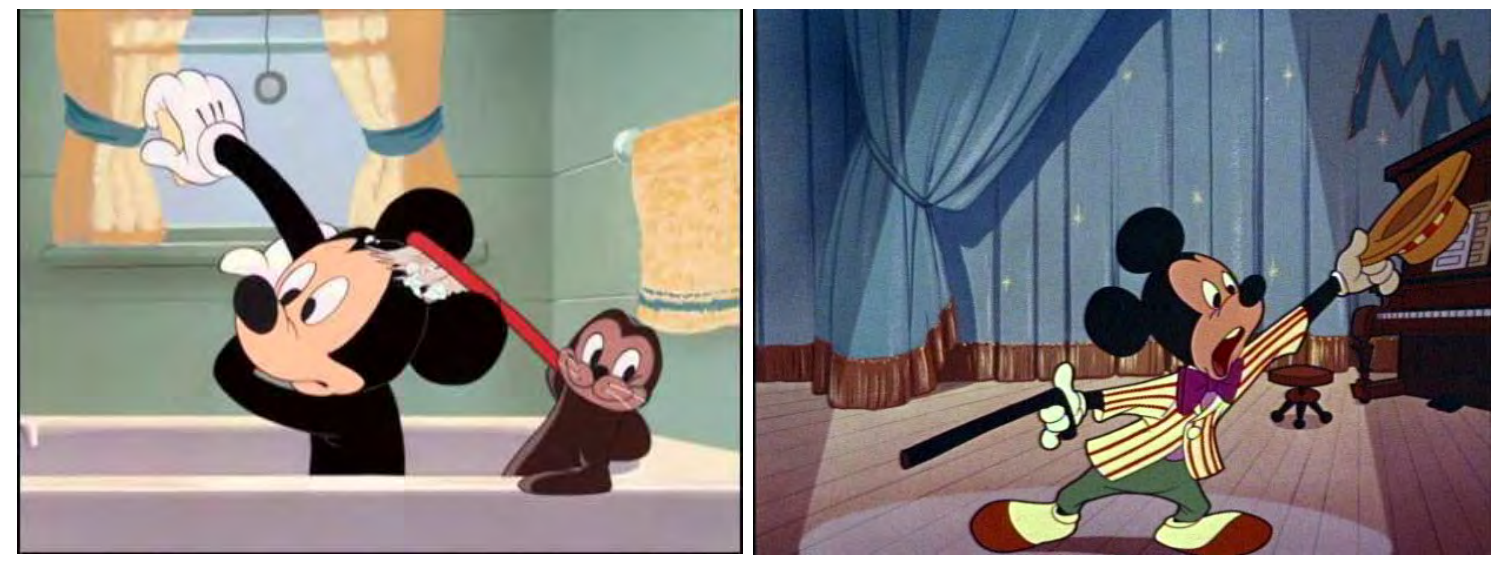

Figura. 22 - "Mickey and the Seal" (1948), um dos melhores exemplos do Mickey "urbano". Figura. 23 - Mickey como mestre de cerimônia em "O Clube do Mickey", sucesso na televisão na década de 1950.
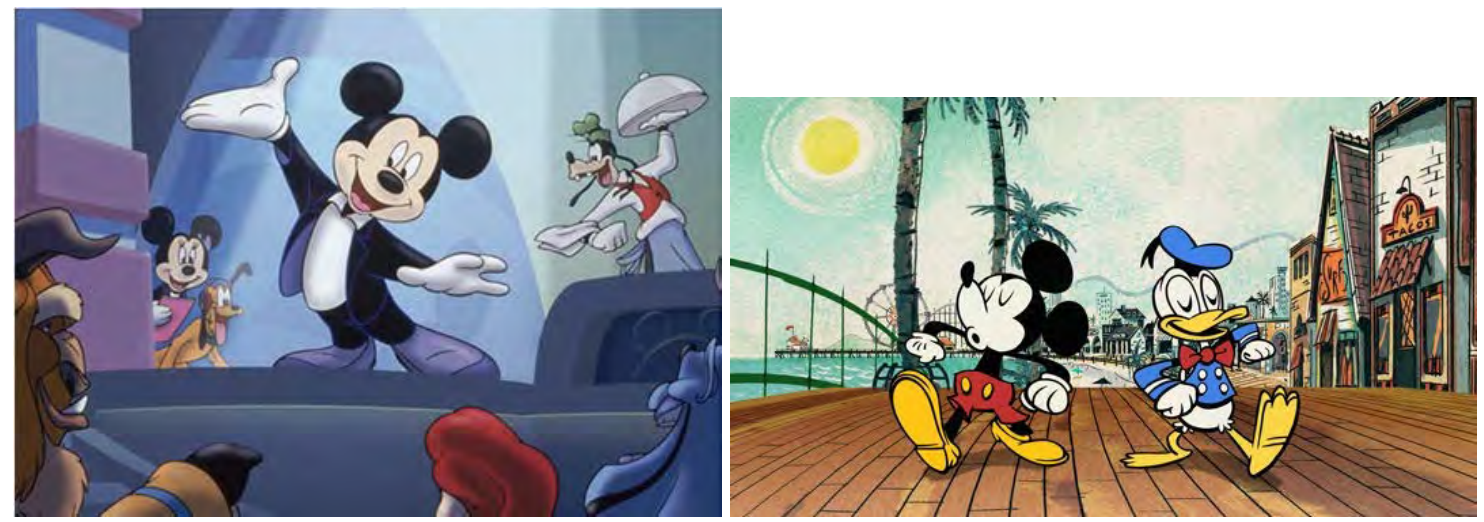

Figura. 24- "House of Mouse" (anos 2000) e Figura 25 - o "novo Mickey" em seus desenhos na década de 2010.

\subsection{A Inovação}

A primeira chave na análise de produção, do ponto de vista tecnológico, é a inovação. Da mesma forma que o cinema de filmagem real (live-action) e das fábricas de produção em série, como a automotiva de Henry Ford, o cinema de animação também conhecerá sua revolução industrial (DENIS, 2007, p. 116). O animador do Mickey, Ub Iwerks, não só era animador, mas um inventor e técnico de efeitos especiais (IWERKS, 2001).

Todos os pioneiros, Winsor McCay, Cohl, John Randolph Bray (implantou o uso de células de animação sobre um cenário único visando reduzir os custos), Bill Nolan (inventor da panorâmica e da estética borracha dos personagens dos anos 1920) e Max e Dave Fleicher (desenvolveram os primeiros filmes híbridos com animação e filmagem real) foram empreendedores com grande senso 
técnico e estético, dentro da nova indústria que se estabelecera. Assim como Walt Disney e outros talentos na área, os estúdios buscam conhecer e desenvolver todas as tecnologias e invenções disponíveis, tudo numa época em que reinava a ideologia do progresso que auxiliava as indústrias não só do cinema, mas do automóvel, das comunicações, entre outras.

Devido a sua natureza econômica (visando lucro), a atividade cinematográfica necessita de equipamentos e tecnologias relativamente sofisticados, que não param de se aperfeiçoar. Portanto, o estudo da inovação e do desenvolvimento tecnológico é um ponto indispensável nesta análise, sendo que:

\footnotetext{
“A evolução do cinema desde sua origem é marcada por uma dinâmica de restrição e potenciais em que a tecnologia desempenhou um papel fundamental. Contudo, o estado da arte não determina soluções únicas. Juntamente com a tecnologia disponível, há uma vasta gama de possibilidades, com suas implicações econômicas e estéticas (CRETON, 2014, pp. 37-38).
}

A inovação é um processo complexo que opera em diferentes níveis e a partir dela é possível explicar o emaranhado de múltiplas causas sócio-técnicas. Para o professor Laurent Creton (2014), da Universidade Sorbonne, nesta perspectiva as descobertas técnicas e as inovações tecnológicas são comparáveis à ideia de cinema, que pode ser também representado como um fenômeno essencialmente idealista. Lembrando André Bazin (2011, p. 22), "a imaginação identifica a ideia cinematográfica a uma representação total e integral da realidade". Nesta perspectiva, o cinema americano é importante pela intensa pesquisa e desenvolvimento nos processos de produção e comercialização, a despeito de toda a evolução técnica que ocorria paralelamente na Europa.

O cinema se funde e evolui graças à combinação de múltiplas inovações. E elas podem ser classificadas não só na dimensão tecnológica, mas também nas dimensões institucionais, artísticas e estéticas, resultando num sutil mix de experiências. E, deste modo, torna-se importante uma análise da inovação setorial e intersetorial (cinema-televisão e outras áreas), na qual as empresas se comprometem a determinadas abordagens estratégicas. Deste ponto é possível compreender os padrões, as possibilidades de melhorias e as necessidades de inovação.

A inovação se divide basicamente em duas dimensões. A primeira é o processo de evolução em razão de sua lógica de aplicação, dependendo da integração de diversos elementos. A estratégica 
dos pequenos saltos apresenta a vantagem de reduzir riscos e de poder construir uma dinâmica em rede das micro inovações, levando em consideração, de forma sofisticada e eficaz, a evolução dos mercados e da tecnologia. Esta dimensão é fundada sobre as práticas progressistas, experimentais e pluralistas (CRETON, 2014, p. 52). Ela é caracterizada por três fatores:

- Capacidade de reduzir os riscos inerentes da ruptura na descoberta das lógicas de continuidade.

- Redução de amplitude de novidades, mesmo se multiplicando.

- Capacidade de adaptar-se à natureza e à amplitude dos saltos em função de situações dos mercados e tecnologias, além de combiná-las no tempo.

A segunda dimensão é a administrativa, em que o sucesso da inovação se traduz por um encontro lucrativo entre oferta e demanda. Alguns fatores-chaves de sucesso podem ser identificados (CRETON, 2014, p. 55):

- A qualidade e a regularidade das práticas de inovação de empresa.

- A abertura do ambiente às ideias novas, às potencialidades, à atitude de pesquisa, à aptidão de combinar elementos provenientes de diferentes campos disciplinares.

- Um bom conhecimento do mercado e de suas evoluções, uma cultura de marketing e a utilização de metodologia e de suas ferramentas correspondentes.

- O pragmatismo considerando a área de aplicação, a matriz de competência e das técnicas profissionais, sabedoria para passar da ideia ao conceito e do conceito à realização.

- O gerenciamento da inovação, saber articular diferentes abordagens, colocar em sinergia diversas competências, inscrever a inovação no quadro de estratégia de desenvolvimento da empresa.

Se analisarmos as produções Disney, veremos que muitas inovações ocorreram no período exploratório da chamada "era de ouro", entre fins dos anos 1920 e a década de 1940: o primeiro desenho animado sonoro, em 1928; um dos pioneiros de sincronização musical com animação, em 1929; o primeiro desenho animado em cores, em 1932; o primeiro uso da câmera multiplana visando profundidade e maior movimento nos filmes, em 1937; o primeiro longa-metragem em cores ("Branca de Neve e os Sete Anões", 1937) e o uso do som do estéreo, em 1940. Vejamos a evolução dos marcos técnicos da animação Disney: 

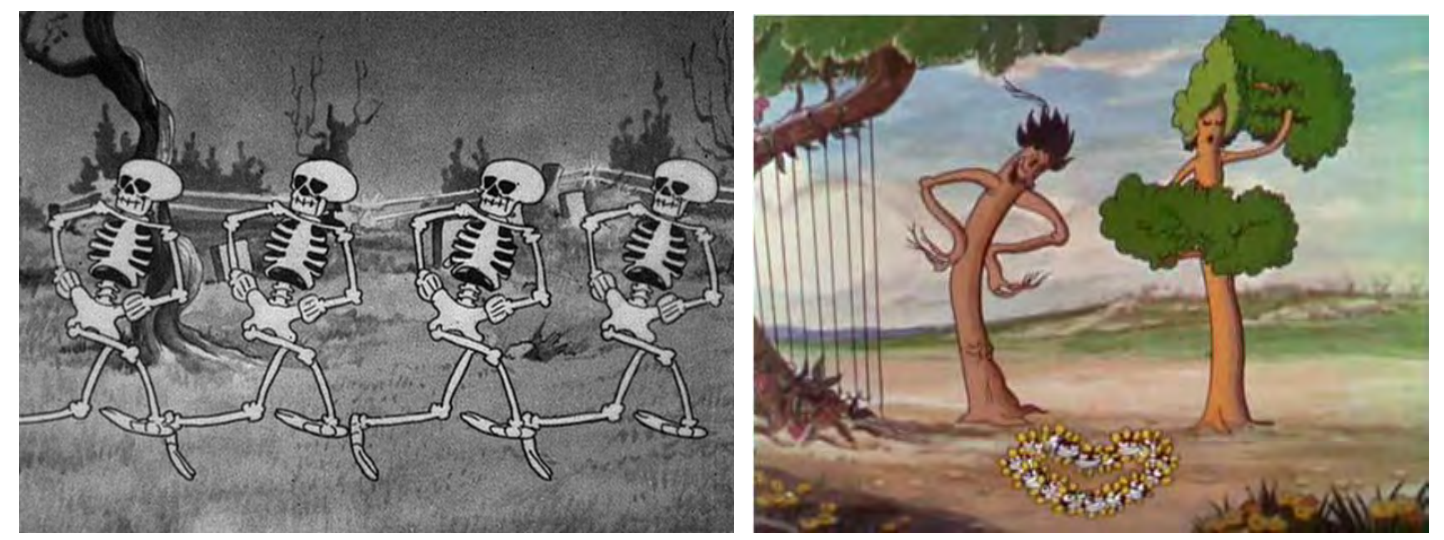

Figura. 26 e Figura.27 - "The Skeleton Dance" (1929) e "Flowers and Trees" (1932)

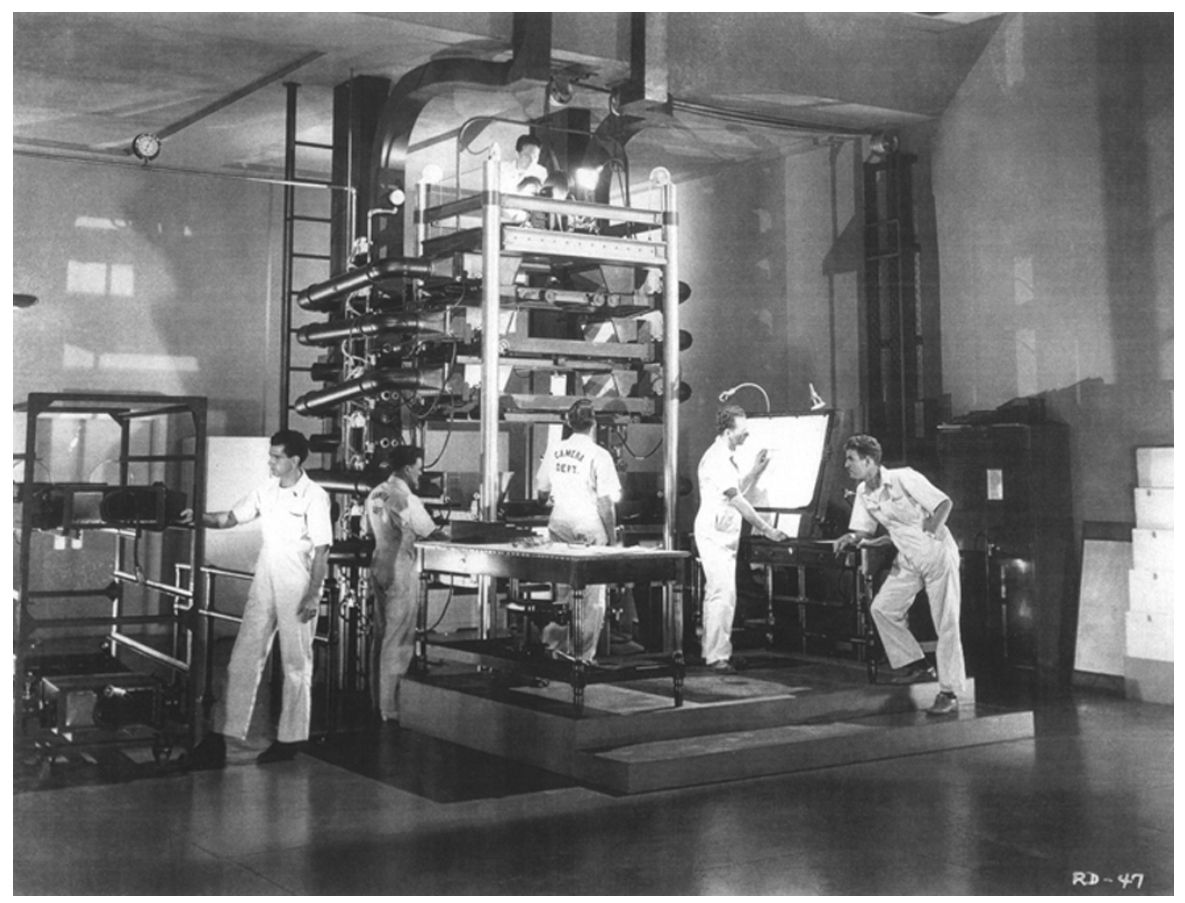

Figura 28 - Câmera Multiplana
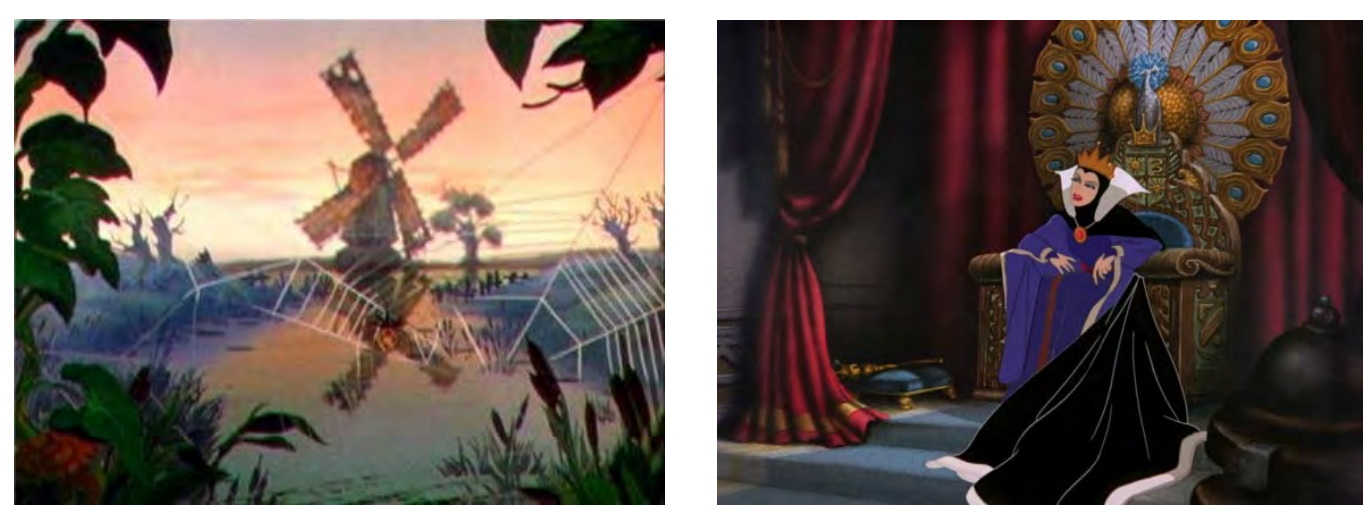

Figura 29 e Figura 30 - O curta-metragem "O Velho Moinho" e o longa "Branca de Neve e os Sete Anões (1937) 


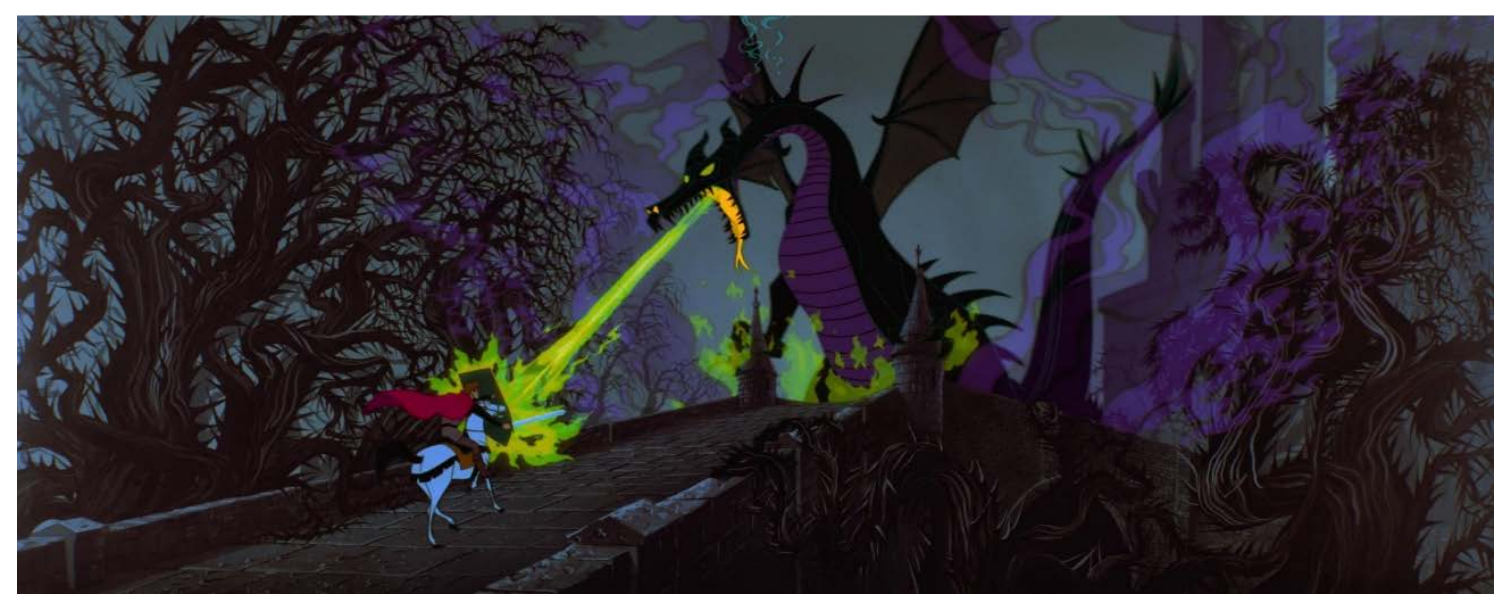

Figura 31- “A Bela Adormecida” (1959) - primeiro longa-metragem em Super Technirama 70mm, atendendo ao formato Cinemascope, popular na década de 1950.

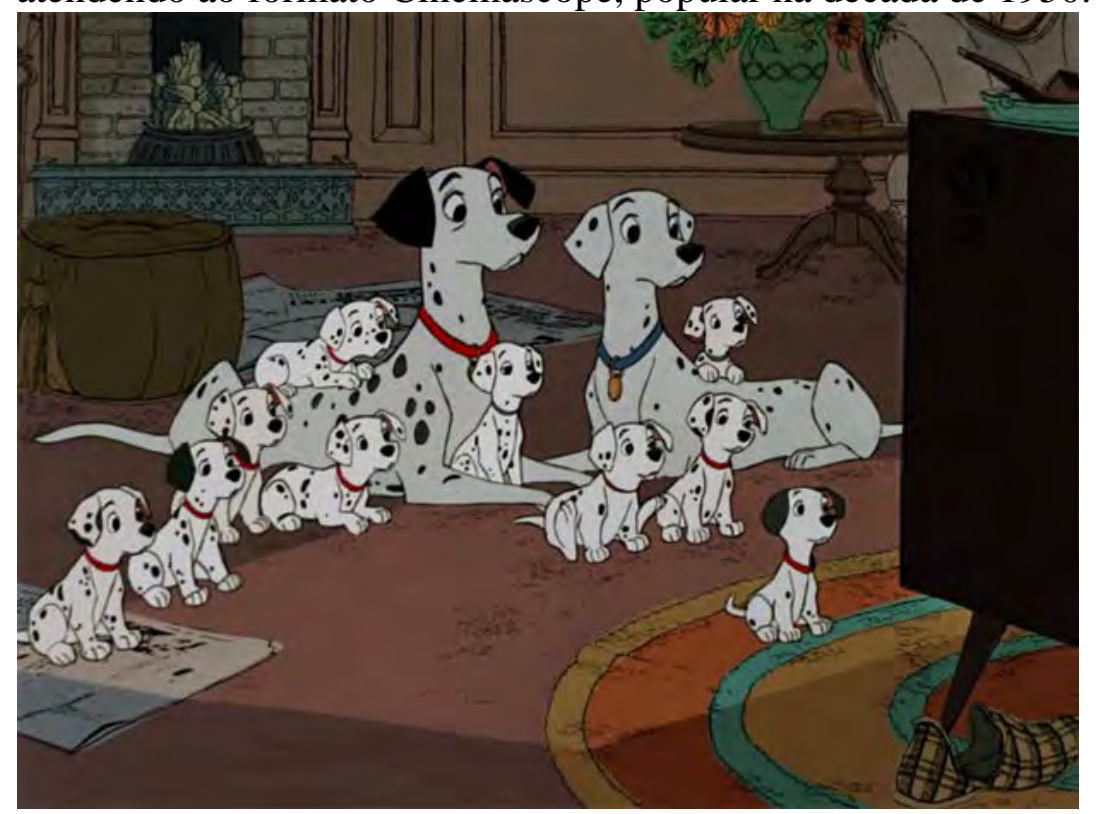

Figura 32 - "101 Dálmatas" (1961) - Necessidades econômicas levaram ao uso da Xerografia para eliminar o processo de transferência dos esboços para a célula de animação.

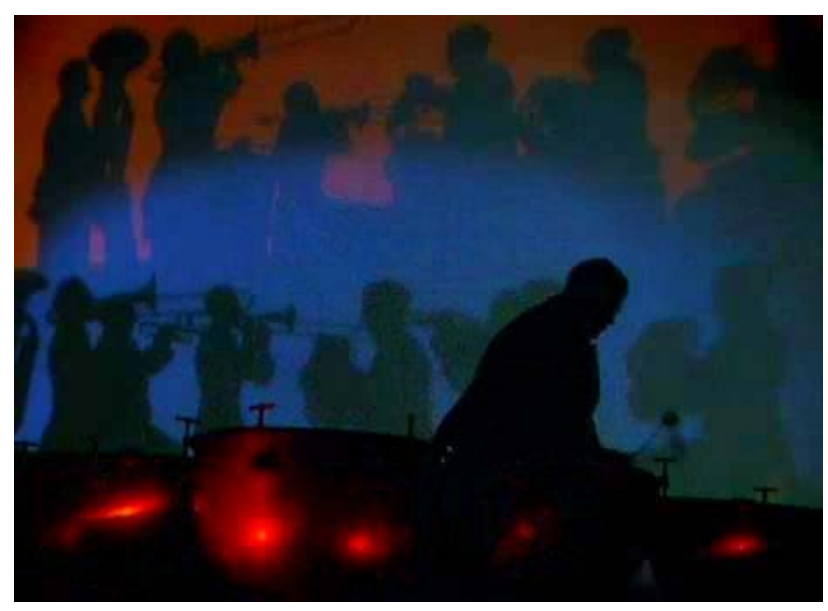

Figura 33 - "Fantasia" de 1940 trouxe duas inovações. O primeiro uso do sistema estereofônico em larga escala. No seu relançamento em 1982, apresentou regravação da trilha em formato digital. 


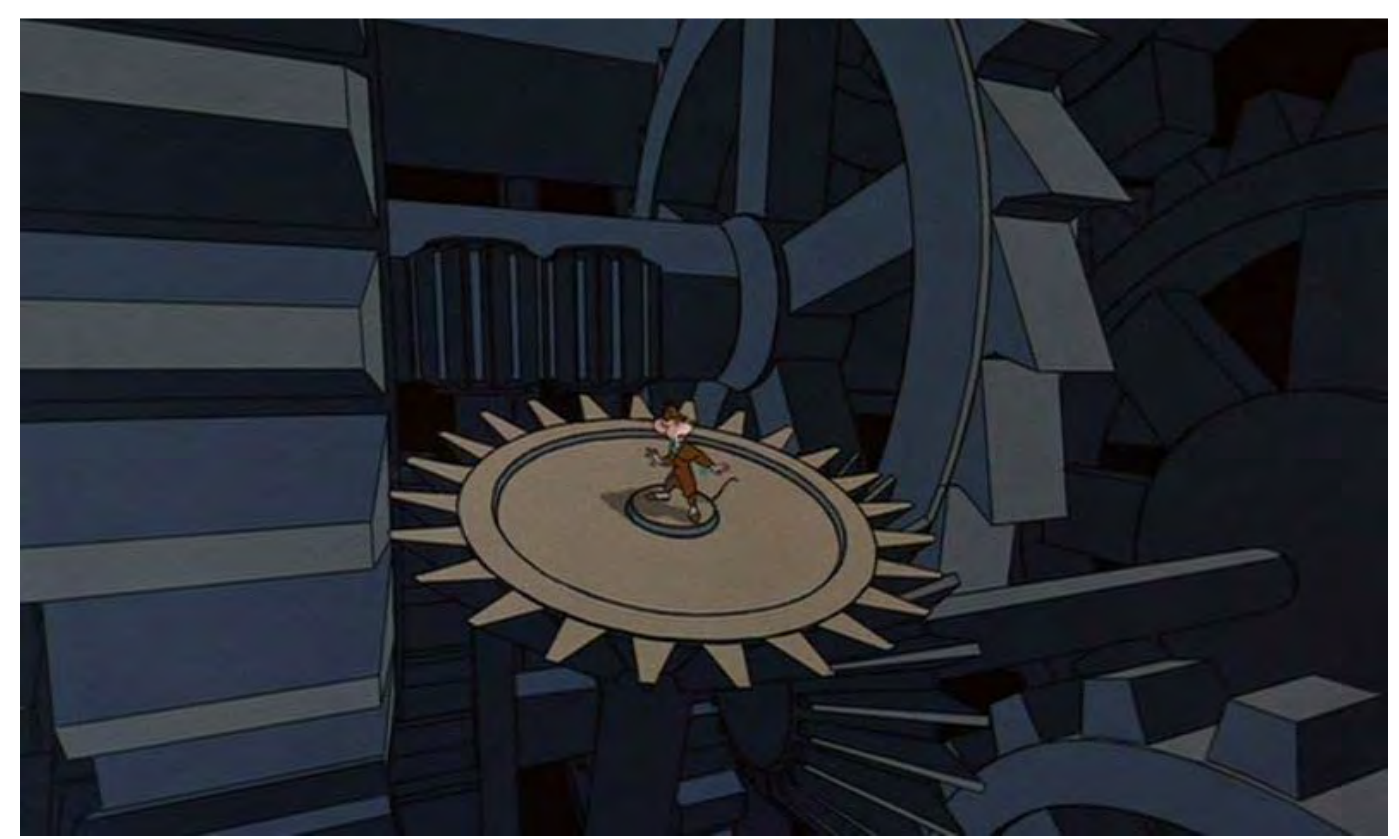

Figura 34 - "O Ratinho Detetive" (1986), o primeiro uso efetivo da animação computadorizada em uma sequência (clímax no relógio Big Ben).
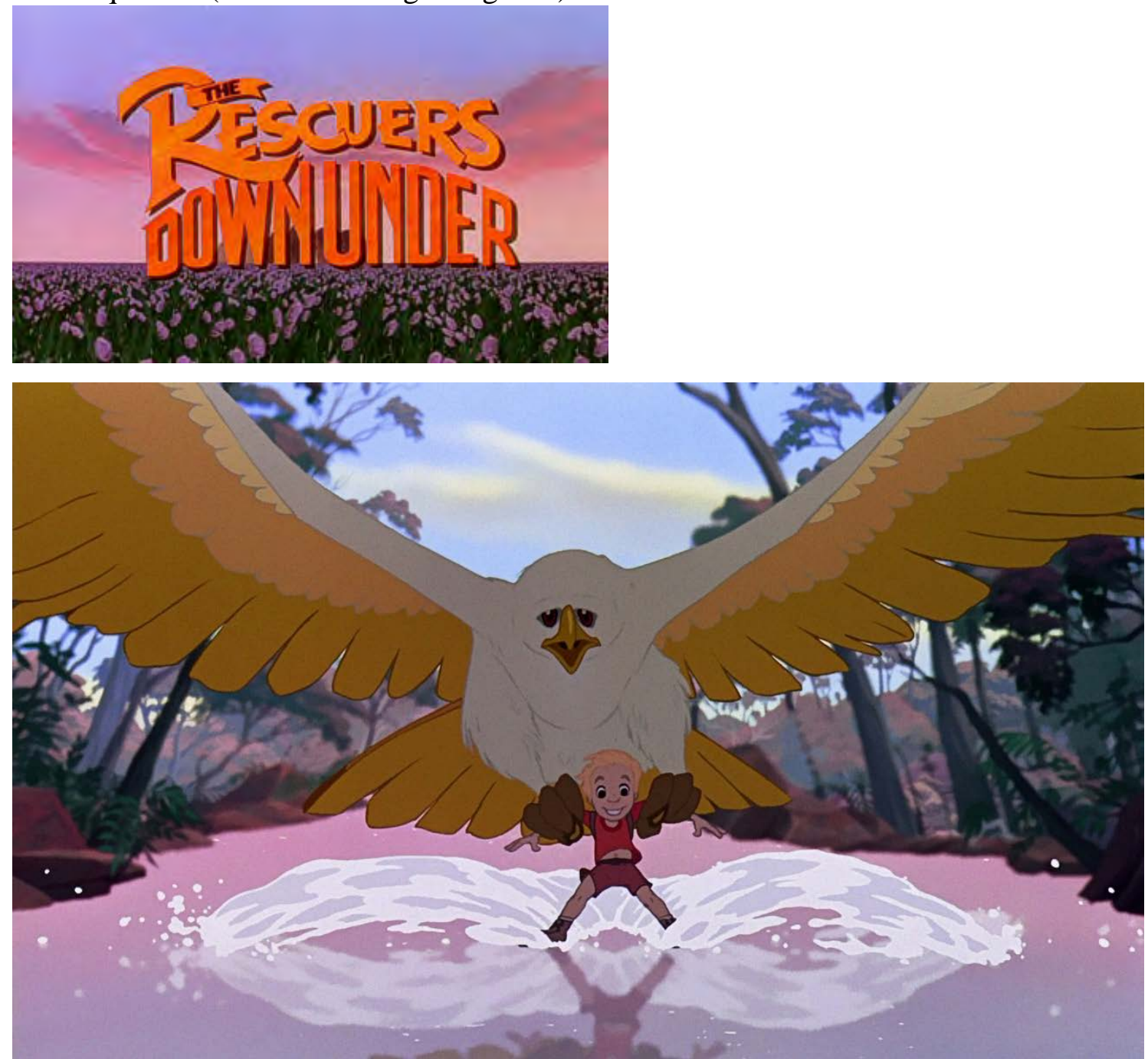

Figura 35 e Figura 36- "Bernardo e Bianca na Terra dos Cangurus" (1990) - Tecnologia CAPS introduziu a colorização digital nos filmes de animação. 
Somente a partir dos anos 1980 e mais sensivelmente nos 1990 é que o cinema e, especificamente, a animação, veriam tantas inovações consecutivas. Algumas grandes, como a introdução do sistema CAPS, teria não somente um impacto estético nas novas produções, como também alteraria a estrutura de trabalho, eliminando inteiramente o antigo departamento de pintura, forçando uma adaptação de toda a equipe que encontrou um espaço reduzido de trabalho.

Um dos principais choques no modelo de produção dos filmes de animação foi a estreia de “Toy Story” em 1995, com fortes consequências culturais, tecnológicas e do próprio mercado forçando uma intensa concorrência e o praticamente sepultamento da técnica tradicional (animação feita a mão no papel).

\subsection{A Indústria}

A segunda chave de análise da produção é a indústria. A produção Disney está inserida dentro de um modelo industrial, onde o capital, o marketing, as redes comerciais, as multinacionais poderosas influem fortemente na produção. A partir dos anos 1980, há uma primazia das chamadas majors (as grandes corporações de mídia), da lógica de competitividade no mundo audiovisual americano e da conquista dos mercados internacionais. E há também o modelo cinema-mundo, em que se aposta na larga escala de difusão. Isso representa o domínio do universalismo do modelo Hollywoodiano na arte de captar ideias e talentos do mundo inteiro e valorizá-los em suas produções. Esse modelo, atuando dentro da globalização, traz elementos tão diversos como a própria tradição norte-americana do liberalismo econômico, da sociedade de consumo, da difusão da cultura como soft power (poder brando de influência sobre outras nações).

Ao mesmo tempo, há uma integração entre global e local, tendo em vista o intenso processo de captação de ideias, histórias e talentos externos, sua adaptação e posterior divulgação em escala global. É o caso, por exemplo, da inspiração dos contos de fadas e livros infantis, cuja origem se baseia na adaptação mais branda da tradição oral dessas histórias na Europa dos séculos XVIII e XIX (DARNTON, 1986). Os filmes irão novamente adaptar essas histórias, seguindo o gosto norteamericano. O sistema Hollywoodiano, portanto, é uma combinação de sistemas cultural, estético e econômico, caracterizando-se, principalmente, por uma pesquisa organizada e uma sistemática de sucessos que se traduz por uma multiplicidade de fórmulas e no seu desdobramento comercial. "O sistema hollywoodiano é muitas vezes associado aos produtos derivados e às espetaculares 
campanhas de marketing fundadas sobre o cross selling. A Disney é uma grande especialista na prática desse caminho, em todos os seus lançamentos. As vendas de produtos derivados estão inseridas na estratégia que integra parques temáticos, licenciamentos, televisão, etc" (CRETON, 1997, p. 109).

A melhor forma de compreender a indústria e o mercado é por meio da abordagem estratégica. Sua qualidade é uma determinante para o sucesso, seja para implementar um projeto, abordar seus mercados ou enfrentar seus concorrentes. No caso de uma indústria criativa, a combinação com arte e tecnologia resulta em uma poderosa arma em um mundo altamente conectado e com fortes concorrentes. Novamente recorremos aqui ao professor Laurent Creton, pois certamente fez um dos melhores estudos relacionados às estratégias de mercado relacionados a economia e cinema:

A estratégia vem do grego "Strategos" que tem sua origem ao chefe do Exército e a uma ampla representação em analogia a práticas militares. Podendo não ser sempre relevantes, [as estratégias] elencam o mapa de atuação, o estado do terreno, as manobras possíveis, as formas de compromisso e, enfim, a estratégia é decidida em etapas e condições. A vitória depende de uma boa execução da estratégia. Os autores do tema "estratégia de guerra" são antigos, destacando os clássicos Sun Tzu e Clausewitz ${ }^{25}$. A partir dos anos 1950, diversas companhias começaram a desenvolver suas políticas gerais acreditando encontrar elementos de reflexão usando como resposta os estudos de liderança de guerra, as campanhas e as batalhas. Toda uma literatura consagrada da arte da guerra aplicada aos negócios floresceu, com boa correspondência às lógicas concorrenciais e de mercados. O pioneiro foi Corporate Strategy (Igor Ansoff) publicado em 1965. (CRETON, 2014, p. 118, tradução nossa)

Uma definição clássica para o termo é que

a estratégia da empresa é o sistema constituído pelo conjunto de análises, decisões e ações referentes a um objeto, em função de suas características adequadas e de seus ambientes, de orientar suas atividades e estruturas, adaptar e mobilizar seus recursos, a fim de otimizar a realização de seus objetivos fundamentais" (CRETON, 2014, pp. 118-119, tradução nossa).

\footnotetext{
${ }^{25}$ Sun Tzu (A Arte da Guerra) e de Clausewitz (Da Guerra) são dois dos teóricos da guerra mais importantes. O soldado prussiano e teorista alemão Carl Von Clausewitz viveu entre os séxulos XVIII e XIX. Influenciado pelas reformas militares prussianas que levaram à derrota de Napoleão, enxergava a guerra como instrumento político - sua afirmação mais famosa é "a guerra é a continuação da política por outros meios". O general chinês Sun Tzu (544 a.C. - 496 a.C.), por sua vez, nunca elaborou uma definição da guerra, porém acreditava ser de vital importância para o Estado. Em sua obra, elenca estratégias de guerra afirmando que "a suprema arte da guera é derrotar o inimigo sem lutar". O uso da força deve ser estrategico para garantir a vitória.
} 
Outra definição aponta que o conceito de estratégia pode ser apresentado a partir de 5 P's: Perspectiva de uma companhia que representa um futuro desejado e realista; Posição como a pesquisa de uma posição favorável no universo concorrencial; Planificação de ações num horizonte temporal; Padrão (Modelo) verificando se a abordagem de análise, decisão e estrutura de implementação são coerentes; Ploy (Estratagema) como o conjunto de coordenadas de ações destinadas a atingir os objetivos pré-definidos (MINTZBERG, 1989).

As estratégias são usadas desde o início dos estúdios de Hollywood, porém foi a partir dos anos 1980 que modelos foram criados para que a análise concorrencial e a abordagem estratégica fossem bem aplicadas. A análise concorrencial é essencial para a abordagem estratégica, especialmente num mundo em constante mudança e sujeito a mais crises. Durante o período dos anos 1920 até 1980 o ambiente concorrencial era relativamente simples e, de repente, uma sucessão de mudanças econômicas, fusões corporativas e novidades tecnológicas implicaram na alteração dos padrões do estúdio resultando no gigantismo da Disney e sua transformação em uma das maiores corporações de mídia do mundo.

A abordagem estratégica, por sua vez, se adapta a uma variedade de indústrias - e as indústrias culturais não fogem à regra. Cada vez mais, a gestão estratégica é importante devido às especificidades das atividades artísticas e culturais resultantes da natureza de produção. Há o problema do "lucro" e diversos produtos podem não gerar diretamente o retorno desejável. Porém, há casos em que as metas não podem ser definidas em termos estritamente econômicos. Há resultados estéticos, culturais e sociais que resultam em um "lucro simbólico", que as pesquisas de mercado/opinião e os critérios usuais de medição são insuficientes para calcular. Portanto, há atividades artísticas e culturais fortemente marcadas por uma força de expressão que não podem ser calculadas por regras, processos e bases de organização em uma racionalização puramente instrumental. A personalidade dos gestores/executivos exerce grande influência na identidade e nas práticas da empresa (ou, no caso aqui, dos estúdios), sejam elas o estilo, a energia, o carisma - e essas qualidades mobilizam o recrutamento de talentos e ideias.

Da mesma forma que a Disney se transformou em uma grande corporação, notamos o quão complexa se tornou a questão da gestão e suas diversas abordagens estratégicas nas últimas duas ou três décadas. Isso não significa que, no passado, o próprio Walt Disney não as usou. Porém, seus usos se davam em contextos muito mais simples. Toda a experimentação dos anos 1930 e 1940 abriu espaço para a padronização e a fórmula, devido à contratação do Instituto Gallup, que começou a 
medir o que satisfazia o público no cinema - a pesquisa de opinião foi a primeira grande interferência direta na produção (OHMER, 2006). Nos anos 1950, a televisão forçou uma abordagem maior da sinergia, resultando na entrada de Walt Disney nesta plataforma muito antes de outros pioneiros (COTTER, 1997). Entre a morte de Walt Disney em 1966 e o início de uma gestão profissional externa, o estúdio se tornou dependente de seus veteranos executivos e artistas, que tinham visões muito conservadoras (administrativa e esteticamente). Perguntava-se a todo momento "-O que Walt faria?" e havia uma intensa inércia na forma de tomada de decisões criativas na produção de filmes. O pouco espaço para experimentações só foi aberto no início dos anos 1980, com curtas-metragens exploratórios e filmes como "Tron: Uma Odisseia Eletrônica" (1982). Por quase uma década, o estúdio fortaleceu uma abordagem pelo viés cultural, devido ao contexto da contracultura que alterou o tom das produções, que se tornaram mais sombrias e adultas. Era preciso repensar e reinventar a produção Disney, que nessa fase era menosprezada mesmo em Hollywood.

A partir de 1984, com a posse dos executivos Michael Eisner (vindo da Paramount) e Frank Wells (oriundo da Warner), a gestão estratégica insere a animação como núcleo de algo muito maior. É necessário diversificar e ampliar a sinergia com televisão, parques temáticos, lojas, produtos licenciados; além da convivência com outros tipos de produtos, que são criados por diferentes subsidiárias. A Disney se torna uma grande corporação de mídia, lutando de igual para igual com forças como a Time Warner e a News Corp. Uma de suas principais estratégias foi a diversificação de produtos e público (KORTEN, 1996). E há alterações profundas nas estruturas de produção, incluindo terceirizações e internacionalizações de estúdios. E igualmente temos a ampliação dos problemas relacionados ao gigantismo da companhia (GROVER, 1997).

Como vimos na parte sobre inovação, a tecnologia tem um peso razoável e, em alguns casos, fundamental, para a evolução da produção de filmes. A animação computadorizada representou um grande marco e um obstáculo para aqueles que produziam filmes na indústria do entretenimento. $\mathrm{O}$ impacto da qualidade dos estúdios Pixar serviu de modelo em um contexto de alta concorrência, que já vinha dos anos 1990 com a popularização de “O Rei Leão” (1994). Os estúdios, que já elevavam seus custos devido à concorrência de talentos, tiveram de investir pesadamente em tecnologia de animação (PRICE, 2008). E, ainda neste contexto, a indústria passou por altos e baixos, ao mesmo tempo em que os grandes estúdios tentavam se reinventar, e os pequenos se multiplicavam com a facilidade e o barateamento da tecnologia. 
O período que compreende os anos 2005-2015 foi de intensa transformação nas tecnologias de comunicação. A estratégia multimídia (integração das diversas plataformas midiáticas) dos anos 1990 enfrentou e continua enfrentando a implosão dos mercados tradicionais: música, varejo, fotografia, imprensa, telefonia, cinema e TV, rádio e transporte. Todos os mercados estão sob intensa pressão das novidades da convergência de mídia, da economia compartilhada, do sucesso das "pequenas telas" (smartphones) e das novas gerações que nascem e vivem um "mundo conectado". Muitas empresas quebraram e outras lutam para sobreviver no mais recente contexto tecnológico e cultural:

Nas indústrias culturais, as complementariedades parecem óbvias, assim como realizar as sinergias. No entanto, as especificidades do negócio são grandes. As prerrogativas relativas a como se comercializam elas também. As sinergias não se decretam: elas são, eventualmente, obtidas graças a uma análise estratégica minuciosa e a uma aplicação de uma gestão de mudança controlada. Na corrida para a formação dos grandes grupos de comunicação, as empresas cujo negócio de base esteja em edição, imprensa e cinema não estão nas melhores posições. Estes (os melhores) são os grupos industriais envolvidos no consumo de eletrônicos, telecomunicações e internet - que desempenham um papel importante (CRETON, 2014, p. 166, tradução nossa).

As grandes corporações de mídia, as gigantes dos anos 1990 e 2000, perderam espaço para as gigantes como Apple, Facebook e Google. Corporações como a Disney entenderam que precisam investir em tecnologia como abordagem estratégica para se conectar aos seus consumidores. Não é surpresa, portanto, que o atual presidente da Disney, Bob Iger, tenha feito, entre suas primeiras negociações, acordos com a Apple (para distribuir filmes e séries no iTunes) e a Pixar (para comprar o estúdio de animação computadorizada). Ao contrário da gestão de Michael Eisner (CEO da Disney entre 1984 e 2005), cujo foco na criação de conteúdos originais era primordial, a atual gestão Bob Iger combina o foco na aquisição de conteúdo externo (grandes marcas e universos de personagens com alto potencial comercial) e investimento em tecnologia - além da expansão internacional. Não surpreende, portanto, que a Disney não tenha um CTO (Chief Technology Officer), mas que o próprio presidente concentre a supervisão do processo de inovação da corporação em todas as suas áreas (estúdios, parques, televisão, internet, etc). 


\subsection{A Criação}

A terceira chave na análise de produção é a criação, ou em outras palavras, a produção do conteúdo - seja ele um filme de animação, uma atração de parque temático, uma história em quadrinhos, uma série de televisão, etc. Mas até que ponto o conteúdo tem a força dos elementos econômicos e tecnológicos já comentados anteriormente? A resposta está no final da gestão do expresidente Michael Eisner quando a The Walt Disney Company apresentava resultados abaixo do esperado justamente em sua área mais sensível - a produção de filmes:

Com seu avião particular, seus guarda-costas, sua ajuda de custo ilimitada e seu estilo de vida de chefe de Estado, Michael Eisner não desconfiou do único terreno que poderia significar para ele um ameaça: a criação. Nas indústrias criativas, que não são fábricas de automóveis nem distribuidoras de ervilhas, é preciso desconfiar dos "creative people", personalidades como Steven Spielberg, Jeffrey Katzenberg, George Lucas, John Lasseter, Michael Moore ou Harveu e Bob Weinstein, que dão as costas e se vão quando são maltratados ou veem ameaçada sua liberdade artística. A independência é a regra não escrita, e mesmo quando essa independência é comprada contratualmente, é necessário salvar as aparências. Quando um filme ou uma cena não lhe agradavam, Eisner simplesmente dizia: "This has to be edited" (teremos de "editar" isso). Leia-se: "cortar". Ou então: "recomeçar do zero". Essa guilhotina ao estilo antigo era inaceitável para os criadores de Toy Story ou os companheiros de Tarantino. A queda de Eisner, que não mostrou espírito coletivo no "Team Disney", pretendendo controlar o trabalho dos artistas, se explica por esse mal-entendido linguístico. $\mathrm{Na}$ expressão "indústrias criativas", a palavra importante é "criação". (MARTEL, 2012, pp. $82-83)$

O que o pesquisador Frédéric Martel destaca quando analisa o mainstream é que a criação do conteúdo pesa muito na gestão, mesmo quando, no caso, Michael Eisner assumiu em 1984 com os lucros anuais de US\$ 100 milhões com uma ação valendo US\$ 1,33, e se despediu do cargo em 2005 com US\$ 4,5 bilhões de lucro e uma ação valendo US\$ 25. Em 2015, na gestão Bob Iger, uma ação vale mais de US\$ 115 e os lucros em 2014 são da ordem de US\$ 7,5 bilhões. O segredo não está somente na tecnologia, mas também em uma nova abordagem estratégica da produção do conteúdo.

Este conteúdo criativo é trabalhado em pelo menos quatro dimensões. A primeira é a dimensão do marketing,- com a estratégia das marcas (Pixar, Lucasfilm, Marvel) e do Blockbuster, focando em grandes produções com alto potencial de retorno. A segunda e terceira dimensões são o do fandom e da transmídia. Em ambos os casos, Henry Jenkins, em seus estudos da convergência de mídias, já destacou a importância dos fãs na produção e no consumo da cultura. O retorno dado pelos 
fãs é uma das razões de Hollywood ter dedicado tanto espaço na última década aos filmes derivados de grandes sucessos dos anos 1980 e 1990 - são remakes (releituras, novas versões), reboots (reinício), continuações, narrativas paralelas ou até mesmo derivados de produtos culturais já testados quanto ao sucesso - as chamadas franquias.

Do ponto de vista cultural, Jenkins ministrou palestra no $54^{\circ}$ Festival de Cinema de Nova York (2014), onde destacou, justamente o que esta pesquisa alertou ainda em seu início em 2011, sobre a importância dos universos dos personagens. Jenkins trabalha a noção de "world building" e citou Disney e Marvel como exemplos recentes de universos que são desenvolvidos já com a narrativa transmídia em mente - de modo que um filme possa ser complementado em outra plataforma midiática, seja por outro filme, games, quadrinhos, livros, seriados, etc - via universos expandidos. Isso força uma mudança na abordagem estratégica das corporações de mídia. A plataforma Cinema/TV deixa de estar no centro da estratégia como fonte criativa para outras plataformas. A marca (branding)/universos de personagens tomam esse lugar central, irradiando conteúdo para todas as plataformas (cinema, TV, impresso, internet, games, entre outras). A Disney tem feito essa abordagem de forma muito efetiva com a Pixar, Marvel, Star Wars (Lucasfilm) e a própria Walt Disney Animation.

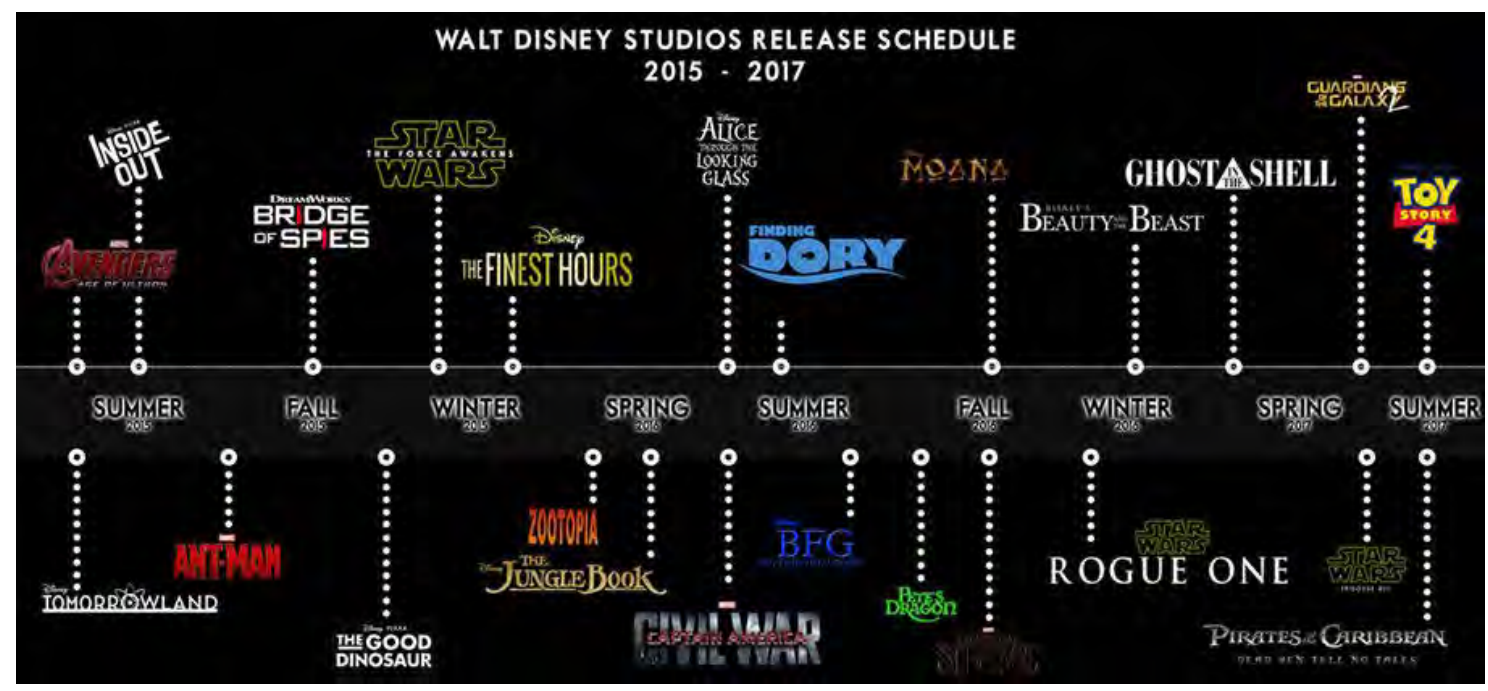

Figura 37 - Gráfico de futuros lançamentos da Disney - muitos filmes das marcas Pixar, Marvel e Star Wars (Lucasfilm)

E há nessa equação a polêmica posição da "arte" desse conteúdo criativo. É fato que o cinema não se reduz a um simples entretenimento e há uma natureza artística envolvida. Trata-se de uma convenção social com uma definição bastante sensível. A arte é fundada sobre o critério da liberdade. Daí o motivo do artista ser representado como um mensageiro do divino. E aí podemos relembrar a 
questão da aura e a mercadoria levantada por Walter Benjamin. Porém, no cinema (ou mesmo nos quadrinhos) onde está o artista?

Uma variável importante da arte no século XX é a questão da representação pelo mundo do dinheiro - a "arte industrial". Fredric Jameson (2006) a vê como foco de resistência para criticar o capitalismo, o que resultou numa fusão entre economia e cultura. Não há praticamente brechas, tendo a arte se colado na mercadoria. Recorrendo novamente ao professor Laurent Creton, a noção de artista e autor oferecem uma bela discussão semântica no âmbito acadêmico: "Sem querer contribuir para danificar a representação amável, a abordagem de um artista como produtor cultural pode se aproximar melhor à sua prática e obra” (CRETON, 1997, p. 36). A exemplo de Creton, o termo "produtor cultural" é mais utilizado em razão de sua característica genérica e porque permite evitar os recursos de formulação que poderiam evocar a ideologia do autor e da criação. Mas afinal, quem cria nos estúdios? O que determina padrões e identidades culturais que podem incentivar tendências e fórmulas?

Há duas correntes em torno da tese da autoria no cinema. Um dos polos é o autoral, a narrativa romântica que denota uma contribuição individual relevante - seja ela do diretor, roteirista ou produtor, resultando no crédito como autor da obra, a despeito de seu controle limitado. No outro polo temos a explicação materialista/coletivista que considera um certo aparato, um conjunto de condição industrial ou mesmo um grupo de talentos como o equivalente funcional de um autor individual (CHRISTENSEN, 2012, p. 13).

Diversos pesquisadores tentam classificar e qualificar a criação nas indústrias criativas. John Thornton Caldwell, por exemplo, em seu livro "Production Culture: Industrial Reflexity and Critical Practice in Film and Television" (2008), faz um estudo etnográfico para desenvolver uma "teoria autoral industrial" que se aplica aos profissionais criativos (os responsáveis por conceber e dirigir um filme) em oposição aos profissionais que apenas executam ideias (operários dos estúdios); e uma "teoria da identidade industrial", que se aplica ao nível dos executivos que consideram os roteiros parte do plano de negócios. No entanto, esta análise é demasiadamente funcionalista, não levando em consideração o impacto cultural dos próprios filmes.

A Disney, por sua vez, sempre destacou em seus vídeos de bastidores/making of, publicações e press releases a importância dada a uma série de profissionais considerados essenciais na criação de um filme - geralmente representados por diretores, roteiristas, supervisores de animação, elenco 
de vozes e compositores da trilha musical. Produtores e "operários do estúdio", abaixo dos titulares, ganham menos espaço. Curiosamente o estúdio ignora o peso dado pelos produtores e pelos executivos no processo criativo. Atualmente, o marketing ganhou um peso ainda maior.

O diretor e historiador Peter Bogdavich, afirma que os diretores têm um peso fundamental na identidade dos filmes. Em seu livro "Afinal, quem faz os filmes" (1997), o autor apresenta uma série de entrevistas com diretores de Hollywood como Fritz Lang, Alfred Hitchcock, Don Siegel e Sidney Lumet, tentando construir um contexto que demonstre a importância deles na criação de filmes tão singulares. Não podemos negar o impacto autoral de nomes tão fortes no cinema, porém um dos entrevistados, o animador e diretor Chuck Jones (com grande carreira na Warner Bros. trabalhando com Pernalonga e os Looney Tunes) revela numa de suas respostas, a importância dada ao produtor Walt Disney na indústria da animação. Questionado sobre a sua opinião de Disney, respondeu:

A maior coisa com que Disney contribuiu foi ter estabelecido a ideia de uma personalidade individual. Pode-se não gostar das personalidades que ele desenvolveu, mas elas eram brilhantemente executadas. Walt não desenhava muito bem, mas ele e um sujeito chamado Ub Iwerks eram, em certo sentido, uma só pessoa - eles tinham vindo juntos de Kansas City -, e Ub foi dos maiores técnicos que já houve. Os dois criaram a ideia de que seria possível construir uma personagem de desenho animado com personalidade que não ficasse só saltando de um lado para o outro. A inovação apareceu de fato em "Three Little Pigs [1933; Bert Gillett dirigiu para Disney] - foi quando se desenvolveram personalidades. Todos nós que viemos depois fomos obviamente marcados por aquilo - e ignorar esse fato é escrever mal a história. Caso se organize um festival de cartuns e se ignore Disney, é o mesmo que fazer um festival de cinema e descartar Griffith, porque todos os instrumentos foram inventados lá. Tudo. Como o modo de fazer uma personagem andar direito - não que ela se mova como um ser humano, mas que se mova do modo como é desenhada. Certa vez eu estava assistindo a Marcel Marceau, e um amigo me disse: "Sei por que você está aqui". Perguntei: "Por quê?", e ele respondeu: "Bem, porque é isso o que você é, um fazedor de pantomimas". Quando ensino desenho, menciono o meu primeiro professor, do Chouinard Art Institute: "Todo artista tem dentro dele 100 mil desenhos ruins. Quanto mais cedo vocês se livrarem deles, melhor". (...). Havia uma porção de coisas erradas em Walt. Mas quem diabos teria investido 3 milhões de dólares - hoje, equivalentes a 20 milhões - em algo como "Fantasia" (1940)?. (BOGDAVICH, 1997, pp. 816-817).

Sem dúvida alguma, Chuck Jones afirmou uma coisa importante. Walt Disney foi um grande produtor e sabia como ninguém organizar, atrair e desenvolver talentos e ideias. E podemos afirmar que os estúdios Disney funcionaram essencialmente de 1923 até o falecimento de seu fundador em 1966 como um estúdio de produtor. Mesmo tendo grandes talentos na direção - Gerry Geronimi, por 
exemplo, dirigiu muitos longas-metragens - era o produtor Walt Disney quem supervisionava e dava a palavra final. Isso combina com a era dos estúdios em Hollywood.

Thomas Schatz em sua obra "O Gênio do Sistema: A Era dos Estúdios em Hollywood” (1991) faz um estudo dedicado à análise do produtor como "arquiteto-chefe" do estilo de um estúdio. Na Hollywood dos anos 1940 os estúdios não tinham capacidade e poderio econômico equivalentes. Uma das poucas características semelhantes entre os estúdios é que a maioria era controlada por judeus os poucos não-judeus incluíam Darryl F. Zanuck (Fox), Howard Hughes e Walt Disney. Na hierarquia de poder em Hollywood, a Metro Goldwyn Mayer (a famosa MGM) - controlada por Louis B. Mayer -, conhecida por épicos como "E o Vento Levou” e musicais em Technicolor como "O Mágico de Oz" (ambos os filmes de 1939), era a majestosa líder. Em seguida estava a Warner Bros. - encabeçada por Jack Warner, um dos irmãos Warner -, com estrutura industrial que sustentava a velha fórmula de filmes com os mesmos atores e uma divisão de "filmes B" (de Bryan Foy) que respondia por metade da produção - esta unidade seria desativada no início da década devido aos tempos de guerra e a um reposicionamento que resultou em filmes de prestígio como "Casablanca" (1942).

Em terceiro e quarto lugares, respectivamente, a Paramount de Adolph Zukor - com artistas de peso sob contrato (Rita Hayworth, Glen Ford e Os Três Patetas, entre outros) e um eficiente controle de custos e reciclagem de materiais que faziam seus filmes parecerem mais sofisticados; e a 20th Century Fox, capitaneada por Darryl Zanuck (oriundo da Warner) apostando em filmes de prestígio como os de John Ford - "As vinhas da Ira" (1940) e "Como era verde meu vale" (1941). Em seguida temos os chamados "estúdios pobres" Columbia e Universal Pictures (esta última especializada em westerns, melodramas e em filmes do gênero Horror) com produções de baixo orçamento. Outras produtoras eram ainda menores: caso da administrativamente caótica, porém charmosa RKO (que distribuiu por muitos anos nos cinemas as produções Disney), da United Artists (que se reduziria basicamente a uma distribuidora) e da Walt Disney Productions (produtora de desenhos animados).

Apesar de Hollywood ainda contar com seus produtores influentes e poderosos, não é possível afirmar que os mesmos controlem os grandes estúdios. Então novamente encontramos a dúvida sobre o que influi nos padrões e identidades culturais. Uma saída interessante (inspirada no livro de Schatz) parece ter sido encontrada por Jerome Christensen, cuja obra "America's Corporate Art: The Studio Authorship of Hollywood Motion Pictures" (2012) foi bem recebida no âmbito acadêmico norteamericano dos estudos do cinema. O autor destaca a segregação existente entre a crítica fílmica e a 
histórica econômica do cinema; e encontra uma alternativa para identificar o autor não uma pessoa real, mas um ente que se qualifica no status de autor pretendido: o estúdio corporativo em si. Neste caso, a hipótese é de que o estúdio e não o diretor, roteirista ou mesmo o produtor podem ser considerados autores dos filmes de Hollywood.

Fazendo um breve panorama, Christensen inicia sua análise formulando as ideias de arte corporativa, identidade corporativa e alegoria do estúdio a partir de uma reportagem da revista Fortune de 1932 sobre a estrutura de produção vertical da MGM. Fazia parte de uma estratégia da revista promover um estúdio de Hollywood como símbolo de sucesso numa época (Grande Depressão) onde tal liderança parecia crucial ao futuro do capitalismo. Segundo a revista, a condição emergente das artes cinematográficas era uma esperança de um futuro sistema capitalista capaz de transcender meramente preocupações comerciais. O que chamava atenção não era o dinheiro envolvido, a tecnologia empregada ou os gênios individuais, mas a organização corporativa do estúdio:

\begin{abstract}
Mais uma vez, de acordo com os critérios acadêmicos, os filmes de Hollywood podem ou não serem classificados como arte. Não importa. A revista Fortune não promete que os filmes de Hollywood serão admirados como arte, ou que serão preservados como tal; ela simplesmente afirma que se algo ocorrer, é que eles contarão como exemplos de arte corporativa (CHRISTENSEN, 2012, pp. 1-2, tradução nossa).
\end{abstract}

Uma diferença a se destacar é que esta arte corporativa não deve ser confundida com o estilo do estúdio (house style), tão importante que é para estabilizar a identidade da marca aos olhos do público (audiência). A revista, em seu perfil dos estúdios MGM, argumenta que o visual e o sentido dos filmes do estúdio foram promovidos por Irwing Thalberg - vice-presidente de produção - visando implementar um estilo próprio (o tal house style), porém servindo a uma estratégia. Para facilitar o entendimento, o autor compara a um exemplo corporativo. Por exemplo, a General Motors, comissionando Diego Rivera para a criação de um mural, e a Warner Bros., contratando Howard Hawks para dirigir "Scarface" no mesmo ano (1932). O ponto central para entender a arte corporativa é que ela funciona como ferramenta para uma estratégia corporativa. Neste caso, a arte promove as intenções estratégicas da General Motors e da Warner, e não de Diego Rivera ou Howard Hawks.

Para Jerome Christensen, trata-se de um conjunto de ações tomadas para obter vantagem competitiva, que é coordenada e implementada por executivos, que podem clamar a autoridade para 
interpretar a intenção da corporação e projetar políticas que irão avançar seus interesses particulares, sejam financeiros, sociais, culturais, etc.

Um dos objetivos comuns é o lucro, sem o qual a corporação não sobrevive - mas isso não é o suficiente para explicar sozinho qual o tipo de estratégia e quais os objetivos da empresa/estúdio. O autor destaca que somente essas produções, entendidas como performances corporativas, podem ilustrar seus objetivos e identificar as estratégias do estúdio. Christensen toma o cuidado de explicar que a estratégia não pode ser confundida com ideologia, apesar das consequências entre os interesses econômicos e as produções culturais resultantes no mercado capitalista. A ideologia opera em um nível superior de abstração, sua operação não é sujeita ao controle de uma pessoa. A estratégia corporativa é representada por uma pessoa artificial na qual a corporação é representada:

Para a estratégia funcionar são necessários ajustes que possam conscientemente interpretar os objetivos de corporação e inventar meios específicos para realizá-los. A ideologia funciona bem em construções que funcionam no mesmo nível da generalidade, tal como "a corporação", ou "capitalismo corporativo" ou "indústria do cinema", mas não explica nem comanda filmes singulares lançados pela Warner, Paramount ou MGM. Na teoria do cinema, o conceito de ideologia é frequentemente usado como ferramenta de "fail-safe" para a seleção de filmes como exemplos, sintomas ou veículos. Entretanto, essa abstração torna esse conhecimento como dado pelas cabeças-mandantes dos estúdios. O cumprimento de suas ações não requer a interpretação de textos como exemplos de estratégia deliberados, variáveis e focada com o objetivo de definir, explicar, considerar ou avançar os interesses particulares de uma corporação - nesse caso o estúdio. Um estúdio pode se assemelhar ao outro por uma tecnologia, duração de filmes e tipos de contrato, mas cada um faz filmes que significam coisas diferentes e avançam objetivos diversos. Estes significados e objetivos são somente entendidos por intepretações atentas e informadas, estrategicamente orientadas e taticamente efetivas de filmes específicos lançados por MGM, Paramount, Warner e Disney - da era clássica até a atualidade. (CHRISTENSEN, 2012, p. 3, tradução nossa)

A tese do autor ressalta que os estúdios são exemplos de corporações modernas, sendo cada um deles capaz de incorporar expressão e personalidade, representando alegoricamente sentidos e avançando pragmaticamente interesses particulares. Uma das consequências foi a formação do consumidor dos filmes de gênero (MGM o estúdio das estrelas, a Universal o estúdio do Horror, etc). No caso, na era clássica do cinema, Chistensen considera exemplos de estúdios as produtoras que estão ligadas a uma cadeia corporativa - caso das 5 grandes (Paramount, Loew's, Warner Bros., FOX e RKO) que possuíam, além de estúdio, uma agência de distribuição e uma rede exibidora de cinemas, 
exercendo assim um oligopólio da indústria, restringindo acesso de recursos e mercado aos produtores - que, sem outra saída, eram dependentes de contratos.

No último capítulo de seu livro, Christensen analisa justamente a fusão entre a Disney e a Pixar em 2006 como execução de uma revisão significativa da forma corporativa de afirmar a "autoria cultural". Isso é importante, porque a Disney publicamente fala em "cultura da Disney", "cultura da Pixar", "cultura da Marvel”, para explicar as estratégias que levam à produção dos filmes e seus produtos derivados. Se, do ponto de vista estritamente econômico, podemos afirmar que a Disney aposta em franquias, na esfera da produção cultural estamos falando em "pressupostos culturais" que levam a determinadas escolhas - se quisermos, como é o caso, analisar a questão complexa das produções na atualidade.

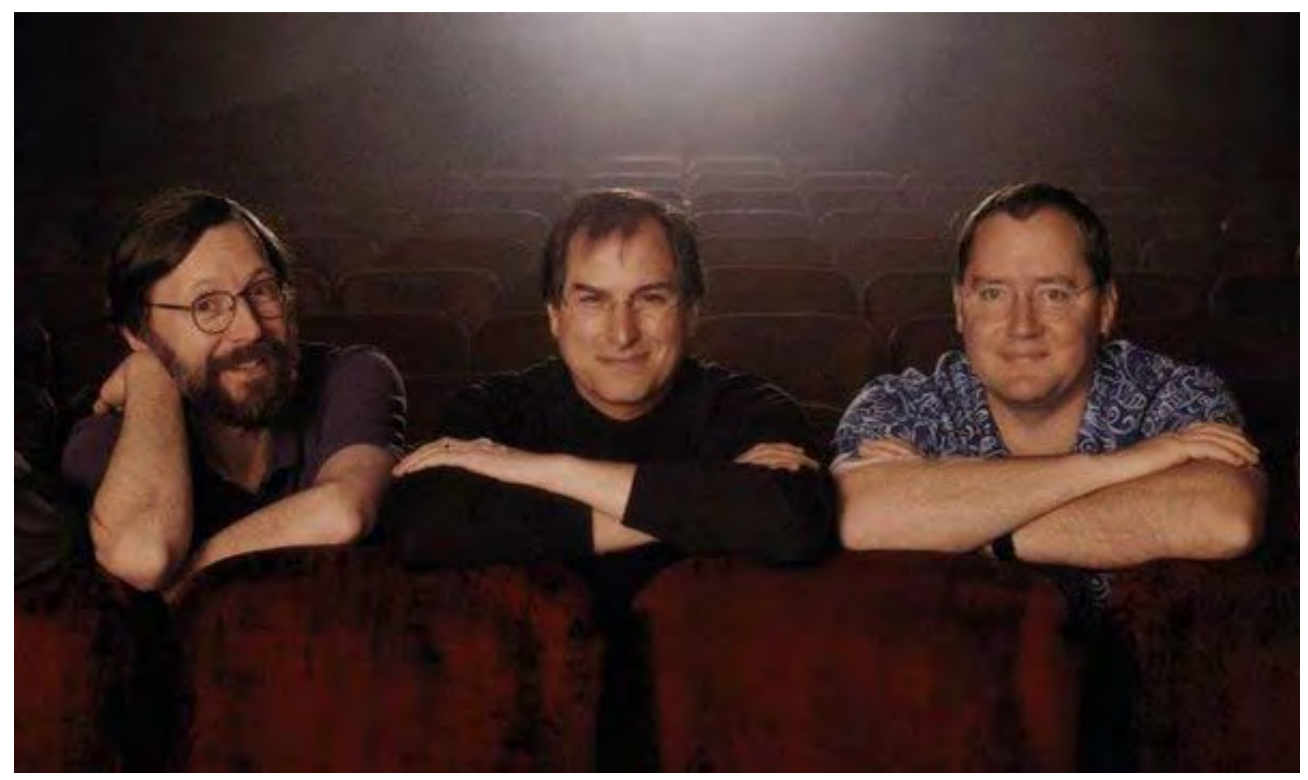

Figura 38 - Ed Catmull, Steve Jobs e John Lasseter - os principais líderes na Pixar

O atual presidente dos estúdios de animação Disney e Pixar, Ed Catmull (2014), lançou um livro que condensa boa parte dessa estratégia de "cultura do estúdio". E começa reafirmando o que elencamos até aqui - a importância do trinômio tecnologia (inovação), indústria (mercado) e arte (produção/conteúdo cultural) e usa como comparação a estrutura de fundação da própria Pixar, que tinha como chefes Steve Jobs (na presidência), John Lasseter (chefiando a área criativa) e o próprio Ed Catmull (chefiando a área tecnológica). Os diversos desafios de retornar um certo protagonismo de decisão aos artistas são explicados de forma a justificar o elevado número de sucessos consecutivos da produtora - não sem os seus riscos, evidentemente. Há uma problemática dessas culturas de estúdio na produção, muito focadas em mantras como "A história é o rei” (Story is king) e "Confie 
no processo" (Trust the process) em que um sistema de avaliação por pares (peer-review) foi montado para discutir periodicamente a evolução das equipes de produção - o chamado Brain Trust, formado somente por membros criativos. Há, evidentemente, choques com as áreas tecnológica e da indústria como veremos nos capítulos 6 e 7. 


\section{OS QUADRINISTAS A CRIAÇÃO DO “UNIVERSO”}

A criação de universos narrativos nunca foi tão importante para a indústria cultural como na atualidade. Como veremos mais adiante, as estratégias de produção implicam cada vez mais em universos expansivos e compartilhados de modo que a indústria possa explorá-los em diferentes suportes midiáticos. Porém, essa noção de "construção de mundos" é muito antiga. E as histórias em quadrinhos talvez sejam o melhor exemplo para descrever e analisar como funciona a cabeça de um criador e como ele pensa o "mundo" de seus personagens. Dois nomes foram escolhidos para esta análise: Keno Don Rosa e Casty. Vejamos as diferenças em suas fórmulas de criação.

\subsection{Keno Don Rosa e a "renovação" dos Patos}

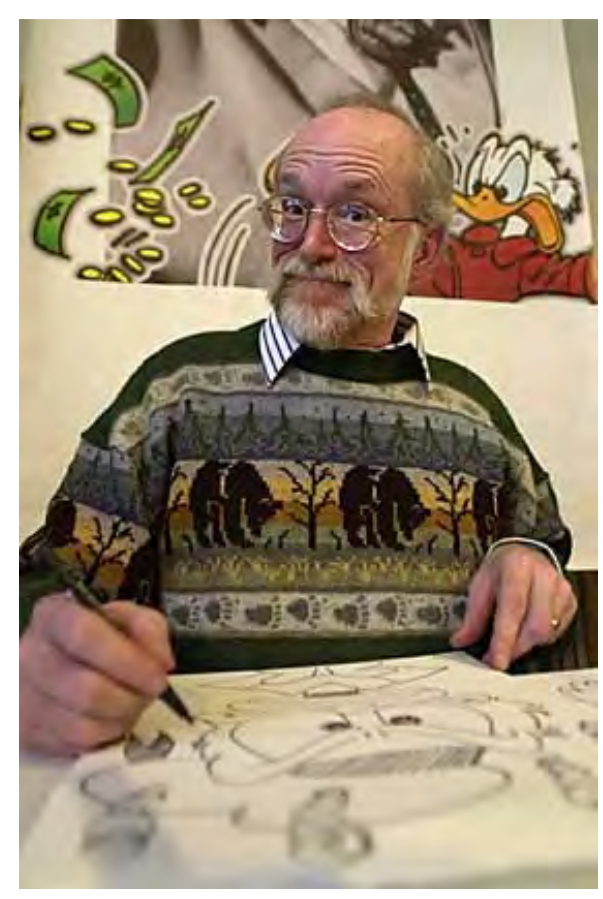

Figura. 39 - Keno Don Rosa

Enquanto os quadrinhos Disney permanecem populares e em produção na Europa no fim do século XX, a esperança de renovação surgiu justamente nos Estados Unidos, onde a produção e edição de HQs Disney tem se mantido errática. Keno Don Rosa nasceu em 1951 em Louisville, Kentucky. Criador de aproximadamente 100 histórias em quadrinhos Disney (INDUCKS, 2014), passou a infância assistindo televisão e lendo gibis. Até por conta da dificuldade de seu pai em ler gibis, Rosa questionou que para quem nunca leu HQs, é difícil entender a linguagem e a questão do espaço entre painéis (LIFE AND TIMES OF DON ROSA, 2010). 
Don Rosa nunca se considerou um cartunista, tendo por grande parte de sua vida considerado a criação de HQs somente um hobby. Fez faculdade de Engenharia Civil na University of Kentucky entre 1969 e 1973, período de forte ebulição política nos EUA, especialmente nas universidades. Ele, porém, não mostrava muito interesse em política e no ativismo universitário ainda que tenha adquirido na época muitos gibis underground e produzido uma série de HQs autorais. Seu foco de renda era o trabalho que exercia na Keno Rosa Tile Company, empresa fundada pelo avô paterno, que na época era chefiado pelo pai Hugo Rosa. Até então, Don Rosa já havia lido e colecionado muitos gibis Disney, mas gostava realmente de determinadas HQs (na época não identificadas) que mais tarde descobriria serem de autoria de Carl Barks (LIFE AND TIMES OF DON ROSA, 2010).

A reviravolta em sua vida ocorreu em 1985, quando descobriu o retorno da revista Walt Disney Comics \& Stories. As HQs Disney haviam desaparecido no fim dos anos 1970 nos EUA. Na capa da revista em questão, Don Rosa se surpreendeu com um material novo de Carl Barks nunca visto por ele. Nesse momento, o artista decide entrar em contato com a editora Gladstone (que possuía o mesmo nome do primo sortudo de Donald, Gastão). Conversando com o editor Byron Erickson, afirmou que era o único americano que nasceu para escrever e desenhar HQs do Tio Patinhas, que este era o seu destino. Esta ousadia mais tarde o converteria na maior novidade Disney nos quadrinhos até então.

Com a indicação positiva para produzir, Don Rosa apresentou em 1986-87 as primeiras páginas, ainda em rascunho, de sua primeira história em quadrinhos, "O Filho do Sol", ao publisher da editora, Bruce Hamilton. Um tanto nervoso pela ideia de produzir novas HQs Disney, este ordenou ao editor que informasse Don Rosa que não iriam publicar. Mas, para sorte do artista, uma oportunidade paga lhe foi dada para continuar "tocando" o projeto.

Um dos motivos da indecisão da editora era por conta do estilo de Don Rosa, fora dos padrões Disney - o chamado off model - com páginas "sujas" parecidas com o trabalho em quadrinhos de Robert Crumb. E a editora queria se prevenir publicando apenas HQs que agradassem e atraíssem leitores. Sobre Crumb, chegou a comentar,

Eu penso que o meu estilo e o de Robert Crumb só são semelhantes porque crescemos fazendo quadrinhos para a nossa satisfação pessoal, sem nunca levar o desenho a sério, e sem nunca tentar alcançar um estilo que agradaria a editora Marvel Comics. Nós desenhamos quadrinhos para nossa diversão (ROSA, 2002). 
Ressalta-se que Don Rosa não tem formação em desenho artístico (LIFE AND TIMES OF DON ROSA, 2010). Seu sucesso se dá no contexto de que havia um declínio geral das histórias em quadrinhos Marvel e DC Comics desde o final dos anos 1960. Em meados dos anos 1980, o mercado se renovou com títulos escritos para fãs antigos, caso de "Cavaleiros das Trevas" de Frank Miller, "Watchmen" (de Alan Moore) e as aventuras de Tio Patinhas (do Don Rosa).
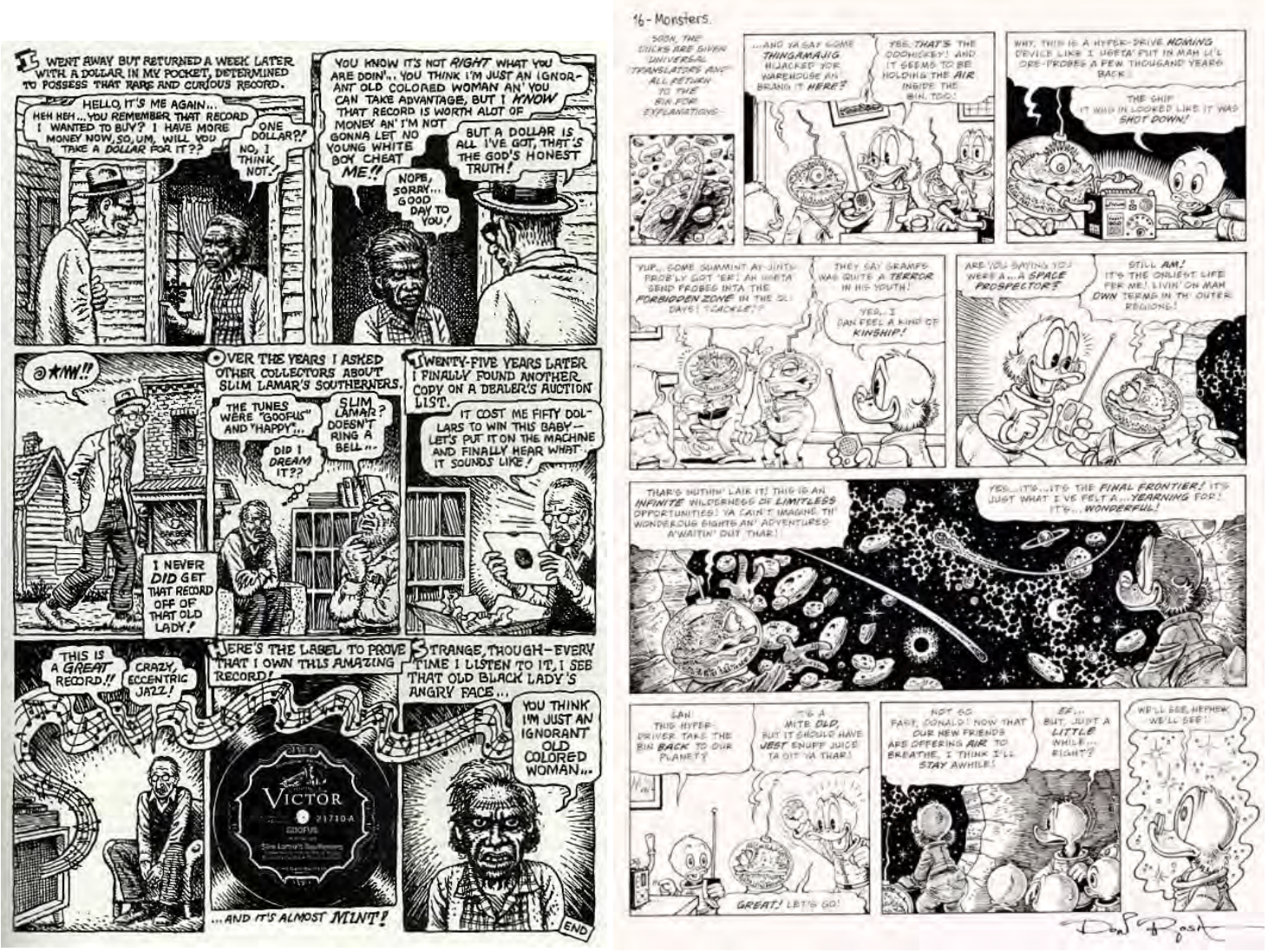

Figura 40 e Figura 41 - Exemplos de páginas com os traços de Robert Crumb (Wierdo no. 4, Robert Crumb, 1981) e Don Rosa (Walt Disney's Comics and Stories 614, Don Rosa, 1997).

Don Rosa consumiu gibis underground enquanto cursava a universidade e chegou a produzir para jornais acadêmicos. Ainda que observasse com certa simpatia as publicações hippies e mesmo a ele fosse pedido algo mais ligado à sátira política, esse aspecto do ativismo nunca o tocou ideologicamente. $\mathrm{O}$ estilo de traço mais ligado ao underground tem origens no próprio gosto do artista, desde os tempos em que colecionava gibis com a ajuda da irmã mais velha.

Se os gibis Disney (por conta das HQs criadas por Barks) já faziam parte de seu cotidiano, outros títulos de interesse incluíam a revista satírica MAD e os quadrinhos do Superman, da DC Comics dos anos 1950 até meados da década de 1960. Do Superman, o que atraía Don Rosa era o aspecto relacionado às histórias ocultas, às origens secretas, uma espécie de continuidade irregular 
onde algum detalhe de uma HQ específica poderia ser mencionado ou inserido como referência em outra HQ, algo que os quadrinhos Disney nunca haviam virtualmente tentado.

O importante é que "O Filho do Sol” ganhou permissão, foi publicada e a HQ teve excelente repercussão. O artista continuou na Gladstone até 1989, quando se desentendeu e pediu demissão por discordar da nova política da editora. No período em questão, as vendas das revistas eram boas, vendendo cerca de 100 mil exemplares por edição. Há um ponto de vista, do próprio Don Rosa, de que talvez a Disney estivesse pressionando a Gladstone a desistir da licença. A partir deste momento, começaram a surgir obstáculos e burocracias, como a Disney pedir para supervisionar antecipadamente os roteiros e arte, para serem aprovadas. Chegou-se ao ponto em que a Disney pediu à Gladstone que não retornasse as artes originais produzidas aos artistas, e Don Rosa considerou que as artes eram sua propriedade - e parte de sua renda era justamente da venda desses originais, para que pudesse sobreviver trabalhando com quadrinhos.

Após uma série de trabalhos freelancers, incluindo roteiros para o seriado de animação Disney “Tale Spin”, Don Rosa iniciou uma nova fase na editora dinamarquesa Egmont, que já publicara HQs dele e estava em busca de material inédito, com parceria de Byron Erickson, também saído da Gladstone. Foi em 1991 que Don Rosa iniciou a criação de sua obra mais marcante e famosa, "A Saga do Tio Patinhas" (The Life and Times of Scrooge McDuck), uma saga em doze capítulos, contando com histórias extras produzidas posteriormente para complementar períodos entre os capítulos originais. Foi publicada no Brasil pela Editora Abril em diversas versões (consultamos a edição de 2007). O propósito era contar toda a história da origem do Tio Patinhas antes que a matriz da Disney em Burbank, Califórnia, decidisse promover sua própria versão “official”. A saga deu a Don Rosa um Eisner Awards em 1995 como melhor série contínua em quadrinhos. A partir de então, Don Rosa publicou uma variedade de HQs do universo dos patos, sempre cultivando um estilo muito próprio, até sua aposentadoria forçada em 2008, por conta, principalmente, de problemas graves nos olhos, que o impediam de trabalhar.

Tendo como ídolo Carl Barks, Don Rosa construiu seu estilo narrativo em torno dos personagens, ambientes e situações inventadas pelo velho mestre. O trabalho de elaboração dessas histórias incluiu muitas referências a fatos e detalhes presentes nas obras de Barks. O artista produziu diversas continuações de histórias "clássicas" de Barks, o que chamou a atenção dos fãs pela alta qualidade de arte e roteiro. Podemos observar a comparação entre as obras de Barks e as continuações de Don Rosa nos exemplos gráficos a seguir: 


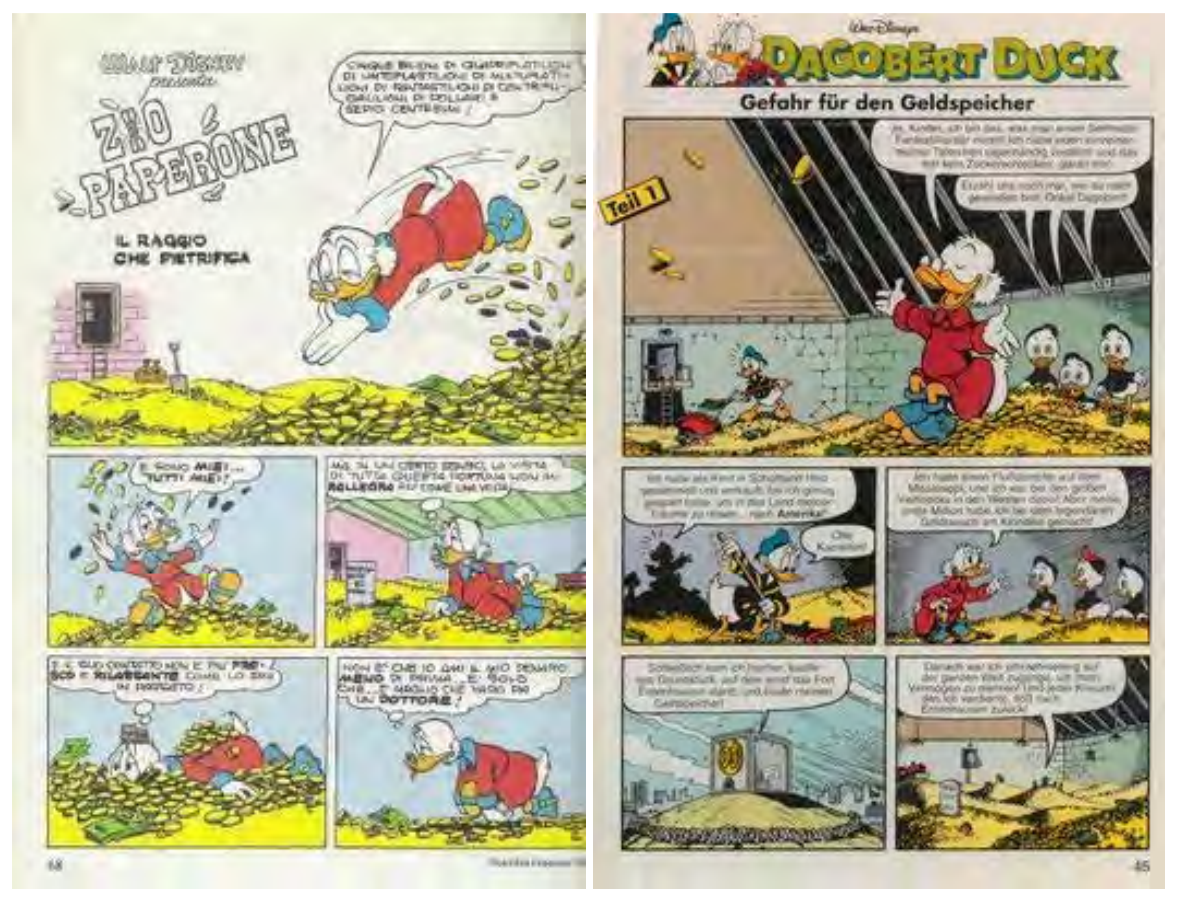

Figura 42 e Figura 43 - "O Ouro e o Repolho" (Barks, 1954) e "Fortuna Deslizante" (Don Rosa, 1987).
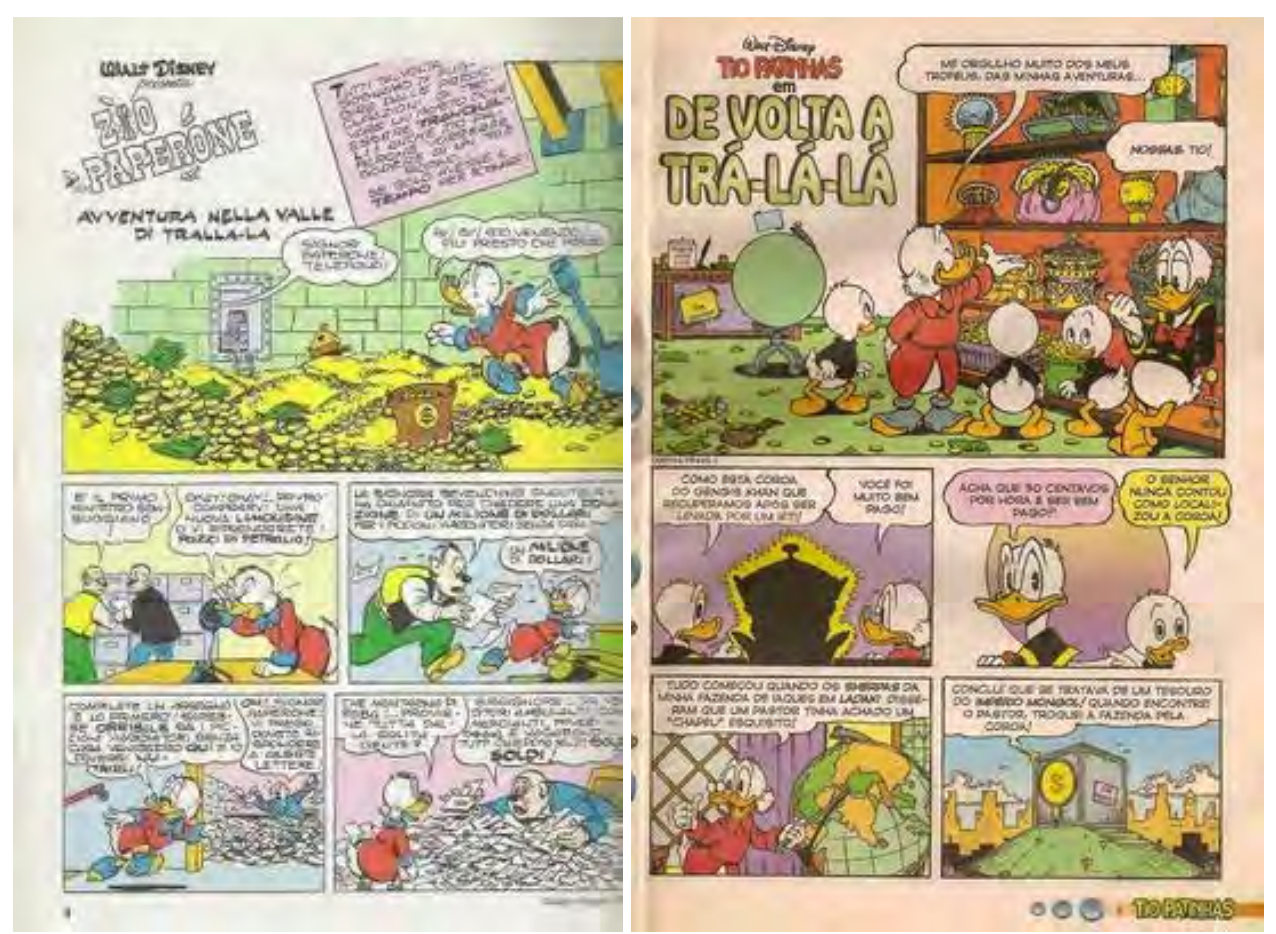

Figura 44 e Figura 45 - "Paraíso Perdido" (Barks, 1954) e "De Volta à Xanadu” (Don Rosa, 1991)

Uma das principais características das obras de Don Rosa é o aspecto cronológico de suas HQs. Em suas histórias, as aventuras de Tio Patinhas e a família Pato ocorrem na década de 1950, 
período em que Barks originalmente escreveu boa parte de suas famosas HQs. Don Rosa, desse modo, eliminava os problemas que ocorreriam de erros de continuidade, especialmente relacionadas à idade do Tio Patinhas. Também se tratava de uma homenagem e as HQs teriam um aspecto temporal ligado diretamente a Barks, o que era de interesse do artista-fã. Por outro lado, Rosa ignora qualquer aspecto de inovação tecnológica ou cultural que possa alterar consideravelmente o universo dos personagens. Para a produção das histórias da Saga do Tio Patinhas, Don Rosa compilou uma série de fatos, piadas e detalhes de HQs criadas anteriormente por Barks para que pudesse utilizar nas novas aventuras.

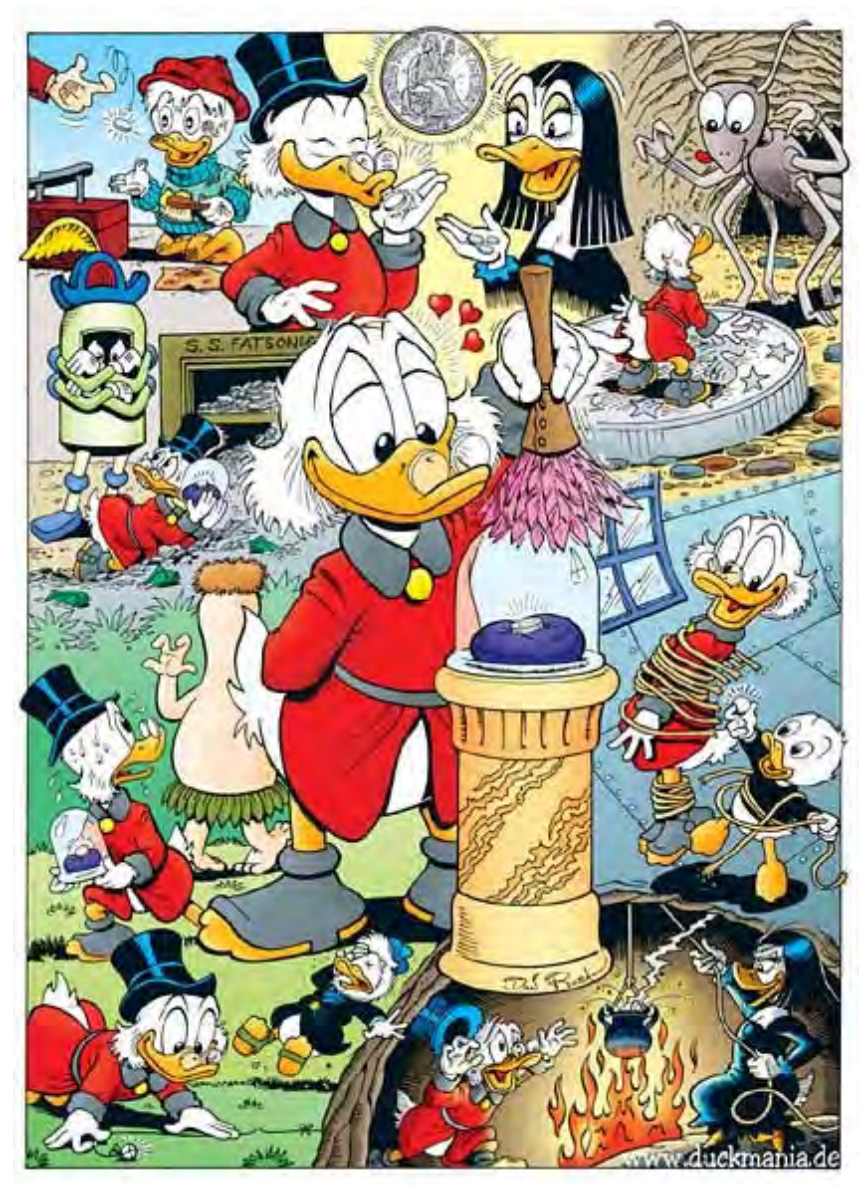

Figura 46 - Pôster ilustra diversos exemplos do traço de Don Rosa, diferente de Carl Barks.

Don Rosa, entretanto, pode ser facilmente diferenciado de Carl Barks por conta do detalhismo de sua obra. As HQs, com especial destaque para a Saga do Tio Patinhas, possuem desenhos extremamente detalhados. Devido à sua formação em engenharia (e não em desenho), usou réguas técnicas para o trabalho. $\mathrm{O}$ artista justifica que aprendeu a desenhar como forma de autoentretenimento, sendo que, quanto mais tempo leva para desenhar, mais detalhismo é inserido, o que resulta em mais tempo para produzir. E é isso o que considera a fórmula do sucesso de suas histórias. Assim como Barks, Don Rosa usa diversas obras de referência do seu acervo como os 60 anos de 
revistas da National Geographic, enciclopédias, livros da Time-Life, ou vai atrás de informações em bibliotecas universitárias e, em tempos mais recentes, até na internet. Se Barks se esmerava nos cenários grandiosos de suas aventuras, Don Rosa dava um passo além, incluindo mais detalhes complexos e rebuscados, acrescentando piadas e ações ao fundo (em segundo plano).

Esta questão do detalhismo de Don Rosa esbarra no problema do tamanho dos gibis. Quando publicado em formatos menores, de forma pixelizada ou com cores fora do registro, sua arte se torna de difícil apreciação. Em alguns dos títulos publicados no Brasil há exemplos dos três problemas ocorrendo ao mesmo tempo. Outra questão é que Don Rosa é textualmente mais prolixo (especialmente na versão original em inglês), por vezes usando até 12 quadros por página (ao invés dos 8 quadros do padrão) por conta de suas histórias serem longas e ele não querer resumi-las.

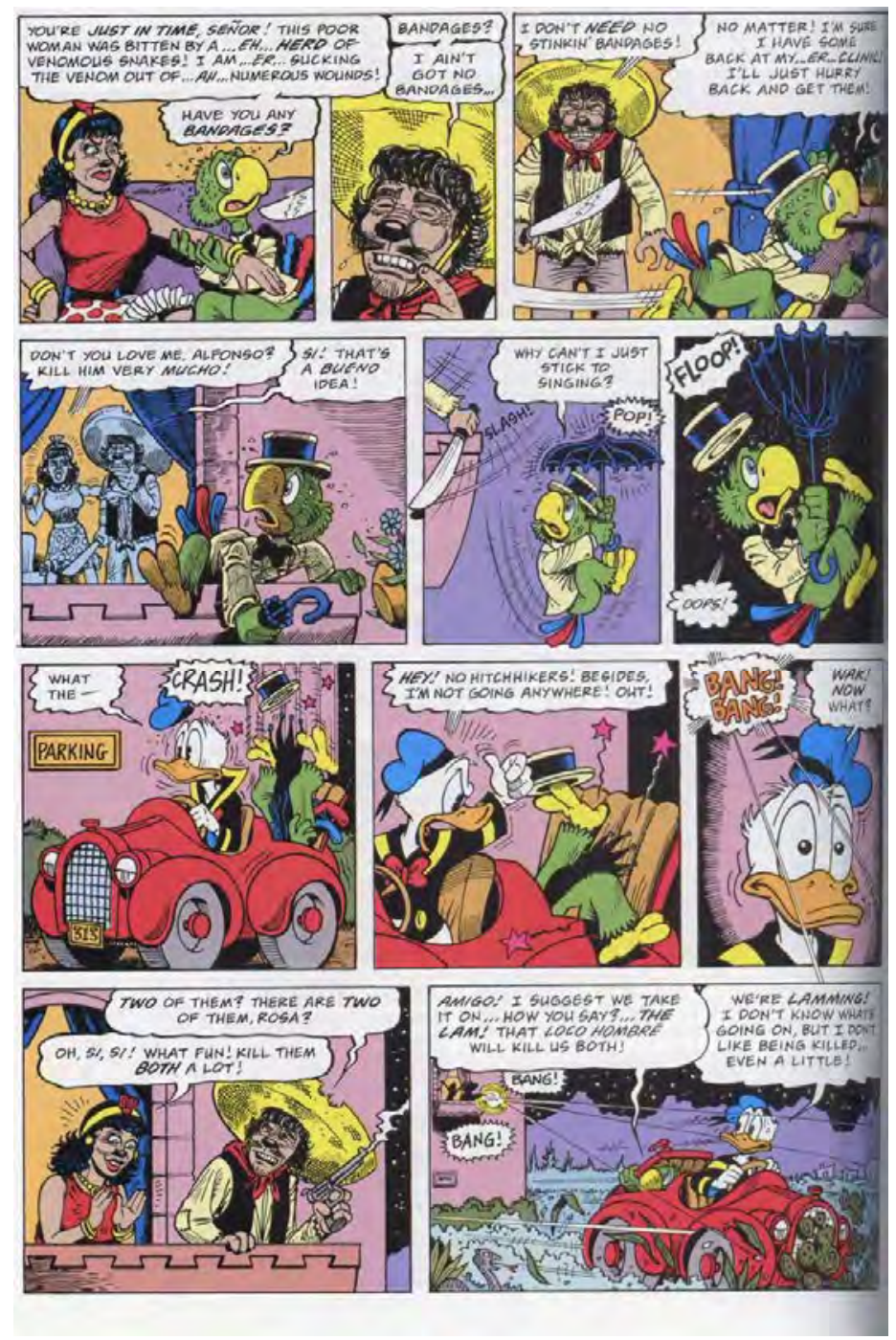

Figura 47 - "O Retorno dos Três Cavalheiros" (Don Rosa, 2000) demonstra a quantidade de paineis e texto. 
Das referências externas ao universo criado por Barks, há exemplos sutis a obras de ficção que Don Rosa apreciava em sua juventude. As inspirações para cenários mais sombrios provavelmente tiveram sua origem em seu interesse, na década de 1960, por populares filmes de terror, inspiradas em revistas de monstros como a "Famous Monsters of Filmland". Outra característica marcante, também inspirada pelo interesse de Don Rosa em filmes e seriados na televisão (ao contrário dos desenhos animados) são as detalhadas cenas de "pastelão" e as alterações ligeiramente planejadas de expressões faciais e cores mais exageradas.

Outro aspecto importante era o nível de interesse das HQs de Don Rosa. Parece óbvio que, seguindo os passos de Barks, também não fosse ignorar um dos detalhes mais pungentes que fizeram suas obras se tornarem tão apreciadas - o fato das histórias não subestimarem os leitores, de modo que tanto a criança como o adulto pudessem realmente ter bom entretenimento. O próprio Don Rosa afirmara que desejava fazer "HQs com aventuras interessantes que respeitem a inteligência do leitor" (ROSA, 2010). Uma das influências de Don Rosa para alcançar a meta era seu interesse por Luluzinha (Little Lulu), da Dell Comics, que já trazia certa crítica à sociedade, ao mesmo tempo em que o traço de John Stanley carregava uma simplicidade comparável ao desenho de Barks. Porém, para Don Rosa, a maior semelhança entre Barks e as HQs de Luluzinha era a linguagem "multinível", em que situações e piadas eram empregadas para entreter crianças e adultos sem prejuízo para um grupo específico de leitores (ROSA, 2010)

Em alguns momentos da obra de Don Rosa, há um excesso de referências e detalhismo, que em certas situações beiram os efeitos da saturação. Graficamente, isso é mais latente se a leitura é feita em formatinho $(13$ X $21 \mathrm{~cm})$, dificultando a interpretação das imagens. Textualmente, o excesso de referências pode causar um obstáculo para o leitor leigo, visto que em algumas situações, por mais que a HQ seja independente quanto a sua compreensão, a graça está em alguma referência a uma ação ou piada de uma obra anterior do Barks. Como analisa Matthew Pustz (1999, p. 121), algumas HQs seriam mais direcionadas para iniciados e não aos iniciantes (estes, sem a necessidade de conhecimento prévio do universo de personagens na leitura) - o que não é o padrão nas HQs Disney de outros autores.

Além da complexidade visual e de certa prolixidade textual, o enfoque restrito dado ao aspecto cronológico das HQs de Don Rosa, especialmente no caso de "A Saga do Tio Patinhas" cria situações-limite em que a criação de personagens ignora outros que não foram criados por Barks, resultando em um "buraco" no universo dos personagens. Seria, por exemplo, como se um novo personagem ignorasse algum outro, ou alterasse um fato histórico do cânone disneyano nos quadrinhos. 
A própria limitação cronológica na década de 1950 traz problemas relacionados à idade dos personagens, tendo em vista que Don Rosa considera, virtualmente, que Tio Patinhas morre assim que Carl Barks parou de produzir histórias em quadrinhos.

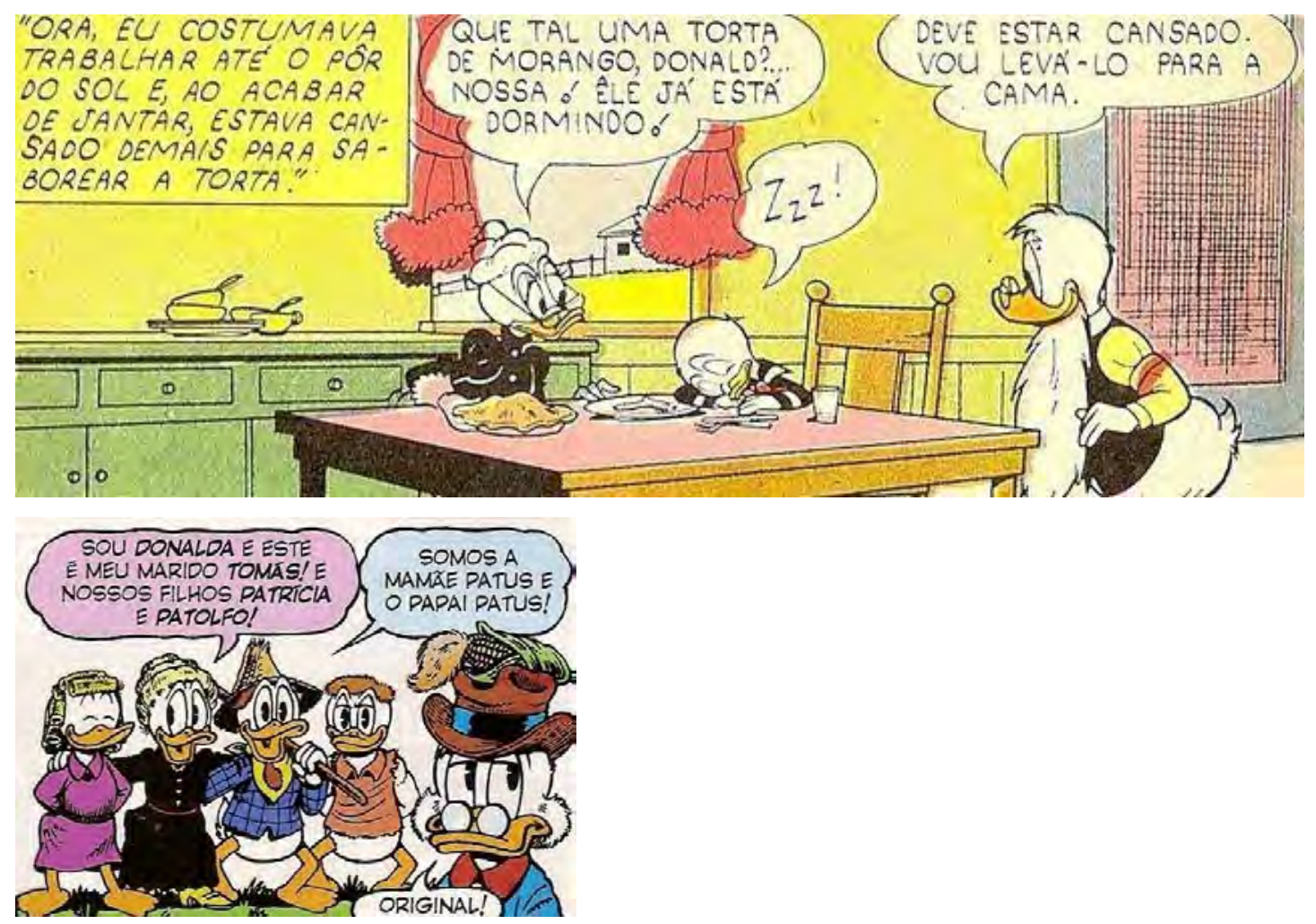

Figura 48 e Figura 49 - O detalhismo cronológico de Don Rosa resulta em "buracos" na árvore genealógica da família Pato. Na Fig 48, Don Rosa apresenta o marido da Vovó Donalda, Tomás Reco, em "O Invasor do Forte Patópolis", no capítulo 10 (1994) da Saga do Tio Patinhas. Entretanto, Tony Strobl já havia introduzido o avô em HQ de julho de 1964 (The Good Old Daze), conforme Fig. 49.

Estes aspectos relacionados ajudam a compreender que, apesar de Don Rosa ser de extrema importância para a produção e popularização dos quadrinhos Disney entre o fim dos anos 1990 e início dos 2000, sua obra não está na mesma esfera criativa de evolução ou expansão em que encaixamos Gottfredson, Murry, Canini ou o próprio Barks. A produção de Don Rosa é, portanto, uma releitura da obra clássica de Carl Barks acrescido de um estilo mais detalhado e auto-referencial. Sua obra se encerra sobre si mesma, impossibilitando que outros artistas "continuem" sua saga a não ser que considerem toda a produção quadrinística Disney um universo alternativo e o de Don Rosa um universo singular dentro de suas pretensões e limitações. É o caso do personagem Tio Patusco, criado por Willian van Horn em 1994, ignorado na família Pato estruturada por Don Rosa. Outra coincidência é que outro personagem (do Barks), Jake McDuck (tio do Tio Patinhas), ganhou o nome de Nicolau Patusco na versão brasileira. Outro personagem ignorado é o Peninha (criado em 1964 
por Dick Kinney e Al Hubbard para o Disney Studio Program), o que chama mais atenção, por ser um personagem mais conhecido nos quadrinhos Disney.

Analisando as ações e gags de suas histórias, podemos sentir a falta de certa qualidade espontânea que Barks tinha. Enquanto Barks era obrigado a fazer, no mínimo, uma HQ de 10 páginas e uma aventura todo mês, Don Rosa fazia uma por vez, levando até seis meses em cada uma. Por possuir uma arte mais caprichada do que outros artistas, que produzem para dar conta de prazos curtos, a obra de Don Rosa é por vezes encarada como se fossem histórias para álbuns, no estilo Asterix, cuja produção sazonal tornava os lançamentos mais valorizados.

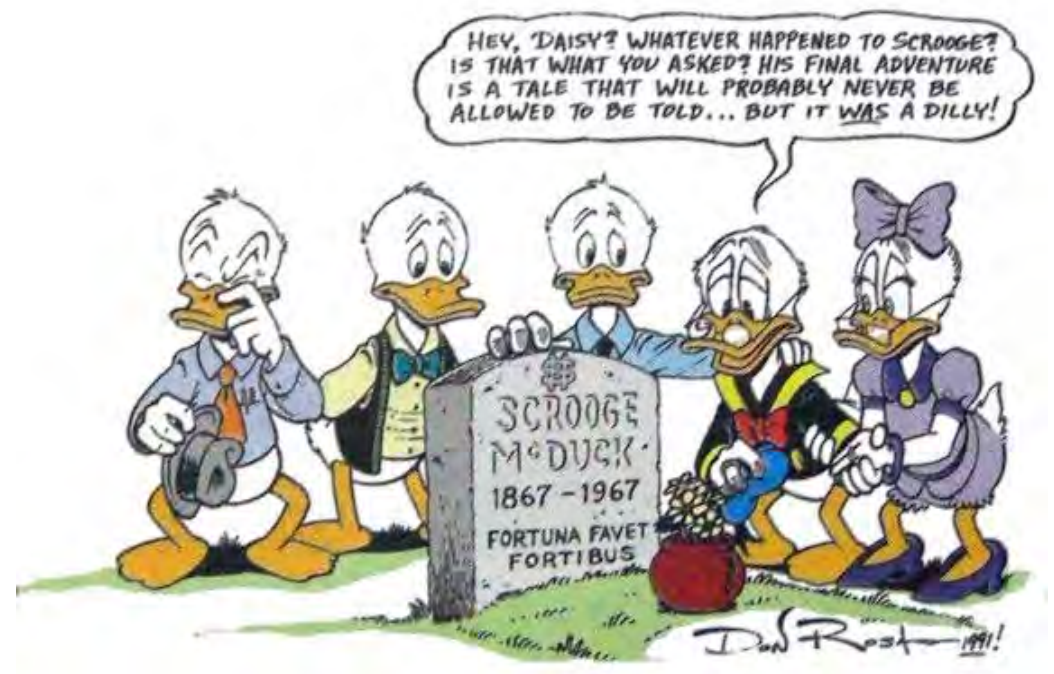

Figura 50 - Em ilustração autônoma para publicação alemã, Don Rosa reforça sua visão de que o Tio Patinhas "morre" em 1967 com a aposentadoria de Carl Barks, o mestre dos patos. (Der Hamburger Donaldist, $\mathrm{n}^{\mathbf{0}} 77,1991$ ).

Podemos concluir que Don Rosa trabalha com metaficção em algo que podemos chamar Disney pós-moderna. É preciso ressaltar que o universo Disney não é tão coerente. Há personagens criados que são usados uma única vez e depois esquecidos. Há variações de um mesmo personagem na Itália e nos EUA (por exemplo, o personagem Pateta tem vários tios-avós). O universo criado por Rosa é o mais singular. Tendo em vista a obra de Don Rosa ter alcançado tamanho sucesso, ressaltase a reflexão de que as HQs Disney permanecem, há pelo menos duas décadas, em um processo de saturação agravado por decisões mercadológicas e editoriais, com poucas oportunidades de explorar uma verdadeira dimensão autoral visando o ineditismo e a atração de leitores. Don Rosa e, como veremos em seguida, Casty, - são provas de que é possível inovar se inspirando nos clássicos. 


\subsection{Casty e o "novo mundo" do Mickey}

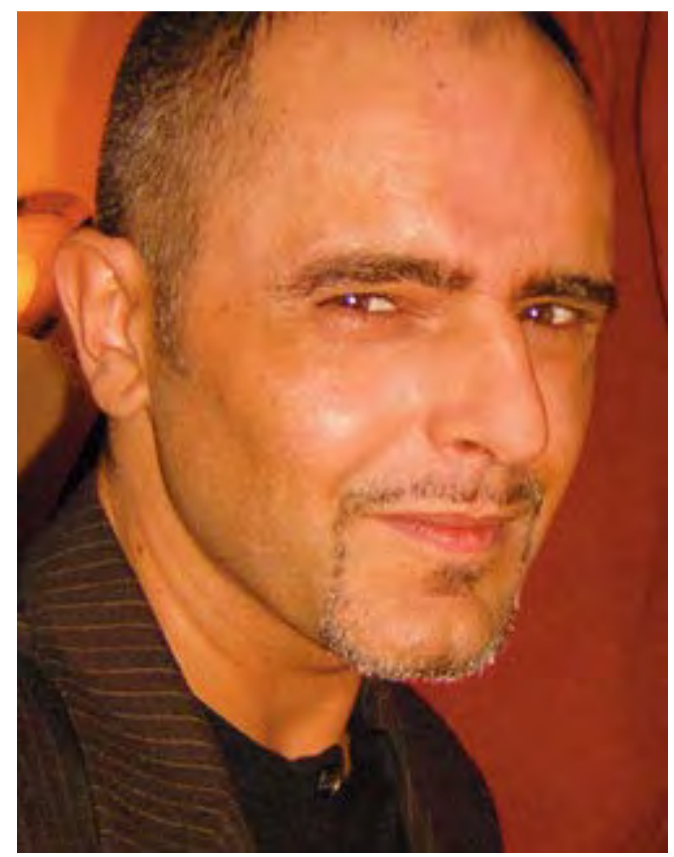

Figura 51 - Andrea Castellan ou simplesmente Casty

Andrea Castellan, italiano nascido em 23 de abril de 1967 em Gorizia (atualmente vive em Gradisca d'Isonzo, região de Friuli Venezia Giulia no nordeste da Itália), é mais conhecido por seu apelido de infância, Casty (MARCIANÒ, 2009). É considerado um dos mais talentosos quadrinistas completos de Disney. É roteirista e desenhista, tendo colaborado com mestres italianos como Giorgio Cavazzano e Massimo De Vita. Diferentemente de Don Rosa, Casty é conhecido por produzir histórias que lidam com o universo não dos patos, mas dos ratos. Mickey Mouse foi renovado sob as mãos dele, o que não é pouco se observarmos as dificuldades que a Disney tem em tornar o personagem, seu ícone corporativo, relevante e interessante para novas gerações. Nos quadrinhos Disney, um sobressalto deste tipo com o Mickey só ocorreu nos anos 1950, quando Carl Fallberg escreveu muitas das histórias desenhadas por Paul Murry nos Estados Unidos. 


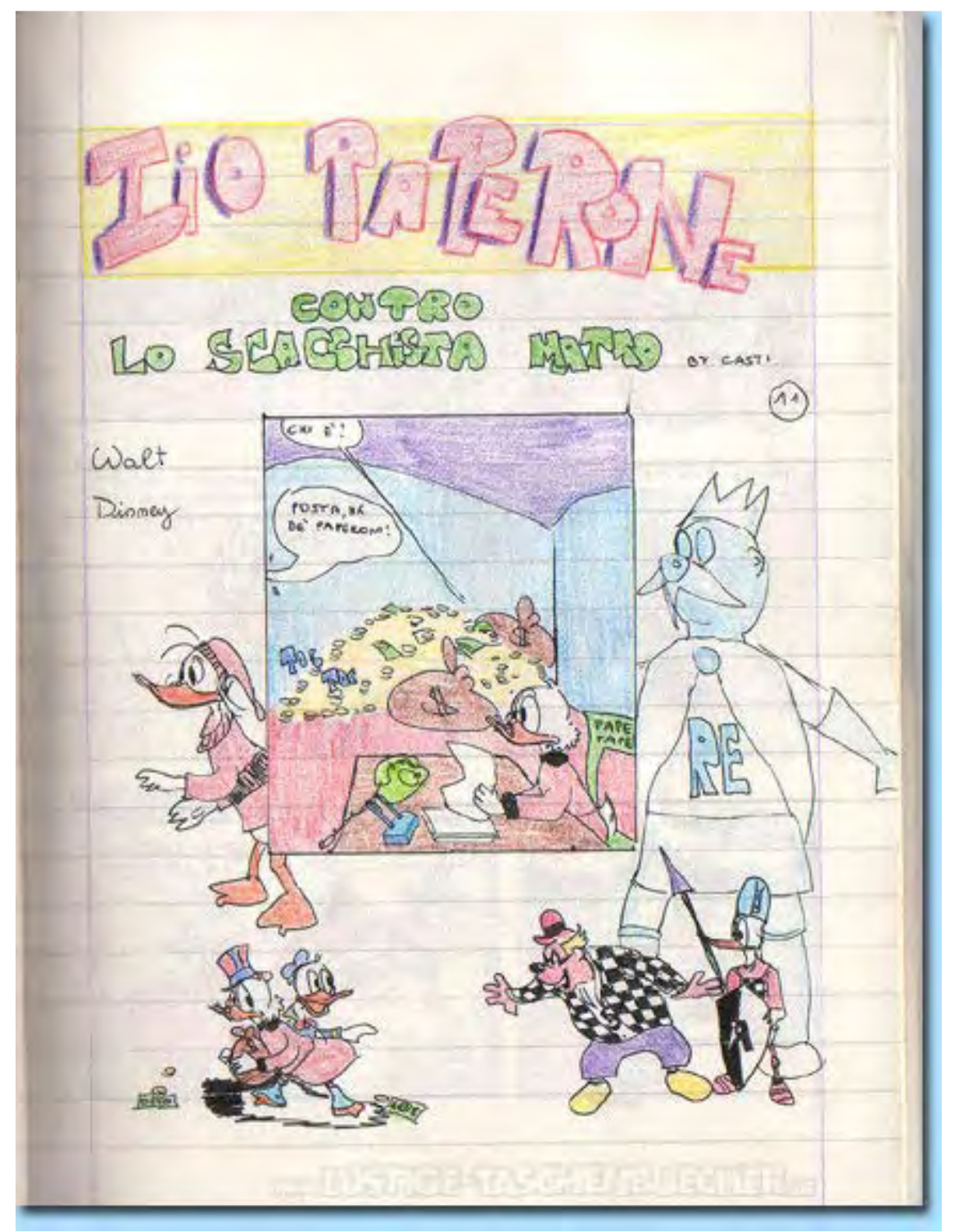

Figura 52 - Aos 10 anos Casty e seu caderno de desenhos. "O curioso é que eu era apenas histórias com os patos, porque aqueles de Mickey Mouse eram muito difíceis de inventar", diz o autor.

Casty começou a desenhar por brincadeira quadrinhos Disney aos 10 anos de idade usando seus cadernos escolares. Seus colegas aguardavam ansiosamente suas historinhas, numa época em que as oficiais eram criadas pelos mais diversos autores. Ele também se interessava pelas produções japonesas com seus robôs gigantes (LISOTTI, 2012).

Mais tarde, começou a trabalhar como ilustrador e designer, com grande interesse em desenhos realistas inspirados por sua preferência por ficção-científica e horror. Enviando seus trabalhos para avaliação, só obteve resposta para trabalhar em quadrinhos não-realistas. Assim, em 1993, começou a escrever histórias em quadrinhos profissionalmente para a revista "Cattivik" uma das mais populares revistas de humor da Itália, criada em 1965 por Bonvi (Franco Bonvicini). Neste 
trabalho, acabou descobrindo seu dom para produzir quadrinhos para crianças. A primeira história de Casty foi publicada em 1994 e o que se seguiu foi uma produção de cerca de 200 histórias para o periódico. Em 1999, também colaborou com outra revista italiana, Lupo Alberto - publicação em quadrinhos estrelada pelo lobo azul criado por Guido Silvestri (Silver) em 1974 (MONTORI, 2014). Seu início oficial com produção Disney se deu em 2002.
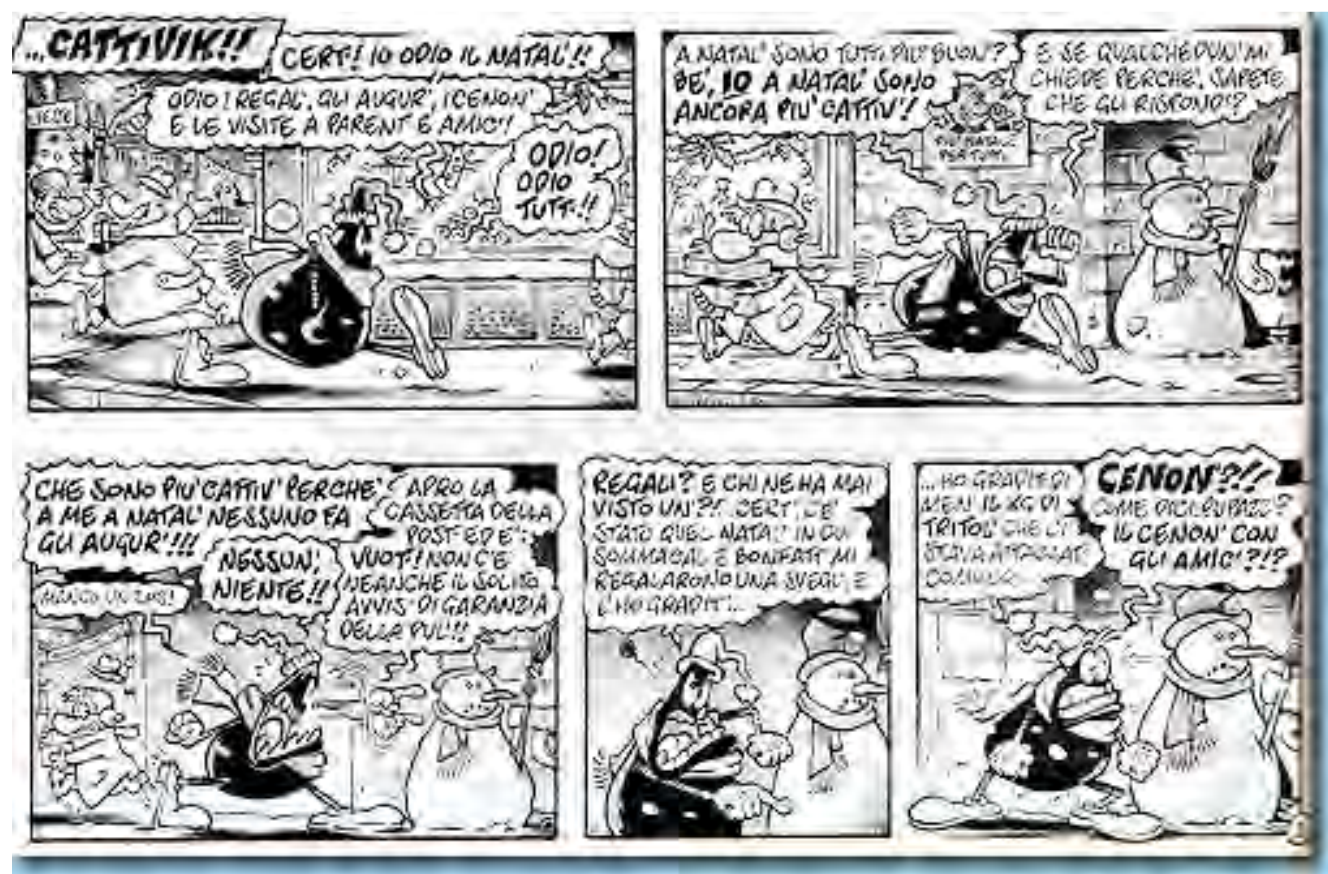

Figura 53 - Cattivik (Créditos Mck/Silver)

Escrever e desenhar - qualidade superior: Casty é considerado um artista completo. Dentro da percepção de que as histórias em que o autor escreve e desenha são melhores, Casty considera não haver grande diferença. No caso, escrever é como doar uma parte de si mesmo, as inspirações que ganharão a narrativa. "O fato é que, terminada a história, isso representa um pedaço de você que vai embora. Não é mais possível retomar aquela criação. Com o desenho ocorre o oposto. O processo está sempre em evolução, sempre um aprendizado" (RESTEL e ALBERT, 2007). Casty sabe que sempre pode melhorar o desenho de um Mickey na próxima história. Isto posto, existe uma compensação entre escrever e desenhar. Fazer os dois é especial, porque ninguém melhor que o próprio autor pode captar o espírito integral da criação: "Pense em Romano Scarpa, Massimo de Vita ou Giorgio Cavazzano, todos designers formidáveis que deram o seu melhor nas histórias por si próprios" (LISOTTI, 2012). Um escritor (roteirista) trabalhando em conjunto com um desenhista pode trocar ideias sobre uma ação ou expressão específica. Por vezes, um desenhista pode incrementar muito o trabalho do roteirista. 
Um dos grandes exemplos da produção italiana são as paródias, sejam elas de filmes ou especialmente da literatura universal. Tendo explorado esse filão por tantos anos, os artistas começam a explorar temas de um passado recente em outras mídias. O melhor exemplo é o cinema, com tantas possibilidades, que variam da fantasia clássica inspirada em "O Senhor dos Anéis" e "Harry Potter, resultando em títulos disneyanos como "Os Mágicos de Mickey” e "Dragonlords", até o universo dos super-heróis, com novas aventuras do Super Pato. Ou, de forma mais complexa, usar personagens tradicionais, como o próprio Superpato, Superpata, Superpateta, Morcego Vermelho e Borboleta Púrpura (cujas histórias formavam antigamente o "Clube dos Herois"), em uma produção com histórias em arco - caso de "Ultra-Heróis" (Ultraheroes), publicado entre fevereiro e abril, originalmente na revista Topolino na Itália.

O processo criativo não é muito diferente de outras mídias, começando com uma sinopse e a elaboração de um roteiro. A diferença ocorre nos detalhes referentes à própria mídia quadrinhos. É necessário se preocupar com o número de páginas, de quadros e o equilíbrio entre desenho e texto nos painéis. A Itália é conhecida por permitir histórias particularmente longas, o que possibilita algumas narrativas arrastadas. Em boas mãos, entretanto, esse espaço é excelente para quem tem talento. Os editores decidem se a história sugerida será produzida e têm o poder de editar ou alterar conteúdo. Nas palavras de Casty, são os "homens das sombras" que também são responsáveis pela criação em nome da editora (LISOTTI, 2012). A criação de uma história de Casty leva de quatro a dez dias para ser escrita e roteirizada em storyboards, a depender da complexidade da trama. Costuma fazer outros trabalhos antes de retomar o roteiro, de modo a revisá-lo e procurar meios de melhorá-lo ou corrigir problemas. Também costuma pedir a opinião de amigos e de seus filhos como se fossem um grupo de avaliação pessoal.

Casty trabalha em um estúdio em casa, trabalha com dois Macs, três cadeiras diferentes (ele as escolhe a depender da tarefa: desenhar ou escrever) e uma cama para descansar ou se recuperar das dores nas costas. Costuma produzir suas histórias no período da tarde e noite, quando há mais tranquilidade. O processo de criação de ideias não surge sempre de uma epifania. Casty se inspira lendo notícias obscuras que procura na internet (uma mina de informações, segundo ele), assistindo filmes antigos e seriados de televisão, inclusive os ruins, que podem render boas sugestões. No início, consumia revistas científicas e documentários. Preserva ideias para situações e piadas em dois notebooks, para que um dia possam ser aproveitadas em futuras histórias. Outra inspiração vem da observação - de cães, gatos ou pássaros melros que frequentam os jardins de sua casa. Mickey Mouse 
e Pato Donald são bichos, portanto, nada mais justo que buscar inspiração também do comportamento engraçado de animais ao seu redor. A cidade onde mora, um popular destino turístico dos alemães na Itália, mostra um equilíbrio perfeito entre modernidade e tradição. Somado ao fato de que fica próximo ao mar, Casty possui muitos elementos para se inspirar (LISOTTI, 2012).

Os editores passam briefings informando procedimentos básicos como, no caso de Mickey, o foco no ambiente urbano, as tramas de detetive e a parceria com o Pateta, para render situações cômicas. A Disney Itália costuma reunir anualmente os autores por dois ou três dias, para que possam se conhecer e conversar sobre a produção de quadrinhos (LISOTTI, 2012). A grande qualidade de Casty foi ter se entediado com esse tipo de história e expandido as possibilidades de uso dos personagens e de seus ambientes. Selecionamos aqui alguns exemplos de histórias dele como quadrinista completo, ou seja, escritor e desenhista (Figuras 54 e 55).
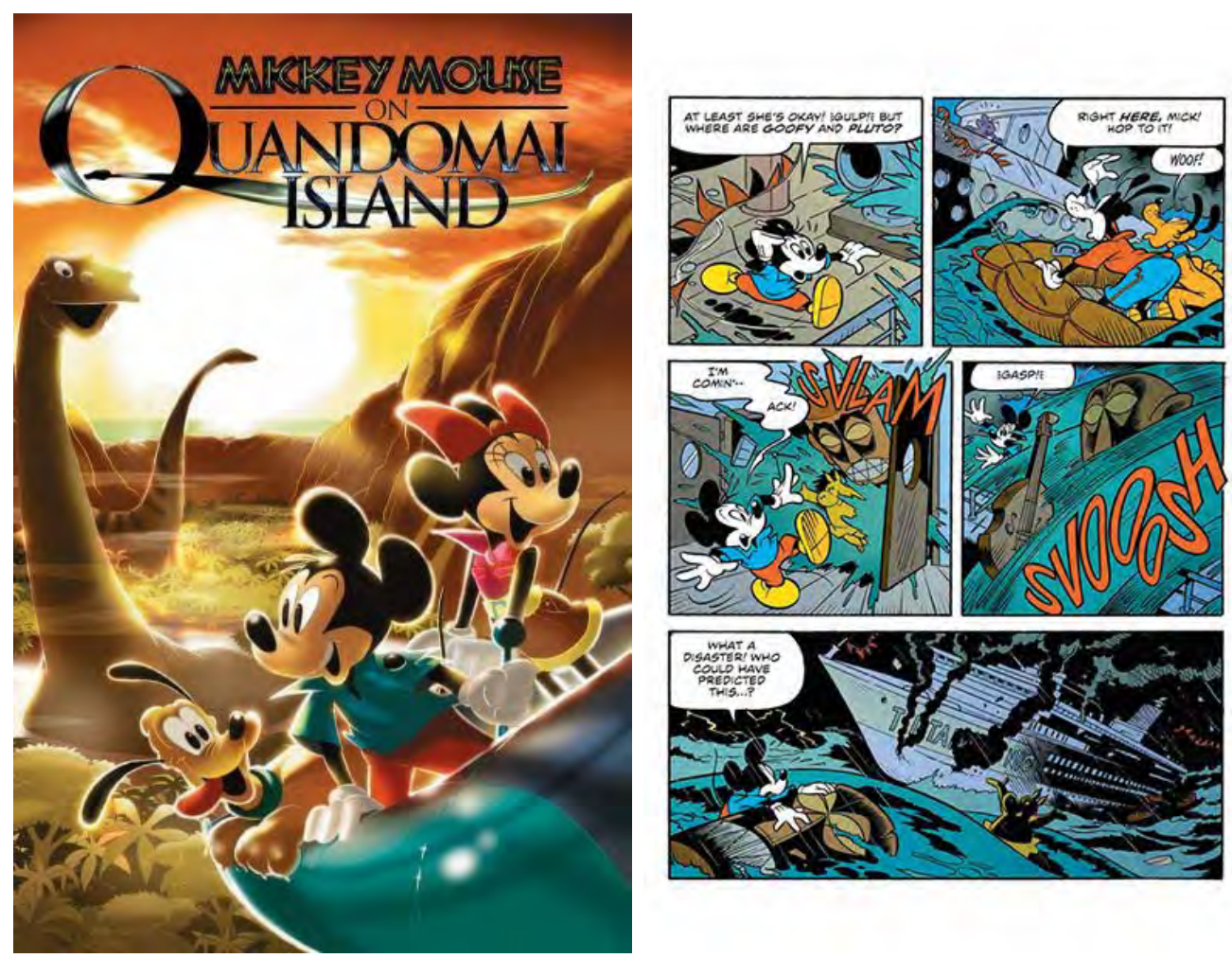

Figura 54 e Figura 55 - "Ilha de Quandomai"

Uma de suas histórias mais significativas e que representa bem seu estilo criativo é "A Ilha de Quandomai” (CASTY, 2010). Segundo Casty: “eu amo esta história porque tem mistério, reviravoltas, humor e um tema ecológico. Não foi fácil usar todos estes elementos em uma única 
história"26. A ilha, cuja tradução seria "Quando sempre", é o ambiente da aventura dos náufragos Mickey, Minnie, Pateta e Pluto, onde se encontrarão com diversas feras antigas de modo a perceberem que a ilha não é nada o que parece.

Aqui temos o desenvolvimento de um mundo próprio onde ocorre a aventura. A ilha remota conta com um personagem novo, caso do físico - o professor Barraquater - único habitante da ilha, e uma série de locais a serem desbravados: instalações misteriosas, vale-pré-histórico, estação científica e uma área com destroços. A narrativa, porém, se utiliza de todos os elementos clássicos e as reincorpora em um estilo contemporâneo.

Um caso de renovação foi o personagem Mancha Negra: o vilão ganhou nova roupagem em histórias mais complexas, com inspirações claras dos filmes de ação e ficção-científica de Hollywood, especialmente quando observadas as sequências de ação. Amplificando a temática "Mickey detetive", Casty cria detalhes no universo de Mickey em que na história o futuro é dominado por robôs em todas as áreas da sociedade. A lógica de funcionamento do robô segue a lógica das três leis da robótica, elaboradas pelo escritor de ficção-científica Isaac Asimov, em seu livro "Eu, Robô" (2014):

1 - Um robô não pode ferir um ser humano ou permitir que um ser humano seja ferido. 2 - Um robô deve obedecer aos seres humanos, exceto se contrariar a primeira lei. 3 - Um robô deve proteger sua própria existência, desde que não contrarie a primeira e segunda lei.

Ocorre que o Mancha Negra consegue criar robôs que não obedecem essas leis, o que cria o caos em toda a cidade. Mickey Mouse consegue encontrar o vilão e descobre em seu esconderijo uma arma poderosa, um exoesqueleto. Casty roteirizou e dividiu a criação com o desenhista Lorenzo Pastrocchio, também um fã de ficção científica.

A série de histórias em quadrinhos resultante, "O Mancha das Trevas" (Darkenblot), se revela um thriller tecnológico futurista com um arco narrativo incrivelmente sólido para os padrões disneyanos (CASTY, 2013). O desenvolvimento de Mancha Negra, um vilão clássico, não subestima

\footnotetext{
${ }^{26}$ Entrevista com Casty pelo site Disney Comics Worldwide. <http://www.wolfstad.com/dcw/blog/2010/01/interviewwith-casty/ > 26 de janeiro de 2010.
} 
a inteligência de seus leitores. O personagem mantém sua verve elegante e seu caráter de gênio do crime. A armadura especial Darkenblot é apenas uma invenção e não o mote principal, funcionando como elemento surpresa para o clímax da história. Os paineis de ação são claramente estruturados no estilo típico dos quadrinhos de super-heróis, embora o tom esteja equilibrado ao padrão disneyano.

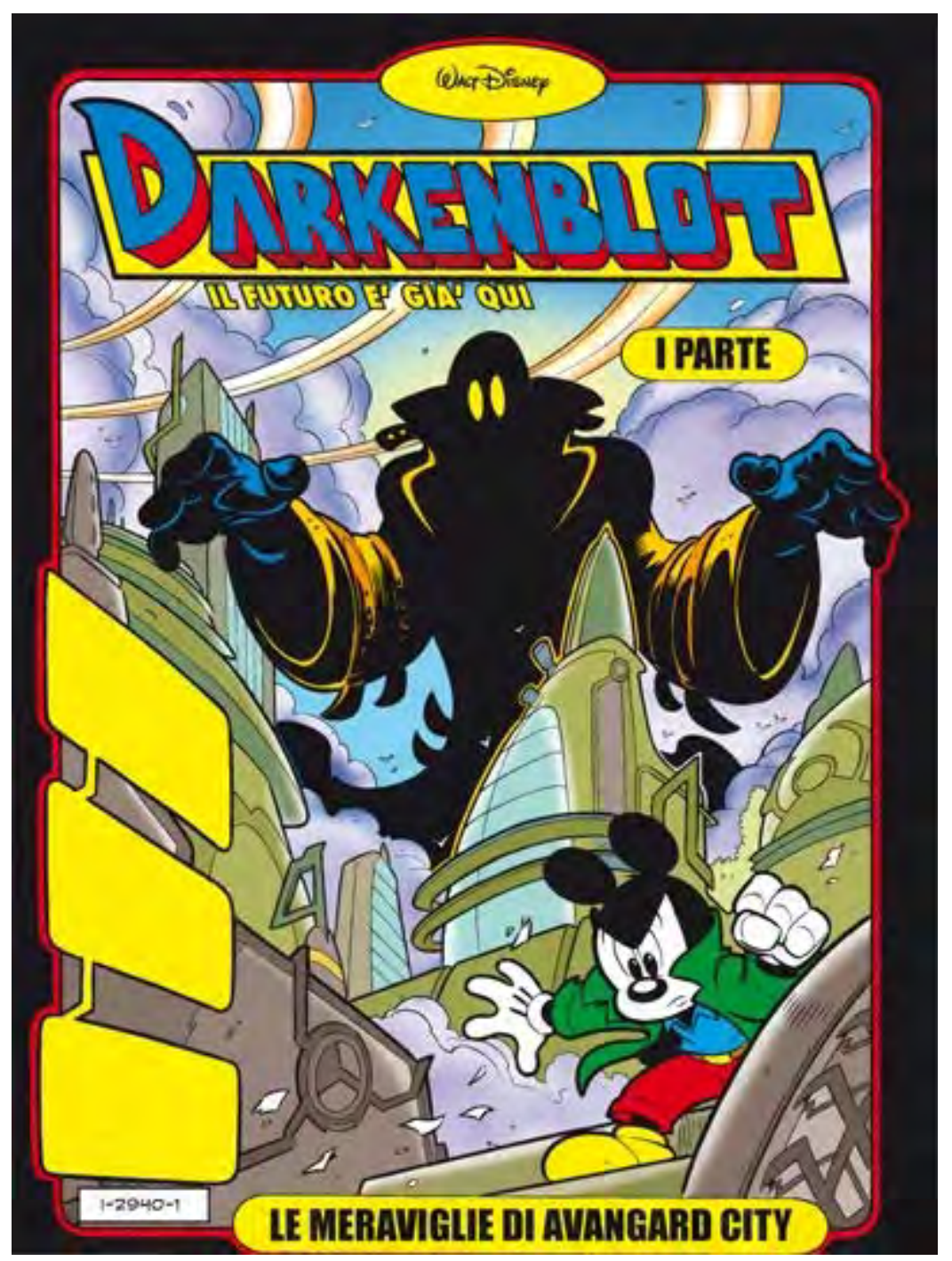

Figura 56 - Mancha das Trevas

O ambiente desta saga retoma a dinâmica da criação de universos. Mickey e Mancha Negra atuam em Robopolis ou Avangard City, uma cidade com mais de 2 milhões de habitantes, cercada por torres urbanas. Há duas fabricantes de robôs: a Kreomatic, produtora do robô Panther, e a Gaspard Robotics Inc, produtora de robô-policiais. Quatro usinas fornecem energia para o funcionamento das indústrias. A cidade conta com personagens e locais específicos para o desenrolar dos acontecimentos. 
Uma característica específica da produção italiana, o personagem Mancha Negra, tira sua máscara e exibe sua verdadeira identidade. Casty e Pastrovicchio tentam ao máximo combinar elementos futuristas com o estilo elegante de Floyd Gottfredson. O resultado é um hibridismo que impressiona pelo traço e pelas cores.

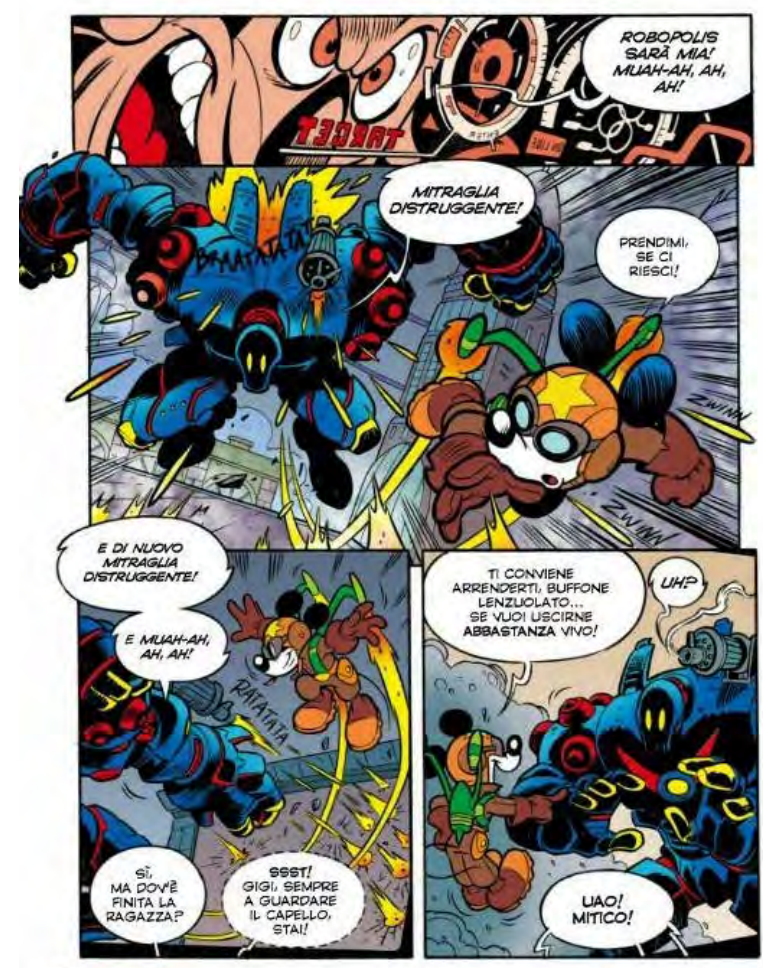

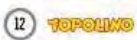

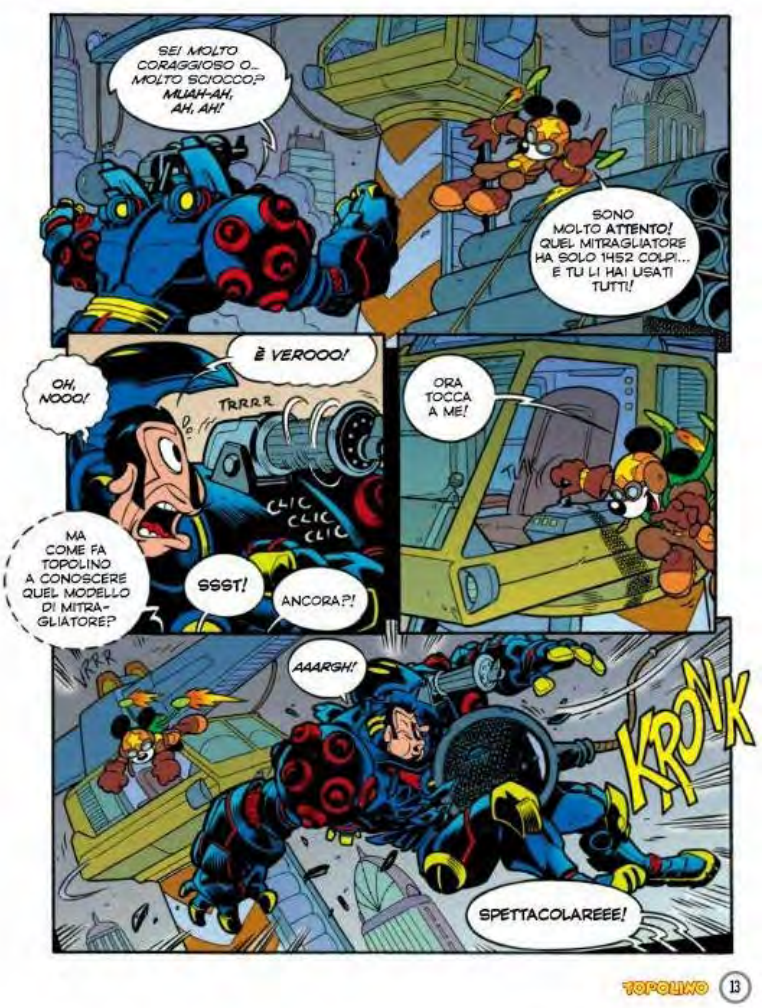

Figura 57 - Cenas de ação exibem hibridismo nos quadrinhos Disney.

Esquálidus, criado por Floyd Gottfredson, o homem do futuro com alergia ao dinheiro, parceiro de aventuras do Mickey em muitas aventuras, era considerado previsível para Casty. Porém, após ler diversas histórias de Gottfredson e Bill Walsh, encantou-se com as possibilidades que o pequeno ser lhe oferecia, especialmente pelo tom surreal, e o fato de Esquálidus ser mais humano que os humanos. Ao longo de décadas, artistas como Romano Scarpa evoluíram o personagem. Para Casty, entretanto, despertou interesse em retomar o personagem do passado. Um grande exemplo do uso de Esquálidus foi em "Mickey e o Mundo do Amanhã" (CASTY, 2008), uma aventura em que Mickey e Esquálidus viajam ao futuro e precisam enfrentar um vilão - o Homem das Rimas - que raptou a Minnie. Para tornar as coisas mais difíceis, o vilão tem em seu poder gigantescos robôs e pretende usá-los para dominar o mundo. Novamente, temos a criação de um ambiente ricamente detalhado para compor a narrativa. A história funciona numa combinação inteligente de temas, elevando a um novo nível as tramas de aventura e mistério do Mickey. 


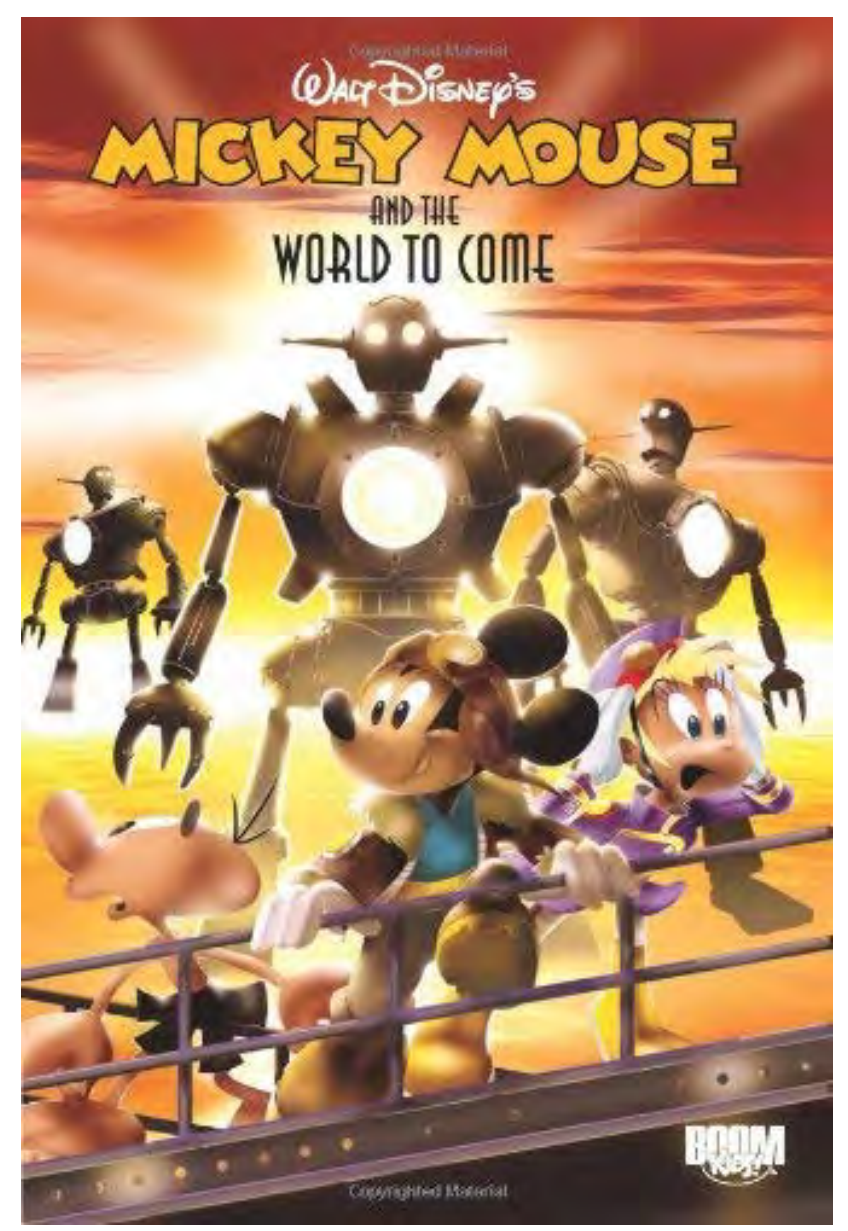

Figura 58 - "Mickey e o Mundo do Amanhã" - trabalho de Casty também publicado nos EUA.

Um último exemplo de resgate histórico se dá com o personagem Atomino Bip Bip, criação de Romano Scarpa publicado em 1959. Trata-se de um átomo ampliado por uma máquina chamada Bambatrone, do professor Tiraprosa. Quando observado, percebeu-se que tinha a forma humanoide. Possui características notáveis, como a transmutação da matéria, a produção de energia, calcular a idade de qualquer objeto e uma memória mesônica ${ }^{27}$ infalível. Casty considera o personagem uma das obras-primas de Scarpa. Tendo o sonho de retomar o trabalho do velho mestre após o personagem ter sido abandonado por anos, aguardou tempo suficiente para elaborar uma história digna. O projeto original é uma trilogia que Casty engavetou, pretendendo reler até que se sentisse pronto para desenhá-la. A primeira parte da trilogia é a história em quadrinhos de 75 páginas "Os Sombronautas" (Topolino e gli Ombronauti) publicada em duas partes na Itália em novembro de 2012 (CASTY, 2013b).

\footnotetext{
27 Tem origem em méson, uma partícula subatômica composta por um quark e um antiquark.
} 

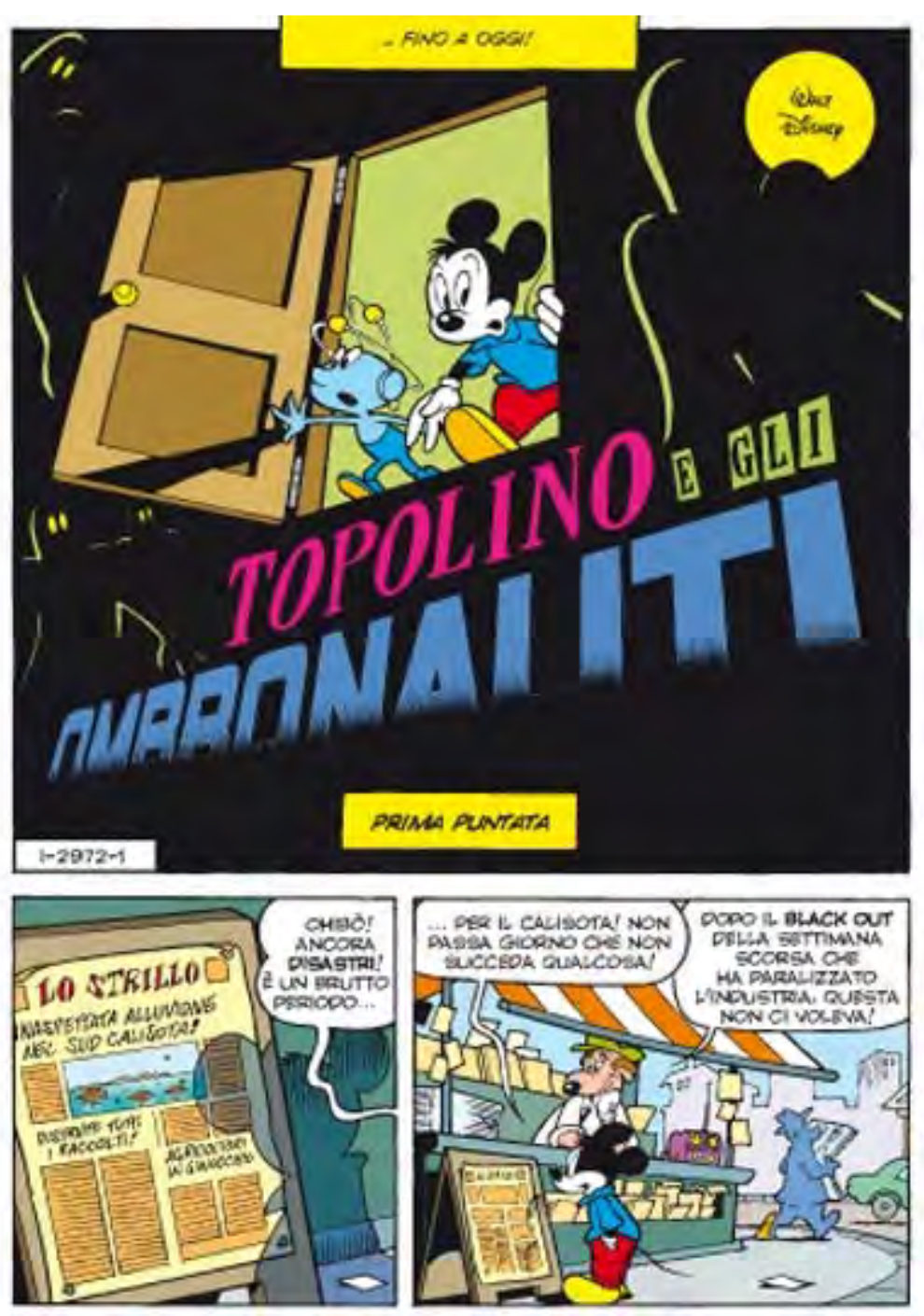

Figura 59 - O retorno de Atomino em "Os Sombronautas"

Trata-se de uma trama de mistério em que Mickey tem dúvidas sobre as benfeitorias feitas por um misterioso mascarado, disposto a pagar indenizações a cada desastre ocorrido na Calisota, a fim de movimentar a economia. Após receber um chamado da polícia, descobre que estava preso na delegacia seu velho amigo Atomino Bip-Bip. Com ajuda de suas características atômicas, Mickey tem acesso a visões holográficas do passado e assim a trama se desenvolve para tentar descobrir a verdadeira identidade do filantropo mascarado. A narrativa é densa, envolve dimensões paralelas, mistério, reviravoltas e o envolvimento de João Bafo de Onça - o rival clássico de Mickey.

Casty, mais uma vez, se preocupa em criar um rico ambiente ou "mundo" onde ocorrem todas as ações. Tal qual Don Rosa, ignorou todas as histórias com Atomino criados por outros autores que não fossem Scarpa, publicadas em anos subsequentes. A proposta era resgatar a visão original de Romano Scarpa e lhe dar uma roupagem contemporânea. As situações são claramente dignas de 
ficção-científica, porém o importante a destacar é como os personagens ampliam sua atratividade em meio a um ambiente bem construído e atrelado a um roteiro bem escrito.

Casty dialoga com seus fãs na internet. Publica no Facebook prévias de seus trabalhos. Fez isso com Mickey e a Ilha de Quandomai e Mickey e o Mundo de Amanhã. Numa rápida busca na internet, é curioso ver que os fãs criticaram o lançamento da história de Atomino por sua brevidade. Casty precisou responder em entrevista, na edição impressa de Topolino 2972 que continuará escrevendo mais duas histórias com o personagem, o que a transformará em uma verdadeira trilogia. A próxima HQ é “O Império de Mickey abaixo de zero”, então prometida para 2015.

Uma das contribuições mais importantes de Casty foi ajudar nesta retomada da popularidade do Mickey nos quadrinhos. Desde criança era fascinado pela palavra "mistério" e o que lhe chamava a atenção era que muitas coisas óbvias para adultos não o são para as crianças (LISOTTI, 2012). Não surpreende que o autor tenha revigorado as tramas de mistério de Mickey, inclusive deixando o personagem mais solto e com a possibilidade de fazer algo estúpido. A especialidade do autor, no entanto, está no campo da ficção científica, mas não propriamente as narrativas envolvendo monstros e naves espaciais. Sua inspiração reside em seriados como "Além da Imaginação" (The Twilight Zone) e "Lost". Quando criança, leu muitos livros de ficção-científica, Júlio Verne sendo um dos autores). Criador de personagens inéditos como Pegadinha (Doppioscherzo) - um vilão que lembra o Coringa do Batman, e Eurasia Tost, uma arqueóloga amiga do Mickey, Casty tem noção de alguns limites na criação de histórias. Perguntado se poderia combinar Indiana Pateta e Eurasia, o autor sabe que a segunda ainda é uma personagem secundária e que ambos pertencem a "contextos semelhantes" mas com tons diferentes de atuação. Cada qual também é ligado a interesses específicos. E revelou um medo: "ser oprimido por pedidos de jovens leitores que gostariam de casar os dois personagens" (LISOTTI, 2012, tradução nossa).

\subsection{Os Universos Disneyanos}

Como podemos explicar a popularidade de autores como Don Rosa e Casty? Ambos trabalham na lógica atrativa de expansão de universos. A diferença sensível é que Don Rosa desenvolveu um universo limitado pela criação de Carl Barks, ou, em outras palavras, as histórias em quadrinhos são baseadas somente no que ele convencionou como "universo Disney-Barksiano". Casty também se inspira em trabalhos de velhos mestres como Floyd Gottfredson e principalmente Romano Scarpa, 
porém não se limita especificamente a criar suas histórias limitadas aos universos deles. Pelo contrário, Casty retroalimenta o universo Disney nos anos 2000, com antigos personagens de décadas passadas com uma nova roupagem e elementos inspirados principalmente da ficção-científica - uma verdadeira mistura de gêneros.

O que pretendemos chamar atenção neste capítulo é para o papel de um roteirista ou artista na criação de um universo em que as histórias são ambientadas. Poderíamos desenvolver longamente um estudo baseado em Física para explicar a questão dos universos alternativos, mas a ideia aqui é nos limitarmos a existência deles e de seu uso potencializado pela indústria do entretenimento. Há, portanto, um universo padrão seguindo uma "continuidade", onde as histórias em quadrinhos Disney são ambientadas, e seus diversos autores, em dezenas de editoras e países, desenvolvem suas criações. Tendo por base essa ideia, roteiristas/desenhistas podem desenvolver universos alternativos isolados dentro de um universo padrão. $\mathrm{Ou}$, de forma mais complexa, desenvolver um universo dentro de outro universo, no que se convencionou chamar de multiversos e, consequentemente, desenvolver trajetórias narrativas que evoluem paralelamente, seja de forma autônoma ou dialogando com universos criados por outros autores. A criação pode ser mais aberta ou fechada, dependendo especificamente das estratégias editoriais ou simplesmente dos ideais criativos de seus autores. $\mathrm{O}$ multiverso é uma meta-continuidade que pode ser concebida em qualquer tempo, pré-estabelecido ou inédito, tendo sua base reconhecida diretamente relacionada à sua origem num universo ou continuidade padrão.

O uso de universos e multiversos não é novo e é fartamente explorado por roteiristas/desenhistas dos quadrinhos Marvel e DC Comics desde os anos 1960. Stan Lee, Jack Kirby, Steve Ditko, entre outros, desenvolveram universos próprios que foram reapropriados por outros criadores. A Marvel, por exemplo, tem grande parte de suas histórias numa "continuidade" conhecida por Terra-616. E dentro dessa continuidade há diversos universos, vários deles paralelos. Tornou- se, assim, possível criar histórias de viagens no tempo, realidades alternativas, alterações nas características e até a morte de super-heróis, reboots (o reinicio de uma história com narrativa inédita) e que, em geral, não se sobrepõem (HOWE, 2012). Porém, com o passar dos anos, a produção de histórias em quadrinhos ousou no desenvolvimento de crossovers em que personagens de um determinado universo interagem com os de outro - Batman e Superman sendo bons exemplos, embora eles já interagissem com heróis de outros universos, como Homem-Aranha, Hulk, Juiz Dredd, Tarzan, entre outros. 
De forma mais prática, como já vimos em Disney, Don Rosa desenvolveu seu próprio universo "Disney-Barksiano", uma abordagem em si mesma que não permite muita invenção dentro das convenções estabelecidas por Cark Barks. Casty, por sua vez, não se fecha em um universo limitado, mas cria um tipo de universo paralelo que dialoga abertamente com o que convencionamos aqui como "universo padrão" - aquele que permeia a criação dos quadrinhos Disney há décadas. E cada universo pode concentrar uma legião de fãs e críticos.

Esse conceito de "universo" funciona nos quadrinhos e no cinema. Assim, podemos afirmar que cada animação Disney funciona dentro de seu próprio universo. E, por razões mercadológicas, foram criados multiversos ou novas camadas, em que personagens de diversos filmes se encontram. Embora não exista oficialmente um filme reunindo todas as princesas ou todos os vilões de animações Disney, há veículos (sejam eventos, shows, filmes para a televisão ou produtos) que misturam todos os personagens em um mesmo universo. Os universos do Mickey, das princesas, dos vilões, das Fadas e, mais fortemente, o dos super-heróis, criaram uma nova oportunidade criativa e comercial para a indústria do entretenimento. E os quadrinhos possuem uma grande importância nessa estratégia.

Embora os quadrinhos Disney de Rosa e Casty sejam excelentes exemplos para compreender a lógica dos universos e porque atraem tipos específicos de fãs em relação ao "padrão", são os quadrinhos de super-heróis com toda sua complexidade de universos que demonstram seu poder midiático nas primeiras décadas deste século. Tornaram-se verdadeiras commodities (matériasprimas) para a indústria do entretenimento. E, se transformam em produtos altamente lucrativos, resultado de uma equação que combina a evolução da tecnologia de interação e consumo, com a influência do cult following, dos fãs e do potencial emergente dos chamados nerds e geeks, pessoas com grande conhecimento e, também, com grande envolvimento em produtos da cultura pop e da tecnologia, afetando um público ainda mais abrangente. O resultado em geral é o aumento dos lucros na indústria cultural. 


\section{A ERA DAS CORPORAÇÕES DE MÍDIA (1984-2005)}

Após desenvolvermos uma análise com exemplos da produção em quadrinhos e animação Disney, incluindo os aspectos tecnológicos, caminhamos para um panorama histórico das gestões que administram a The Walt Disney Company, com especial atenção às duas últimas gestões (Michael Eisner 1984-2005) e Bob Iger (2005 - atualidade ${ }^{28}$ ) e com especial viés no processo de decisão que envolve os estúdios de cinema. A produção de quadrinhos faz parte do mecanismo de supervisão da matriz, porém conta com maior autonomia de seus editores. Neste momento buscamos analisar a evolução dos processos estratégicos da produção audiovisual e, mais adiante, como os quadrinhos se inserem como matéria-prima criativa em um período no qual a Disney busca recursos para assegurar sua posição na indústria cultural.

\subsection{Início da gestão Michael Eisner}

"Nós não temos a obrigação de fazer arte. Não temos a obrigação de fazer uma afirmação. Não temos a obrigação de fazer história”, afirmou Michael Eisner (STEWART, 2005, p. 529) em memorando famoso publicado em sua época na Paramount. Dizia que não era obrigação fazer filmes de arte e sim entretenimento que desse retorno financeiro. Defendia que mesmo um filme de baixo orçamento não era salvo por um grande diretor ou elenco se o roteiro e a premissa fossem ruins.

Entre 1966 até o ano de 1984 os estúdios Disney passaram por um período de "depressão criativa”. Filmes live-action eram produzidos por inércia, replicando as fórmulas já testadas antes. Não à toa, as comédias disneyanas dos anos 1970 eram a chacota de Hollywood pelo conteúdo antiquado e brega. As animações igualmente reproduziam o problema. O estúdio inicialmente produziu ideias aprovadas pelo próprio Walt Disney ou que fossem seguros o suficiente para não custarem tão caro ao estúdio.

A administração que sucedeu Walt Disney após sua morte era formada por executivos que replicavam a divisão entre criativos (homens do Walt) e de negócios (homens do Roy, irmão de Walt), porém não com a mesma qualidade. Roy O. Disney, irmão de Walt, faleceu em 1971. O único grande investimento feito neste período foi a construção do Walt Disney World e do parque temático Epcot, inaugurados respectivamente em 1971 e 1982 em Orlando, Flórida. O estúdio fracassava em

28 2016. O contrato vigente de Bob Iger termina em 2018. 
experiências de ficção científica, como no caso do filme "O Buraco Negro" (1979), cuja comparação com o primeiro "Star Wars" (1977) não foi boa no aspecto técnico e narrativo, e até em filmes de suspense e dramas.

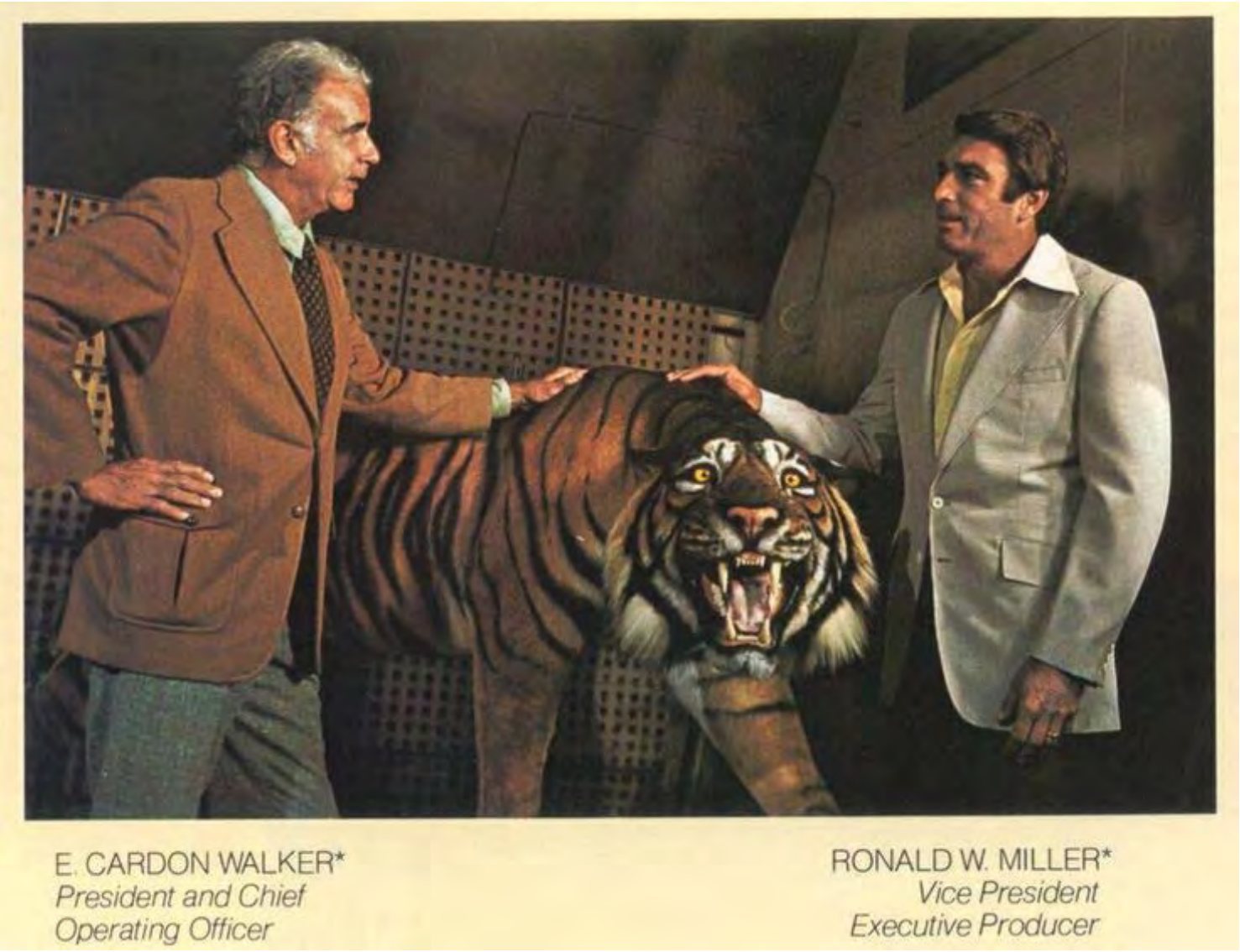

Figura 60 - Walker e Miller foram os líderes da Disney após os irmãos Disney.

A ascensão de Ron Miller (Fig. 60), genro de Walt Disney, até então um produtor em vários projetos de cinema, graças ao apoio dado pelo sogro, para o cargo de presidente, trouxe algum respiro ao estúdio, porém também enormes turbulências. Ao mesmo tempo em que o estúdio queria renovar criativamente a produção de filmes, não ousava investir o suficiente (TAYLOR, 1987). Os "nine old men", que ainda restavam, trabalhavam como diretores ou mentores após amargar uma década em projetos nos quais não podiam expressar o máximo de sua qualidade técnica. Como bem disse o historiador John Canemaker, "nos anos 1970 os nine old men eram como grandes chefs de cuisine cozinhando hot-dogs" 29 . O sopro de criatividade veio com o então jovem executivo Thomas L Wilhite, responsável por aprovar uma série de projetos experimentais no estúdio, entre eles o filme de ficção-científica “Tron: Uma Odisseia Eletrônica” (1982) e curtas-metragens próximos do horror,

\footnotetext{
${ }^{29}$ Entrevista ao website Animation Blast, de Amid Amidi, em 2002. O website não existe mais.
} 
do então jovem diretor Tim Burton. Todos os projetos, porém, não trouxeram retorno financeiro ou de prestígio ao estúdio (KALLAY, 2011). O público juvenil da década de 1980 era atraída por filmes de Steven Spielberg e George Lucas.

Com a queda do faturamento, um investimento bilionário no parque temático Epcot e uma série de decisões desastrosas que levaram o estúdio a se tornar o último lugar para se trabalhar em Hollywood, era inevitável que em algum momento a Walt Disney Productions enfrentaria problemas ainda mais profundos. Inicialmente, houve a renúncia de Roy E. Disney do conselho de administração, lançando uma campanha de renovação do quadro administrativo, visando uma nova gestão e recuperação do prestígio do estúdio (TAYLOR, 1987). Ele era contrário a muitas das ações executadas pela empresa e lhe dava arrepios ouvir executivos comentarem que não precisavam mais do estúdio (a produção não estava rendendo como antes, mas poderiam lucrar com os relançamentos das antigas produções). Isso para Roy era como gerenciar um museu, não um estúdio (HAHN, 2009). No mesmo dia da renúncia, um especulador corporativo chamado Saul Steinberg iniciou a compra de milhões em ações, visando uma aquisição hostil do estúdio. Ele não estava interessado em salvá-lo. A ideia era explorar os ativos ainda considerados valiosos, como o acervo de animações e filmes antigos. Deste modo, o especulador leiloaria e dividiria os bens entre futuros compradores: os estúdios, o acervo, os parques temáticos, etc.

A Disney, por sua vez, foi obrigada a adquirir uma série de empresas fora de seu metiê, algumas até com dívidas, para inflar o valor do estúdio e impedir a especulação. O que se seguiu foi uma batalha nos bastidores para ver quem ficaria com o espólio desta guerra. Ao mesmo tempo em que a Disney negociava um greenmail, uma espécie de pagamento para recomprar as ações de Steinberg, Roy E. Disney iniciava conversas com investidores bilionários, como o texano Sid Bass, para que pudessem comprar ações e pressionar o conselho da Disney a trocar o presidente e iniciar uma nova gestão (TAYLOR, 1987).

Na prática, como percebemos, envolvia também uma briga de família, pois a operação visava retirar do cargo Ron Miller, marido da prima de Roy. A então gestão Milller perdeu em todas as frentes. Adquiriu empresas que não eram de sua área, pagou a multa ao especulador que lucrou com sua ação (hoje considerada ilegal) e finalmente perdeu seus líderes. Roy E. Disney, com ajuda de seu associado Stanley Gold e do bilionário Sid Bass, conseguiram impor uma nova administração (TAYLOR, 1987). Dois nomes foram escolhidos. Michael D. Eisner, ex-chefe da Paramount, considerado um promissor executivo criativo, e Frank G. Wells, ex-presidente da Warner Bros entre 
1973 e 1982, conhecido como bom executivo financeiro. Ambos estavam dispostos a recuperar o prestígio do estúdio com uma boa dose de ousadia. A ideia foi replicar novamente a dupla "Walt e Roy" tendo um executivo criativo e um financeiro (GROVER, 1997, p. 28-29). Da Paramount, vieram outros executivos criativos, com destaque maior para Jeffrey Katzenberg, o workaholic executivo que cuidava das operações diárias de produção de filmes, negociando com agentes e supervisionando as filmagens (MASTERS, 2000, 160-161).

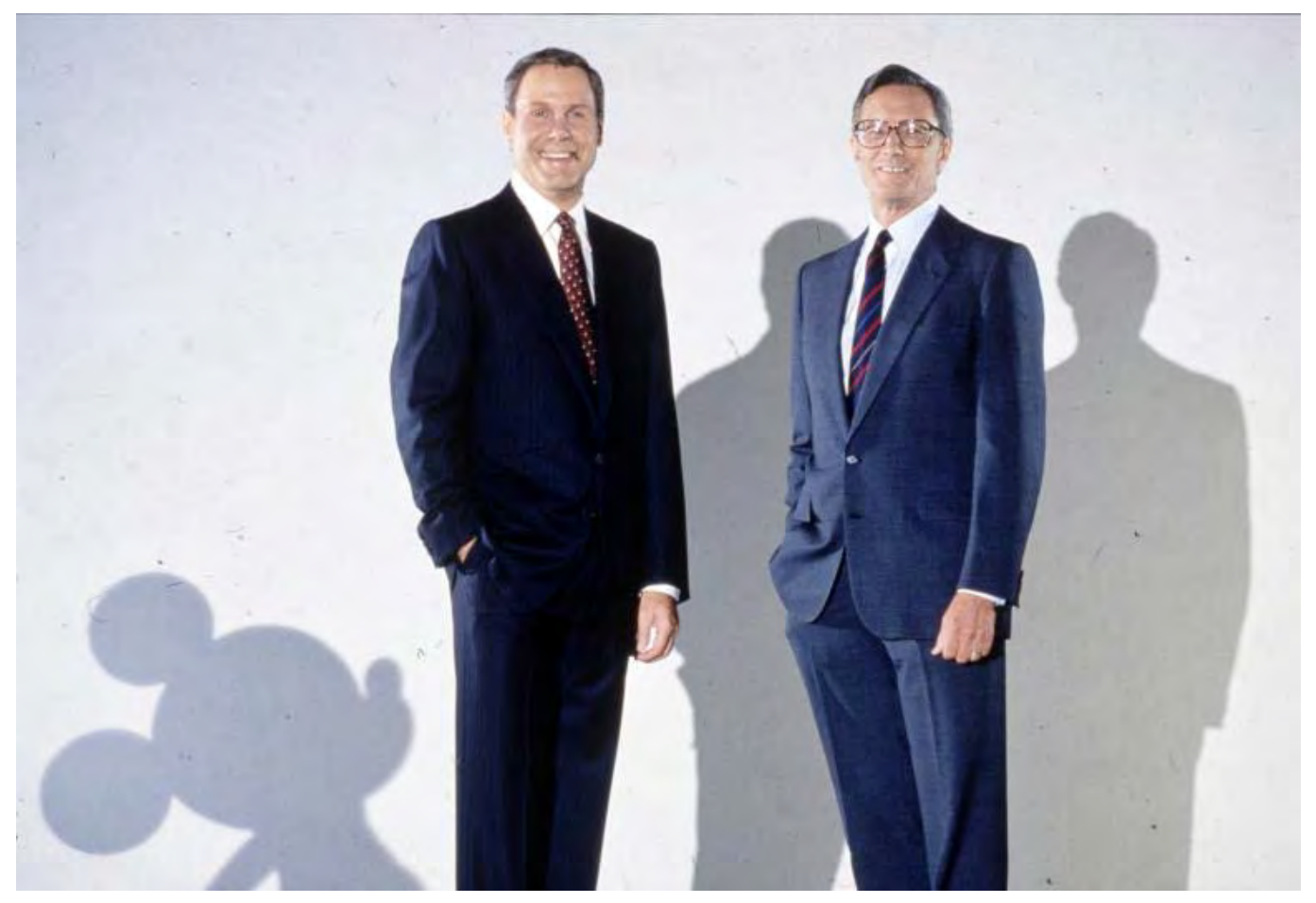

Figura 61 - Michael Eisner e Frank Wells - a dupla que fez renascer a Disney.

A nova rotina no estúdio pregava maior eficiência. Eisner e Katzenberg chegavam muito cedo e saíam tarde, demitiram mais de 400 dos antigos funcionários e executivos acostumados ao ritmo da antiga administração, muitos ainda do tempo de Walt Disney, incluindo um time de 12 fotógrafos que estavam empregados para registrar todo tipo de evento no estúdio, uma prática adotada pelo próprio Walt. Os novos contratados eram quase todos oriundos da Paramount (GROVER, 1995, p. 50).

Um dos primeiros passos foi recorrer a talentos criativos e caros. Michael Jackson foi contratado para estrelar um novo filme 3D chamado "Captain EO”. Francis Ford Coppola dirigiu e George Lucas assinou a produção, que durava 17 minutos e custou US\$ 17 milhões - um valor alto, equivalente em número absoluto ao custo integral da Disneylândia em 1955. George Lucas também produziu uma experiência de simulador inspirada em seus filmes "Star Wars" chamada "Star Tours", em que os visitantes embarcam em uma nave rumo à lua do planeta Endor. O projeto logo excedeu 
os US\$ 30 milhões previstos (MASTERS, 2001, p. 70-72). Lucas posteriormente contribuiria com projetos envolvendo ficção-científica e Indiana Jones. Era evidente, portanto, que o talento criativo era importante (os parques se tornaram relevantes novamente e atraíram a mídia) e que a Disney necessitava criar seus novos talentos internos (GROVER, 1997, p. 66-67).

\subsection{A Filosofia da Produção}

Para entender a filosofia de produção Disney entre os anos 1980 e 1990, é necessário voltar no tempo, quando Michael Eisner era ainda um executivo na rede de televisão norte-americana ABC. Foi lá que construiu uma carreira promissora como executivo criativo, lançando programação infantil vespertina, os primeiros especiais de TV com os Muppets de Jim Henson (JONES, 2013), e seriados de grande sucesso como "Laverne \& Shirley" (1976), "Welcome Back, Kotter" (1975) e "Happy Days" (1974) - esta última estrelada pelo jovem Ron Howard, com histórias ambientadas numa cidade norte-americana idealizada dos anos 1950 e 1960. O departamento de pesquisa da rede ABC chegou a rejeitar a proposta da série, listando problemas do conceito. Eisner e seu então chefe Barry Diller tinham aversão a qualquer pesquisa de mercado, chamando-a de vodu. O seriado foi produzido e rapidamente transformou-se em um fenômeno cultural (GROVER, 1997).

Eisner e Diller se tornaram proficientes no desenvolvimento de séries e shows cuja história básica poderia ser resumida a uma ou duas simples sentenças. Essa criação de Diller ficou conhecida na indústria como "high concept". Os dois executivos instituíram esta postura quando migraram para os estúdios Paramount (Eisner assumiu o cargo de presidente e chefe de operações em novembro de 1976), onde juntos produziram uma sucessão de "high concepts" um atrás do outro, seja no cinema ou na TV. No primeiro caso, por exemplo, a executiva Dawn Steel vendeu a ideia de produzir o filme musical "Flashdance - Em Ritmo de Embalo" (1983) usando como premissa o high concept. "É um Rocky feminino", aludindo ao filme "Rocky: Um Lutador” estrelado por Sylvester Stallone em 1976 (MAIR, 1998, p. 82). Na televisão, Matt Groening conseguiu aprovar o grande sucesso "Os Simpsons" (1989) com o mote "uma celebração da família americana da forma mais selvagem" (MAIR, 1998, p. 171).

Na Paramount, Barry Diller e Michael Eisner também puseram em prática o que passou a ser conhecido como "teoria do tentpole". Tratava-se da produção de blockbusters que permitissem que o estúdio produzisse filmes menores, viáveis e menos comerciais, ou seja, uma espécie de âncora para produções mais arriscadas. A ideia vinha de Irwing Thalberg, que dizia que uma companhia lucrativa 
poderia escolher fazer um filme que não fosse uma grande máquina de fazer dinheiro, desde que o filme elevasse o prestígio do estúdio (MAIR, 1998, p. 79). Seguindo esta estratégia, executivos criativos, com paixão e tenacidade, promoveram grandes projetos. Jeffrey Katzenberg teve a visão para promover um filme para cinema baseado no seriado "Jornada nas Estrelas" (Star Trek 1979), indo contra avaliações internas do estúdio (MAIR, 1998, p. 80). Michael Eisner, por sua vez, conseguiu amarrar um contrato com Steven Spielberg e George Lucas para produzir "Os Caçadores da Arca Perdida" (Raiders of the Lost Ark, 1981), a primeira aventura do arqueólogo Indiana Jones no cinema. Estes filmes se tornaram tentpoles para filmes criticamente aclamados, porém menos lucrativos como "O Homem Elefante" (The Elephant Man, 1980), "Gente como a gente" (Ordinary People, 1980) ou "Reds" (1981) - este último baseado na vida do jornalista John Reed. As decisões não eram infalíveis e muitos roteiros recusados provaram-se sucesso em outros estúdios, mas esses lapsos eram raros.

Michael Eisner, Jeffrey Katzenberg e Dawn Steel formavam um grupo de executivos conhecidos em Hollywood como "Killer Dillers", que tinha autonomia para seguir diretrizes em busca de resultados eficientes e financeiramente viáveis. Entre as diretrizes estavam acompanhar de perto o dia-a-dia das produções; controlar prazos e custos; evitar pacotes contratuais onerosos com estrelas e seus agentes; promover diretores, produtores e roteiristas; atenção aos detalhes para alcançar mais qualidade; sem resultados positivos, não hesitar em fazer mudanças, nem que resultassem em alterações e demissões na equipe (MAIR, 1998, p. 76-77). Dentre os executivos do grupo, Eisner tinha um senso de "gosto popular" ligado a um apelo mais jovem e familiar. Tornou-se rapidamente o favorito quando a Disney precisou de ajuda.

Em sua entrevista com Ray Watson (presidente do conselho da Walt Disney Productions), Eisner mostrou que sabia das possibilidades da Disney e do quanto a Paramount já estava saturada. A corporação Gulf \& Western (que depois venderia o estúdio de cinema e TV para a Viacom em 1994, e posteriormente se fundiria com a rede de TV CBS em 1999) não deu indicações de que promoveria Eisner. Seu chefe, Barry Diller, também estava prestes a se mudar para a Fox. A Disney estava, em 1984, numa posição parecida com a Paramount e a ABC quando Eisner iniciou sua carreira nas duas empresas. A Disney produzia apenas alguns poucos filmes por ano, um longa-metragem de animação a cada quatro anos e não havia produção para televisão. Havia enormes oportunidades tendo em vista que, diferente da Paramount, Disney tinha parques temáticos e produtos licenciados com potencial de promoção cruzada. A marca era única e um ativo insuperável. (SCHWARTZ, 1999, p. 122-123). 
Jeffrey Katzenberg, antigo parceiro de Paramount, foi contratado para gerenciar as operações diárias de produção do estúdio. No início, todos do primeiro escalão contribuíam no processo. O estúdio ainda permanecia pequeno, produzia cerca de uma dezena de filmes por ano, e cada um deles era visto com grande importância. Eisner afirma em sua biografia que

da mesma forma que na Paramount, desenvolvemos nossas próprias ideias, insistimos em estar envolvidos de perto no processo criativo, e produzimos filmes por menos dinheiro que nossos competidores. Sendo modesto, tentamos recriar o antigo sistema de estúdio, contratando jovens roteiristas com contratos exclusivos para fazer outros filmes - frequentemente sem retorno, oferecíamos a eles a chance de dirigir filmes. Atores também retornavam para fazer outros filmes na Touchstone, mesmo antes de recrutá-los para projetos Disney" (SCHWARTZ, 1998, p. 158, tradução nossa).

Desse modo, Better Midler retornou para trabalhar em "Por Favor, Matem Minha Mulher" (Ruthless People), onde fazia a esposa de Danny DeVito, e “Que Sorte Danada” (Outrageous fortune), além de dublar a cadela grã-fina Georgette na animação “Oliver e sua Turma” em 1988 (este, um projeto com selo Disney).

\subsection{Pequenas e Grandes Telas}

A primeira decisão foi promover a marca para a audiência de massa. A saída obvia foi restaurá-la, relançando o nome Disney na TV em horário nobre. A série "Disneylândia" (The Wonderful World of Color/Disney) começou em 1954, passou por várias redes de TV e tornou-se um dos títulos mais longevos, permanecendo décadas no ar. Graças ao acordo com a rede ABC no início, Walt pôde construir a Disneylândia. E os efeitos foram maiores. O nome do parque se tornou popular nos Estados Unidos, antes mesmo de ser inaugurado. A presença de Walt como apresentador ajudou a humanizar o estúdio e elevá-lo ao nível de uma figura maior. O fato dele falar com sotaque do meio-oeste e não ser um ator o tornava ainda mais carismático. E o programa era o veículo perfeito para promover e criar hype dos novos filmes, como o caso do documentário sobre o filme "20 Mil Léguas Submarina" (1954).

Em 1983, Card Walker CEO e presidente, visando alavancar o lançamento do Disney Channel na TV a cabo, encerrou o programa Disneylândia na TV aberta. Eisner e Wells discordavam da estratégia. $\mathrm{O}$ canal premium fechado teria assinantes interessados em acessar a programação Disney o dia inteiro. A presença de um programa no horário nobre, em rede aberta, era uma imensa 
possibilidade de exibir uma imagem renovada da Disney com programação de alta qualidade. (SCHWARTZ, 1998, p. 149). A ideia resultou no The Disney Sunday Movie (1985) um programa com telefilmes originais apresentado pelo próprio Michael Eisner, após recusas de Cary Grant, Dick Van Dyke, Ron Howard, Julie Andrews e Paul Newman (SCHWARTZ, 1998, p. 151). O programa foi exibido no Brasil pelo SBT como "Cine Disney", a partir de 1988 (MOTTA, 1988, p. 6).

No início da primavera de 1985, Eisner reuniu, assim como fazia na Paramount, executivos e todo o pessoal criativo numa reunião que era, na verdade, uma maratona de ideias, conhecida internamente como "Gong Shows" - inspirado num programa de TV dos anos 1970, de gosto duvidoso, onde calouros eram gongados. Todas as pessoas eram encorajadas a sugerir ideias, mesmo que fossem as mais difíceis e malucas. O entendimento é que a maioria delas seria "gongada" - sem ofender sentimentos alheios. Geralmente outras empresas fazem esse tipo de reunião e as ideias fornecidas são banais e seguras. Nos Gong Shows, o ambiente é mais descontraído e, apesar de cansativo e doloroso, as reuniões são produtivas. (SCHWARTZ, 1998, p. 150). Foi assim que ideias para os telefilmes do Cine Disney foram criadas. E futuramente ideias para animações como "Hercules" e "Tarzan" foram aprovadas - esta última, originalmente, seria uma versão cômica estrelada pelo Pateta, produzida pelo estúdio satélite no Canadá para o mercado de vídeo. O projeto "Pocahontas" (1995) foi aprovado a partir de uma única imagem.

$\mathrm{Na} \mathrm{TV}$, o primeiro grande sucesso da nova gestão não foi uma animação e sim uma série liveaction chamada "Super Gatas" (The Golden Girls, 1985). Foi uma aposta arriscada, da história da amizade entre 3 amigas na faixa dos 60 anos, morando juntas, incluindo a mãe octogenária de uma delas. Outro sucesso foi criado na base do tradicional gênero sitcom de família, "Home Improvement" (1991), estrelando Tim Allen, ator que fazia muito sucesso atuando em comédias de stand-up no teatro. Era a figura perfeita para interpretar a si mesmo como um "homem real" irônico e iconoclasta.

No cinema, houve um problema sério. O plano da nova administração era produzir agressivamente um número maior de filmes do que o estúdio normalmente lançava anualmente, e com mais qualidade. Era necessário encontrar uma forma de se proteger, caso o estúdio investisse pesado em filmes que, por alguma razão, não fossem bem de bilheteria. A saída encontrada por Frank Wells foi uma parceria com um advogado de Nova York chamado Roland Betts, que, reunindo uma série de investidores individuais em todos os EUA, levantaria a soma de US\$ 200 milhões até o final de 1985, para que custeassem em associação uma série de filmes da Disney. É por isso que vemos nos créditos de vários filmes a associação da Silver Screen Partners, em suma, investidores que 
financiavam os filmes sem esperar um retorno que comprometesse diretamente a Disney, ou seja, o que havia era uma divisão de faturamento - se um filme tivesse bom faturamento para a Disney, os parceiros da Silver Screen também tinham. (SCHWARTZ, 1998, p. 154).

Em meados dos anos 1980, a Disney tinha pouco prestigio e respeito. "A saída foi ignorar grandes estrelas, efeitos especiais e diretores renomados, deixá-los em segundo plano. Fruto da necessidade, o estúdio substituiu dólares com criatividade e estrelas nas quais acreditávamos no potencial" (GROVER, 1997).

Nesse aspecto, Disney buscava diretores que quisessem ousar na Disney, e contratava bons atores que estivessem com a carreira em baixa. Na prática, o estúdio alavancou as carreiras de artistas como Better Midler, Richard Dreyfuss e Nick Nolte e, apesar de mantê-los por contratos longos para diversos filmes, com o passar dos anos seus salários aumentaram de acordo com o aumento do status de celebridade. (KATZENBERG, 1991, p. 14). O primeiro filme nesse esquema foi "Um Vagabundo na Alta Roda" (Down and Out in Beverly Hills", 1986). Foi possível produzir o filme por modestos US\$ 14 milhões (SCHWARTZ, 1998, p. 156). O filme foi importante, pois mostrava um sinal claro a toda Hollywood de que a Disney estava disposta a se afastar da imagem negativa que tinha no mercado, que via o estúdio como o mais fraco, repleto de filmes ruins há pelo menos 10 anos, o que dificultava a contratação de bons roteiristas, diretores, produtores e atores. Ron Miller iniciou o processo com a criação da Touchstone em 1983, e finalmente o estúdio conseguia produzir filmes distantes do foco primordialmente familiar e infantil.

Com classificação "R" (adultos), um filme produzido pela Disney (usando seu selo adulto Touchstone) continha palavrões e cenas de sexo. A exibição-teste, com a presença de Roy E. Disney, deixou todos nervosos, mas ele compreendeu a estratégia e aprovou o filme (SCHWARTZ, 1998, p. 157). Logo em seguida veio a comédia "Splash: Uma Sereia em Minha Vida”, estrelando Tom Hanks e Daryl Hannah, com direção de Ron Howard, o que foi o estopim para uma série de grandes sucessos como "Três Solteirões e um Bebê" (adaptado da versão francesa de grande sucesso "Trois Hommes et un Couffin” (1985) - custou US\$ 16 milhões e faturou US\$ 168 milhões.

Vejamos com o filme "Três Solteirões e um Bebê" (1987) como Eisner calculou a estratégia potencial de um blockbuster. Ele assistiu ao original francês enquanto negociava a Euro Disney em Paris. Ficou tão fascinado com a reação do público no cinema que ordenou a compra do filme para fazer um remake. Fez Katzenberg pagar US\$ 1 milhão pelos direitos (uma soma astronômica na 
época). E achava que o projeto era tão certeiro que pensaram em contratar o Dustin Hoffman e o Bill Murray para os papeis principais (GROVER, 1997, p. 99) - grandes estrelas na época - só que eles dobrariam o orçamento do filme com seus salários. No fim, mesmo com dificuldades de negociação, decidiram contratar dois atores de sucesso da TV (Tom Selleck de "Magnum P.I." e Ted Danson de "Cheers", mais um de sucesso moderado (Steve Guttenberg). E contrataram Leonard Nimoy (mais conhecido por seu papel como Sr. Spock em "Jornadas nas Estrelas") que possuía pouca experiência na direção, incluindo alguns episódios de Star Trek. Para tornar a produção ainda mais barata, as filmagens foram realizadas em Toronto por conta dos valores mais baixos para filmar e, para evitar atrasos, as filmagens começaram antes mesmo do roteiro ser concluído (GROVER, 1997, p. 100).

Segundo essa estratégia, 27 dos primeiros 33 filmes da Disney se tornaram lucrativos nos 3 anos seguintes, sendo 19 filmes de sucesso consecutivos. Deles, uns seis tiveram lucro superior a US\$ 50 milhões. A estratégia de fazer filmes mainstream por preços moderados se mostrou acertada, ainda que a crítica começasse a torcer o nariz pelo que rotulavam de "comédias da Touchstone" - mais adultas, formulaicas e físicas. Em sua defesa, Eisner afirmava que apenas preencheram uma lacuna do mercado. E quando a crítica começou a pegar no pé do estúdio, a Disney já estava desenvolvendo outros tipos de filme, como "Bom Dia, Vietnã” (1987), "Sociedade dos Poetas Mortos” (1990), ambos estrelados por Robin Williams) e a comédia familiar "Querida, Encolhi as Crianças” (1989), uma super produção repleta de efeitos especiais. (SCHWARTZ, 1998, p. 160-161).

Os primeiros problemas de produção começaram quando dois executivos, que competiam entre si, começaram a cobrar mais espaço e autonomia, David Hoberman e Ricardo Mestres. Sob o risco de perder um bom gestor, Eisner foi informado por Katzenberg que o mercado exibidor havia quase dobrado em uma década, aumentando a demanda por mais filmes. E não havia como um estúdio gerenciar mais do que uma dezena de filmes em produção ao mesmo tempo. Temendo perder um dos executivos, Katzenberg sugeriu a criação de um segundo estúdio, paralelo a Touchstone Pictures, para acomodar as demandas. O exemplo vinha da concorrência. A Columbia havia aberto a Tri-Star e a MGM havia feito uma fusão com a United Artists. Convencidos, os chefes da Disney criaram a Hollywood Pictures, colocando Ricardo Mestres como presidente. Em três anos, a produção total mais que dobrou - de uma dezena para quase trinta filmes. Eisner reconheceu que o crescimento foi grande demais para o próprio bem do estúdio, e mais tarde pagaria o preço por isso. (SCHWARTZ, 1998, p. 162). O preço? Pelo quinto ano consecutivo a Disney obteve lucros de filmes live-actions; porém, pela primeira vez, eram baseados praticamente num único filme - em 1990, foi o caso de “Uma Linda Mulher" (Pretty Woman). 


\subsection{Dick Tracy X Batman}

Cinema não é ciência. Esse memorando é oferecido como uma reflexão e uma nova visão de pensamento do nosso negócio. (Jeffrey Katzenberg ${ }^{30}$ )

Uma das grandes apostas da Disney teve um sucesso relativo - "Dick Tracy" (1990), uma adaptação dos quadrinhos de Chester Gould, estrelada por Warren Beatty, Al Pacino, Dustin Hoffman e Madonna. Com orçamento gigantesco, o estúdio tendo que atender as mais diversas demandas de Beatty, também diretor, e pela primeira vez investindo numa poderosa campanha de marketing para transformar o filme num blockbuster. A crítica não perdoou, fazendo comparações diretas com "Batman" de Tim Burton. Enquanto "Dick Tracy" custou pesados US\$ 46 milhões para um estúdio acostumado a gastar pouco por projeto, faturando US\$162,7 milhões mundialmente, "Batman", dirigido por Tim Burton na Warner e lançado em 1989 custou US\$ 48 milhões, faturando US\$ 411,3 milhões mundialmente ${ }^{31}$. O homem-morcego ganhou a disputa folgadamente.

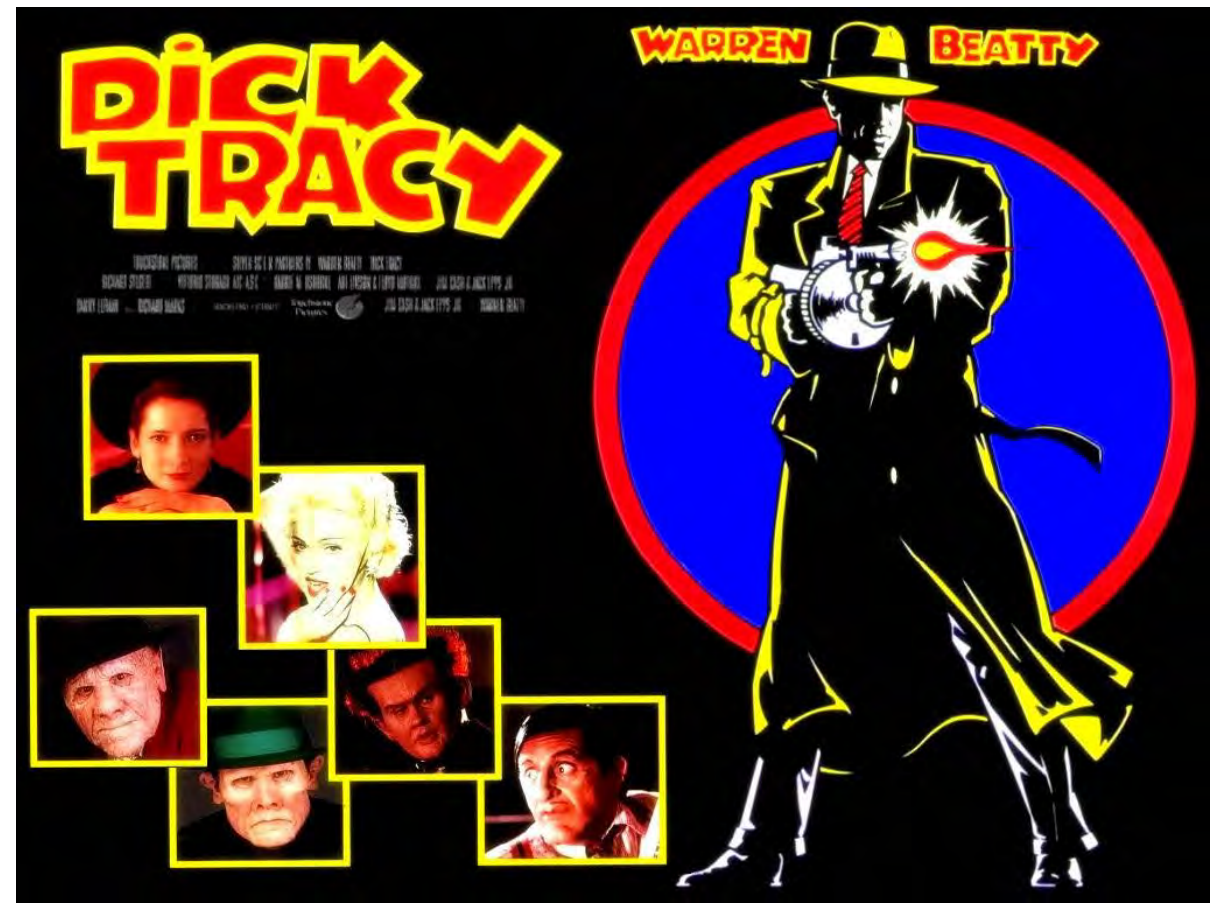

Figura 62 - Pôster de "Dick Tracy".

\footnotetext{
${ }^{30}$ Memorando interno distribuído por Katzenberg aos demais executivos na Disney (KATZENBERG, 1991).

${ }^{31}$ Dados de bilheteria disponíveis no website Boxofficemojo - <http://www.boxofficemojo.com>
} 


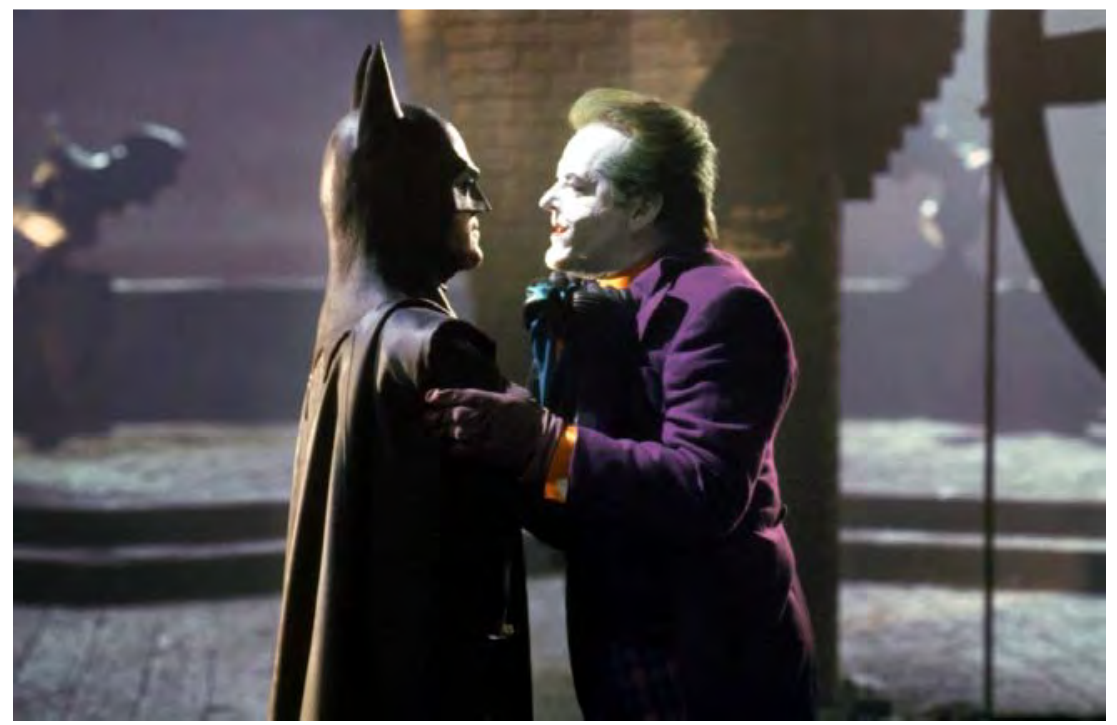

Figura 63 - Batman foi o grande sucesso da Warner em 1989.

Foi a primeira disputa direta de filmes baseados em personagens populares dos quadrinhos, desde o sucesso de "Superman", dirigido por Richard Donner em 1978 (que havia custado US\$ 55 millhões e faturado US\$ 300 milhões). Os demais filmes produzidos pela Disney em 1990 foram pífios nas bilheterias, para fazer a diferença no balanço financeiro. Katzenberg ficou indignado com o que julgava ser um "desvio de rota" da filosofia aplicada na Disney por eles, decidindo escrever o que pensava inspirado no memorando escrito por Michael Eisner dez anos antes na Paramount. A versão de Katzenberg, escrita com ajuda de Dan Wolf, escritor de discursos da própria Disney, possuía 28 páginas, e reforçava a filosofia dos tempos da Paramount, inspirado nas ideias de Michael Eisner e Barry Diller (então presidente da Paramount). O único problema é que o memorando, enviado por fax para uma dezena de executivos da Disney, vazou para a imprensa, incomodando muita gente. Especialmente Eisner, pois o texto citava nominalmente nomes como Warren Beatty, o que podia dar sinais truncados para a indústria do cinema.

No memorando, Katzenberg advoga contra o que chama de "bankable stars", uma estratégia em que um grande ator ou atriz funcionam como o chamariz de um filme, ou, em outras palavras, a garantia de sucesso de uma produção. Em 1990, nomes de atores como Jack Nicholson e Robert Redford despontavam como "garantias de sucesso". O executivo ponderou que Dustin Hoffman, por exemplo, nunca foi responsável por fazer um filme se tornar um grande sucesso em seu fim de semana de estreia, porém seu talento foi instrumental para tornar uma série de filmes um sucesso fenomenal. A questão era até que ponto o talento podia ser mensurado e premiado por grandes salários. As produções não deveriam depender unicamente de atores. Esse novo star-system, entretanto, ganhou 
incrível força nos anos 1990 com artistas ganhando salários milionários para ancorar filmes - Will Smith, Jim Carrey, Robin Williams, Sylvester Stallone, Bruce Willis, Whoopi Goldberg, Johnny Depp, entre outros. Era mais um ingrediente que se somava ao poderio dos produtores e diretores que também vendiam filmes - fenômeno fortalecido, a partir do final dos anos 1970, com Steven Spielberg, George Lucas e Francis Ford Coppola. Eisner já alertava que a Disney poderia trabalhar com eles, mas que o ideal seria procurar os grandes nomes do futuro (SCHWARTZ, 1998, p. 144).

Até então, Eisner promovia fortemente a "filosofia singles and doubles". Mas aos poucos, esse conceito foi substituído pela "Yes, but Philosophy..." ou "Sim, é muito caro, mas é uma grande oportunidade" ou "Sim, vamos gastar muito no marketing, mas temos muito a perder se não apostarmos" ou, ainda, "Sim, a continuação do filme requererá um grande orçamento, mas há o potencial da franquia". (KATZENBERG, 1991, p.2.)

O memorando escrito em 1991 no contexto do insucesso de "Dick Tracy" (1990), um filme de orçamento alto, marketing pesado e aspectos criativos cuidadosamente produzidos, foi tragado por comparações com "Batman” (1989), de Tim Burton. Katzenberg chama a atenção para o frenesi causado pela busca da bilheteria baseada no "sucesso do fim de semana de estreia". Sua tese diz que isso levaria a uma escalada nos custos de produção, que poderia levar toda a Hollywood ao colapso, relembrando o período entre os anos 1950 e 1960, quando os estúdios investiram pesado em "filmes eventos" que só encontraram o prejuízo - caso de "Cleópatra”, de 1963, cujo orçamento foi de US\$ 44 milhões (US\$ 186 milhões pela inflação em 1990), feito para tentar repetir o sucesso de "BenHur”, em 1959. A consequência foi a decadência dos grandes estúdios e o crescimento da produção independente.

Nos anos 1990, o ciclo se inverteria com as majors obtendo uma vitória retumbante sobre os independentes. Katzenberg alertava, portanto, sobre os riscos dessa nova estratégia de produção. $\mathrm{O}$ executivo apontava que o aumento dos custos se desdobrava também em toda a cadeia produtiva. Atores, diretores, roteiristas e seus agentes, todos pediriam uma fatia do bolo. Um artista que ganhou 6 milhões em um filme e soubesse de outra estrela ganhando \$ 10 milhões, comunicaria ao seu agente que só trabalharia por US\$ 12 milhões em seu próximo filme. Seria uma histeria comparável aos lemingues correndo o mais rápido possível em direção ao mar. Katzenberg usa, como bom exemplo, o filme "Uma Linda Mulher" de 1990, produzido de forma modesta e ancorado na história e não propriamente em suas estrelas (KATZENBERG, 1991, p.6). 
Sucessos de 1990 como "Uma Linda Mulher", "Ghost, Do Outro lado da Vida" e "Esqueceram de Mim", ensinavam a lição de que apesar de todo o hype e barulho promocional, no fim das contas o público buscará filmes que ele deseja ver. E esses filmes são, basicamente, mais do que o contrário, baseados primordialmente em dois elementos básicos: "uma boa história" que foi "bem executada". Sem hype, estrelas, efeitos especiais, elencos gigantescos, megaorçamentos, etc. (KATZENBERG, 1991, p.7).

Katzenberg está, portanto, advogando contra a mentalidade dos blockbusters, preferindo uma estratégia econômica que permitisse que a Disney produzisse de 25 a 30 filmes ao ano sem que houvesse perda de tempo, esforço e dinheiro em mega-produções - tendo em vista que isso retirava a atenção dos filmes menores. Isso não significa, entretanto, o fim dos blockbusters. Katzenberg defendia uma abordagem inteligente de produção. Uma saída eram os acordos de co-produção com parceiros como Andy Vajna (Cinergi) - mega-produções visando o mercado internacional, que seriam lançados sob o selo Hollywood Pictures, trazendo lucro a um tipo de projeto que a Disney não se envolveria diretamente. Ou, então, acordos com Don Simpson e Jerry Bruckheimer e seus filmes de ação.

Em 1991, a Disney possuía quatro grandes filmes em produção: “Cenas em um Shopping” (Scenes From a Mall), "Billy Bathgate - O Mundo a Seus Pés" (Billy Bathgate), "Nosso querido Bob" (What About Bob?) e "The Rocketeer", este último baseado na graphic novel de Dave Stevens e orçado em US\$ 35 milhões, uma alta soma na época. Disney continuaria apostando nesses filmes, pois não tinham grandes estrelas, o lucro seria unicamente do estúdio, que ainda teria os direitos, controlaria o licenciamento e ainda teria contratos cobrindo continuações. "Dick Tracy", portanto, foi encarado como uma grande e penosa experiência. Ainda que tenha alcançado um bom retorno financeiro e tenha sido bem recebido por boa parte da crítica, o filme estava sendo encarado como divisor de águas entre os executivos da Disney.

Pensando em filmes pequenos, uma saída para a Disney, baseada numa ideia do próprio Katzenberg, foi adquirir a Miramax Films em 1993. Gerenciada pelos Irmãos Weinstein, a Miramax tinha uma história de sucesso em Hollywood por adquirir e distribuir filmes independentes de alta qualidade como "Cinema Paradiso" (1988) e "Meu Pé Esquerdo" (1989). Em comum, os filmes eram pequenos, com orçamentos modestos, porém com enorme repercussão positiva da crítica e grandes colecionadores de prêmios. Jocosamente referenciados pela imprensa, os Weinstein ganharam o prestígio de serem sempre os favoritos em premiações como o Oscar e o Festival de Cannes. Com 
filmes adultos sofisticados, muitas vezes controversos e com boa autonomia, a Miramax se tornou uma força complementar perfeita. E a filosofia dos Weinstein era igual à de Eisner - focavam primeiro na ideia criativa e se recusavam a bancar grandes estrelas e diretores. Preferiam, usando exemplos esportivos do beisebol, "hitting singles" do que os mais difíceis "home runs" e "grand slams" - daí a origem da filosofia "singles and doubles". A Miramax foi comprada pela Disney pelo preço de um filme de alto orçamento, porém adquiriram o talento dos Weinstein e o acervo de grandes sucessos. (SCHWARTZ, 1998, p. 165). A Disney fornecia mais financiamento de projetos e espaço no mercado exibidor e, em troca, a Miramax facilitava a aproximação de atores, diretores e produtores que ainda relutavam em trabalhar na Disney. Um desses casos foi o sucesso "Pulp Fiction: Tempo de Violência” (1994) que trouxe Quentin Tarantino, John Travolta, Samuel L. Jackson e Uma Thurman, tornando o filme um sucesso de mais de US\$ 100 milhões.

\subsection{O Inchaço do Estúdio}

Apesar do aumento da produção e do prestígio, os filmes da própria Disney estavam indo muito mal. Três anos após o memorando de Katzenberg, o estúdio fugia cada vez mais da filosofia que norteou o estilo de produção dos primeiros anos. Em 1993, somente dois filmes podiam ser considerados sucessos genuínos - "Jamaica abaixo de zero" (Cool Runnings, 1993) e “A Incrível Jornada” (Howard Bound: The Incredible Journey, 1993). Todos os demais filmes pareciam ser experiências olvidáveis. Eram muitos filmes em produção sem uma grande premissa, e sem uma razão importante de ser, somada à diminuição da atenção dada ao desenvolvimento de cada projeto.

Uma boa parte do problema era que a parceria com Jeffrey Katzenberg, chefe dos estúdios, que funcionava de modo perfeito nos primeiros anos, estava se deteriorando. Com quase 10 anos na Disney, o executivo buscava maior autonomia visando uma futura promoção ao posto de presidente. Eisner sabia que muitos estúdios e redes de TV de sucesso tinham dois grandes nomes no topo da cadeia de comando. $\mathrm{Na}$ ABC, Eisner dividia o poder com Fred Pierce e depois com Fred Silverman. $\mathrm{Na}$ Paramount, dividiu poder com Barry Diller. A concorrente Universal passou quase duas décadas com a dobradinha Lew Wasserman e Sid Sheinberg. A Warner tinha um par perfeito com Bob Daly e Terry Semel. (SCHWARTZ, 1998, p. 167).

Para serem efetivos, Eisner dizia que executivos precisam ser muito organizados e permanecer calmos para "apagar os incêndios” antes que se alastrem nas várias divisões e projetos da corporação. 
Se um desses episódios não é controlado (o que ocupa 75\% do tempo), o executivo não consegue se concentrar naquilo que é mais importante - adicionar valor ao processo criativo.

Em março de 1994, Frank Wells apresentou um relatório sobre a década em produção. Nos primeiros cinco anos, todos os filmes, com exceção de alguns, foram considerados um sucesso. Especificamente no que diz respeito à animação, o lucro médio foi de aproximadamente US\$ 200 milhões ao ano, uma forte performance comparada a qualquer estúdio em Hollywood (GROVER, 1997). Nos quatro anos subsequentes - resultado da expansão da produção com a Hollywood Pictures, a Disney lançou setenta e seis filmes, praticamente o dobro do período anterior, e somente trinta e três foram lucrativos, ou basicamente pouco mais de 40\%. Eliminando os custos extras de gerenciamento que absorviam parte dos lucros, o estúdio na verdade perdeu dinheiro. A conclusão de Wells era que este perfil não podia ser bom para se manter no negócio. O que os números mostravam é que não importava o quão baixo fossem os custos de produção. Ao produzir muitos filmes ruins, perdiam dinheiro, mesmo com eles custando pouco e com complementação do marketing. A solução era produzir menos filmes e dar mais atenção ao processo criativo (SCHWARTZ, 1998). Produzir cerca de 15 filmes ao ano (o máximo que Katzenberg podia gerenciar ao mesmo tempo, considerava Wells), não mais que 24 filmes ao ano, só que em forte parceria com Michael Eisner, tendo em vista que ambos estavam tendo cada vez mais suas atenções dedicadas a outras áreas da companhia.

A estratégia de contratar novos talentos e artistas em baixa e mantê-los presos para novos projetos também pagou seu preço. Com a reversão nos sucessos, os funcionários do estúdio começaram a reclamar de como eram tratados. Um pequeno recuo de Katzenberg fez com os que os agentes de talentos sentissem a possibilidade de explorar os estúdios. Interessados não na saúde financeira do estúdio ou nos orçamentos dos filmes e sim em obter o máximo de valor aos seus clientes - iniciou-se uma pressão para a valorização dos talentos contratados pela Disney.

\subsection{A Tecnologia e a Sinergia}

A criação de um novo departamento chamado Corporate Synergy and Special Projects, liderado por Lorraine Santoli. Sinônimo do lema "trabalhando juntos", podemos definir o conceito de sinergia como:

A sinergia é um conceito de alto padrão nos negócios que, quando estrategicamente incorporado dentro da diversidade de uma corporação, pode 
elevar projetos de alta prioridade a níveis vertiginosos no plano do consumidor. Mas, sendo algo grande, sinergia precisa começar do alto, do topo da companhia, onde é adotado como uma ferramenta vital do marketing para fazê-lo funcionar" (SANTOLI, 2015, p. 81, tradução nossa).

Todos os filmes produzidos em 1990 tiveram por fim ser exibidos na televisão. Katzenberg já chamava atenção para o foco necessário na experiência do cinema (cujo retorno financeiro era mais controlável pelo estúdio). A questão não era se a tela é maior ou menor e sim que a TV traz uma experiência individual em contraste ao coletivo do cinema. Não é tanto que os efeitos sejam mais impressionantes na tela grande, ou o som mais poderoso ou os detalhes mais acentuados que elevam a experiência, e sim o sentimento emotivo contagiante que faz com que uma comédia se torne melhor graças ao riso coletivo ou que um filme de horror seja mais assustador com o susto de toda uma plateia (KATZENBERG, 1991, p. 23). Katzenberg conclui que as pessoas passaram a alugar os filmes em locadoras por duas razões: conscientemente, elas simplesmente querem rever o filme; mas, subconscientemente, elas desejam evocar a memória da experiência no cinema.

Empresas japonesas começaram a comprar estúdios de cinema. A razão era clara - eram empresas de hardware. A noção por trás disso, segundo Katzenberg é que os japoneses pensavam que, se pudessem controlar o software (filmes dos estúdios), haveria grandes vantagens de sinergia de integração vertical com seu hardware (equipamentos eletrônicos). Isso faz sentido se você produz automóveis e pode adquirir uma empresa de auto-peças (KATZENBERG, 1991, p.24).

Seguindo o exemplo da China nos anos 2000, o Japão dos anos 1980 usou de seu poderio econômico para travar uma guerra cultural adquirindo empresas norte-americanas. Na área do entretenimento, tudo começou quando a Sony entrou no mercado do VCR com seu sistema Betamax, somente para perder para o formato VHS. O chairman da Sony, Aiko Morita, concluiu que a história teria sido diferente se a Sony possuísse um estúdio americano e fosse possível dirigir o mercado colocando filmes no formato de fitas Betamax. O pensamento é absurdo, segundo Katzenberg (1991, p. 24). Adquirindo a Columbia Pictures, a Sony [em 1991] controla menos de 15\% do "software de Hollywood". A questão é que isso não foi o suficiente para conquistar os estúdios. O sistema Beta perdeu não por falta de cooperação de Hollywood, mas porque os esforços de produção e marketing das marcas VCR e VHS tiveram sucesso. A concorrente da Sony, Matsushita, tinha filosofia similar:

Agora a Matsushita está fazendo o que considero ser um movimento defensivo em seguir o caminho de seu concorrente comprando a MCA (dona da Universal Studios). Isso não é diferente do que ocorreu em nosso negócio anos atrás quando os 
estúdios seguiram os outros ao entrar no mercado de exibição. Do mesmo modo que os produtores japoneses de hardware, os estúdios acreditavam que algum tipo de sinergia/integração vertical poderia ocorrer se pudessem controlar as telas onde seus filmes eram exibidos. Salas de cinema foram comprados a preços exorbitantes, perdendo boa parte de seu valor nos anos seguintes. (KATZENBERG, 1991, p. 24)

O insucesso nos resultados dos filmes live-action eram encobertos pelo incrível sucesso das produções de animação. Em 1993, a animação lançada nos cinemas e também justamente do homevideo, incluindo os relançamentos dos clássicos da época de Walt Disney, geraram um lucro de US\$ 622 milhões (SCHWARTZ, 1998, p. 170).

Nada causou mais transformação na Disney, nesta época, do que a implantação de uma forma mais eficiente de sinergia. A ideia de sinergia é antiga na Disney, se considerarmos que em 1929 Walt Disney negociou num lobby de hotel uma oferta de U\$300 para colocar o Mickey Mouse num relógio. Walt, precisando do dinheiro, aceitou, e acabou lançando um departamento que um dia viria a ser a "Disney Licensing" (Licenciamento Disney) (THOMAS, 1994). Walt abriu a porta para um novo ativo para o estúdio, o conceito de sinergia. O irmão de Walt, Roy, chamava inicialmente essa utilização cruzada de "integração" de recursos.

O conceito de sinergia atingiu seu auge na corporação americana nos anos 1980 e 1990, apesar de poucas organizações tirarem vantagem de fazê-la funcionar em suas companhias, certamente não de algum modo próximo como a Disney fez. Lorraine Santoli, autora de um livro que descreve seu trabalho na Disney construindo essa estrutura, suspeita que;

[as outras] companhias não tinham um CEO ou presidente que acreditassem que a sinergia poderia funcionar apesar das possibilidades quase ilimitadas se fosse integrado de forma apropriada dentro da companhia. E ninguém tinha ideia de como fazer unidades de negócio disparatas, todas contidas em seus próprios silos e com suas próprias agendas, dar um passo no domínio de marketing da outra e fazê-las trabalhar juntas harmoniosamente (SANTOLI, 2015, p. 81-82).

Na Disney pré-anos 1980, a propaganda era vista como algo dispendioso, que consumia muito dinheiro. Restavam as promoções e principalmente a publicidade, criada por uma equipe muito criativa que se aproveitou bem de eventos e datas comemorativas para atrair a imprensa americana e de todo o mundo. Lançamentos de filmes, reuniões do Clube do Mickey, aniversário dos 50 anos do Pato Donald em 1984, com patos sendo doados para dezenas de zoológicos dos EUA, cada um sendo repercutido pela imprensa local. Jack Lindquist era o cabeça do marketing Disney. Ao contrário da celebração do Mickey, que percorreu os EUA de trem, Donald ganhou um jato 727 para percorrer o 
país com seus amigos, além de um convidado especial - Clarence Nash (o dublador), que pela primeira vez teria destaque junto à imprensa, aparecendo e fazendo a voz do personagem (LINDQUIST, 2010).

Com a chegada de Eisner e Wells, em 1984, o marketing foi renovado e a aposta em sinergia foi colocada em ação a partir dos parques temáticos (o negócio mais lucrativo da Disney, se lembrarmos que o estúdio ia mal).

A primeira coisa foi estender os horários dos parques. De 1958 a 1985, a Disneylândia fechava as segundas e terças-feiras. Pela primeira vez, o parque ficaria aberto 365 dias no ano. A segunda coisa foi exponenciar o marketing por via da propaganda:

A grande diferença entre antes e depois Michael e Frank é que antes nossa propaganda era limitada e muito local até 1984. Nossos orçamentos eram pequenos e nosso foco havia sido em promover o parque através da publicidade e promoções ao invés da propaganda, porque este último custava dinheiro que [os chefes] eram relutantes em gastar. (SANTOLI, 2015, p. 25, tradução nossa).

Campanhas mundiais de filmes, quadrinhos, e demais produtos foram atreladas a efemérides como o aniversário de 30 anos da Disneylândia em 1985, os 50 anos do lançamento nos cinemas de "Branca de Neve e os Sete Anões" (1987) e aos 60 anos do Mickey Mouse" (1988).

A terceira providência era aumentar o retorno financeiro. Os ingressos dos parques temáticos sofreram um aumento. Eisner justificava esses aumentos com outros tipos de diversão. Alegava que as pessoas gastavam muito mais dinheiro pela experiência em um teatro na Broadway ou uma viagem de cruzeiro no Caribe, tendo nos parques um retorno em forma de entretenimento muito maior (SCHWARTZ, 1998).

A quarta providência foi explorar valores criativos para fabricar valor lucrativo. Com o estúdio enfraquecido, a saída foi atrair talentos consolidados externos para os parques (George Lucas e Michael Jackson), atrair os jovens da geração MTV (a Disneylândia investiu num espaço chamado Videopolis, com apresentação de conjuntos e bandas musicais ao vivo), e convidou diretores do calibre de Spielberg e Zemeckis para colaborar no estúdio, o que resultou na produção de "Uma Cilada para Roger Rabbit" (Who Framed Roger Rabbit, 1988), o filme que simbolicamente representa a renascença da animação Disney. 


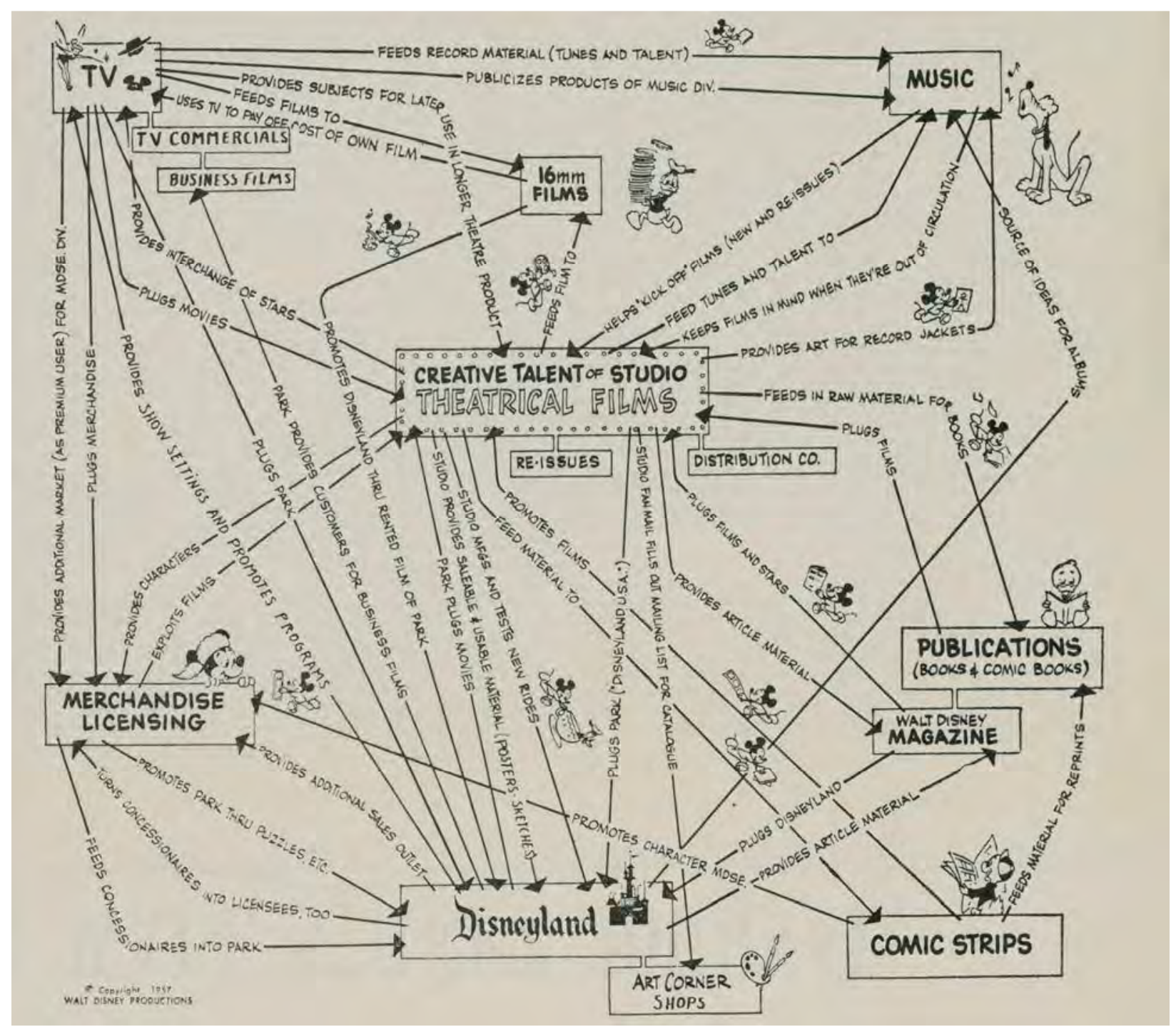

Figura 64 - A sinergia Disney em 1957 - o núcleo central era a produção de filmes.

Sob a gestão de Eisner e Wells, a Disney se tornou uma máquina de sinergia azeitada, onde cada unidade de negócio serviu como uma engrenagem na roda que faz o trabalho ter mais sucesso. A ideia era pautada no fundador, Walt Disney, o primeiro a perceber o potencial da sinergia. Uma reportagem do Wall Street Journal em $1958^{32}$ mostra o próprio Walt Disney revelando que a fórmula do lucro Disney é "sonho, diversidade e nunca perder um ângulo”. Acompanhando, há uma ilustração mostrando como a "integração" entre os diversos departamentos permeava o estúdio na época.

A fórmula, em resumo, é explorar todas as oportunidades possíveis de ativos como o Mickey Mouse ou os Três Porquinhos - primeiro os diversificando em uma ampla variedade de atividades, e

\footnotetext{
${ }^{32}$ Walt's Profit Formula: Dream, Diversity, and Never Miss an Angle" em The Wall Street Journal (4 de fevereiro de 1958)
} 
então combinando para que uma unidade explore a outra. Filmes se transformavam em experiências reais na Disneylândia com desdobramentos na TV e noutras áreas de negócio.

Em 1958, por exemplo, a animação A Bela Adormecia já estava há 3 anos em produção. Em 1955, na inauguração do parque, já havia o Castelo da Bela Adormecida, seu interior foi adornado por dioramas com cenas tridimensionais do filme. O licenciamento já havia negociado com empresas para o lançamento de brinquedos, roupas, além de uma adaptação literária com a Simon \& Schuster de Nova York. Na TV, em outubro, o programa Disneylândia exibia referências repetidas ao filme. Um mês depois, a divisão fonográfica lançava a grandiosa trilha de George Bruns, inspirada na obra de Tchaikovsky. E seis meses antes do lançamento do filme, em 1959, a divisão de quadrinhos (seus artistas de comic strip) lançava a história da Bela Adormecida nas tiras distribuídas em jornais nacionalmente. E após a estreia do filme, a estratégia renovaria seu ciclo da mesma forma de país em país obtendo assim todo seu potencial lucrativo (SANTOLI, 2015).

A questão de um líder que entenda a dinâmica é importante, se notarmos que, 15 anos após a morte de Walt, a companhia perdia boa parte de seu poderio em animação, o licenciamento desabou, bilheterias minguaram, o faturamento da Disneylândia estagnou e a audiência dos programas Disney na TV caíram a ponto das redes não se interessarem mais. (SANTOLI, 2015, p. 84).

Nos anos 1990, com a intensa expansão da corporação Disney:

Linda Warren foi contratada para desenvolver uma metodologia para intensificar as promoções cruzadas. Lorraine Santoli desenvolveu um programa de comunicação sistemático para fazer com que a "mão direita" soubesse o que a "esquerda" estava fazendo nas mais de 60 unidades independentes dos segmentos de negócios da Disney, desse modo cada um podia tirar vantagem de todas as oportunidades de sinergia. A própria Disney criou um programa chamado Disney Dimensions, um evento em que os executivos eram convocados por duas semanas para assistir, por dias inteiros, apresentações sobre o que era produzido em todas as unidades e departamentos. E até mesmo um profissional de comunicação foi contratado para promover essas informações aos empregados e executivos em níveis abaixo daqueles que participaram do programa. (SANTOLI, 2015, p. 98-99, tradução nossa).

Há duas origens básicas de projetos de sinergia, de acordo com Santoli. Primeiro, aqueles que começam em uma unidade de negócios específica (um lançamento de filme, o aniversário de um parque, etc). Isso levou à criação de um calendário com datas comemorativas de filmes, aniversário 
de personagens e datas importantes para o estúdio, parques, e demais segmentos, usado de forma que as unidades pudessem se planejar com muita antecedência. Segundo, projetos que começam como uma campanha do "guarda-chuva" da Disney envolvendo a corporação inteira, e geralmente se relacionam a eventos de aniversário (60 anos Mickey, 50 anos do Pato Donald, 75 anos dos estúdios Disney). Muitas vezes projetos de sinergia podem ser uma combinação das duas coisas. A compra do time de hóquei no gelo da NHL, Mighty Ducks em 1993 (vendido pela Disney em 2005) foi um dos exemplos. O sucesso de um filme "Mighty Ducks" em 1993 levou à criação de uma franquia via time de hóquei (Anaheim Ducks), que depois se tornou seriado de animação na TV (Os Super Patos no Brasil, 1996-97). Temos aqui uma explicação do poder das fusões:

O ritmo acelerado de fusões entre empresas nas décadas de 1980 e 1990 resultou em uma intensa fragmentação nos negócios. Em 2015, dez megacorporações (casos da Nestlé, Procter \& Gamble e L'Oreal) produzem quase tudo que compramos de produtos domésticos, alimentos e roupas. O controle na área de mídia onde a Disney está inserida é exercida por cinco corporações - contra 50 existentes em 1983. As cinco maiores companhias de mídia (Disney, Time Warner, Viacom, News Corp. e Comcast) faturam juntas mais de US\$ 275 bilhões, valor superior ao PIB de vários países desenvolvidos. Pouco mais de 200 executivos controlam a informação consumida por quase 300 milhões de norte-americanos (SANTOLI, 2015, p. 88, tradução nossa).

A mesma problemática se repete mundialmente com outras grandes concentrações. A Disney não tinha mais como se concentrar somente no que era produzido em seus próprios estúdios. Por um lado, ganhava poder e mais campos de produção. Por outro, a variedade por vezes sacrificava a qualidade.

Mais fusões e aquisições rendem muito dinheiro, o que serve de isca para a entrada de novos investidores e na elevação do preço de suas ações. A companhia anexa mais ativos e, se tiverem sucesso, o processo é renovado de forma repetida, expandindo horizontes. Por outro lado,

o aspecto negativo é que muitos ativos levam a uma fragmentação intensa e na descentralização das decisões. Se os departamentos e divisões não dividem um serviço ou produto, o negócio "A" pode não se relacionar com o negócio "B". Quando essa integração ocorre de forma perfeita, o resultado é impressionante - Michael Eisner dizia que "na Disney, $1+1=3$ !" comprovando a importância da sinergia (SANTOLI, 2015, p. 89, tradução nossa). 
É importante falarmos de sinergia e seus efeitos porque isso definiu, no início do século XXI o enfoque cada vez maior nas marcas. O raciocínio é simples. Se alguém atrelar todas as promoções e divulgações em torno de uma marca, torna-se mais fácil toda a logística e a criação de produtos derivados nas mais diversas unidades: torna-se mais fácil e eficiente um filme desdobrar-se em especiais ou séries de TV, eventos públicos, atrações e shows em parques temáticos, quadrinhos e publicações em geral, pois isso facilita as oportunidades comerciais e até mesmo a cobertura da imprensa. 


\section{ANIMAÇÃO DISNEY E A “NOVA GERAÇÃO” (1980-2000)}

A animação Disney tem sua origem em 1923 com a fundação do primeiro estúdio. Entretanto, o estilo e o visual se desenvolveram de forma acelerada entre as décadas de 1920 e 1940 (conhecido como período experimental) e posteriormente com uma evolução gradual já dentro de um padrão aceito e popular pela audiência americana. O período experimental contou com diversos animadores pioneiros, que começaram a desenvolver ferramentas para tornar a animação cada vez mais sofisticada em apelo e dinâmica (THOMAS, JOHNSTON, 1981). Foi o caso de Ub Iwerks (o primeiro animador de Mickey Mouse), Norman Ferguson (o principal responsável pelo Pluto), Hamilton Luske (um dos mais analíticos do estúdio), Fred Moore (design atrativo), Bill Tytla (o melhor animador da Era de Ouro da animação) e, podemos incluir Art Babbitt (com uma técnica das mais apuradas, entrou em forte atrito com Walt Disney por liderar a greve do estúdio em 1941).

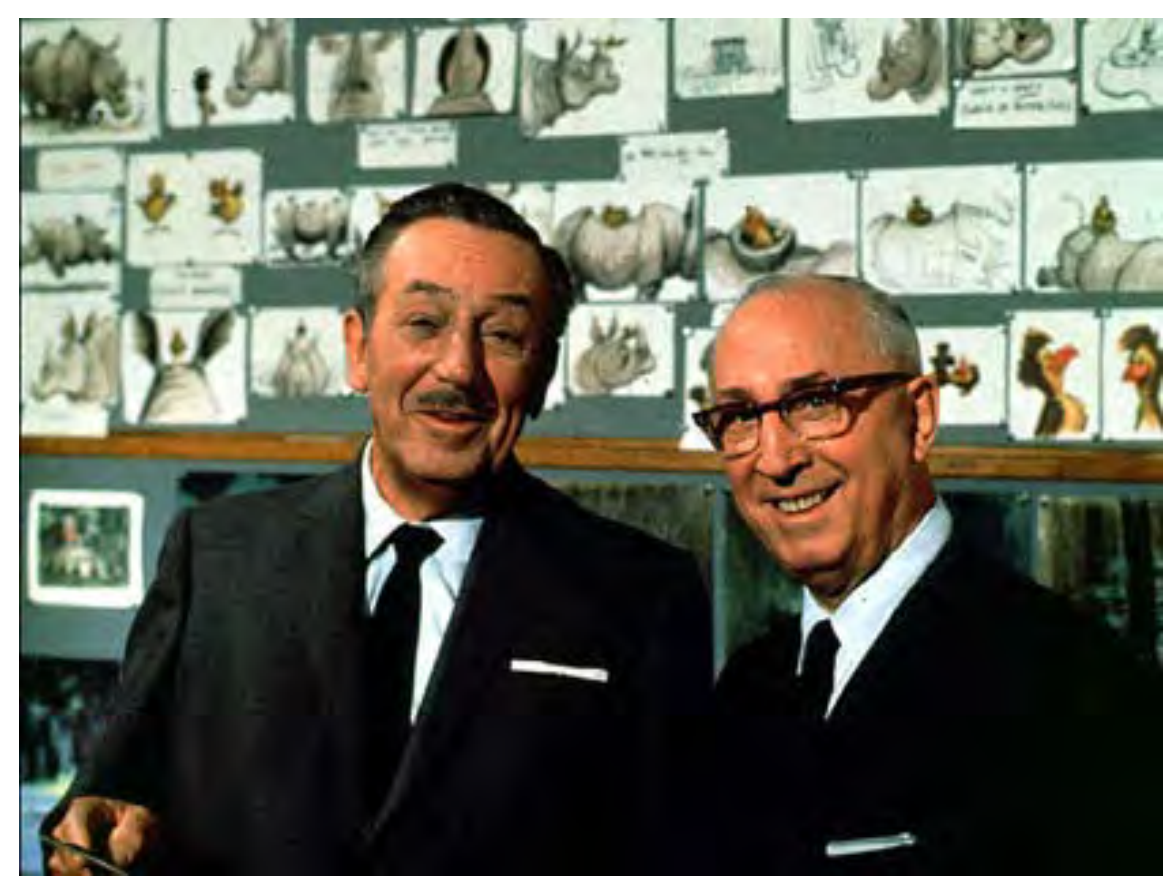

Figura 65 - Walt Disney e seu irmão Roy Oliver Disney (1965).

Esses nove animadores formavam um grupo divulgado pela Disney como o núcleo de animação clássica Disney. Era formado por Les Clark, Marc Davis, Ollie Johnston, Milt Kahl, Ward Kimball, Eric Larson, John Lounsbery, Wolfgang Reitherman e Frank Thomas. Os nove, junto com toda a equipe de animadores, foram responsáveis por sacramentar o estilo e visual Disney e por sofisticar os princípios básicos da animação, entre eles o estica e puxa, antecipação, arcos, timing, 
exagero, apelo, ação secundária ${ }^{33}$ (CANEMAKER, 2001). Esta geração conviveu com os pioneiros e expandiu os horizontes da animação nos anos experimentais da década de 1940, no retorno ao normal da produção pós-guerra nos anos 1950 - quando Disney lançou clássicos como "Cinderella” (1950), “Alice no País das Maravilhas" (1941)", "Peter Pan” (1953), “A Dama e o Vagabundo" (1955) e "A Bela Adormecida" (1959). O historiador Charles Solomon chama esse período entre 1946 e 1960 de “era de prata da Disney", período de refinamento dentro de um padrão já consolidado e mais comercial com a popularização da televisão, e numa época em que Walt Disney já desviava sua atenção para a construção da Disneylândia (SOLOMON, 1994, p. 183).

Os nove animadores mais conhecidos permaneceriam na Disney pelas décadas de 1960, 1970 e 1980, quando há uma queda na qualidade geral dos filmes, mas sem uma tentativa de sofisticar a atuação dos personagens. Foram anos seguidos de crises e retrações em meio à morte de Walt Disney e toda a transformação cultural que o mundo sofria na música, no cinema e nos costumes. Os críticos, que até os anos 1940 exaltavam o revolucionário Walt Disney, passaram a condená-lo por sua breguice, sentimentalismo antiquado e por se restringir aos valores sociais da classe média branca de religião protestante dos Estados Unidos - especialmente em relação aos filmes live-action. Porém, é possível verificar que muitas de suas produções tentaram apresentar noções progressistas, ainda que isso ocorra mais fortemente a partir dos anos 1970 (BRODE, 2004).

Desde a morte de Walt Disney, o departamento de animação foi encolhendo de 630 artistas para menos de 200. Muitos dos mais talentosos deixaram a Disney, frustrados com a impossibilidade de usar suas habilidades em projetos mais ousados. Um deles foi Tim Burton. O mais promissor foi Don Bluth, membro da chamada "geração perdida", que se viu envolta na disputa de egos pelo controle criativo do estúdio (HULETT, 2014). Os membros dessa geração eram muito novos para se impor aos chamados "nine old men" e toda a geração de antigos artistas que estavam na Disney desde os anos 1930. E muito velhos para impor um senso de novidade aos artistas recém saídos da CalArts (California Institute of the Arts), que começavam ser admitidos e tutorados na Disney. A CalArts é uma faculdade fundada por Walt Disney em 1961 após a fusão de duas instituições que possuíam dificuldades financeiras - a Chouinard Art Institute (fundada em 1921) e a Los Angeles Conservatory of Music (fundada em 1883). Daquele caldo de contracultura surgiu a chamada "nova geração",

\footnotetext{
${ }^{33}$ São elementos dos 12 Princípios da Animação. "Estica e puxa", por exemplo, têm o propósito de dar a sensação de peso e flexibilidade aos objetos desenhados. Antecipação é usada para preparar o público para uma ação do personagem, timing se refere ao número de frames desenhados que é traduzido na velocidade da animação, o apelo equivale ao carisma; e ação secundária é aquela que dá mais vida a uma cena dá suporte a ação principal (THOMAS E JOHNSTON, 1981). 
empolgada com a possibilidade de explorar novas possibilidades no estilo da animação clássica, que no final dos anos 1970 só era produzido na Disney - o Santo Graal para os jovens universitários em busca de emprego. Quase todos atingiram boas posições posteriormente, como animadores, diretores de arte, cineastas e produtores.

Além dos animadores oriundos da CalArts, diversos jovens talentosos participavam do treinamento interno da própria Disney com algum mentor (geralmente um dos "nine old men") e seguiam carreira no estúdio, caso de Andreas Deja, polonês que vivia na Alemanha. Os membros dessa geração foram responsáveis por um novo período criativo na Disney entre os anos 1980 e 2000. Embora não seja possível neste trabalho analisar detalhadamente o impacto de vários nomes, buscamos ilustrar (7.1. Exemplos Gráficos da Animação Disney) diversas páginas com o trabalho supervisionado por eles durante o período. Nomes como os de Glen Keane, Andreas Deja, Ruben Aquino, Mark Henn, John Pomeroy, Eric Goldberg, Nik Ranieri, Ken Duncan e James Baxter são, sem dúvida, representativos do melhor da animação contemporânea.

Sem muita saída para a "geração perdida", Don Bluth (Fig. 66) reuniu um grupo que, nas horas vagas, trabalhava em projetos paralelos aos que faziam na Disney. Graças ao investimento de um grupo de antigos executivos da Disney, uma empresa chamada Aurora Productions conseguiu financiamento para bancar um longa-metragem de animação (SOLOMON, 1994, p 287). O misto de frustração com a situação na Disney e a expectativa de uma nova produtora com liberdade para explorar novidades resultou na demissão de 12 animadores: Don Bluth, Gary Goldman, John Pomeroy, Lorna Pomeroy, Heidi Guedel, Linda Miller, Emily Juliano (todos animadores), Frank Jones, Dave Spafford, Vera Law, Diane Landau e Sally Voorhees (animadores assistentes). O êxodo foi o suficiente para atrasar a conclusão da animação "O Cão e a Raposa" e acirrar um clima de animosidade entre os executivos do estúdio (representado por Ron Miller,) e os três grupos de artistas - os mais velhos, os mais novos e os excluídos (HULETT, 2014). 


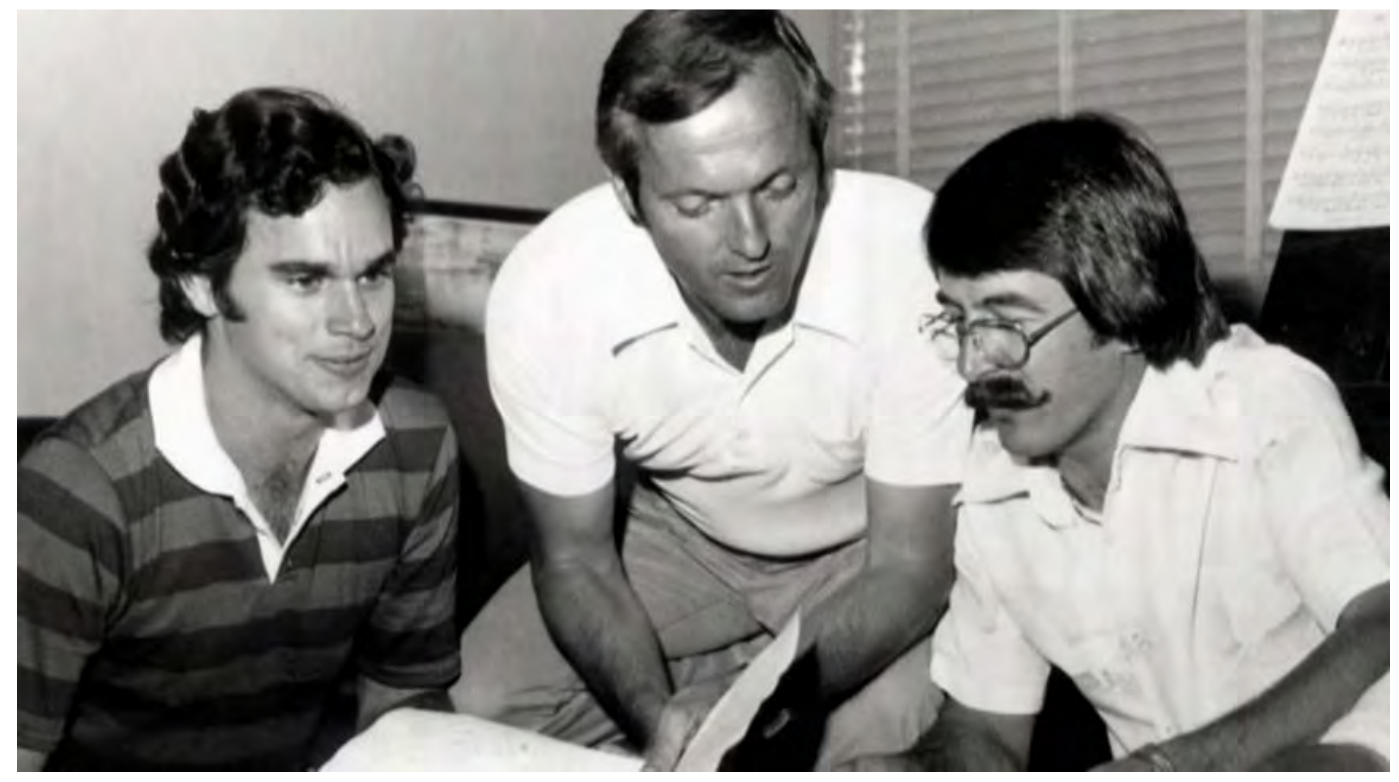

Figura 66 - John Pomeroy, Don Bluth e Gary Goldman, os primeiros do êxodo de animadores.

O grupo de Don Bluth produziu "A Ratinha Valente" (The Secret of Nimh", 1982), tecnicamente superior a tudo o que a Disney produzira na última década, e seria a primeira equipe de produção a finalmente concorrer fortemente com os lançamentos Disney por pelo menos uma década (SOLOMON, 1994). John Pomeroy, que fez parte da equipe de Bluth, viria a se tornar um dos grandes talentos da animação de sua geração, com excelente senso de narrativa, e com uma técnica apurada que dava peso aos personagens, Pomeroy foi o único do grupo inicial a se demitir que conseguiu retornar à Disney em meados dos anos 1990, onde supervisionou a animação de personagens importantes como o capitão John Smith ("Pocahontas"), o cartógrafo e linguista Milo Thatch (“Atlantis: O Reino Perdido") e o Pássaro de Fogo em "Fantasia 2000”.

A Disney, porém, passaria boa parte dos anos 1980 com seus animadores em constante sensação de incerteza. E isso continuou mesmo com a chegada da nova gestão. Dias antes de Wells e Eisner assumirem a Disney, Roy E. Disney sugeriu que gostaria de tomar conta do departamento de animação, por suspeitar que era o único que conhecia como aquilo funcionava (HULETT, 2014).

No final de 1984, assim que assumiu a chefia dos estúdios, Katzenberg falou a Eisner que gostaria de transferir o grupo de animadores para fora do backlot (a área onde ficam os estúdios), para que seus escritórios pudessem ser usados pelos produtores, diretores e roteiristas com as quais a Disney havia assinado contratos de longo prazo. Mesmo que tenham descoberto depois que a mudança foi um erro, não era mais possível voltar atrás. Roy não teve grandes objeções ou não quis confrontação (HAHN, 2009), e desse modo a equipe foi transferida para uma série de galpões 
próximo a Burbank, na região de Glendale. Houve dois tipos de reações. Uma foi de medo e preocupação de que o departamento estava sendo menosprezado e que em algum momento poderia ser extinto. A segunda é que os animadores viam uma oportunidade de se esforçar ao máximo para provar que ainda era possível produzir grandes animações nesse novo momento pelo qual passava o estúdio (SCHWARTZ, 1998, p. 172).

Um mês e pouco após assumirem os cargos, Roy convidou Wells, Eisner e Katzenberg para conferirem uma animação que estava em desenvolvimento. O projeto bem visto entre os animadores era "Basil of the Baker Street", a história de um rato detetive que mora embaixo da casa do Sherlock Holmes em Londres. Os responsáveis pelo projeto eram diretores que entraram na Disney em 1975: John Musker, oriundo da CalArts e Ron Clements, que entrou via programa de novos talentos da própria Disney. O projeto empolgava um grupo de artistas insatisfeito com os rumos do filme mais ambicioso do estúdio, "O Caldeirão Mágico" (The Black Cauldron, 1985), uma fantasia envolvendo magia e espadas, que estava em produção há mais de quatro anos. Katzenberg chocou a velha guarda do estúdio ao editar o filme diretamente na película. Considerava certas cenas violentas e assustadoras demais, e decidiu retirá-las do filme. Nas palavras de Katzenberg, "isso foi o equivalente a iniciar a

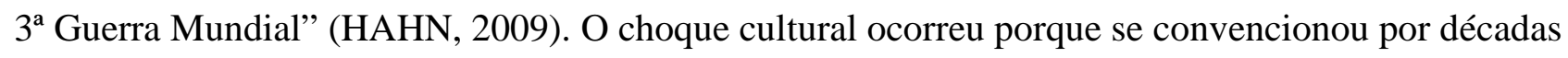
"editar" os filmes ainda durante o longo processo da construção da narrativa via storyboards (aqueles quadros parecidos com histórias em quadrinhos que apresentam o andamento da história). E para adicionar mais ingredientes ao embate, "O Caldeirão Mágico" - uma produção de US\$ 25 milhões, faturou nas bilheterias US\$ 21 milhões. Seu concorrente animado tecnicamente inferior no ano de 1985 era “Os Ursinhos Carinhosos”, que faturou respeitosos US\$ 34 milhões. Mudanças profundas na produção Disney estavam a caminho.

Uma delas se referia aos orçamentos de produção. Os executivos perguntaram aos diretores Musker e Clements quanto custaria o filme. Ao ouvir "Uns vinte e poucos milhões [de dólares]" receberam um "Queremos que façam pela metade. Questionados sobre quanto tempo a produção levaria para ser concluída, ao ouvir que seria uns dois anos responderam, "Nós queremos em um!" (MASTERS, 2001, p. 214). Dispostos a romper com vícios do velho sistema Disney, os executivos estavam convencidos de que podiam reduzir drasticamente os valores. Se trinta minutos de animação para uma série de televisão é feita por US\$ 350mil a 500 mil, imaginavam que poderiam produzir um longa-metragem de animação com menos de uma hora e meia de duração por US\$ 1,5 milhão. De fato, a produção de cinema custava muito mais. A produção daquele momento, "O Ratinho Detetive" custaria US\$ 14 milhões. De fato, Eisner e Katzenberg sabiam que a qualidade da animação para 
televisão era pobre. Porém, calculavam como seria se a qualidade de cinema rendesse duas ou três vezes mais em comparação à TV - custando algo entre US\$3 ou US\$ 4,5 milhões. Algumas cenas do projeto em desenvolvimento foram enviadas para outros países para testar se algumas partes da produção (layout, pintura de cenários, efeitos) poderiam ser criadas por um preço mais baixo. Roy E. Disney, que havia saído de uma batalha para mudar a gestão do estúdio, não queria ver a queda da qualidade da animação. Os experimentos foram cancelados (MASTERS, 2001, p. 214-215).

Outro choque cultural ocorreu justamente no desenvolvimento dos filmes. Eisner e Katzenberg achavam difícil compreender o filme, assistindo por horas os diretores apresentando somente os storyboards. E, para piorar, o "O Ratinho Detetive" tinha problemas estruturais em seus três atos - não havia ainda um começo-meio-final consolidado. O processo de storyboard vinha desde os tempos pioneiros do estúdio. E o próprio Walt supervisionou o andamento dos trabalhos por 30 anos. Eisner decidiu manter os storyboards, mas criar um novo sistema em que era necessário apresentar primeiro um roteiro, assim como faziam com todos os demais filmes live-action do estúdio (GROVER, 1997). O que ele não sabia era que aquela simples sugestão mudava fundamentalmente o modo como os filmes de animação eram produzidos nos últimos 50 anos.

Em 1986, Don Bluth e seu grupo de egressos da Disney produziram "Fievel: Um Conto Americano" (An American Tail”, produzido pela companhia de Steven Spielberg, Amblin, tornandose a primeira animação de sucesso fora da Disney a faturar mais de US\$ 84 milhões - US $\$ 47$ milhões apenas no mercado norte-americano. "O Ratinho Detetive” rendeu US\$ 25 milhões. De repente, pela primeira vez a Disney pareceu não ser a única capaz de dominar o campo como nos últimos 50 anos (SOLOMON, 1994).

Uma das primeiras decisões para fomentar novos projetos foi a implantação dos chamados "Gong Shows", as reuniões onde todos (artistas, técnicos, executivos, etc) podiam sugerir as mais variadas ideias para filmes. Assim que a produção de "O Ratinho Detetive" foi acelerada, a Disney iniciou a prospecção de novos projetos. Katzenberg sugeriu uma nova versão de "Oliver Twist", de Charles Dickens, mas dessa vez uma adaptação musical estrelada por cães e gatos, com canções de pop-stars conhecidos. A ideia era dar um sinal de que a Disney estava se modernizando, com um filme contemporâneo ambientado em Nova York.

Neste período, Katzenberg ainda não estava interessado em animação, mas aos poucos foi ganhando respeito pelo processo de produção, se tornando um de seus maiores guardiões ao lado de 
Roy E. Disney. Para "Oliver e sua Turma” (1988), contratos foram fechados com Billy Joel, Bette Midler, Huey Lewis, Barry Manilow e Ruth Pointer. O filme não tinha o mesmo tipo de humor e sensibilidade musical que os futuros filmes teriam como grande força, como o próprio Michael Eisner admitiu (SCHWARTZ, 1999, p. 179), mas foi o suficiente para faturar US\$ 50 milhões nas bilheterias (bem mais que as duas animações anteriores). E, mais importante, eclipsou o lançamento da concorrência - a animação "Em Busca do Vale Encantado" (The Land Before Time, 1988) - produção de Spielberg com a equipe de animação de Don Bluth.

Porém, o processo criativo já havia mudado. Peter Schneider (Fig. 67), supervisionando as operações diárias, havia colocado em execução diretrizes para forçar o fomento de ideias. Em “Oliver e sua turma" (1988), o projeto era tocado por dois diretores - Rick Rich e George Scribner. O executivo demitiu Rich, que era beligerante com ele, e manteve Scribner, que era mais cooperativo. Schneider trouxe características do Teatro para o negócio da animação. Os cineastas deviam formar equipes baseadas no talento e com quem gostariam de trabalhar, evitando uma forma de hierarquia institucionalizada. Se alguém tivesse um ponto de vista seguro simplesmente desaparecia. Parecia a decisão correta na época. Um debate emergiu sobre a necessidade dos profissionais defenderem suas ideias, pois mais desenhos acabavam jogados no lixo do que aparecendo nas telas.

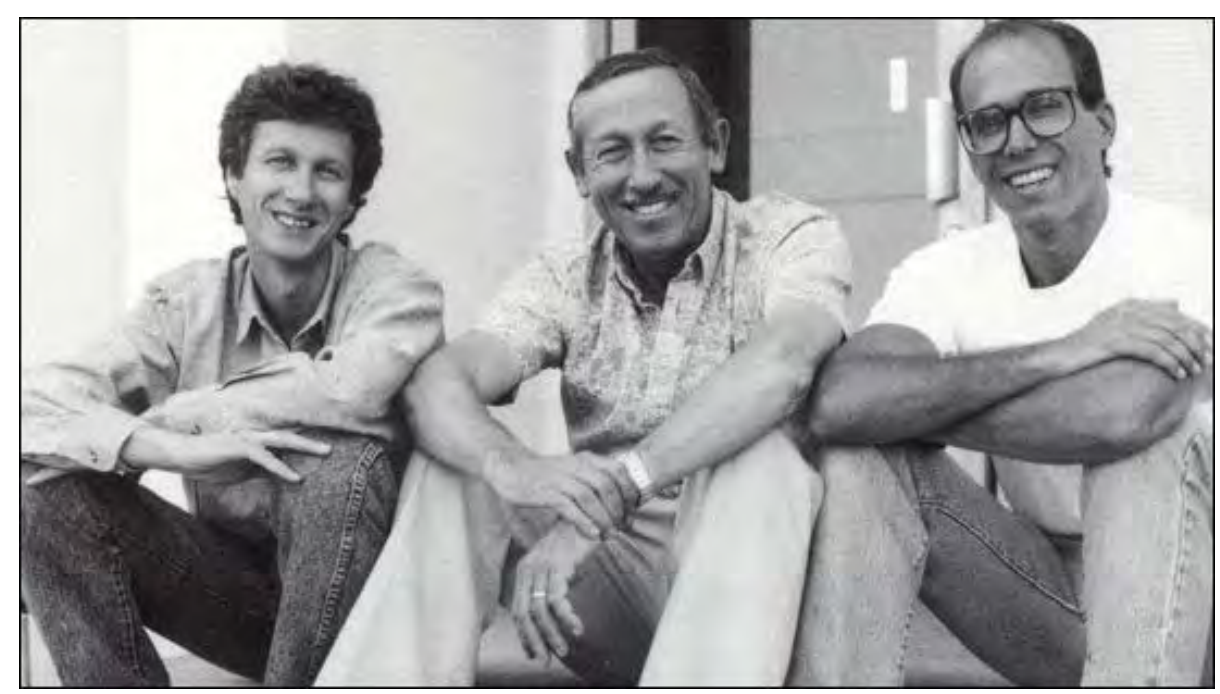

Figura 67 - Peter Schneider, Roy Edward Disney e Jeffrey Katzenberg, responsáveis pelas produções no estúdio.

O processo criativo era, em boa medida, relativamente democrático. Thomas Schumacher o definia como "Darwinismo Cultural". Ele queria dizer que boas ideias são bem-vindas, não importa de quem fossem, incluindo novatos nos departamentos. Os filmes tomavam muitos anos de produção e cada decisão criativa era vista e revista, desafiada e escrutinada, trabalhada e retrabalhada, dizia 
Schumacher. Com o sucesso dos primeiros filmes, Jeffrey Katzenberg começou a realmente se envolver profundamente com as animações. Era uma forma dele soltar seu lado de executivo criativo, mas também um meio de se expor para a imprensa (SCHWARTZ, 1998, p. 180). Eram projetos que ele podia executar sem tanta interferência de Michael Eisner e uma forma de, talvez, preparar terreno para uma futura ascensão profissional.

Após “Uma Cilada para Roger Rabbit” (1988), o projeto “A Pequena Sereia” (1989) foi mais um marco no que se tornaria o início de uma nova era de ouro da animação Disney. O projeto surgiu de um dos "Gong Shows" realizados em meados de 1985. Ron Clements, recém saído da direção de "O Ratinho Detetive” propôs uma adaptação do conto de Hans Christian Andersen, "A Pequena Sereia". Houve uma preocupação inicial dos executivos presentes, pois a Disney lançara em 1984, poucos meses antes do início da nova administração, um filme live-action chamado "Splash: Uma Sereia em Minha Vida" (1984) que tinha justamente uma sereia como protagonista (GROVER, 1997). O conto dinamarquês original é pesado e a protagonista morre no fim, mas na versão do script de Clements a história foi convertida de modo a contar como a sereia Ariel se torna humana e, assim, pode se casar com o príncipe Eric. Para alcançar seu objetivo, precisa negociar e entregar sua voz à bruxa do mar, Úrsula. E, no fim, ela não apenas retoma sua voz como conquista o príncipe. Tão logo aprovado o projeto, a maior decisão criativa, que traria um impacto na animação Disney por pelo menos uma década, foi trabalhar com o compositor Alan Menken e o letrista Howard Ashman.

A ideia veio de David Geffen, um dos amigos e conselheiros mais próximos de Jeffrey Katzenberg. Geffen era um empresário de muito sucesso no ramo fonográfico e havia investido também em cinema e teatro. Ele havia co-produzido um musical off-Broadway chamado "A Pequena Loja dos Horrores" (Little Shop of Horrors, 1982) cuja música foi criada por Ashman e Menken. O letrista estava tentando uma nova vida em Los Angeles. No início de 1986, Katzenberg apresentou uma série de projetos de animação e "A Pequena Sereia" foi o que mais chamou atenção do letrista, que aceitou a trabalhar novamente com Menken (HAHN, 2009).

O processo foi incrivelmente colaborativo. Os diretores Musker e Clements trabalham em uma sala ao lado do escritório dos compositores Ashman e Menken. Em salas adjacentes ficavam os animadores Glen Keane e Mark Henn, dois dos maiores animadores da nova geração. Todos se consultavam regularmente, buscando melhorar cada vez mais a produção (SCHWARTZ, 1998, p. 184). 
Howard Ashman, entretanto, foi a pessoa que fez toda a diferença do ponto de vista criativo - um legítimo exemplo do que chamamos de "storyteller" (contador de histórias). O letrista era um grande conhecedor das antigas animações da Disney, um fã incondicional de "Peter Pan" e tinha um grande senso de história teatral, por ter crescido neste ambiente em sua cidade natal, Baltimore. Além de suas atribuições musicais, foi responsável por mudar o tom de diversos personagens, desde transformar a bruxa do mar Úrsula em algo muito maior, inspirado na dragqueen Divine, ou fazer com que o esnobe e sério caranguejo Sebastião se tornasse um protetor de Ariel, com traços caribenhos. Inseriu mais humor nos diálogos e alterou a trilha musical para que tivesse mais reggae, calypso e doo-wop, tornando o filme algo diferente do que se viu até então. (SCHWARTZ, 1998, p. 184). Alan Menken, por sua vez, criou melodias que ele mesmo rotulava de "pastiche expansivo", tamanha capacidade de adaptar e combinar gêneros muito diversos.

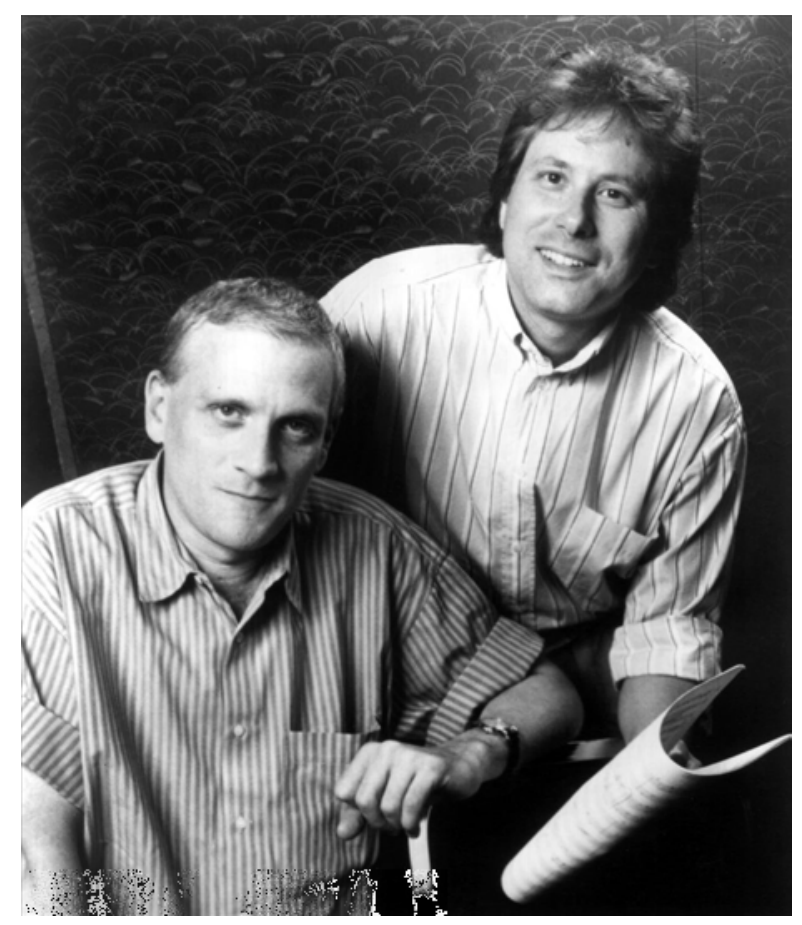

Figura 68 - Os compositores Howard Ashman e Alan Menken.

Ashman criou na Disney o que se costuma chamar de canção "I want". Trata-se de uma canção nesse formato de musical em que a personagem protagonista expressa seus desejos, o que espera da vida no futuro, e o público passa a torcer para que ela consiga. A novidade estreou com a sereia Ariel se expressando na canção "Part of your World". Curiosamente, essa ideia quase naufragou devido a uma exibição-teste do filme com crianças, ainda com a animação preliminar a lápis. As crianças se dispersaram e começaram a correr ou a fazer outra coisa - Katzenberg, presente no cinema, não gostou de ver as reações e ordenou o corte da canção. Ashman não gostou, porém foi o animador 
Glen Keane, supervisor de animação da personagem e responsável pela cena que lhe fez uma forte defesa de sua função. O chefe voltou atrás, reconhecendo, após a finalização, que a cena é uma das mais memoráveis no filme. A canção "Under the Sea”, um showstopper (tipo de número musical que arranca mais aplausos) digno da Broadway, levou o Oscar de Melhor Canção, e o filme se tornou o maior sucesso de animação da Disney até então, faturando US\$ 84 milhões só nos Estados Unidos. As novidades musicais se tornaram marcas na animação Disney nos anos 1990 (GROVER, 1997). A esta altura, a equipe nos estúdios Disney saltara de 150 para cerca de 550 funcionários em cinco anos.

Durante a festa anual na casa de praia de Jeffrey Katzenberg, em Malibu, entre tantas estrelas lá estava Howard Ashman. Após “A Pequena Sereia”, o letrista e produtor estava envolvido em um projeto Disney que lhe atraíra muita atenção, "Aladdin". Sabendo dos problemas em "A Bela e a Fera”, Katzenberg convenceu o letrista a compor canções para o filme, mesmo sendo contra sua vontade largar "Aladdin”. O executivo reuniu os diretores e os compositores Ashman e Alan Menken para informar-lhes que "A Bela e a Fera" agora seria um musical (HAHN, 2009). Após vencerem o Oscar de Melhor Canção e trilha sonora por "A Pequena Sereia”, Howard Ashman revelou ao colega Alan Menken que era portador do vírus HIV. Mesmo assim, Ashman continuou trabalhando em "A Bela e a Fera”, até que sua saúde se deteriorou. No final da produção, ele já supervisionava os trabalhos de sua casa em Nova York. Havia emagrecido muito, perdido a visão e sua voz estava baixa demais para conversar. Faleceu em 14 de março de 1991, meses antes da estreia do filme.

Como parte da campanha de publicidade, o estúdio decidiu exibir uma versão preliminar do filme (conhecida como "work in progress") ainda com boa parte da animação a lápis e em preto e branco, durante a New York Film Festival. O que era altamente arriscado devido a conhecida plateia esnobe nova-iorquina, tornou-se uma surpresa, quando um auditório inteiro explodiu em aplausos por vários minutos. O filme ganhou tanto prestígio que a crítica considerava que o melhor musical da Broadway naquele ano estava nos cinemas. O resultado foi uma indicação inédita de "A Bela e a Fera” à categoria de Melhor Filme no Oscar. Perdeu para "O Silêncio dos Inocentes", mas garantiu um novo status para o mundo da animação. Três canções foram indicadas ao Oscar. Uma delas ganhou, além da trilha sonora também vencedora. "Aladdin" se tornou o projeto seguinte do estúdio. As canções da parceria de Menken com Howard Ashman foram aproveitadas e o letrista Tim Rice foi contratado para compor outras três. A influência de Ashman foi tão forte que suas sugestões para melhorar os filmes continuam sendo lembradas em reuniões dos diretores dos filmes e executivos. 


\subsection{Exemplos Gráficos da Animação Disney}

Apresentamos nas próximas páginas diversos exemplos gráficos da animação Disney, ilustrando a variedade de técnicas, estilos e inspirações entre as décadas de 1980 e 2000. Foram selecionados trabalhos de nove supervisores de animação da chamada "nova geração", os responsáveis pelo design final e poses-chave de seus personagens. São eles: John Pomeroy, Glen Keane, Mark Henn, Ruben Aquino, Eric Goldberg, James Baxter, Ken Duncan, Nik Ranieri e Andreas Deja. Desses, somente Mark Henn e Eric Goldberg permanecem nos estúdios Disney em 2016. 
Destacamos a animação da transformação da Fera ("A Bela e a Fera", 1991) - esboços do supervisor de animação Glen Keane (Fig. 69 a 74).

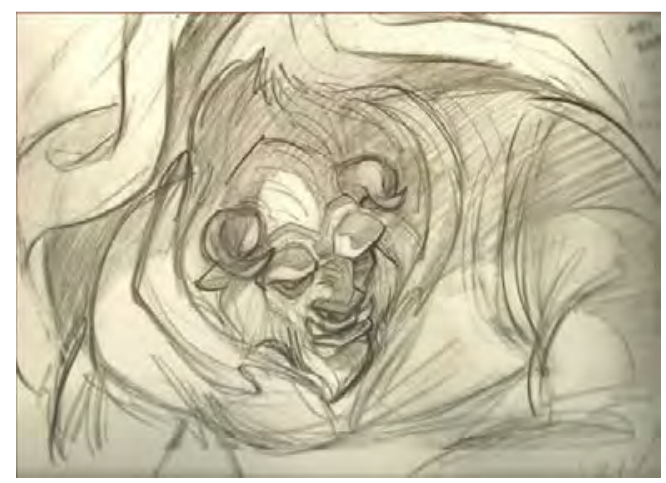

Figura 69 - Clímax do filme com a transformação da Fera (evolução até Fig. 74)

Figura 70
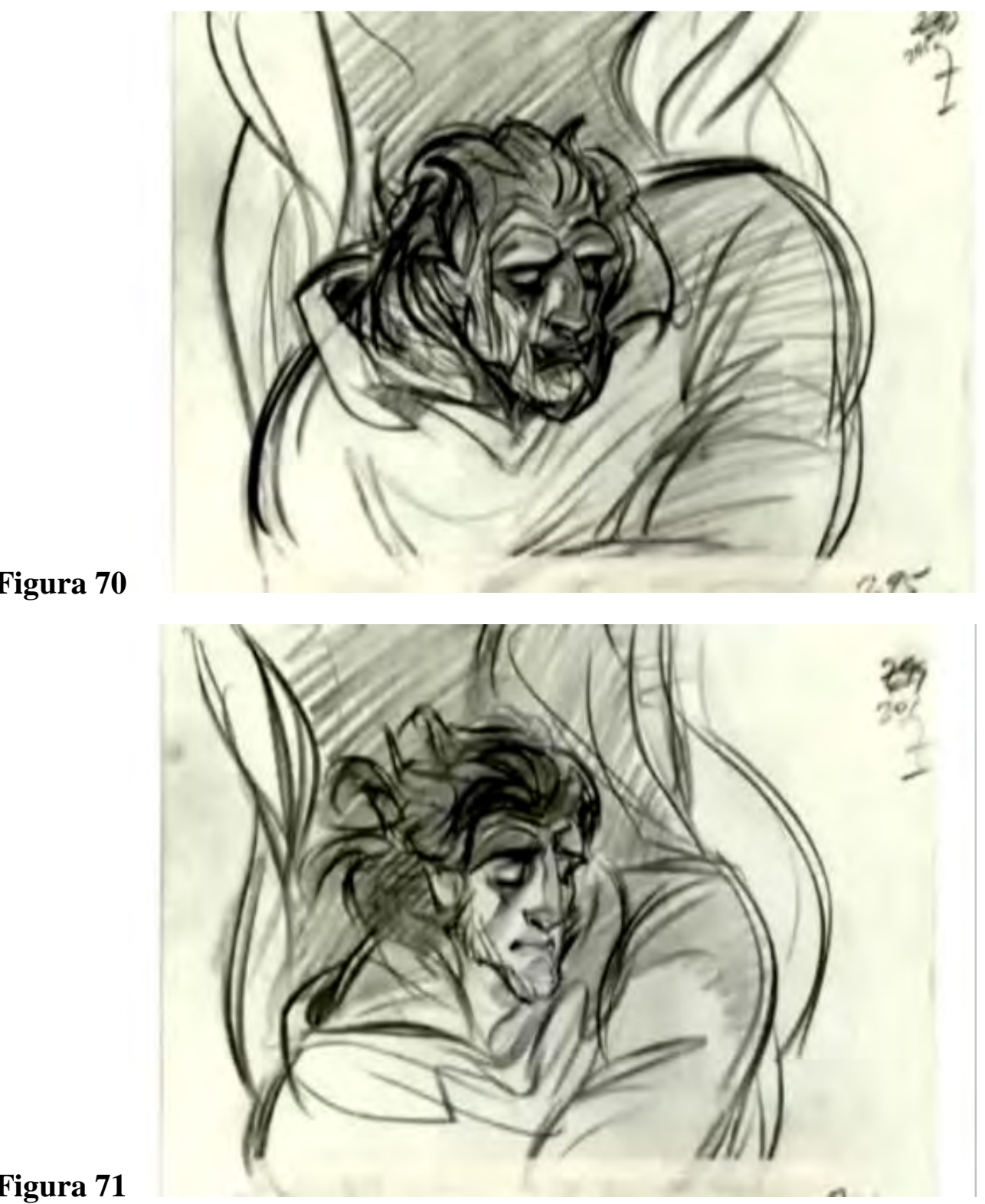

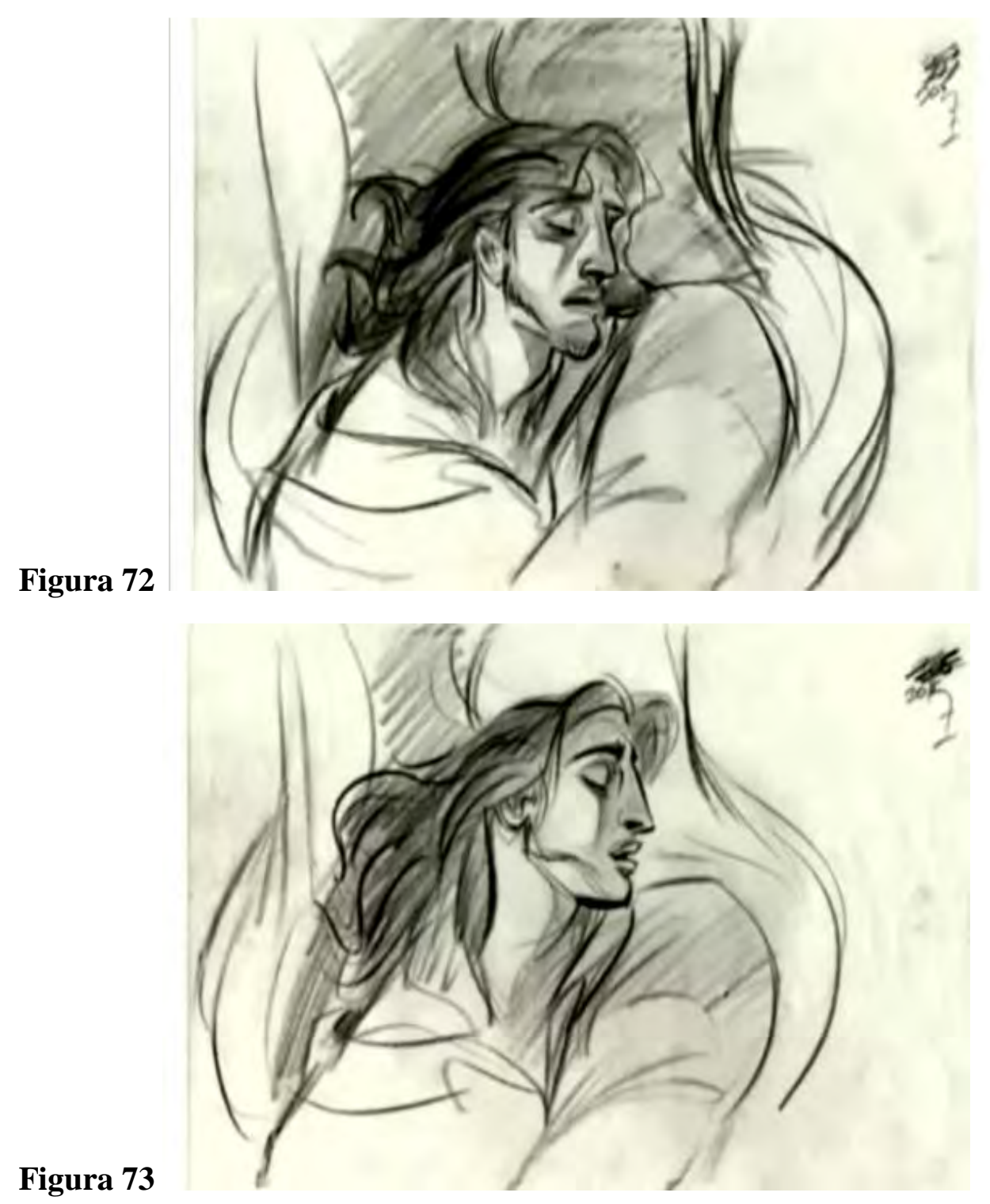

Figura 73

Figura 74

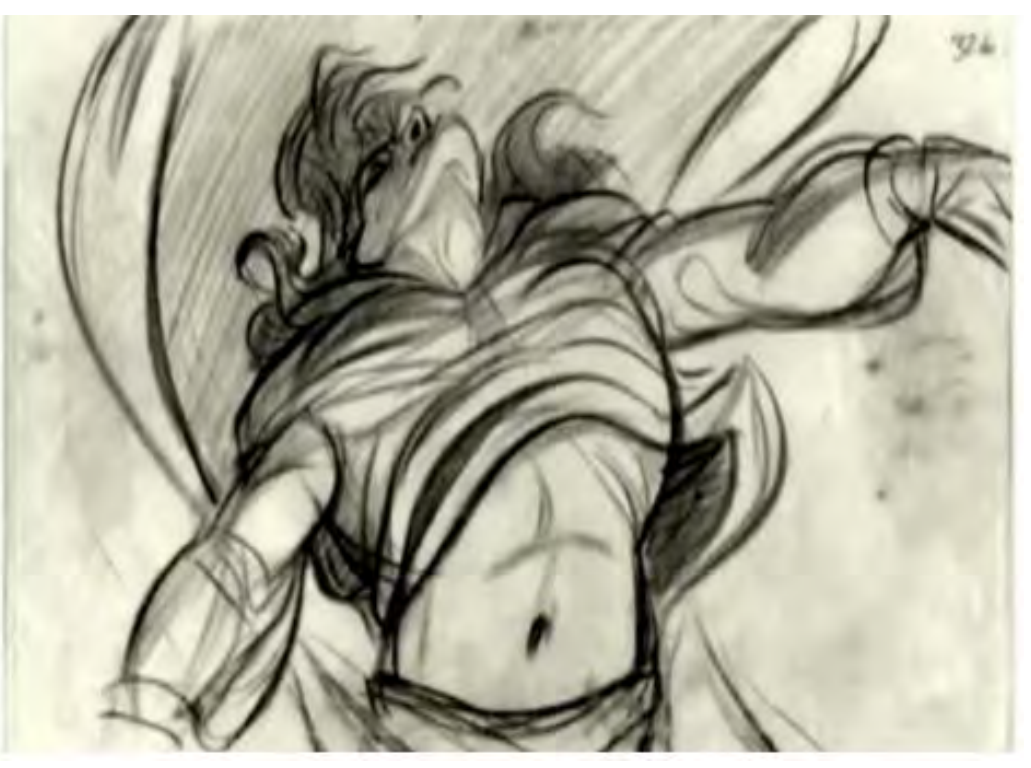




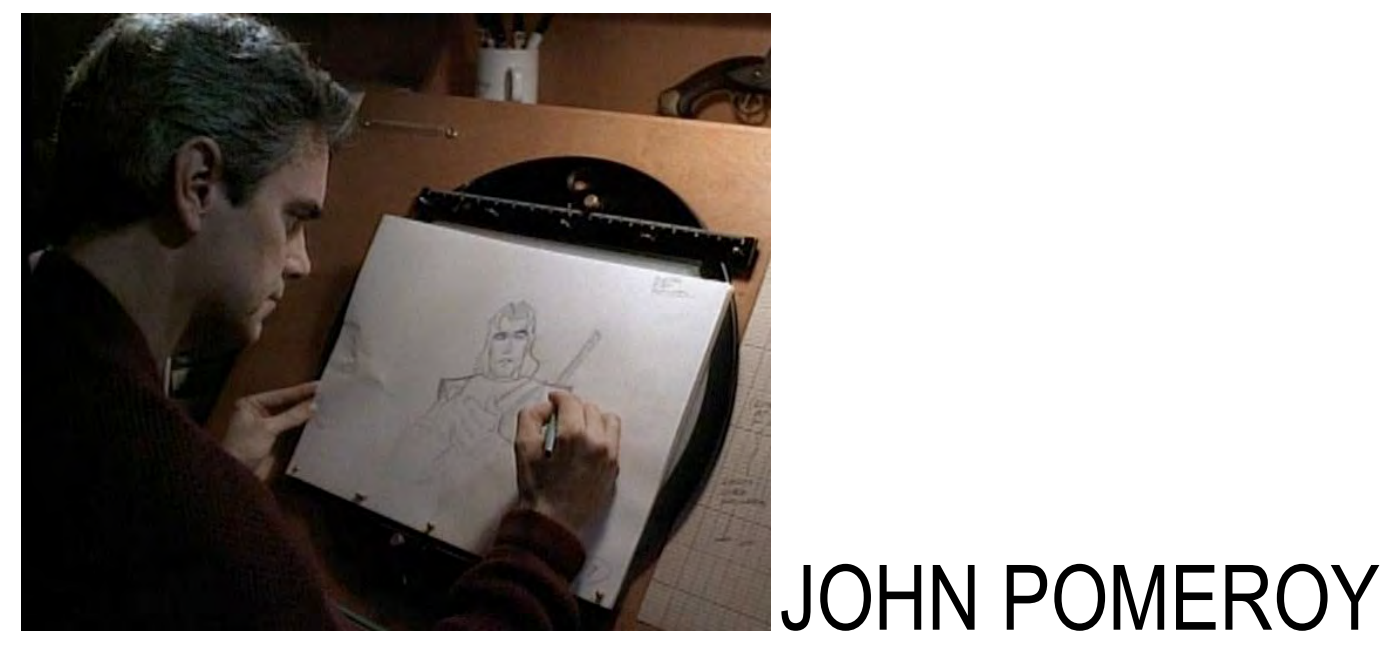

Figura 75 - John Pomeroy

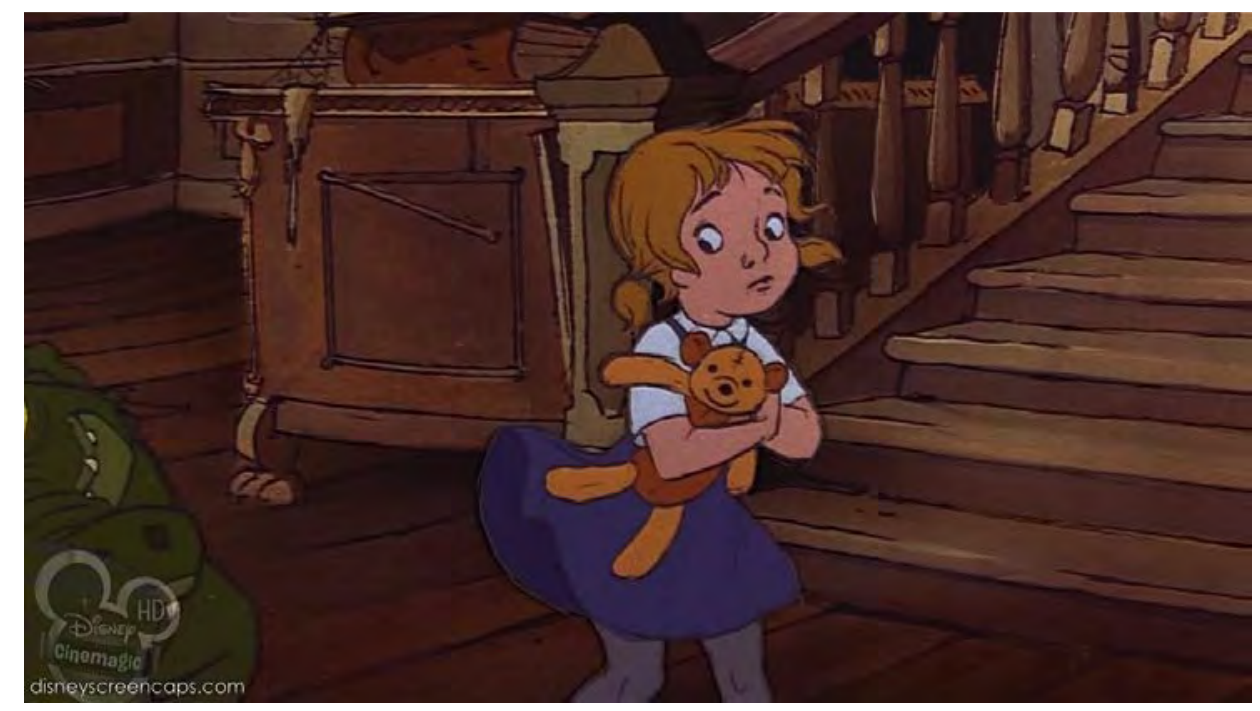

Figura 76 - Penny (“Bernardo e Bianca”, 1977)

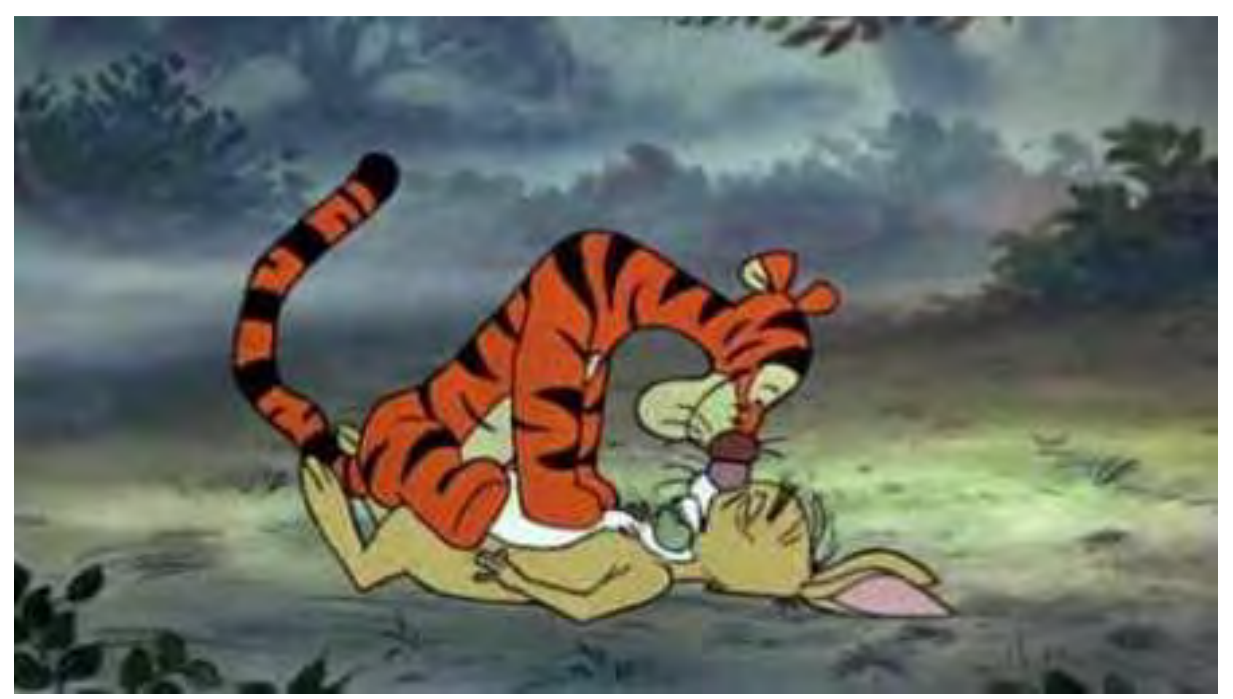

Figura 77 - Tigrão ("Winnie the Pooh and Tigger Too", 1974) 

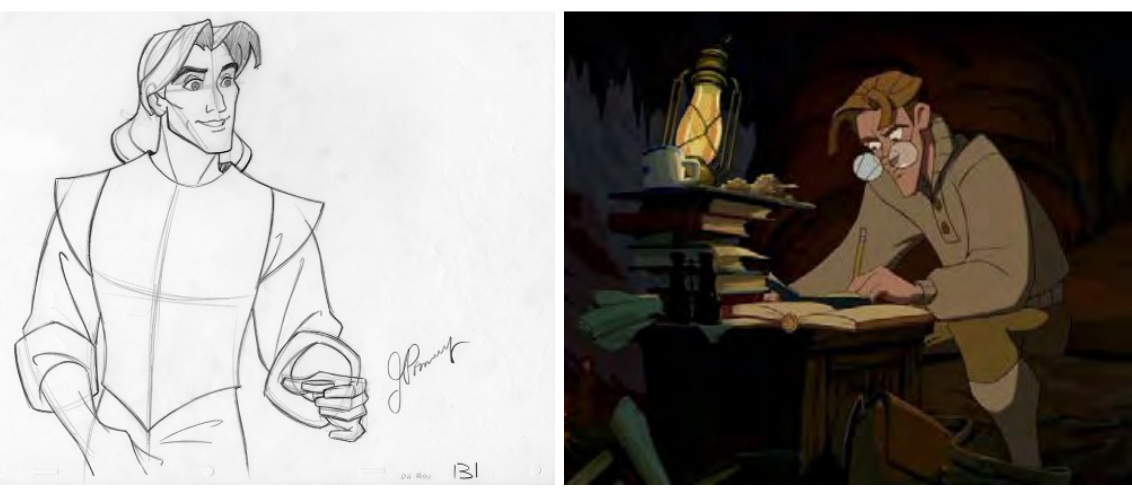

Figura 78 - Capitão John Smith ("Pocahontas, 1995). Figura 79 - Cartógrafo e linguista Milo Thatch (“Atlantis: O Reino Perdido", 2001).

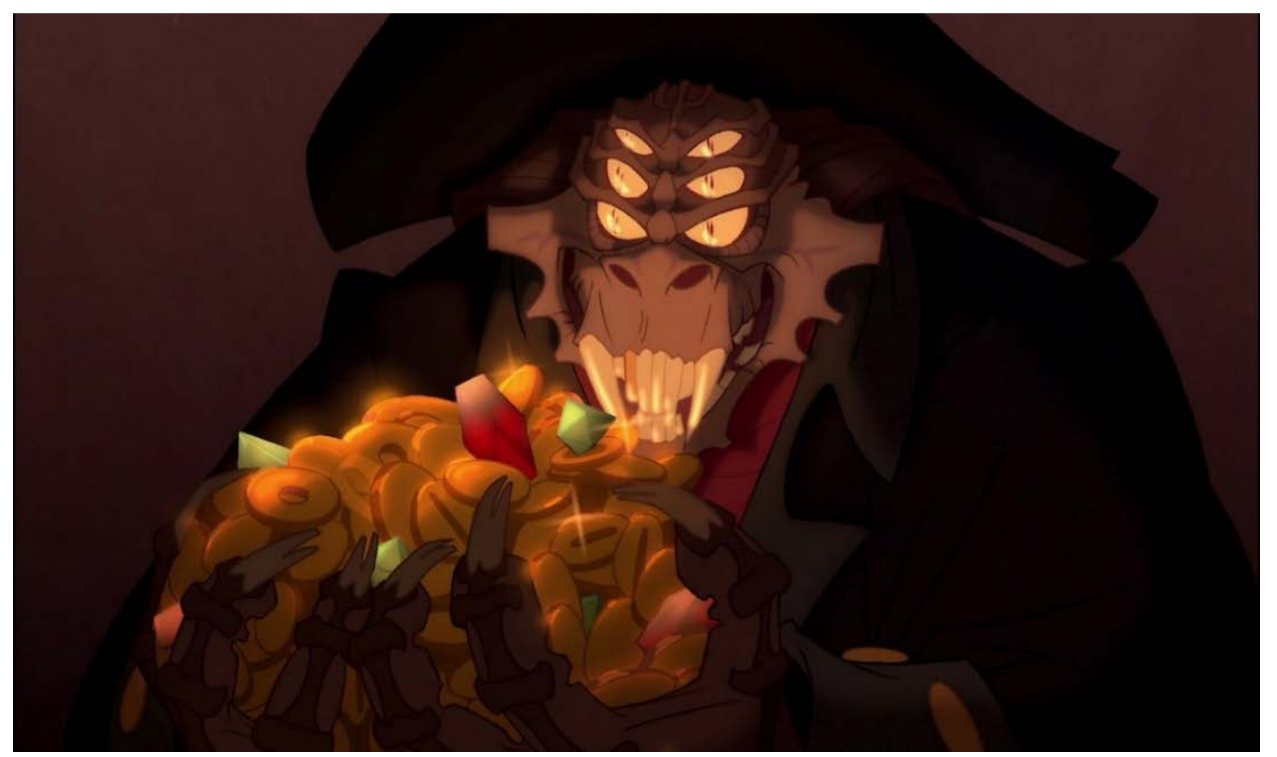

Figura 80 - Capitão Nathaniel Flint (“Planeta do Tesouro”, 2002).

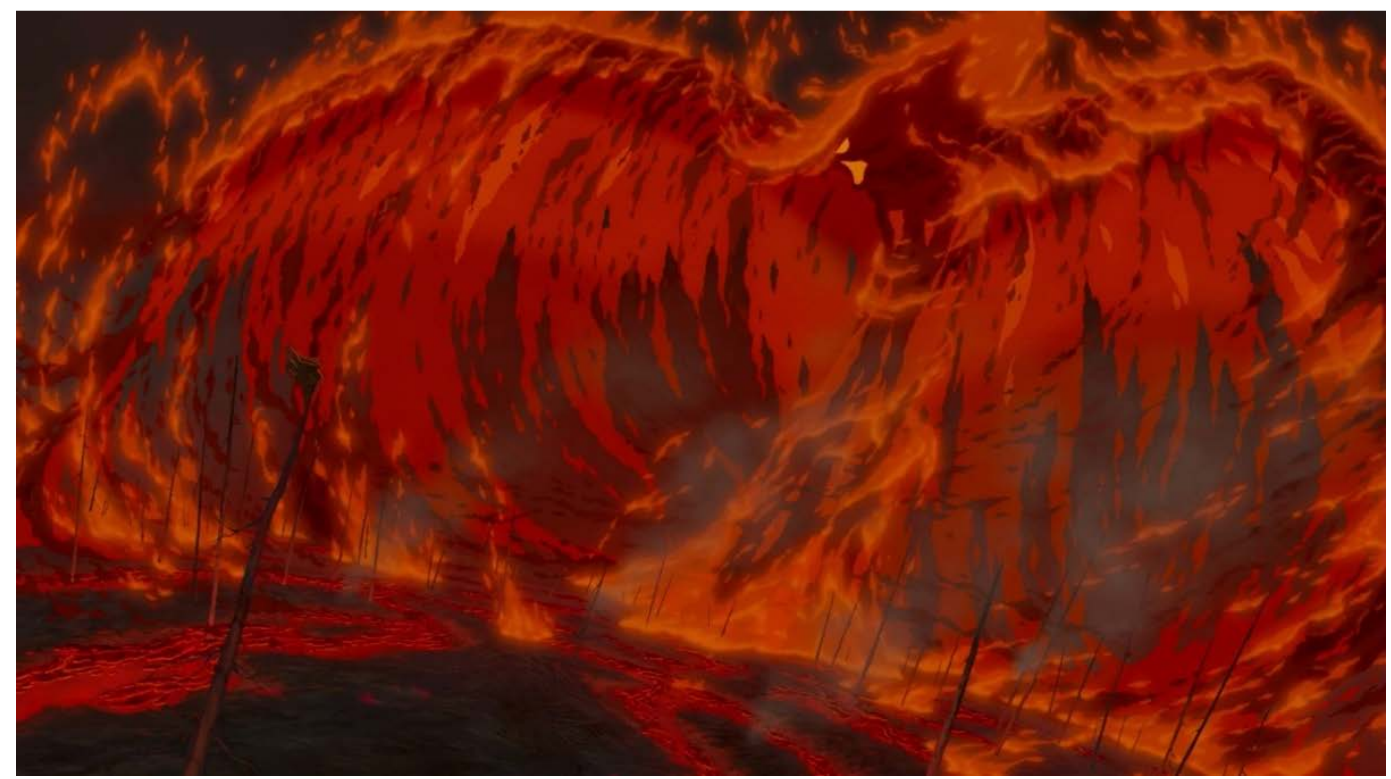

Figura 81 - Pássaro de Fogo (“Fantasia 2000”, 1999) 


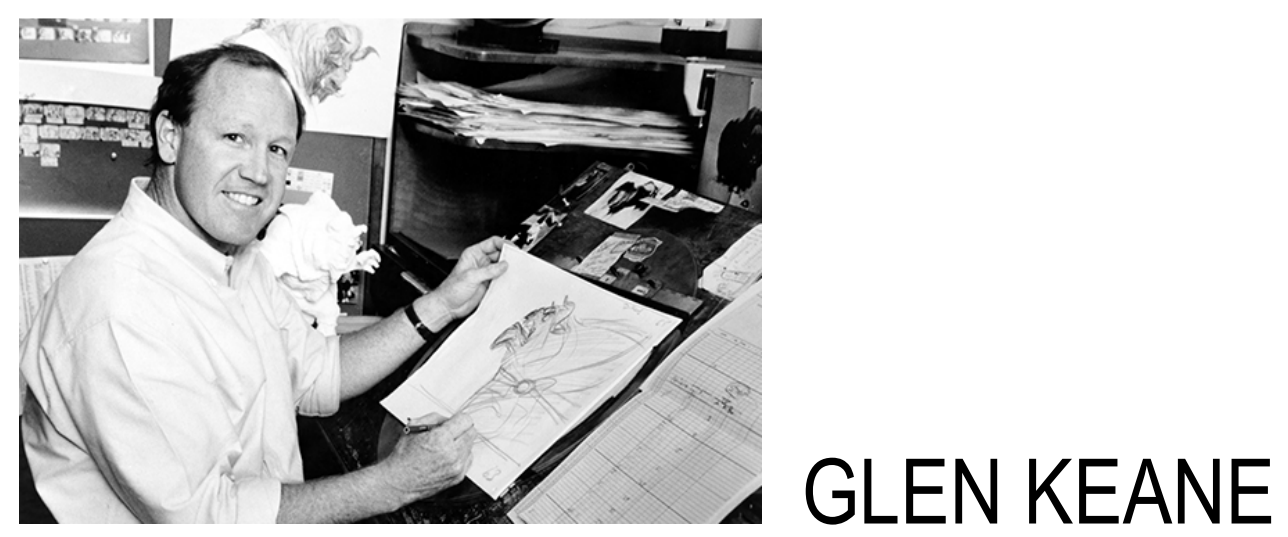

Figura 82 - Glen Keane

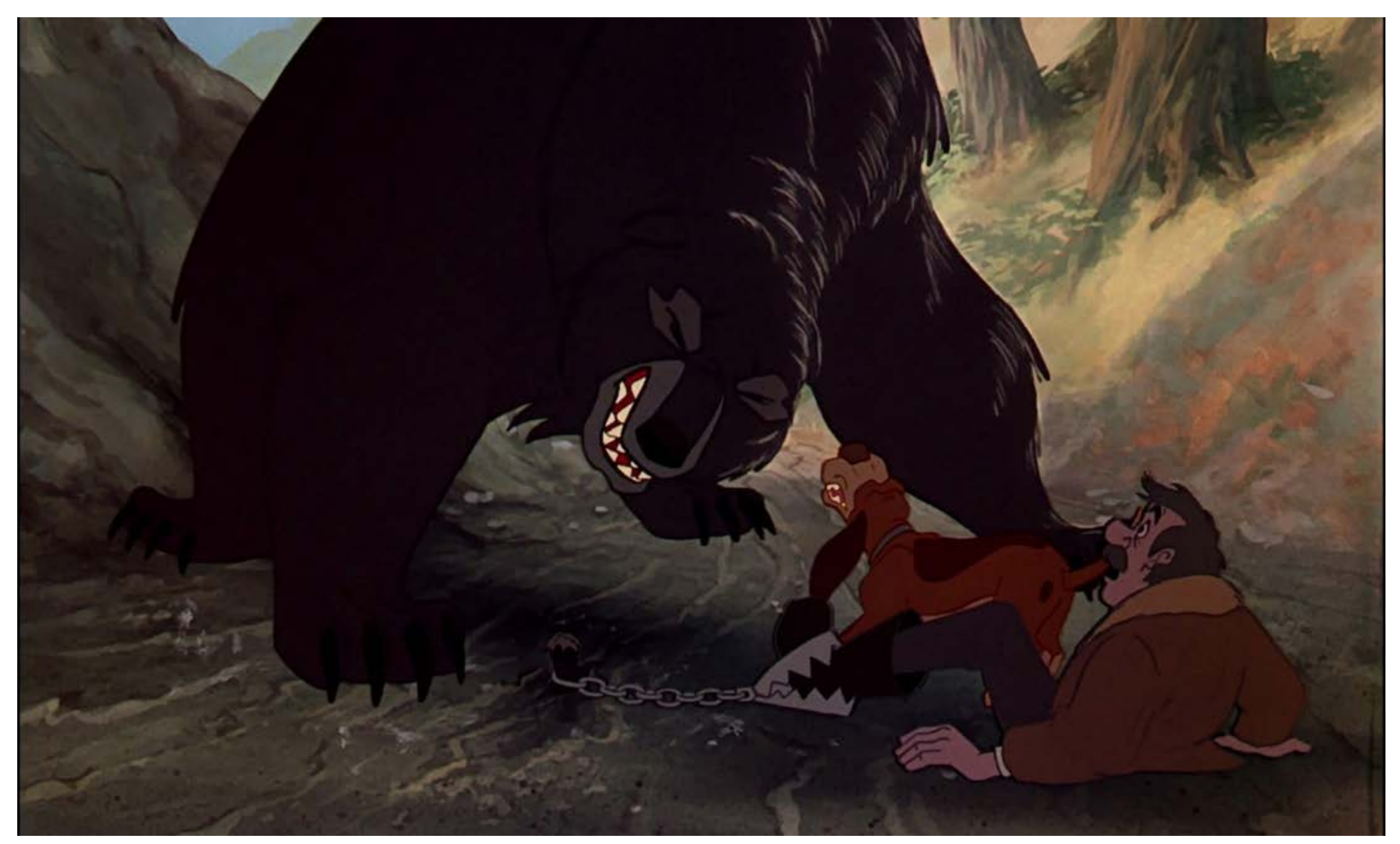

Figura 83 - Urso (“O Cão e a Raposa”, 1981).
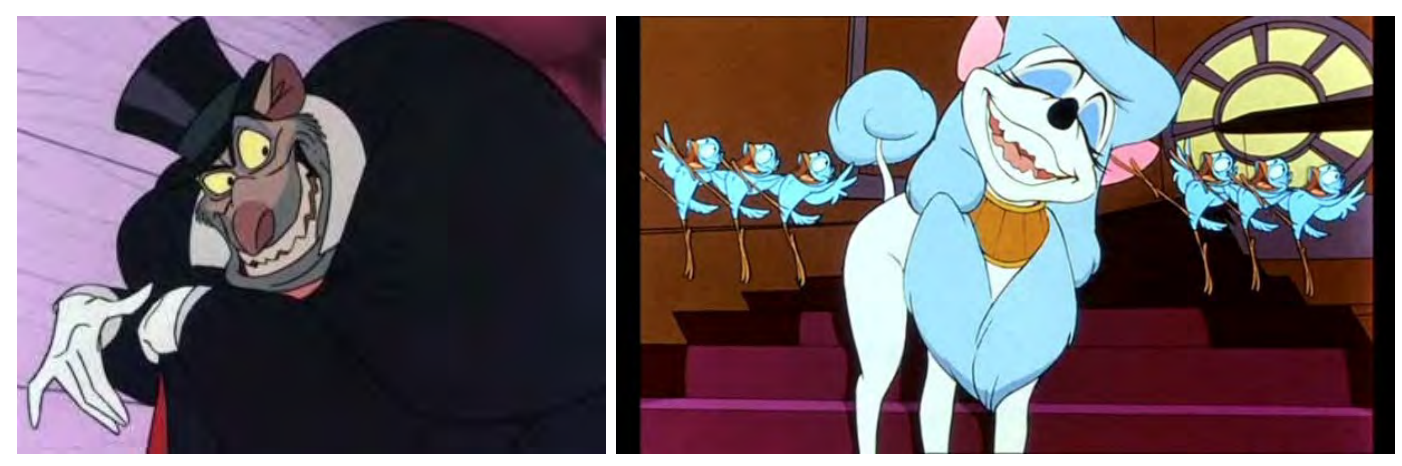

Figura 84 - Prof. Ratagão (“O Ratinho Detetive”, 1986). Figura 85 - Georgette (“Oliver e sua Turma", 1988). 


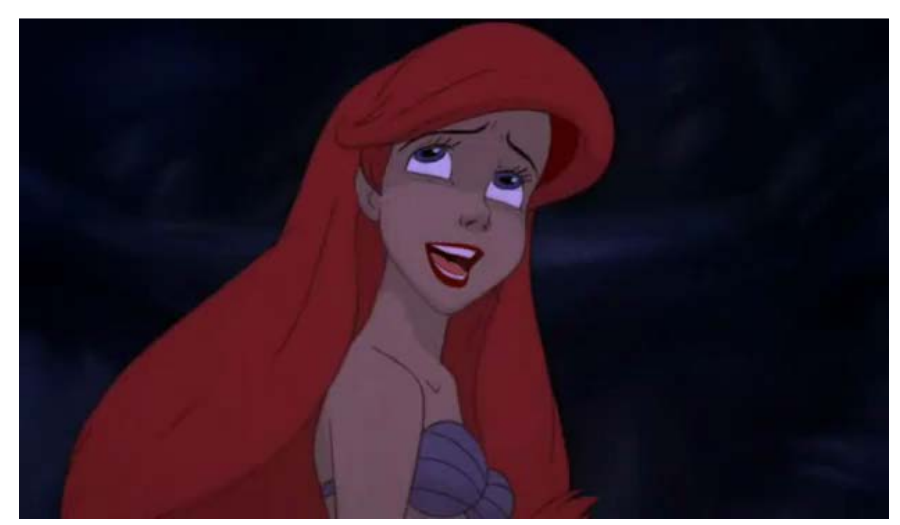

Figura 86 - Ariel (“A Pequena Sereia”, 1989).

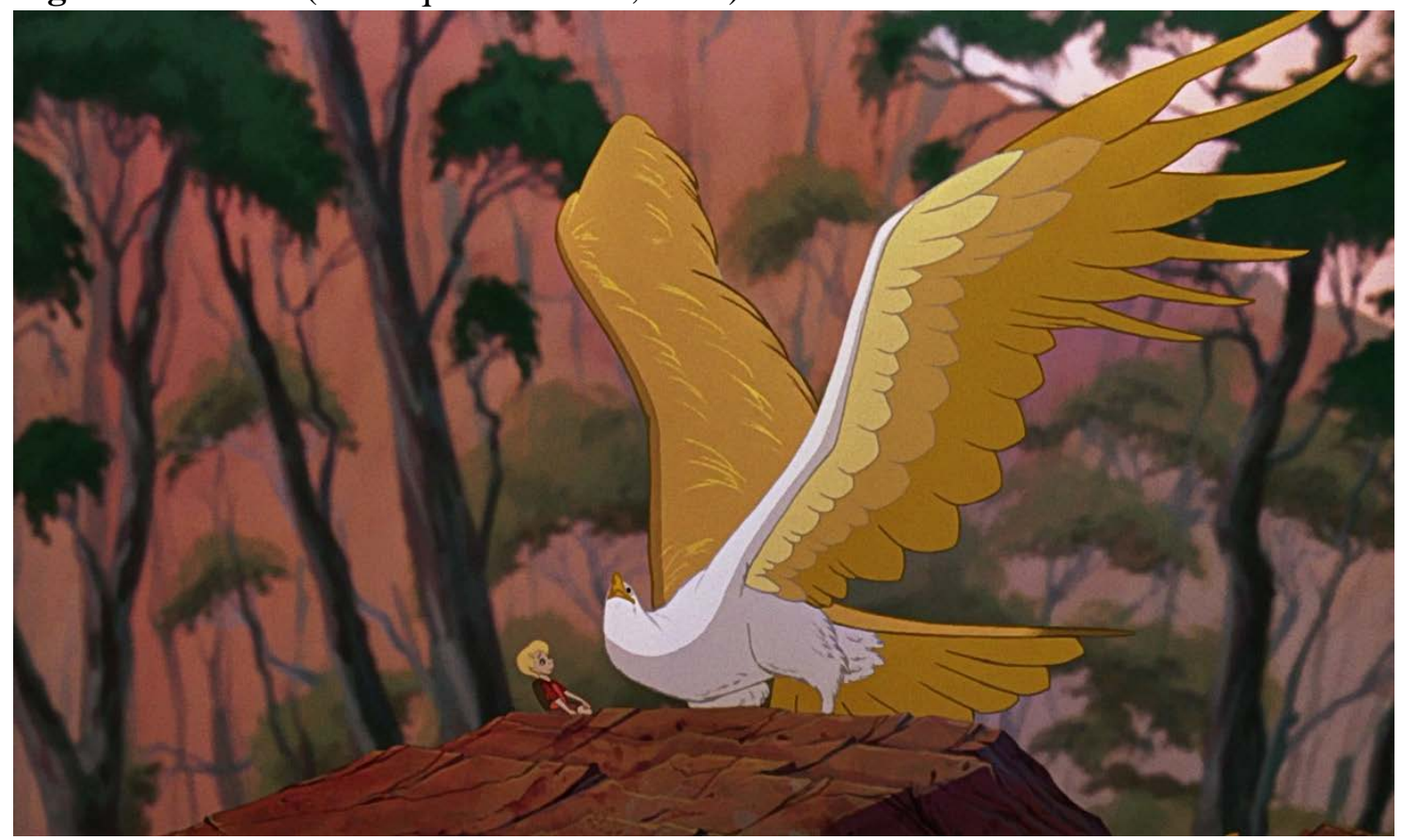

Figura 87 - Águia Marahute (“Bernardo e Bianca na Terra dos Cangurus”, 1990).

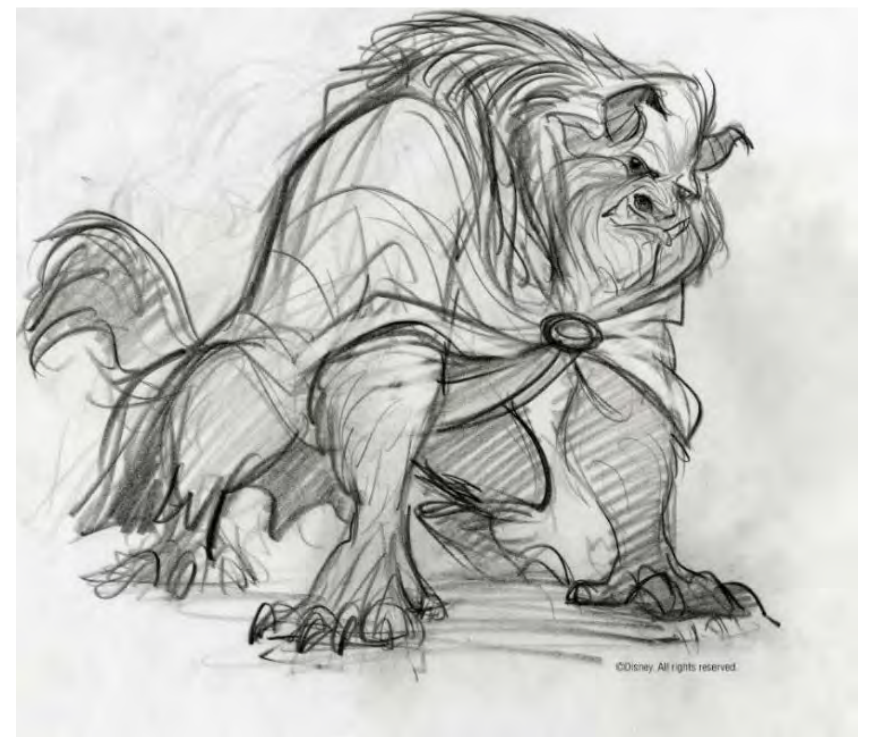

Figura 88 - Esboço da Fera (“A Bela e a Fera”, 1991). 


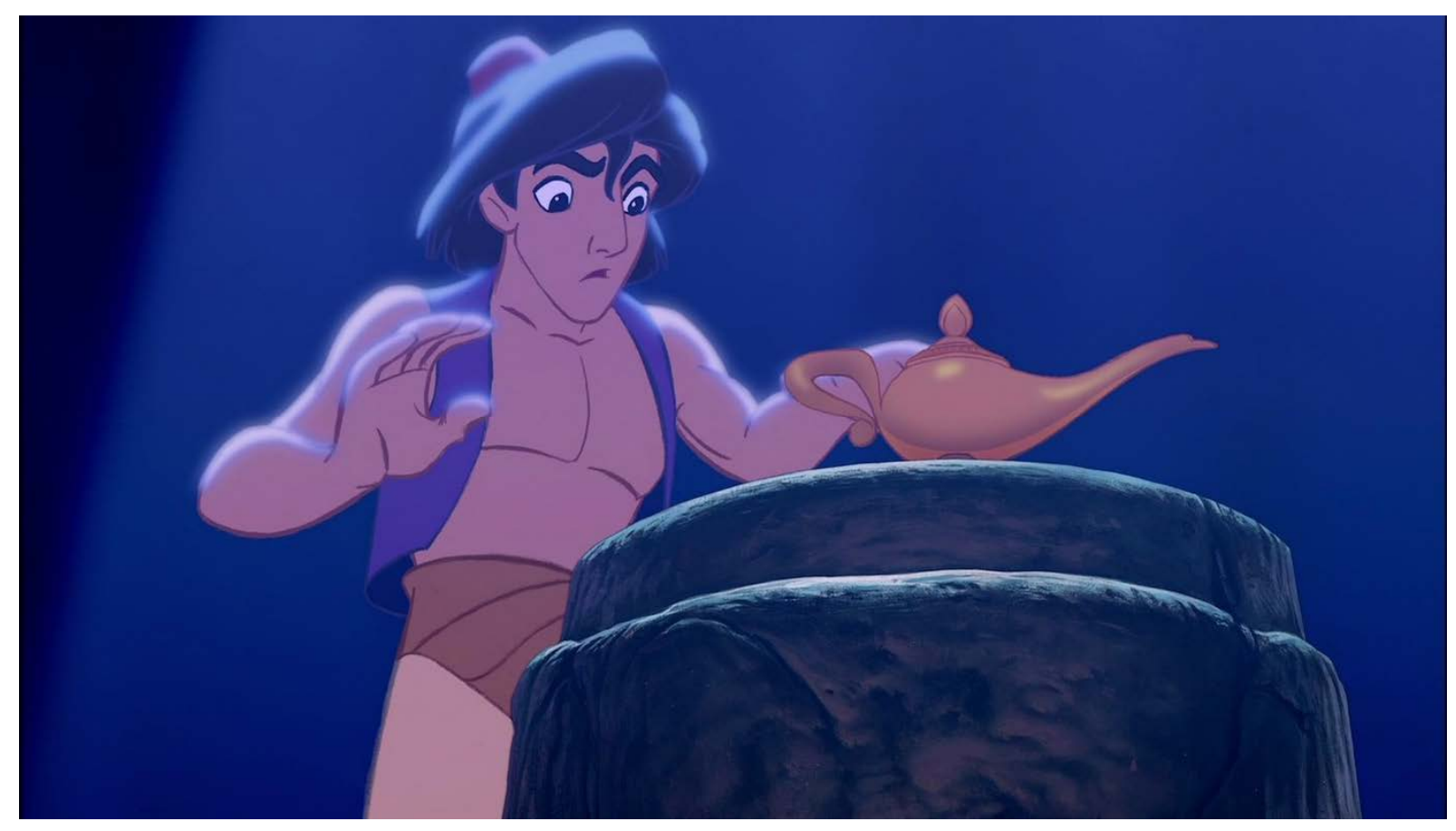

Figura 89 - Aladdin (“Aladdin”, 1992).

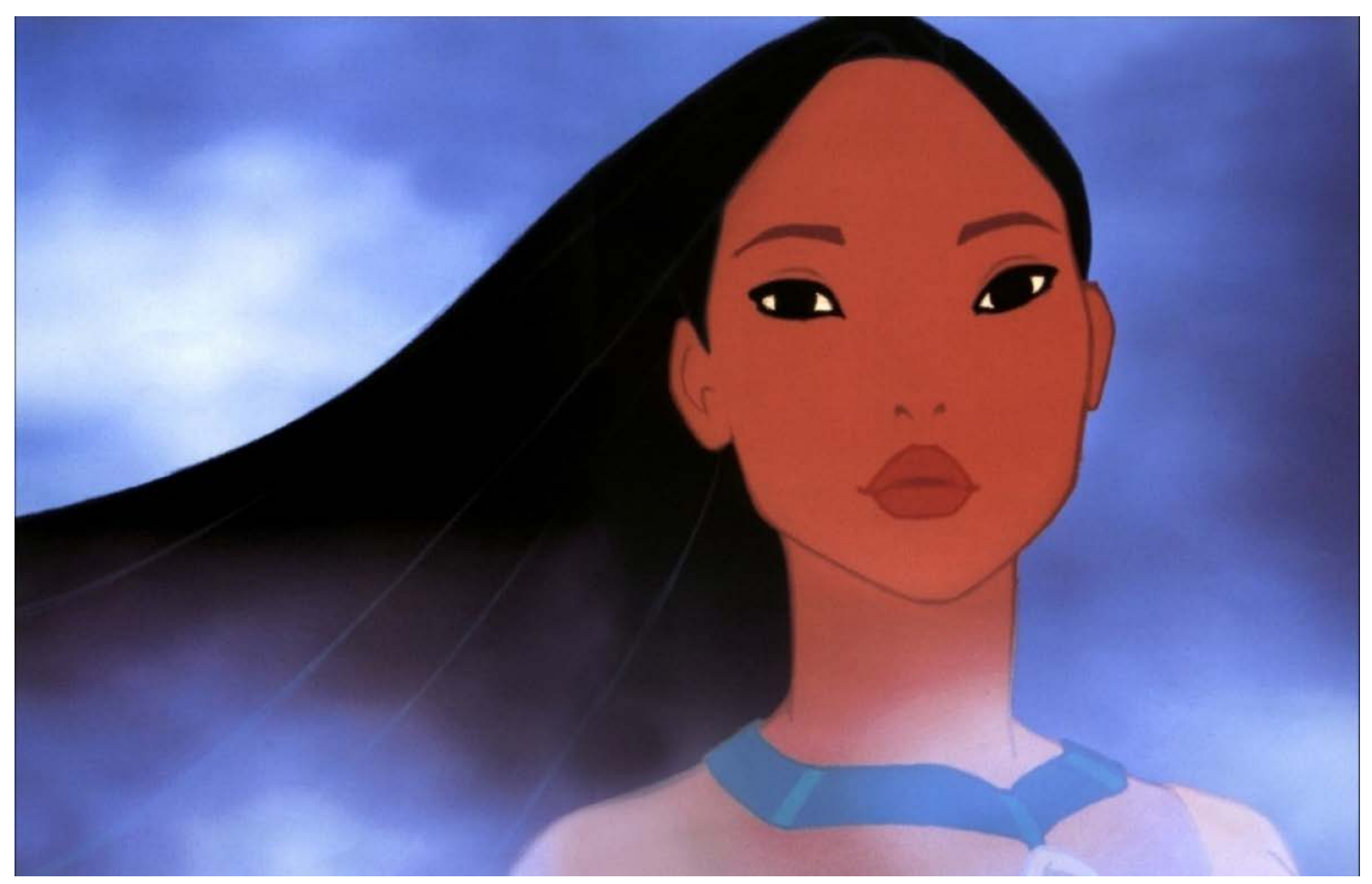

Figura 90 - Pocahontas (“Pocahontas", 1995). 

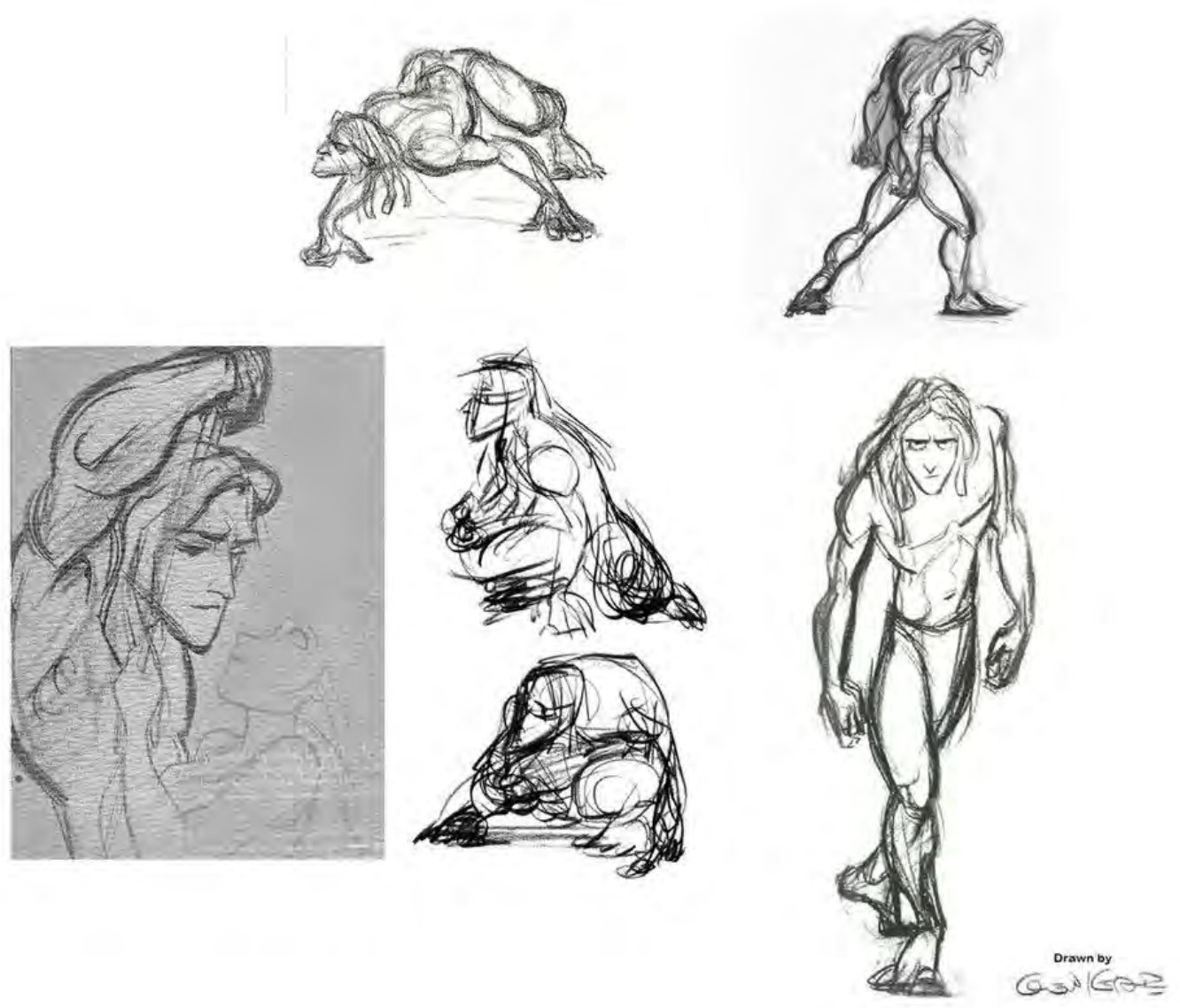

Figura 91 - Esboços de Tarzan (“Tarzan”, 1999).

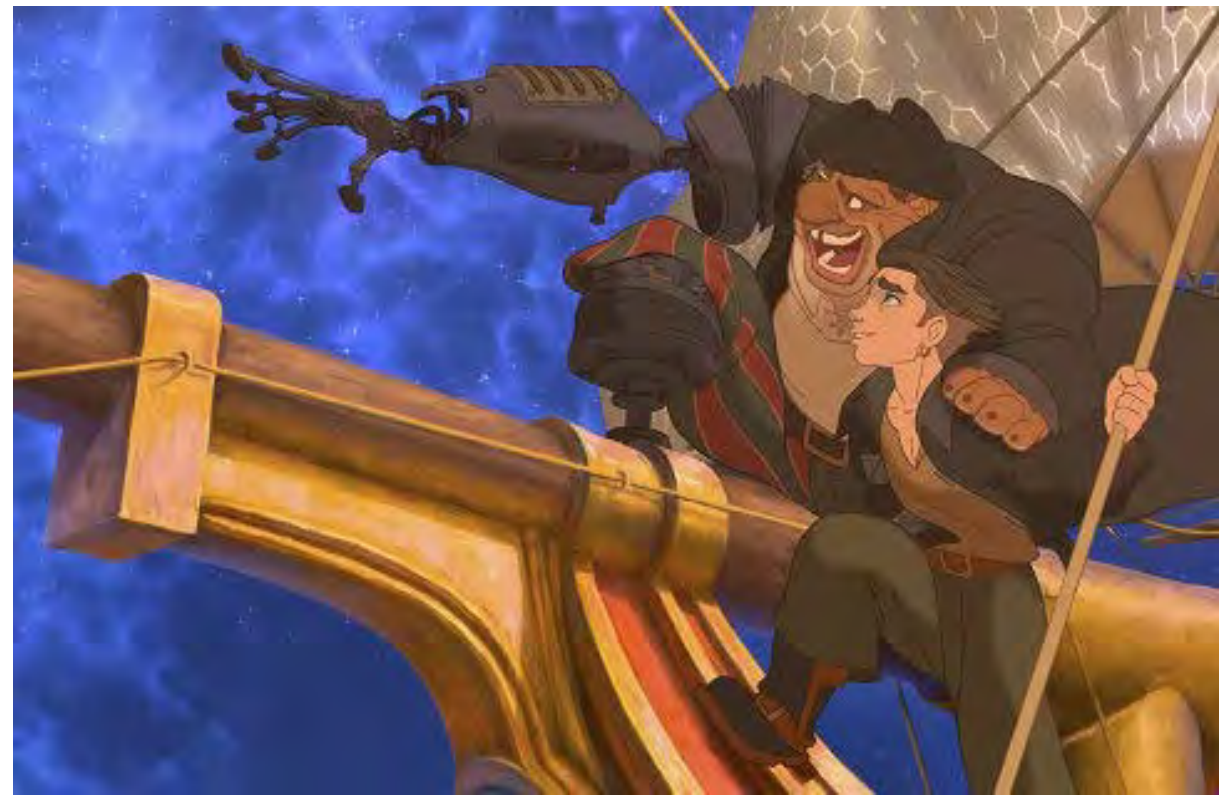

Figura 92 - Pirara John Silver, personagem combinando elementos tradicionais e digitais ("Planeta do Tesouro", 2002). 


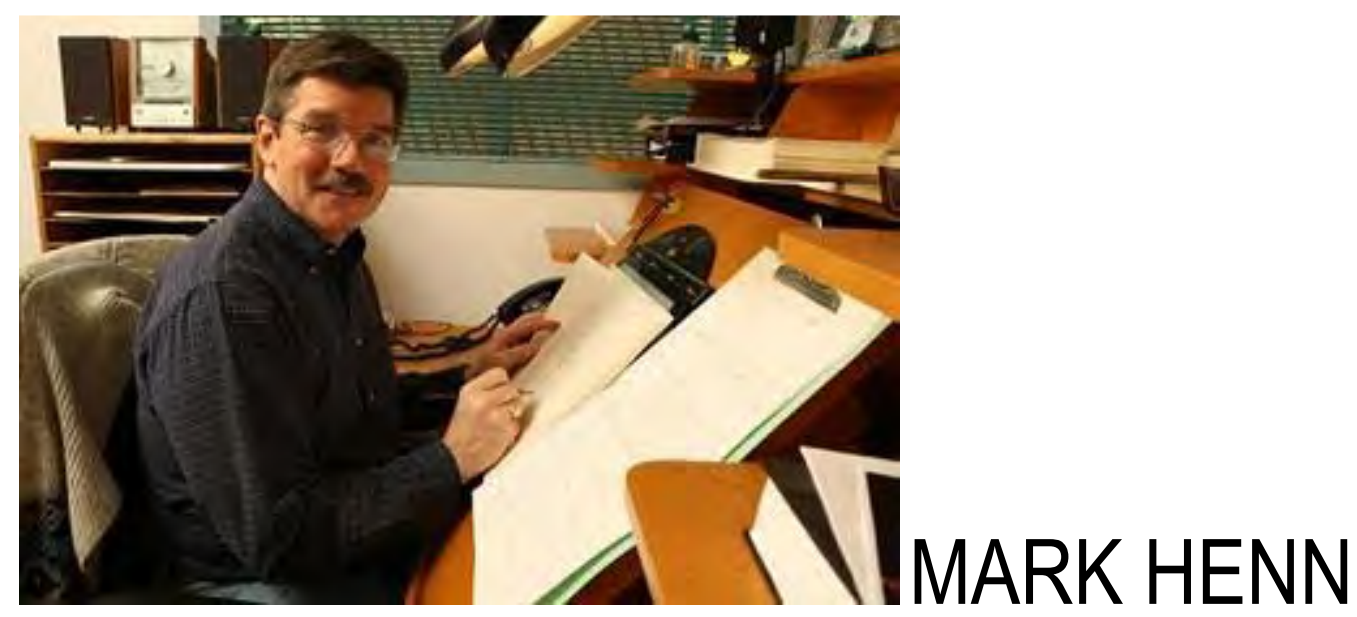

Figura 93 - Mark Henn

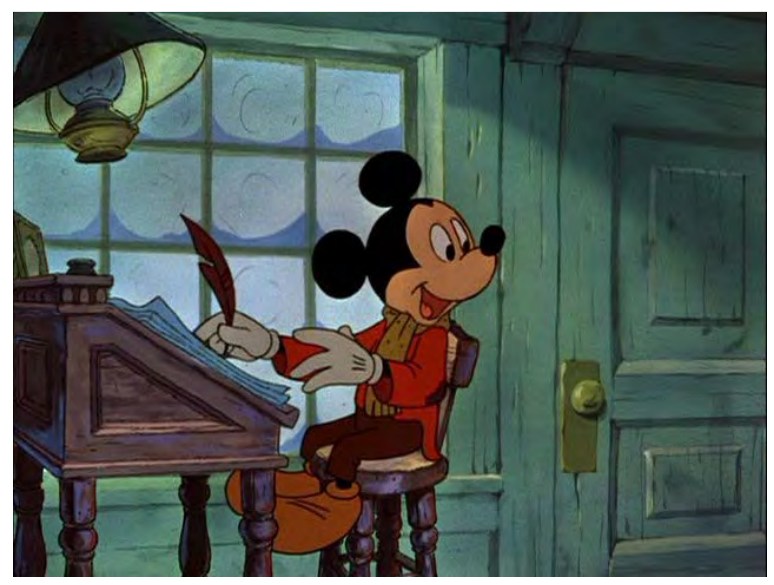

Figura 94 - Mickey Mouse no curta-metragem "O Natal de Mickey Mouse” (1983).

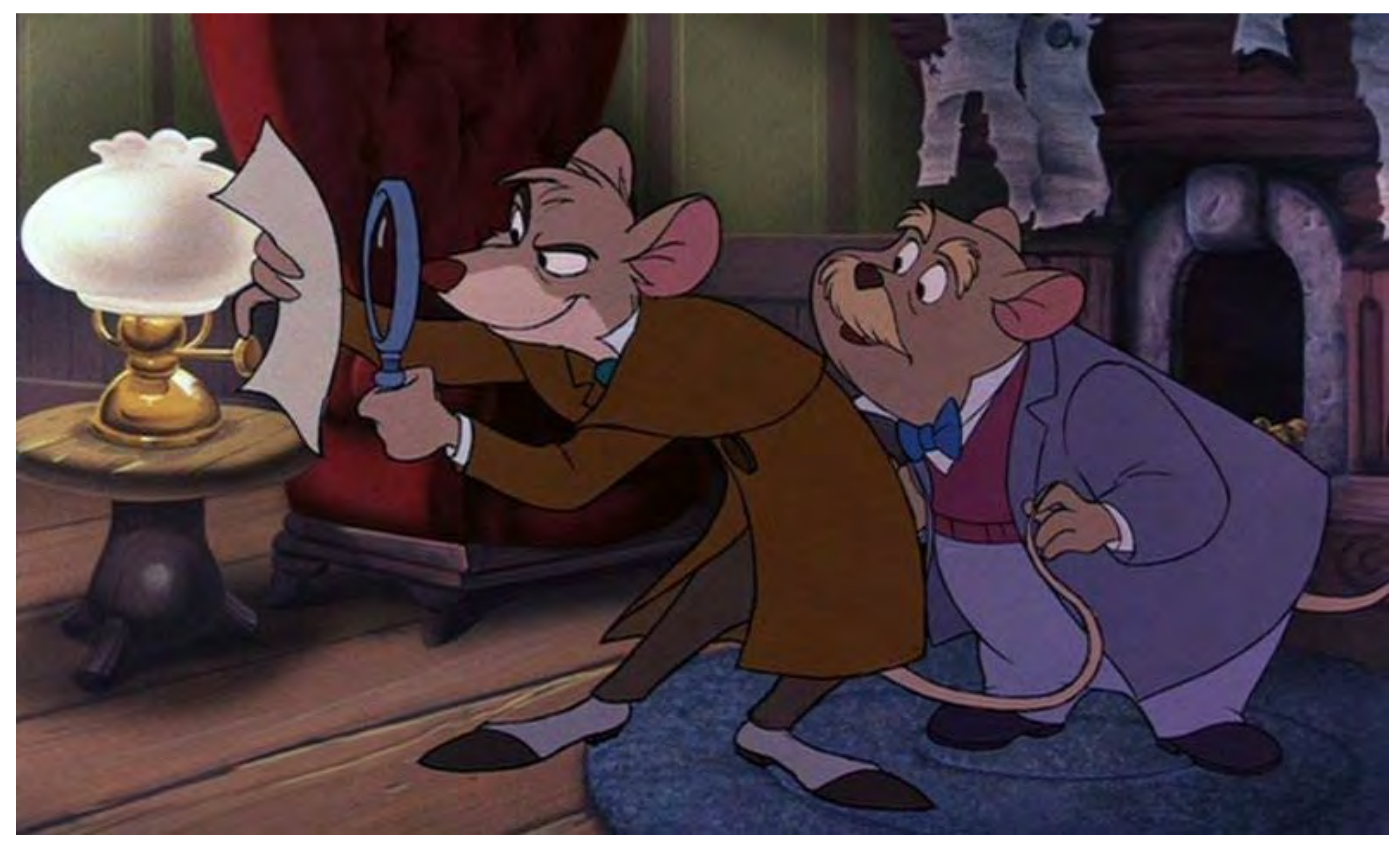

Figura 95 - Detetive Basil e Watson (“O Ratinho Detetive”, 1986). 

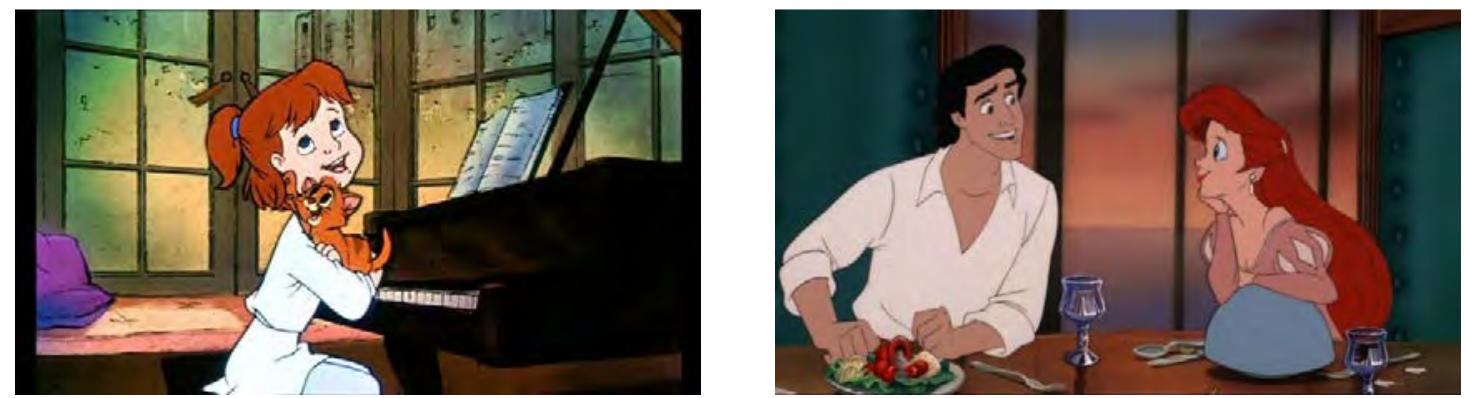

Figura 96 - Jenny e Oliver (“Oliver e sua Turma”, 1988). Figura 97 - Ariel na cena do jantar (“A Pequena Sereia", 1989).
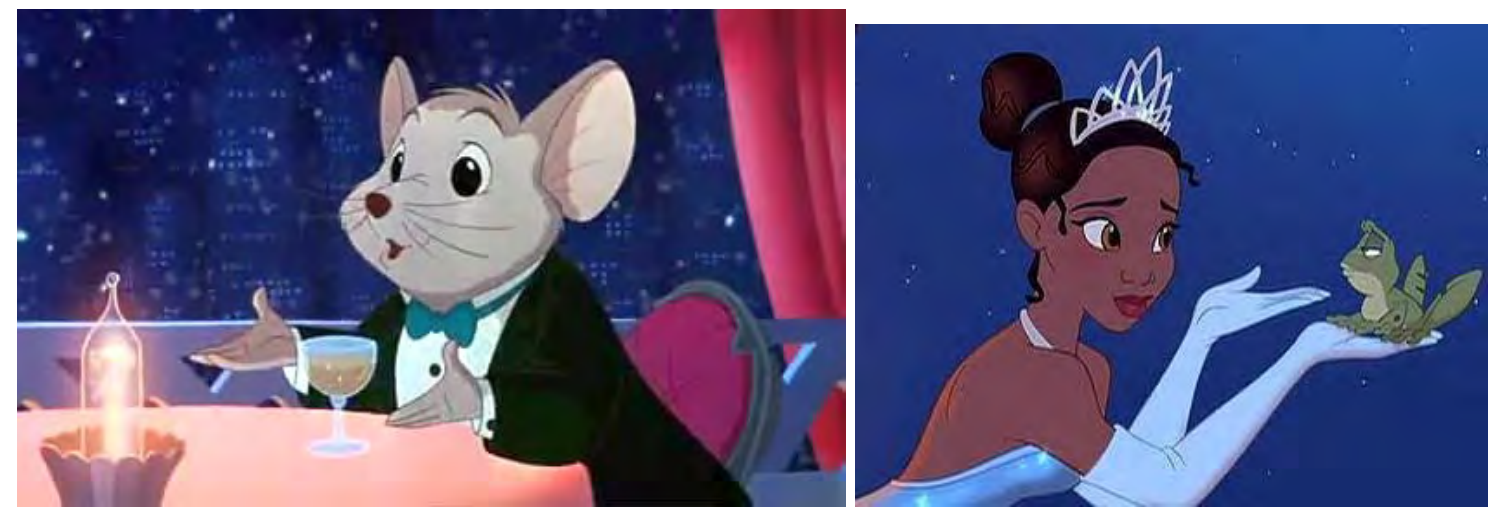

Figura 98 - Bernardo ("Bernardo e Bianca na Terra dos Cangurus", 1990). Figura 99 - Tiana ("A Princesa e o Sapo”, 2009).
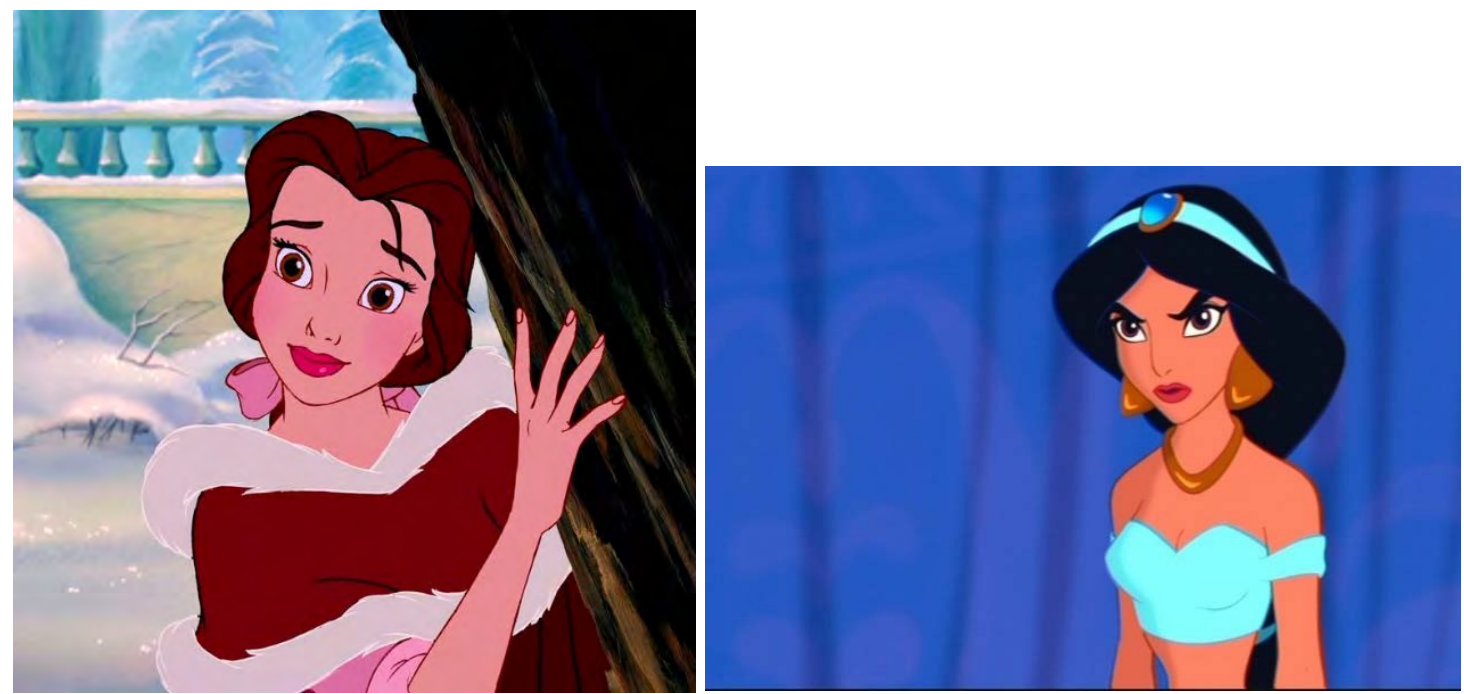

Figura 100 - Bela na sequência "Something There" ("A Bela e a Fera", 1991). Figura 101 Princesa Jasmine (“Aladdin”, 1992). 


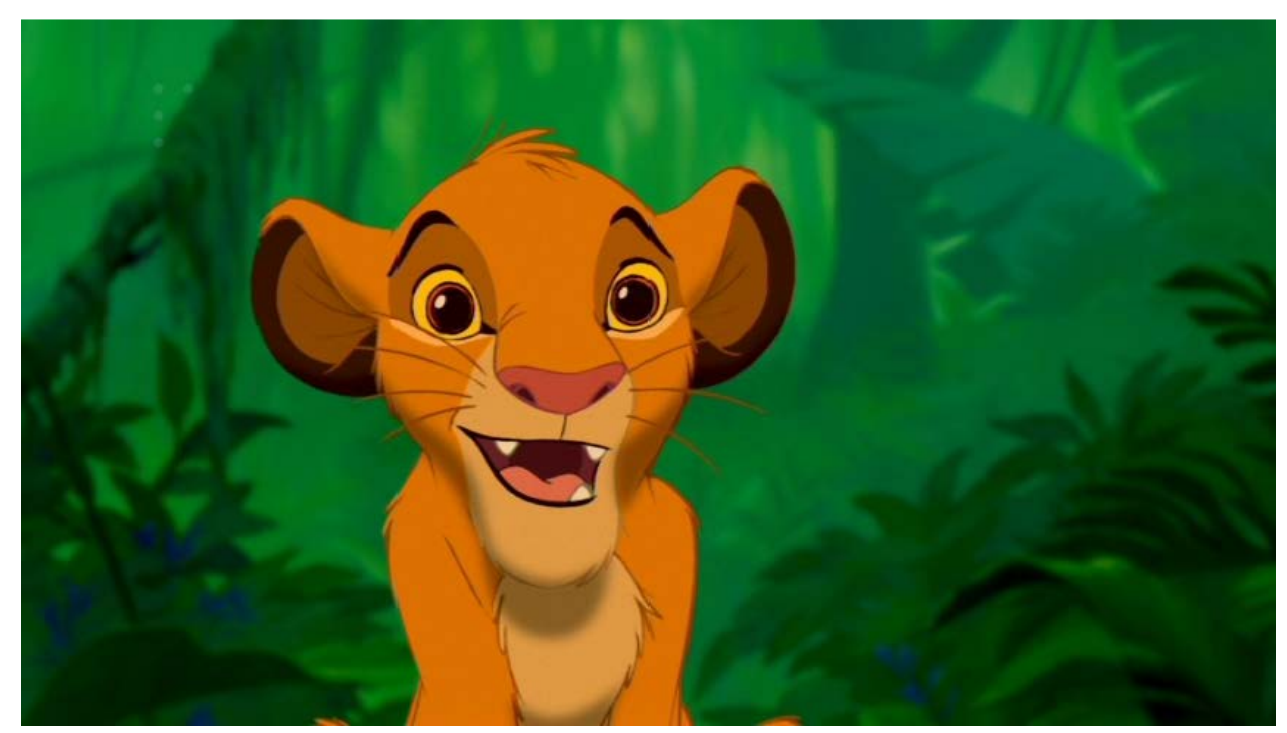

Figura 102 - O jovem leão Simba (“O Rei Leão”, 1994).

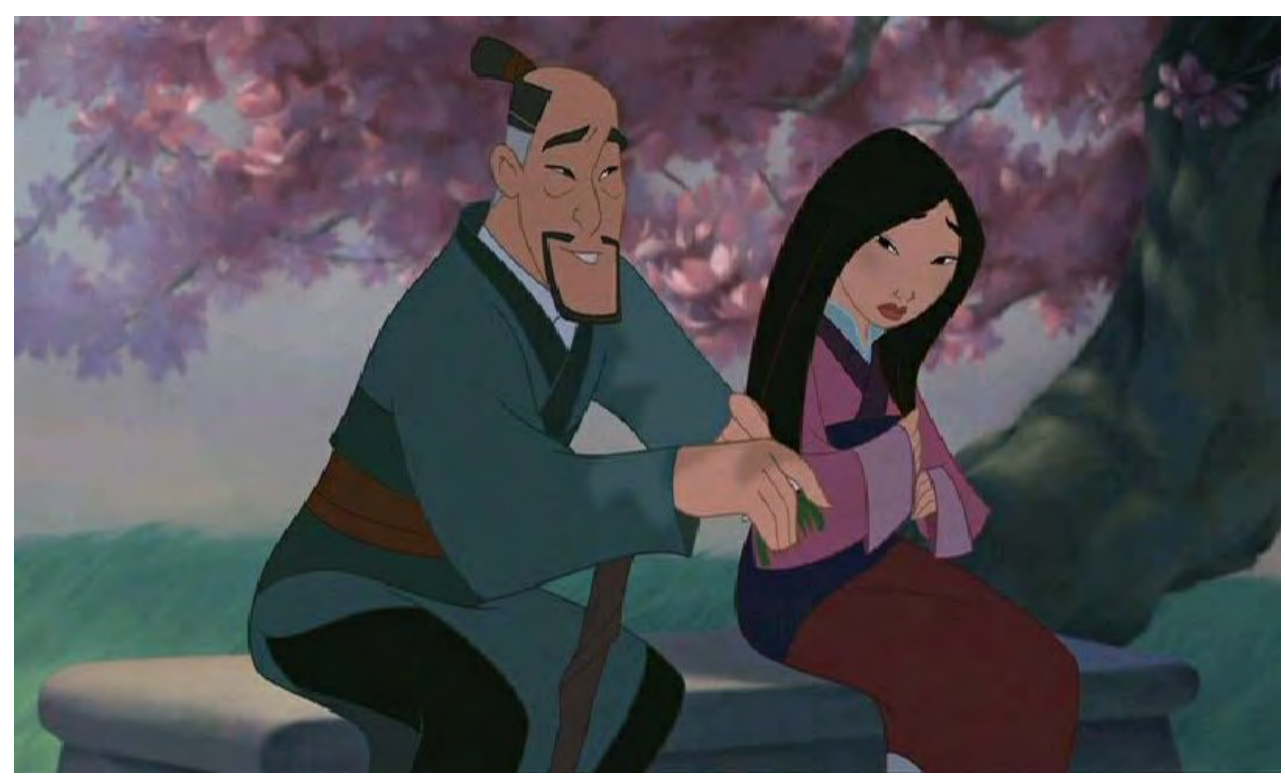

Figura 103 - Fa Zhou e sua filha Mulan (“Mulan”, 1998).

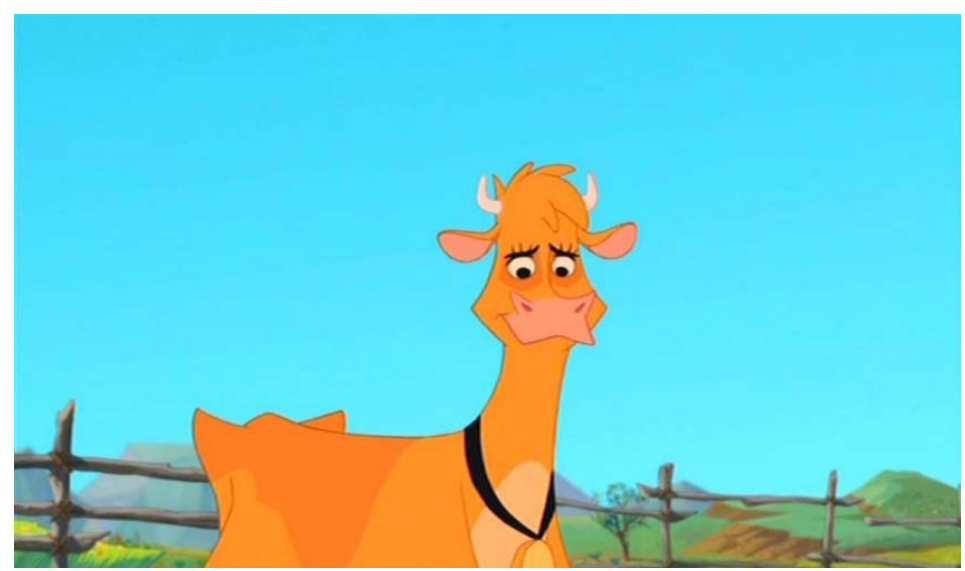

Figura 104 - Grace (“Nem que a Vaca Tussa”, 2004). 


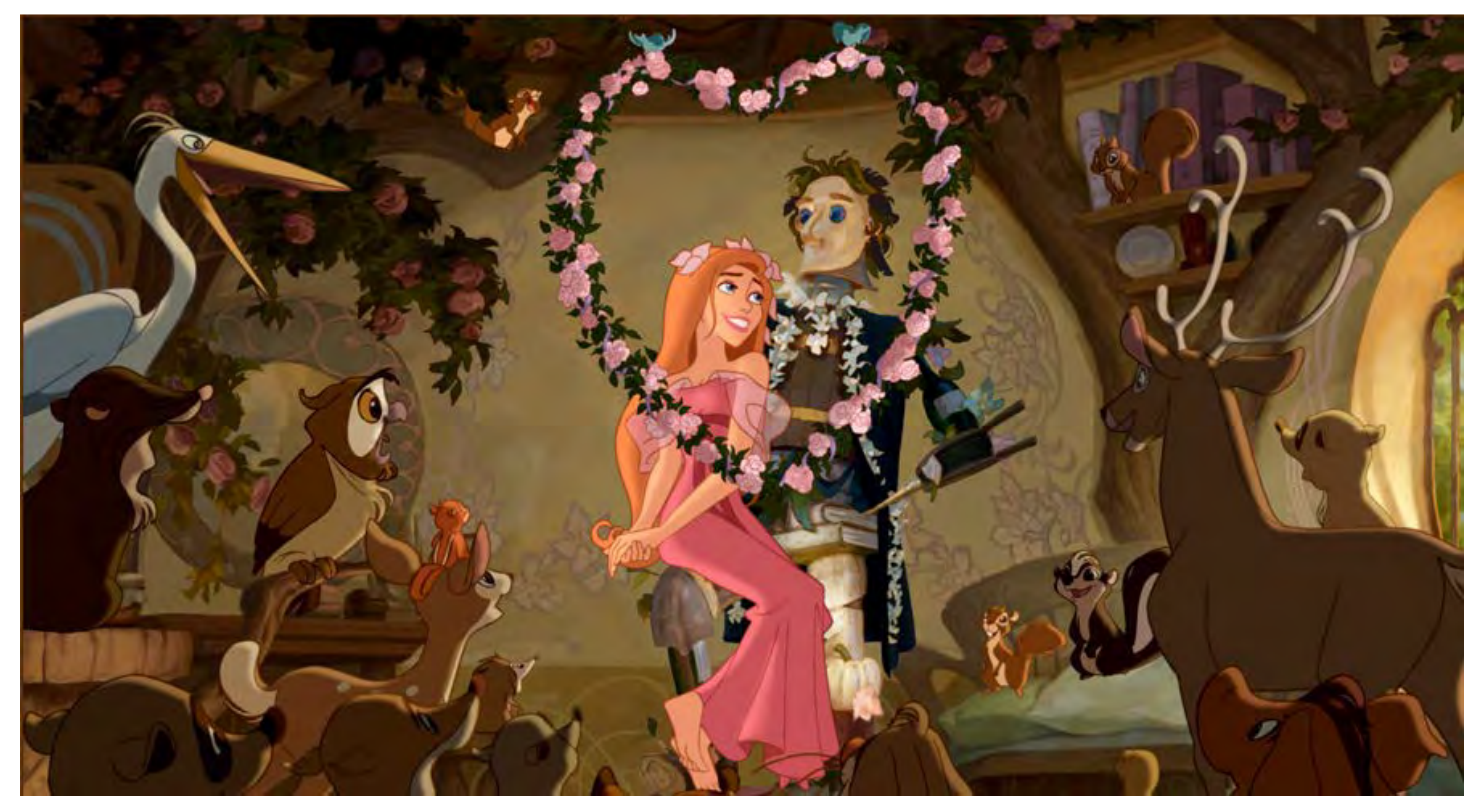

Figura 105 - Princesa Giselle (“Encantada”, 2007).

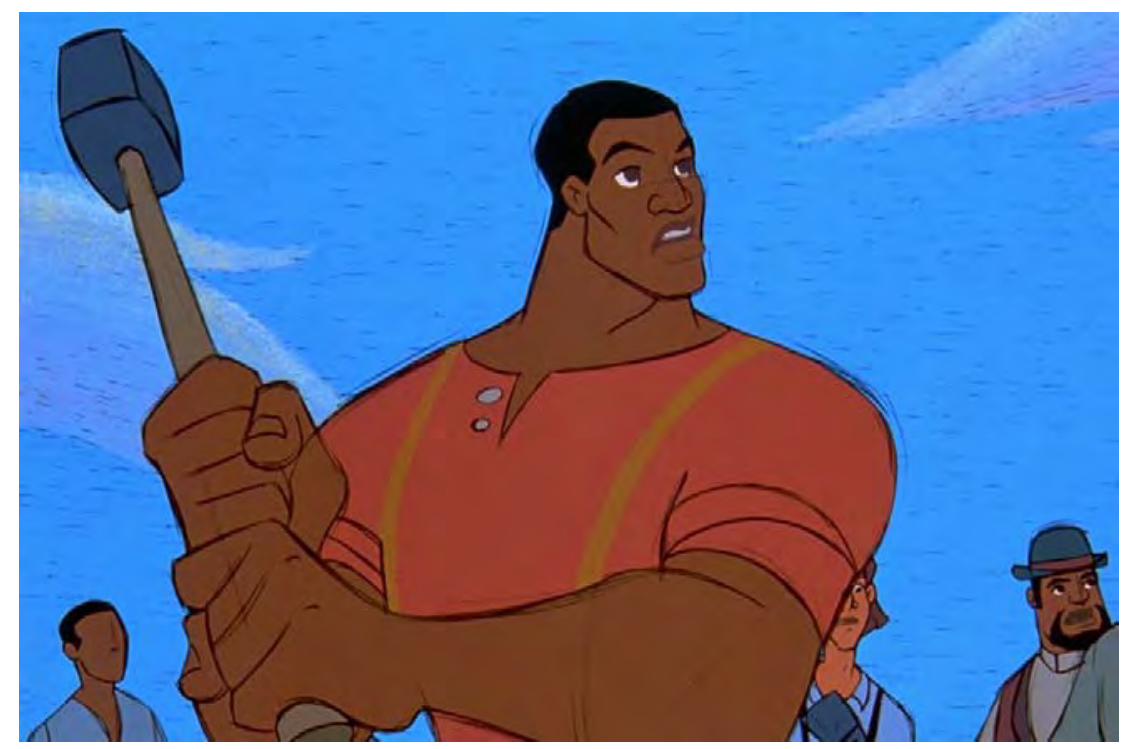

Figura 106 - Direção do curta-metragem “John Henry” (2000).

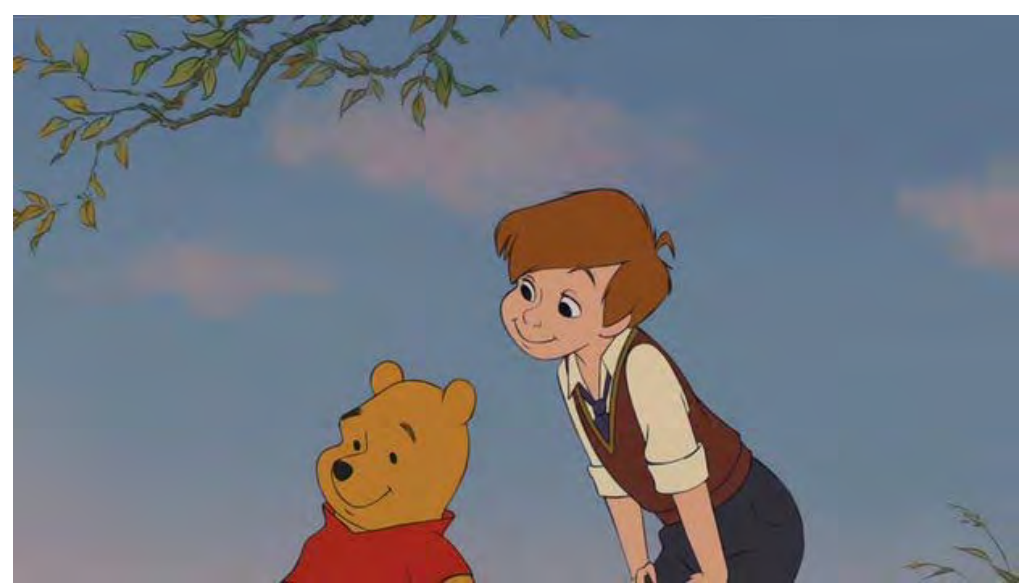

Figura 107 - Winnie the Pooh e Christopher Robin (“Ursinho Pooh”, 2011). 


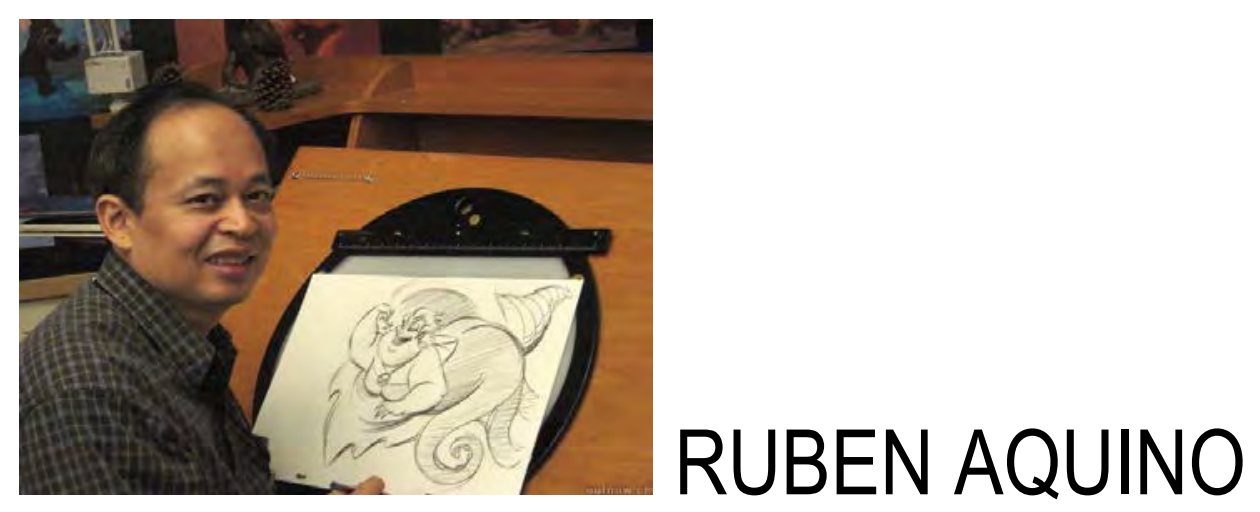

Figura 108 - Ruben Aquino

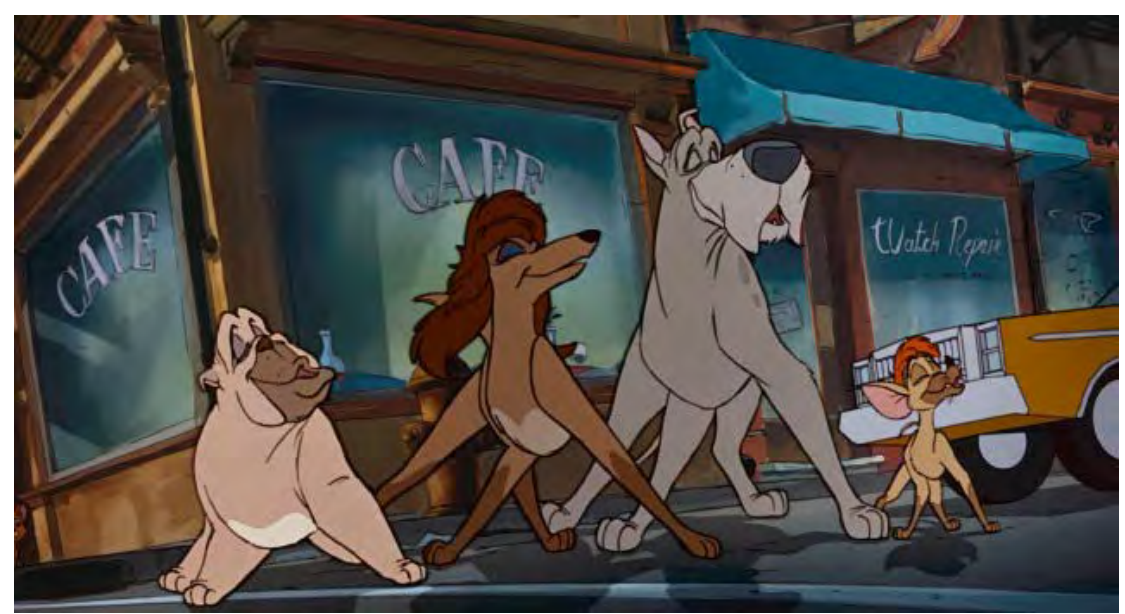

Figura 109 - Buldogue Francis (“Oliver e sua Turma”, 1988).

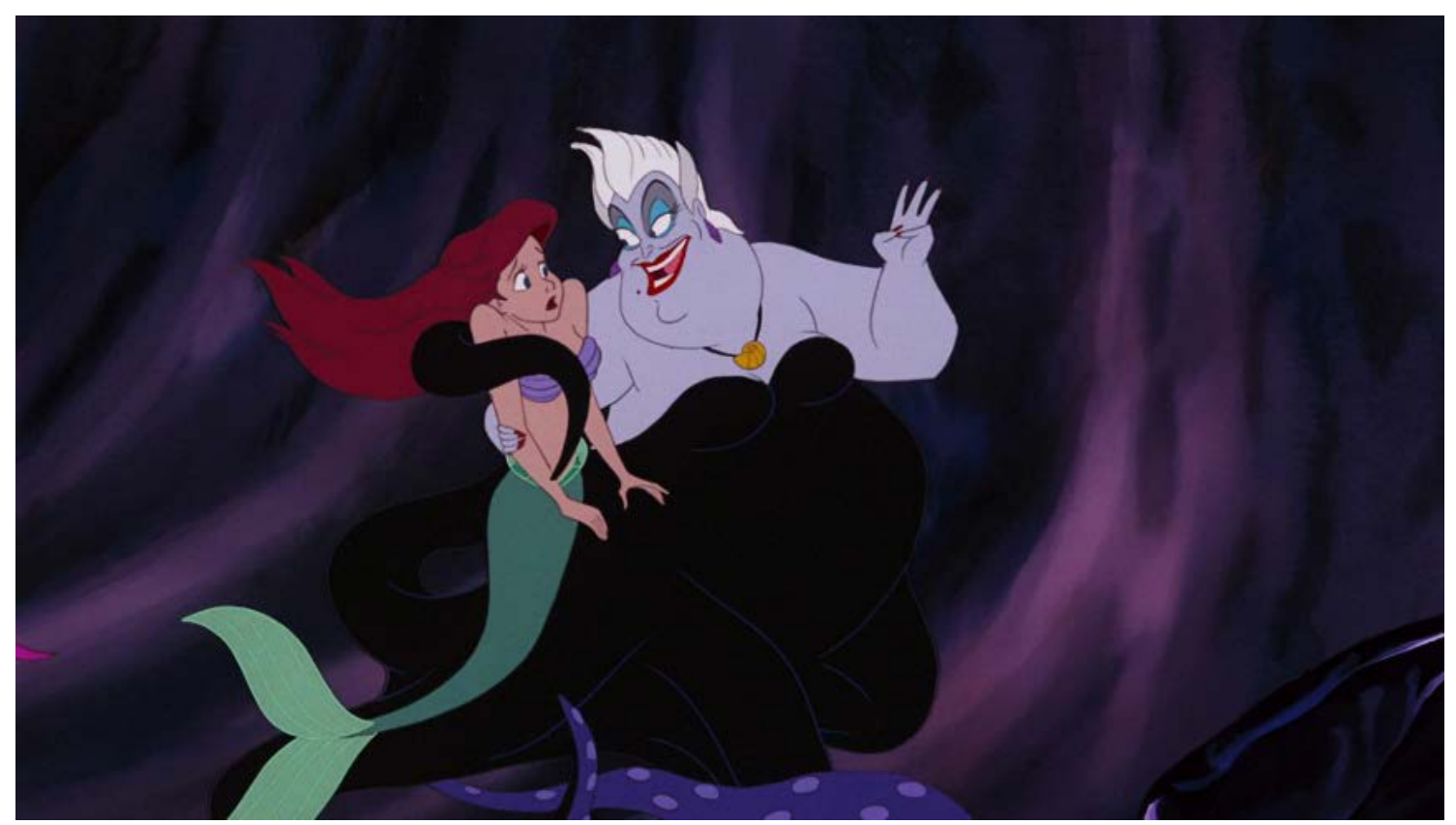

Figura 110 - Úrsula (“A Pequena Sereia”, 1989) 


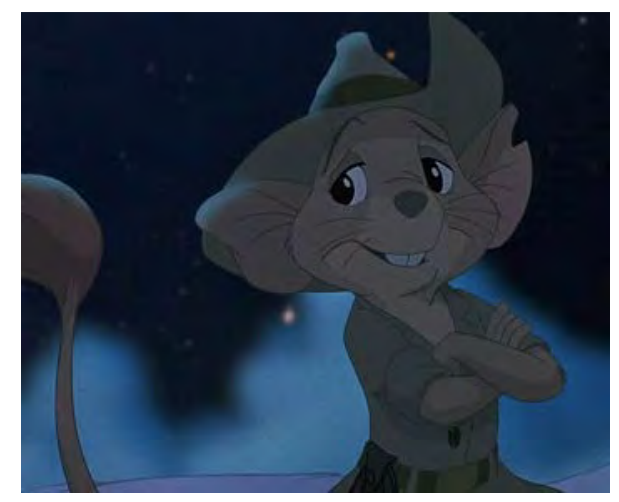

Figura 111 - Jake, o canguru ("Bernardo e Bianca na Terra dos Cangurus”, 1990).

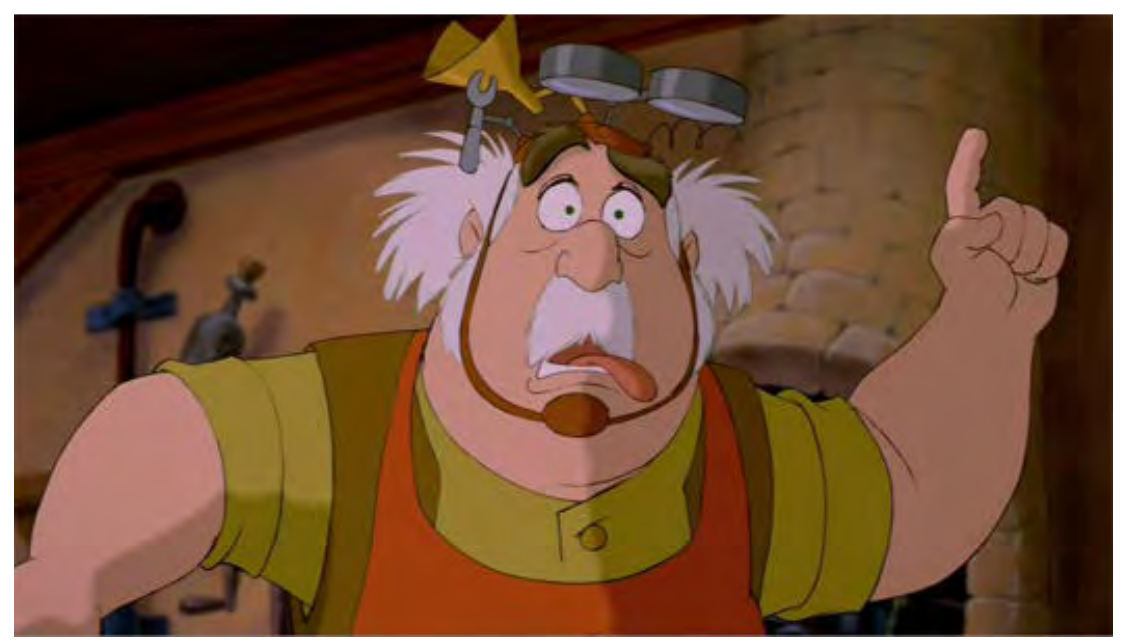

Figura 112 - Maurice (“A Bela e a Fera”, 1991).

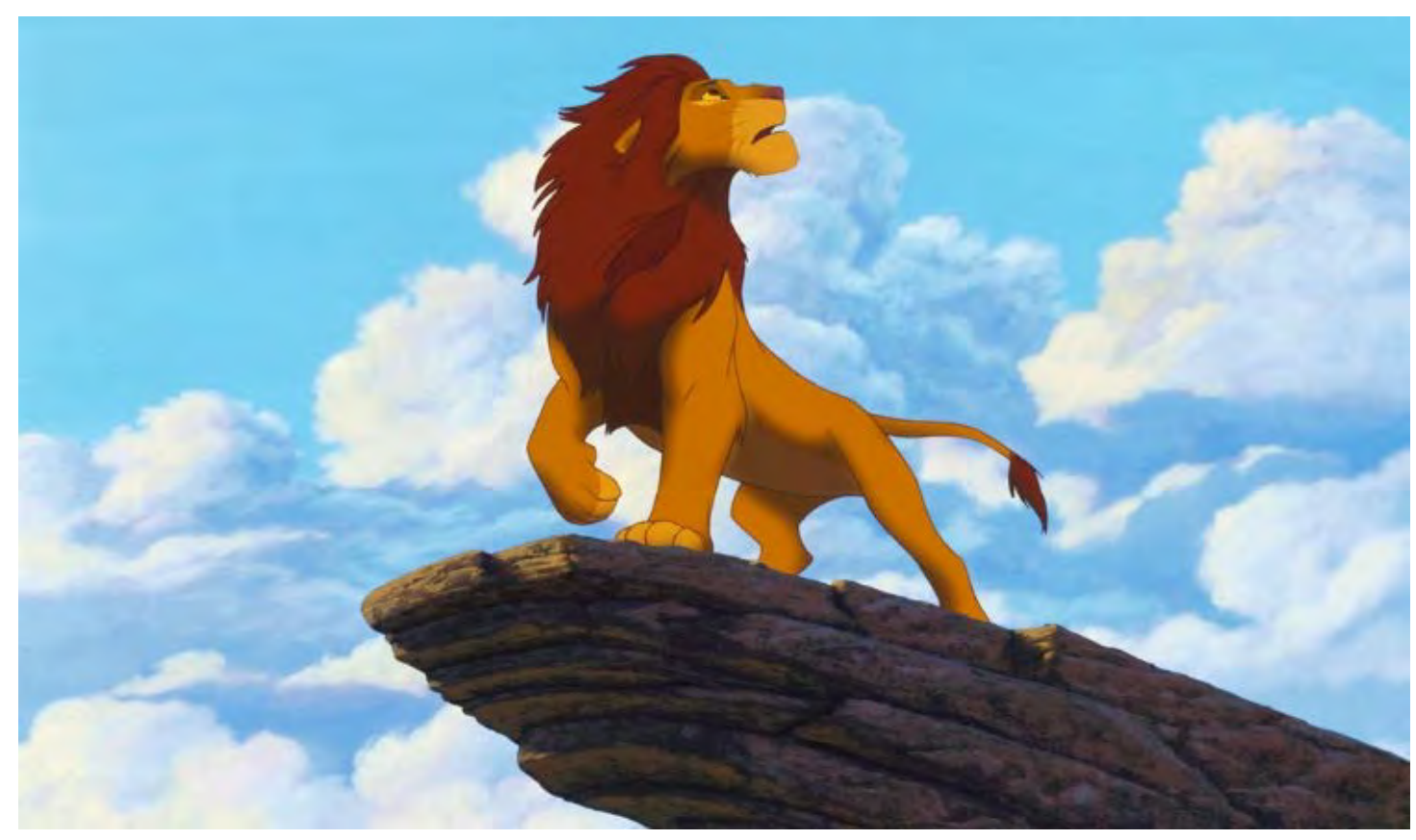

Figura 113 - Simba adulto (“O Rei Leão”, 1994). 


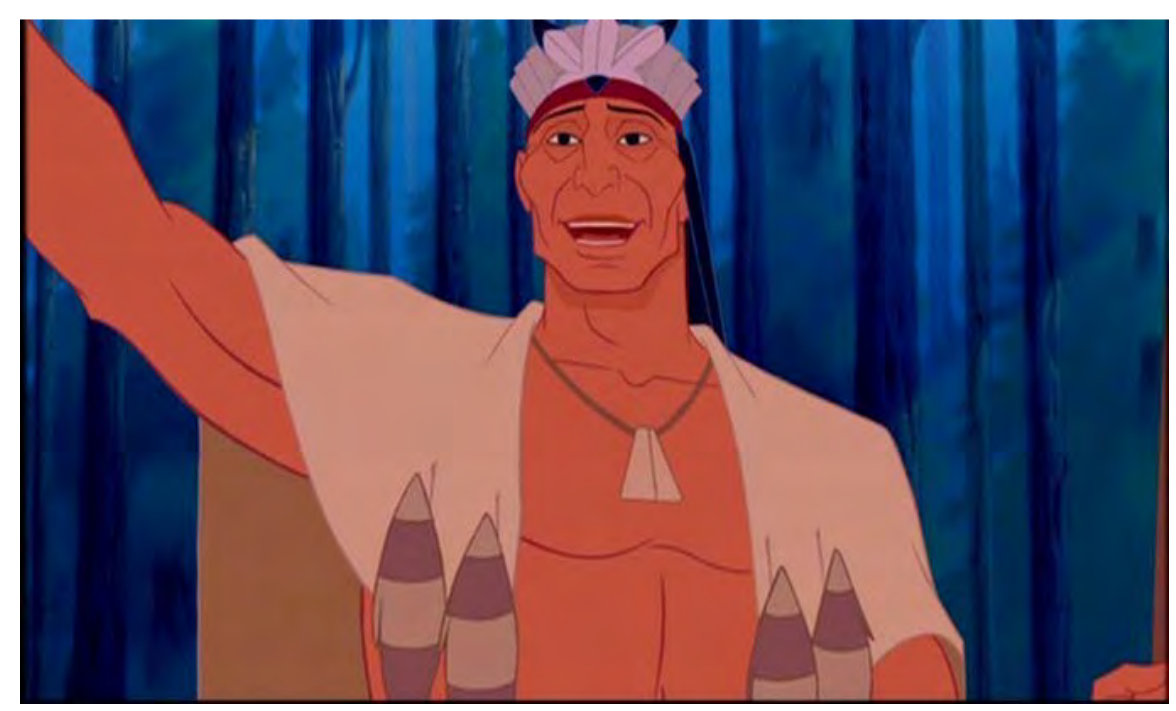

Figura 114 - Chefe Powhatan (“Pocahontas”, 1995).

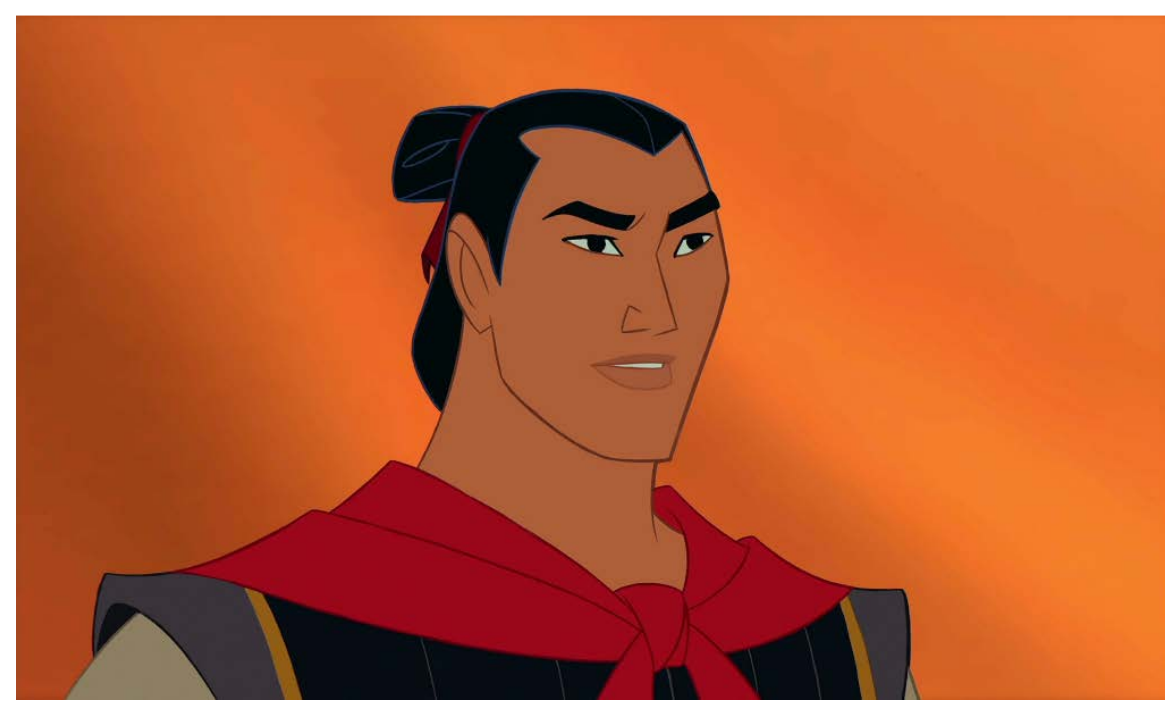

Figura 115 - Capitão Li Shang (“Mulan”, 1998)
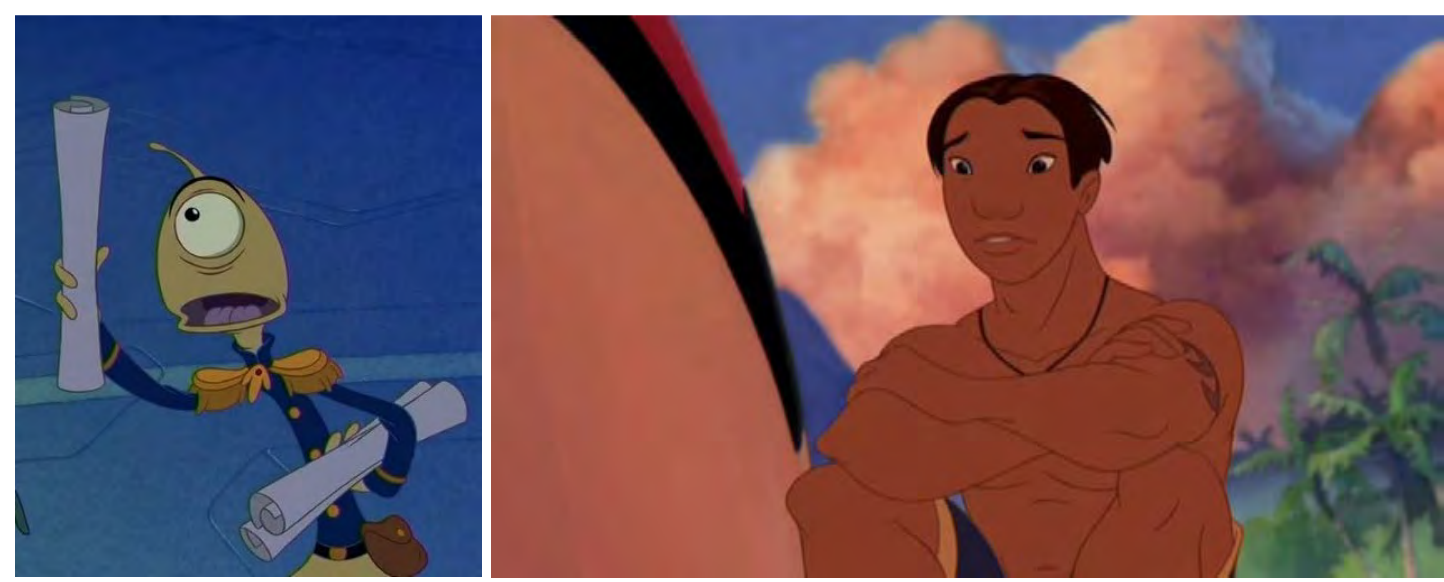

Figura 116 - Pleakley (“Lilo \& Stitch", 2002) e Figura 117 - David Kawena ("Lilo \& Stithc", 2002). 


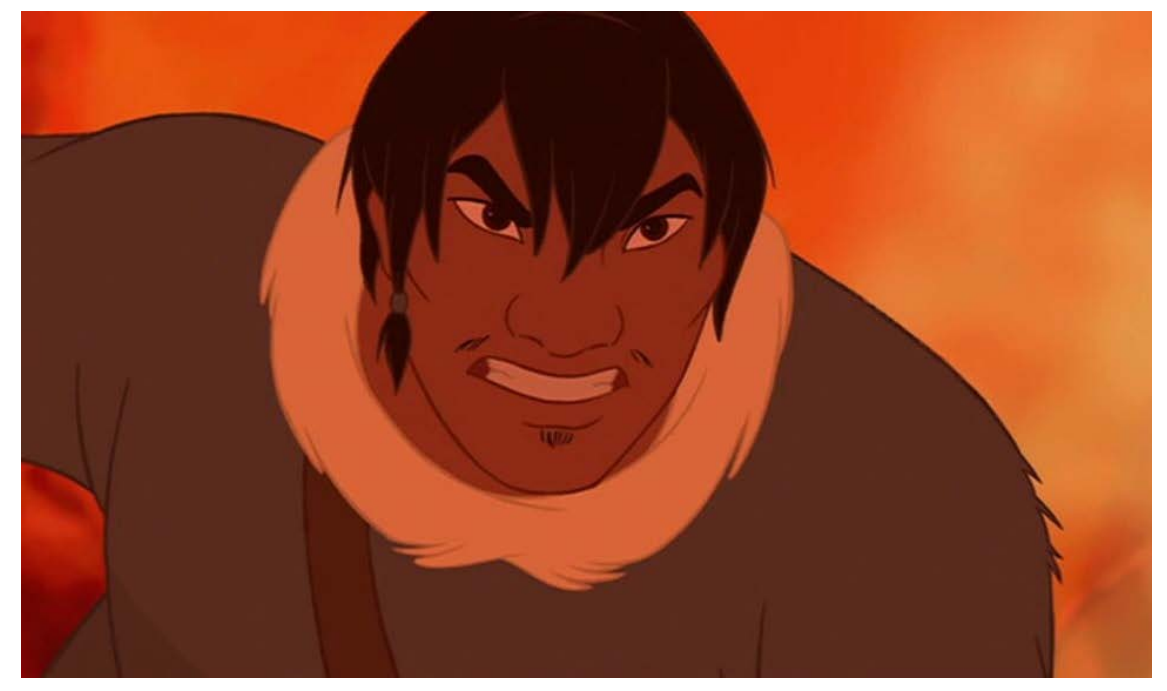

Figura 118 - Denahi (“Irmão Urso”, 2004).

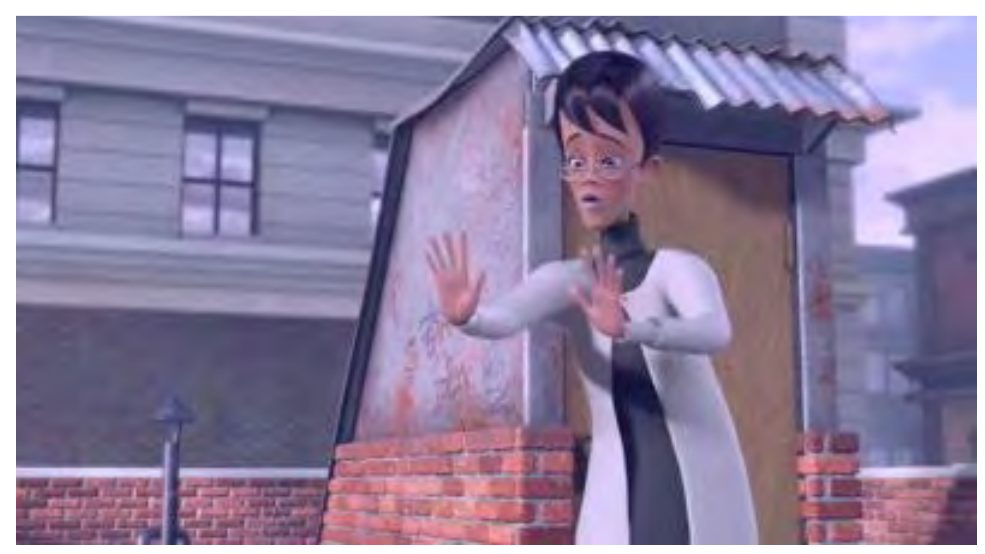

Figura 119 - Mildred (“A Família do Futuro”, 2007)

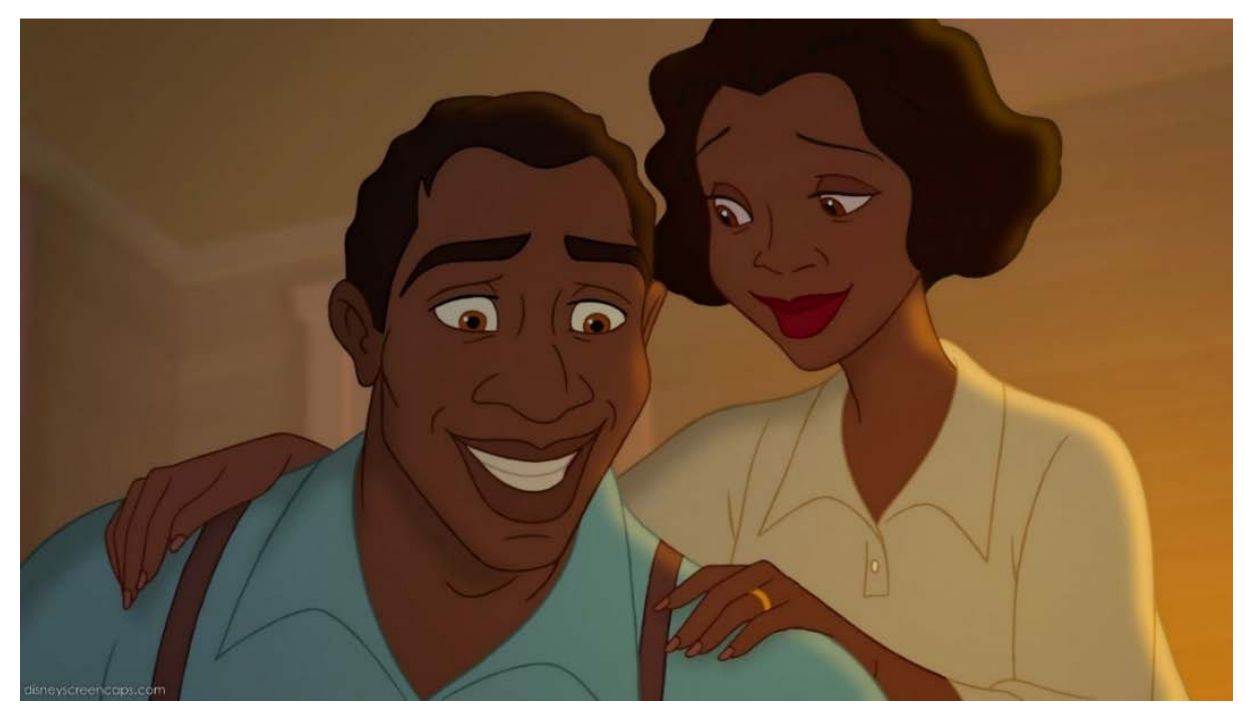

Figura 120 - James e Eudora (“A Princesa e o Sapo”, 2009). 


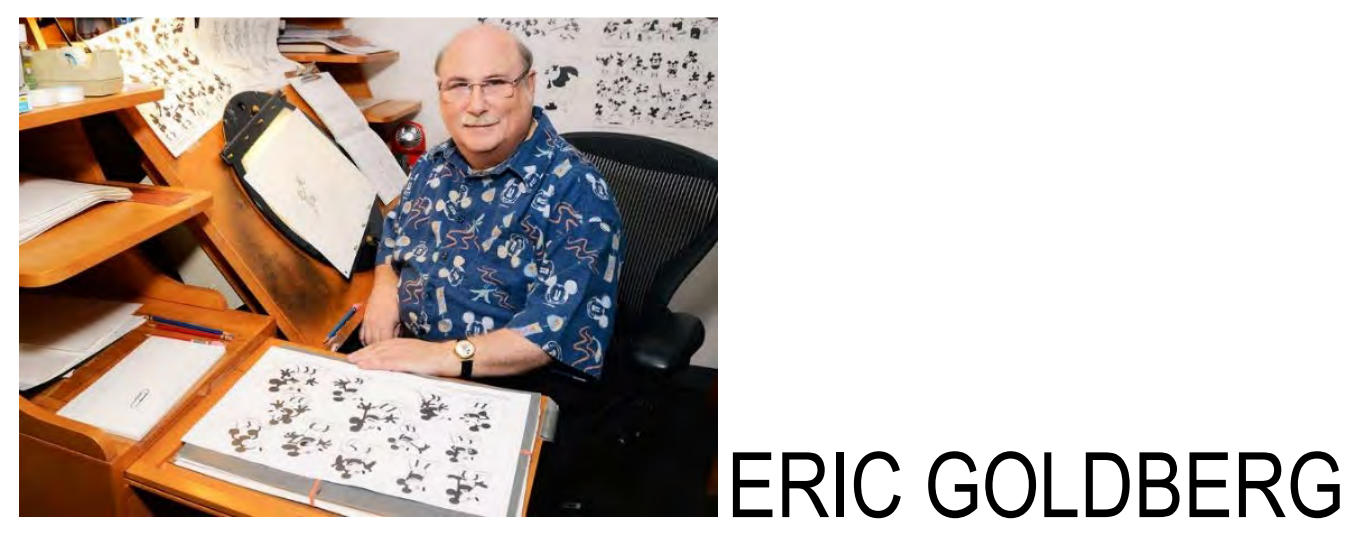

Figura 121 - Eric Goldberg

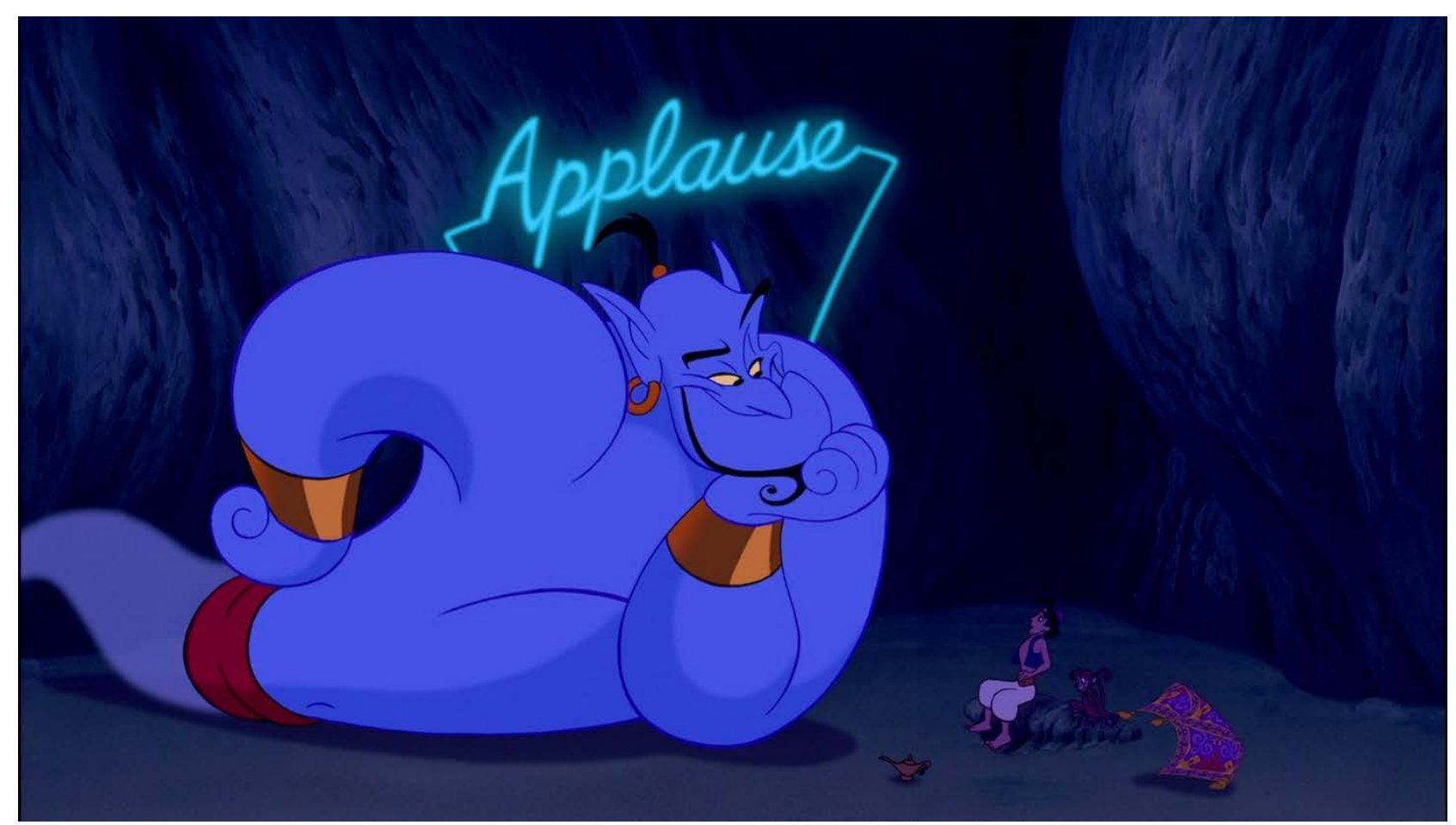

Figura 122 - Gênio (“Aladdin”, 1992).

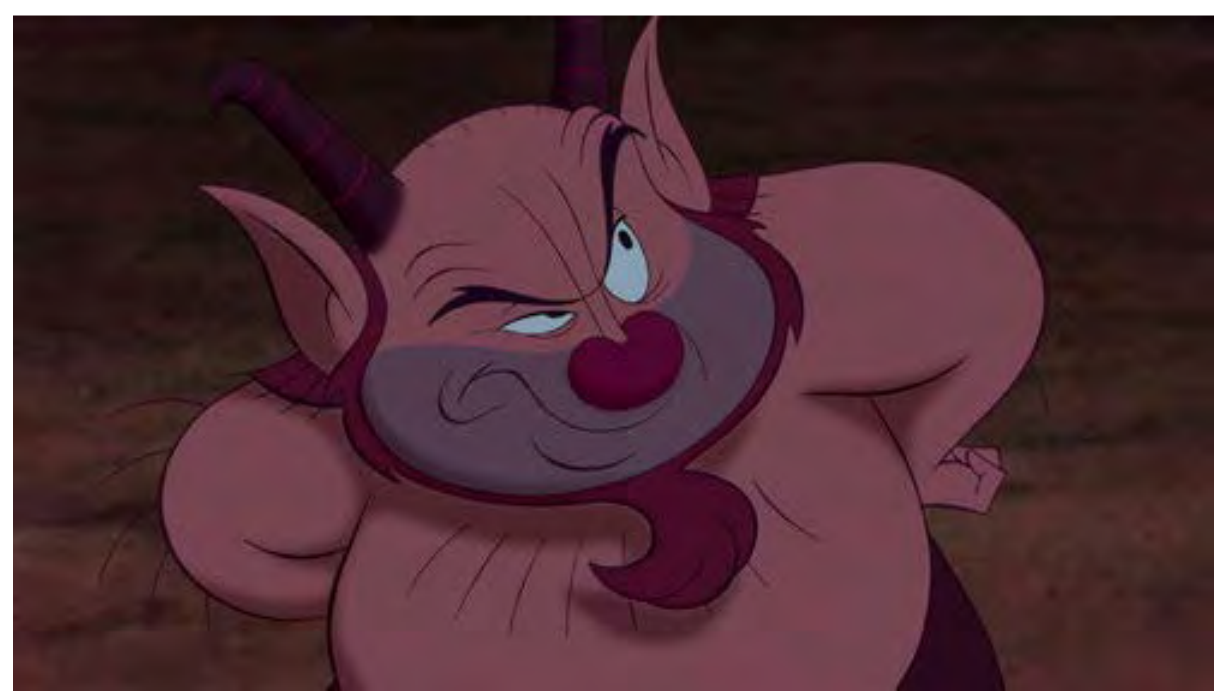

Figura 123 - Philoctetes (“Hercules”, 1997). 


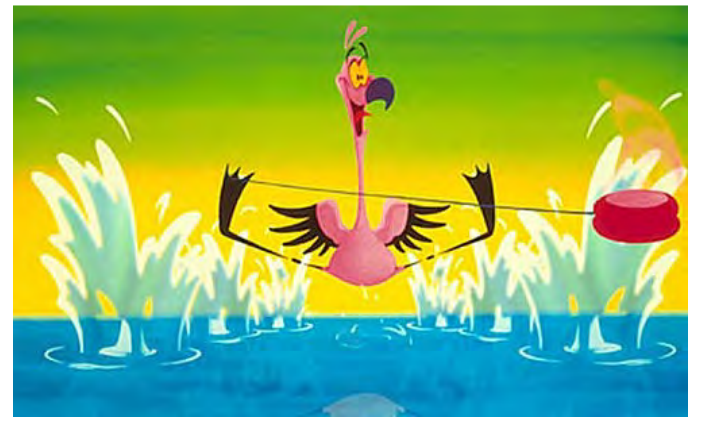

Figura 124 - O que um flamingo faria com um ioiô ("Fantasia 2000", 1999).

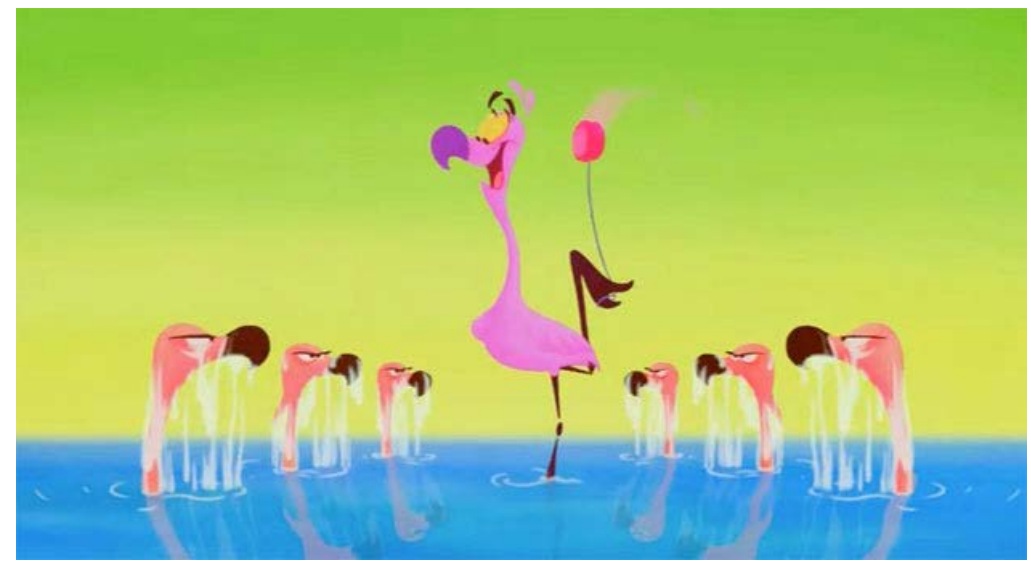

Figura 125 - Segmento "Carnaval dos Animais" (“Fantasia 2000”, 1999).
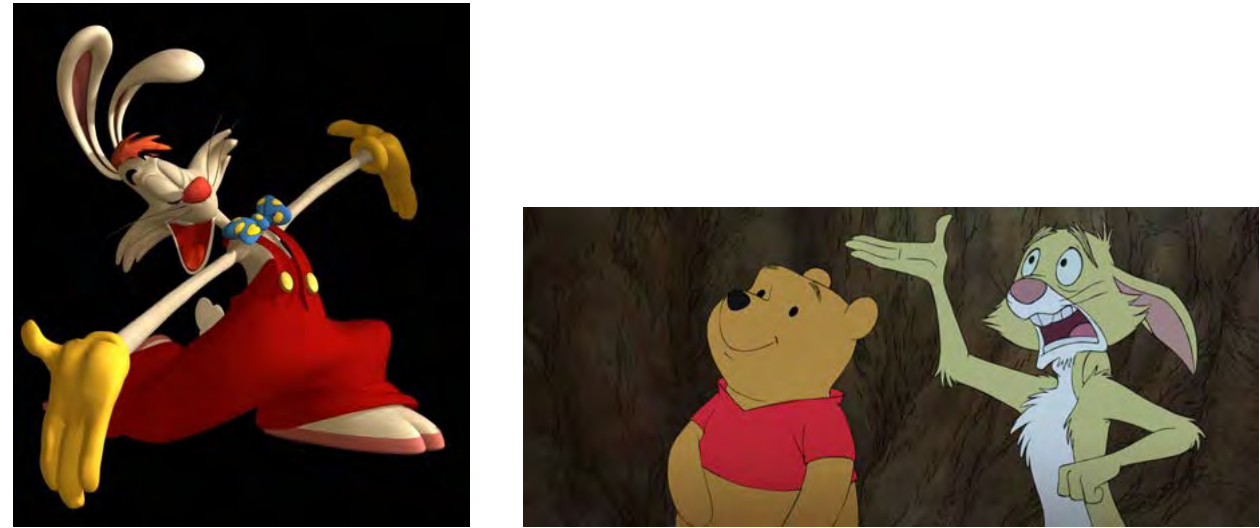

Figura 126 - Teste para um novo filme com Roger Rabbit computadorizado (1999). Figura 127 - Coelho ("Ursinho Pooh", 2010).

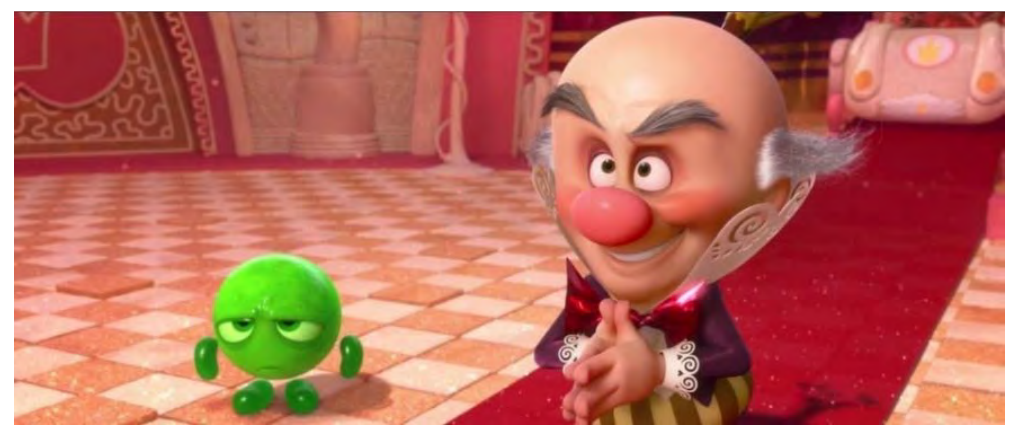

Figura 128 - Amargo Bill e Rei Doce (“Detona Ralph”, 2012). 


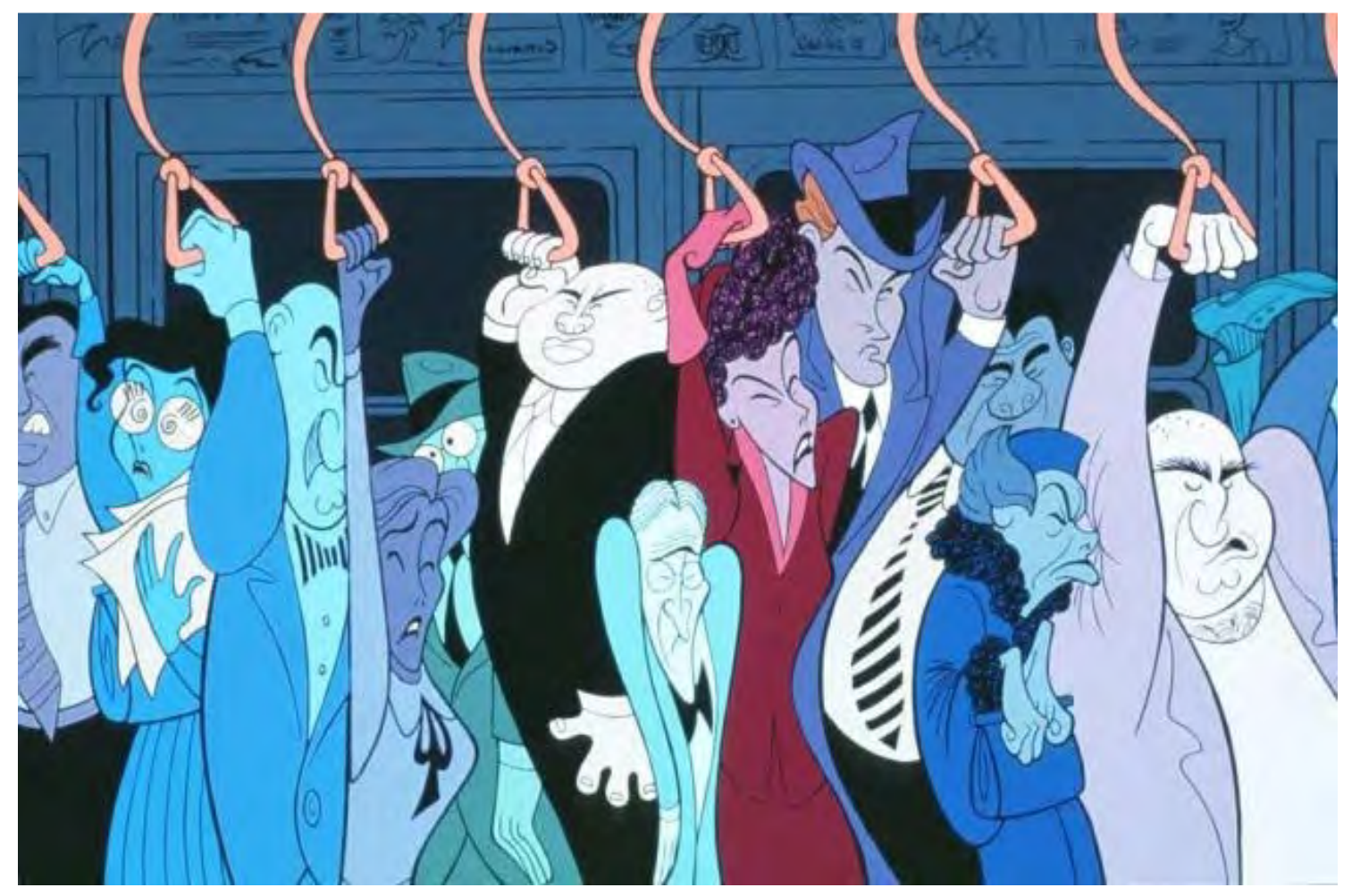

Figura 129 - Inspirado nos traços do caricaturista Al Hirschfeld, segmento "Rhapsody in Blue" ("Fantasia 2000, 1999).
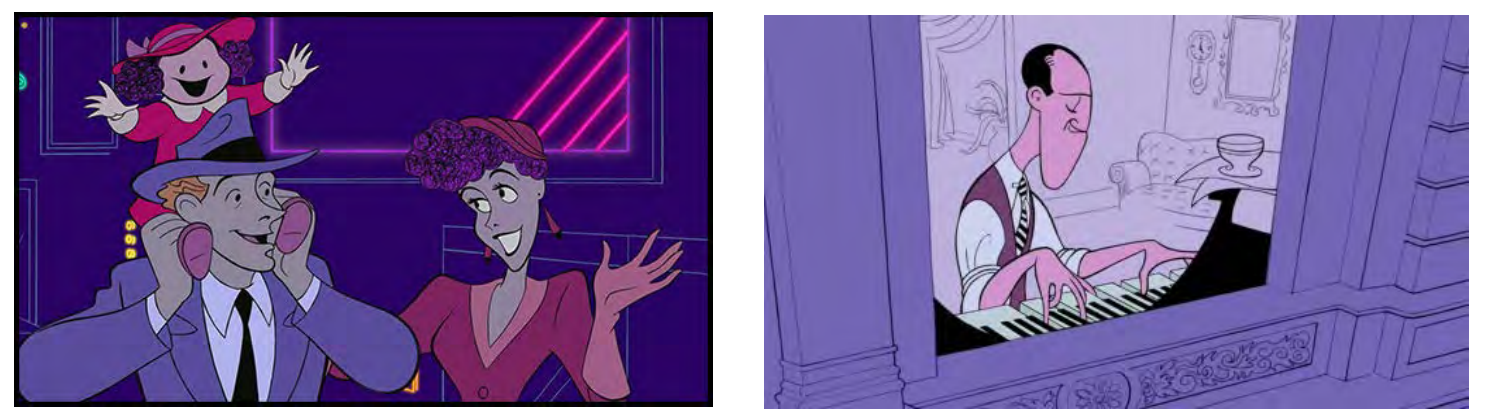

Figura 130 - "Rhapsody in Blue". Figura 131 - George Gershwin ("Fantasia 2000", 1999).

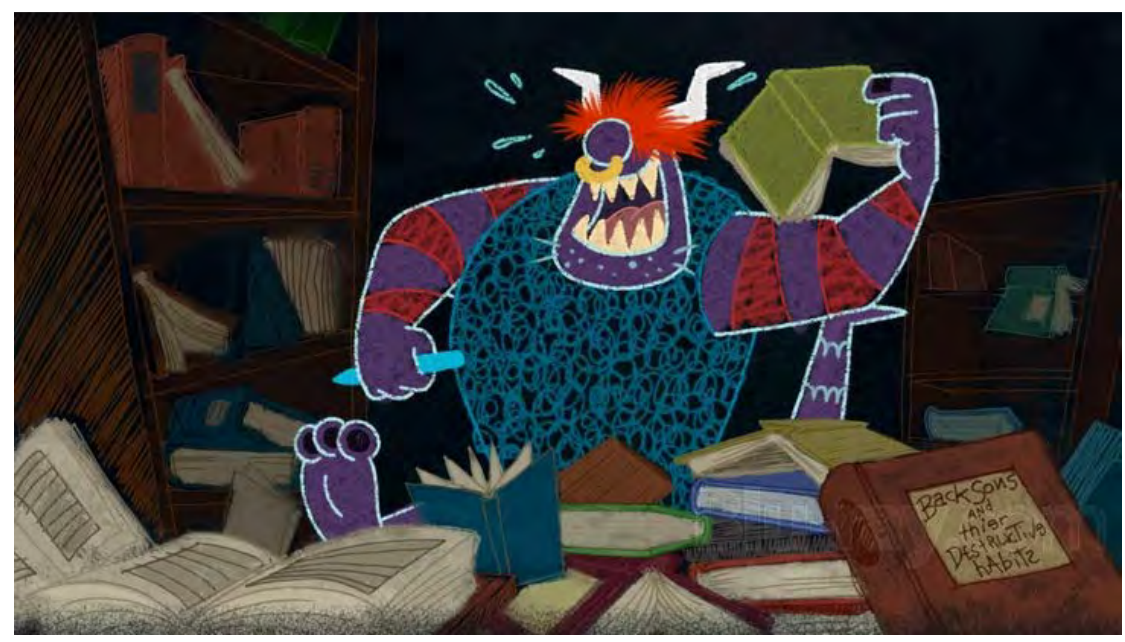

Figura 132 - Sequência do monstro Voltogo ("Ursinho Pooh”, 2010). 


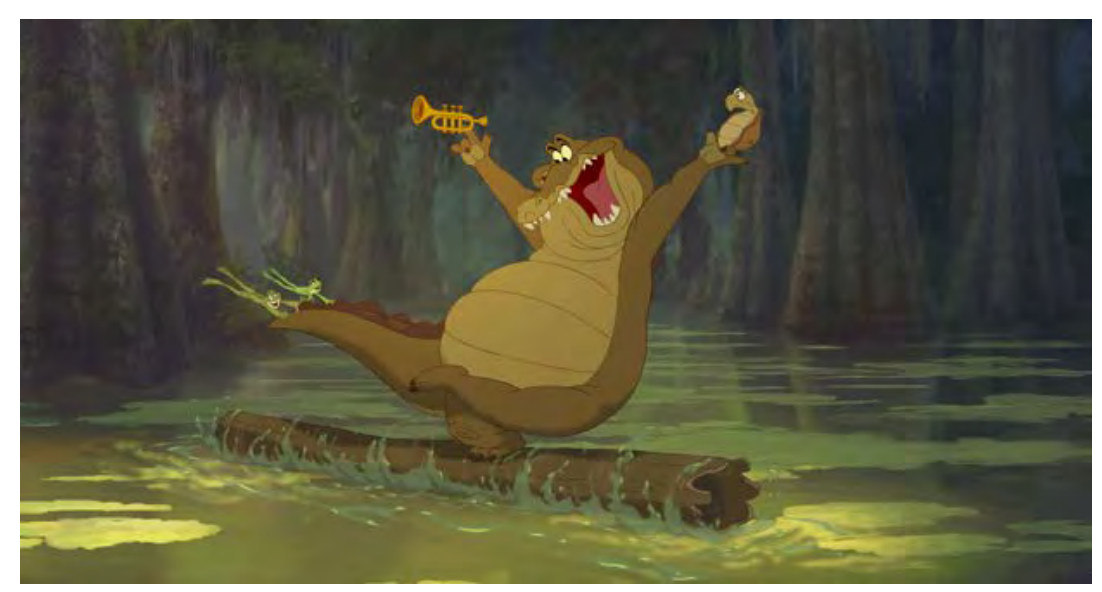

Figura 133 - Crocodilo Louis (“A Princesa e o Sapo”, 2009).

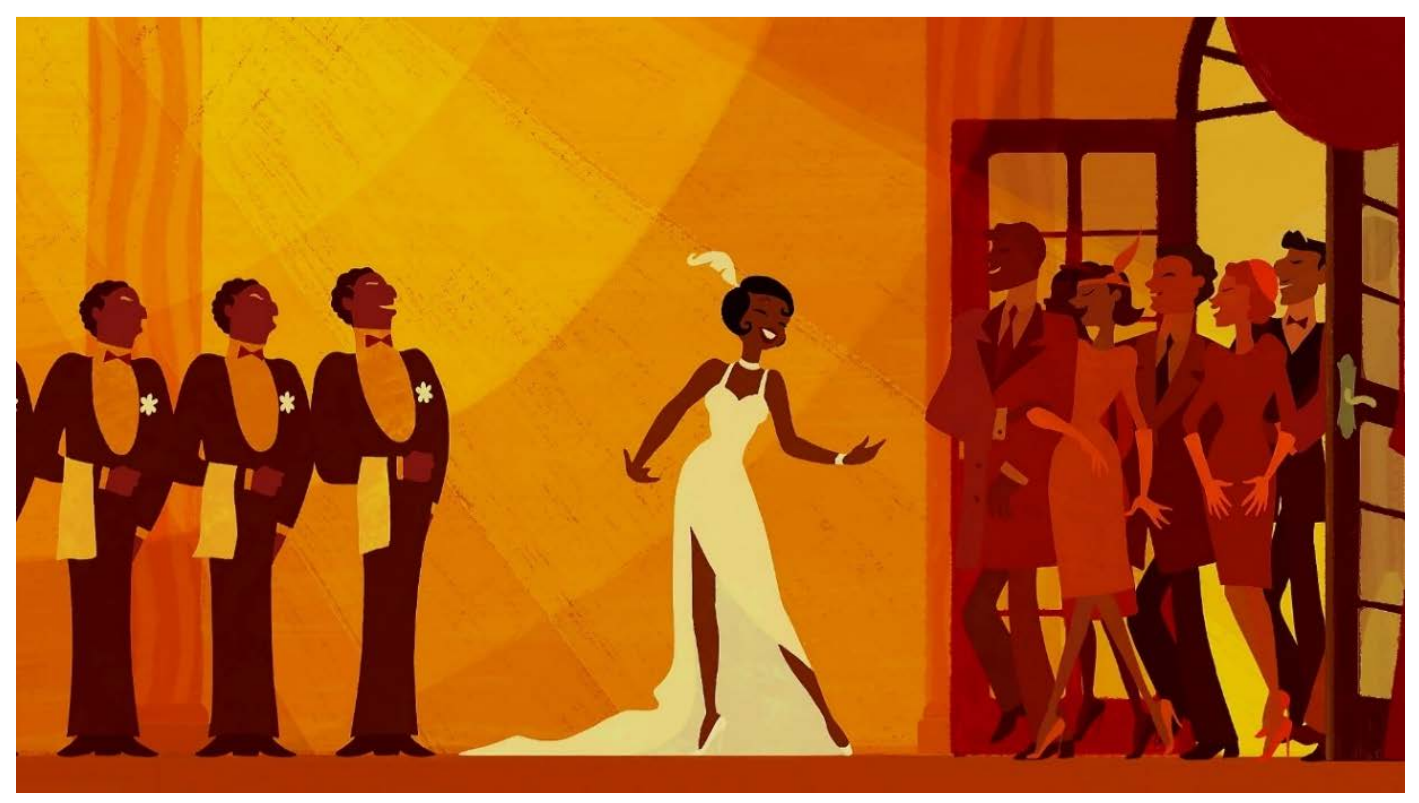

Figura 134 - Sequência "Almost there", inspirado nas pinturas do afro-americano Aaron Douglas. (“A Princesa e o Sapo", 2009).

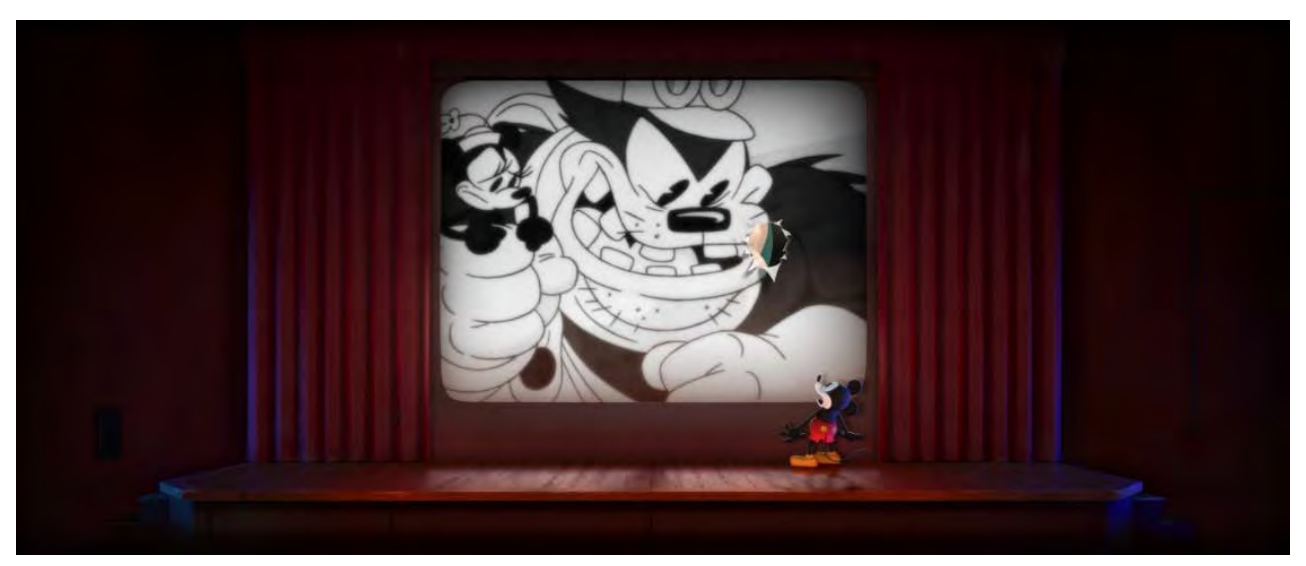

Figura 135 -João Bafo de Onça no curta-metragem "Hora de Viajar” (2014). 


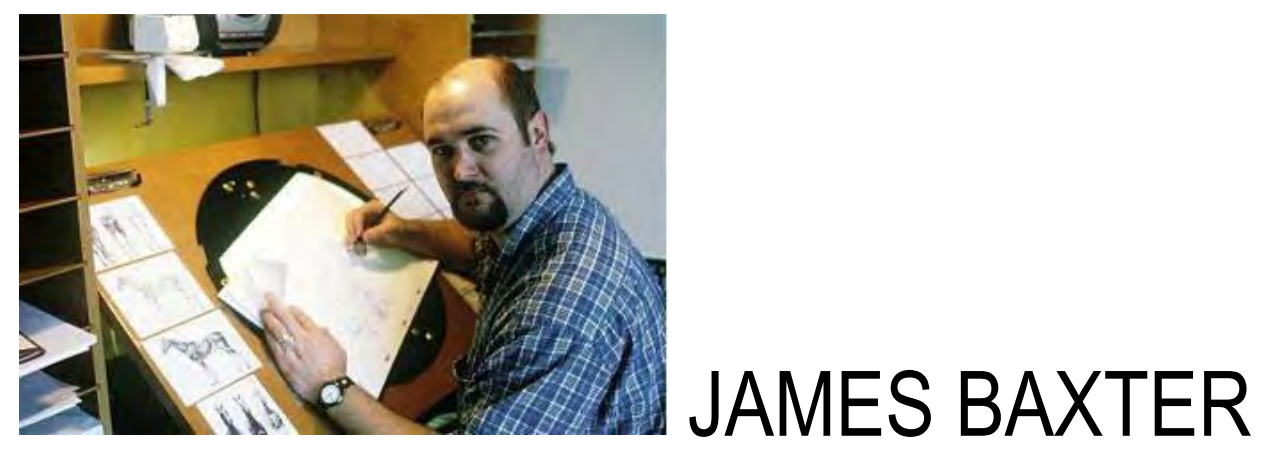

Figura 136 - James Baxter

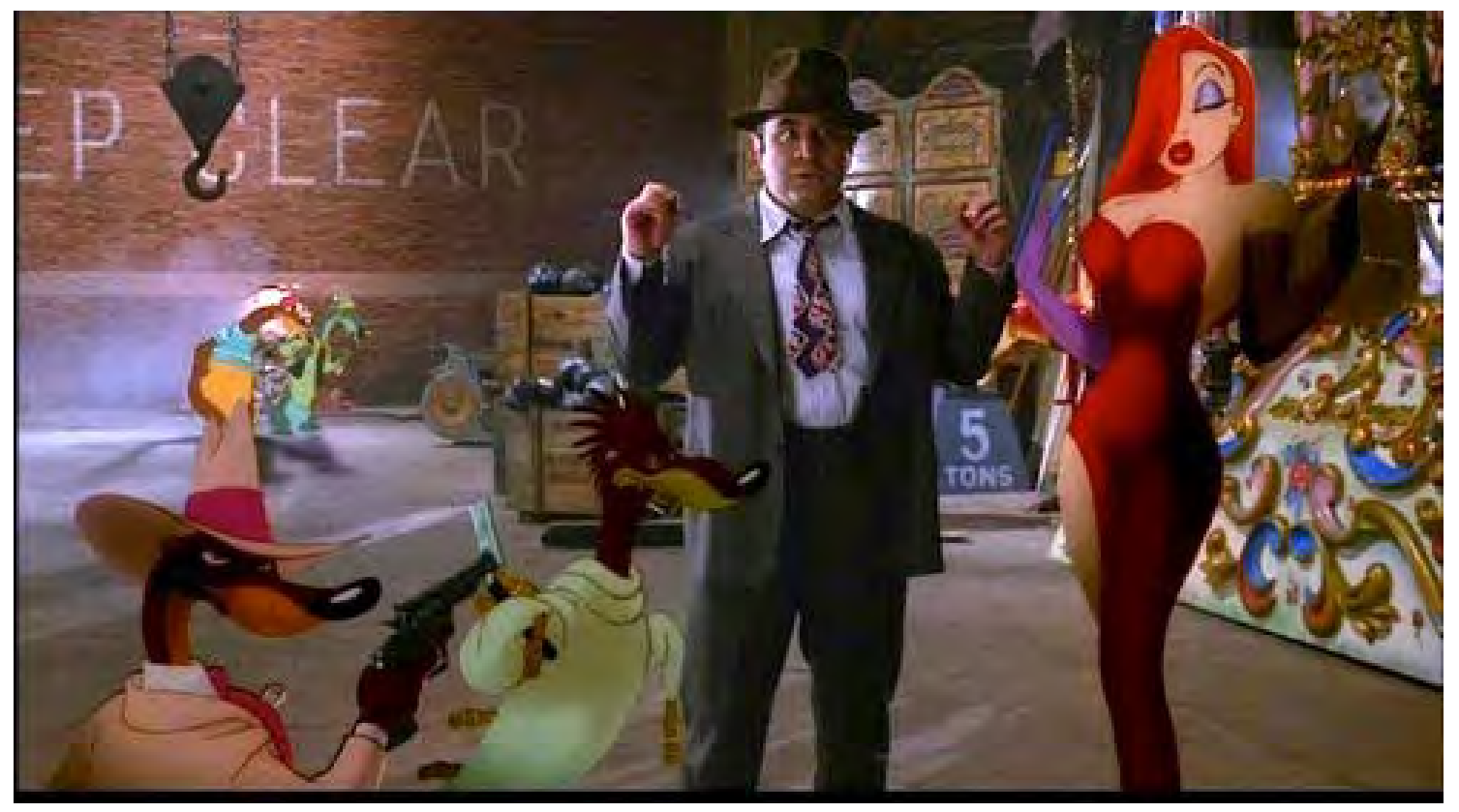

Figura 137 - Doninhas (“Uma Cilada para Roger Rabbit”, 1988).
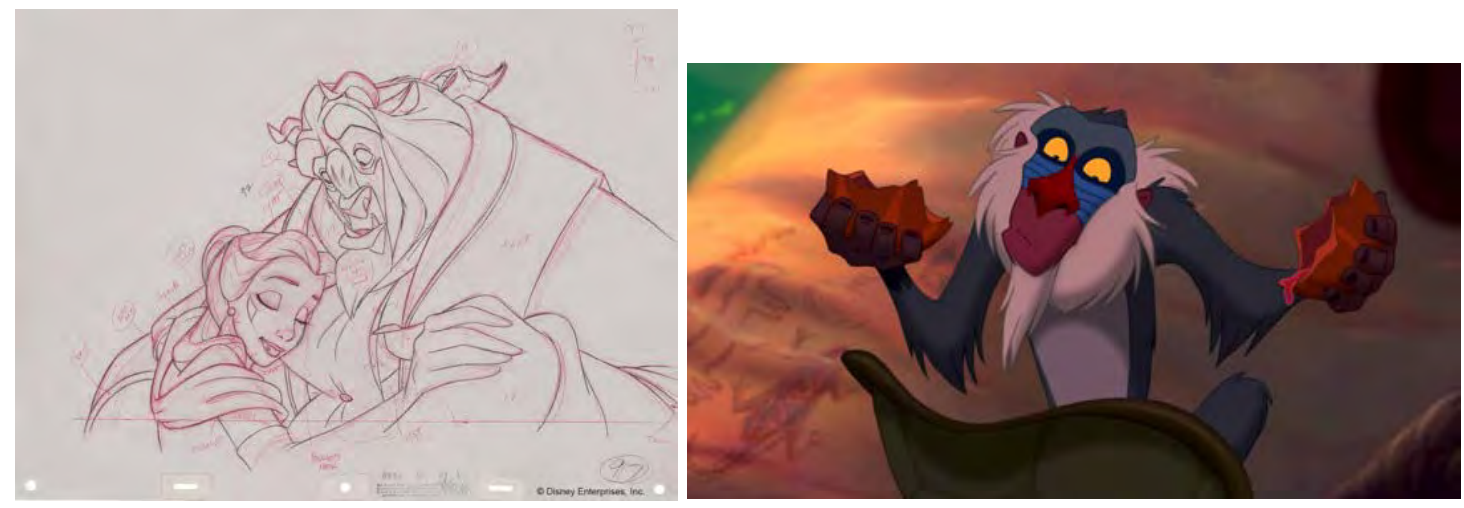

Figura 138 - Bela (“A Bela e a Fera”, 1991). Figura 139 - Rafiki (“O Rei Leão”, 1994). 


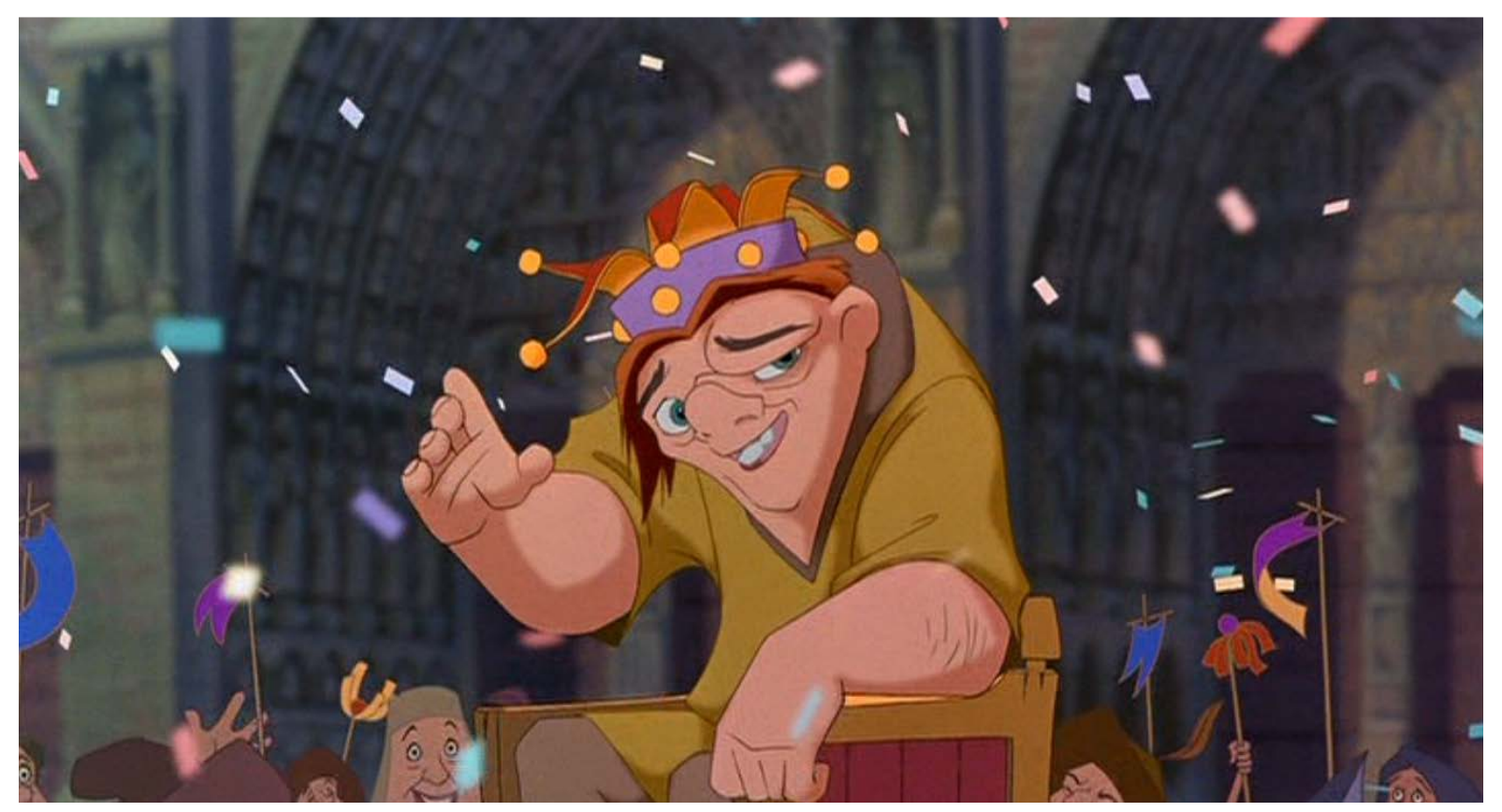

Figura 140 - Quasímodo (“O Corcunda de Notre Dame”, 1996).

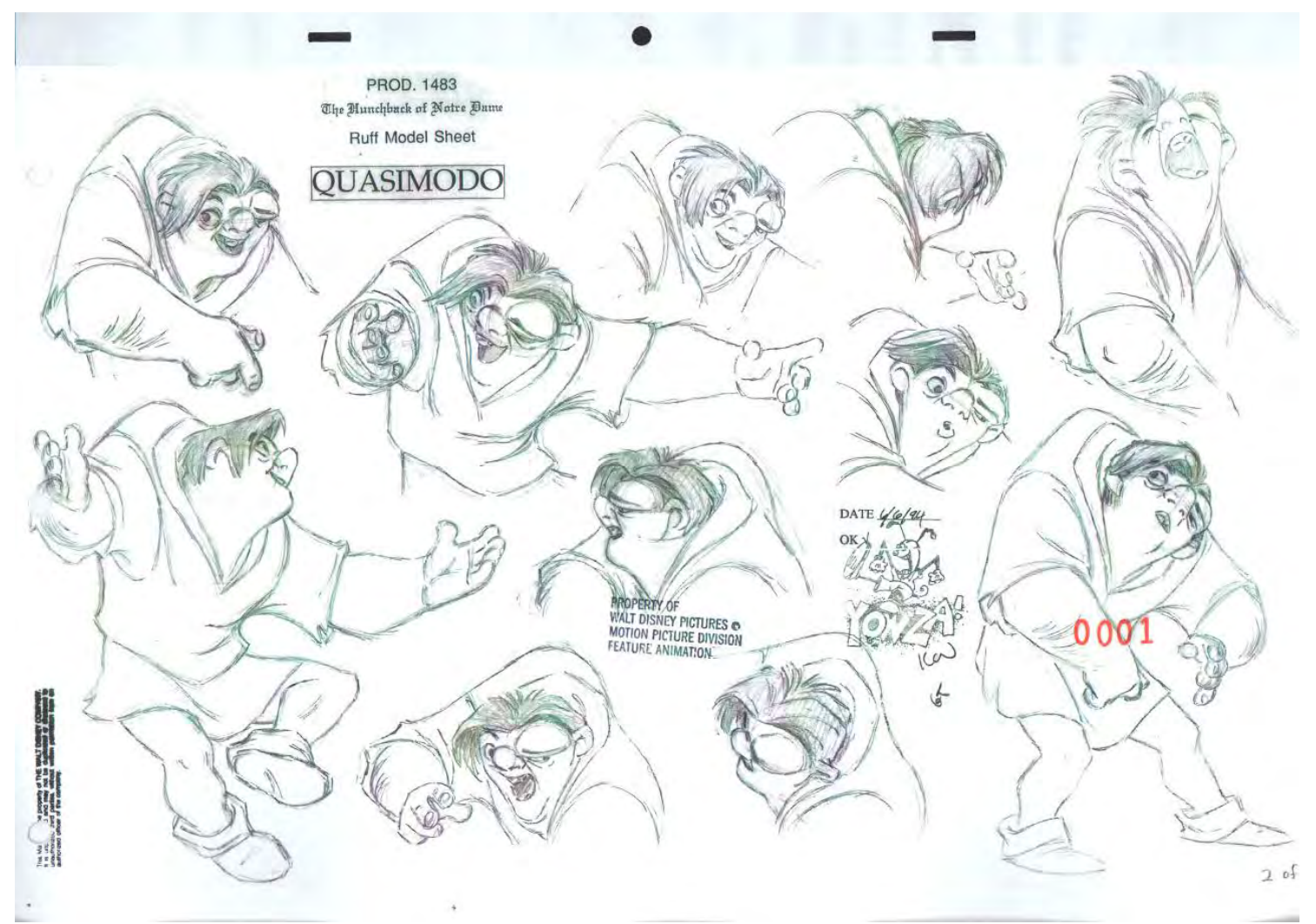

Figura 141 - Model Sheet (o guia-modelo) do personagem Quasímodo. 


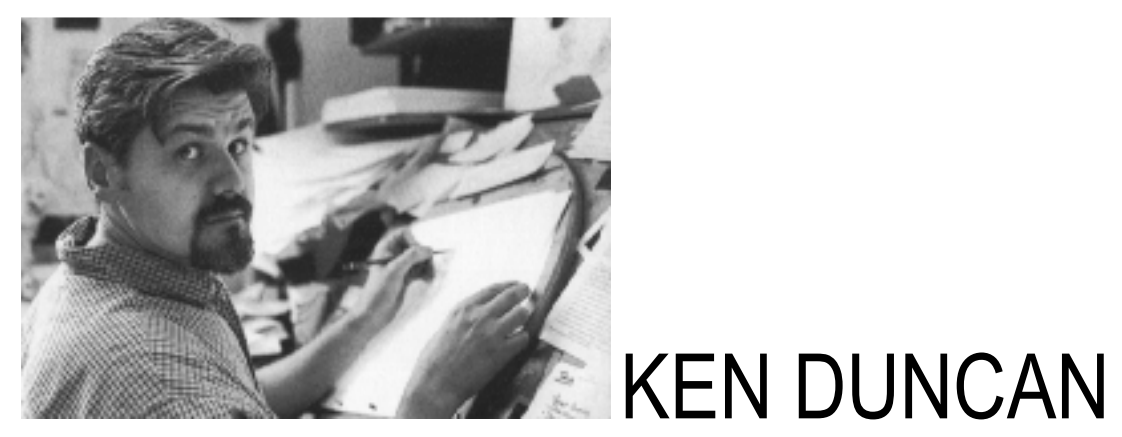

Figura 142 - Ken Duncan
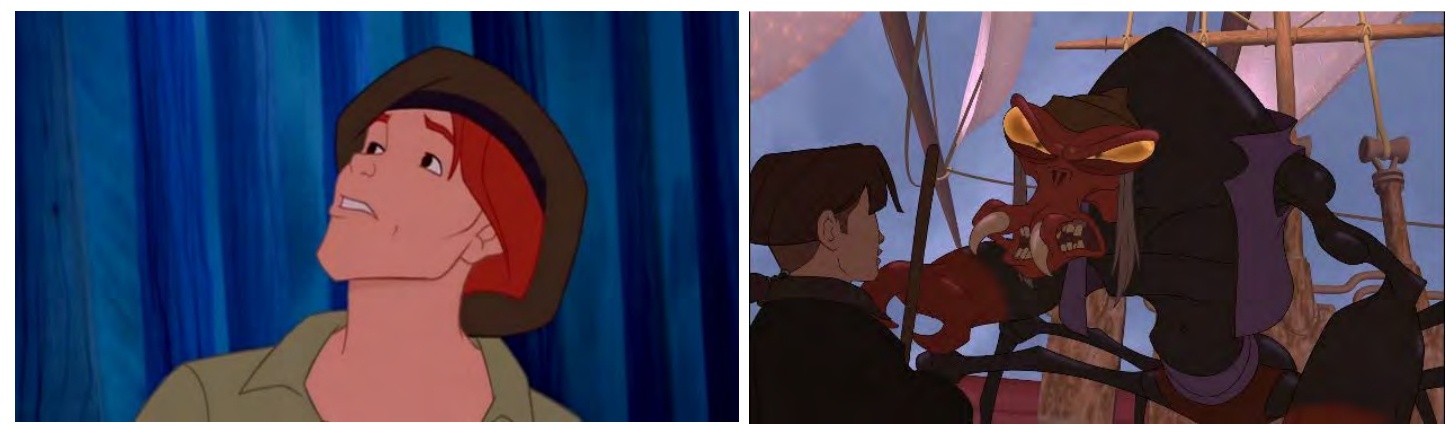

Figura 143 - Thomas ("Pocahontas", 1995). Figura 144 - O vilão Scroop ("Planeta do Tesouro" 2002).

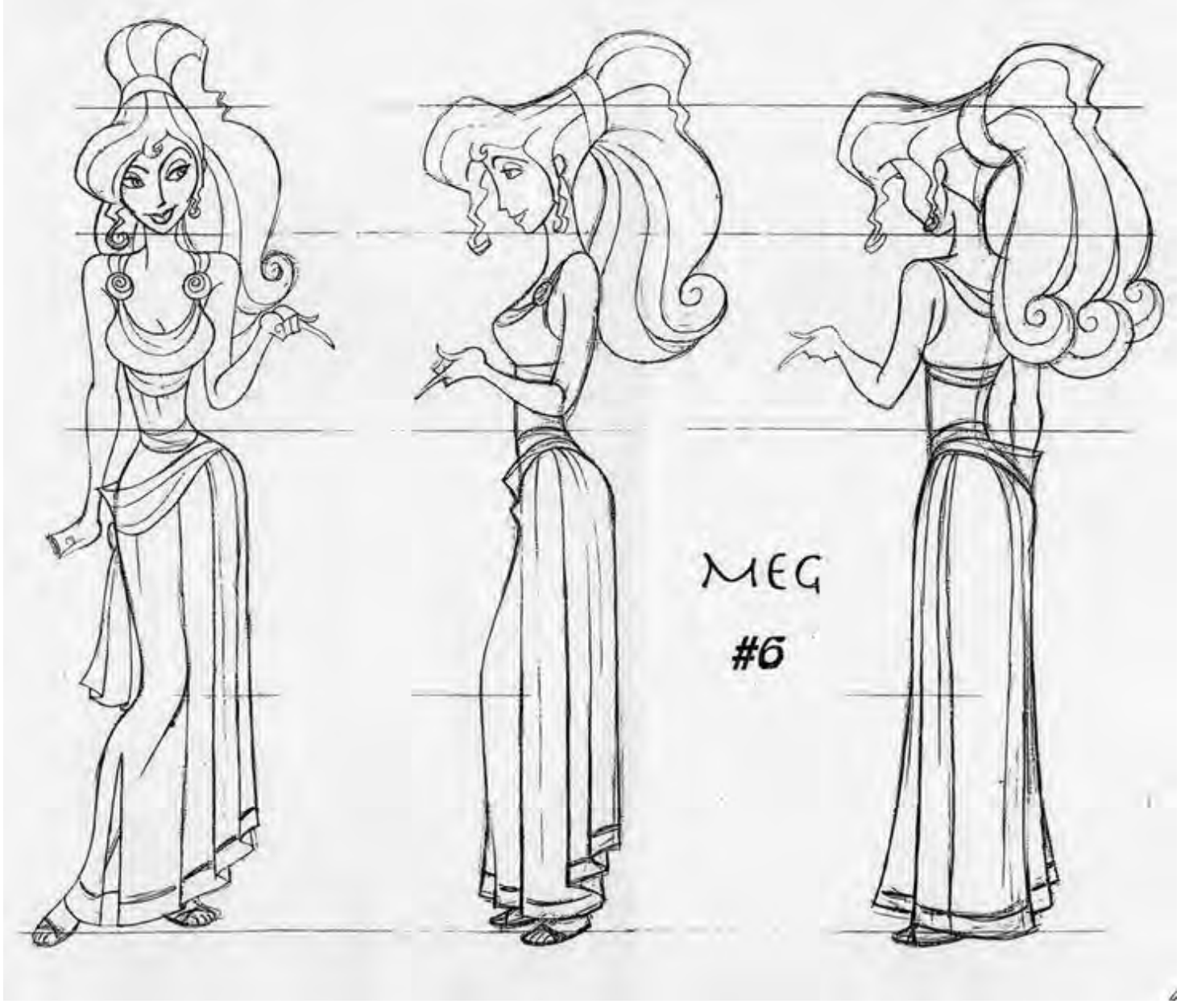

Figura 145 - Modelo-guia da personagem Mégara ("Hercules”, 1997). 


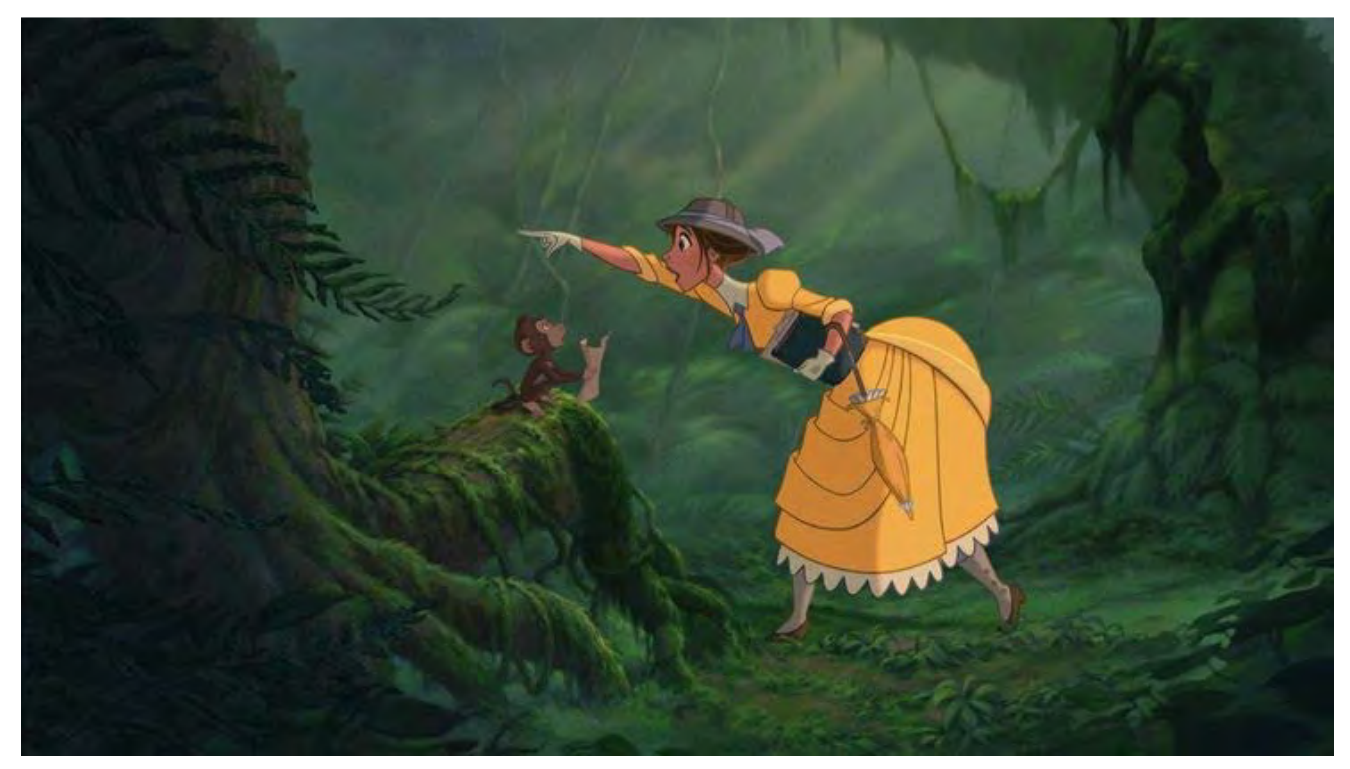

Figura 146 - Jane (“Tarzan”, 1999).

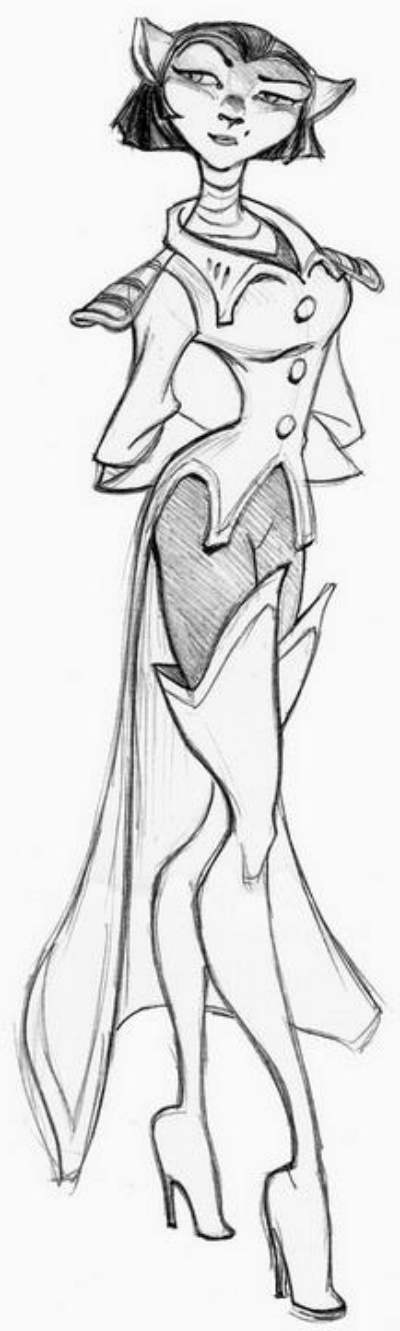

Figura 147 - Capitã Amelia ("Planeta do Tesouro", 2002). 


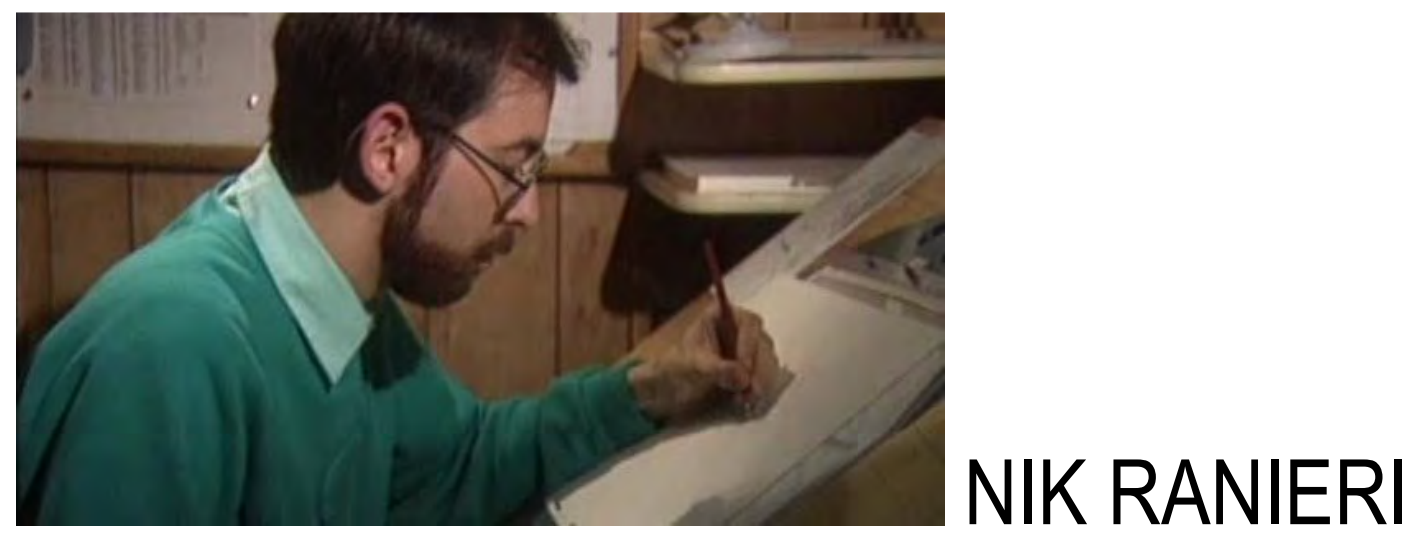

Figura 148 - Nik Ranieri

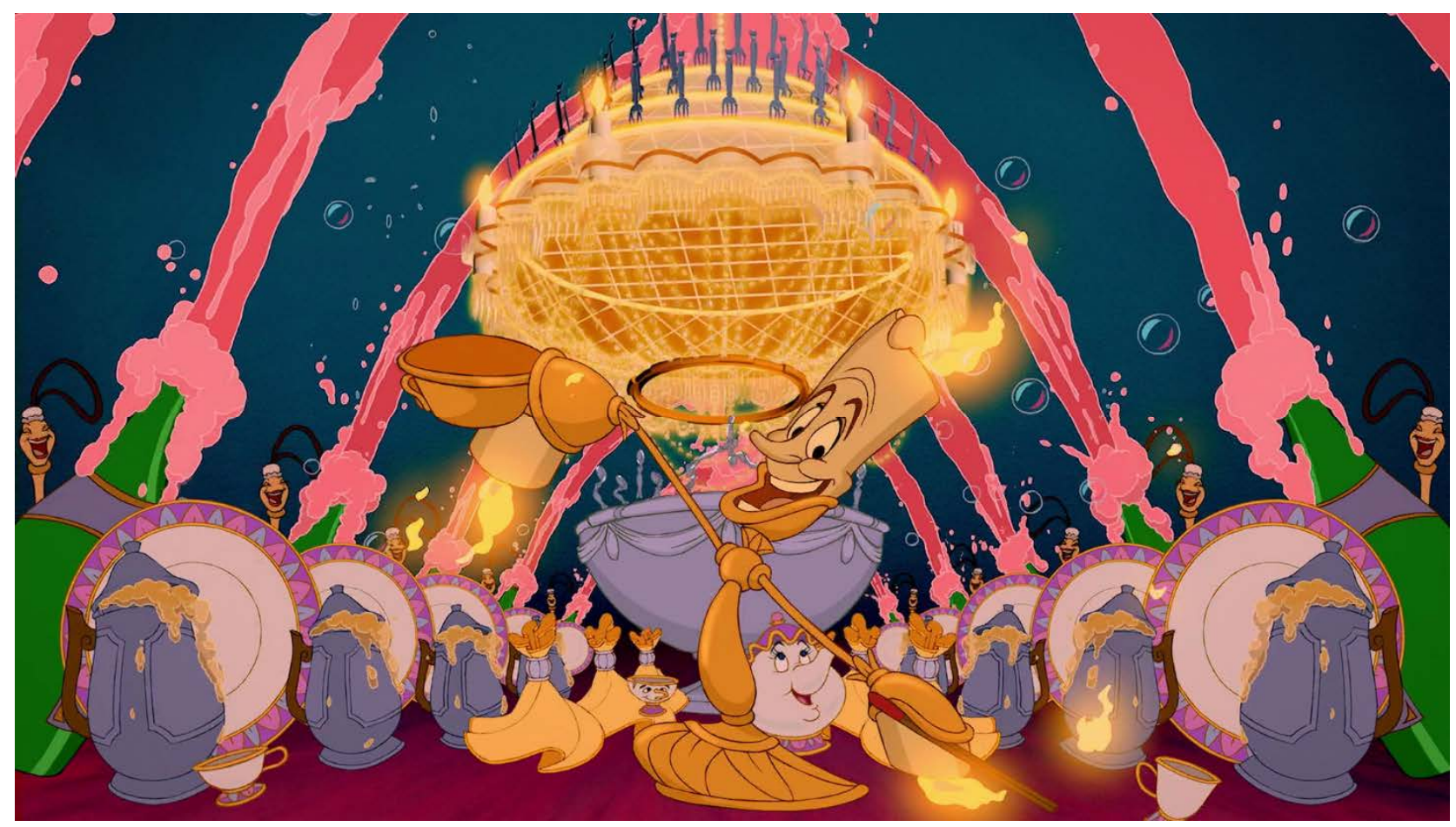

Figura 149 - O castiçal Lumière (“A Bela e a Fera”, 1991).
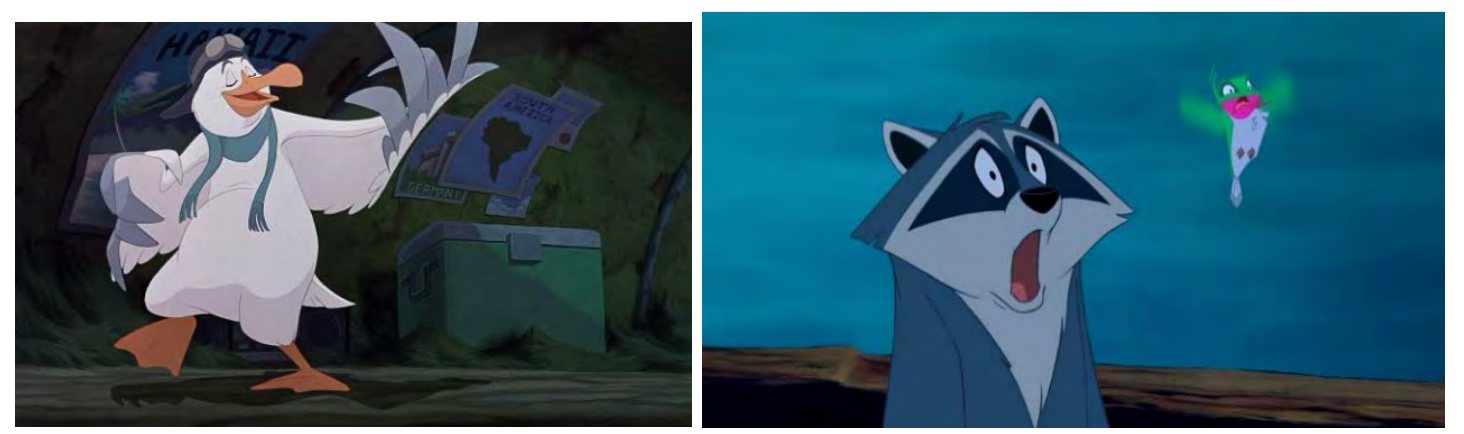

Figura 150 - O albatroz Wilbur (“Bernardo e Bianca na Terra dos Cangurus”, 1990) e Figura 151 O gaxinim Meeko ("Pocahontas", 1995). 


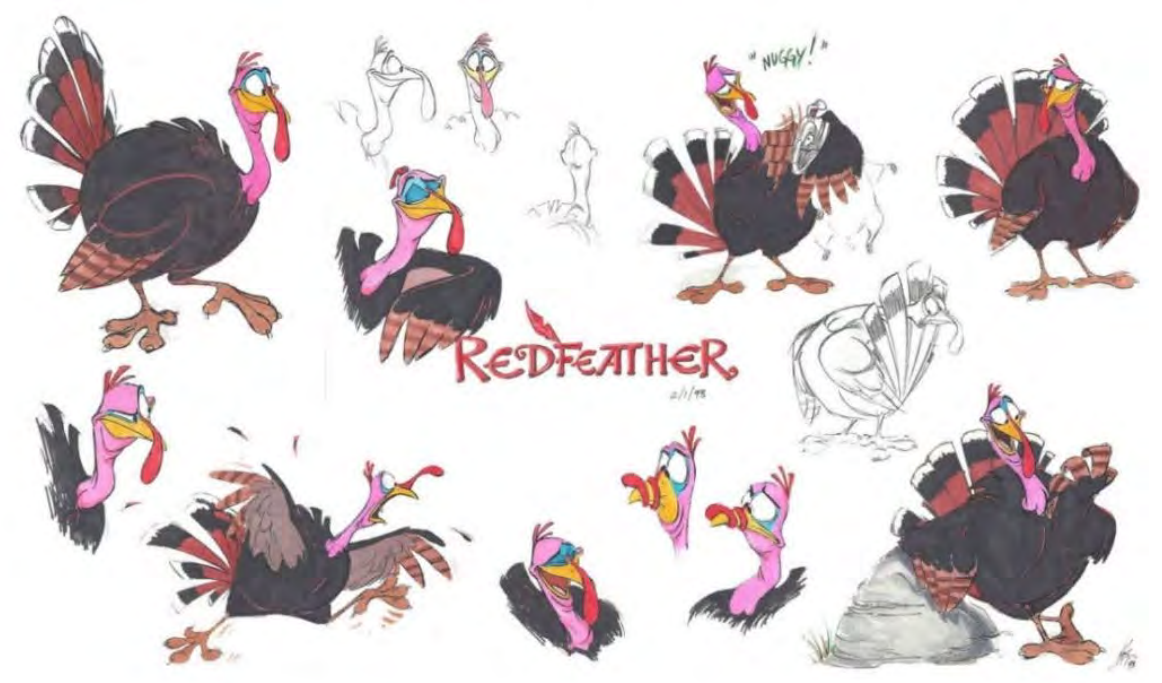

Figura 152 - O peru Redfeather, descartado quando optou-se por uma história mais séria e sem bichos falantes em "Pocahontas" (1995).

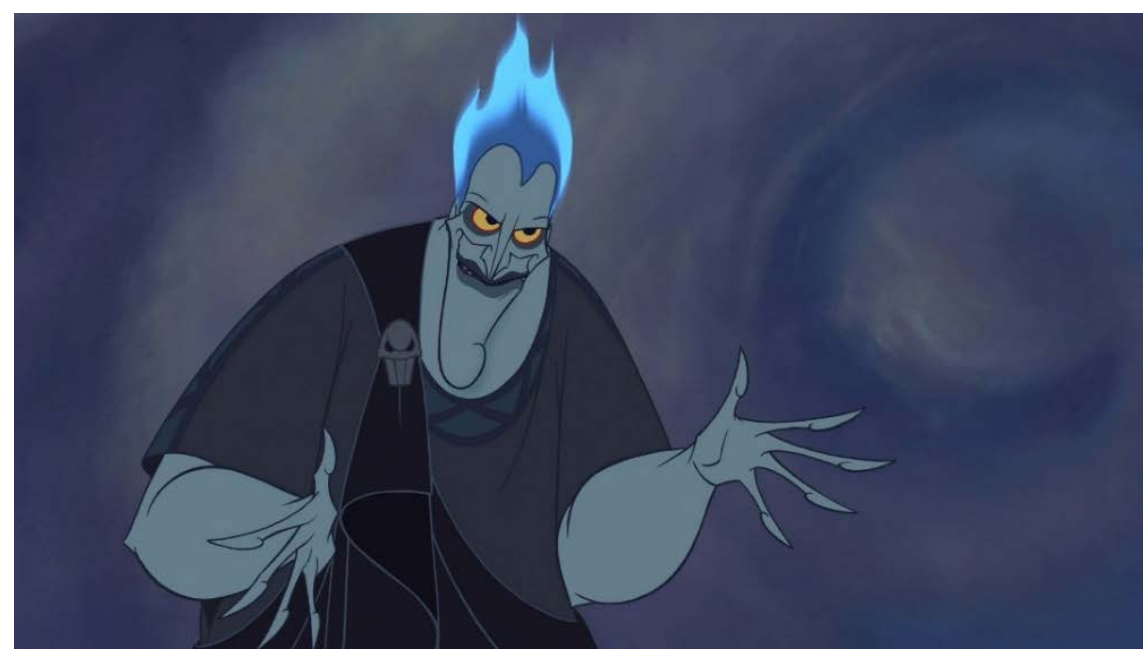

Figura 153 - O vilão Hades (“Hercules”, 1997).

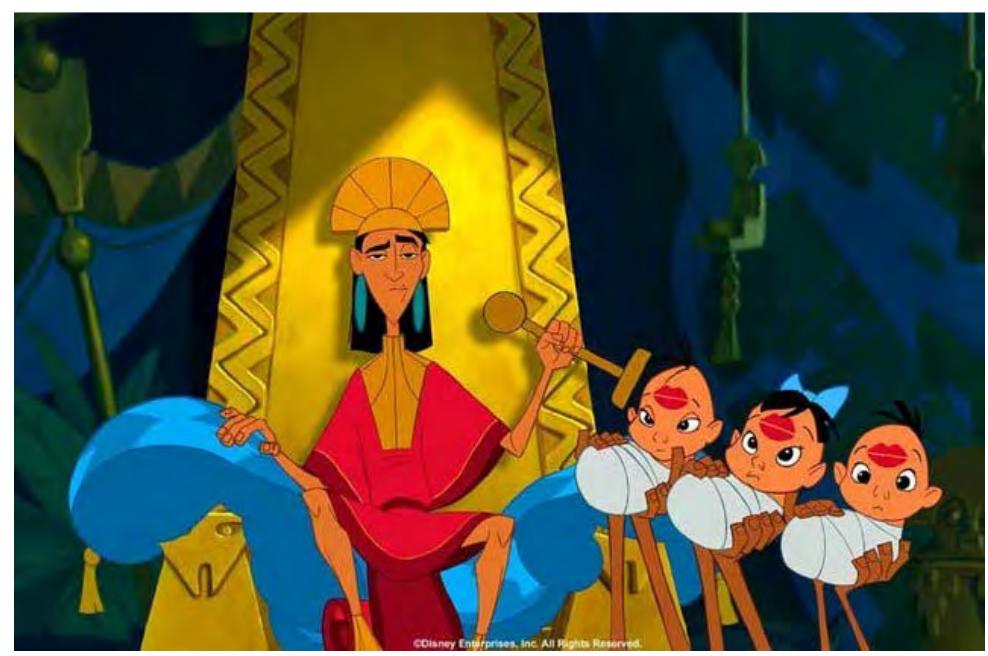

Figura 154 - Imperador Kuzco (“A Nova Onda do Imperador”, 2000). 


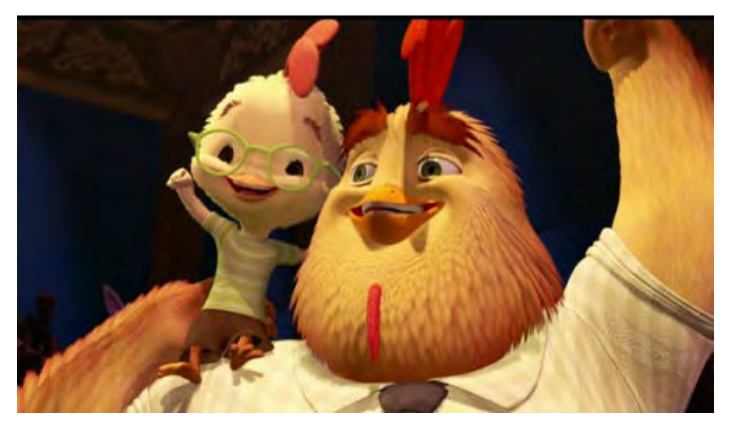

Figura 155 - Pedro Galo ("O Galinho Chicken Little", 2005).

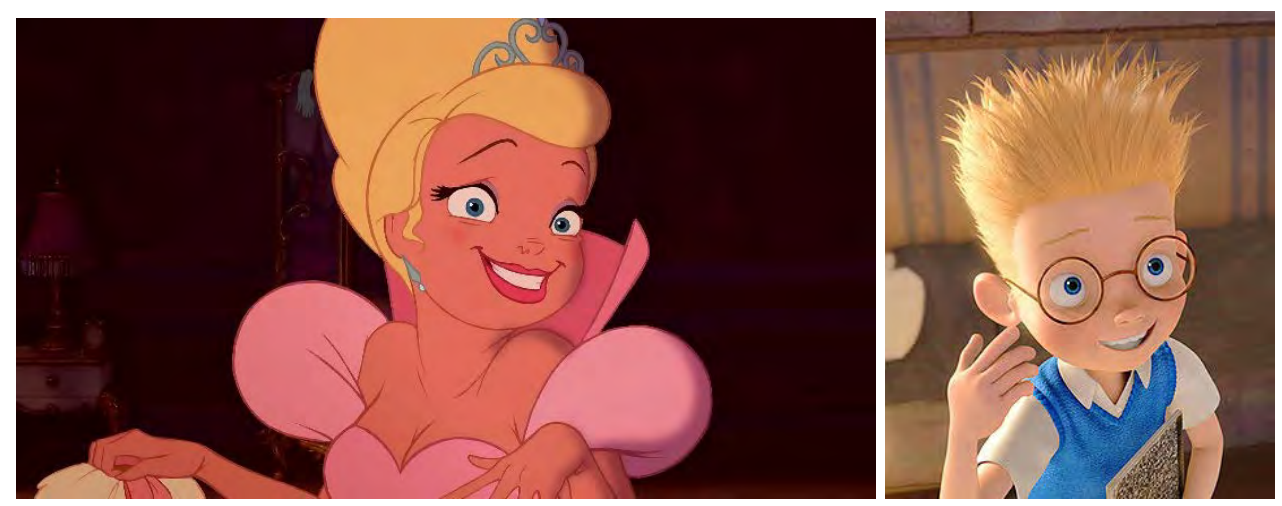

Figura 156 - Charlotte La Bouff (“A Princesa e o Sapo”, 2009). Figura 157 - Lewis (“A Família do Futuro", 2007).

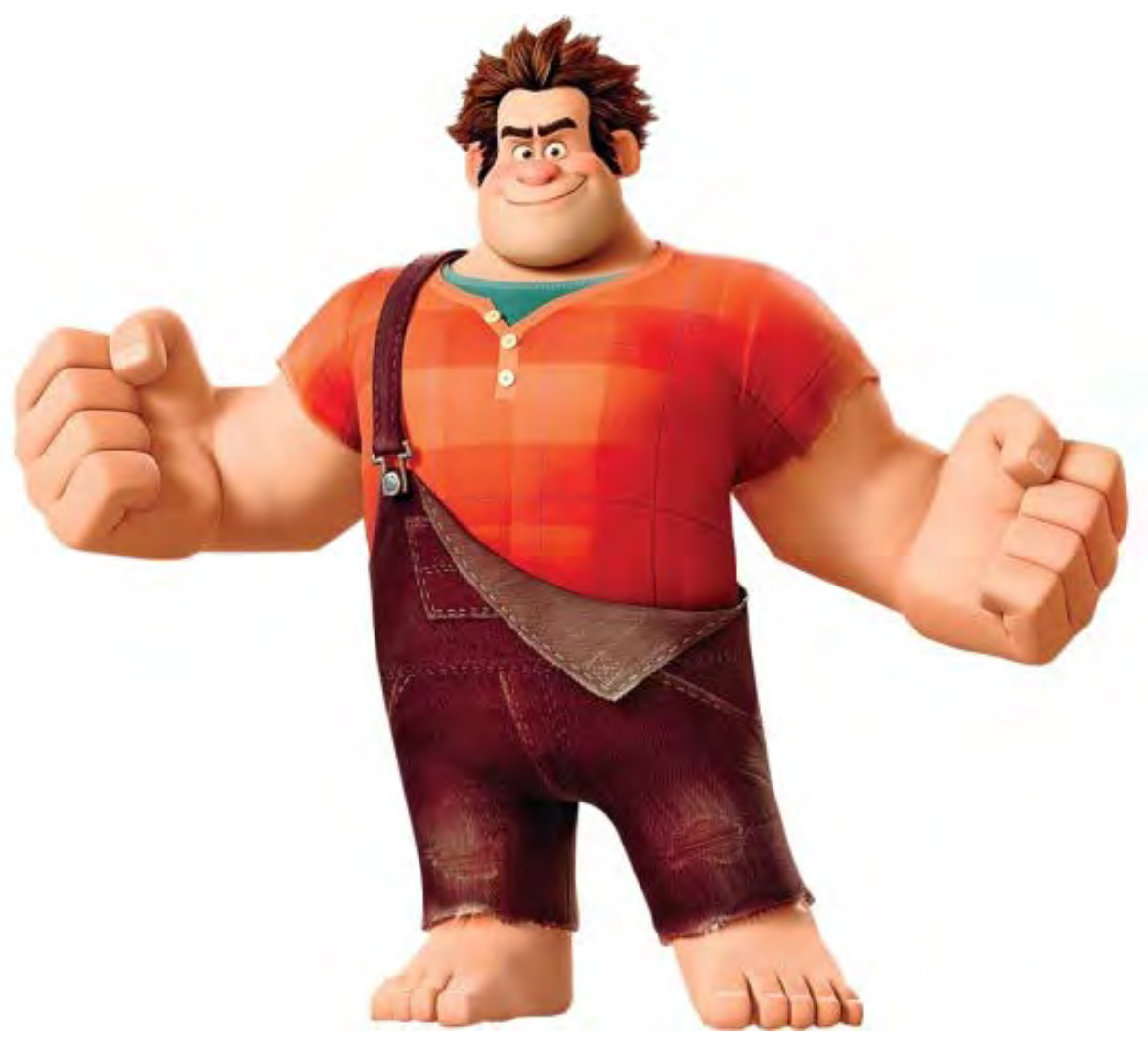

Figura 158 - Ralph (“Detona Ralph”, 2013) 


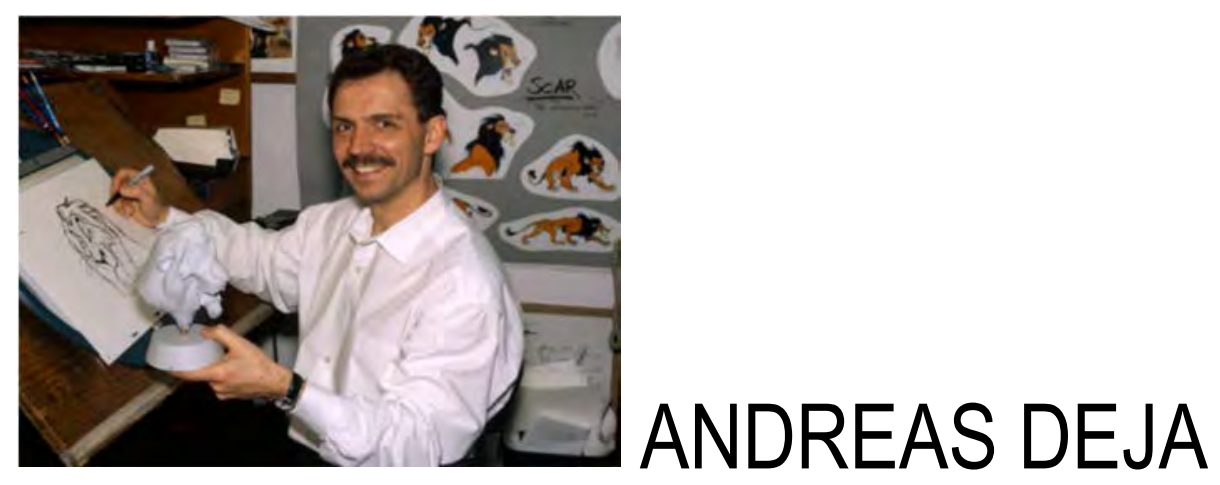

Figura 159 - Andreas Deja
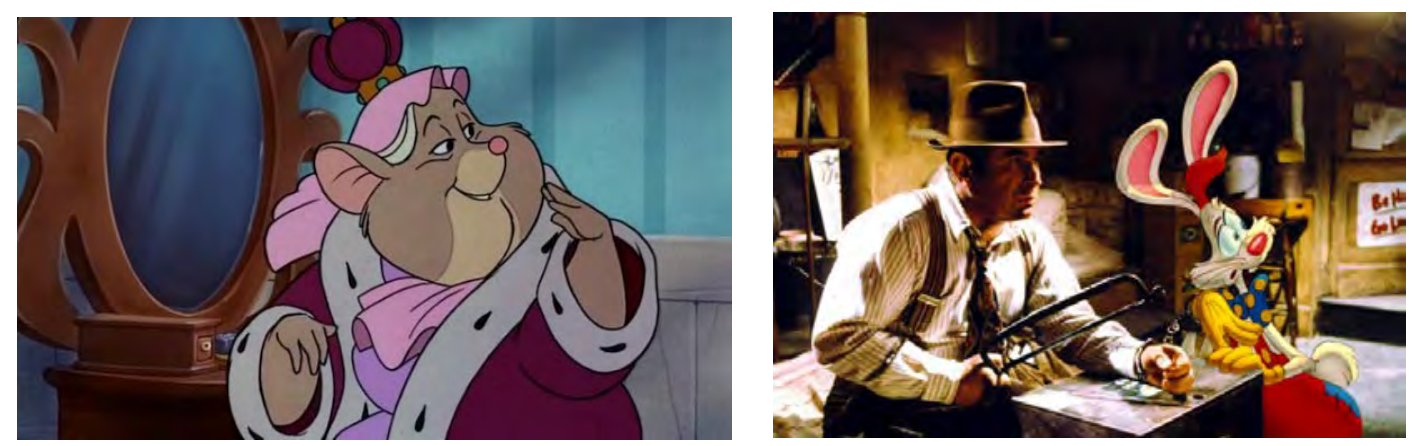

Figura 160 - Rainha (“O Ratinho Detetive”, 1986). Figura 161 - Roger Rabbit, gorila Bongo e Mickey Mouse em "Uma Cilada Para Roger Rabbit” (1988).

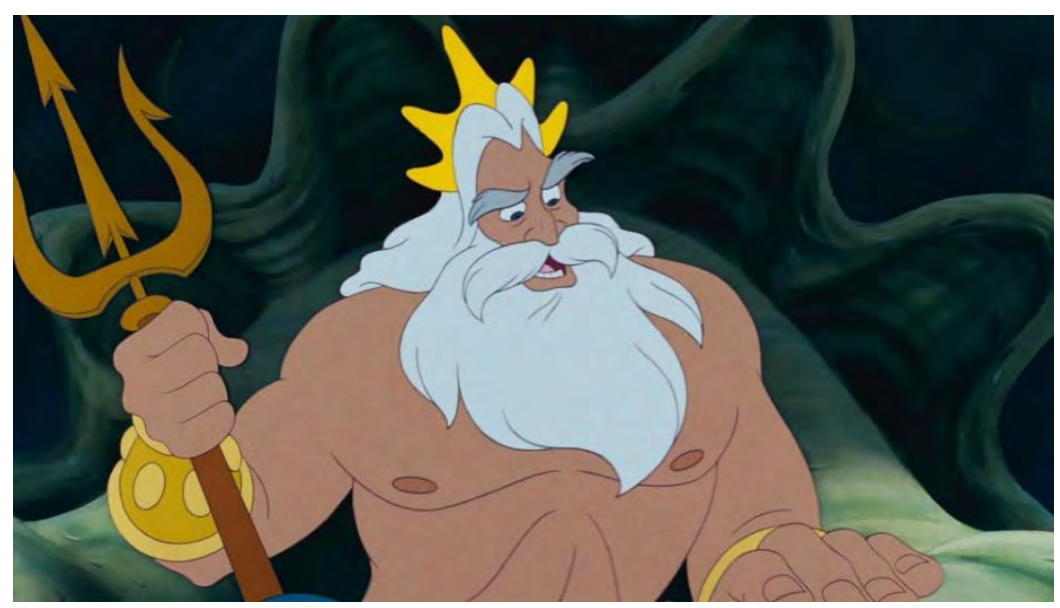

Figura 162 - Rei Tritão (“A Pequena Sereia”, 1989).

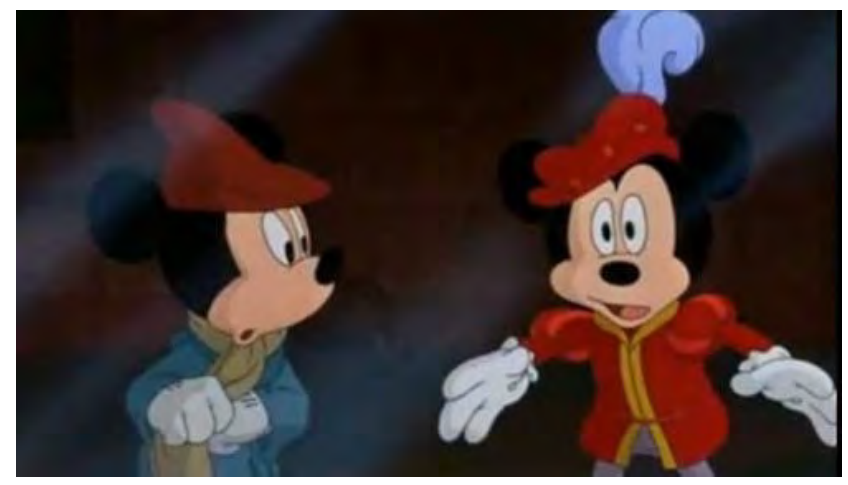

Figura 163 - Mickey Mouse em “O Príncipe e o Mendigo” (1990). 


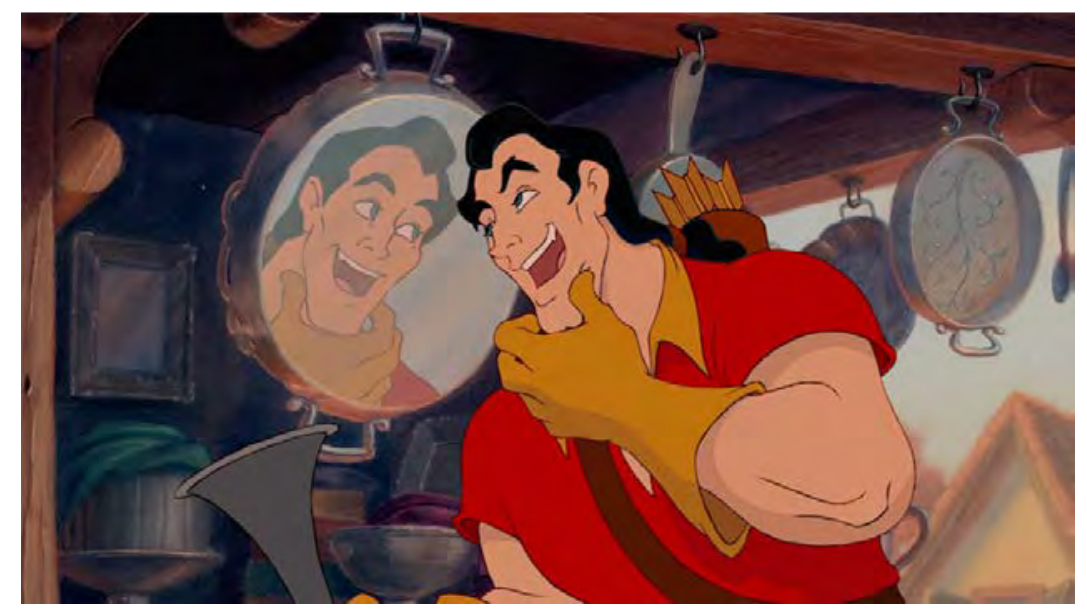

Figura 164 - O vilão Gaston (“A Bela e a Fera”, 1991).

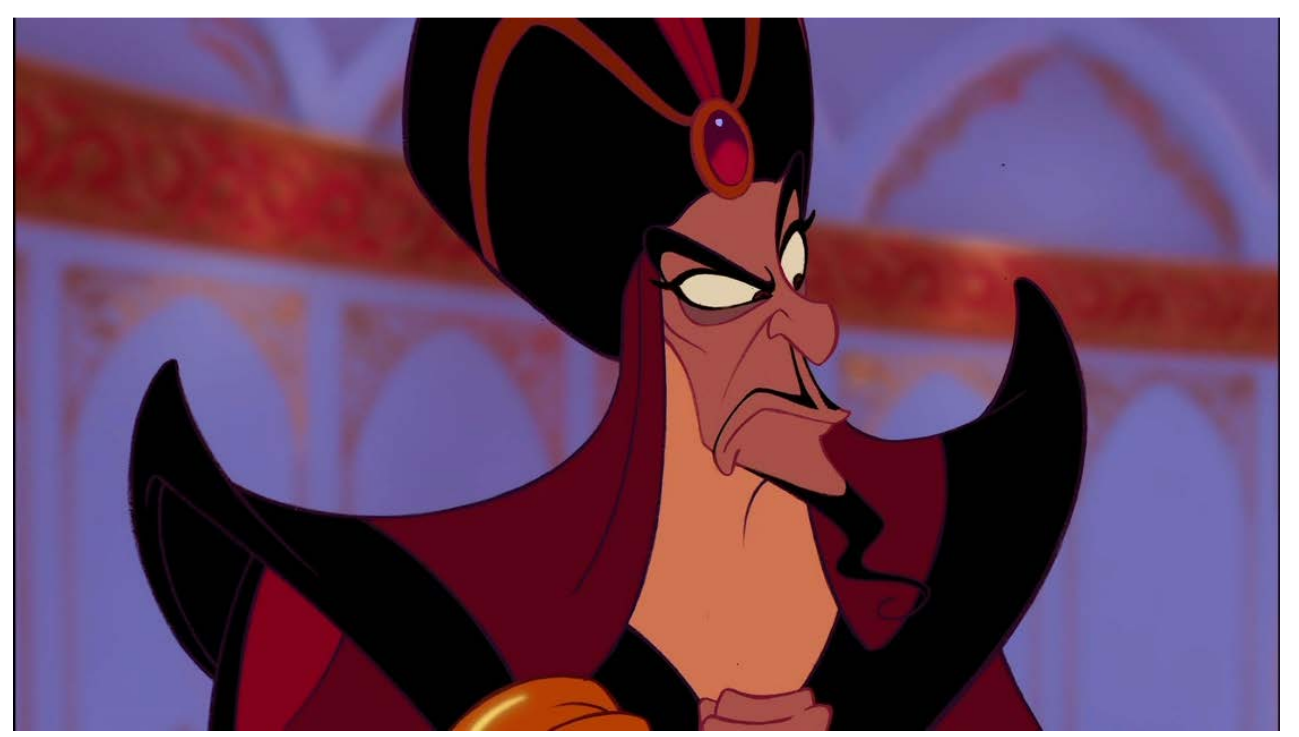

Figura 165 - O vilão Jafar (“Aladdin”, 1992).

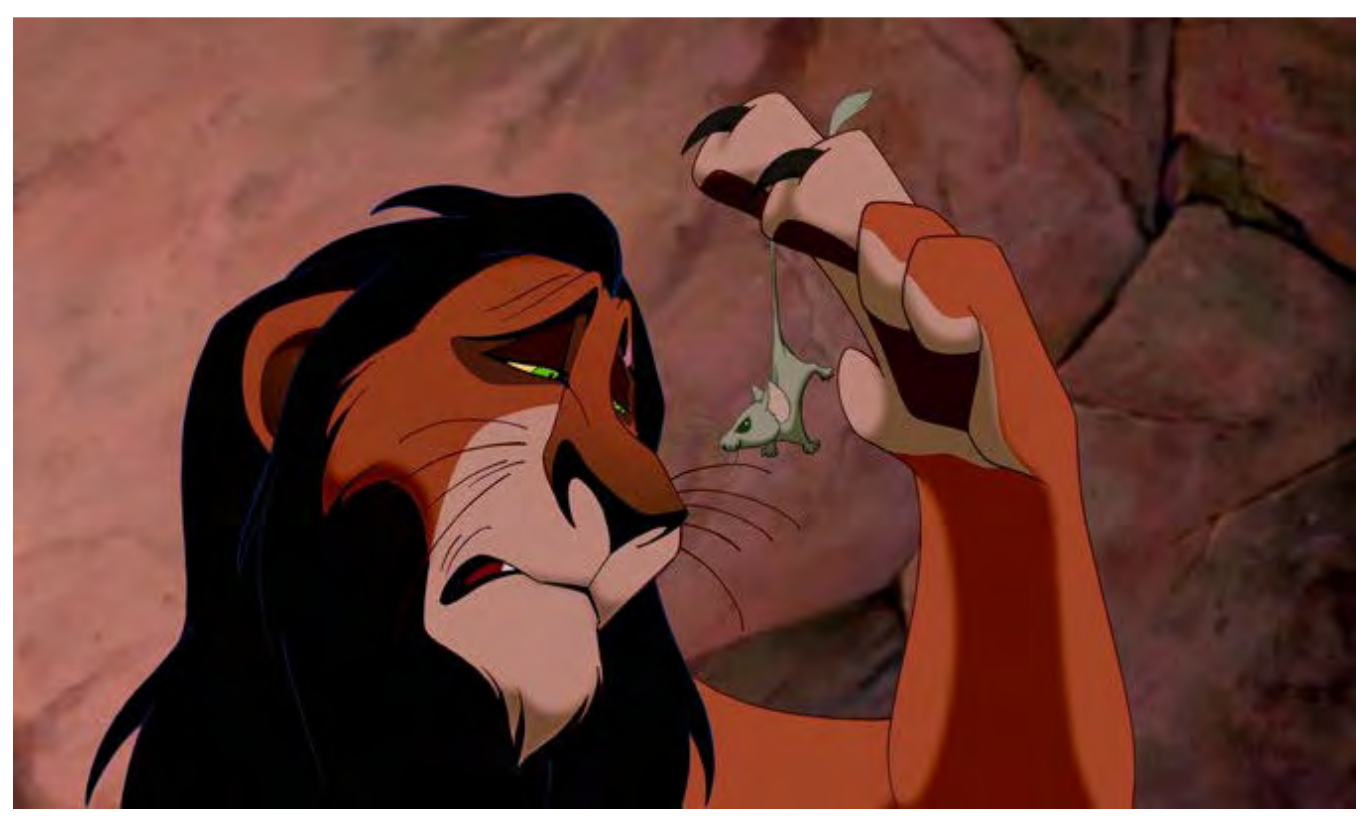

Figura 166 - O vilão Scar (“O Rei Leão”, 1994). 

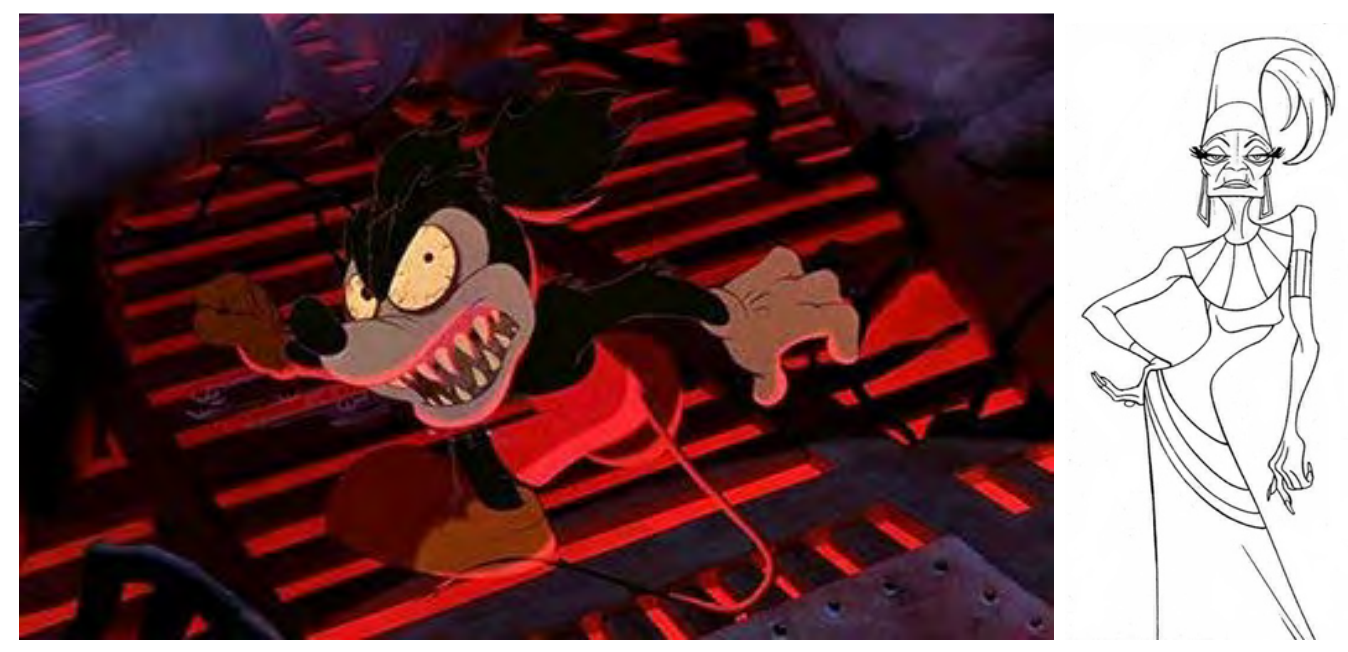

Figura 167 - Mickey Mouse no curta-metragem "Cérebro Fugitivo" (1995).

Figura 168 - A primeira versão da vilã Yzma (descartada) em “Kingdom of the Sun".

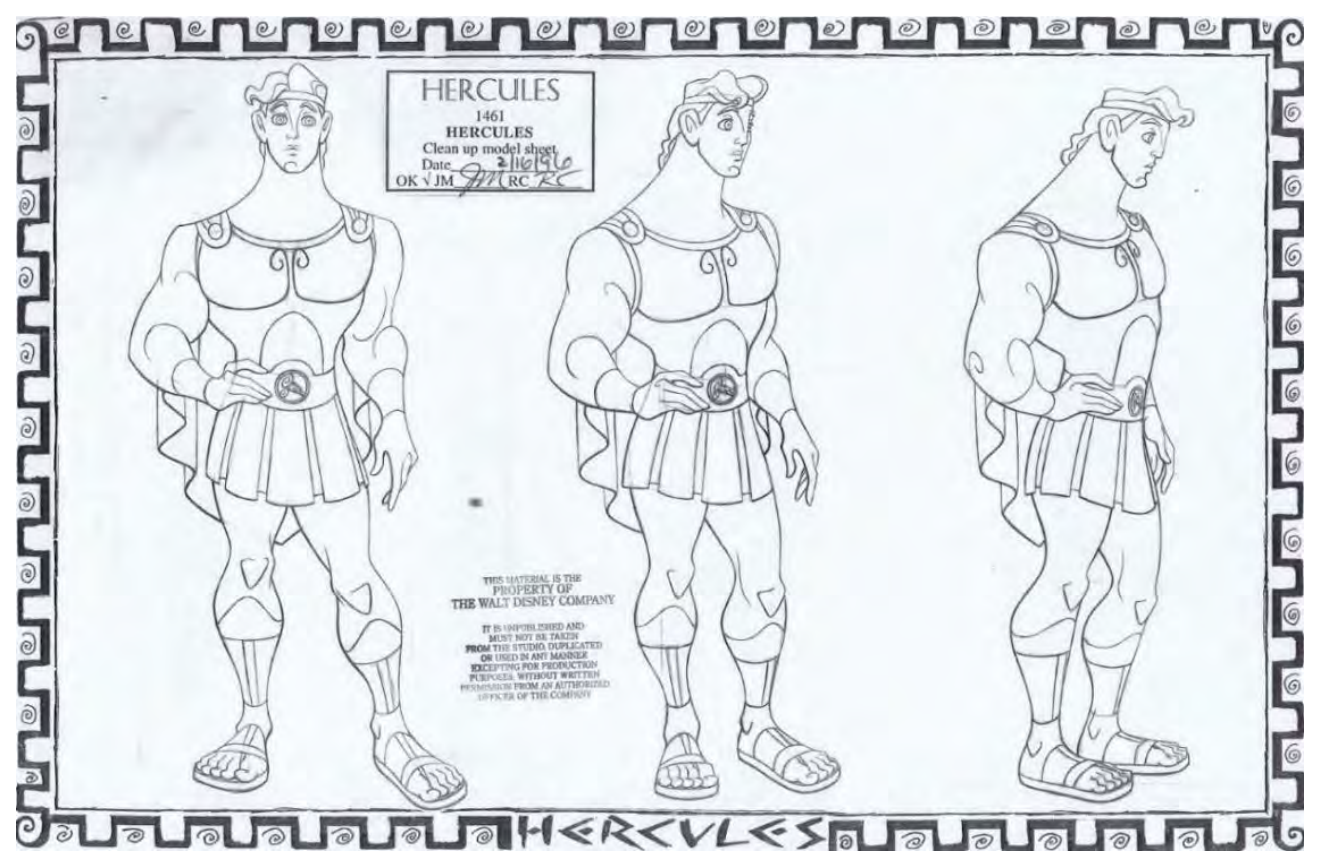

Figura 169 - Modelo-guia do protagonista Hercules ("Hercules”, 1997).

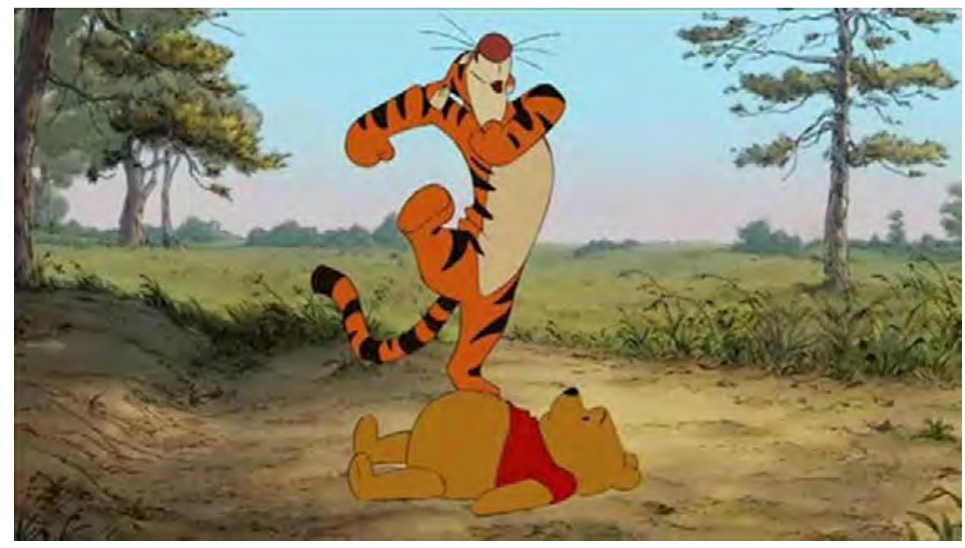

Figura 170 - Tigrão (“Ursinho Pooh”, 2010). 


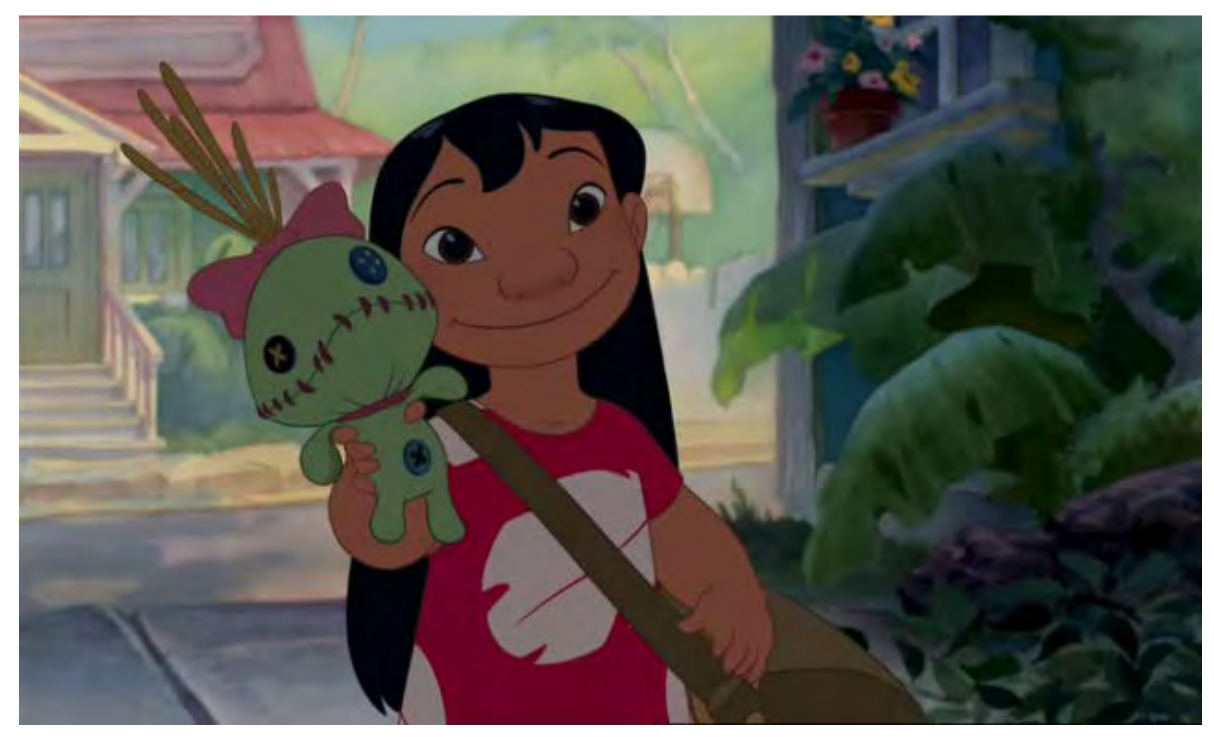

Figura 171 - Lilo (“Lilo \& Stitch”, 2002).

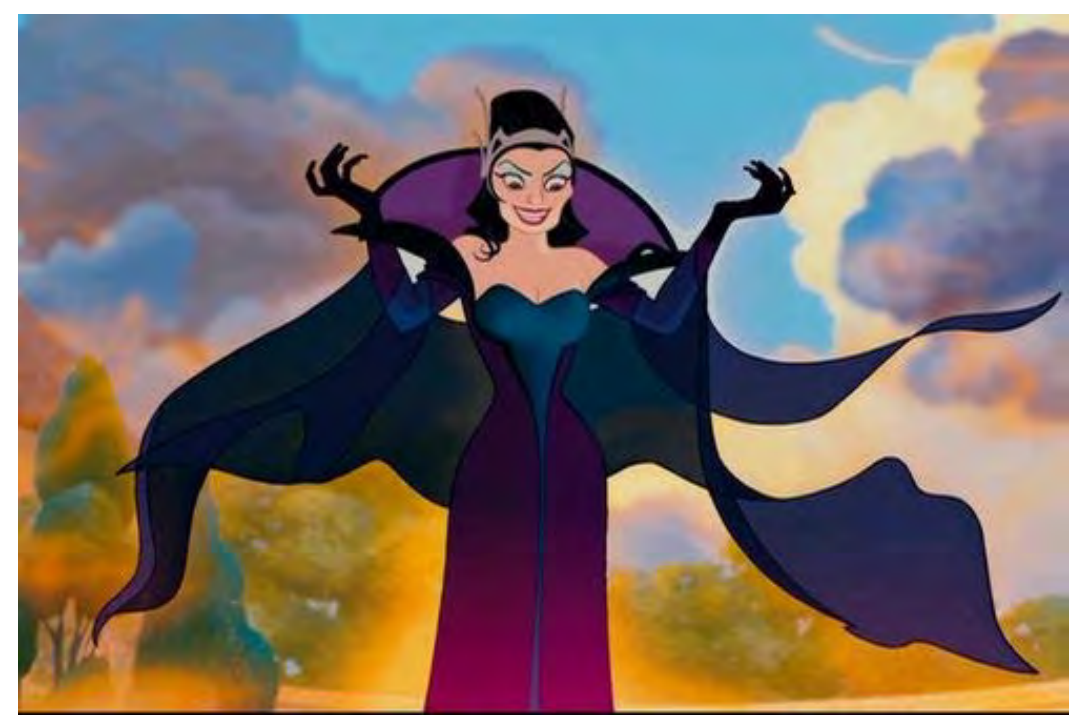

Figura 172 - A vilã rainha Narissa ("Encantada", 2007).

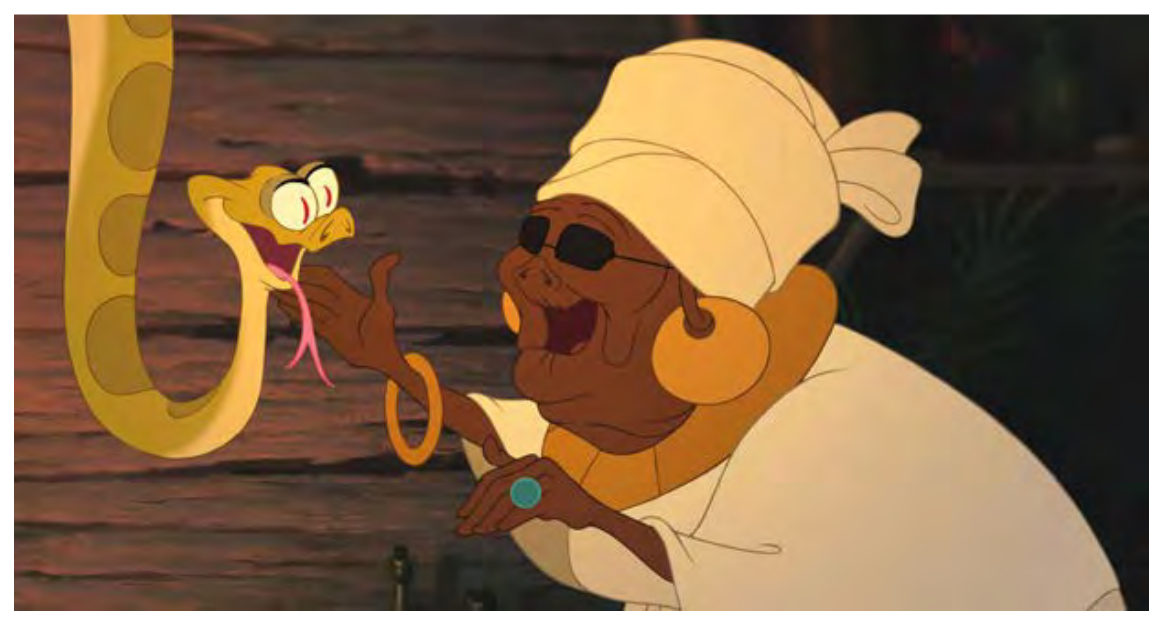

Figura 173 - A feiticeira Mama Odie (“A Princesa e o Sapo”, 2009). 


\subsection{Novas Tecnologias na Animação}

Antes de continuarmos no panorama da produção da animação tradicional, iniciamos aqui uma análise da evolução da animação computadorizada, mais conhecida como CG ou CGI (Computer Generated Image ou Imagem Gerada por Computador). Qualquer análise de sua evolução é incompleta. A animação computadorizada não seguiu uma evolução linear de altos e baixos, com nomes destacados, como no caso da animação tradicional feita a mão - caso de Walt Disney, Hayao Miyazaki, Chuck Jones ou Ray Harryhausen. É mais semelhante à história da televisão, em que não há uma figura central como Thomas Edison ou Marconi como inventor para usarmos como referência (SITO, 2015).

O desenvolvimento da animação computadorizada foi lento, durou décadas e teve origem em diferentes locais e de forma simultânea. A complexidade é tamanha, que livros tentando sistematizar o tema são recentes. É o caso do livro do animador e professor Tom Sito (2015) da USC (University of Southern California), que analisa o desenvolvimento da animação CGI nas seguintes áreas:

1. Academia (universidades)

2. Pesquisa militar (Defesa) e industrial

3. Efeitos especiais para filmes live-action

4. Games

5. Cineastas experimentais e avant-garde

6. Pesquisa corporativa

7. Animação comercial

A evolução em cada uma dessas áreas ocorre de forma paralela e isolada socialmente uma da outra até que os conglomerados de mídia verticalmente integrados nos anos 1980 obrigaram a uma convergência (SITO, 2015, p.8). Nos anos 1960 e 1970 já existiam computadores, ao mesmo tempo que o videotape era considerado uma tecnologia avançada. Uma das características para seu entendimento era intelectual. Nos primeiros 30 anos da animação computadorizada, era necessário ter título de doutorado em matemática ou engenharia para saber o que se estava fazendo. Atualmente, um animador de Hollywood pode ter somente a educação pública básica para trabalhar com as ferramentas técnicas. A redução dos preços tornou possível até que jovens e crianças se aventurem na área. 
A Disney sempre inovou em sua história e já fazia experiências com computadores no fim dos anos 1960, com a aquisição de um Honeywell 516 para uso na Disneylândia. Em 1983, adquiriram dois IMI (Integrated Micro-Electronics Inc.) com 1 megabyte de memória e 10 megabytes de disco rígido. Um deles novamente foi usado pelos imagineers (os engenheiros responsáveis pela criação de atrações nos parques temáticos). O outro IMI foi instalado no estúdio, na tentativa de criar um sistema experimental para substituir a câmera multiplano (SITO, 2015, p. 225). O primeiro grande salto da animação computadorizada na Disney foi em "Tron: Uma Odisseia Eletrônica” (1982) - mesmo utilizando produtoras externas, seu impacto promoveu uma série de projetos experimentais dentro do estúdio (KALLAY, 2011).

Usando um computador IMI 500, a Disney criou pequenos objetos computadorizados caldeirões, uma bola luminosa e um barco no filme "O Caldeirão Mágico" (1985), representando o primeiro uso oficial numa animação Disney. Para o projeto seguinte, "O Ratinho Detetive" (1986), o animador Mike Peraza desenvolveu o clímax do filme, tendo um tabuleiro de xadrez computadorizado. Porém, a Disney mudou de ideia e bancou uma viagem de pesquisa à Londres, para que o clímax envolvesse uma perseguição entre as engrenagens do Big Ben. O processo, segundo Tom Sito (2015, p. 228) não era tão simples. A animação feita no IMI (basicamente uma grade) era transferida para um computador HP com o software de rendering MOVIE.BYU. Depois, as linhas eram impressas, fotocopiadas em acetatos e depois pintadas à mão. E, ainda assim, era necessário restaurar os desenhos usando animadores de efeitos.

Para o animação “Oliver e sua turma” (1988), a Disney enviou um grupo de jovens animadores ao Art Center of Pasadena para serem treinados na técnica CGI. Outro pequeno grupo foi enviado ao Wave Front, em Santa Barbara. Um curso também foi ministrado no estúdio por Vibeke Sorensen, professor de animação digital da CalArts. Segundo Sito (2015, p. 228) o antigo computador IMI foi substituído pelo avançado SGI Iris 2400 Turbo com o software Wavefront, de Bill Kovacs. O código do software foi fornecido, para que o estúdio pudesse criar uma impressora. Em troca, Kovacs usaria a arquitetura CADCAM. Não surpreendentemente, devido a tanta novidade, houve atritos entre os dois grupos - animadores e técnicos. Tina Price se tornou a líder do primeiro grupo e uma espécie de ponte com o segundo. Em "Oliver", todos os elementos em CGI continuavam a serem impressos e pintados à mão, de modo que o resultado se mostrasse equilibrado com o restante do filme.

É importante destacar que, paralelamente, a Pixar já estava desenvolvendo sua animação digital, porém com outro viés. A Disney sabia dos passos da pequena empresa digital e decidiu bancar 
o desenvolvimento de curtas-metragens experimentais. O primeiro deles, "Oilspot and Lipstick" (1986), tendo como protagonistas um casal de cães apaixonados que são ameaçados por um monstro feito de lixo. O filme foi dirigido pelo veterano Mike Cedeno e os custos foram menores usando peças de carros já criadas para cenas do filme de animação "Oliver e sua Turma” (1988).

Roy E. Disney começou a prestar atenção no que era chamado "end of production", centrado no departamento Ink \& Paint, onde artistas arte-finalizavam, fotocopiavam e pintavam os acetatos. Era o maior departamento do estúdio, tipicamente com o dobro da força de trabalho em relação aos animadores que desenham a ação. Estúdios concorrentes cortavam custos enviando essa fase da produção para países cuja mão-de-obra era mais barata. A qualidade final, entretanto, sempre deixava a desejar, pois, afinal, os animadores estrangeiros eram pagos por volume de trabalho realizado e não por qualidade. Eisner e Katzenberg, ainda recém-chegados ao estúdio, planejavam enviar esse processo para a Coreia do Sul. Uma parte de "A Pequena Sereia" chegou a ser enviada para ser pintada na China (SITO, 2015, p. 229).

A inovação nesta fase da produção se chama CAPS - Computer Animation Production System. Os promotores dessa inovação tecnológica que ajudou a relançar a animação foram Roy E. Disney e Peter Schneider, este último um executivo contratado no final de 1985 para dirigir as operações diárias do estúdio de animação sob as asas de Jeffrey Katzenberg, de modo a reduzir as faíscas do relacionamento com os animadores. A trajetória de Schneider vinha das artes cênicas, tendo gerenciado e dirigido uma série de teatros em Chicago e Nova York (GROVER, 1997). Em 1983, mudou-se para a California para ajudar a dirigir um festival de artes planejado em conjunto com as Olimpíadas de Los Angeles, em 1984. Foi recomendado para o cargo na Disney por Robert Fitzpatrick, então chefe da CalArts. Schneider, por sua vez, contratou colegas profissionais do Teatro e apontou um auxiliar seu, Thomas Schumacher, para ser produtor em "Bernardo e Bianca na Terra dos Cangurus". Schumacher teve uma carreira em ascensão, passando a chefe do desenvolvimento de histórias até chegar a finalmente substituir Schneider anos mais tarde. Desde 2002 preside a Walt Disney Theatrical Productions, responsável pelos musicais Disney na Broadway. Peter Schneider foi responsável por melhorar a eficiência da produção - colocar relógios de ponto, atualizar o processo de pintura nos filmes, se era necessário o uso de mais computadores, como executar o treinamento de novos profissionais, etc. (HAHN, 2009).

O marketing historicamente pode ser uma pedra no sapato de muitos funcionários criativos. Quando um memorando ordenando a alteração do título "Basil of the Baker Street” para "The Great 
Mouse Detective" (para facilitar a assimilação com o público) chegou aos ouvidos dos artistas, um animador elaborou um memorando falso, assinado por Schneider, informando que filmes antigos teriam seus títulos alterados para coisas óbvias como "O Garoto que se tornou real” (Pinóquio) ou "Sete homenzinhos ajudam uma garota" (Branca de Neve e os Sete Anões). Schneider considerou o ato uma afronta a sua posição e ordenou tomar conhecimento da identidade do autor - que foi guardada em segredo pelos animadores. Uma série de choques entre as brincadeiras internas e o executivo resultou em uma reunião coletiva onde tudo foi posto em pratos limpos - e Schneider terminou ganhando o respeito dos animadores (HAHN, 2009).

Um dos primeiros projetos de Schneider em outubro de 1985 foi o sistema CAPS (SCHWARTZ, 1998, p. 180). Os arquitetos chefes do processo eram Lem Davis e Dave Inglish, que se aproximaram de Roy sugerindo a ideia. Esta nova tecnologia tinha o potencial de revolucionar os filmes de animação, tanto para aumentar a eficiência como para dar aos artistas novas capacidades criativas, que eram o equivalente a trocar a escrita a mão por um computador pessoal. Peter e Roy tentaram vender a ideia para Katzenberg, Wells e Eisner. O custo estimado era de US\$ 12 milhões. Hoje o valor é considerado irrisório, porém, na época, foi considerado um investimento alto demais em um negócio que ainda não se provava lucrativo o suficiente. Wells era o mais cético por acreditar que a Disney não era uma empresa de pesquisa e que o projeto certamente custaria mais que o dobro do que os técnicos previam. Como a ideia tinha forte apoio de Roy E. Disney, Eisner convenceu Wells de que era necessário dar um voto de confiança e a ideia foi aprovada. Wells, entretanto, estava certo. O desenvolvimento do sistema CAPS não poupou dinheiro e terminou custando mais de US\$ 30 milhões, o equivalente ao orçamento de um grande filme. Porém, foi uma revolução tecnológica e artística no estúdio. O CAPS permitia que os desenhos dos animadores fossem escaneados e coloridos digitalmente. Os cenários permitiam a mesma coisa, somada à possibilidade de manipular e aumentar o número de camadas no mesmo quadro, que permitiam dar uma sensação tridimensional aos filmes, substituindo definitivamente a necessidade de uma câmera multiplano. Quem ajudou na concretização do sistema CAPS foi justamente a Pixar;

Uma [das primeiras iniciativas da Disney em ressuscitar seu departamento de animação] foi procurar maneiras de computadorizar o processo, e a Pixar obteve o contrato em nome de Alvy Ray Smith, co-fundador junto com Edwin (Ed) Catmul da produtora computadorizada de Steve Jobs. Ela criou um pacote de hardware e software customizados. O CAPS foi usado pela primeira vez em 1988, para a cena final de "A Pequena Sereia", na qual o rei Tritão diz adeus a Ariel. A Disney comprou dezenas de unidades do Pixar Image Computer, e o CAPS tornou-se parte integrante de sua produção (ISAACSON, 2011, p. 261). 
Sem testar a tecnologia em algum curta-metragem experimental, o CAPS foi colocado em prática no filme "Bernardo e Bianca na Terra dos Cangurus" (1990). A animação foi um fracasso comercial, mas se tornou a primeira animação tradicional produzida digitalmente em Hollywood.

Em resumo, a evolução da animação computadoriza na Disney tem relação direta com suas necessidades: economia de custos, facilitar a criação de cenas complexas e executar sequências que causem no público o "wow factor" (cenas que impressionem o público). E evidentemente, por causa da quantidade de tempo e custo envolvido para produzir uma cena, o "wow factor" era muito bem explorado. Se um musical da Broadway (ou mesmo os musicais animados da Disney) possuem um grande número de produção que mais impressiona o público, os showstoppers são como os Wow Factors do cinema, funcionando como grandes demonstrações da última tecnologia disponível de animação para provocar surpresa, exaltação e repercussão. Neste ponto, a tecnologia da animação computadorizada, em seus diferentes graus de sofisticação desde os anos 1980, provou-se um bom ingrediente para atrair atenção do público. Em linhas gerais, o Wow factor é um jargão da indústria para retratar algo feito por uma empresa ou, no caso, estúdio, para superar as expectativas do consumidor em fornecer um grande produto ou experiência excepcional. É algo que a pessoa vê e imediatamente pensa ou fala "Uau!" (Wow!). Do ponto de vista do marketing, isso é visto como o momento da magia.

O artifício não é novo. Parece ter origem no que Henry Jenkins analisou como "the wow clímax", o ponto alto emocional de atos apresentados por artistas de vaudeville. Seria o momento final do auge do espetáculo, após um crescimento gradual das emoções da audiência ao que era apresentado a ela. Os críticos consideravam vulgar e sensacionalista, porém Jenkins (2006) demonstra como a vitalidade desses atos se fortalece na cultura pop. Os estúdios Disney conscientemente se aproveitaram das ferramentas tecnológicas para impressionar seu público, filme após filme. O fator é importante porque consumidores ou espectadores investem mais tempo, dinheiro e interesse naquilo que os impressiona mais. Do ponto de vista criativo, as ferramentas fornecem possibilidades para ideias complexas que não poderiam ser realizadas até então. Fatores financeiros e temporais limitaram drasticamente o uso dessas novas tecnologias de ponta, o que resultou em consecutivos esforços concentrados para que determinadas sequências de filmes pudessem alcançar os objetivos criativos. Entre os exemplos temos a sequência do baile em "A Bela e a Fera" (Fig. 174), a fuga da caverna em “Aladdin" (Fig. 175), o estouro da manada de gnus em "O Rei Leão" (Fig. 177) e a multidão digital em "O Corcunda de Notre Dame" (Fig. 176). Esse fator foi consequentemente aproveitado também pelos designers de games, além de gadgets e aplicativos interativos. 


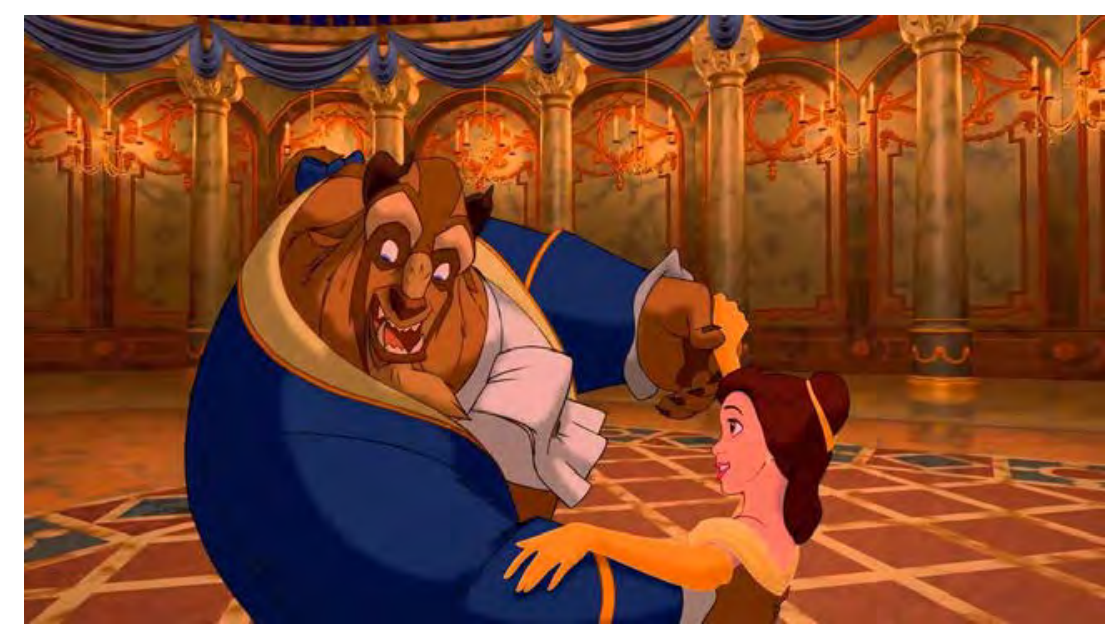

Figura 174 - Complexa cena do salão de baile em "A Bela e a Fera" (1991)

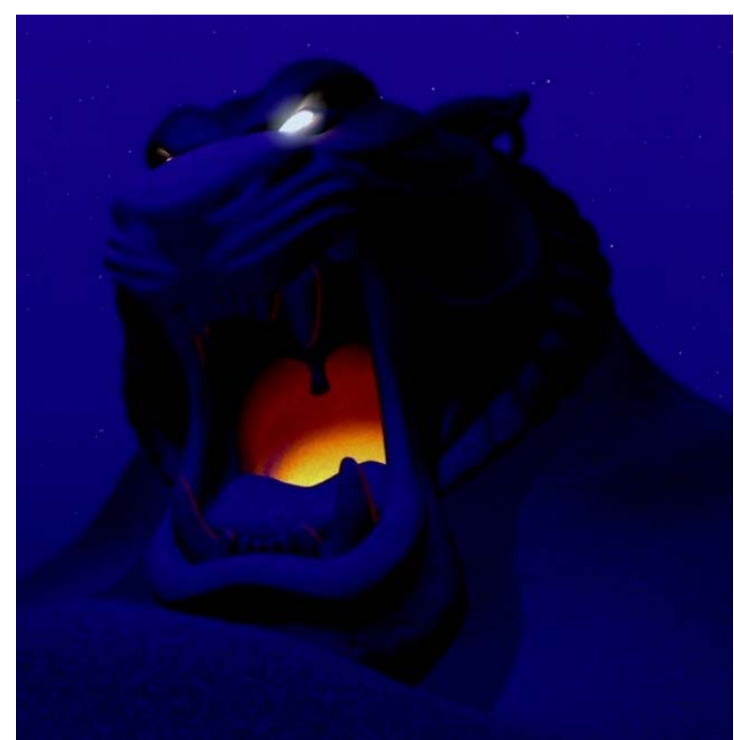

Figura 175 - Cavernas das Maravilhas - uso de CGI em “Aladdin” (1992)

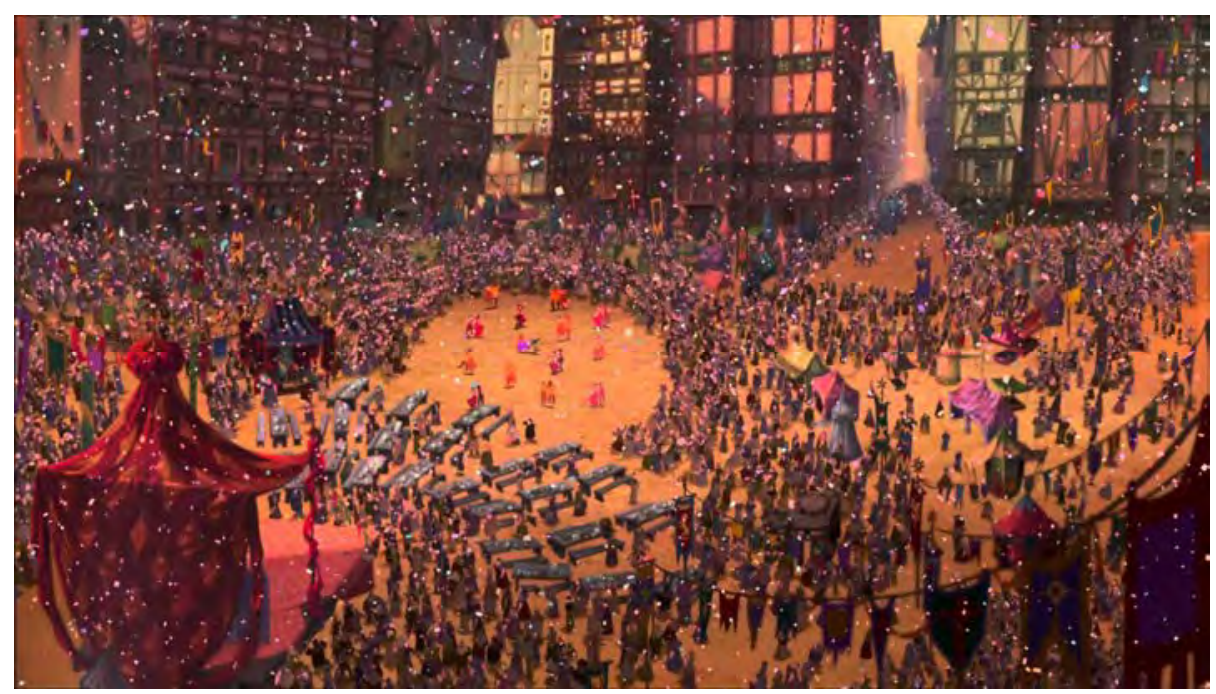

Figura 176 - Multidão digital em "O Corcunda de Notre Dame” (1996) 


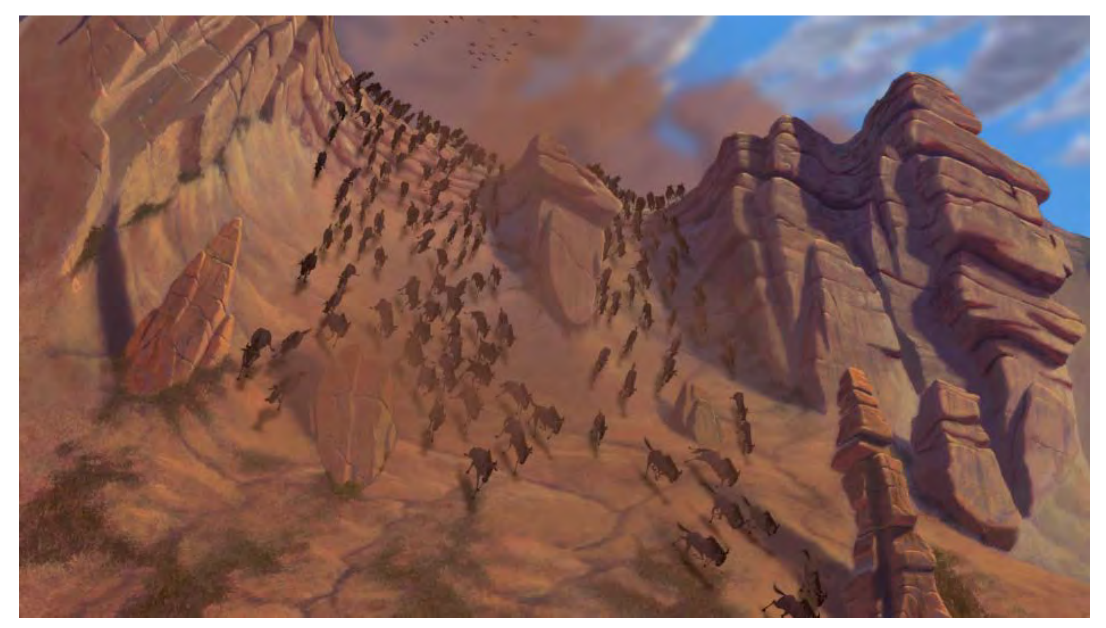

Figura 177 - Estouro da manada em “O Rei Leão” (1994)

\subsection{O Surgimento da Pixar}

O desenvolvimento da animação computadorizada seguiu um caminho diferente na Pixar. O seu viés era menos funcionalista e mais relacionado ao interesse científico de Ed Catmull, ao interesse criativo de John Lasseter e ao interesse empreendedor de Steve Jobs. Lasseter foi aluno na CalArts. Pertenceu à turma de 1974, onde estudou o estilo clássico de animação com vários colegas que depois tiveram carreira promissora, como Tim Burton, John Musker e Brad Bird. Em 1979, foi aceito na Disney, fazendo parte da então nova geração que era treinada para seguir a essência da animação Disney com tutoria dos velhos mestres. Lasseter colaborou com o então jovem Glen Keane em "O Cão e a Raposa” (1981). Glen é considerado um dos mestres de sua geração e seu primeiro grande trabalho pode ser visto na intensa sequência da climática luta entre a raposa e o urso, no final do filme (HULETT, 2014). Cortes no orçamento e o êxodo de animadores liderados por Don Bluth impediram o uso da câmera multiplano para efeitos dimensionais. E havia um clima de que a animação como se conhecia estava em extinção e um temor de que os animadores se tornariam obsoletos. O computador em si era visto com grande ceticismo na sociedade, o que podia ser notado no pessimismo das ficções científicas da época.

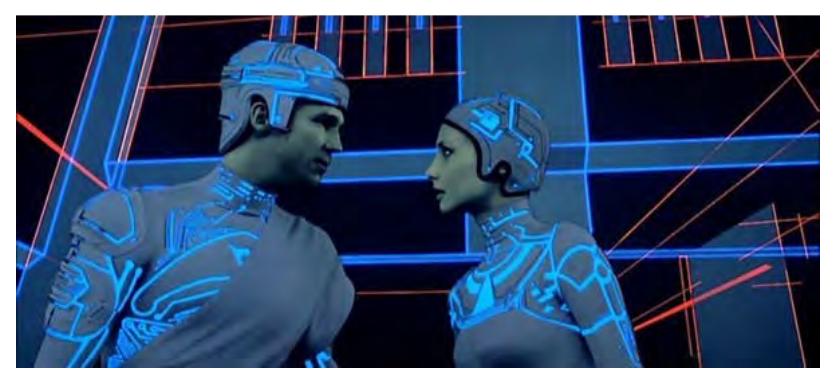

Figura 178 - “Tron” revolucionou o uso da animação computadorizada em 1982. 
O uso da nova tecnologia em "Tron: Uma Odisséia Eletrônica” (1982) impressionou os jovens animadores tradicionais, e, ao mesmo tempo, trouxe uma depressão, pois o filme mostrava que a tecnologia superava muitas das limitações de movimento (especialmente nos cenários) em relação a animação tradicional (Fig. 178). A técnica trazia um enorme potencial para o meio. Não tardou para que um projeto experimental fosse sugerido e aprovado. A aprovação para a produção do teste partiu de um jovem executivo no estúdio - Tom Willhite. O mesmo executivo viu talento em outro animador (o então jovem Tim Burton), deprimido pelo estilo tradicional Disney, e fez com que ele produzisse curtas no seu próprio estilo. Inspirado pela obra "Onde Vivem os Monstros" (Where the Wild Things Are) de Maurice Sendak, o teste de animação de alguns segundos propunha criar e movimentar os cenários digitalmente, porém os personagens seriam animados tradicionalmente.
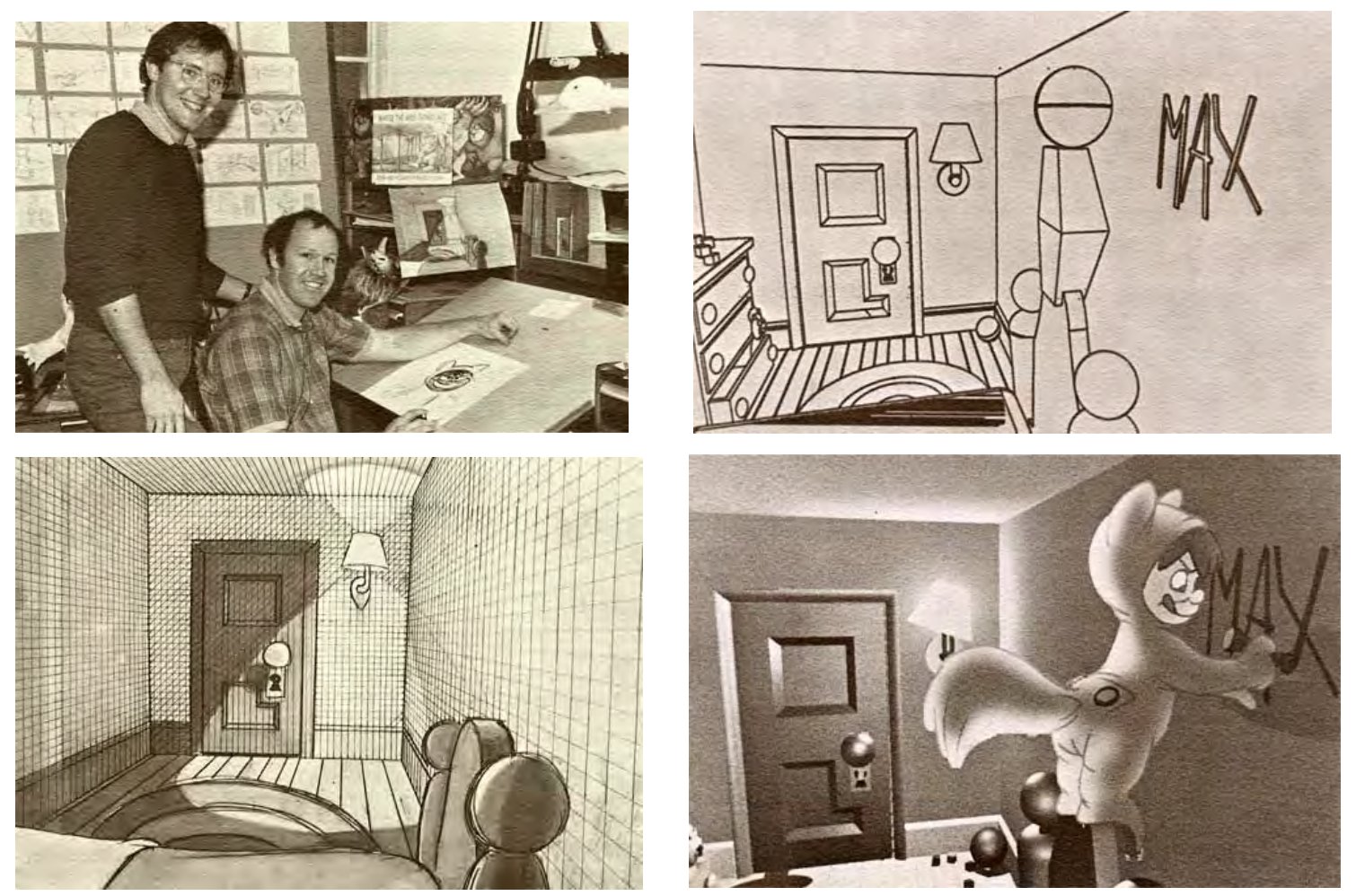

Figura 179, 180, 181 e 182 - John Lasseter e Glen Keane produzindo "Where the Wild Things Are".

Intrigados com a idéia, a Disney liberou um orçamento para o teste. E, claro, John Lasseter criaria os cenários e dirigiria os movimentos de câmera (algo complicadíssimo em animação tradicional), e Glen Keane faria a animação tradicional. O teste final, com cerca de um minuto e meio impressionou todos na Disney, até o então presidente Ron Miller. Infelizmente, o custo estimado para produzir um filme longa-metragem usando essa técnica era muito alto, tornando o projeto proibitivo. Para se ter uma idéia, o custo seria tão alto, que a Disney nunca recuperaria o valor investido depois de lançado. Desse modo, a Disney cancelou "Where the Wild Things Are". Glen Keane retornaria 
para outros projetos em animação tradicional, e John Lasseter conseguiria aprovação de um orçamento para trabalhar com uma equipe em um filme baseado numa história curta chamada "The Brave Little Toaster", novamente apostando no potencial do computador. Após a conclusão do teste, a exibição aos executivos não foi nada boa. Ao tomarem conhecimento de que a animação computadorizada, em tese, custaria o mesmo que uma animação tradicional, expuseram que só faria sentido o estúdio investir nessa novidade se a animação computadoriza fosse produzida de forma mais rápida e barata. Ed Hamson, diretor do estúdio, em alguns minutos cancelou o projeto e terminou com o contrato de Lasseter (IWERKS, 2007).

Edwin Catmull era um acadêmico com título de doutorado pela New York Institute of Technology (NYIT). A instituição era a única nos EUA a investir milhões de dólares no uso do computador em diversas formas. Catmull tinha interesse em tornar mais fácil o uso do computador pela indústria do cinema e foi responsável pelo desenvolvimento de softwares de pintura e demais ferramentas para animação. Seu software TWIN era capaz de converter um desenho a lápis em peça digital, podendo o animador manipulá-lo diretamente no computador (IWERKS, 2007). Não demorou para que Catmull se tornasse membro do laboratório de computação gráfica da University of Utah, onde usou suas qualidades artísticas para desenvolver novos meios de movimentar formas. Seu primeiro teste, uma mão computadorizada, terminou sendo incluído no filme de ficção-científica “Ano 2003 - Operação Terra” (Futureworld, 1976) se tornando o primeiro uso de animação computadorizada num filme live-action (SITO, 2015).

A história da Pixar, que revolucionaria a história do cinema, começa com o cineasta George Lucas. Após a estreia de "Star Wars" (1977), Lucas percebeu que era necessário dar um passo adiante em relação aos efeitos e câmeras ópticas desenvolvidas para seu filme. A ideia era explorar a animação digital formando uma nova divisão de sua empresa, a Lucasfilm. Com a contratação de Ed Catmull, a nova divisão desenvolveu novas ferramentas de produção digital, scanner a laser, sistemas de edição digital e o uso de computadores gráficos com alto volume de processamento. O primeiro grande teste com animação digital produzido pela Industrial Light \& Magic de Lucas ocorreu no filme “Jornada nas Estrelas II: A Ira de Khan" (Star Trek II - The Wrath of Khan, 1982), com uma cena em que a câmera rodopia sobre a vista de um planeta incandescente. O plano da empresa era continuar explorando a técnica. 
O encontro entre John Lasseter, recém-saído da Disney, e Ed Catmull ocorreu durante a Computer Graphics Conference de 1983 em Long Beach, California, onde o segundo se apresentou como conferencista. Curioso pelo projeto "The Brave Little Toaster", cancelado pela Disney, observou em Lasseter a possibilidade de integrar em sua equipe um animador que pudesse desenvolver design de interface em meio aos demais colegas, todos físicos e cientistas de física e computação com $\mathrm{PhD}$ (IWERKS, 2007). O primeiro curta-metragem de animação, "The Adventures of André \& Wally B.” (1984), teve como inspiração as formas geométricas de Mickey Mouse, e tentou usar as antigas técnicas utilizadas na animação convencional como blur, estica e puxa, flexibilidade, entre outras coisas nunca vistas em animação computadorizada. Uma frase dita por Lasseter afirma que "a arte desafiava a tecnologia e a tecnologia inspira a arte" (IWERKS, 2007, tradução nossa). A necessidade do aumento de velocidade e resolução gráfica na produção forçou Catmull e sua equipe a desenvolverem um novo computador - o Pixar Image Computer - considerado o mais avançado graficamente, utilizado na medicina e para análise de imagens de satélites. Os preços dessa tecnologia eram altos demais e a demanda para aquisição era baixa, o que desmotivou George Lucas. O cineasta estava interessado em produzir animação, mas os custos nos anos 1980 eram proibitivos, e não lhe interessava ter uma divisão que produzisse e vendesse computadores e softwares.

O destino trouxe uma terceira figura, o jovem empreendedor Steve Jobs. Com apenas 21 anos, havia fundado a Apple Computer, revolucionando a noção de interface no computador pessoal. Após uma visita ao departamento de animação da Lucasfilm, acompanhado do cientista Alan Kay, Jobs ficou impressionado com o potencial daquela equipe que pensava muito à frente de seu tempo. Embarcando na ideia ambiciosa de produzir futuramente um longa-metragem de animação digital, terminou comprando a Pixar de George Lucas por US\$ 10 milhões (PRICE, 2009).

A história da evolução da Pixar a partir dos curtas-metragens experimentais é muito bem documentada, porém destacamos os lançamentos de "Luxo Jr." (1986), que desenvolveu a personalidade de um abajur (que se tornaria parte da logomarca da Pixar) e "Tin Toy" (1988) vencedor do Oscar, que mostrava um bebê interagindo com brinquedos - o primeiro trabalho complexo envolvendo animação de formas orgânicas (PAIK, 2007). A Pixar continua a usar a produção de curtas-metragens para testar as mais novas ferramentas de animação computadorizadas, dando chance aos seus artistas de desenvolver produções mais pessoais. 
Se a animação caminhava bem, o mesmo não podia ser dito da produção de computadores e softwares. Apesar da criação de ferramentas gráficas como o Renderman e o CAPS, e o fornecimento de softwares para empresas de grande calibre como Microsoft e Apple, o balanço financeiro insistia em permanecer no vermelho. Jobs aumentou seu investimento para US\$ 50 milhões, obtendo controle total da empresa. A saída foi a venda da divisão de hardware, incluindo toda a tecnologia proprietária, para a Vicom Systems - incluindo a transferência de 18 dos 100 funcionários da Pixar. Curiosamente, a Disney comprava o Pixar Computer Image para o uso da tecnologia CAPS (PRICE, 2009).

A Pixar basicamente se concentrou no software Renderman (usado para criar imagens 3-D), no licenciamento do CAPS para a Disney, e na produção de comerciais - este último se tornou pedagógico ao ensinar os animadores a respeitar prazos e orçamentos. Em 1990, a Pixar aumentou a produção de comerciais em animação para diversas empresas, criou vinhetas tridimensionais para o canal Nickelodeon, etc., e mudou sua sede de San Rafael para Richmond, mais próximo de San Francisco, Califórnia (IWERKS, 2007). A redução da equipe foi se tornando drástica e a Pixar só foi salva pois a Disney decidiu fechar um acordo de US\$ 26 milhões para produzir três filmes de animação computadorizados.

Um fato importante é que Jobs e Lasseter se complementavam:

Lasseter, um tipo gregário, brincalhão, que gostava de abraçar as pessoas e usava camisas floridas havaianas. Mantinha o escritório atravancado de brinquedos e ótima qualidade e adorava cheeseburguer. Na Pixar, Jobs era mais tranquilo e respeitava o talento criativo de Lasseter e, mesmo após ser impiedoso em reuniões cobrando resultados financeiros, era capaz de escutar Lasseter e permitir o investimento em novos projetos. Lasseter, por sua vez, respeitava Jobs por apreciar o talento artístico, e por sua capacidade de entrelaçar essa criação com a tecnologia e o comércio. A Disney, por sua vez, tinha pleno conhecimento do talento de Lasseter, tendo tentado recontratá-lo por três anos consecutivos (SCHLENDER e TZTZELI, 2015, p. 146).

Jobs era "um vegetariano irritadiço, magro, que preferia ambientes austeros e em ordem" (ISAACSON, 2011, p. 262-263). Tinha imenso talento para negociação e vendas, um senso estético apurado e seu marketing seduzia milhões de aficcionados ao redor do mundo para produtos que eles não sabiam que desejavam. As famosas apresentações dos produtos feitas por ele eram sempre acompanhadas de grande suspense e idolatria - foi assim com o Macintosh (1984), o NeXT (1988) o iMac (1998), o iBook (1999), o iPod (2001), o iPhone (2007) e o iPad (2010) - produtos belos, calculosamente funcionais e cultuados. Um produto da Apple passou a transmitir eficiência, segurança e status ao seu usuário. Do mesmo modo que Walt Disney, Jobs era como um maestro 
regendo uma orquestra e tinha grande habilidade para gerenciar de forma metódica e exigente o melhor dos membros que o cercavam - do designer de seus gadgets, Johnny Ive, ao engenheiro e cofundador da Apple Inc., Steve Wozniak. Era capaz de se intrometer nos detalhes estéticos dos materiais usados, tanto num iPhone como nas escadarias de uma loja da Apple (SCHLENDER, TZTZELI, 2015).

\subsection{A parceria Disney e Pixar}

A parceria para a produção do primeiro longa-metragem de animação computadorizada não foi das mais fáceis. Havia o choque entre o funcionalismo da Disney e o idealismo da Pixar, o desafio de agregar as técnicas da animação tradicional com a digital e ainda os egos de seus diretores que buscavam meios eficientes de produzir um filme que desse retorno lucrativo. A Disney arcava com o financiamento e a distribuição e a Pixar Animation Studios produziria os filmes (MASTERS, 2000). De cada lado havia supervisores que controlavam e demonstravam encantamento ou , a depender do curso da produção - eles eram Steve Jobs pelo lado da Pixar e Jeffrey Katzenberg na Disney.

Para alinhavar a parceria entre Disney e Pixar, Steve Jobs precisou ser mais maleável do que o acordo que acabou sabotando entre a Next e a IBM devido ao seu estilo mercurial. Jobs acreditava que a tecnologia da Pixar podia revolucionar o próprio modelo de negócio do cinema de animação, pensando que poderia acelerar a criação e reduzir os custos de produção. E se mostrou ofendido com o que chamava de pensamento antiquado da Disney em não apreciar essa tecnologia (ISAACSON, 2011). Katzenberg, sabendo muito mais de produção cinematográfica, afirmara que não estava interessado na tecnologia e sim no storytelling de Lasseter. O conceito de storytelling ${ }^{34}$, tão em voga em tempos de mídias sociais, era muito valorizado no período do renascimento da animação Disney nos anos 1990.

\footnotetext{
${ }^{34}$ Storytelling está relacionada a uma narrativa no sentido da capacidade em contar histórias relevantes. Tem origem nas ligações interpessoais criadas pelo ato de contar uma história. Está presente na literatura, no teatro, no audiovisual, nos games, entre outros, sendo que na década de 2010 se fortalece somado a convergência de mídias (JENKINS, 2009).
} 


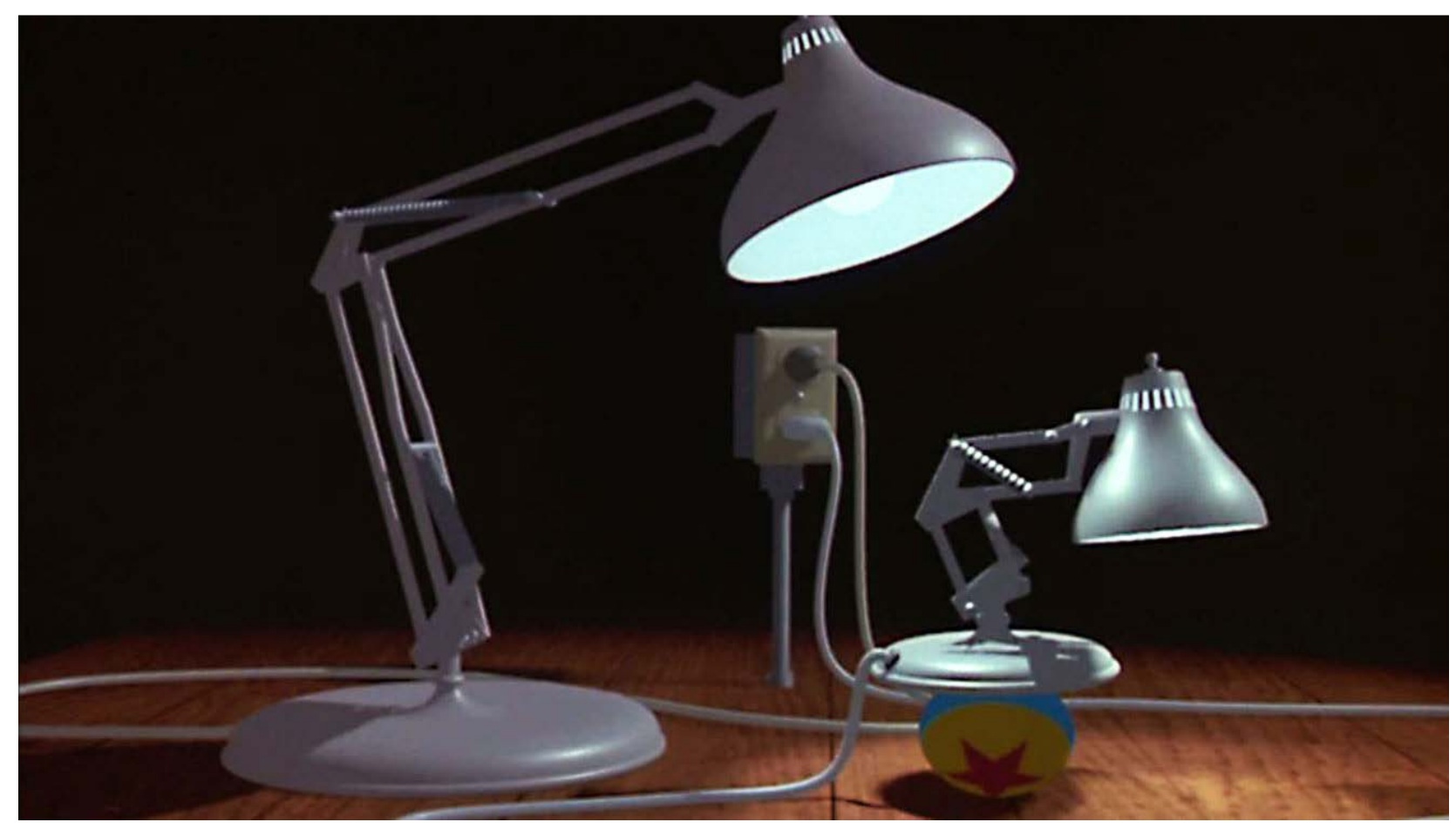

Figura 183 - "Luxo Jr.”, curta-metragem demonstrou que animação CGI podia mostrar emoção.

A Disney considerava Lasseter um gênio na arte de contar histórias. Katzenberg considerava que o curta-metragem "Luxo Jr.", com seus cinco minutos, tinha mais humor e emocional do que muitos filmes com duas horas de duração (SCHLENDER, TZTZELI, 2015, p. 169). Naquele momento o executivo da Disney estava certo. Não acreditava na tecnologia como novo modelo de negócio para a animação e o motivo era simples. Os artistas e os contadores de histórias irão querer continuar a evoluir a tecnologia, desse modo a tecnologia de hoje será obsoleta em dez anos (ou bem menos).

Na visão de Katzenberg, não importa quanta tecnologia você invista na arte de produzir uma animação - um bom filme sempre custará caro, a despeito do custo da tecnologia aos poucos facilitar o acesso e a produção da animação independente. Os dados comprovam essa ideia. "Toy Story" (1995) custou cerca de US\$ 20 milhões e "Universidade Monstro" (2013) custou US\$ 200 milhões (com o marketing incluído). Os orçamentos foram inchando de acordo com a evolução da tecnologia, conforme podemos observar na tabela a seguir: 


\begin{tabular}{|c|c|c|c|c|c|}
\hline \multicolumn{6}{|c|}{ PIXAR ANIMATION STUDIOS } \\
\hline \multicolumn{6}{|c|}{$\begin{array}{l}\text { Orçamentos aprovados, não representando valores finais e custos de marketing e distribuição. Valores } \\
\text { em milhões de dólares. Fonte dos dados: BoxOfficeMojo.com (Dezembro 2015) }\end{array}$} \\
\hline \multirow[t]{2}{*}{ Filme } & \multirow{2}{*}{$\begin{array}{c}\text { Data de } \\
\text { Lançamento }\end{array}$} & \multirow[t]{2}{*}{ Orçamento } & \multicolumn{2}{|c|}{ América do Norte } & \multirow{2}{*}{$\begin{array}{l}\text { Bilheteria } \\
\text { Mundial }\end{array}$} \\
\hline & & & Estreia & Bilheteria & \\
\hline Toy Story & $\begin{array}{r}\text { November 22, } \\
1995\end{array}$ & $\$ 30$ & $\$ 29.1$ & $\$ 191.8$ & $\$ 362.0$ \\
\hline A Bug's Life & $\begin{array}{r}\text { November } 25, \\
1998\end{array}$ & $\$ 120$ & $\$ 33.3$ & $\$ 162.8$ & $\$ 363.4$ \\
\hline Toy Story 2 & $\begin{array}{r}\text { November 24, } \\
1999\end{array}$ & $\$ 90$ & $\$ 57.4$ & $\$ 245.9$ & $\$ 485.0$ \\
\hline $\begin{array}{l}\text { Monsters, } \\
\text { Inc. }\end{array}$ & $\begin{array}{r}\text { November } 2, \\
2001\end{array}$ & $\$ 115$ & $\$ 62.6$ & $\$ 255.9$ & $\$ 528.8$ \\
\hline $\begin{array}{l}\text { Finding } \\
\text { Nemo }\end{array}$ & May 30, 2003 & $\$ 94$ & $\$ 70.3$ & $\$ 339.7$ & $\$ 895.6$ \\
\hline $\begin{array}{l}\text { The } \\
\text { Incredibles }\end{array}$ & $\begin{array}{r}\text { November } 5, \\
2004\end{array}$ & $\$ 92$ & $\$ 70.5$ & $\$ 261.4$ & $\$ 631.4$ \\
\hline Cars & June 9, 2006 & $\$ 120$ & $\$ 60.1$ & $\$ 244.1$ & $\$ 462.0$ \\
\hline Ratatouille & June 29, 2007 & $\$ 150$ & $\$ 47.0$ & $\$ 206.4$ & $\$ 623.7$ \\
\hline WALL-E & June 27, 2008 & $\$ 180$ & $\$ 63.1$ & $\$ 223.8$ & $\$ 521.3$ \\
\hline$U p$ & May 29, 2009 & $\$ 175$ & $\$ 68.1$ & $\$ 293.0$ & $\$ 731.3$ \\
\hline Toy Story 3 & June 18,2010 & $\$ 200$ & $\$ 110.3$ & $\$ 415.0$ & $\$ 1,063.2$ \\
\hline Cars 2 & June 24, 2011 & $\$ 200$ & $\$ 66.1$ & $\$ 191.5$ & $\$ 559.9$ \\
\hline Brave & June 22, 2012 & $\$ 185$ & $\$ 66.3$ & $\$ 237.3$ & $\$ 539.0$ \\
\hline $\begin{array}{l}\text { Monsters } \\
\text { University }\end{array}$ & June 21, 2013 & $\$ 200$ & $\$ 82.4$ & $\$ 268.5$ & $\$ 743.6$ \\
\hline Inside Out & June 19,2015 & $\$ 175$ & $\$ 90.4$ & $\$ 356.2$ & $\$ 851.3$ \\
\hline \multicolumn{2}{|c|}{ Total } & $\$ 2.126 .0$ & $\$ 977.0$ & $\$ 3.893 .2$ & $\$ 9.361 .5$ \\
\hline \multicolumn{2}{|c|}{ Média } & $\$ 141.7$ & $\$ 65.1$ & $\$ 259.5$ & $\$ 624.1$ \\
\hline
\end{tabular}

Tabela 9 - Valores de produção e faturamento na Pixar. 


\begin{tabular}{|l|c|c|c|}
\hline \multicolumn{2}{|l|}{ PIXAR - Recepção público e crítica (três websites compiladores de críticas) } \\
\hline Fonte dos dados: BoxOfficeMojo.com (Setembro de 2015) \\
\hline \multicolumn{1}{|c|}{ Film } & $\begin{array}{c}\text { Rotten } \\
\text { Tomatoes }\end{array}$ & $\underline{\text { Metacritic }}$ & CinemaScore \\
\hline Toy Story & $\underline{100 \%}$ & $92 / 100$ & $\mathrm{~A}$ \\
\hline A Bug's Life & $92 \%$ & $77 / 100$ & $\mathrm{~A}$ \\
\hline Toy Story 2 & $100 \%$ & $88 / 100$ & $\mathrm{~A}+$ \\
\hline Monsters, Inc. & $96 \%$ & $78 / 100$ & $\mathrm{~A}+$ \\
\hline Finding Nemo & $99 \%$ & $90 / 100$ & $\mathrm{~A}+$ \\
\hline The Incredibles & $97 \%$ & $90 / 100$ & $\mathrm{~A}+$ \\
\hline Cars & $74 \%$ & $73 / 100$ & $\mathrm{~A}$ \\
\hline Ratatouille & $96 \%$ & $96 / 100$ & $\mathrm{~A}$ \\
\hline WALL-E & $96 \%$ & $94 / 100$ & $\mathrm{~A}$ \\
\hline Up & $98 \%$ & $88 / 100$ & $\mathrm{~A}+$ \\
\hline Toy Story 3 & $99 \%$ & $92 / 100$ & $\mathrm{~A}$ \\
\hline Cars 2 & $39 \%$ & $57 / 100$ & $\mathrm{~A}-$ \\
\hline Brave & $78 \%$ & $69 / 100$ & $\mathrm{~A}$ \\
\hline Monsters University & $78 \%$ & $65 / 100$ & $\mathrm{~A}$ \\
\hline Inside Out & $98 \%$ & $94 / 100$ & $\mathrm{~A}$ \\
\hline
\end{tabular}

Tabela 10 - Recepção da crítica especializada compilada em websites da área.

A Pixar não cedeu a tecnologia de produção solicitado por Katzenberg e Jobs tropeçou ao não pedir uma fatia do faturamento com a venda dos filmes no mercado de vídeo - negócio que se mostrava tão ou mais lucrativo que o cinema. O acordo permitia à Disney ser proprietária de todos os direitos autorais das novas animações da Pixar e pagava cerca de $12,5 \%$ da renda da bilheteria. E ainda tinha o controle criativo, podendo suspender a qualquer momento o filme, pagando apenas uma pequena multa. Outra cláusula dava à Disney a opção (e não a obrigação) de fazer os dois filmes restantes constantes no contrato e ainda teria o direito de produzir, com ou sem a parceria com a Pixar, continuações dos filmes usando os personagens já criados (ISAACSON, 2015, p. 300).

A relação inicial não foi nada fácil. Diversas apresentações com sugestões de ideias para o filme “Toy Story” foram rasgadas e criticadas. Os personagens deveriam ser mais ardilosos, o filme não deveria ser focado somente no público infantil, apesar do título, e ainda houve a sugestão para que Lasseter assistisse filmes como "Os Acorrentados" e "48 Horas", com dois personagens muito diferentes que eram obrigados a conviver juntos e criar vínculos. O resultado após várias sessões de avaliação foi uma exibição-teste monstruosa em novembro de 1993, quando a equipe da Pixar levou metade do filme em produção para que os executivos da Disney em Burbank, Califórnia, pudessem assistir o desenvolvimento das sugestões. O resultado se mostrou desastroso, com os personagens tendo perdido totalmente o encanto. Peter Schneider, executivo que nunca apoiou a ideia de permitir que um estúdio externo produzisse filmes para a Disney, pediu por sua suspensão, que foi avalizada 
pelo seu superior, Katzenberg. No entanto, a justificativa com maior franqueza para o filme estar ruim veio do produtor Thomas Schumacher: "Porque não é mais o filme deles. Eles estavam seguindo as observações de Katzenberg, e o projeto saíra completamente dos trilhos” (ISAACSON, 2015, p. 302).

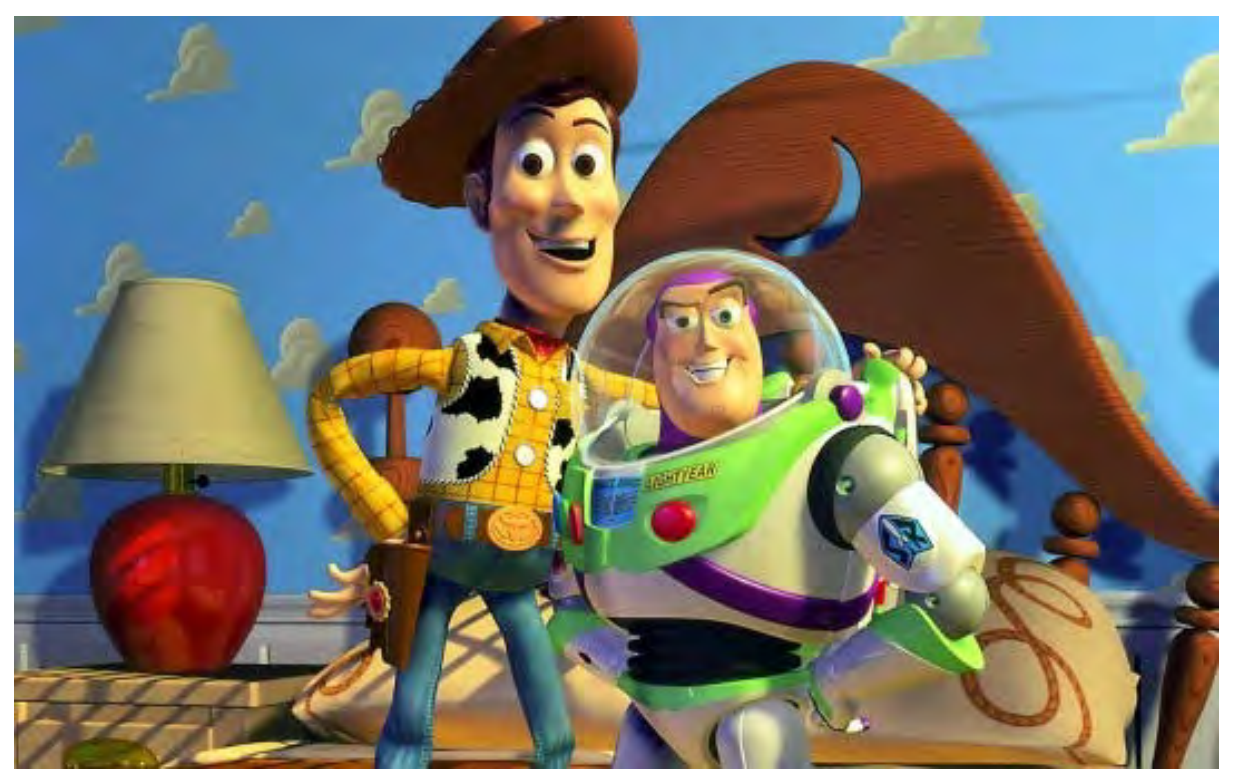

Figura 184 - “Toy Story” (1995), o primeiro longa-metragem de animação CGI.

O diretor John Lasseter concordara que o filme estava péssimo e pediu nova oportunidade para reescrever o roteiro. Steve Jobs, por sua vez, não se envolvia na parte criativa por seu temperamento mercurial nas decisões envolvendo gosto e design. Porém, ficou do lado dos artistas e pagou do próprio bolso as "reformas" necessárias no filme. O novo roteiro demorou três meses e o orçamento de US\$ 17 milhões já não era mais suficiente para produzir o filme. Uma nova guerra entre Jobs e Katzenberg começou. O primeiro acusava impiedosamente o segundo de ter estragado o projeto causando o prejuízo. O segundo alertava que a equipe Pixar contava com o benefício da ajuda criativa da Disney, e que não poderia ser cobrado por isso. Com os artistas em clima de colapso e os executivos travando briga de foices, o papel de conciliador sobrou para o cientista - Ed Catmull era a figura diplomática e sabia ver os pontos positivos do executivo da Disney (ISAACSON, 2015, p. 303). A situação toda quase levou Jobs a vender a Pixar em 1994, o que foi revertido com a garantia da distribuição do filme pela Disney e pela produção ter retornado aos trilhos. O orçamento chegou aos US\$ 30 milhões. Steve Jobs percebeu que não podia depender tanto da Disney e articulou uma estratégia para que a Pixar ganhasse legitimidade. Para deixar de ser mero fornecedor e obter o controle total, planejou lançar IPO (oferta pública de ações) na Bolsa de Valores de Nova York. A data foi escolhida a dedo: 29 de novembro de 1995, uma semana após a estreia de "Toy Story" - o 
primeiro longa-metragem de animação computadorizada da história do cinema, faturando um total de US\$ 362 milhões (PRICE, 2009).

Rusgas permaneceram entre Pixar e Disney. A Disney promoveu a estreia mundial de "Toy Story" (1995) em Los Angeles, sem a presença de Jobs. A Pixar promoveu sua própria estreia em San Francisco, tendo na plateia convidados do Vale do Silício. Questões foram levantadas pela imprensa e pela indústria: “Toy Story” era um filme Disney ou Pixar? A Disney apenas promovia e distribuía? A Pixar era contratada para fazer o filme para a Disney? A crítica exaltava mais a "tradição Disney" do que o surgimento da Pixar (ISAACSON, 2015, p. 305). Essas questões embaraçosas para os verdadeiros criadores levaram a uma série de estratégias que incluiu a proeminência, em qualquer trailer ou cartaz, da frase "Walt Disney Pictures apresenta um filme da Pixar Animation Studios". A Pixar alcançou grande sucesso com a venda de suas ações na Bolsa, tornando o estúdio finalmente um excelente negócio para Steve Jobs. A animação ganhou um Oscar especial pelo ineditismo técnico. A equipe criativa obteve "luz verde" para iniciar um novo filme, Vida de Inseto (A Bug's Life, 1998) e temos o início da trajetória de sucesso financeiro e prestígio crítico das animações Pixar (PRICE, 2009).

\subsection{O Home-Vídeo e a Saturação da Produção}

A produção pode ser guiada por forças de diferentes origens. Uma das mais comuns é a concorrencial. A Disney, como já observamos, retornou para a televisão nos anos 1980, com a produção da seriados (live-action e animados), telefilmes e especiais. O desafio mais comum de qualquer estúdio é acertar na distribuição. A Disney teve muita sorte pois seu presidente, Michael Eisner, conseguiu negociar o conteúdo justamente com o seu ex-chefe.

O magnata australiano Rupert Murdoch comprou o estúdio da 20th Century Fox de Marvin Davis, fomando o que seria conhecido futuramente como a corporação de mídia News Corp.. Em 1984, Barry Diller havia se transferido da Paramount para o cargo de chairman e CEO da Fox Inc., controladora do estúdio de cinema. A aquisição por Murdock possibilitou que Diller realizasse seu sonho de lançar uma quarta rede de TV, rivalizando com as gigantes ABC, NBC e CBS (SCHWARTZ, 1998). A rede Fox foi lançada em 1986, com uma proposta ousada de inicialmente não funcionar como uma rede tradicional. Apostava em programação local e no horário nobre havia seriados originais mais picantes e arriscados que os exibidos pelas concorrentes - caso de "Um Amor de Família" (Married with Children) e "Os Simpsons" (The Simpsons). Em meados de 1988, Diller 
e Eisner tiveram uma negociação difícil para levar o Disney Channel para a Europa via TV por assinatura, usando a operadora via satélite Sky Television, de propriedade da News Corp. (GROVER, 1997, p. 188).

Quando a Disney lançou um pacote inédito de seriados animados, oferecido em um programa chamado "Disney Afternoon", a Fox, por intermédio de Barry Diller, imediatamente comprou para exibir os desenhos na programação vespertina de suas emissoras afiliadas. Porém, a mesma Fox foi responsável por um declínio pontual da animação Disney. No inicio de 1990, a Disney comprou uma emissora de TV independente na região de Los Angeles chamada KHJ. Buscando meios de melhorar o desempenho de audiência, a solução encontrada foi retirar o Disney Afternoon da estação local da FOX e transferí-lo para a KCAL - o novo nome do canal comprado pela Disney (SCHWARTZ, 1999, p. 192).

A decisão enfureceu Barry Diller que, sentindo-se traído por ajudar a fomentar a produção Disney, considerava que as emissoras da Fox tinham que ser priorizadas. O executivo da Fox retaliou das três piores formas possíveis. Inicialmente, retirou a programação Disney de outras seis emissoras da Fox. E depois decidiu investir na produção própria de programação infantil, o que era estimulado pelas afiliadas. Finalmente, a Disney perdeu o poder de barganhar a venda da programação com as afiliadas da Fox, pois a major ameaçava as afiliadas de desfiliação. O que se seguiu foi uma batalha na justiça, com a Disney acusando a Fox de interferência contratual e monopólio de programação infantil. O processo judicial prejudicou os dois lados. A Fox reduziu a pressão sobre as afiliadas e a Disney ainda manteve a programação infantil lucrativa por mais dois anos - em 1992, desistiu do processo, pois ele dificultava outros tipos de negociações com a Fox e com sua proprietária, a News Corp. no mercado internacional (GROVER, 1997, p. 195). A maior vingança da Fox contra a Disney, porém, foi o sucesso de suas novas produções próprias. Começou de forma provocativa com a série animada "Peter Pan e os Piratas", inspirado num personagem já explorado pela Disney, e culminou com “Power Rangers”, um dos maiores sucessos televisivos da década de 1990.

Se a TV é capaz de acirrar os ânimos entre os estúdios, o mercado ascendente de home-vídeo representou um divisor de águas e ampliou a produção de animação para o cinema e a televisão de diferentes formas. O negócio do home-video e a popularidade do videocassete ajudou a dar combustível à indústria da animação. Por muitos anos a Disney teve a estratégia de relançar seus filmes nos cinemas por curtas temporadas, normalmente a cada 7 anos, para atingir uma nova geração. Era uma ótima fonte de renda para o estúdio. Em 1984, por exemplo, o filme "Pinóquio" (1940) 
estava programado para um relançamento nos cinemas no Natal. Mesmo não sendo dos mais populares nos cinemas, a animação conseguiu render US\$ 26 milhões em sua exibição. Com a ascensão do videocassete não somente nos lares americanos, mas ao redor do mundo, era natural que a Disney pensasse em apostar nessa área. Até então o home-vídeo era um negócio pequeno para a Disney. O faturamento na área era de US\$ 70 milhões no início dos anos 1980 e, em geral, os títulos lançados em VHS eram filmes antigos e compilações de curtas e longas de animação. Nunca os clássicos haviam sido testados no mercado (GROVER, 1997). Os demais estúdios já estavam aproveitando bem o uso de seus acervos dos cinemas em outras mídias. Utilizando a estratégia das “janelas”, ou seja, um período de tempo de espera em que um título que saiu do cinema precisava esperar para depois ser lançado em VHS, e posteriormente ter janelas para suas exibições na TV a cabo e TV aberta (ULIN, 2014).

Na Disney havia o sentimento conservador de que lançar os clássicos da animação em VHS seria arriscar diluir o valor que eles tinham em seus relançamentos periódicos nos cinemas. A ideia superficial era que a família que comprasse o VHS não pagaria para rever o filme no cinema anos mais tarde. Não havia percepção na época de que existia um mercado promissor de VHS voltado para crianças e em meados dos anos 1980 o mercado era primordialmente voltado para locação. Oferecer as animações clássicas era o equivalente a perder um ativo que periodicamente retornava dinheiro ao estúdio. O primeiro teste fora feito justamente com "Pinóquio" para experimentar o mercado de home-video. Porém, a um custo elevado de US\$ 79,95 ante o comum na época, em torno de US\$ 29,90. A ideia era encorajar os consumidores a alugar do que comprá-lo, minimizando a chance do filme permanecer na casa das pessoas (SCHWARTZ, 1998). Após muita discussão entre os membros do primeiro escalão da Disney, um executivo foi fundamental para alterar a percepção de todos. Bill Mechanic fora responsável por montar o departamento de TV paga de mais sucesso de Hollywood. Enquanto na Paramount, seu departamento conseguiu vender as produções do estúdio por preços sem precedentes para a TV a cabo (GROVER, 1997, p. 128). Na Disney, foi responsável pelos programas especiais de televisão. Em agosto de 1985, Bill Mechanic foi nomeado presidente de home-video da Disney, com a ação de baixar os preços para US\$29,90 - o resultado foi a venda de mais de 600 mil fitas, tendo sido usado pouco marketing. Rapidamente o estúdio descobriu que crianças eram mais sensíveis em rever múltiplas vezes seus filmes favoritos. E que saía mais barato comprar do que alugar diversas vezes um título.

Para o lançamento seguinte, "A Bela Adormecida", que teve escala internacional, Mechanic foi mais incisivo na pressão para convencer que o mercado de home-video era positivo. Para eliminar 
a questão chave de que os lançamentos em VHS eliminavam a capacidade de gerar retorno no longo prazo, o executivo promoveu cálculos para provar a vantagem do VHS. O raciocínio foi simples. Ele imaginou a Disney relançando "A Bela Adormecida" quatro vezes no cinema ao longo de 28 anos (respeitando a tradicional janela ou intervalo de 7 anos entre eles). Resultaria em aproximadamente US\$ 125 milhões de bilheteria. Em contraste, estimou que o lançamento em VHS do filme pela primeira vez renderia US\$ 100 milhões em vendas. E ainda calculou que a inflação a longo prazo corroi o valor de compra, ou seja, receber hoje era melhor que o dólar recebido no futuro. Em suma, o dinheiro recebido poderia ser usado para produzir novos filmes ou gerar uma renda extra. Com uma campanha de marketing maior de US\$ 7 milhões, "A Bela Adormecida" chegou ao mercado vendendo mais de 1,3 milhão de fitas VHS.

A cada lançamento a Disney aprendia novos meios de conquistar mercado. "Cinderella" havia sido relançado nos cinemas faturando US\$ 34 milhões. Seu lançamento em VHS não estaria restrito somente a locadoras e lojas de vídeo. Alcançando os grandes magazines como Target e Wal-Mart, o VHS da animação vendeu 6 milhões de cópias, gerando faturamento de quase US\$ 100 milhões. No ano seguinte, Disney eliminou intermediários criando sua própria distribuidora de vídeo e estabelecendo contato direto com as redes de varejo. "Mogli: O Menino Lobo" foi o primeiro lançamento independente da Disney em vídeo, vendendo 9 milhões de VHS. Em 1992, “101 Dálmatas" vendeu 14 milhões de fitas - os números todos somente no mercado norte-americano (SCHWARTZ, 1999, p. 189).

As primeiras animações clássicas foram lançadas em VHS, porém a Disney mantinha dois títulos em estado quase sacrossanto, "Branca de Neve e os Sete Anões" (1937) e "Fantasia" (1940). Fruto dessas discussões, Eisner teria se interessado na ideia original de Walt Disney de relançar "Fantasia" nos cinemas com novos segmentos. Em 1990, assistiu a um ensaio da Filarmônica de Nova York no Lincoln Center, na época dirigida pelo popular maestro Leonard Bernstein. Eisner queria saber a opinião do maestro sobre um novo "Fantasia", combinando música erudita e os Beatles. O maestro não somente gostou como se interessou em participar do projeto. No entanto, não escapou em cutucar Eisner quando este comentou de modo entusiasmado sobre usar a orquestra para interpretar os Beatles: “Sr. Eisner, só precisamos de quatro músicos!”. (SCHWARTZ, 1999, p. 190). Bernstein faleceu de câncer de pulmão seis meses após o encontro e a ideia de incluir os Beatles no filme foi esquecida. 
Em sua biografia (SCHWARTZ, 1999), Eisner detalhou as discussões para relançar os clássicos mais protegidos. Durante as discussões do mercado de home-video, Eisner recebeu as projeções de venda de um potencial lançamento de "Fantasia" em VHS. Os números eram astronômicos, a ponto de convencê-lo a se reunir com Roy E. Disney, sua esposa Patty e seus quatro filhos para discutir a possibilidade de lançar o filme em vídeo. Três argumentos foram usados. $\mathrm{O}$ primeiro, é que o filme de 1940 nunca teve a exposição merecida junto ao grande público, a despeito da descoberta feita pelos hippies, que lotaram os cinemas em 1969. Oura razão é que o lançamento promoveria a restauração do filme. Somente três de cada 24 frames mantinham sua cor original. Com a tecnologia de restauração digital, seria possível fazer o filme parecer tão perfeito como quando seu lançamento original. E, finalmente, os lucros do lançamento em VHS poderiam financiar um novo filme, que Roy Disney supervisionaria. A família Disney aceitou a proposta e o filme vendeu 15 milhões de cópias em VHS em 1991. No ano seguinte, a decisão de lançar "Branca de Neve" foi ainda mais fácil pois os direitos autorais entrariam em domínio público na Itália e havia o temor da pirataria tomar conta da distribuição da animação. A animação vendeu 50 milhões de VHS e a Disney, depois, ainda conseguiu estender os direitos autorais.

O gigantismo do mercado de home-video e os lucros provenientes tiveram um impacto profundo na produção. A Disney, que produzia uma animação a cada 18 meses, estava disposta a produzir uma anualmente. O mantra de Jeffrey Katzenberg dirigindo o estúdio era "maior, melhor, mais rápido e mais barato", o que contribuiu para intensas reclamações de artistas e técnicos sobre o paradoxo entre "maior e melhor" e "mais rápido e barato". Eisner acreditava que metas, pressão e exaustão forçavam os artistas a superarem o que achavam possível (HAHN, 2009). Porém, estava claro que a melhora na qualidade necessitaria mais dinheiro e mais talentos, ou seja, uma expansão.

Estruturalmente, a Disney teve uma primeira expansão quando abriu um estúdio satélite na Flórida. A ideia era oferecer uma oportunidade aos visitantes do parque temático Disney-MGM Studios (atual Disney's Hollywood Studios) conferir como as futuras animações eram produzidas e observar atrás de enormes vidros (o espaço tinha o apelido interno de aquário) os animadores trabalhando. Mestres da nova geração de animadores, como Ruben Aquino e Mark Henn, permaneceram muitos anos na Flórida, treinando novos animadores e produzindo seus personagens. O que no início era um pequeno espaço de produção dentro de um parque planejado para minar a concorrência de outro parque na região - Universal Studios -, transformou-se num celeiro de novos talentos que produziram curtas-metragens, trechos de filmes e até longas inteiros como "Mulan" (1998), “Lilo \& Stitch” (2001) e “Irmão Urso" (2003). 
Com o sucesso de animações como "A Bela e a Fera" (1991) todos pareciam querer ter o crédito pelos sucessos, menos aqueles que de fato o tinham produzido diretamente. Roy E. Disney sentia-se esquecido na Disney. Havia dois motivos para isso. O primeiro é que Roy, apesar de todo seu entusiasmo, não era uma voz muito ativa em reuniões ou suas ideias não eram em grande parte consideradas seriamente. O outro motivo é que Katzenberg era o chefe workaholic dos estúdios e estava claramente se aproveitando dos holofotes após as estreias de sucesso. Michael Eisner, o CEO, também ficava incomodado com a situação, apesar dele próprio ser um executivo midiático. Frank Wells, o presidente, era o mais altruísta e permanecia nas sombras no meio de grandes personalidades e egos, sendo uma espécie de conciliador (HAHN, 2009). Durante as festividades pelo sucesso de "A Bela e a Fera", Eisner anunciou, como recompensa pelo sucesso, a construção de um novo edifício para o estúdio de animação em Burbank, que até então ficava espalhado pelos galpões industriais em Glendale.

O prédio, desenhado em linhas pós-modernas pelo arquiteto Robert M. Stern, tem um gigantesco chapéu do Mickey feiticeiro de "Fantasia" (1940) bem em seu centro - onde funcionaria o escritório de Roy E. Disney, o maior interessado na iniciativa para os animadores. Diversos profissionais encaravam o novo edifício como um ato da corporação em apenas divulgar o "produto animação" e criticavam a estrutura interna do edifício, que segregava os grupos de trabalho - um apelido maldoso para o prédio era "câmara de gás pós-moderno” (LUND, 2005). Jeffrey Katzenberg, por outro lado, não estava sabendo de nada até o anúncio na festa. Profundamente irritado por não ter tomado conhecimento antes, considerou o anúncio inadequado e injusto com ele. Finalmente ficava claro o clima de animosidade entre Eisner, Katzenberg e Roy Disney (HAHN, 2009).

Do ponto de vista dos artistas, a pressão na aceleração dos projetos e a busca intensa por mais qualidade trouxe problemas de saúde, como estafa e síndrome do túnel de carpo ${ }^{35}$ em muitos dos profissionais. Os próprios artistas do estúdio tiveram parcela da culpa por sempre tentarem se superar em meio a pressão. Ficaram famosos, animadores começaram a dar entrevistas na mídia impressa e na TV e representavam o estúdio em eventos especiais. A concorrência com os novos estúdios, a partir da segunda metade dos anos 1990, levou os animadores a ganharem salários mais altos, bônus generosos, e de repente se via os estacionamentos repletos de carros BMW e Porshes, e os animadores começaram a ser representados por advogados e agentes de

\footnotetext{
${ }^{35}$ Síndrome causada pela compressão do nervo mediano que passa por um canal estreito no punho chamado de Túnel do Carpo. Os sintomas podem ser choque, dor, dormência, formigamento e perda da destreza das mãos.
} 
Hollywood. A situação piorou com o aumento da concorrência em Hollywood e a ambição dos profissionais (HAHN, 2009, tradução nossa).

No estúdio satélite de Paris, a divisão Disney Movietoons, produzindo animações com orçamentos um pouco menores que os correlatos nos Estados Unidos, mas ainda assim com boa qualidade, concluiria "Pateta - o Filme" (1995) após a experiência positiva com "DuckTales: O Tesouro da Lâmpada Perdida" (1990). Outro estúdio satélite na Flórida foi ampliado e preparado para produzir seu primeiro longa-metragem integralmente - "Mulan" (1998).

Se "Aladdin" havia sido um grande sucesso comercial”, o estúdio não estava preparado para a repercussão que teria "King of the Jungle" ou o que seria chamado depois de "O Rei Leão". Conhecido internamente como "Bambi na África", o projeto da animação começou, na realidade, como um "filme B". Katzenberg, na ressaca do sucesso do romance musical "A Bela e a Fera", estava impressionado com a perspectiva de "Pocahontas" superá-lo nesse quesito. Considerado pelo executivo um "sucesso certeiro" - segundo ele era um "Romeu e Julieta" ou "Amor, Sublime Amor" com índios americanos (HAHN, 2009). "O Rei Leão" era visto mais como um experimento, uma incógnita do ponto de vista do interesse do público. Após a reunião em que fez esses comentários, uma boa parte dos melhores animadores dos estúdios foram trabalhar em "Pocahontas". Não houve fé em "O Rei Leão". A verdade é que a animação, que lidava com temas como o amadurecimento, a responsabilidade e o ciclo da vida, agradou o público e a crítica, tornando-se o maior sucesso da Disney por mais de uma década (MASTERS, 2000).

\subsection{Verticalização e Crise}

Muitas vozes na Disney afirmam que Eisner instituiu excelentes bases criativas e intensa expansão com qualidade nos primeiros dez anos de sua gestão de produção conservadora. (STEWART, 2005, p. 31-32). O processo acelerado de expansão nos anos 1990, que visava proteger a Disney de ameaças de aquisição pela concorrência, levou o executivo a entrar na onda das fusões. Quase comprou os direitos dos Muppets de Jim Henson (Fig. 185), em 1990, porém o fato de Eisner não conceder certos pontos do acordo inicial provocou o afastamento da família Henson. Jim Henson, que já colaborava em alguns projetos com a Disney, morreu em 1991. A Disney só conseguiria adquirir os Muppets em 2004. O maior negócio, entretanto, foi a fusão com a gigante da mídia Capital Cities/ABC, incluindo a rede de TV $\mathrm{ABC}$, os canais esportivos ESPN, uma rede de rádio, diversos negócios editoriais e 
participações em canais por assinatura. Havia no negócio até um pacote de animações para televisão gigantesco, pertencente à DIC Entertainment.

Os estúdios Disney oficializaram a verticalização corporativa. Ela não estava sozinha nesse tipo de medida administrativa. A Time Warner, a Viacom, a Universal Studios e outras gigantes sofreram o mesmo processo nos anos seguintes. O processo de intensa concentração da mídia gerou propriedades cruzadas e intrincadas redes de negociação e produção. As corporações de mídia se tornaram entidades poderosas, com grande poder de persuasão, influindo em questões políticas nacionais, culturais, econômicas e geopolíticas (KORTEN, 1995). Em muitas das corporações, o inchaço provocou problemas sérios de gestão e executivos caíram em consequência de estratégicas erráticas ou simplesmente porque perdiam o foco em negócios considerados essenciais em suas estruturas.

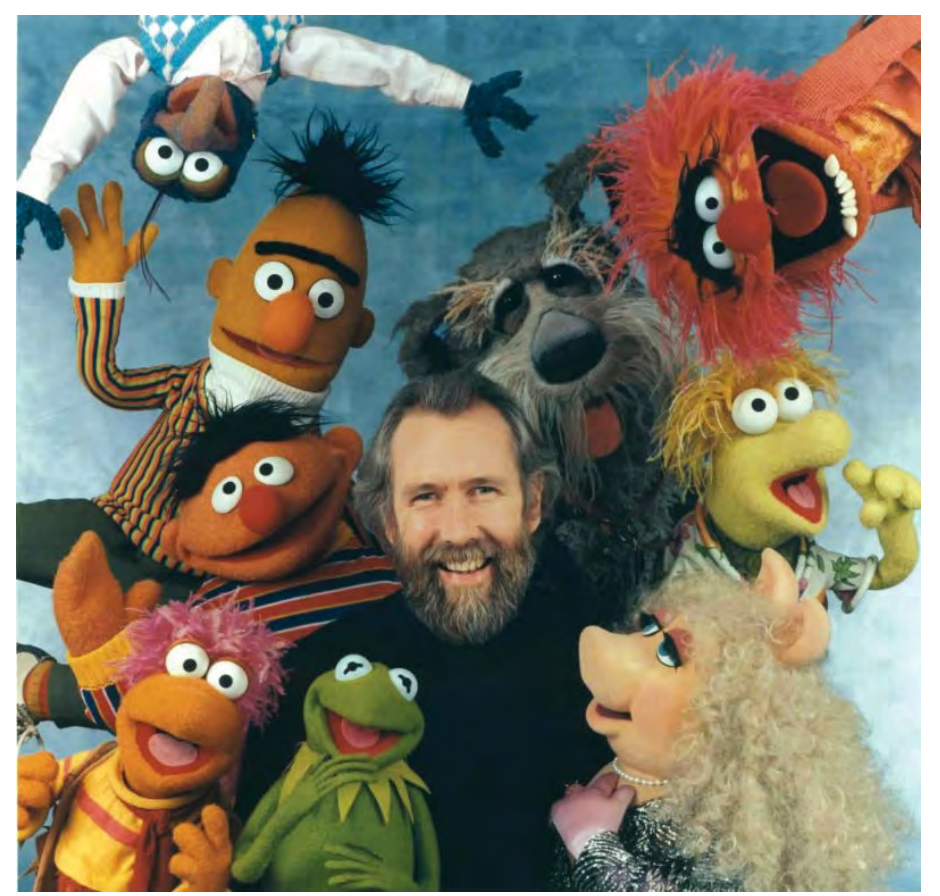

Figura 185 - Jim Henson e suas criações, os Muppets.

O estúdio foi abalado pela morte trágica do executivo Frank Wells em 1994, em um acidente de helicóptero quando retornava de um resort em Nevada. Wells era um ávido alpinista e, das sete montanhas mais altas do mundo, só não escalou o Everest. Na Disney, seu papel como executivo $\mathrm{n}^{\circ}$ 2 era bem mais calmo. Agia praticamente como um ombudsman do CEO Michael Eisner, apagando diversos "incêndios" entre departamentos e executivos e auxiliando, sendo a "cabeça financeira" a limitar um pouco Eisner de seus rompantes criativos. Entretanto, Wells não conseguiu impedir 
problemas antes desse período. Não conseguiu estancar o aumento de atrito entre Eisner e Katzenberg, que chefiava os estúdios (PRICE, 2007, p. 167-169).

Com a morte de Wells, o chefe dos estúdios Jeffrey Katzenberg passou a fazer lobby pelo posto de $n^{\circ} 2$ na corporação. Eisner, por sua vez, não se sentia confortável com todos os holofotes recebidos pelo colega, que parecia tomar para si o crédito por todos os sucessos. Katzenberg não teria o cargo e encarava o assunto como uma reviravolta de uma decisão antiga de Eisner de que o cargo seria dele na eventualidade da saída de Frank Wells. Isto posto, o chefe dos estúdios percebeu que não haveria ascensão profissional para ele na Disney e que a saída seria deixar a empresa. $O$ estresse da morte de Wells, a eventual saída de Katzenberg e crises vindas especialmente de investimentos na Disneylândia de Paris levaram Eisner ao hospital, com dores no peito, onde precisou colocar um marca-passo (SCHWARTZ, 1999). Katzenberg deixou o estúdio em setembro de 1994. Uma batalha nos tribunais, que se arrastou por anos, visando direitos e bônus relacionados ao seu contrato e filmes lançados sob sua supervisão, levaram-no a ganhos da ordem de US\$ 250 milhões (MASTERS, 2000).

Tem início em 1995 o período de expansão da produção do cinema de animação em Hollywood. O sucesso de "O Rei Leão" mexeu com os concorrentes, que decidiram investir no filão. Jeffrey Katzenberg, por sua vez, conhecendo bem como a produção funcionava, associou-se ao diretor Steven Spielberg e ao empresário da música David Geffen para fundar a DreamWorks SKG, um estúdio originalmente planejado com divisões de cinema, televisão, música, games e até mesmo um parque temático. $\mathrm{O}$ escopo do projeto não sobreviveu ao peso da realidade financeira. Muitas divisões não alçaram voo, por motivos variados. Os seriados de TV da produtora, que seriam exibidos na rede $\mathrm{ABC}$, sofreriam problemas agora que a Disney era a proprietária. Os filmes live-action da divisão de cinema não eram nada excepcionais. Pesava contra o estúdio o fato de Spielberg não se comprometer exclusivamente com a sua nova casa. Preferia trabalhar também para parceiros conhecidos na Universal e na Paramount (KIMMEL, 2006).

A divisão da DreamWorks que mais acertou foi justamente a de animação, liderada por Katzenberg. Primeiramente, fundiu as operações da Amblimation, uma equipe de animadores situada na Irlanda que produzia filmes de Spielberg. Depois partiu para a estratégia de atrair os melhores animadores da Disney, oferecendo condições vantajosas e muito maiores. A Disney enviou executivos para convencer animadores, técnicos e diretores a permanecer com contrapropostas, incluindo ofertas criativas. Os diretores John Musker e Ron Clements, por exemplo, sempre quiseram 
criar uma animação baseada em "A Ilha do Tesouro", porém ambientada no espaço, com direito a alienígenas e espaçonaves em forma de caravela. Katzenberg sempre rejeitou a ideia.

Na guerra de salários, Eisner ofereceu a oportunidade e os diretores permaneceram na Disney onde fariam anos mais tarde a animação "Planeta do Tesouro" (Treasure Planet, 2002). Poucas das maiores estrelas da animação Disney aceitaram mudar de estúdio (SCHWARTZ, 1999), mas foi o suficiente para a DreamWorks montar uma equipe de produção superior em qualidade à de Don Bluth nos anos 1980. Com uma proposta ousada de propor filmes mais sofisticados, adultos (embora ainda para toda a família) e com design diferenciado, a DreamWorks Animation apostou em produções como "O Príncipe do Egito" (The Prince of Egypt, 1998) baseado na história de Moisés, "O Caminho para El Dorado" (The Road to Eldorado, 2000) e "Spirit - O Corcel Indomável” (Spirit - Stallion of the Cimarron, 2002).

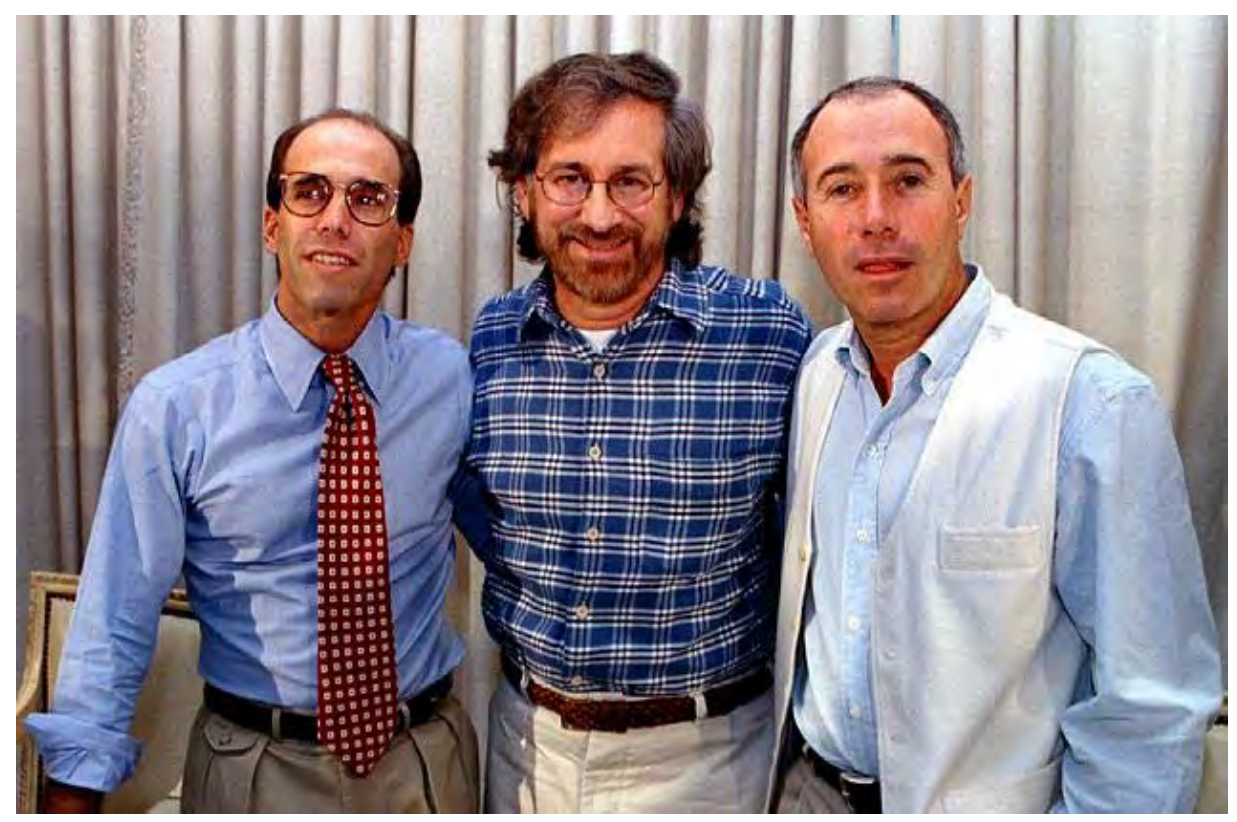

Figura 186 - Os sócios da DreamWorks SKG: Katzenberg, Spielberg e Geffen.

A animação digital também ganhou força. Conhecendo a relação entre Disney e Pixar, a DreamWorks fechou acordo com uma produtora digital chamada Pacific Data Images (PDI), para produzir filmes como "FormiguinhaZ" (AntZ, 1998) e "Shrek" (2001). Esse período é conhecido por uma intensa guerra entre os estúdios. A Disney, que já tinha sabotado a estreia de "Anastasia" (1997) da Fox, relançando nos cinemas, na mesma época, “A Pequena Sereia”, agora decidira jogar grandes produções contra as animações da DreamWorks. O mais famoso fato desta guerra, cujo resultado chegou a ter destaque na imprensa, foi a decisão da Disney em lançar o live-action "Poderoso Joe" 
(Might Joe Young) contra a estreia de "O Príncipe do Egito" em dezembro de 1998. Katzenberg, numa aposta arriscada e irritado com a tentativa de sabotagem, forçou sua equipe a apressar a produção de "FormiguinhaZ" e o antecipou seis meses sua estreia, para 2 de outubro. Não foi por acaso. A Pixar lançaria em 25 de novembro a animação "Vida de Inseto" (A Bug's Life) e os filmes tinham formigas como protagonistas. John Lasseter acusou Katzenberg não só de plágio, mas de tentar usá-los para chantagear a Disney (a DreamWorks adiaria a estreia se a Pixar convencesse a Disney a desistir da estratégia de sabotagem) (LAPORTE, 2010, p. 180). No final "FormiguinhaZ" estreou antes, a Disney jogou o filme do gorila Joe contra "O Príncipe do Egito" e, felizmente para a Pixar, "Vida de Inseto" foi um grande sucesso de bilheteria e crítica.

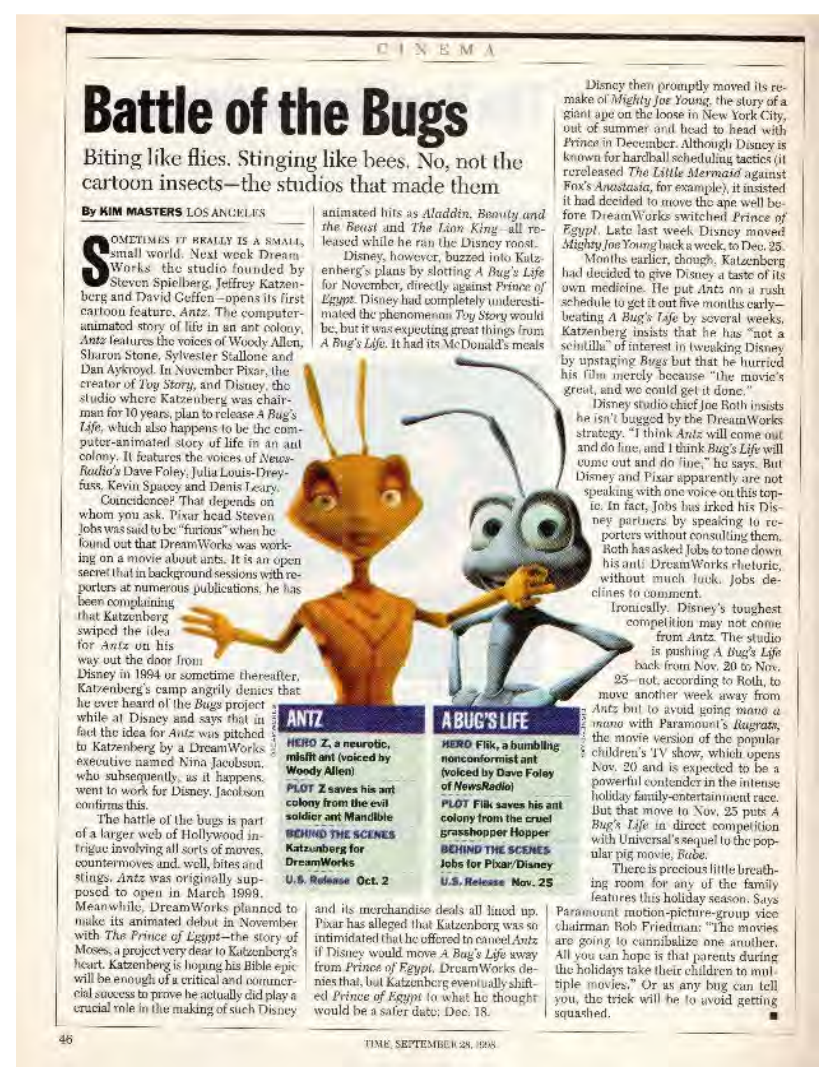

Figura 187 - A batalha das formigas foi destaque na imprensa (Revista Time - MASTERS, 1998)

$\mathrm{Na}$ Disney, isso foi encarado como um só dos problemas que começavam a afetar a produção do estúdio. O aumento do microgerenciamento, com Eisner se intrometendo em todas decisões da Disney, parece ter começado em 1995, com a indicação de Michael Ovitz - dono da maior agência de talentos em Hollywood - a Creative Artists - ao cargo de presidente, o cargo $\mathrm{n}^{\mathbf{o}} 2$ na hierarquia da companhia. A filha de Walt Disney, Diane Disney Miller, sabia que Ovitz era o melhor amigo de Eisner. E que, a partir disso, ele estava tratando a Disney como seu clube particular. (STEWART, 2005). A indicação se mostrou desastrosa e o executivo foi demitido em 1997, sendo-lhe garantida 
uma milionária indenização. Eisner aparentemente começou a desconfiar das decisões delegadas aos executivos das diversas divisões (e da possibilidade de alguém brilhar e potencialmente o substituir no futuro) e começou a pessoalmente se envolver cada vez mais na supervisão. Enquanto os canais esportivos ESPN eram lucrativos, a rede ABC patinava em audiência. Sem aparente recuperação a curto prazo, Eisner tomou a decisão de transferir toda a equipe de Nova York para um novo prédio erguido em Burbank, California. A decisão foi traumática, pois custou o início do êxodo de diversos executivos e profissionais criativos.

Os parques temáticos e os estúdios ficaram em segundo plano e seus respectivos presidentes (Judson Green e Joe Roth) acabaram destituídos (STEWART, 2006, p. 320-21). Os estúdios tinham ordem de cortar custos, eliminar contratos milionários que deixavam artistas exclusivos em projetos e reduzir despesas operacionais. Eisner tentava reforçar sua filosofia "singles and doubles" de filmes com orçamentos baratos, mas com novas pressões de filmes "evento" ou "tentpole", com grandes estrelas e efeitos especiais, e ainda por cima mantendo a fatia de mercado conquistado pela Disney. Uma das mudanças foi promover Peter Schneider, então chefe dos estúdios de animação, para chefiar todas as produções, incluindo as live-action dos estúdios Disney. Em seu lugar, seria promovido Thomas Schumacher. A situação nos estúdios de animação se tornou preocupante. "O Rei Leão" rendeu lucro de US\$ 1 bilhão, incluindo home vídeo e produtos licenciados. Porém, os três filmes seguintes do estúdio não renderam o equivalente. E, mais grave, os orçamentos estavam crescendo em ritmo acelerado. Se "O Rei Leão" custou o equivalente a US\$ 74 milhões (incluindo custos operacionais), "Hercules" custou US\$ 179 milhões. Somente com salários dos animadores a Disney investia US\$ 100 milhões, em meio à disputa com a DreamWorks para prender os talentos (MASTERS, 2000).

A concorrência com a animação não se restringia à DreamWorks: a Warner produziu "A Espada Mágica - A Lenda de Camelot" (Quest for Camelot, 1998) e o cult "O Gigante de Ferro" (The Iron Giant, 1999); a Fox continuava com os trabalhos de Don Bluth, filmes como "Titan A.E." (2000), entre outros lançamentos menores de outros estúdios. Os orçamentos superavam os US\$100 milhões, se assemelhando ao custo de qualquer blockbuster de Jerry Bruckheimer, como “Armageddon" (1998) ou "Pearl Harbor" (2001). A Disney havia adotado uma estratégia agressiva de otimizar sua estrutura para produzir dois longas-metragens de animação anuais. As produções começaram a ter problemas sérios de produção, devido à falta devida de supervisão por parte dos chamados "executivos criativos". Paralizações forçadas para consertar erros de desenvolvimento deixavam dezenas de animadores parados (STEWART, 2005). Eles foram aproveitados, ao longo dos 
anos, na produção dos segmentos musicais de "Fantasia 2000". A tabela 11 mostra o aumento no valor dos custos de produção:

\begin{tabular}{|c|c|c|c|c|c|c|c|}
\hline \multicolumn{8}{|c|}{$\begin{array}{l}\text { WALT DISNEY ANIMATION STUDIOS - ORÇAMENTOS X BILHETERIA X AVALIAÇÃO DA } \\
\text { CRÍTICA }\end{array}$} \\
\hline \multicolumn{8}{|c|}{$\begin{array}{l}\text { Orçamentos aprovados, não representando valores finais e custos de marketing e distribuição. Algumas } \\
\text { produções gastaram mais, outras menos. Os valores estão em dólares. }\end{array}$} \\
\hline Filme & $\begin{array}{l}\text { Data de } \\
\text { lançamento }\end{array}$ & $\begin{array}{l}\text { Bilheteria na } \\
\text { estreia }\end{array}$ & Orçamento & $\begin{array}{l}\text { Bilheteria Améric } \\
\text { do Norte }\end{array}$ & $\begin{array}{c}\text { Bilheteria } \\
\text { Mundial }\end{array}$ & $\begin{array}{l}\frac{\text { Crítica }}{\text { Rotten }} \\
\underline{\text { Tomatoes }}\end{array}$ & $\begin{array}{c}\text { Crítica } \\
\text { MetaCritic }\end{array}$ \\
\hline $\begin{array}{l}\text { The Black } \\
\text { Cauldron }\end{array}$ & $\begin{array}{r}\text { July } 24, \\
1985\end{array}$ & $\$ 4,180,110$ & $\$ 25,000,000$ & $\$ 21,288,692$ & $\mathrm{~S} / \mathrm{D}$ & $55 \%$ & $\mathrm{~S} / \mathrm{D}$ \\
\hline $\begin{array}{l}\text { The Great } \\
\text { Mouse } \\
\text { Detective }\end{array}$ & $\begin{array}{r}\text { July } 2, \\
1986\end{array}$ & $\$ 3,220,225$ & $\$ 14,000,000$ & $\$ 38,625,550$ & $\mathrm{~S} / \mathrm{D}$ & $81 \%$ & $\mathrm{~S} / \mathrm{D}$ \\
\hline $\begin{array}{l}\text { Oliver \& } \\
\text { Company }\end{array}$ & $\begin{array}{r}\text { November } \\
18,1988 \\
\end{array}$ & $\$ 4,022,752$ & S/D & $\$ 74,151,346$ & S/D & $43 \%$ & S/D \\
\hline $\begin{array}{l}\text { The Little } \\
\text { Mermaid }\end{array}$ & $\begin{array}{r}\text { November } \\
17,1989\end{array}$ & $\$ 6,031,914$ & $\$ 40,000,000$ & $\$ 111,543,479$ & $\$ 211,343,479$ & $92 \%$ & S/D \\
\hline $\begin{array}{l}\text { The } \\
\text { Rescuers } \\
\text { Down } \\
\text { Under }\end{array}$ & $\begin{array}{r}\text { November } \\
16,1990\end{array}$ & $\$ 3,499,819$ & S/D & $\$ 27,931,461$ & $\$ 47,431,461$ & $68 \%$ & $\mathrm{~S} / \mathrm{D}$ \\
\hline $\begin{array}{l}\text { Beauty and } \\
\text { the Beast }\end{array}$ & $\begin{array}{r}\text { November } \\
22,1991 \\
\end{array}$ & $\$ 9,624,149$ & $\$ 25,000,000$ & $\$ 218,967,620$ & $\$ 424,967,620$ & $93 \%$ & S/D \\
\hline Aladdin & $\begin{array}{r}\text { November } \\
25,1992\end{array}$ & $\$ 19,289,073$ & $\$ 28,000,000$ & $\$ 217,350,219$ & $\$ 504,050,219$ & $94 \%$ & S/D \\
\hline $\begin{array}{l}\text { The Lion } \\
\text { King }\end{array}$ & $\begin{array}{r}\text { June } 24, \\
1994\end{array}$ & $\$ 40,888,194$ & $\$ 45,000,000$ & $\$ 422,783,777$ & $\$ 987,483,777$ & $90 \%$ & $83 / 100$ \\
\hline Pocahontas & $\begin{array}{r}\text { June } 23, \\
1995 \\
\end{array}$ & $\$ 29,531,619$ & $\$ 55,000,000$ & $\$ 141,579,773$ & $\$ 346,079,773$ & $56 \%$ & $58 / 100$ \\
\hline $\begin{array}{l}\text { The } \\
\text { Hunchback } \\
\text { of Notre } \\
\text { Dame }\end{array}$ & $\begin{array}{r}\text { June } 21, \\
1996\end{array}$ & $\$ 21,037,414$ & $\$ 100,000,000$ & $\$ 100,138,851$ & $\$ 325,338,851$ & $73 \%$ & $\mathrm{~S} / \mathrm{D}$ \\
\hline Hercules & $\begin{array}{r}\text { June } 27, \\
1997\end{array}$ & $\$ 21,454,451$ & $\$ 85,000,000$ & $\$ 99,112,101$ & $\$ 252,712,101$ & $83 \%$ & $\mathrm{~S} / \mathrm{D}$ \\
\hline Mulan & $\begin{array}{r}\text { June } 19, \\
1998 \\
\end{array}$ & $\$ 22,745,143$ & $\$ 90,000,000$ & $\$ 120,620,254$ & $\$ 304,320,254$ & $86 \%$ & $71 / 100$ \\
\hline Tarzan & $\begin{array}{r}\text { June } 18, \\
1999\end{array}$ & $\$ 34,221,968$ & $\$ 130,000,000$ & $\$ 171,091,819$ & $\$ 448,191,819$ & $88 \%$ & $79 / 100$ \\
\hline $\begin{array}{l}\text { Fantasia } \\
2000\end{array}$ & $\begin{array}{r}\text { December } \\
17,1999 \\
\end{array}$ & $\$ 2,911,485$ & $\$ 80,000,000$ & $\$ 60,655,420$ & $\$ 90,874,570$ & $82 \%$ & $59 / 100$ \\
\hline Dinosaur & $\begin{array}{r}\text { May 19, } \\
2000\end{array}$ & $\$ 38,854,851$ & $\$ 127,500,000$ & $\$ 137,748,063$ & $\$ 349,822,765$ & $65 \%$ & $56 / 100$ \\
\hline $\begin{array}{l}\text { The } \\
\text { Emperor's } \\
\text { New } \\
\text { Groove }\end{array}$ & $\begin{array}{r}\text { December } \\
15,2000\end{array}$ & $\$ 9,812,302$ & $\$ 100,000,000$ & $\$ 89,302,687$ & $\$ 169,327,687$ & $85 \%$ & $70 / 100$ \\
\hline $\begin{array}{l}\text { Atlantis: } \\
\text { The Lost } \\
\text { Empire }\end{array}$ & $\begin{array}{r}\text { June } 15, \\
2001\end{array}$ & $\$ 20,342,105$ & $\$ 120,000,000$ & $\$ 84,056,472$ & $\$ 186,053,725$ & $49 \%$ & $52 / 100$ \\
\hline $\begin{array}{l}\text { Lilo \& } \\
\text { Stitch }\end{array}$ & $\begin{array}{r}\text { June } 21, \\
2002\end{array}$ & $\$ 35,260,212$ & $\$ 80,000,000$ & $\$ 145,794,338$ & $\$ 273,144,151$ & $86 \%$ & $73 / 100$ \\
\hline
\end{tabular}




\begin{tabular}{|l|r|r|c|c|c|c|c|}
\hline $\begin{array}{l}\text { Treasure } \\
\text { Planet }\end{array}$ & $\begin{array}{r}\text { November } \\
27,2002\end{array}$ & $\$ 12,083,248$ & $\$ 140,000,000$ & $\$ 38,176,783$ & $\$ 109,578,115$ & $68 \%$ & $60 / 100$ \\
\hline $\begin{array}{l}\text { Brother } \\
\text { Bear }\end{array}$ & $\begin{array}{r}\text { November } \\
1,2003\end{array}$ & $\$ 19,404,492$ & S/D & $\$ 85,336,277$ & $\$ 250,397,798$ & $38 \%$ & $48 / 100$ \\
\hline $\begin{array}{l}\text { Home on } \\
\text { the Range }\end{array}$ & $\begin{array}{r}\text { April } 2, \\
2004\end{array}$ & $\$ 13,880,771$ & $\$ 110,000,000$ & $\$ 50,030,461$ & $\$ 103,951,461$ & $54 \%$ & $50 / 100$ \\
\hline $\begin{array}{l}\text { Chicken } \\
\text { Little }\end{array}$ & $\begin{array}{r}\text { November } \\
4,2005\end{array}$ & $\$ 40,049,778$ & $\$ 150,000,000$ & $\$ 135,386,665$ & $\$ 314,432,837$ & $36 \%$ & $48 / 100$ \\
\hline $\begin{array}{l}\text { Meet the } \\
\text { Robinsons }\end{array}$ & $\begin{array}{r}\text { March 30, } \\
2007\end{array}$ & $\$ 25,123,781$ & $\mathrm{~S} / \mathrm{D}$ & $\$ 97,822,171$ & $\$ 169,333,034$ & $66 \%$ & $61 / 100$ \\
\hline $\begin{array}{l}\text { Bolt } \\
\text { November } \\
21,2008\end{array}$ & $\$ 26,223,128$ & $\$ 150,000,000$ & $\$ 114,053,579$ & $\$ 309,979,994$ & $89 \%$ & $67 / 100$ \\
\hline $\begin{array}{l}\text { The } \\
\text { Princess } \\
\text { and the } \\
\text { Frog }\end{array}$ & $\begin{array}{r}\text { December } \\
11,2009\end{array}$ & $\$ 24,208,916$ & $\$ 105,000,000$ & $\$ 104,400,899$ & $\$ 267,045,765$ & $85 \%$ & $73 / 100$ \\
\hline $\begin{array}{l}\text { Tangled } \\
\text { November } \\
24,2010\end{array}$ & $\$ 48,767,052$ & $\$ 260,000,000$ & $\$ 200,821,936$ & $\$ 591,794,936$ & $90 \%$ & $71 / 100$ \\
\hline $\begin{array}{l}\text { Winnie the } \\
\text { Pooh }\end{array}$ & $\begin{array}{r}\text { July } 15, \\
2011\end{array}$ & $\$ 7,857,076$ & $\$ 30,000,000$ & $\$ 26,692,846$ & $\$ 33,152,846$ & $90 \%$ & $74 / 100$ \\
\hline $\begin{array}{l}\text { Wreck-It } \\
\text { Ralph }\end{array}$ & $\begin{array}{r}\text { November } \\
2,2012\end{array}$ & $\$ 49,038,712$ & $\$ 165,000,000$ & $\$ 189,422,889$ & $\$ 471,222,889$ & $86 \%$ & $72 / 100$ \\
\hline Frozen & $\begin{array}{r}\text { November } \\
27,2013\end{array}$ & $\$ 67,391,326$ & $\$ 150,000,000$ & $\$ 400,738,009$ & $\$ 1,274,219,009$ & $89 \%$ & $74 / 100$ \\
\hline Big Hero 6 & $\begin{array}{r}\text { November } \\
, 2014\end{array}$ & $\$ 56,215,889$ & $\$ 165,000,000$ & $\$ 222,527,828$ & $\$ 657,827,828$ & $89 \%$ & $74 / 100$ \\
\hline Fonte dos dados: BoxOfficeMojo.com & & & & & \\
\hline
\end{tabular}

Tabela 11 - Orçamentos, Faturamento e Recepção Crítica das animações Disney.

"Fantasia 2000" é um caso que resume bem a história do estúdio nos anos 1990. O filme servia primeiramente para dar a Roy E. Disney um projeto que não tinha envolvimento direto de Katzenberg (evitava-se o atrito). Era alvo de todo tipo de sugestões, não escapando nem aquelas vindas do CEO. Provavelmente emocionado por ter assistido a formatura de seu filho Eric no Ensino Médio, Michael Eisner insistiu com Roy E. Disney que incluísse a marcha "Pompa e Circunstância", popular em casamentos e formaturas, por seu grande valor sentimental na vida das pessoas. A equipe do filme recebeu friamente a proposta, tendo em vista que a marcha não era considerada nem uma das maiores obras de Elgar e, sendo uma marcha, trazia dificuldades para desenvolver uma narrativa. Eisner sugeriu uma procissão de príncipes e princesas de todos os filmes Disney com seus bebês - ideia considerada inadequada e rapidamente descartada pela produção do filme. Esse tipo de interferência atrasava e pesava no orçamento na lenta produção de "Fantasia 2000”. (STWEART, 2005, p. 289). Alguns dos segmentos demonstravam tecnologia de ponta. "O Soldadinho de Chumbo" e "Pinheiros de Roma" apresentavam cenas misturando animação tradicional e computadorizada -antes mesmo da estreia de “Toy Story” em 1995. Porém, a produção lenta e a estreia somente em dezembro de 1999 tirou totalmente a surpresa das conquistas técnicas. 

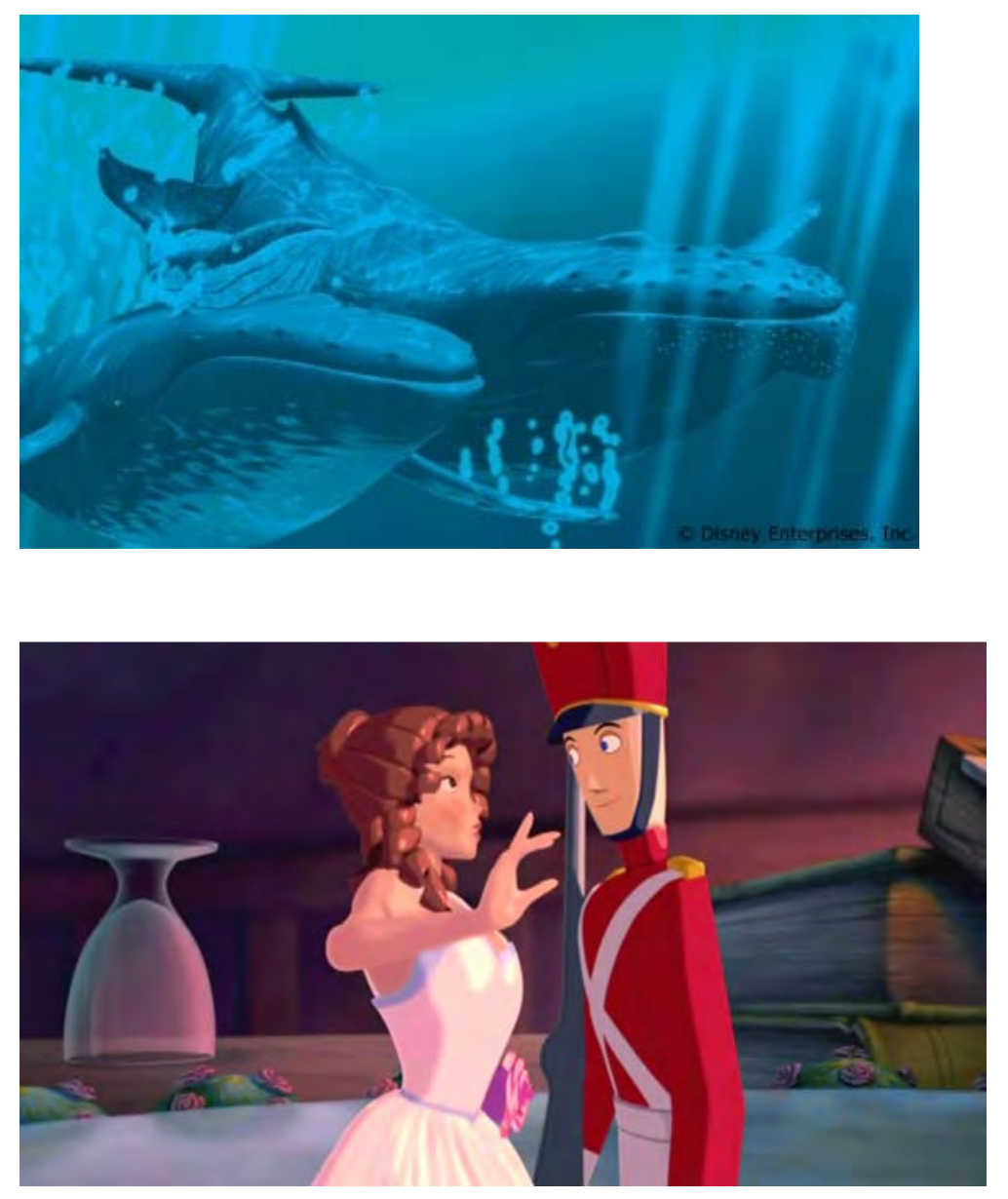

Figura 188 e Figura 189 - Segmentos "Pinheiros de Roma" e "O Soldadinho de Chumbo" de "Fantasia 2000", experimentos de interação entre animação tradicional e computadorizada.

\subsection{Saturação e Estagnação}

O sucesso das animações Disney nos cinemas possibilitou um outro tipo de exploração no lucrativo mercado de home-vídeo. Apoiado em "Aladdin" (1992) que havia se tornado o maior sucesso de vendas em VHS, a Disney criou um novo departamento, atrelado inicialmente à "Walt Disney Television Animation" (GROVER, 1997). Utilizando os serviços de uma rede de estúdios ao redor do mundo (Canadá, Japão, Coreia do Sul, França e Austrália), novos filmes, na realidade continuações ou derivados dos clássicos foram produzidos. Geralmente tinham como características o orçamento barato, um trabalho técnico e artístico inferior (com exceções honrosas como a equipe do estúdio australiano), narrativas pobres e trilhas sonoras fracas. A cargo da matriz ficava a aprovação dos storyboards. Paralelamente ao grande número de animações nos cinemas, o mercado foi inundado 
com animações "menores". O animador Brian Mitchell cunhou um novo termo para essas produções - cheapquels 36 (mistura das palavras "sequência" e "barato").

O excesso dessas animações no mercado de vídeo resultou numa saturação. As estreias em forma de evento começaram a rarear. Alguns desses filmes ruins estavam previstos para estrear nos cinemas primeiro, um risco de banalizar e perder a confiança do público nas produções do estúdio. Isso representou o início da derrocada da animação tradicional em meio à ascensão da animação computadorizada. Eisner criou um novo patamar administrativo entre os artistas e os chefes dos estúdios. De repente, uma série de "vice-presidentes criativos", a maioria, se não todos, formados em administração ou contabilidade, estava discutindo roteiros, elaborando ideias e tomando decisões sobre o modo de produzir animações sem nunca terem trabalhado na área. $\mathrm{O}$ departamento de desenvolvimento visual perdeu toda sua relevância dentro do novo sistema. (LUND, 2005).

O levantamento feito pelo website Cartoon Brew (AMIDI, 2015), apresenta dados interessantes no nível macro. Do ponto de vista criativo, durante a era Eisner (até 2005) a Disney raramente usou seus primeiros clássicos do período entre "Branca de Neve e os Sete Anões" (1937) e "A Bela Adormecida" (1959) na estratégia das "continuações em vídeo" - foram somente quatro filmes. Desde 2005, portanto, já na gestão Bob Iger, foram dezesseis produzidos, inspirados nos filmes do mesmo período posterior a 1959. Outro dado é que a transição dos remakes de filmes liveaction e derivados de animação coincide com o colapso do mercado de home-vídeo nos anos 2000. O último projeto deste tipo, segundo a estratégia original de continuações, prelúdios ou derivados, foi A Pequena Sereia 3: A História de Ariel (The Little Mermaid: Ariel's Beginning, 2008).

Finalmente, um dado importante é que somente um filme derivado emergiu dos sete produzidos entre "Planeta do Tesouro" (2002) e “A Princesa e o Sapo" (2009):

O período coincide com a fase de crise criativa e com o aumento da exploração dos títulos clássicos antigos. Comprova a importância da criação contínua de conteúdo original de qualidade que ressoa no público, ao mesmo tempo que o acervo antigo de títulos permite enfrentar períodos de crise criativa" (AMIDI, 2015).

\footnotetext{
${ }^{36}$ Brian Mitchell postou o termo pela primeira vez no fórum profissional dos animadores Animation-Nation.com. <http://mitchellsketch.blogspot.com.br/2007/03/no-more-cheapquelsreally.html> 
O website Cartoon Brew elaborou uma tabela compilando os dados referentes a produção das animações derivadas. As colunas se referem aos clássicos originais, seguidos de continuações para o cinema, continuações para o home-vídeo, remaker em live-action para o cinema, derivados em animação para o home-video e seriados de TV (Tabela 12). Amid Amidi (2015) ressalta a tendência da Disney na de década de 2010 a investir não propriamente em continuações em animação, mas em remakes live-action de seus clássicos e suas derivações.

\begin{tabular}{|c|c|c|c|c|c|}
\hline \multicolumn{6}{|c|}{ Disney Sequels, Remakes, Spinoffs, and Series } \\
\hline $\begin{array}{l}\text { WAGDISNEP } \\
\text { ANIMATED FILMS }\end{array}$ & $\begin{array}{l}\text { Animated } \\
\text { Sequel| } \\
\text { Prequel } \\
\text { (Theatrical) }\end{array}$ & $\begin{array}{l}\text { Animated } \\
\text { Sequell } \\
\text { Prequel } \\
\text { (D2V) }\end{array}$ & $\begin{array}{l}\text { Live-Action } \\
\text { Remakes } \\
\text { Spinoffs } \\
\text { (Theatrical) }\end{array}$ & $\begin{array}{c}\text { Animated } \\
\text { Spinoff or } \\
\text { Followup } \\
\text { (D2V) }\end{array}$ & $\begin{array}{l}\text { Animated } \\
\text { TV } \\
\text { Series }\end{array}$ \\
\hline $\begin{array}{l}\text { Snow White and the } \\
\text { Seven Dwarfs (1937) }\end{array}$ & & & & & 2014 \\
\hline Pinocchio (1940) & & & Development & & \\
\hline Fantasia (1940) & 1999 & & 2010 & & \\
\hline Dumbo (1941) & & & $\begin{array}{l}\text { In } \\
\text { Development }\end{array}$ & & \\
\hline Bambl (1942) & & 2006 & & & \\
\hline \multicolumn{6}{|l|}{ Saludos Amigos (1943) } \\
\hline \multicolumn{6}{|l|}{$\begin{array}{l}\text { The Three } \\
\text { Caballeros (1944) }\end{array}$} \\
\hline \multicolumn{6}{|l|}{$\begin{array}{l}\text { Make Mine } \\
\text { Muslc (1946) }\end{array}$} \\
\hline \multicolumn{6}{|l|}{$\begin{array}{l}\text { Fun and } \\
\text { Fancy Free (1947) }\end{array}$} \\
\hline \multicolumn{6}{|l|}{ Melody Time (1948) } \\
\hline \multicolumn{6}{|l|}{$\begin{array}{l}\text { Ady of Ichabod } \\
\text { and Mr. Toad (1949) }\end{array}$} \\
\hline Cinderella (1950) & & 2002,2007 & 2015 & & \\
\hline $\begin{array}{l}\text { Allce In } \\
\text { Wonderland (195i) }\end{array}$ & $r$ & & 2010,2016 & & 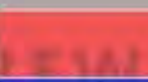 \\
\hline Peter Pan (1953) & 2002 & & Development & $\begin{array}{l}2008,2009,2010 \\
2012,2014,2015\end{array}$ & 2011 \\
\hline $\begin{array}{l}\text { Lady and } \\
\text { the Tramp (1955) }\end{array}$ & & 2001 & & & \\
\hline Sleeping Beauty (1959) & & & $\begin{array}{l}2014, \text { in } \\
\text { Development }\end{array}$ & & \\
\hline 101 Dalmatlans (1961) & & 2003 & 1996,2000 & & 1997 \\
\hline \multicolumn{6}{|l|}{$\begin{array}{l}\text { Sword in } \\
\text { the Stone (1963) }\end{array}$} \\
\hline Jungle Book (1967) & 2003 & & $\begin{array}{l}1994,1998(\mathrm{D} 2 \mathrm{~V}) \\
2016\end{array}$ & & 1996 \\
\hline \multicolumn{6}{|l|}{ Aristocats $(1970)$} \\
\hline \multicolumn{6}{|l|}{ Robin Hood (1973) } \\
\hline $\begin{array}{l}\text { Many Adv. of Winnic } \\
\text { the Pooh (1977) }\end{array}$ & $\begin{array}{l}2000,2003 \\
2005,2011 \\
\end{array}$ & & Development & 1997, 1999, 2002, 2005 & 1988,2007 \\
\hline Rescuers (1977) & 1990 & & & & \\
\hline $\begin{array}{l}\text { Fox \& } \\
\text { the Hound (1981) }\end{array}$ & & 2006 & & & \\
\hline
\end{tabular}




\begin{tabular}{|c|c|c|c|c|c|}
\hline \multicolumn{6}{|l|}{ Black Cauldron (1985) } \\
\hline \multicolumn{6}{|l|}{$\begin{array}{l}\text { Great Mouse } \\
\text { Detective (1986) }\end{array}$} \\
\hline \multicolumn{6}{|l|}{ Ollver \& Co. (1988) } \\
\hline Little Mermaid (1989) & & 2000,2008 & & & 1992 \\
\hline $\begin{array}{l}\text { Beauty \& } \\
\text { the Beast (1991) }\end{array}$ & & $\begin{array}{l}1997,1998 \\
1999\end{array}$ & 2017 & & \\
\hline Aladdin (1992) & & 1994,1996 & In & & 1994 \\
\hline Lion King (1994) & & 1998,2004 & & & 1995,2016 \\
\hline Pocahontas (1995) & & 1998 & & & \\
\hline $\begin{array}{l}\text { Hunchback of } \\
\text { Notre Dame (1926) }\end{array}$ & & 2002 & & & \\
\hline Hercules (1997) & & & & 1999 & 1998 \\
\hline Mulan (1998) & & 2005 & Development & & \\
\hline Tarzan (1999) & & 2002,2005 & & & 2001 \\
\hline \multicolumn{6}{|l|}{ Dinosaur $(2000)$} \\
\hline $\begin{array}{l}\text { Emperor's New } \\
\text { Groove }(2000)\end{array}$ & & 2005 & & & 2006 \\
\hline $\begin{array}{l}\text { Atlantis: The Lost } \\
\text { Empire (2001) }\end{array}$ & $\mathrm{CA}$ & 2003 & N & 8 & $2 \sqrt{19}$ \\
\hline Lllo \& Stitch (2002) & & 2005 & & 2003,2006 & 2003 \\
\hline \multicolumn{6}{|l|}{ Treasure Planet (2002) } \\
\hline Brother Bear (2003) & & 2006 & & & \\
\hline \multicolumn{6}{|l|}{$\begin{array}{l}\text { Home on } \\
\text { the Range (2004) }\end{array}$} \\
\hline \multicolumn{6}{|l|}{ Chlcken Little (2005) } \\
\hline \multicolumn{6}{|l|}{$\begin{array}{l}\text { Meet the } \\
\text { Robinsons (2007) }\end{array}$} \\
\hline \multicolumn{6}{|l|}{ Bolt (2008) } \\
\hline \multicolumn{6}{|l|}{$\begin{array}{l}\text { Princess and } \\
\text { the Frog (2009) }\end{array}$} \\
\hline Tangled $(2010)$ & & & & & 2017 \\
\hline Wreck-It Ralph (2012) & $\begin{array}{l}\text { In } \\
\text { Development }\end{array}$ & & & & \\
\hline Frozen $(2013)$ & $\begin{array}{l}\text { In } \\
\text { Development }\end{array}$ & & & & \\
\hline BIg Hero 6 (2014) & Development & & & & \\
\hline Zootopla (2016) & & & & & \\
\hline
\end{tabular}

Tabela 12 - Levantamento das produções derivadas da Disney (AMID, 2015) 
Em novembro de 1999, Toy Story 2 foi lançado nos cinemas com sucesso de público e crítica, faturando mais de US\$ 80 milhões em sua estreia no feriado de Ação de Graças. O filme, originalmente, era um projeto direto para vídeo que foi resgatado pelo executivo Joe Roth e refeito por John Lasseter para estrear nos cinemas. Eisner, relutantemente, aceitou “Toy Story 2", mesmo sendo uma sequência, que contasse do acordo que previa filmes originais entre a Disney e a Pixar. Eisner, no entanto, insistiu em que um terceiro Toy Story não contaria do acordo, que não tiraria do lugar "Carros" como o último filme do contrato entre Disney e Pixar, especialmente porque o filme trazia enormes oportunidades para a unidade de produtos (especialmente o interesse na indústria de brinquedos). O próprio Steve Jobs, incensado pela imprensa (Fig. 190) fez lobby para que o acordo fosse revisto, porém sem sucesso (STEWART, 2005).

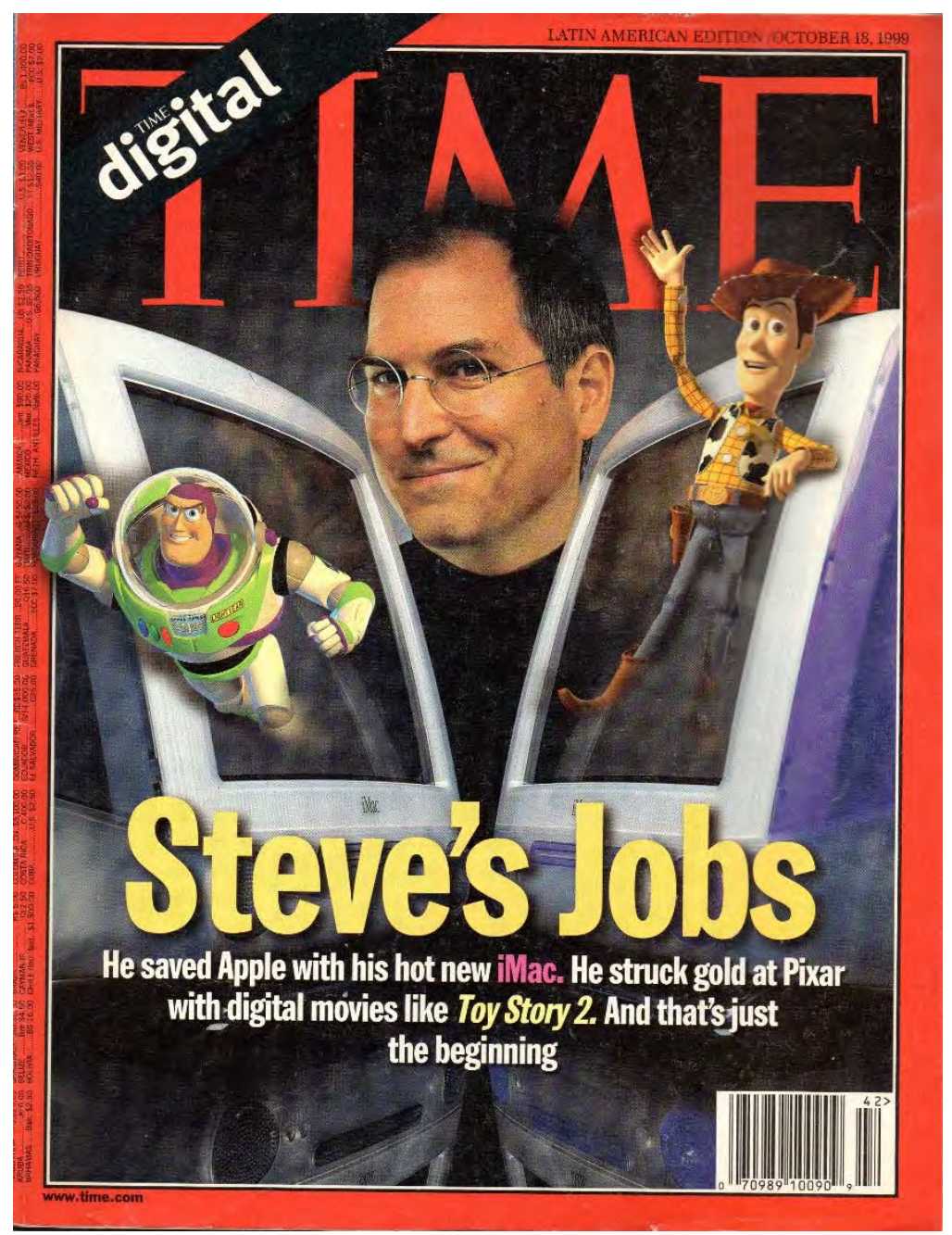

Figura 190 - O sucesso de Steve Jobs na Apple e na Pixar é destaque na imprensa. 
A concorrência com a Pixar estava pesando na comparação com os resultados fracos das produções Disney. Joe Roth, então chefe dos estúdios, chegou a sugerir que a negociação prosseguisse de forma ousada, propondo a compra da Pixar pela Disney, unificando os estúdios e suas equipes criativas. Todas as novas produções seriam “digitais". Disney teria Steve Jobs (querido por Wall Street) e John Lasseter (a cabeça criativa do estúdio). A proposta foi rejeitada. (STEWART, 2005, p. 290).

2001 foi um ano emblemático. Nunca se produziu tanta animação em Hollywood. Mercados internacionais, inclusive o brasileiro, começaram a abrir estúdios e a atrair profissionais de qualidade. A concorrência de países com o custo de mão-de-obra baixo causou uma migração considerável de produções dos EUA para a Ásia, Austrália e Brasil. A velocidade com que produções eram lançadas e como o público os consumia, em meio às novidades tecnológicas levaram à saturação do mercado a um novo estágio. A animação tradicional "Atlantis: O Reino Perdido" (2001) se tornava um dos filmes com recepção mais fraca nas bilheterias. Ao mesmo tempo, a animação computadorizada "Shrek" (2001), da DreamWorks, se tornou um dos maiores sucessos da história da animação - sendo vencedor do primeiro Oscar na categoria de Melhor Animação.

Como é possível haver crise com alguns filmes fracassando e outros com sucesso em meio a um volume consideravelmente alto de produção em relação ao passado? Para explicar os efeitos de saturação e os da transição com base tecnológica, aproveitamos para discutir a relação "comunicação e velocidade".

Um fator importante é a influência do conceito de aceleração, e como isso está presente na vida das pessoas graças à evolução da tecnologia, principalmente na década de 2000. Vicente Romano (1998) analisa essas transformações nas telecomunicações, enumerando vários fatores que explicam os processos de aceleração e percepção. Um dos pontos é que, graças às novas tecnologias de comunicação, trabalha-se o tempo todo. As pessoas não param de trabalhar graças ao non-stop da modernidade. Essas novas tecnologias trazem a aceleração, que se torna o valor máximo da comunicação, tirando de cena a reflexão e o tempo de vida. A informação passa a ser uma mera mercadoria. A produção e a reprodução das mesmas ideias de forma rápida e barata pelos estúdios se mostra, a longo prazo, um negócio arriscado.

Para explicar essa explosão de informática, Norval Baitello Jr.(1999) afirma que houve uma explosão informacional na sociedade humana de nosso tempo. Como também se pode dizer que a 
investigação da comunicação humana passa por uma explosão similar, entendendo que apenas uma visão mais abrangente poderá enxergar o objeto de muitas faces que é o processo comunicativo do homem. E se concordarmos que os processos comunicativos são construções de vínculos, então temos que dizer, também, que a rede dos objetos com os quais nos comunicamos encontra-se em franca expansão, tal qual o universo. Essa expansão significa não apenas o espaço e tempo cada vez maiores, como também as relações internas estão cada vez mais numerosas. Há, portanto, um crescimento para fora e para dentro. Baitello ainda fala sobre o impacto da eletricidade e dos meios eletrônicos, dizendo que a apropriação do tempo não mais se dá apenas por meio da durabilidade da mensagem conservada, mas pelo somatório dos tempos dos milhões de receptores.

Qualquer ideal de progresso, isto é, de aperfeiçoamento da organização social, deve, portanto, levar em consideração a análise do tempo, ou, melhor dizendo, dos diferentes tempos, a fim de descobrir suas contradições e ver suas possibilidades de superação (ROMANO, 2002).

Vicente Romano (2002) afirma que o estresse do tempo é um fenômeno típico das "sociedades avançadas" e que, desde a industrialização, os homens foram condicionados a trabalhar pelo tempo cronometrado, o tempo do relógio. Esse tempo tornou-se algo valioso, e sua "perda" causa enorme angústia e efeito negativo no homem. E como cita Paul Virilio (1996), existem consequências sociais e políticas. Podemos analisar a questão do tempo, no que diz respeito à animação, em três faces independentes (que se relacionam entre si), como descritas a seguir.

1- A primeira é a “aceleração (velocidade) de produção". É o tempo do processo de produção de um filme de animação. Em diversos períodos das últimas décadas, o processo cinematográfico sofreu mudanças com as novidades tecnológicas. A invenção da xerografia no fim dos anos 1950 trouxe a demissão em massa dos arte-finalistas (inkers) que repetiam os desenhos dos animadores. A criação de softwares especializados para colorização no final dos anos 1980 resultou na extinção do departamento de pintura dos estúdios Disney. E nos anos 2000 houve um aumento da produção computadorizada em detrimento das técnicas tradicionais (animação feita a mão).

Embora a gênese do projeto continue na mão do homem, diversos processos sofreram mutações com o uso da tecnologia. Os argumentos para a instalação e a modernização são quase sempre os mesmos: economia de mão-de-obra, dinheiro e tempo. Mas é possível constatar que, nessas variadas modernizações no sistema de produção, o número de empregados de fato caiu em alguns tipos de trabalho, mas não houve tanta economia de dinheiro e muito menos de tempo 
(especificamente no caso Disney). Desse modo, a evolução tecnológica trouxe uma sensação falsa de aceleração. Houve uma aceleração, mas não se produz tão rápido quanto se pensa.

2- A segunda face é a "aceleração estética". Se a influência pela tecnologia não diminuiu tanto o tempo de produção, talvez isso possa causar uma sensação de aceleração maior se a mudança partir do próprio homem-artista, o animador. A partir dos anos 1950, com a popularização da televisão, muitos estúdios descobriram uma nova mídia para seus filmes. No caso da animação, era quase impossível produzir para televisão no mesmo ritmo e padrão do cinema. A saída encontrada foi a produção num estilo artístico mais simples e menos complicado, preocupando-se menos com noções realistas do desenho. Esse tipo de animação, que também foi experimentada no cinema, é chamada de "animação limitada".

A dupla de artistas William Hanna e Joseph Barbera ficou conhecida por investir maciçamente e pressionar seus empregados a produzir mais rápido por um preço muito menor - o chamado faster \& cheaper (mais rápido e mais barato). Outra característica foi a repetição de cenas, ou seja, da mesma animação feita para uma cena repetida em outra. Isso foi muito usado nos primórdios da animação, mas deixado de lado a partir da era de ouro (anos 1930 e 1940). De fato, a animação a partir dos anos 1960 ganhou um ritmo mais rápido, inspirado no cotidiano das pessoas. Mesmo os longas-metragens capitalizavam gírias e estilos musicais do período. Não havia tanto espaço para visuais e personagens tão detalhados e realistas. Ampliou-se o uso de personagens mais bidimensionais (com pouca profundidade e construção na narrativa). Essa aceleração estética com base nos rumos da produção para televisão (e não de cinema) condicionou e determinou o tempo presente.

Para combater a produção industrial de desenhos animados na televisão, os estúdios Disney só puderam enfrentar a concorrência nos cinemas investindo mais em sofisticações como o formato cinemascope (tela mais larga), produções formatadas para a terceira dimensão, e criando personalidades ainda mais elaboradas. Por mais que, nos anos 1960 e 1970, as histórias dos longasanimados sejam fracas e superficiais, houve um avanço para que a importância do personagem na narrativa fosse maior (PEGORARO, 2011).

Outra grande mudança ocorreria em meados dos anos 1990, com o surgimento dos primeiros filmes animados por computador e sua crescente popularização, que apontou para uma nova estética da animação. Essa nova estética não só se concentra no personagem, mas em todos os elementos gráficos. Na verdade, o mundo da animação sofre mudanças estéticas de forma cíclica. 
3- A terceira face é a "aceleração temática e de recepção", que trata do conteúdo do produto cinematográfico e suas consequências para a comunicação. Os primeiros longa-metragens dos anos 1930, hoje muitas vezes considerados tediosos, lentos e infantis, na verdade carregam uma forte carga de conteúdo adulto. Eram comuns críticas negativas ao conteúdo de filmes como "Pinóquio" (1940) e "Fantasia" (1940), este último especialmente devido ao último segmento, que mostra o demônio Chernabog.

Nos anos 1940, a temática dos filmes migrou para um conteúdo pró-guerra com elementos pedagógicos e educativos. Neste período, a comunicação por meio da animação teve papel fundamental para informar e educar o povo americano e os aliados dos Estados Unidos. Dos anos 1950 aos 1980, os filmes sofreram uma regressão temática, perdendo um pouco do caráter adulto, ampliando o caráter pedagógico voltado para o público infantil - especialmente devido à popularização e à produção voltada para a TV. Com a popularização de certos filmes live-action nas décadas de1970 e 1980, a partir de produções como as de Steven Spielberg e George Lucas, a Disney e suas novas concorrentes viram-se forçadas a inserir um conteúdo mais sofisticado em suas produções se quisessem acompanhar a nova geração. Surgia, então, uma geração ligada cada vez mais ao tempo e aos recursos tecnológicos. Como explica Harry Pross (1980), amplia-se a economia de sinais, ou seja, em menos tempo possível coloca-se mais informações. A consequência é o processo de saturação das pessoas que as recebem. Esse tempo de mídia influencia o tempo de cultura.

Vicente Romano (2002) cita que é necessária uma ecologia do tempo, um vínculo real com indivíduos e sociedades para humanizar a vida. Não importa tanto a quantidade de tempo e sim sua qualidade. Havia a preocupação com a produção cultural do tempo. O conteúdo dos filmes animados ganhou novamente características mais adultas, ainda que somado a uma excessiva busca pelo politicamente correto. As situações na tela ocorrem de forma mais rápida e elas contêm mais elementos de violência.

Jeffrey Katzenberg, chefe dos estúdios Disney, havia alertado sobre sua intenção de mostrar que a animação nunca deveria ser rotulada como gênero infantil. Tanto que "A Bela e a Fera" (1991) espantou a indústria cinematográfica quando foi indicado ao Oscar de Melhor Filme. Para Katzenberg, a animação não é um gênero e sim uma técnica. Esta poderia transmitir comédia, aventura ou até mesmo terror. Ele tentou algumas experiências quando fundou a DreamWorks Animation, em 1994, com Steven Spielberg, e obteve sucesso com filmes como "Shrek" (2001) e 
"Madagascar" (2005). A Pixar conseguiu transmitir um conteúdo mais adulto e violento em "Os Incríveis" (2004) que na verdade é um filme de ação disfarçado de comédia.

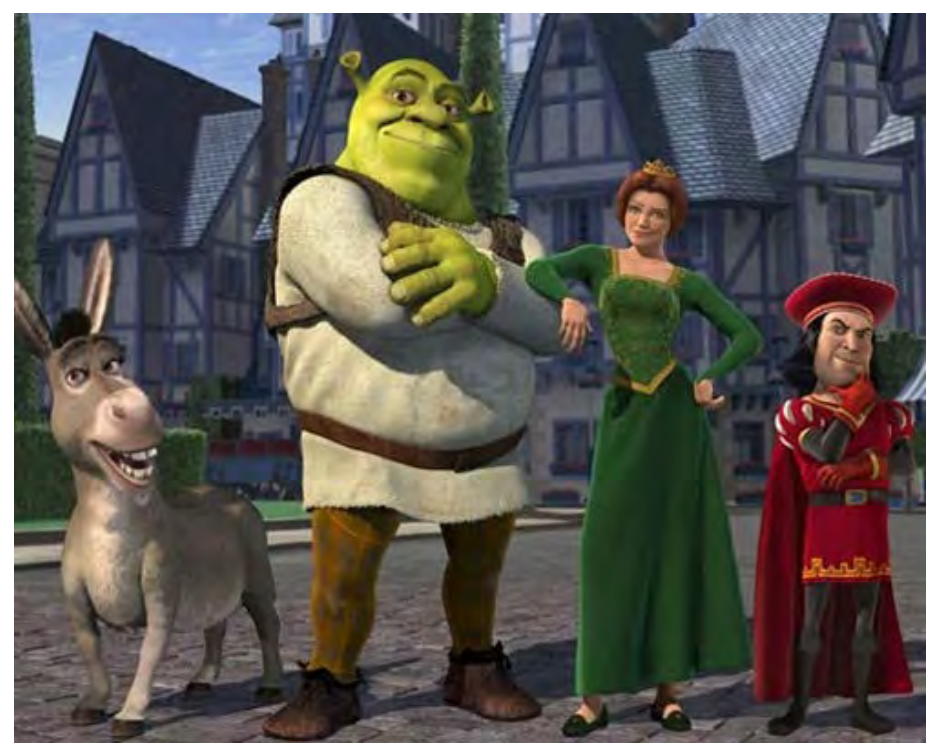

Figura 191 - "Shrek” da DreamWorks desbancou a Disney em 2001 como animação de maior sucesso.

Os filmes do começo do século XXI trazem conteúdos mais adultos, porque as crianças já sofrem com a comunicação de conteúdo mais desumanizador. Elas já têm suas primeiras experiências midiáticas (eletrônicas) com conteúdos mais eróticos e violentos, ainda que num sentido mais psicológico do que propriamente físico. E, assim como os adultos, se tornaram escravas do tempo. Como afirma Vicente Romano (2002), atualmente precisamos nos libertar do tempo. No cinema, qualquer forma de comunicação mais lenta é repudiada por grande parte do público. E até mesmo o tempo de assistir à televisão ou de ir ao cinema é contado como tempo útil. Esse tempo do ócio precisa entrar no ritmo que o homem vive no cotidiano, e o indivíduo precisa estar adaptado para sentir que seu dia rendeu ao máximo. Esse processo cultural influencia o tempo do indivíduo, que depois influencia a própria cultura.

Questionado em 2015 sobre a questão da maturidade precoce das crianças que assistem animações e como isso influi na produção, Bob Iger (atual presidente da Disney) comentou:

Houve um momento na Disney, cerca de uma década atrás quando se deram conta de que o mundo estava mudando que houve uma compressão da idade como fator. Isso significa que as crianças estão amadurecendo mais cedo em relação a esse padrão conhecido. Isso foi provado nos EUA e na Europa Ocidental, com destaque para o Reino Unido. Então se antigamente um garoto deixava de se interessar pelas 
narrativas Disney com 10 anos, hoje no mundo moderno ele deixa com 5 anos. As garotas que deixavam esse conteúdo aos 12-13 anos, hoje abandonam com 10. A Pixar é diferente pois seus filmes têm um público sofisticado [inclui mais adultos]. Foi desse modo que a Disney começou um esforço para produzir conteúdo "nãoDisney" para manter essas crianças interessadas. Esse público automaticamente retorna quando se tornam pais e mães, mas há uma grande lacuna. E havia o pensamento que era possível produzir coisas relevantes para preencher essas lacunas. [A Disney faz pesquisas para saber o que as pessoas gostariam de ver, e Iger pessoalmente não acredita que esses dados realmente registrem a verdade, especialmente em termos de resultado. E a decisão tomada foi produzir melhor o que já faziam. Iger era frequentemente questionado se a Disney devia mudar seus padrões - permitindo mais violência, inserindo um tipo de diálogo mais adulto e ousado. O executivo acredita que simplesmente precisam ser melhores no que já fazem]. Não propriamente mais sofisticados, mas atrativos. Talvez personagens um pouco mais realistas, embora Ana e Elsa em "Frozen" não sejam. Mas funcionou e vem atraindo um público maior! O conteúdo criativo da Pixar é encarado como mais sofisticado por sua própria natureza de produção. Marvel, Lucasfilm e a ESPN são investimentos autônomos em relação aos filmes Disney ou Pixar. Não são marcas visando propriamente preencher as lacunas etárias de consumo (IGER, 2015).

A redução do tempo no consumo de informação já havia sido detectada pela Disney nos anos 1980. Enquanto construíam a Disneylândia de Paris, pesquisas internas indicavam que o público esperava que informações fossem transmitidas de maneira mais rápida. Atrações como o passeio de barco "It's a Small World" ganharam novo projeto, reduzindo seu tempo de duração e concentrando sua mensagem (FINCH, 1995, p. 448). Estratégias realizadas entre os anos 1990 e 2010 incluíram a divisão de gêneros e faixas etárias. Um bom exemplo foi na TV por assinatura. O universal Disney Channel, dedicado a toda família, foi aos poucos convertido em três - Disney Channel, Disney XD (anteriormente conhecido como Jetix) e Club Disney. O primeiro se tornou mais focado no público feminino tween (pré-adolescentes entre 10 e 13 anos), o segundo ao tween masculino, e o terceiro ao público infantil com programação que inclui a exibição de clássicos.

\subsection{Tradicional, “Tradigital” e Digital}

Outra discussão é a popularização da técnica de animação CGI sobre a animação tradicional. As imagens produzidas no computador geraram uma grande fascinação no público, não só pela complexidade que podia alcançar, como também pelas ferramentas que poderiam fazer com que qualquer um pudesse produzir animação. A transformação da técnica também tem relação com a velocidade e a percepção do público. O animador Daniel Messias comentou sobre a arrancada do CGI, dizendo que "até o fim da década de 1980, a animação brasileira se restringia à produção voltada para a publicidade na televisão. Nenhum estúdio conseguia sobreviver sem fazer publicidade. O 
computador e, logo em seguida, a TV a cabo, mudaram muito essa realidade" (comunicação pessoal $)^{37}$.

Para o roteirista Rhett Wickham, a estratégia do foco na animação computadorizada é mais uma artimanha de Hollywood para manipular gostos e lucrar mais. Ele comentou ${ }^{38}$ que "Brad Bird gosta de dizer sempre que Hollywood é como um tubarão idiota. Ele vai aonde o sangue está. Se na semana que vem, o grande sucesso for um filme sobre um assalto, então no próximo ano veremos mais filmes sobre criminosos". Ele também cita o problema por parte do público: "O público se comporta de modo semelhante. Ele tem uma consciência coletiva que responde ao que é pedido para fazer, como ouvir críticos sem formar suas próprias opiniões". Dessa forma, Rhett questiona o papel da crítica que simplesmente atende a interesses maiores. Ele conclui afirmando que "muito raro um filme sobrevive baseado somente no "boca-a-boca". O crítico de cinema Leonard Maltin também tem opinião similar:

\begin{abstract}
"Não entendo porque a imprensa foi tão rápida em se apegar ao CGI, culpando a animação tradicional por tudo que é errado na indústria. A situação pode mudar visto que um grande grupo de filmes CG será lançado [em 2006], e nem todos eles podem ter sucesso. Isso pouco tem a ver com a mídia, mas com a mensagem. As pessoas espertas que trabalham com CGI são os primeiros a entender isso. John Lasseter frequentemente diz que os filmes são baseados em histórias e personagens fortes. Mas muitas pessoas não escutam." (MALTIN, entrevista com o autor ${ }^{39}$ )
\end{abstract}

Essa noção de indústria manipulando o público, legitimando uma "afirmação", pode ser notada quando Jeffrey Katzenberg, ao lançar o filme "Spirit: O Corcel Indomável”, citou na imprensa que o filme, na verdade, foi produzido utilizando a técnica "tradigital", misturando elementos tradicionais e digitais. Como a produção dos filmes geralmente é longa, e seu estúdio ainda tinha este para lançar, esse novo termo foi encarado com ironia por parte da indústria, visto que já se propagava que "o digital era o futuro".

Quando a Fox lançou o filme “Avatar” (2009), de James Cameron, nos cinemas demonstrou uma revolução de efeitos no uso do 3D estereoscópico, forçando os estúdios a rapidamente investir no formato. De repente, tornou-se cool as pessoas irem ao cinema e usar óculos especiais. Filmes comuns foram convertidos no formato. A própria Disney lucrou no modismo quando lançou "Alice no País das Maravilhas" (2010), dirigido por Tim Burton. Porém, uma hora o mercado saturou, com dezenas de filmes em 3D. Jeffrey Katzenberg confirmou esse problema, afirmando que a novidade

\footnotetext{
${ }^{37}$ Entrevista ao autor, por e-mail, em 31 de maio de 2004.

${ }^{38}$ Entrevista ao autor, por e-mail, em 16 de novembro de 2005.

${ }^{39}$ Em entrevista ao autor por e-mail em 16 de abril de 2006.
} 
tecnológica foi estragada pelo excesso de filmes ruins (SNIDER, 2012), e somente não ocorreu uma estagnação na produção de filmes 3D como resultado dessa saturação porque os estúdios entenderam que não podem vender somente a experiência de assistir em 3D. Os filmes precisam vender uma boa história.
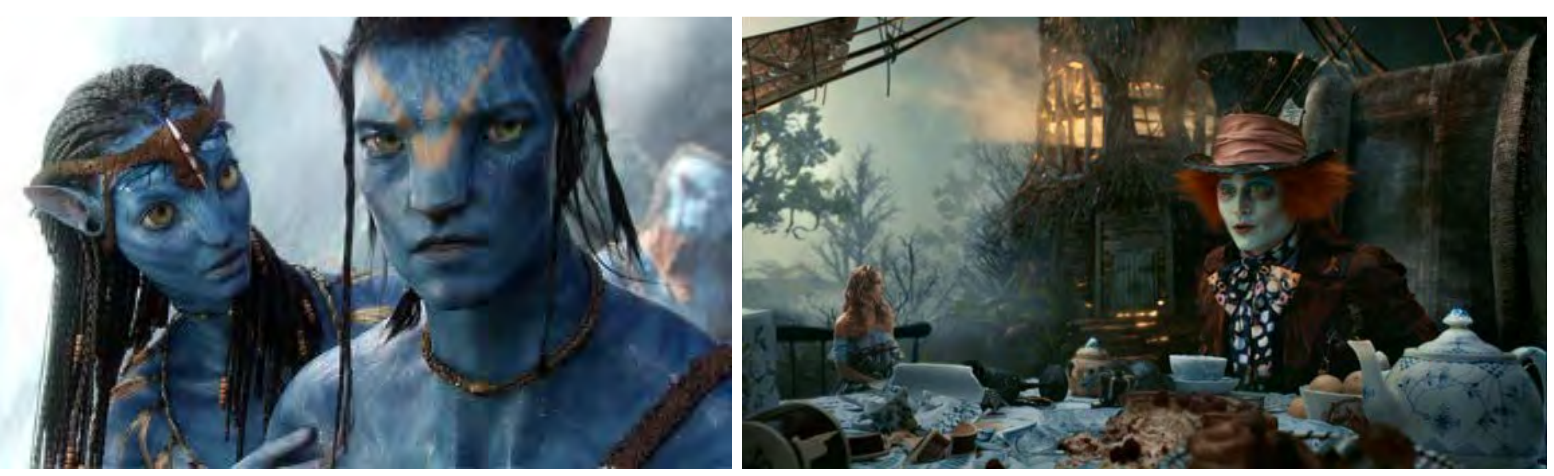

Figura 192 e Figura 193 - Os filmes "Avatar" e "Alice no País das Maravilhas" apostaram no formato 3D para atrair público.

Do ponto de vista criativo, também parece não ter havido uma mudança substancial. Dos primeiros curtas-metragens mudos pioneiros até "Branca de Neve", em 1937, a animação era uma extensão da tira em quadrinhos dos jornais. O humor tinha origem na simples narrativa em três painéis, que foram consequentemente estendidos para um desenho animado de três minutos. Esse perfil começou a mudar, muito lentamente, quando Disney tentou contar histórias nas Silly Symphonies. A estrutura de contar uma narrativa em três atos era algo inédito na animação, tendo em vista que as pessoas no início do século XX não acreditavam que o público suportaria sentar num cinema e assistir um "cartoon" por mais cinco minutos. Walt Disney sabia disso, e sua grande sacada foi se focar em duas coisas com sua equipe: personagens convincentes e performances críveis guiando uma história interessante. Nesse sentido, vejamos o que nos afirmou o roteirista Rhett Whickham:

Uma vez a equipe Disney tendo provado que não só poderia criar personagens críveis, únicos e convincentes, mas também usá-los como motor para guiar a história com um protagonista, um antagonista, e temas como o "amor vence tudo" ou "boas coisas vem para aqueles que são verdadeiros consigo mesmo" (os temas de "Branca de Neve" e "Pinóquio"), então a mídia se desenvolveu como uma forma séria de entretenimento fílmico. O que isso necessitava e o que Walt Disney foi pioneiro, com conhecimento dos animadores, era a sinceridade da atuação que poderia ser lida em pequenos gestos, gestos simples, movimentos sutis e refinados que caricaturavam a vida real sem fazê-lo "cartoonish" ou reduzi-lo em visuais simples de tiras em quadrinhos. A sinceridade está nos olhos, nos gestos, no timing, todas as coisas que qualquer ator considera. Então é preciso saber quando e onde, e como empurrar a realidade só um pouco para que a sensação de performance é especial e única, 
ultrapassando os limites da vida real. Walt fez crescer e amadurecer um quadro de atores muito dotados que aprenderam isso trabalhando em filme após filme, e finalmente se tornaram atores de seu tempo - no papel (comunicação pessoal) ${ }^{40}$.

O dilema da "era da informática" é que o quadro de talentos da chamada "nova geração" -ou segunda geração - (iniciada nos anos 1970 e terminando em meados dos anos 2000) aprendeu sua arte diretamente dos pioneiros, aprenderam como atuar no papel, desenhando, e não manipulando um "rig" (esqueleto digital que permite adicionar movimentos e expressões) de um modelo no computador. Iniciando com "O Cão e a Raposa" (1981) e trabalhando em filmes consecutivos, os animadores se tornaram grandes atores também.

Na proveitosa conversa que tivemos com Whickham em 2005, chegamos à conclusão de que o obstáculo é o tempo. Por exemplo, leva-se tempo para um chamado animador "tradicional" parar de pensar em coisas como "como desenhar alguma coisa", "como mover um design em 360 graus e torná-lo realístico", "como fazer um desenho ter carisma" e "como fazer um gesto ou pose ser lido" - transmitindo a emoção através de uma postura ou silhueta. O processo é aprender como, onde e quando "avançar" um desenho além do que poderia ser anatomicamente possível na vida real, e então se consegue uma pose extrema que instantaneamente traz vida a uma cena. Outra tarefa é como criar um personagem fazendo algo que um ator de carne e osso não pode ou não faz, porém, com a animação adicionando algum detalhe, há um estalo que lhe dá personalidade quando a ação está contida em 24 frames (por segundo). Então, é preciso também aprender a manipular as ferramentas da área e como fazer coisas como antecipação, exageros e redução do tempo dos gestos. Há detalhes que na vida real pareceriam rebuscados ou falsos se feitos por um ator de verdade; os animadores adicionam uma ilusão de realidade para tornar os personagens mais carismáticos e realistas.

Essas questões técnicas, preocupações de todo artista que trabalha no papel, vão para o segundo plano após anos de experiência. Elas ficam no fundo da mente e o artista passa a se preocupar mais com questões que interessam ao público - pormenores de um personagem como "quem sou eu?", “o que desejo?”, “como me sinto?”, “como farei para conseguir o que desejo?”- e, desta forma, a performance recebe nuances que não teria antes. Com a excelência no traço e as ferramentas técnicas em segundo plano, o animador pode finalmente explorar com maestria os aspectos emocionais da performance.

\footnotetext{
${ }^{40}$ Entrevista com o autor, por e-mail, em 14 de novembro de 2005. (tradução nossa)
} 
O que ocorreu nos anos 2000 é que veteranos de alto nível foram “convidados” a trocar o lápis pelo computador. E isso significou levá-los de volta aos níveis mais básicos da compreensão do que é animação. Com um monitor, um teclado, um mouse e os softwares, o animador precisou aprender novamente como alcançar os limites de expressão que até então eram encarados com naturalidade. Sutilezas e nuances precisaram ser aprendidas novamente. E obviamente havia o limite dos próprios softwares, que ainda não conseguiam produzir o tipo de pose, movimento ou sutileza que o animador gostaria de fazer. Isso só é possível após anos de feedback em produção. Mover um lábio, um olho, um músculo - cada parte requer modificações progressivas. Se um animador deseja uma abertura de olho ainda não permitida pelo modelo digital, os engenheiros precisam alterar o programa. $\mathrm{O}$ trabalho se tornou mais complexo e rústico, com o animador precisando estar em contato direto com o designer e o engenheiro do computador. O processo obviamente foi mais traumático para alguns veteranos. Para eles, o computador tornava a criação mais lenta. Para os jovens, tudo ainda era experiência, porém os conhecimentos básicos podem ser ensinados em poucos meses. Não é surpresa, portanto, que muitos espectadores tenham criticado muitos filmes de animação computadorizada, considerando os personagens esteticamente feios, plásticos e duros. Para uma nova geração, o processo é mais fácil. Mas, novamente, é preciso tempo para que a tecnologia vá para o segundo plano na mente do animador. É por isso que a partir de 2010 vemos mais exemplos de sutilezas e performances poderosas que podem ser associadas à animação tradicional.

A qualidade da animação Disney vem justamente da experiência de longo prazo, do convívio de colegas que conheciam muito bem uns aos outros, conheciam os gênios de cada um, as especialidades e os limites num processo que durou décadas. A "nova geração" (última a produzir animação tradicional em série) também cresceu unida e havia uma compreensão comum, uma experiência conjunta que apoiava o desenvolvimento artístico. Quando o conjunto é desmontado, a qualidade é colocada em perigo e isso se alastra em todos os níveis de produção. O que explica a Pixar ser tão boa em animação computadorizada desde seu início e a Disney não ter repetido o sucesso quando migrou da técnica tradicional para a digital? Não é somente pela qualidade no desenvolvimento das histórias, mas porque eles são uma companhia de colegas que aprenderam a fazer isso juntos, filme após filme, desde o início. O grande valor está no convívio, no tempo, e ajuda a explicar porque muitos estúdios concorrentes não tiveram vida longa. A Disney sofreu uma decadência pois perdeu parte de seus animadores na concorrência dos anos 1990, perdeu outra parte devido à evolução da tecnologia e uma outra por estratégias erradas de gestão. Não começando mais cedo um período de transição, simplesmente queimou uma geração no auge de sua excelência técnica. Alguns conseguiram migrar, outros se tornaram mentores para os mais jovens, e é justamente a 
geração dos anos 2000 que está crescendo unida e nos trazendo produções mais tecnicamente perfeitas. Veteranos como Floyd Norman comentam que os segredos do sucesso estão na história da Disney, como vemos na figura 194.

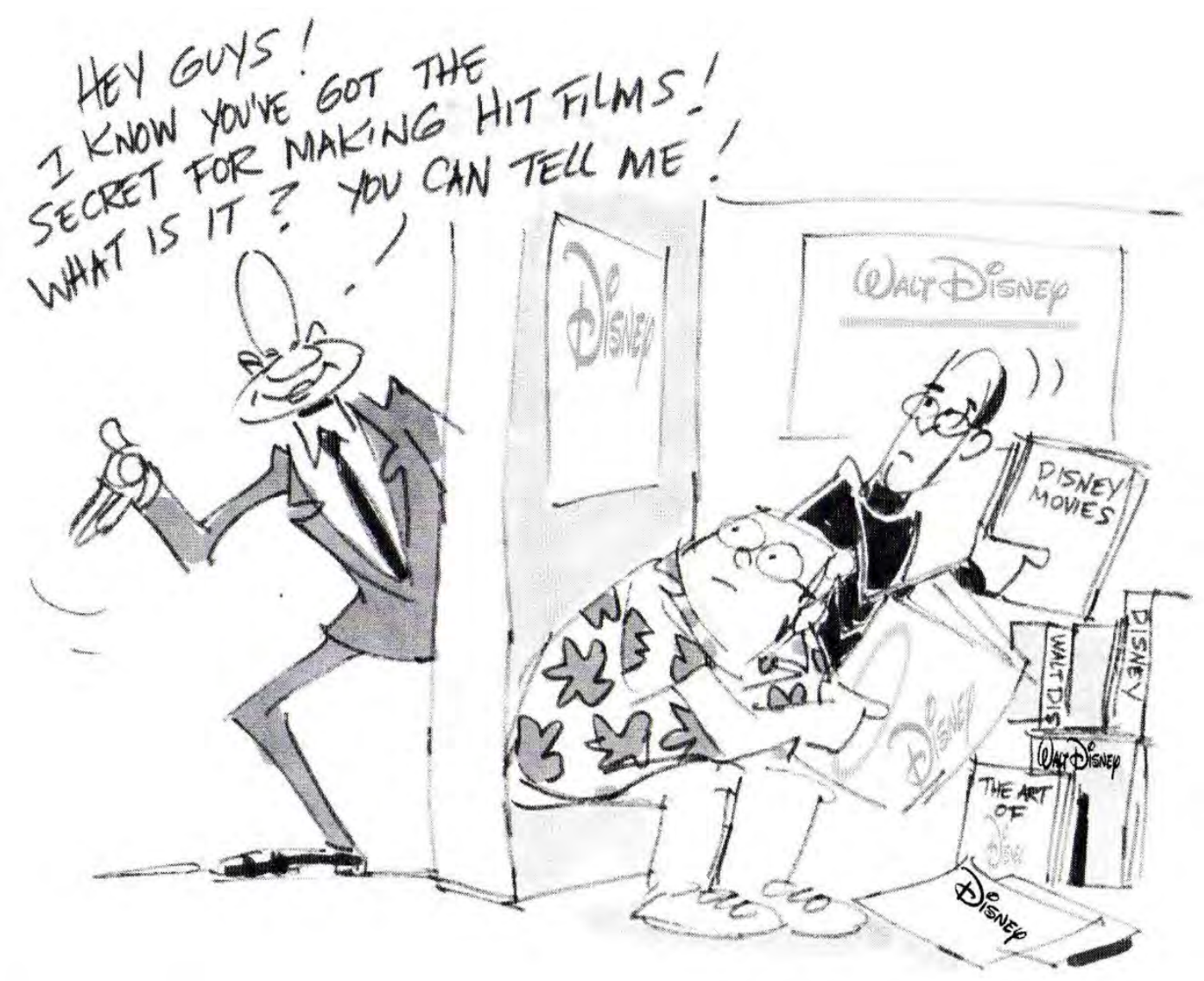

Figura 194 - Cartoon de Floyd Norman: Michael Eisner quer saber de Steve Jobs e John Lasseter o segredo para fazer filmes de sucesso.

A saturação dos filmes de animação e a rápida transição para a tecnologia de animação computadorizada resultaram em um processo de meltdown (colapso) dos estúdios Disney. A partir de 2001, houve uma sucessão de quedas de executivos e estratégias que derrubaram o moral da equipe criativa. Corporações inspiradas por gurus dos negócios como Tom Peters (1997) aplicavam o conceito de downsizing em suas empresas, muito popular a partir do final dos anos 1990. Trata-se do fim da fidelidade da empresa ao funcionário. Roteiristas, animadores, compositores, diretores... por mais veteranos e especialistas que fossem, podiam ser dispensados para extinguir contratos caros e de longo prazo. Novos contratos passaram a ser por obra. Terminado um projeto, o profissional é demitido até arrumar um outro. Os veteranos, aproveitando o baixo custo dos computadores e 
softwares de produção, montaram seus estúdios independentes, oferecendo trabalho individual ou de pequenos grupos aos grandes estúdios. Vejamos, na tabela 13, os principais fatos que demonstram o "colapso" do estúdio:

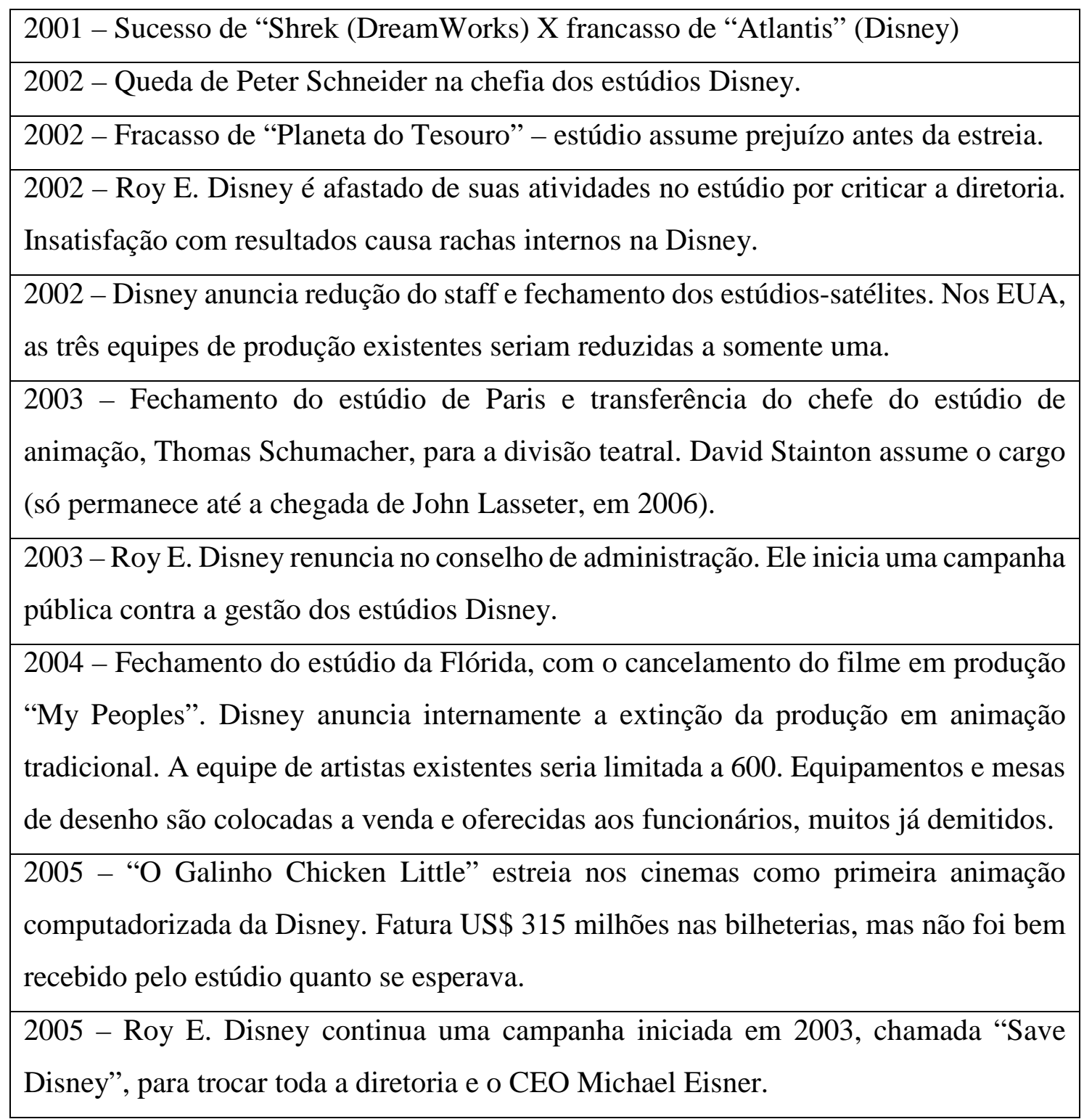

Tabela 13 - Evolução do “colapso” (meltdown) Disney no início dos anos 2000.

No período de crise, o CEO Michael Eisner não tem outra saída senão aplicar mais fortemente o microgerenciamento. Ao invés de delegar aos presidentes de cada setor do estúdio mais autonomia, instituiu uma nova camada intermediária de "executivos criativos", cuja tarefa era supervisionar e lhe repassar o progresso da produção. Na prática, os problemas demoravam a chegar nos níveis superiores e só eram reportados ao Eisner quando já era tarde demais. Esses comitês se tornaram moda em Hollywood e, no caso da Disney, não trazia muitos resultados positivos. Apesar da presença de 
produtores veteranos, em geral eram convidados somente executivos e vice-presidentes criativos do "nível intermediário". O jornalista James Stewart (2005) acompanhou Eisner em 11 de junho de 2003 em uma reunião criativa da equipe do cinema de animação, chefiado por David Stainton e assim relatou o evento:

Eisner normalmente atendia esses encontros uma ou duas vezes ao mês. Roy E. Disney não estava presente, a despeito de Stainton ter lhe falado que ele seria bemvindo. (Roy afirmara que lhe pediram para não participar das reuniões após a saída de Schumacher). É uma reunião na hora do almoço. O grupo pega sanduiches e refrigerantes e se acomodam ao redor de uma mesa de conferência. Em um cavalete estão quadros com as previsões de lançamento de futuros filmes: "Teacher's Pet e "Os Incríveis" em 2004, "Heffalump" para 2005.

Stainton destaca que Heffalump é baseado em um personagem [do universo do] Ursinho Pooh. "Nós nunca fizemos um efalante", ele diz. "[O departamento de produtos] deseja mais personagens".

Eisner assente. "Deixe os produtos longe disso", ele pede.

Pam Coats diz que ela tem um novo título para outro projeto, "Angel and Her No Good Sister". Dolly Parton é a voz de uma das personagens.

"É bonitinho", diz Eisner. "Mas parece algo pequeno..."

"Eu gosto", interfere Stainton. "É um conflito automático".

Eisner concorda. "Eu gosto. O título muda todo o filme".

Eles mudam a discussão para o roteiro. "Nós não queremos que você o cancele", Coats declara ao Eisner. Ele havia lido dois atos de "Angel" e não gostado. A história gira em torno de uma "maldição do ovo azul". Na versão atual, Coats explica, "Elgin diz 'O amor pode superar a maldição'. Ele fica nocauteado. Eles arrastam Elgin para Rose..."

"O que você quer dizer com nocauteado?", Eisner questiona. "Ele não pode ficar inconsciente por três dias. Ele não pode estar em coma ou em recuperação..."

Alguém explica, "É uma coisa de Viagens de Gulliver".

"Ele não pode ficar inconsciente", Eisner continua.

"Isso deixa a história de amor viva", Coats praticamente implora.

"Bom, eu gosto do ângulo Viagens de Gulliver", Eisner diz, apesar de não soar convencido.

Três filmes [de animação] estão competindo para a data de lançamento do Natal de 2006: "Gnomeo e Julieta", "Fraidy Cat" e "Wilbur Robinson".

"Não tenho paixão por nenhum deles", diz Eisner.

Stainton destaca que Gnomeo e Julieta tem Elton John compondo a trilha musical.

"Podemos conseguir três hits do Elton?", Eisner pergunta.

Stainton sugere que "Chris [Montan, presidente da Walt Disney Music] está apostando em Elton para isso. Ele gostou das primeiras duas canções. Elton está muito bom".

A discussão desvia para o Natal de 2007. Eisner acabou de ler um roteiro de Rapunzel. "Alguém me disse que uma mulher com cabelos longos é antiquado", afirma Eisner.

"Daí o motivo disso precisar ser um tipo de comédia estilo "Legalmente Loira", responde Mary Jane Ruggels, outra vice-presidente criativa.

"A Bela Adormecida [animação de 1959] era algo de 1938", Eisner diz. "O final era forçado, assim como Planeta do Tesouro - de repente termina. Não era engraçado ou astuto". Vocês têm certeza que podem salvar isso? A Rainha de Gelo é melhor? "Você quer dizer A Rainha da Neve", corrige Ruggels.

"Eu gosto da ideia A Megera Domada [para o tom de A Rainha da Neve]", comenta Eisner. "Pegue a Martha Stewart. Ela é dura, esperta - uma adversária valorosa. Se 
ela fosse um capacho de mulher ninguém iria atrás dela. Marlo Thomas costumava me telefonar sobre o marketing de "That Girl". Ela disse, 'Se eu fosse um homem seria presidente da sua rede de TV".

Eisner expressou alguma reserva sobre a equipe escalada para "A Rainha da Neve", e complementou, "John Lasseter. Se fizermos um novo acordo com a Pixar..."

Stainton em sobressalto: "Você quer dizer quando fizermos um novo acordo com a Pixar".

"Eu disse ao John, você pode ter A Rainha da Neve. Ele adorou. John disse, 'Eu quero fazer um filme de princesa'."

Eisner pergunta sobre a sinopse de A Rainha da Neve.

"A Rainha da Neve é uma vadia terrível", Ruggels diz. "Quando seus pretendentes tentam derreter seu coração, a Rainha da Neve os congela".

"Cada um deveria ser um impostor, mas diferente", Eisner comenta dos pretendentes.

"E então aparece o cara comum", Ruggels continua.

"Isto é perfeito!", Eisner exclama. "Tenho receito de ouvir mais".

"O cara normal aparece, ele não é tão bom assim, mas ele é uma boa pessoa. Ele começa a descongela-la.... ela derrete."

"É fantástico", responde Eisner. "Finalmente. Tivemos vinte reuniões sobre isso".

"Teremos um tratamento (estágio antes do roteiro) em duas semanas", promete Ruggels.

"Podemos ter [esse filme] para 2006?, pergunta Eisner.

"Sem chance", responde Coats.

Mais ideias surgem na reunião. Princesa Sapo, Rumpelstilskin, You Don't Know Jack about the Beanstalk, Hansel and Gretel (João e Maria, porém com uma reviravolta - as crianças são as vilãs e a bruxa boazinha), Mother Goose (Mamãe Ganso) como um tipo petulante, estilo Queen Latifah; e algo mais, talvez "Aïda", que apresentaria uma "princesa" africana. Eisner se preocupa que ainda é muito liveaction. "Qual é a peça de Howard Ashman que podemos incluir?", ele questiona, numa das muitas vezes que o nome de Ashman é falado na reunião.

"Isso é bom", Eisner conclui, "um bom começo". Ele se levanta para sair. "Eu amo A Rainha da Neve". (STEWART, 2005, p. 435-437 tradução nossa)

Isso ajuda a explicar decisões variadas, como não incluir personagens negros no ambiente africano de "Tarzan" (1999) para evitar ferir sensibilidades, ou excluir por segurança qualquer tipo de faca e espada em "Planeta do Tesouro", que obviamente pedia duelos de espadas. Ou até mesmo decisões simplórias, como alterações pontuais de títulos como "Kingdom of the Sun" para "Kingdom in the Sun", além de aprovar ideias baseadas em premissas como "Que tal fazermos O Rei Leão com ursos?”, o que resultou na animação "Irmão Urso" (2003). A ideia teve origem com o próprio Michael Eisner, convencido após "O Rei Leão” de que o público queria ver mais filmes com animais.

Uma das apostas no final dos anos 1990 foi montar uma produtora autônoma dentro da Disney chamada Secret Lab, que produziu "Dinossauro" (Dinosaur, 2000), combinando personagens digitais e cenários reais filmados. O resultado foi satisfatório, porém a produtora foi fechada no mesmo ano após o cancelamento do filme seguinte, "Wild Life", um projeto com animação totalmente computadorizada, levemente inspirado em "Pigmaleão" de Bernard Shaw, mas cuja história tinha 
elementos arriscados demais para uma produção disneyana, lidando com moda, glamur e um humor adulto.

Em 20 de novembro de 2003 começa um longo período que culminaria na queda de Michael Eisner como CEO da Disney. Roy E. Disney é informado por membro do conselho de administração de que ele não seria reconduzido ao posto. Chocado com a notícia, Roy preferiu renunciar, porém sem antes escrever uma carta, detalhando as falhas de gestão de Eisner. Desta vez a batalha não era contra um CEO enfraquecido, como na época de Ron Miller, não havia uma oferta hostil para conquistar a corporação, não havia um racha no conselho administrativo e nem havia condições para montar uma batalha para comprar ações e forçar a eleição de novos diretores. Era apenas o nome Disney, encarnado por Roy, contra o que ele chamava de gestão problemática, que limitava a atuação de críticos internos. A equipe criativa observava com preocupação a evolução da crise, como podemos ver no cartoon de Floyd Norman (Figura 195).

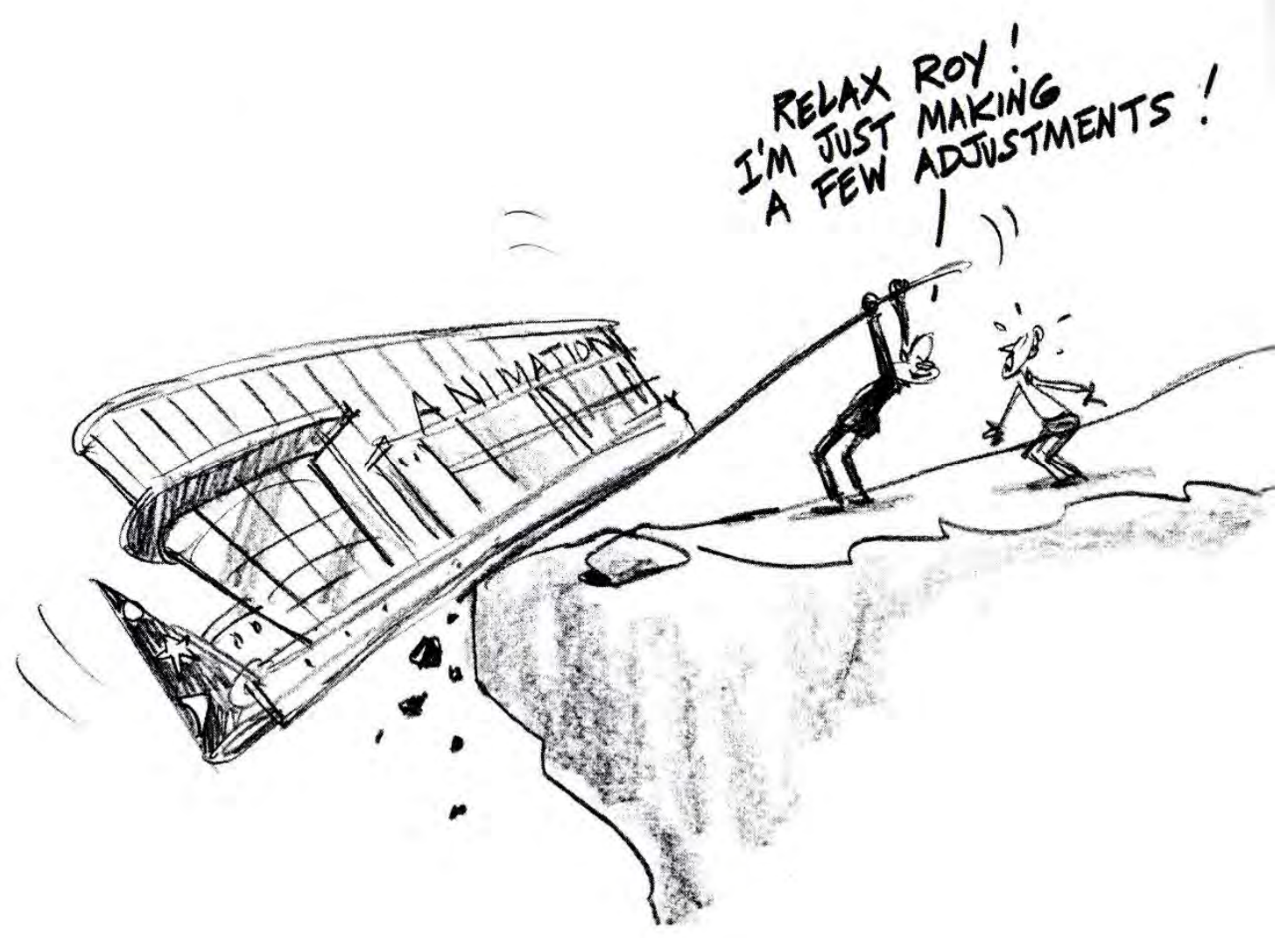

Figura 195 - Cartoon de Floyd Norman descrevendo o clima de crise nos estúdios Disney - Eisner diz: "Relaxe, Roy! Eu estou fazendo alguns ajustes!". 
Roy pode ter sido barrado de acompanhar as produções no estúdio, porém os animadores se tornaram seus mais fieis parceiros em sua batalha contra o conselho de administração para derrubar Michael Eisner. Um dos feitos mais famosos veio de um trio - Dave Pruiksma, supervisor de animação em "A Bela e a Fera" e "O Rei Leão", o roteirista Tim Hauser e um diretor, Steve Moore. Eles escreveram uma carta pública após o próprio Roy ter publicado a sua de renúncia. A carta é um documento importante, não somente pelo seu apoio de Roy E. Disney, mas porque comprovava um sentimento crítico vindo da área criativa, os artistas confirmando o problema da baixa autoestima no estúdio, sobre a qual Roy tentava alertar outros diretores e acionistas:

Nós, os membros abaixo-assinados da comunidade da animação, desejamos estender nosso apoio total a Roy E. Disney e Stanley Gold em sua busca para apoiar as tradições de excelência que uma vez definiram o nome Disney. [Roy] protegeu a divisão Feature Animation de um novo grupo no estúdio, que não tinha o senso de seu potencial continuado. Sem o Roy, a Pequena Sereia, A Bela e a Fera, Aladdin e O Rei Leão não seriam realidade, muito menos a renascença artística da companhia e sua reviravolta financeira.

Porém, após uma sequência de sucessos de crítica e de bilheteria, os artistas da animação foram cada vez mais mantidos fora dos papeis de liderança. Neste novo padrão corporativo nos tornamos um pouco mais do que operários fabris ou trabalhadores não-qualificados no estúdio que ajudamos a reconstruir. Micro-gerentes vindos de fora da mídia fomentaram um ambiente de trabalho altamente tóxico, gerando um mal-estar criativo que continua sem controle.

A tradição única de contar a história visualmente, a animação de humor e personalidade em que o estúdio Walt Disney havia prosperado, foram trocadas pelo jargão politicamente correto, falas antiquadas, e [fórmulas prontas] que o público tem se recusado a responder. A rejeição do Sr. Eisner ao legado de Walt Disney tem sido um fracasso colossal. Mesmo assim, este é o homem que tem sido pago mais de US\$ 700 milhões em compensação desde 1996, enquanto o departamento de animação em sido dizimado por pink slips (jargão para o ato feito por executivos para demitir os funcionários).

Agora, artistas qualificados ficam desempregados enquanto executivos ganham mais. Uma única forma Americana de arte, o filme animado Disney, está pendurado precariamente no equilíbrio. - reduzido para a produção de extensões de franquias direto-para-vídeo baratas feitas por comissão.

Sem o Roy, quem protegerá o legado dos 70 anos da Disney de se tornar mais do que uma marca vazia?" (STEWART, 2005, p. 472-473, tradução nossa)

A carta, publicada online (não mais disponível na internet em seu site original), em duas semanas atraiu mais de 4.500 assinaturas de profissionais da animação atuantes, ex-funcionários da Disney e entusiastas. $\mathrm{O}$ tom da carta e a movimentação online chamaram a atenção da imprensa e não passaram despercebidos pela Disney. E nem pela atenta concorrência. 
Com o estúdio em turbulência, a audiência da rede $\mathrm{ABC}$ decadente em quarto lugar (dentre as quatro maiores redes) e com o faturamento dos parques temáticos, prejudicado após os efeitos negativos ao turismo pós-atentados de 11 de setembro de 2001, a crise chamou a atenção de uma das gigantes da TV a cabo nos EUA.

O grupo Comcast, focado em TV a cabo e tendo assimilado com sucesso uma fusão anterior com a gigante da telefonia AT\&T, recebeu de sua direção estratégica a sugestão de aquisição de uma empresa. Ironicamente, a empresa era presidida por Steve Burke, antigo executivo de primeiro escalão da Disney. Sob sua gestão, o número de assinantes pulou de 4,5 milhões para 21,5 milhões. Estudos internos apontavam que a empresa, focada basicamente em distribuição de conteúdo (adquirindo os direitos de exibição de centenas de canais), agora possuía a massa crítica necessária (20 milhões de assinantes) para lançar o lançamento de um canal fechado lucrativo - a Comcast estava pronta para adquirir uma empresa que produz "conteúdo". Apesar das reservas de Burke sobre os parques temáticos, cujo faturamento caiu após os atentados, a Comcast decidiu fazer uma oferta para abocanhar a The Walt Disney Company (STEWART, 2005, p. 478). Eisner, evidentemente, não estava interessado e nem ouviu a proposta, que chegava a US\$ 54 bilhões.

A crise por todos os lados culminou nos eventos da reunião de acionistas da Disney, realizada em Filadélfia em 3 de março de 2004. Roy E. Disney fez uma declaração sobre criatividade:

Criatividade é uma coisa divertida. É uma força viva, que respira com uma vida própria e tende a florescer entre indivíduos e em pequenos grupos. A Disney precisa continuar nossa trajetória de criatividade e de sucesso financeiro confiando nos talentos e imaginações de suas pessoas criativas - e eu não posso enfatizar o suficiente a palavra confiança - e então apoiá-los com os recursos necessários. Nós precisamos instalar uma nova equipe de gestores. Falando como alguém com o nome de Disney, é minha certeza acreditar que nós não somos uma commodity. Tão logo continuemos a acreditar no poder das ideias criativas, nossos melhores anos continuarão adiante". (STEWART, 2005, p. 510, tradução nossa)

Os acionistas votaram em peso contra o CEO Michael Eisner. Sob pressão, o conselho decidiu não renovar o contrato dele, após sua expiração em setembro de 2006. O próprio executivo percebeu sua situação e, às vésperas de completar 20 anos na presidência da Disney, escreveu uma carta expressando o plano de se aposentar ao fim do contrato (STEWART, 2005, p. 524). O conselho, no entanto, decidiu romper laços e iniciar uma busca por um sucessor em 20 de setembro de 2004. Após avaliação de candidatos externos, Bob Iger, o número 2 na hierarquia Disney, foi o escolhido para a sucessão. Uma nova era estava começando. 


\section{8 . A ERA DO IMPÉRIO DA TECNOLOGIA}

[Sóbrio, discreto, com expressões e penteados simetricamente perfeitos, Iger é conhecido também pelo intenso controle das informações internas. Sob sua gestão, reduziram drasticamente a público de rumores, informações dos bastidores de produção e dados de novos projetos. Frédéric Martel quase lhe perguntou] "se era verdade, como se diz, que ele era tão obcecado com o controle da informação e os vazamentos nos meios de comunicação que tinha uma televisão no chuveiro - mas não tive coragem. Eu já sabia, por experiência própria, que não se pode esperar grande coisa fazendo perguntas ao dirigente de uma grande multinacional como a Disney" (MARTEL, 2012 p. 82).

Em 13 de março de 2005, Iger assumiu como CEO da The Walt Disney Company. Um misto de esperança e incerteza povoava os pensamentos de funcionários, artistas, executivos e entusiastas. A Disney da era Bob Iger pega o que era apenas um flerte entre entretenimento e tecnologia e a transforma em uma relação sólida. Em um mundo com mudanças rápidas de impacto na tecnologia, com dezenas de canais de distribuição indo do YouTube ao Netflix, aos aplicativos dos smartphones, e às novas integrações entre TV, rádio e internet, o público agora pode escolher conteúdos dos mais variados tipos de qualidade, custo e formato para assistir como e quando quiser. A era das poderosas corporações de mídia foi atropelada pelas corporações da tecnologia do início do século XXI.

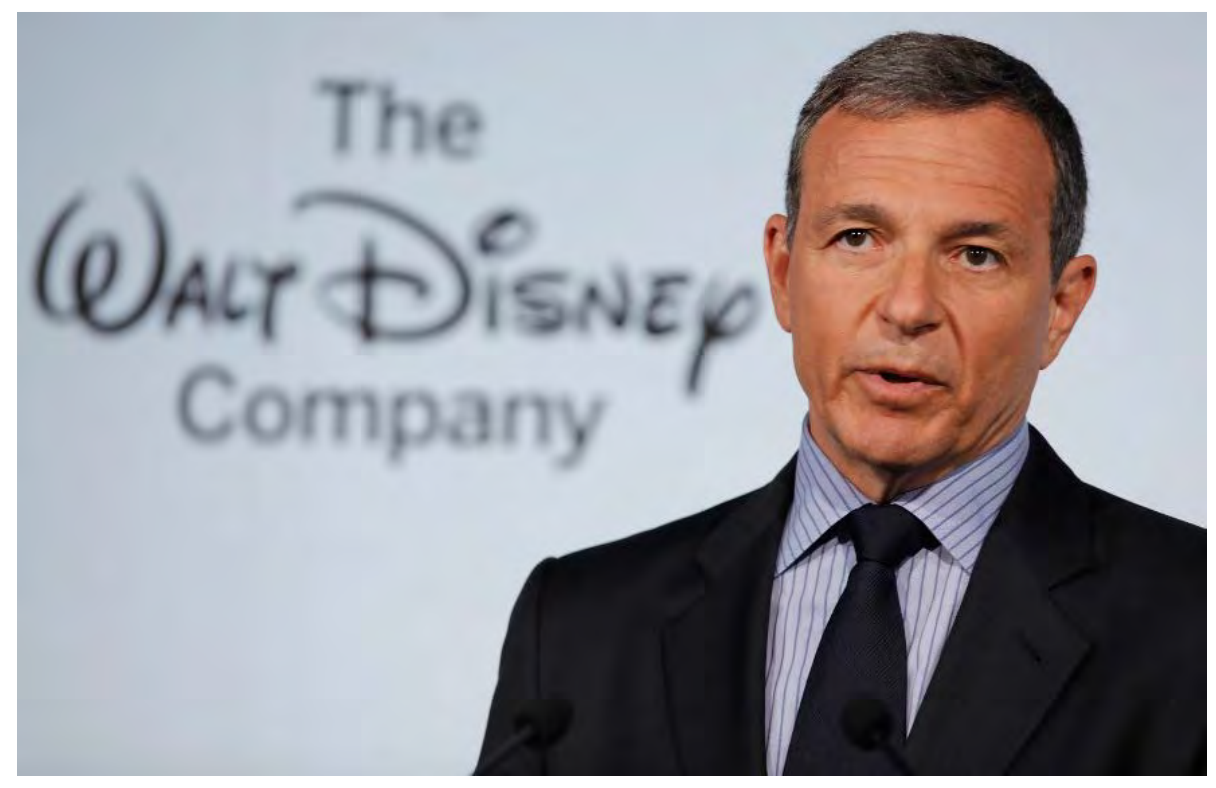

Figura 196 - Bob Iger, atual CEO da The Walt Disney Company. 
Primeiramente, Bob Iger fez uma limpeza geral na estrutura da Disney, ganhando o simbólico aval da família Disney, reestruturando a hierarquia administrativa dos vários departamentos e selecionando chefes para cada um deles de forma a delegar a eles a autonomia necessária para que pudessem gerenciar com mais eficiência e qualidade. Roy E. Disney ganhou o título simbólico de “diretor emérito" e apoiou a gestão até sua morte em 2009. A confiança passou a ser um elemento importante para as operações diárias do estúdio e demais divisões da corporação.

A doutrina Bob Iger é caracterizada por três prioridades estratégicas (LEV-RAM, 2015):

1. Propriedade Intelectual - basicamente storytelling de alta qualidade atrelado a uma marca foi o que propiciou a aquisição de companhias criativas como a Pixar Animation Studios, a Marvel Entertainment e a Lucasfilm.

2. Abraçar a tecnologia, o que é um desafio devido a dinâmica inconstante do público sempre em busca das novidades da cultura digital - saber o que o público compra, quando e como compra, qual seria o preço justo, quais são os concorrentes na multiplicidade de um novo mercado onde Google e Facebook são as companhias de informação mais poderosas, superando as corporações de mídia.

3. Ampliação do mercado global - com investimento em novos territórios, por exemplo, a inauguração da Disneylândia de Xangai em 2016. Alguns territórios, caso da China e Índia, têm sido importantes para a exploração da indústria do entretenimento (MARTEL, 2012).

\subsection{A gestão Bob Iger e o foco em tecnologia}

Houve uma acelerada evolução tecnológica desde os primeiros experimentos de comunicação em rede. Em 1969 a primeira rede, ARPAnet (Advanced Research Projects Agency Network), foi financiada pelo Departamento de Defesa dos Estados Unidos e utilizada pelos militares durante a Guerra Fria. A rede permaneceu limitada e se expandiu entre universidades "hi-tec", institutos de pesquisa e laboratórios - todos compartilhando informações, inicialmente militares. Nascia para o Pentágono a noção essencial de que era possível criar uma infraestrutura de comunicações que sobreviveria à retirada ou destruição de qualquer computador ligado à rede. Para as universidades, "a Net oferecia "acesso livre" aos usuários, professores e pesquisadores, e que eram eles comunicadores" (BURKE, BRIGGS, 2006, p. 301). O serviço de provedores comerciais surgiu nos anos 1980 e se popularizou nos 1990 (EUA). A Internet passou a ser conhecida e usada pelo público comum e o e- 
mail se tornou sua função mais importante, tornando mais rápida a comunicação pessoa-a-pessoa. Com o desenvolvimento de novos satélites e computadores, as notícias viajavam muito mais rápido que antes, possibilitando que a rede noticiosa CNN transmitisse ao vivo a Guerra do Golfo em 1991. Aos poucos, essa tecnologia da informação rápida foi barateada e a internet passou a ser viável comercialmente.

Trata-se da segunda fase da Internet. As pessoas acessavam a rede utilizando modem e conexão via telefone. Porém, o tempo gasto em conteúdo era limitado. Pagava-se caro pela conexão, ela podia ser instável e o conteúdo existente em geral era limitado e mais formal. No final dos anos 1990 vislumbrou-se a banda larga como uma tecnologia que simplesmente tornaria a conexão mais rápida - facilitando transmissão de e-mails com arquivos pesados, imagens e áudio com qualidade superior e, é claro, os vídeos. Embora o audiovisual tivesse mais limitações, diversas ferramentas de comunicação entre pessoas e grupos já existiam. Provedores como Netscape, Yahoo!, AOL (America Online), entre outros, hospedavam fóruns e listas de discussão e outros como o Geocities garantiam a possibilidade da criação de websites pessoais. A principal característica da banda larga não foi melhorar velocidade ou ampliar o poder das mídias sociais, e sim a perenidade, a possibilidade de se manter conectado ininterruptamente a partir de uma conexão a cabo.

Com a banda larga foi possível sofisticar também o comércio eletrônico (e-commerce) e a indústria cultural descobriu uma nova ferramenta para promover suas produções. No caso do cinema, um exemplo notável foi o da popularização do filme "A Bruxa de Blair":

Todos se lembram do filme "A Bruxa de Blair", contando a história, justamente, a de alunos americanos de cinema que se perdem numa floresta quando faziam um filme; realizado com uma câmera de vídeo rudimentar, ao custo de 35 mil dólares, o filme foi apresentado no festival de Sundance e divulgado basicamente pela Internet - o primeiro caso decisivo de marketing quase inteiramente online. Ele arrecadou 248 milhões de dólares em todo o mundo em 1999. Nesse ano, os dirigentes dos estúdios finalmente entenderam, graças a esse modesto projeto estudantil, que Hollywood seria revolucionada pela Internet. "Com a bruxa de Blair, fomos tomados pela incerteza e medo, literalmente - e desde então não nos livramos dele", confirma em conversa comigo um dirigente da Universal em Los Angeles. (MARTEL, 2012, p. 202) 
A Disney era uma das companhias mais espantadas com a evolução, mas principalmente a valorização dos portais na Internet. Eram locais que serviam de ponto de partida para os usuários, muitas vezes assinantes, pois vários, em sua origem, eram provedores de acesso. Numa época de grande valorização das empresas de Internet, o então CEO Michael Eisner se manteve fiel a outro de seus dogmas que era criar as coisas internamente, ou seja, criar um negócio para a internet dentro da Disney. Ele recusou a proposta de seu número 2, Michael Ovitz, de comprar ações para adquirir uma pequena parte da Yahoo! Um grupo de executivos da Disney examinou várias opções. Em agosto de 1997 recomendou uma parceria com a Yahoo!. O chefe financeiro Tom Staggs negociou um acordo em que a Disney adquiria de 10 a 15\% de ações na Yahoo! por US\$ 180 milhões, em retorno do portal dar acesso proeminente a todos os websites da Disney. Era consenso que os portais emergiriam como forças dominantes do negócio da Internet (STEWART, 2005).

A Disney, assim como as demais corporações de mídia, chegara atrasada para estabelecer seu próprio portal sem um investimento maciço e de risco. A alternativa era alavancar os websites existentes e as fortes marcas, criando uma parceria com um dos grandes portais. A escolha caíra sobre a Yahoo!, porém a AOL apresentou uma ameaça de proporções titânicas. A empresa sugeriu que a Disney comprasse a AOL, ou mesmo que a AOL pudesse comprar a Disney. A proposta levou o CEO Michael Eisner a telefonar ao seu correlato da AOL Steve Case para reclamar da sugestão e rejeitar tal possibilidade. Porém, a noção da AOL vir a comprar a Disney estava deixando de ser maluquice, tendo em vista que as ações da AOL estavam atingindo níveis estratosféricos. Ela teria cacife para comprar qualquer corporação de mídia disponível. Meses de negociação e as conversas com a Yahoo se encerraram. A equipe de executivos continuava a ver alternativas, mas o preço das ações dos portais continuava subindo, tornando o negócio um lance de valor astronômico (STEWART, 2005). Eisner considerou os valores absurdos para companhias que não apresentavam lucro, nem estratégia para isso. Ele estava determinado a não pagar com dinheiro, e também a não usar ações baseadas nos ativos sólidos da Disney.

A decisão final foi criar um portal próprio. A Disney já possuía participação na Starwave, que gerenciava os sites da ESPN e da ABC. Em junho de 1998, investiu em $43 \%$ das ações da Infoseek, o terceiro site de busca mais popular após Yahoo! e Excite (MALONEY, 1998). A Disney juntou as forças de suas subsidiárias para criar um portal chamado "Go". O resultado foi desastroso pois o portal ficava muito atrás dos portais do Yahoo!, AOL e Microsoft, não atraindo a massa de usuários 
esperada para garantir propaganda e conteúdo. As operações eram caras e distribuídas entre as sedes tecnológicas e criativas em Seattle, Sunnyvale, Burbank, Nova York e Briston, Connecticut (cidade sede do website da ESPN). E as culturas da Starwave e da Infoseek eram difíceis de combinar. O primeiro presidente da Go, Jake Winebaum, saiu para fundar a Business.com. Steven Bornstein assumiu o desafio. (STEWARD, 2005, p. 338).

Descobriu um caos maior ainda, com 2 mil empregados distribuídos em nove países, os vários sites das empresas da Disney separadas das unidades operacionais que as criavam e fundiam com a Go. Não havia razão comum e ninguém liderando. Problemas tecnológicos também eram mais graves que o imaginado. A sugestão draconiana de Bornstein era admitir derrota e fechar o portal, focandose nas quatro áreas onde a Disney podia fazer dinheiro operando seus próprios websites: Disney, ESPN Sports, Disney Travel e ABC News. Eisner considerou a sugestão uma heresia, afirmando que o executivo era pessimista só porque operava um trem enquanto observava aviões pairando sobre ele. Não havia plano, e ações do portal seriam oferecidas ao público em novembro. A Disney não queria sofrer riscos e a Go.com foi estabelecida como empresa autônoma em relação à Disney, para se proteger das oscilações do mercado (MASTERS, 2000, 437):

[Eisner expandiu a Disney mas não tinha como opção um grupo muito diversificado], quer atuar num segmento vasto, é verdade, mas bem definido. Em torno dessas atividades, ele integra e favorece a cooperação e a sinergia, mas não vai muito além disso. Ele não se mostra inclinado a estimular a concorrência interna não regulamentada, como hoje em dia se faz com frequência nos conglomerados de mídia (...). Tipicamente "old media", ele tampouco acredita na "convergência" entre conteúdos e tecnologias: como a maioria dos chefões de Hollywood nas décadas de 1990 e 2000, mostra-se invariavelmente desconfiado, amargo e hostil em relação à Internet. Ele fez questão de que o grupo Disney continuasse sendo um "pure player" (uma empresa centrada em sua atividade principal), e se privilegiou investimentos afins, em setores próximos facilmente abordáveis, nem por isso quis que a Disney se transformasse num grupo generalista para além da atividade dos "conteúdos". Fora de questão seguir o exemplo da Sony, da Orange, da Reliance ou ainda, mais recentemente, da General Electric, um conglomerado no qual as indústrias de conteúdo representam apenas uma parte da renda, juntamente com a informática para o grande público, a eletricidade ou as telecomunicações. O negócio da Disney, segundo Eisner, é o "content” [conteúdo]. (MARTEL, 2012, p. 69). 
Paralelamente, os negócios na internet da Disney continuavam dando prejuízo. Em fevereiro de 2000 já se assumia que não havia como reverter o prejuízo e não dava para competir e ganhar. A estratégia do portal era um fracasso. "Go.com" nunca seria outra Yahoo ou AOL. Novamente a solução era abandonar o portal e criar sites usando as extensões das diversas marcas - Disney, ABC, ESPN, parques temáticos - e extinguir uma divisão exclusiva de internet. Internamente era visto como suicídio corporativo, porém a honestidade e convicção foi vista de forma positiva. (STEWART, 2015, p. 358).

Em um sinal de capitulação, a Disney fez uma troca na bolsa de valores usando ações da própria corporação em janeiro de 2001. Coincidia com o fim da euforia das empresas de internet e o que comumente se chamou de "Bolha da internet". Na prática, fora apenas um sobressalto. A Internet ainda estava dando os primeiros passos e novos modelos de negócios estavam surgindo.

Uma vingança para Eisner foi ver a AOL-Time Warner passar por um longo período turbulento graças à desvalorização da AOL e os problemas de gerenciamento conjunto das duas grandes empresas unificadas. Trocas de executivos e presidentes não foram suficientes e a AOL foi separada da Time-Warner em 2009. A Disney, porém, não ficou sem prejuízo. Eisner fora seduzido pelas novidades da internet, investindo alto em empresas do ramo e pagando mais de US\$ 1 bilhão (no papel) para criar o portal "Go.com” (MASTERS, 2000, p. 438). Com a decisão de recomprar as ações do portal para encerrar o negócio, a Disney fora forçada a assumir mais um prejuízo de US\$ 790 milhões. Sem dúvida, as corporações de mídia levaram uma rasteira das empresas de internet.

O próximo passo na evolução das novas mídias foi conexão sem fio. Somado à alta velocidade de conexão e o fato dela ser perene, esta nova fase é caracterizada pelo surgimento e popularização de diversos gadgets portáteis como os tablets, sendo o telefone celular smartphone o principal deles. O comércio foi beneficiado e a comunicação entre as pessoas tornou-se ainda mais dinâmico. A proliferação das mídias sociais levou à criação dos aplicativos, desenvolvidos por empresas iniciantes de tecnologia (start-ups) que conseguem investimento e, com sorte, se tornam corporações bilionárias devido à descoberta de demandas adormecidas dos usuários. Um novo desdobramento na tecnologia foi a criação da "nuvem" - um meio de terceirizar o serviço de computação. O conteúdo dos usuários passaram a ser armazenados nesta "rede aérea" nos serviços oferecidos mais diversos (FlickR, Gmail, Dropbox, Evernote, Amazon, etc). A despeito das preocupações com segurança, uma infinidade de 
aplicativos nesta "faixa" da Internet se popularizaram e continuam sendo criados, atendendo as necessidades mais diversas (RADFAHRER, 2012).

Finalmente, na década de 2010, estamos no limiar da chamada Quarta Revolução Industrial com as novas tecnologias se desenvolvendo nas áreas de inteligência artificial, robôs eficientes, impressão 3D, realidade virtual, aplicações da nanotecnologia e da chamada "internet das coisas". Esta última aplicada a todo tipo de equipamento que contenha um sensor ou microchip que informe quando o produto for usado ou tiver acabado. Será possível, por exemplo, obter tradução instantânea em qualquer língua em suportes eletrônicos variados ou uma geladeira informar seu supermercado que itens acabaram e precisam de reposição. Essa conexão eletrônica entre produto e fabricante alterará a cadeia de logística, melhorará a compreensão do fabricante sobre os gostos e necessidades de seu consumidor e mais adiante a sofisticação da automação na chamada Industria 4.0 com a integração entre produção e sistema de análise de dados (ROMEDER, 2015).

A Quarta Revolução Industrial se refere a fusão das tecnologias ao longo dos mundos físico, digital e biológico que está criando capacidades e impactos drásticos inteiramente novos nos sistemas político, social e econômico. A velocidade, escala e natureza sistêmica dessa transformação tem o potencial de perturbar todos os setores e chamar atenção para a questão da essência da natureza e identidade humana. A proposta do nosso Encontro este ano é construir uma compreensão mútua desta mudança, que é essencial se nós queremos moldar nosso futuro coletivo de um modo que reflita no final que o ser humano deve estar no centro", afirma o professor Schwab. (MATHUROS, 2016

O princípio básico é que conectar máquinas, serviços, sistemas e negócios estão criando redes inteligentes em torno de toda a cadeia produtiva, de modo a poder controlar uma a outra autonomamente. Os três fatores-chave das mudanças causada pela Quarta Revolução Industrial em curso são físicos, digitais e biológicos. Na Física, temos novas descobertas com o grafeno (substância mais forte que o aço), robôs com inteligência artificial mais avançados, além de veículos aeroespaciais e automóveis que se locomovem autonomamente. Na Biotecnologia, há operações de edição genética, barateamento da sequência genômica, melhorias neurotecnológicas para o cérebro e avanços na medicina, como os estudos para o retardo do envelhecimento. As mudanças digitais implicam novos modelos de comunicação e negócios, criação de mais serviços descentralizados, controles automáticos de logística e produtividade contínua (SCHWAB, 2016). 
O desafio é como transformar a democracia no caminho dessas mudanças. As assimetrias continuarão com a criação de uma nova divisão internacional do trabalho, com alguns países sendo ainda mais capazes de gerir tecnologia de ponta com melhora de renda e qualidade de emprego, em detrimento do atraso dos demais países. O processo inclui o aumento da desigualdade entre os trabalhadores mais qualificados, com maiores oportunidades e salários, enquanto os demais ficarão restritos a empregos com menor remuneração e estabilidade.

Ao contrário de Eisner, Bob Iger sabia que a Disney não podia virar as costas para a tecnologia. E esse é um ponto chave para compreender sua gestão e como toda a produção funciona após o ano de 2005. O conselho de administração da Disney foi renovado, incorporando novos diretores com ampla experiência na indústria da tecnologia. John S. Chen, diretor do conselho da Disney desde 2004, é presidente (CEO) da BlackBerry. Desde 2010 no conselho, Sheryl Sandberg, é presidente (COO) ou a número 2 do Facebook, tendo passagem anterior pelo Google. Segundo esta última, referindo-se às grandes possibilidades das duas áreas: "Há muitas companhias que se focam em conteúdo e muitas outras em tecnologia, mas penso que Disney é uma das poucas que fazem ambas igualmente" (LEV-RAM, 2015, p. 51).

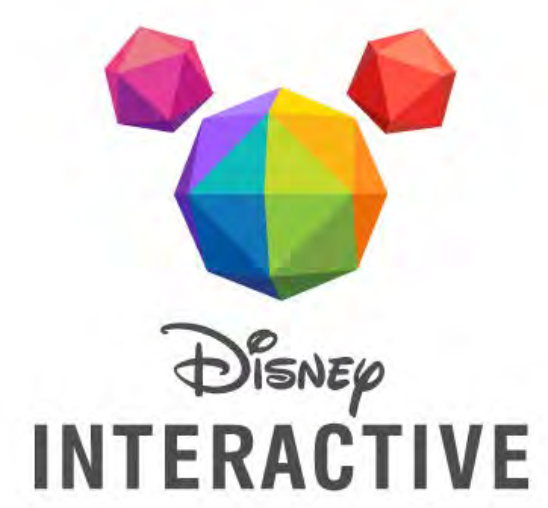

Figura 197 - Logomarca da Disney Interactive. 

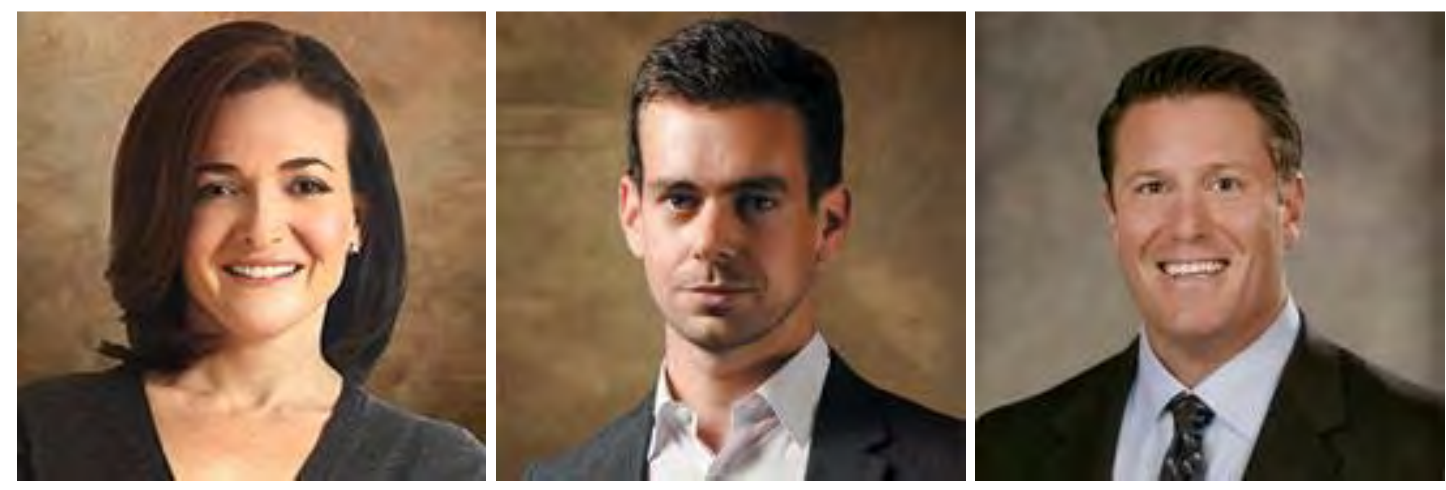

Figuras 198, 199 e 200: - Sheryl Sandberg, Jack Dorsey e Kevin Mayer (Fonte: Disney Corporate)

Jack Dorsey, diretor desde 2013, é fundador e ex presidente do conselho do Twitter, Inc e desenvolvedor da Square, Inc (provedora de serviços de pagamento). Kevin Mayer, executivo que começou na Disney em 1993 como executivo de planejamento estratégico e com experiência nas áreas Interativa e Internet, foi vice-presidente executivo da divisão de Internet (responsável pelas operações e gestão dos websites mais populares, incluindo ESPN.com e ABCNews.com). No início de 2016,Mayer está em um novo cargo, criado em junho de 2015 - Chief Strategy Officer coordenando desenvolvimento dos negócios, tecnologia de informação para a corporação, gerenciamento de marcas e franquias, aquisições e alianças corporativas globais.

A decisão de criar uma chefia de tecnologia (CTO ou Chief Technology Officer) parece ser uma precaução ainda maior vindo de um presidente como Iger, que praticamente agia como um, afinal as corporações de mídia precisam pensar como corporações de tecnologia. Estúdios, parques temáticos, televisão, games, licenciamento, cada um tem seu próprio chefe de tecnologia. Eles se reúnem periodicamente para discutir desafios, tentar prever o futuro e estabelecer estratégias.

Não é surpresa, portanto, que uma das áreas mais focadas seja a da Disney Interactive (criada em 2008), responsável por criar experiências de alta qualidade em vídeo games multi-plataforma, vídeos de curta duração, games sociais e destinações digitais em atuais e futuros suportes de mídia. A palavra "experiência" não deve ser ignorada. Ela está no cerne da retórica Disney para justificar seus investimentos em criação. A Disney investe milhões anualmente, desde 2014, no programa Disney Accelerator ${ }^{41}$, convidando start-ups a serem supervisionadas por mentores. O propósito é o desenvolvimento de produtos e serviços que resultem em novas ideias de experiência, que transformem o entretenimento e a mídia. Seja uma experiência interativa com animação, serviços interativos nos parques temáticos ou produtos que agreguem valor às marcas da Disney, o programa

\footnotetext{
${ }^{41}$ http://disneyaccelerator.com/. Acesso em 28 jan. 2016.
} 
tem tido bons resultados. O robô BB-8 do novo filme "Star Wars: O Despertar da Força" foi desenvolvido em 2014 pela start-up Sphero Uma versão em brinquedo controlada via smartphone foi o suficiente para que a "nova experiência" fosse aproveitada pela Disney.

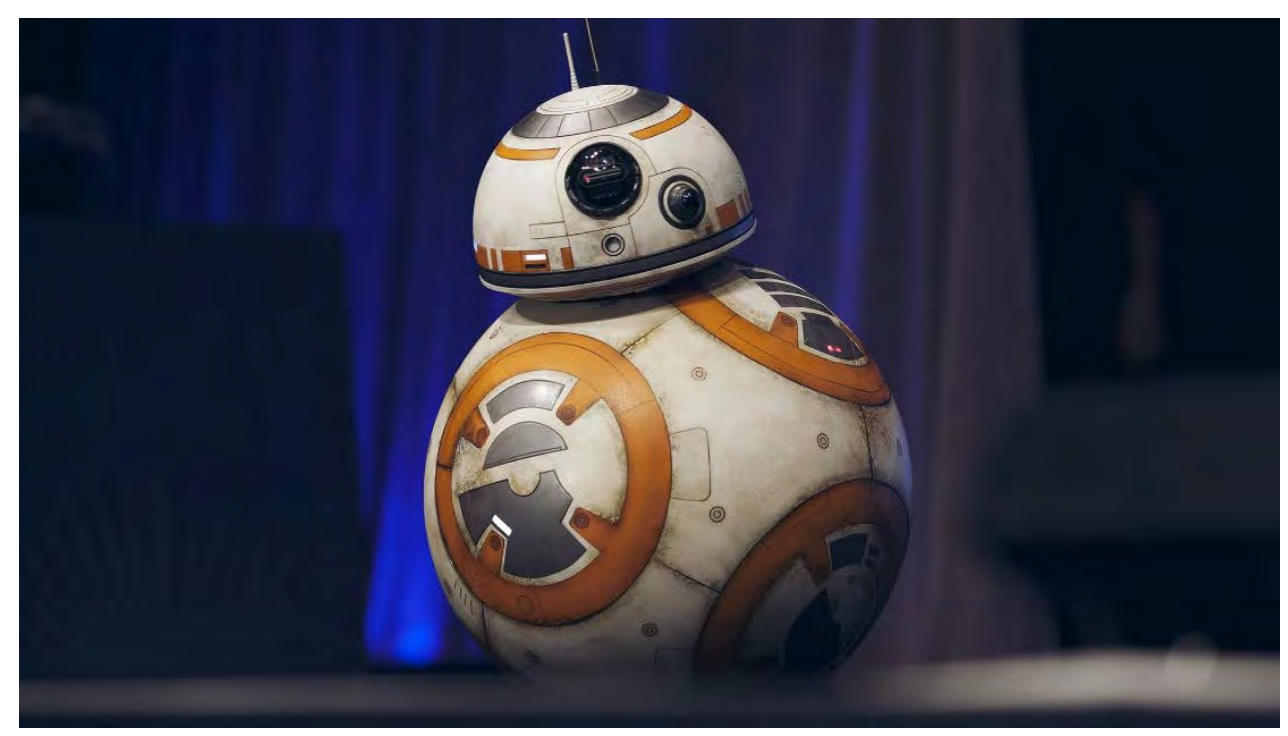

Figura 201 - O robô BB-8 da saga "Star Wars”, criado em parceria com a empresa start-up Sphero.

Estimulada pela indústria de games, a Disney investe US\$ 65 milhões em tecnologia de realidade virtual para adaptar conteúdo antigo, criar novas experiências em transmissões esportivas e possibilitar que cineastas filmem conteúdos com imagens em altíssima definição e capacidade de imersão (semelhante à câmera desenvolvida por James Cameron no filme 3D “Avatar” (2010)) e nos flixels, tecnologia para uso de múltiplos drones com projetores de imagens em espetáculos nos parques temáticos.

A “experiência" também foi a justificativa por trás do projeto Disney NextGen, baseado na Big Data. A tecnologia fez com que os dados puros deixassem de ser estáticos e banais. Eles são agora um recurso para os negócios e são usados para produzir valor econômico. Isso só foi possível com a criação de novas tecnologias de processamento para calcular um volume gigantesco de informação para análise de dados. É usado em serviços teoricamente banais, como corretores ortográficos e filtros anti-spam nos e-mails, porém é devido a essa análise que a Amazon consegue vender mais livros, que o Netflix investe em seriados originais, que o Youtube recompensa usuários 
produtores de vídeo e mídias sociais consegue encontrar amigos distantes. Há uma mudança nas relações de interação baseada no fornecimento e posterior análise da informação:

Em essência, big data relaciona-se com previsões. Apesar de ser descrito como um ramo da ciência da computação chamado inteligência artificial e, mais especificamente, uma área chamada "aprendizado de máquina", esta ideia é enganosa. Big data não tem a ver com tentar "ensinar" um computador a "pensar" como ser humano. Ao contrário, trata-se de aplicar a matemática a enormes quantidades de dados a fim de prever probabilidades: a chance de um e-mail ser spam; de as letras "mas" na verdade significarem "mais"; de a trajetória e velocidade de uma pessoa que atravesse a rua significarem que ela a atravessará no tempo - o carro com piloto automático precisa reduzir apenas um pouco a velocidade. O segredo é que esses sistemas funcionam porque são alimentados por enormes quantidades, que formam a base das previsões. Além disso, os sistemas são criados para se aperfeiçoarem com o tempo, ao continuamente analisar os melhores sinais e padrões a fim de encontrar mais dados para uso" (MAYER-SCHÖNBERGER, CUKIER, 2013, p.8)

Em resumo, muitos dos aspectos do nosso mundo, sujeitos apenas à visão humana, serão complementados ou substituídos por sistemas computadorizados. Livrarias recomendando livros que você clicou mas não comprou, Google ranqueando os sites mais relevantes, Facebook exibindo notícias a partir de nossos gostos, etc. O serviço Netflix, por exemplo, exibiu com sucesso o seriado "House of Cards". Trata-se de uma refilmagem de uma série britânica dos anos 1990, disponível no próprio acervo. A partir da análise dos dados, a empresa pôde observar os hábitos de seus usuários, como descobrir que fãs da série assistiam a filmes com o ator Kevin Spacey. Os dados também mostravam que esses espectadores eram fãs do diretor David Fincher. O Netflix, interpretando esses dados, convidou o ator e o diretor e investiu no novo "House of Cards" (2013), um dos maiores sucessos de audiência na Internet (LITTLETON, 2016).

Uma grande aposta foi adaptar a tecnologia RFID (Radio-Frequency IDentification) ou Identificação por Radiofrequência para criar o programa Disney NextGen (Next Generation). Tratase de um programa bilionário iniciado em 2011 cujos testes se iniciaram em 2013 e atualmente encontra-se em operação nos parques temáticos do Walt Disney World (Orlando, Flórida). Todos os visitantes recebem ou podem adquirir uma pulseira chamada MagicBands (pulseiras mágicas) Figura 202. Trata-se de um sistema inteligente que combina radiofrequência e convergência com aplicativos utilizados em celulares smartphones e tablets. O novo sistema concentra todos os serviços 
já existentes, prometendo maior eficiência no serviço - como, por exemplo, os cartões que servem como chave nos hotéis, os tickets dos parques temáticos, a reserva do almoço ou jantar (podendo pedir os seus pratos com antecedência, tornando o serviço dos restaurantes mais eficiente), o Fast Pass (ou fura-fila das atrações), o PhotoPass (serviço de fotógrafo profissional que lhe envia posteriormente as fotos feitas durante a visita). A pulseira também serve como cartão de crédito.

Alguns dos serviços, porém, têm intuitos mais estratégicos do que a Disney promove. O próprio Fast Pass é promovido como um serviço gratuito em que os visitantes retiravam um cartão que lhes dava direito a retornar e visitar uma atração em outro horário, enfrentando uma fila muito menor ou inexistente. Porém, extraoficialmente, registra-se que o intuito é logístico. Ao invés de deixar milhares de pessoas horas na fila, é melhor fornecer um passe posterior que dá aos visitantes a oportunidade de perambular, consumindo mais produtos, alimentos e visitando atrações menos concorridas.

A convergência com tablets e celulares smartphone é outra inovação. Não somente os parques Disney estão fornecendo acesso wi-fi gratuito (esta abertura ao "mundo exterior" é algo novo após décadas do pensamento isolacionista de que os visitantes precisam estar focados no ambiente que visitam), como há um incentivo ao cadastramento de hóspedes e visitantes no aplicativo My Magic Experience, onde é possível agendar jantares, marcar encontros com personagens, verificar horários de funcionamento e duração de filas, etc. Este processo interativo parece vir ao encontro de inovações de gamification - uma tentativa de usar as estratégias interativas dos games na vida real (McGONIGAL, 2012.

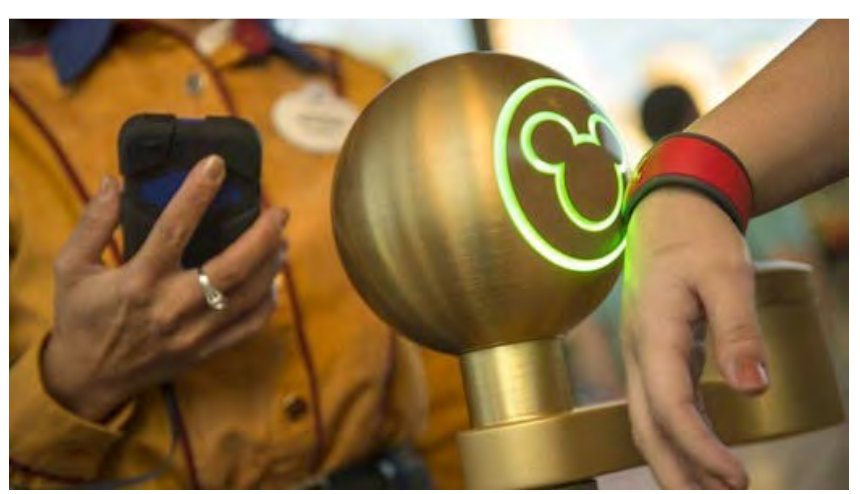

Figura 202 - As pulseiras mágicas do projeto Disney NexGen. 
O que um projeto aparentemente confinado em hotéis e parques temáticos pode contribuir para a produção cultural? Há duas questões-chave que merecem atenção. A primeira, uma questão ética sobre o uso das informações - trata-se da criação de um banco de dados e do controle da informação. Seria possível levantar o quanto um determinado grupo de turistas gasta em produtos, o que ele mais aprecia, qual seu almoço preferido, quais atrações lhe atrai mais, etc. $\mathrm{O}$ sistema inteligente pode verificar que uma família agendou a visita em uma determinada atração, porém ainda está em seu hotel e não chegará a tempo. Portanto, pode liberar a entrada a outras pessoas. O projeto chegou a ser discutido no Congresso americano por conta da legislação que proíbe a coleta e o uso de informações de menores de 13 anos, o que resultou em intenso debate ético:

Em uma era em que mecanismos de segurança constantes passam a ser quase despercebidos pelas pessoas, o cotidiano nos transforma em "servos voluntários" de uma vigilância invisível, mas que nos vê. Ela está diluída na internet, mídias sociais e fiscalização digital (BAUMAN, 2014).

A Disney constantemente revisa sua política de privacidade e modificou pontos polêmicos, a fim de preservar informações pessoais.

Esse controle da informação baseado na coleta "gratuita" de dados significa um grande poder para as empresas detentoras, que possuam capacidade de interpretá-los para aplicação em projetos. Facebook e YouTube são dois bons exemplos. O professor Robert Darnton (2012) analisou essa questão da proteção de dados, alertando sobre os riscos do domínio do conhecimento por única empresa. O Google se ofereceu para digitalizar gratuitamente não só todo o acervo de 17 milhões de livros da Biblioteca da Universidade Harvard, mas de outras grandes bibliotecas públicas americanas. A Google entregaria uma cópia digitalizada do acervo, em troca de poder explorar comercialmente os títulos. Harvard queria a democratização do conhecimento com acesso gratuito aos livros. Google queria cobrar para o acesso do banco de dados da biblioteca. O preço? O Google também decidiria. Seria a comercialização de um acervo construído com muito custo desde 1638. Os livros em domínio público não tinham problema, porém Darnton se recusou a disponibilizar os livros protegidos por direitos autorais. Harvard decidiu apostar num projeto de Biblioteca Pública Digital da América, bancada por uma coalização de pessoas na tentativa de criar um território comum de cultura. 
A segunda questão em relação à MagicBand é justamente a influência ou o impacto de um projeto como este no campo da produção cultural. A partir do momento que um banco de dados coleta informações de milhões de consumidores, é plausível acreditar que os algoritmos possam ser utilizados para definir quais personagens, histórias, aventuras estejam no gosto daquele público. O consumo passa a influir ainda mais na produção. O que já ocorre por meio das pesquisas tradicionais de mercado, avaliando se determinado projeto tem atratividade local ou de abrangência mundial e seus potenciais lucrativos, poderá ganhar uma dinâmica diferente com base nas informações de dezenas de milhões de visitantes anuais dos parques temáticos, especialmente o Walt Disney World, que recebe turistas do mundo todo.

E, como não poderia deixar de ocorrer num mundo em constantes mudanças tecnológicas, a Disney não deve expandir as pulseiras mágicas para os parques temáticos fora da Flórida. A Disneylândia de Xangai, com inauguração em junho de 2016, usará um sistema aprimorado a partir dos smartphones, economizando a fabricação e envio de pulseiras (PALMIERI, 2016).

\subsection{Estratégias: A Cauda Longa e o Blockbuster}

A produção não está isolada das outras fases mercadológicas, como o marketing, a distribuição e o consumo. Parece-nos importante analisarmos o que há de novo e o que influi diretamente nas mudanças dos processos de produção. Comecemos com o marketing, que cada vez mais interfere nas decisões do que é ou não produzido e como isso é efetuado. Raymond Williams enfatiza o papel influenciador da publicidade e das comunicações:

Uma característica fundamental de nossa sociedade é uma coexistência pacífica entre uma nova tecnologia e formas sociais bastante antigas. A publicidade é a expressão mais visível dessa combinação. Em suas formas contemporâneas principais, ela é o resultado de um fracasso para encontrar meios de decisão social em questões de produção e distribuição relevantes para uma economia de larga escala e em crescente integração. (WILLIAMS, 2005, p. 260)

Assim, podemos dizer, a grosso modo, que a publicidade e o marketing exercem pesada influência no poder decisório por trás do que é produzido e lançado pela indústria em geral e, no caso 
específico, do entretenimento. Em um período em que observamos tantas novidades tecnológicas, redução da velocidade nas ações cotidianas e transformações no comércio, o consumidor tem a sua disposição uma infinidade de produtos a um clique de acesso. E ainda há a concorrência entre suportes midiáticos - hoje uma telenovela ou um jogo de futebol não concorrem diretamente com a programação da emissora concorrente, e, sim, com a internet, o celular, o cinema, os canais por assinatura, etc. O marketing, portanto, tenta buscar um caminho nesse oceano de possibilidades. Há pelo menos duas teorias principais em relação ao marketing de produtos culturais e uma análise delas resulta em um melhor entendimento de como as novas produções são feitas.

A tese mais popular na última década é a baseada nos mercados de nicho - a popularmente conhecida como teoria da "cauda longa". Ela foi proposta a partir de um artigo escrito pelo editor da revista Wired por Chris Anderson, e se transformou em um livro de grande sucesso. A teoria da cauda longa pode ser resumida da seguinte forma:

Nossa cultura e nossa economia estão cada vez mais se afastando do foco em alguns hits relativamente pouco numerosos (produtos e mercados da tendência dominante), no topo da curva da demanda, e avançando em direção a uma grande quantidade de nichos na parte inferior ou na cauda da curva de demanda. Numa era sem as limitações do espaço físico nas prateleiras e de outros pontos de estrangulamento da distribuição, bens e serviços com alvos estreitos podem ser tão atraentes em termos econômicos quanto os destinados ao grande público. Mas isso não é o suficiente. A demanda deve seguir a nova oferta. [...] A cauda longa começa com um milhão de nichos, mas apenas isso não é significativo, até que eles sejam procurados por pessoas que os almejam (ANDERSON, 2006, p. 50).

Podemos resumir a teoria, de outra forma, em dois pontos. O primeiro é que uma grande variedade de produtos está à disposição porque, quando não é necessário estocá-los fisicamente nas lojas, os custos de operação desaparecem. Ferramentas eletrônicas de busca e recomendação selecionam um recorte para que os consumidores online, sufocados, possam comprar. Produtos que podem ser digitalizados, caso da música, vídeo e informação passam a ter um custo de distribuição quase nulo, ampliando o tamanho da cauda (Figura 203).

O segundo ponto é que o autor defende que os canais online alteram a forma da curva de demanda, ou seja, os consumidores passariam a não se direcionar propriamente aos produtos de massa 
(os hits ou sucessos), transferindo seu consumo para produtos restritos aos seus interesses pessoais. Por esta visão, a cauda longa não seria apenas mais longa pela intensa variedade de produtos, mas ela tenderia a engrossar porque esse público descobriria e consumiria mais produtos de acordo com os seus gostos particulares. A soma dessa variedade de produtos de nicho, que provavelmente não venderia ou não encontraria espaço em uma grande loja física, poderia trazer um faturamento maior que a soma dos hits, os produtos que geralmente são vendidos para um número maior de consumidores.

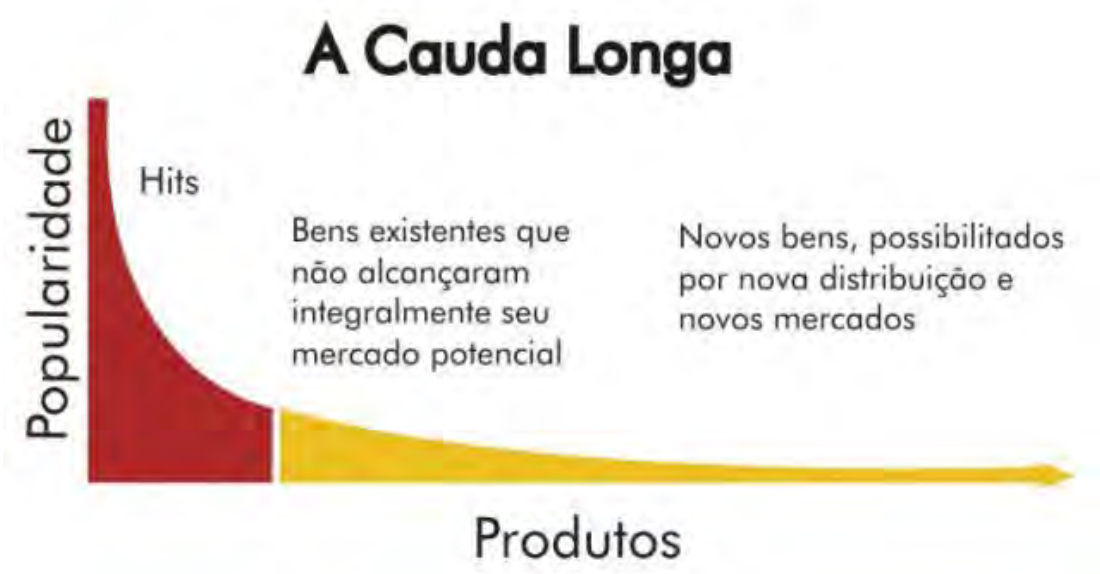

Figura 203: Gráfico da Cauda Longa.

Chris Anderson resume os principais temas da cauda longa, afirmando que

há muito mais nichos do que hits [...], os custos para atingir esses nichos estão caindo drasticamente [...]. Assim, em muitos mercados, agora é possível oferecer muito maior variedade de produtos. [...] Um vasto espectro de ferramentas e técnicas como recomendações e classificações - são eficazes para esse propósito. Tais "filtros" são capazes de impulsionar a demanda ao longo da Cauda. [...] A curva de demanda se torna mais horizontal e mais longa [...] são tantos os produtos de nicho que, como um todo, podem compor um mercado capaz de rivalizar com os hits. [...] A cauda longa nada mais é do que a cultura sem os filtros da escassez econômica (ANDERSON, 2006, p. 51).

Esta teoria é interessante porque a Disney, e todas as suas concorrentes, se aproveitaram da ideia do mercado de nicho. Os anos 1990 e 2000 foram ricos em alta diversificação, ampliação de marcas (brands) e tentativas de venda de produtos customizados e estratificados. Muitos projetos não deram o resultado esperado, mas outros, como 
disponibilizar filmes, séries e músicas no iTunes ou investir em plataformas de streaming de vídeo como o Hulu (uma espécie de YouTube dos estúdios) apresentaram resultados interessantes.

Isso não significa que os hits, as grandes e caras produções que apelam a massa sejam dispensáveis. Anderson defende que a cultura dos blockbusters (arrasa-quarteirões) está em decadência, mas ela ainda é importante para orientar a indústria da mídia e do entretenimento. Por sua visão, os estúdios de Hollywood adotam a postura de investir alto em diretores, atores e técnicos de sucesso para trazer uma certa previsibilidade a um negócio imprevisível. O hit não é sinônimo de "bom gosto" e sim de previsibilidade (o protagonista nunca morre, o final é sempre feliz, quanto mais efeitos especiais melhor, etc). Mas mesmo quando esses grandes talentos produzem fiascos, os estúdios (gravadoras, editoras, etc) se salvam por adotarem uma abordagem de portfólio para reduzir seus riscos:

Como os capitalistas de risco, diversificam suas apostas entre vários projetos, investindo em cada um apenas o suficiente para dar-lhe alguma chance na luta pelo sucesso e torcem para que, na melhor das hipóteses, a maioria dos projetos atinja o ponto de equilíbrio e apenas uns poucos sejam fracassos. Isso significa que as exceções que se transformarem em sucesso compensarão a mediocridade dos outros. (ANDERSON, 2006, p. 37).

Essa teoria da previsibilidade alçada ao sucesso comprova que todo produto cultural deve necessariamente passar pelo teste econômico para sobreviver. E essa mentalidade de hits significaria que a história do entretenimento é escrita pelos blockbusters, cuja medida é aferida pelos resultados das bilheterias. Esta dinâmica seria replicada nas bancas de jornal, nas livrarias, nas lojas, nos supermercados, etc. Portanto, pela teoria da cauda longa teríamos uma democratização das formas de produção.

A teoria da cauda longa, ainda que extremamente popular, não é unanimidade. Há uma outra corrente do marketing que defende que a cultura dos hits permanece inabalável e fornece elementos concretos para justificar seus altos investimentos, na esperança de lucros bilionários. Esta corrente de pensamento é representada pelo livro "The Winner-Take-All Society" dos economistas Phillip Cook e Robert Frank (1995). A obra foi inspirada por um artigo anterior de Sherwin Rosen, publicado em 
1981, intitulado "The Economics of Superstars", que analisa o efeito das super estrelas do show business - em que os talentos que representam o topo em seu campo de atuação cada vez mais se distanciam de talentos menores.

O livro de Cook e Frank parte da premissa das transformações que ocorrem rapidamente na década de 1990, dentre as quais se destacam os seguintes aspectos: novas tecnologias, como a criação de canais de distribuição nacionais que permitem que um indivíduo entre no mercado (um artista que antes ficaria limitado a um público local de sua cidade, agora pode gravar um CD e vendê-lo nacionalmente); a queda nos custos de transporte relativos a certos produtos (CDs, por exemplo, são mais leves que gravações em vinil para o transporte); limitação de espaço mental, em que memorizamos somente poucas coisas que gostaríamos de consumir em relação à vastidão de produtos disponíveis; enfraquecimento de regulações e da sociedade civil - anteriormente com maior regulamentação era possível limitar os mercados hegemônicos, que agora possuem mais liberdade com a demanda de preços altos; e o processo de reiteração do feedback positivo (ou, em outras palavras, "o sucesso gera sucesso") em que a propaganda "boca-a-boca" força um ciclo virtuoso que reforça o poder dos talentos que já estão no topo em seu campo de trabalho.

Tendo essas premissas como base, os autores destacam três pontos importantes. O primeiro, é que talentos menores não substituem grandes talentos, ou seja, num mercado competitivo, ninguém vai consumir o "segundo melhor" produto de qualquer indústria se tiver acesso e puder consumir o "primeiro". O segundo ponto é que as pessoas são inerentemente sociais, aumentando o valor dos produtos culturais consumidos por outras pessoas. E o terceiro ponto defende que, quando o custo marginal de reproduzir e distribuir um produto é baixo (como no caso da digitalização de produtos antes físicos), a vantagem do valor de venda de um vendedor é enorme (ELBERSE, 2008).

A professora da Harvard University, Anita Elberse (2013), segue esta linha de pensamento e a reforçou no livro "Blockbusters", em que estuda o fenômeno dos hits, no caso os blockbusters ou tent poles. A partir de estudos de casos referentes ao mundo do cinema, dos esportes, da música e da moda, a autora procura desmistificar ou encontrar brechas na teoria da cauda longa, em busca de uma prova de que os blockbusters ainda se mantêm a melhor estratégia para a produção cultural. Ela afirma que: 
Há diversas teorias sobre os motivos da indústria do entretenimento ser organizada do modo que é, e como poderia ser melhor. E com o advento da tecnologia digital que torna possível para virtualmente todas as pessoas se tornarem produtores de conteúdo e compartilhadores de suas criações com o mundo, existe muita especulação sobre como o ambiente do entretenimento pode mudar, para melhor ou para pior: a "velha mídia" está morta, alguns dizem. Estúdios aprenderão a parar de apostar alto em projetos dispendiosos e supervalorizar financeiramente os atores, e ao invés disso apostarão em "tiros no alvo" com ideias mais baratas. Músicos estarão livres das algemas das gravadoras. As ligas esportivas não precisarão mais de canais como a ESPN e irão diretamente aos consumidores via Web. Uma vez os consumidores se tornando hábeis a consumir qualquer coisa que desejam, eles irão se distanciar dos hits (grandes sucessos). Ou eles irão optar pelo denominador comum mais baixo de conteúdo, arruinando nossa cultura. Pagar por conteúdo é antiquado - gratuito é o futuro. E a lista continua. (ELBERSE, 2013, p. 5, tradução nossa)

É importante ressaltarmos que a autora não faz julgamento de gosto, se um produto é bom ou ruim, ou mesmo questiona as decisões criativas. O foco é explicar "como o mercado de entretenimento funciona do modo que é, e quais estratégias ajudarão a construir negócios duráveis. O tipo de negócio, em outras palavras, que entrega os tipos de produtos que um vasto número de pessoas aprecia" (ELBERSE, 2013, p. 7).

Nesse sentido, Elberse menciona duas questões-chave.

Em primeiro lugar, ela defende que o aumento da distribuição dos canais online sinaliza que logo as "velhas" regras do negócio do entretenimento não serão mais aplicáveis. Neste caso, está em jogo a popularização de negócios como o YouTube e a dúvida se eles são uma saída para democratização do conteúdo e distribuição - conceito defendido por Swingewood (1978). Para a autora, a resposta simplista seria "sim"; porém, um olhar mais cauteloso revela que a realidade não seria tão simples. Um negócio como o Netflix, que vende a transmissão em streaming de filmes e seriados novos e antigos, obteve um de seus maiores retornos comerciais e de prestígio investindo pesado em uma série exclusiva, "House of Cards"; o site Hulu (projeto iniciado pela rede NBC) transmite produção de vídeo promocional com ganhos maiores a seus realizadores; e a Metropolitan Opera está transmitindo seus espetáculos em salas de cinema ao redor do mundo. "Uma lição crítica 
aqui se torna clara: blockbusters se tornarão mais - não menos - relevantes para a cultura popular, e a estratégia dos blockbusters irá prosperar" (ELBERSE, 2013, p.11).

A segunda questão envolve a emergência dos canais online e se eles irão finalmente enfraquecer o papel dos produtos e distribuidores de conteúdo tradicionais já estabelecidos. Apesar do grande alcance e da facilidade da produção e distribuição online, Elberse afirma que é difícil que talentos dessa produção cultural prosperem num modelo que depende apenas de exibição online (YouTube, por exemplo) e fãs em redes sociais (Facebook, Twitter, entre outros). Assim,

Com as tecnologias digitais se tornando cada vez mais sofisticadas e onipresentes, os talentos criativos perseguirão a oportunidade de promover suas criações diretamente aos consumidores? Se positivo, significaria que o fim de muitas empresas de entretenimento estabelecidas estaria próximo. Entretanto, de acordo com a pesquisa, esse cenário extremo é improvável: é virtualmente impossível para a maioria das pessoas criativas prosperar sem os benefícios que essas empresas fornecem. Mesmo assim, a produção "faça-você-mesmo" e a distribuição aumentam os problemas críticos para até mesmo as maiores corporações de entretenimento (ELBERSE, 2013, p. 12).

A "estratégia Blockbuster", reforçada por Elberse numa tentativa de questionar a teoria da "Cauda Longa" de Chris Anderson, descreve que os grandes filmes-evento (tent poles ou blockbusters) possuem um custo maior de produção, requerem um custo maior de divulgação, mas o levantamento feito por ela demonstra que o retorno financeiro deles é proporcionalmente muito maior do que produções de baixo-custo (e de nicho) que possuem pouca ou nenhuma divulgação - cujo retorno financeiro resulta em empate de custos ou pequena margem de lucro (Figura 204). 


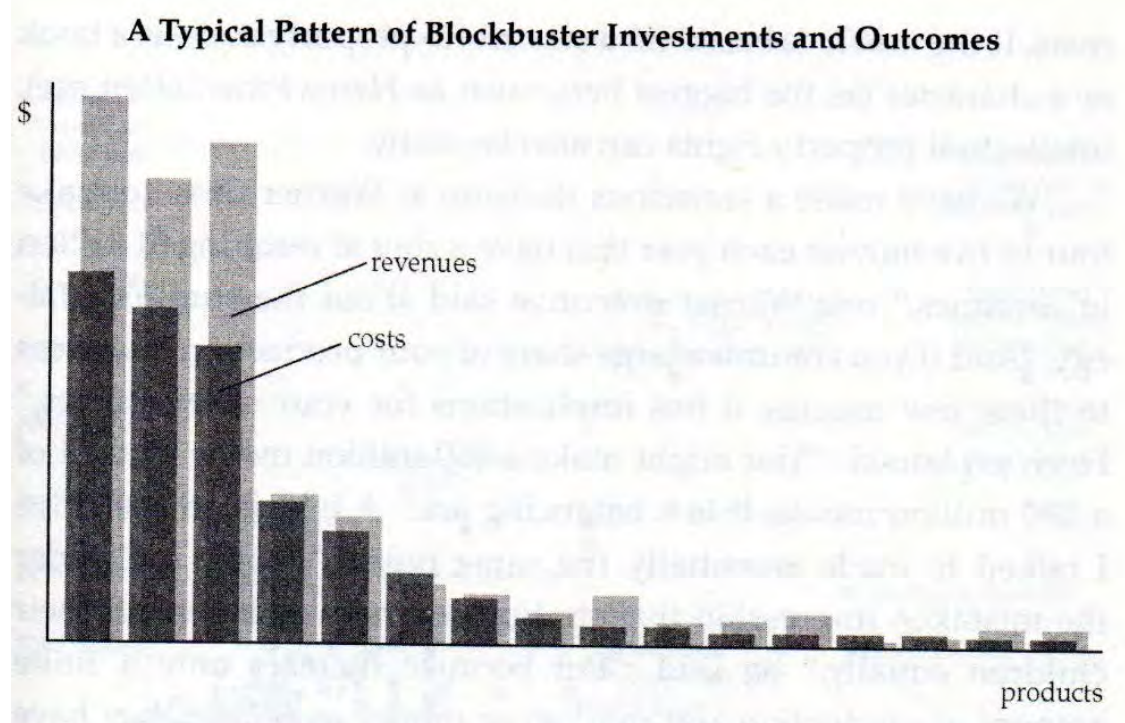

Figura 204 - Gráfico demonstra que custos maiores de produção e marketing resultam em retorno financeiro maior no caso de blockbusters (ELBERSE, 2013, p.19).

Analisando de outra forma: estúdios, editoras e produtoras em geral obteriam melhores resultados apostando alto em menos produções do que pouco em muitas. Há um risco envolvido - a própria Disney arcou com prejuízo de mais de US\$ 200 milhões no fiasco cinematográfico "John Carter: Entre dois Mundos" (2012), filme com orçamento de US\$ 306,6 milhões (SYLT, 2014), o que prova que a teoria está longe de ser infalível. Porém, a autora ouviu do executivo Alan Horn, então presidente dos estúdios Warner, que pesquisas demonstravam que as pessoas iam cinco ou seis vezes ao cinema por ano, em média. No mercado internacional esse índice é menor. Então a estratégia da Warner foi apostar alto em produção e marketing de filmes com alto potencial de retorno - em geral produtos oriundos de sucessos literários como Harry Potter ou franquias baseadas em quadrinhos de super-heróis como Batman, Lanterna Verde, ou mesmo continuações de filmes "menores" que (tendo conquistado sucesso) depois teriam tratamento de "grande produção" - caso do filme "Se Beber, não case" (2009).

O executivo Alan Horn defende que essa estratégia de apostar alto em grande elenco, efeitos especiais, grandes equipes e propriedades culturais (livros, gibis e games) já testadas garantiram mais sucesso na Warner durante o período dele como presidente (ELBERSE, 2009, p. 38). Fica nítido na análise que a estratégia do blockbuster afeta de forma tirânica as prioridades da produção cultural leia-se o que será aprovado, como será feito e quem estará envolvido. E por que este estudo de caso 
é importante? Alan Horn atualmente é presidente dos estúdios Disney e está aplicando a estratégia aqui descrita, ao fazer uso de grandes propriedades como Marvel, Lucasfilm e Pixar.

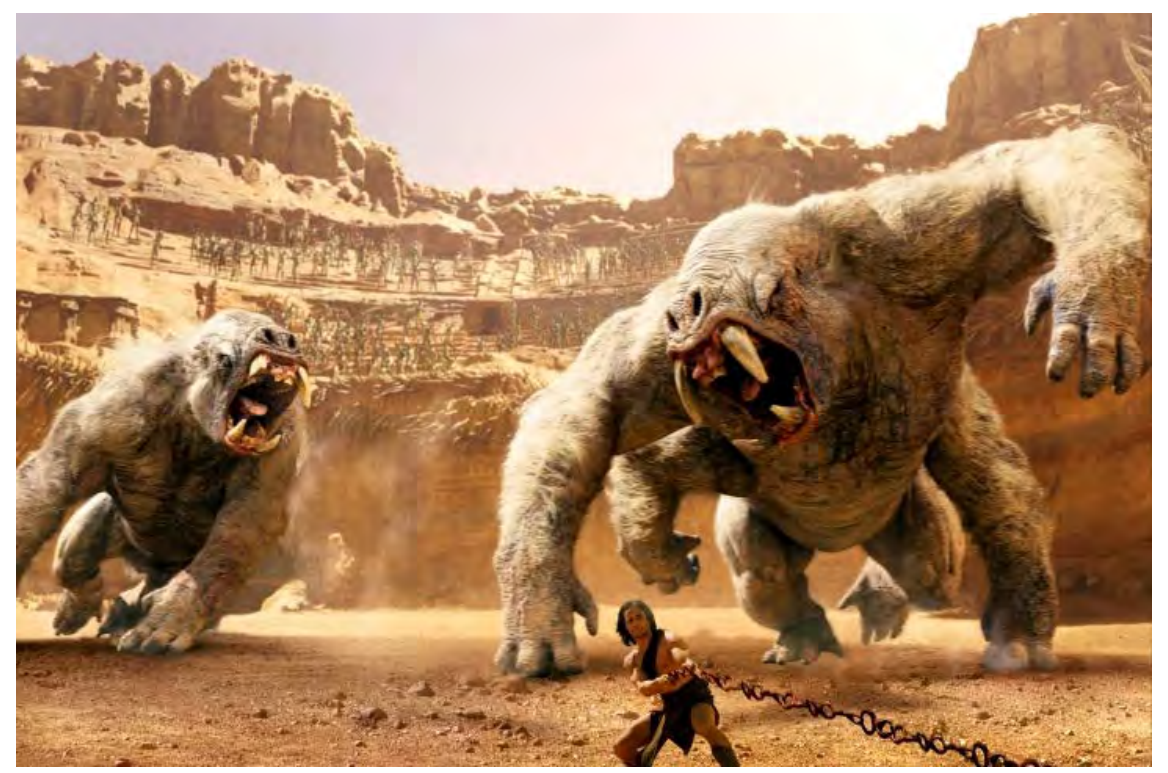

Figura 205 - “John Carter: Entre Dois Mundos", um dos maiores investimentos e fracassos.

A estratégia Blockbuster, porém, possui brechas para a crítica. Não somente pelos altos riscos de qualidade, conteúdo e até mesmo financeiros aos estúdios envolvidos, mas porque não pode suplantar a teoria da cauda longa. Elberse tem como ponto-forte de seu estudo um levantamento que prova que $91 \%$ dos títulos musicais baixados comercialmente pela internet são feitos cada um menos de 100 vezes (ELBERSE, 2008). Enquanto agregados, o valor é bastante razoável. Porém, como produtos individuais, representam um investimento de produção e divulgação que não compensa pelo baixo volume consumido. A compensação só existe se os valores de custo forem muito baixos (como nos produtos digitais) e se a loja possuir um catálogo grandioso (exemplo da Amazon.com).

As lojas físicas, atualmente em declínio, não podem trabalhar com esses riscos. Se as grandes cadeias de lojas de música fecham, CDs e filmes passam a ser vendidos por "hiperlojas" com grande volume de produtos diversificados. Porém, o espaço é limitado. O estudo de Elberse indica que as lojas optam por produtos que apelem para a massa, ou seja, são os do tipo "blockbuster" que geralmente encontraremos. Os mais obscuros serão encontrados ou nas lojas menores que sobrarem ou em comércios virtuais na internet. Trata-se da inversão da "teoria da cauda longa". O que indica que a curva de demanda está sendo alterada, mas não está claro como os produtores de conteúdo (seja do mainstream ou independentes) irão se adaptar a essas novidades. 


\subsection{PIXAR}

Em minha experiência, a coisa de impacto mais significativo no orçamento de um filme - mas nunca aparece no orçamento - é a moral. Se você tem baixo autoestima para cada US $\$ 1$ investido, você recebe 25 centavos de valor. Se você tem autoestima alta, para cada US\$ 1 você recebe US\$ 3 de valor. As empresas deveriam prestar mais atenção para a moral." Brad Bird, diretor de animações "O Gigante de Ferro" e "Os Incríveis" e do filme "Missão Impossível: Protocolo Fantasma"42.

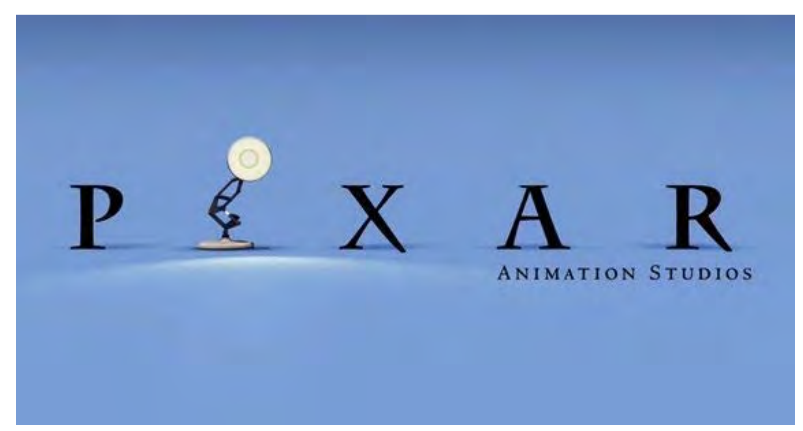

Figura 206 - Logomarca da Pixar Animation Studios.

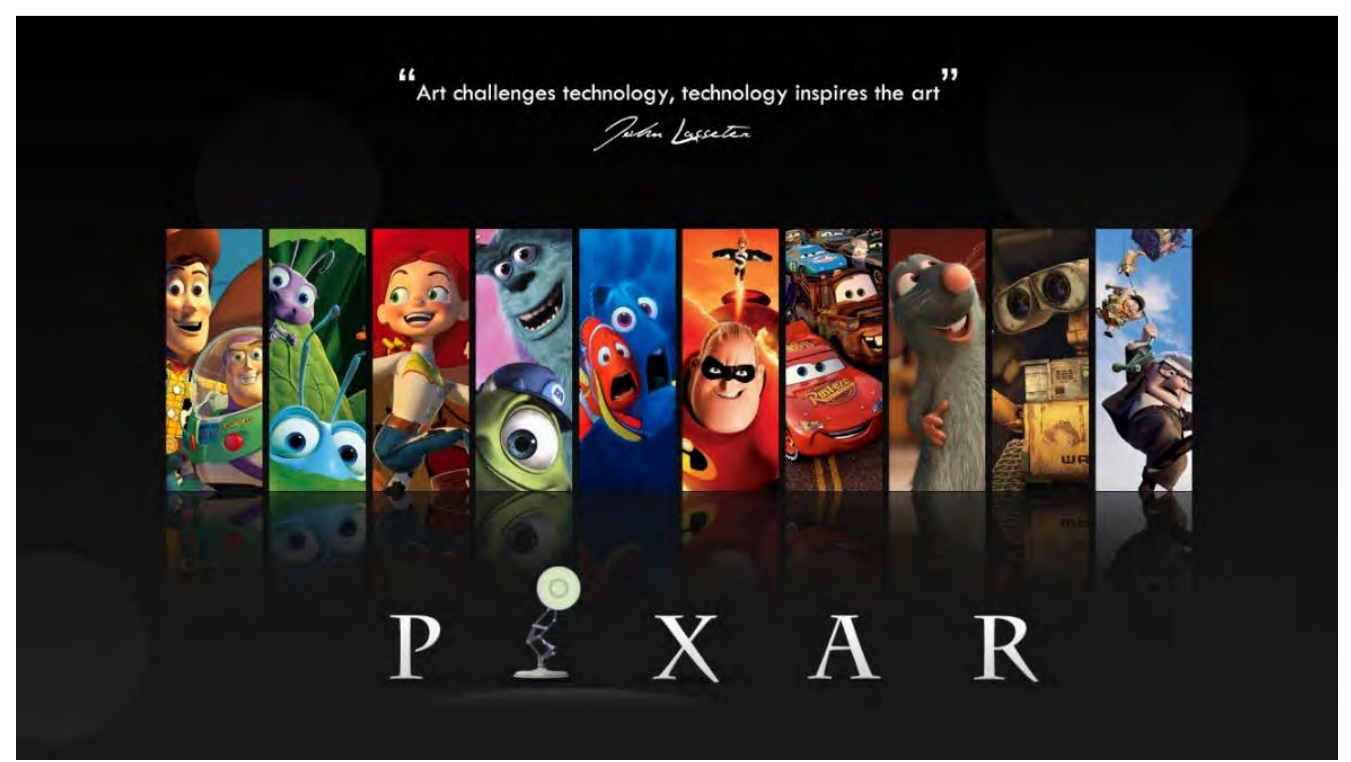

Figura 207 - Imagem do website da Pixar com a frase de Lasseter atrelando arte e tecnologia.

Michael Eisner era um executivo criativo, um homem de "conteúdos”. Foi responsável pela acelerada expansão da Disney, por sua integração vertical, e por concentrar todos os produtos

\footnotetext{
${ }^{42}$ Lembrado pelo animador e professor da USC, Tom Sito, em um post no Facebook - dezembro de 2015.
} 
criativos numa lógica em que todos sejam distribuídos por um mesmo grupo. A compra da rede ABC serviu para proteger os estúdios de forças externas e garantir a exibição de conteúdos Disney e não se lançar no negócio da distribuição. Foi infeliz ao recusar a compra dos direitos de "Harry Potter" e "O Senhor dos Anéis", além de perder a valiosa parceria com os irmãos Weinsten da produtora Miramax. Ao mesmo tempo em que a Disney se ampliava como corporação, reduzindo o foco nos estúdios, aumentava também a briga de egos, o descontentamento e a fuga de talentos. Tinha verdadeira aversão por agregar elementos externos que não pudessem ser desenvolvidos internamente, e era um negociante difícil. Não surpreende, portanto, sua dificuldade nas reuniões com Steve Jobs. Em 2005 a partir de Bob Iger, tudo passa a ser diferente, como resume Martel:

Bob Iger não é um construtor de impérios, mas um gestor. Quem construiu a multinacional foram o próprio Sr. Walt Disney e Michael Eisner, que transformou um estúdio independente e especializado, símbolo do capitalismo protestante familiar americano, em um verdadeiro conglomerado multinacional, na época da financeirização da economia. Com isso, a Disney se transformou em um verdadeiro emblema da cultura mainstream globalizada (MARTEL, 2012, p. 66).

Um passo importante foi retomar contato com Steve Jobs, cuja relação com a Disney vinha abalada nos últimos anos. As turbulências começaram quando Michael Eisner denunciou no comitê do Senado dos Estados Unidos, em fevereiro de 2002, os anúncios divulgados pela Apple promovendo o aplicativo ITunes: "Existem empresas de computadores que têm cartazes e anúncios de páginas inteira dizendo: Rip. Mix. Burn. Em outras palavras, eles podem roubar um produto e distribuí-lo para todos os amigos se comprarem esse determinado computador" (ISAACSON, 2011, p. 451). Eisner foi infeliz na declaração, pois confundia o sentido de "rip", não um ato de roubar como pensava e, sim, a ação de importar arquivos de um CD para um computador. Foi o suficiente para irritar Steve Jobs e iniciar uma série de telefonemas entre as empresas para reduzir os danos.

O confronto aberto se deu quando um e-mail de Eisner, dirigido ao Conselho de Administração da Disney, dizia que a Pixar acabaria renovando o contrato de qualquer jeito e alertava que poderia negociar o acordo em bons termos (para a Disney) depois que a Pixar concluísse a produção de "Procurando Nemo" (Finding Nemo, 2003). Eisner afirmou: “Ontem vimos pela segunda vez o novo filme da Pixar, Procurando Nemo, que será lançado em maio próximo. Será um banho de realidade para aqueles caras. É razoável, mas nem de longe se compara aos filmes anteriores. Claro 
que eles pensam que é ótimo" (ISAACSON, 2011, p. 453). O e-mail vazou para o jornal Los Angeles Times e "Procurando Nemo" se tornou a maior bilheteria da história da animação até então, com US\$ 340 milhões de faturamento na América do Norte. Foi sucesso de crítica e um campeão de vendas de DVDs, com 40 milhões de cópias vendidas.

O troco veio quando Steve Jobs propôs um acordo tão agressivo que a Disney não tinha outra opção senão rejeitá-lo: a Pixar ficaria com os direitos dos filmes e dos personagens que criasse, pagaria apenas 7,5\% à Disney pela distribuição e os dois filmes na época em produção, "Os Incríveis" e "Carros", passariam a ser regidos pelo termo do novo contrato (SCHLENDER, TZTZELI, 2015, p. 335). Somente dois dias após as indicações ao Oscar, com "Procurando Nemo" entre os filmes sortudos, Steve Jobs encerrou as negociações, publicando seca declaração na imprensa:

Após dez meses tentando acertar um acordo com a Disney, nós estamos desistindo. Nós tivemos uma grande parceria juntos - uma das mais bem sucedidas na história de Hollywood - e é uma vergonha que a Disney não participará dos sucessos futuros da Pixar. (STEWART, 2005, p. 480, tradução nossa).

A Disney, por sua vez, divulgou uma resposta conciliatória:

Nós tivemos uma fantástica parceria com a Pixar e desejamos a Steve Jobs e a maravilhosa equipe criativa lá, liderada por John Lasseter, muito sucesso no futuro. Embora nós gostaríamos continuar nossa colaboração de sucesso sob termos aceitos mutuamente, Pixar compreensivelmente escolheu caminhar por conta própria para crescer como uma companhia independente. (STEWART, 2005, p. 480, tradução nossa).

Eisner, por sua vez, montou uma equipe a toque de caixa num estúdio que chamou de Circle 7 Animation, e ameaçou começar a produzir continuações das animações Pixar já existentes, começando por um "Toy Story 3", que a equipe de Lasseter havia reprovado meses antes. Com o trauma da baixa qualidade técnica e artística das continuações dos clássicos Disney para o mercado de home-vídeo, Jobs começou a expressar descontentamento: "Quando você vê o que a empresa fez lançando Cinderela II, dá medo de pensar no que aconteceria"; e, numa teleconferência com jornalistas, afirmou que, enquando a Pixar fazia sucessos, a Disney produzia "porcarias 
constrangedoras”. Negava qualquer auxilio criativo de Eisner e da Disney nas produções Disney e esbravejou: “A verdade é que faz anos que há pouca colaboração criativa com a Disney. Vocês podem comparar a qualidade de criação de nossos filmes com a qualidade de criação dos últimos três filmes da Disney, e julguem por vocês mesmos a criatividade de cada uma delas" (ISAACSON, 2015, p. 454).

Iger tinha uma visão clara dos problemas enfrentados por Eisner:

Michael não entendia que os problemas da Disney na animação estavam mais agudos do que nunca. Isso se manifestava na maneira como tratava a Pixar. Ele nunca sentiu até que ponto precisava realmente da Pixar. Toda negociação precisa ser resolvida com concessões. Nenhum dos dois é mestre em concessões (ISAACSON, 2015, 456).

Um ano antes, precisamente em janeiro de 2004, chegou-se ao ponto de Steve Jobs anunciar a John Lasseter e Ed Catmull o fim do acordo com a Disney - e para o desespero dos dois ouvintes, os direitos sobre o uso dos personagens até então criados (incluindo os do filme "Carros", ainda em produção) seriam perdidos para a Disney. Imediatamente, outros estúdios começaram a entrar em contato e chegou-se a um impasse. O estúdio Pixar só tinha três saídas: encontrar um novo distribuidor e suportar uma nova parceria arriscada, construir sua própria empresa de distribuição (o que implicaria num vultuoso investimento financeiro e cuja equipe criativa não queria gerenciar) ou permanecer com a Disney renovando o contrato.

Havia outro problema numa eventual negociação com outro estúdio. Os concorrentes da Disney já estavam montando ou já possuíam acordos ou estúdios com produções de animação computadorizada. A Fox conta a BlueSky (“A Era do Gelo”), a Sony Animation produz seus próprios filmes (“Tá Chovendo Hambúrguer”). A Universal tem acordo exclusivo com a Illumination Entertainment da franquia "Meu Malvado Favorito". A DreamWorks era, após a Pixar, a produtora de animação mais equilibrada. E a Disney, que antes estava por baixo, começava a lançar animações computadorizadas mais avançadas e com qualidade narrativa superior. A Pixar, na prática, apesar de 
liderar com o maior número de produções sucesso de público e crítica, estava em meio a um oceano de produtoras com acordos de distribuição fechados ${ }^{43}$.

Catmull, entretanto, já dizia ter conhecimento de que o plano de longo prazo de Steve Jobs sempre havia sido vender a Pixar para a Disney, por mais que ele não confirmasse sua ideia. Catmull desconfiou, por exemplo, de Jobs ordenar que ninguém falasse nada para a pesquisa do livro "Disney War" do jornalista James Stewart (2006), que cobria a história do período turbulento nos estúdios Disney. Ele alegava que ninguém sabia o que aconteceria na Disney. Catmull ligou os pontos e desconfiou que Jobs somente esperava a hora certa de vender. E ela veio com a indicação de Bob Iger à presidência da Disney (SCHLENDER, TZTZELI, 2015, p. 336-337).

Quando a Disney adquiriu a Pixar, houve muita discussão em torno da controvérsia e dos riscos do negócio. Até então, a filosofia do antecessor Michael Eisner era fomentar a criação internamente, ao invés de procurar externamente. Há riscos na produção criativa e mais ainda quando se paga acima de US\$ 7 bilhões por uma produtora. Por se tratar de um estúdio ainda jovem, o risco estava na aposta no futuro do que propriamente no acervo e no passado. A Pixar oferecia novas oportunidades para a Disney, em um período de crise criativa interna. Existe a história de que Iger visitou a Disneylândia de Hong Kong e, durante um desfile, percebeu que todos os personagens populares do momento eram produzidos pela Pixar (IWERKS, 2007). O estúdio era extremamente popular, tinha prestígio da crítica e inovava tecnologicamente a cada produção. Outro motivo era porque a animação, como alma da Disney, sempre havia sido o elemento de mais valor dentre tudo o que foi criado pelo estúdio. E se a compra da Pixar não foi necessariamente uma garantia de sucesso, representou no mínimo o aumento dessa probabilidade. Ed Catmull e John Lasseter (Figura 208), que então chefiavam a Pixar, foram convidados a presidir a Walt Disney Animation Studios, mantendo a cultura dos dois estúdios.

\footnotetext{
${ }^{43} \mathrm{Em} 28$ de abril de 2016 a DreamWorks Animation foi vendida para a corporação de mídia Comcast por US $\$ 3,8$ bilhões. A transferência de propriedade se concretizou em 22 de agosto de 2016, data em que o CEO Jeffrey Katzenberg deixou o cargo faturando US \$391 milhões com a transação. A presidente da DreamWorks Animation, Ann Daly, também deixou o cargo com ganhando uma rescisão contratual de US\$ 40 milhões. Katzenberg prestará assessoria para a nova DreamWorks Media. A Comcast é proprietária da rede de TV NBC e dos estúdios Universal Pictures. Nota incluída na versão corrigida da tese.
} 


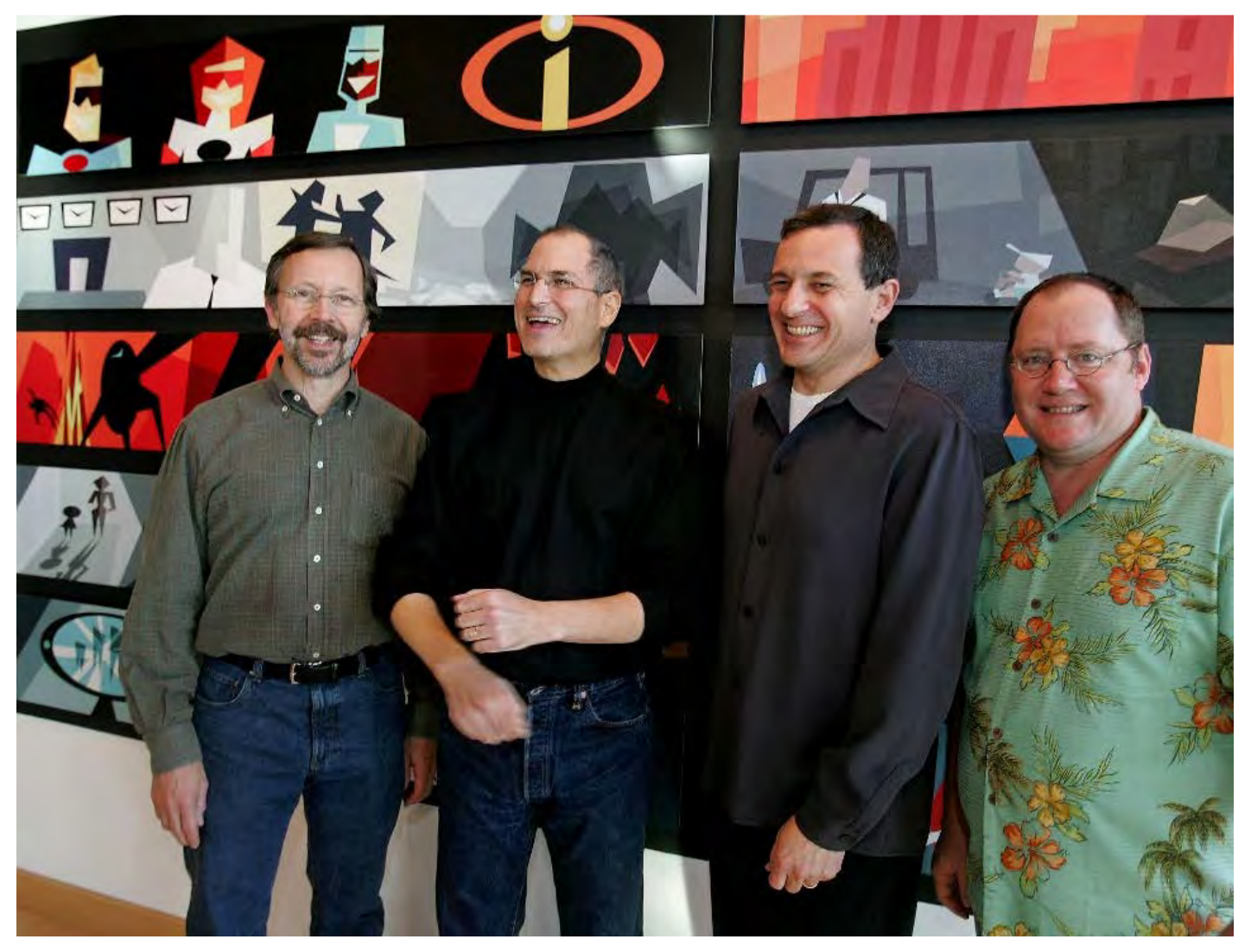

Figura 208 - Ed Catmull, Steve Jobs, Bob Iger e John Lasseter no anúncio da compra da Pixar pela Disney.

No dia em que Bob Iger foi apontado pelo conselho de administração como novo CEO, ele telefonou para o Steve Jobs dizendo que uma nova gestão assumiria e que talvez a relação entre Disney e Pixar poderia ser salva. Jobs, com seu peculiar modo cético de ser, respondeu honestamente “OK, eu pensava que você era igual aos outros". Jobs era muito vocalmente honesto para o bem ou para o mal, a ponto de telefonar ao CEO da Disney e comentar "Olá, Bob. Ontem assisti o novo filme que vocês lançaram e ele é horrível!" SCHLENDER e TZTZELI, 2015). Iger, um ávido usuário do iTunes para o consumo de música, comentou com Jobs as possibilidades futuras de um tipo de iTunes em vídeo como uma nova espécie de experiência na web. Jobs ficou surpreso e lhe mostrou um protótipo rudimentar de um iPod de vídeo (até então só existia o de áudio). Muito rapidamente, foi negociado um acordo, fechado em 5 dias, em que a Apple lançaria seu novo iPod de vídeo e a Disney forneceria os três seriados de mais sucesso no momento - "Desperate Housewives", "Lost" e "Grey's Anatomy" para o iTunes. Foi essa experiência que aproximou Steve Jobs e aumentou sua confiança na Disney. 
Bob Iger se aproximou com uma ideia chamada por ele próprio de "maluca" - comprar a Pixar - ideia que Steve Jobs não considerou tão maluca assim. E assim foi iniciada outra negociação. Pelo lado da Disney havia sérias preocupações como salvar o relacionamento com a Pixar e salvar a animação produzida pela própria Disney. Após cuidadosas consultas com Ed Catmull e John Lasseter, Jobs lhes assegurou que faria o possível para tornar a transição para a Disney o menos traumática possível. Ele conseguiu aprovação de muitas demandas, incluindo a manutenção do nome Pixar e da estrutura autônoma do estúdio. Ao invés do choque de culturas, imaginavam que era possível aliar as qualidades, mantendo as entidades produtoras separadas. Outro cuidado foi o fato de Steve Jobs ter contado privadamente a Bob Iger (somente após conversar com seu médico e sua esposa) sobre o retorno do seu câncer em 2006 e o prognóstico de mais uns 5 anos de vida. Considerava ser honesto discutir o assunto horas antes do anúncio da aquisição da Pixar pela Disney. Iger raciocinou que não estava adquirindo o próprio Steve Jobs e sim a marca Pixar, seus melhores talentos criativos e técnicos e uma grande quantidade de filmes e personagens populares. O acordo foi fechado fazendo de Steve Jobs o maior acionista da Disney naquele momento com 7,7\% das ações da companhia (SCHLENDER e TZTZELI, 2015, p. 344).

Qual o denominador comum na decisão de uma aquisição criativa? Para Iger, a prioridade é a alta qualidade criativa e grandes marcas de entretenimento como núcleo do plano estratégico da companhia. Dentro das aquisições, acompanham também um pequeno contingente de pessoas responsáveis por essa alta qualidade, o que é valioso. A importância das marcas tem relação com o alto número de opções num universo de escolhas que o público tem a sua frente - cria grandes vantagens. As franquias de filmes dessas marcas foram baseadas na seguinte filosofia de produção: filmes ou franquias de filmes com marca, com possibilidade de cruzamento com outras áreas da companhia, se expandindo por outros territórios globalmente e com maior possibilidade de perenidade no tempo - Pixar, Marvel e Lucasfilm se encaixam na estratégia. De certo modo, essa qualidade perene é uma grande qualidade das animações antigas. Porém, os novos criadores continuam sob o controle da indústria:

É verdade (...) que muitos empresários criativos adotam uma postura deliberadamente antiartística, afirmando que suas produções não são arte, mas entretenimento. Tal posição é dominante em particular em Hollywood, onde os profissionais do cinema negam frequentemente a dimensão artística de seus filmes. Walt Disney já declarava que desejava apenas "divertir e fazer as pessoas rirem"... agradando-as, em vez de se preocupar em exprimir ou realizar criações obscuras". Mais recentemente, Steven Spielberg e Jeffrey Katzenberg afirmam: "O essencial reside numa boa história, somos contadores". A finalidade última não é a criatividade artística, mas o sucesso comercial, a rentabilidade dos filmes (...). Mas isso não basta para recusar a elas qualquer dimensão artística. Existem no capitalismo artista 
tensões, quando não contradições, entre organização empresarial e criação, marketing e arte, mas estas não são insuperáveis, não eliminam as orientações propriamente criativas e estilísticas. Em toda parte, a meta do ganho se cruza com os tratamentos de tipo artístico. Se o capitalismo artista funciona com contradições, ele também põe em prática mecanismos de conciliação e aliança dinâmica entre racionalização e magia cultural, economia e arte, estratégia de desenvolvimento e imaginação criativa, de que resultam universos de sonho com valor artístico. (LIPOVETSKY, SERROY, 2014, p. 72-73).

“Casablanca” (1942) e “Cidadão Kane” (1941) permanecem clássicos, porém perderam relevância do ponto de vista do consumo de massa. Diferentemente dos filmes live-action clássicos de Hollywood, os pouco mais de cinquenta filmes de animação produzidos por Walt Disney desde 1937 permanecem sendo assistidos através dos anos - seja em relançamentos nos cinemas, em VHS, Laserdisc, DVD, Blu-ray ou agora em streaming com enorme sucesso e grande retorno comercial. Não são tantos os produtos que sobrevivem ao teste do tempo. E isso é um atestado da alta qualidade criativa envolvida. E talvez uma resposta para a "fórmula mágica" esteja no próprio Walt Disney, que respeitava muito o passado, se preocupava com o presente, porém, ao mesmo tempo era um grande futurista. Ele não conseguia pensar em um ou dois anos à frente - sua mente tentava alcançar uma década. Não é surpreendente, portanto, que Walt já estivesse produzindo partes de seu programa "Disneylândia" em cores prevendo a popularidade da televisão colorida ou investindo no projeto de sua "cidade do amanhã" chamada Epcot. Aliás, esse pensamento de longo prazo não deixa de ser um ponto de reflexão nas primeiras duas décadas do século XXI com tecnologias e costumes evoluindo tão rapidamente.

\subsection{Fabricando criatividade}

Uma das coisas que Iger descobriu quando comprou a Pixar é que todos os filmes vêm da cabeça de um diretor. A ideia, a história fundamental foi criada pelo diretor, pela paixão dele. É ele quem inicia o processo. Na Disney, o processo foi invertido, com diretores sendo normalmente escalados para ideias dos outros (SWISHER, 2015). Iger cita, por exemplo, o grande sucesso "Frozen: Uma Aventura Congelante" (2014) como exemplo, a despeito da grande turbulência que esse projeto passou ao longo de uma década na Disney. Vejamos, a seguir, alguns elementos do choque de culturas entre os dois estúdios e conhecer os métodos e a retórica da "cultura Pixar". 
A aquisição da Pixar pela Disney trouxe vários desafios. Um deles é que a Disney buscava os talentos de seus novos membros para resgatar a qualidade de seus próprios filmes. Preocupava, por exemplo, o fato dos artistas e técnicos da Pixar não estarem sob contrato - poderiam deixar o estúdio quando quisessem. Os funcionários da Pixar, por outro lado, temiam a destruição de seus valores pela burocracia de uma corporação. O contrato incluía questões maiores, como preservar o pagamento de bônus à equipe quando os filmes superassem um patamar nas bilheterias, até a preservação de rituais e práticas tão diversas como liberdade para criar cartões de apresentação, manutenção de festas e atividades recreativas dentro do estúdio (caso do popular concurso de aviões de papel) e continuidade da permissão para que os funcionários pudessem decorar suas salas e cubículos de trabalho expressando sua individualidade (ISAACSON, 2011). Esses fatores não podem ser relacionados diretamente ao sucesso dos filmes, mas o estúdio os manteve por manter o moral alto da equipe.

O layout dos dois estúdios também ilustrava as diferenças. A sede da Pixar, em Emeryville (vizinha da cidade de San Francisco), havia sido supervisionada pessoalmente por Steve Jobs, numa das poucas vezes em que se envolveu profundamente em algo relacionado à criação no estúdio. Grandes espaços comunais, jardins e atividades recreativas foram construídos. Jobs queria a interação forçada da equipe para troca de ideias. Uma de suas ideias para isso era projetar os banheiros somente no grande hall de entrada, o que, logisticamente, seria um pesadelo para quem trabalhasse nos andares superiores. Todos os empregados são livres para se expressar criativamente decorando seus espaços de trabalho de acordo com seus gostos pessoais. A Disney era o inverso. Hospedados num edifício pós-moderno dos anos 1990, os dois primeiros dos quatro andares são claustrofóbicos com pouca iluminação. No quarto, um gigantesco portal para as salas dos executivos intimidava qualquer um que tentasse se aproximar. O ambiente era mais estéril, a despeito das exposições de "arte Disney" que comumente decoram paredes nos corredores (CATMULL, 2014, 252-253).

A chegada de uma nova gestão implicou na transformação dos salões executivos em salas de discussão dos filmes em produção. John Lasseter e Ed Catmull transferiram seus escritórios para o segundo andar, no meio da estrutura. E houve a filosofia de se manterem o máximo possível acessíveis para as equipes de produção, demonstrando transparência e confiança. Houve também a introdução de uma filosofia de flexibilização dos resultados. Os executivos da Disney eram acostumados a projetar os progressos de sucesso de forma exata. A nova filosofia pensava em variáveis que pudessem desviar o progresso da trajetória ascendente temporariamente, mas que, eventualmente, o sucesso financeiro talvez fosse maior que o calculado inicialmente. A Pixar era cautelosa, pois sabia 
os efeitos de saturação causados pelo efeito “O Rei Leão" em 1994. Crescimento desordenado resulta em produção caótica.

Um passo importante foi tentar implantar um "comitê criativo" na Disney. A Disney já possuía há pouco tempo um grupo de diretores veteranos que se reuniam em reuniões do chamado "Story Trust”. O obstáculo é que as discussões eram muitas vezes inócuas, pois as decisões finais vinham de outras fontes. Os diretores recebiam "anotações" de três origens: uma do departamento de desenvolvimento do estúdio, uma do chefe do estúdio e uma diretamente do próprio CEO Michael Eisner. O mais alarmante é que as três não sugeriam alterações nas "anotações". Eram notas mandatórias com listas do que deveria ser alterado nos filmes, ao lado de quadrados que deviam ser preenchidos para confirmar que a "sugestão" fora executada. Para piorar, ninguém dentre os grupos de "sugestão" havia trabalhado diretamente em filmes e as notas eram conflitantes entre si. O processo esquizofrênico resultou em filmes ruins.

A Pixar projetou uma réplica do "Brain Trust", o grupo de veteranos que analisava os filmes em produção formados por nomes como o próprio John Lasseter, Andrew Stanton, Pete Docter, Joe Ranft, Brenda Chapman, e mais recentemente Lee Unkrich, Brad Bird, Gary Rydstrom, Bob Peterson e Brad Lewis. Trata-se na prática de uma reunião de avaliação entre pares (peer-review) inspirada no ambiente acadêmico, proposta apoiada por Ed Catmull (2014, p. 92-93). Os diretores e argumentistas recebem o feedback de seus pares seguindo geralmente um processo de, primeiramente, a indicação dos aspectos positivos, e, posteriormente, as críticas. As condições sociais desencorajam as pessoas a dizerem a verdade àquelas percebidas em posição superiores. E quando há muitas pessoas presentes numa sala, há uma pressão para que o avaliado vá bem. Avaliações muito fortes podem intimidar colegas, subconscientemente assinalando que não estão interessados. O processo é pensado para que a avaliação seja feita com candura, porém com franqueza. Ela é essencial ao processo e importante para que um projeto seja desafiado além de seus limites.

A vantagem é obviamente receber feedback de pessoas que entendem o processo de "storytelling” e que já estiveram na mesma posição antes da pessoa cujo trabalho está sendo avaliado. Outro aspecto é que, oficialmente, o "Brain Trust" não tem autoridade para impor mudanças. Porém, o processo de produção recebe as pressões das exibições-teste (onde todos os funcionários convidados podem dar sugestões), do marketing e do próprio mercado. Não é incomum na Pixar a troca ou retirada de diretores que, lembrando Iger, criaram a história inicial de suas cabeças. Foi assim com 
Jan Pinkava ("Ratatouille", 2007) e Brenda Chapman ("Valente", 2012) e na Disney, Glen Keane (“Enrolados", 2010)

A Disney rapidamente assimilou essa ferramenta de avaliação, porém não sem tropeços. Quando o projeto “American Dog” (Bolt - Supercão, 2009) passou por problemas que culminaram na saída de seu diretor original, Chris Sanders, o produtor Clark Spencer pediu ajuda de colegas da Pixar. John Lasseter e Ed Catmull proibiram, impondo que os dois estúdios deveriam manter seus limites e era uma forma de forçar que cada estúdio pudesse resolver desafios de produção sem recorrer ao outro. Da mesma forma, os animadores foram instruídos a não esperar que os problemas se tornem maiores. No que ficou conhecido como "Toyota speech", a ideia era replicar o compromisso da companhia automotiva de permitir seus empregados na linha de montagem tomar decisões quando encontrassem problemas. Ninguém precisava mais pedir permissão para fornecer soluções. Até então havia uma cultura do medo para aqueles que desviassem dos protocolos aceitos pela Disney. Há o caso de uma cena completa do hamster Rhino em "Bolt - Supercão", em que a equipe calculava em seis meses o tempo para refazê-la. Três membros refizeram a cena num único fim de semana (CATMULL, 2014, p. 264).

A capacidade de Lasseter e Catmull para gerenciar dois estúdios de animação também era questionada. Havia executivos que defendiam o fechamento das instalações da própria Disney em prol da Pixar. Não foi o caso. Porém, a distância entre as equipes (Disney próximo a Los Angeles e Pixar próximo a San Francisco) força os dois executivos a viajarem semanalmente para dividir atenção entre os estúdios.

Do ponto de vista técnico, o debate entre animação tradicional (2D) e computadorizada (3D) chegou a um impasse. A nova gestão permitiu que a Disney produzisse uma nova animação tradicional. Os custos foram baixos e o retorno lucrativo. "A Princesa e o Sapo" (2009) também é um marco por ter presença da primeira princesa negra numa animação Disney. Porém, uma série de eventos prejudicou a técnica. O fato da animação estrear pouco antes do arrasa-quarteirão "Avatar", apresentando uma revolução no uso do 3D estereoscópico, aumentou a percepção de que a animação 2D tradicional era vista como antiquada. Pesou contra a percepção interna do estúdio de que o título “A Princesa e o Sapo" remetia ao público feminino. A qualidade não podia ser espera somente da técnica e do storytelling, mas também do posicionamento e do marketing (CATMULL, 2014, p. 2690. 
Havia uma percepção inicial de que a produção deveria se dividir entre Disney 2D e Pixar 3D; porém, os diretores buscavam liberdade para explorar a técnica que funcionasse melhor aos seus projetos. O caso mais emblemático foi a adaptação do conto de fadas Rapunzel. O projeto permaneceu em produção por mais de uma década, com vários hiatos e cancelamentos no seu desenvolvimento. Eisner havia avalizado o mestre da animação Glen Keane estreando como diretor no projeto, que continha desafios técnicos como a animação do longuíssimo cabelo da protagonista. Outro desafio, do ponto de vista narrativo, era o fato da Rapunzel permanecer presa numa torre, o que limitava muito a ação. Eisner, num dos seus rompantes criativos, sugeriu que o conto se transformasse numa comédia irônica chamada "Rapunzel Unbraided", ambientada na cidade de San Francisco, onde a protagonista de algum modo seria transportada para o mundo dos contos de fadas. A proposta era típica de seu tempo. No início dos anos 2000, a Disney insistia em projetos tematicamente muito variados e mais sérios, tentando atrair o público adolescente. A concorrência apostava em animações cômicas, com ironias e repletas de referências da cultura pop. "Shrek" (2001), da DreamWorks, foi o primeiro exemplo, e a própria Disney apostou nessa abordagem em "O Galinho Chicken Little” (2005). Segundo Rhett Wickam (comunicação pessoal) ${ }^{44}$;

\begin{abstract}
Sobre a questão da "velocidade" e do "ousado", acredito que o público, a audiência ocidental em particular, tornou-se acostumada a um entretenimento que numa avaliação atenta é realmente muito frívola e pré-digerida. Somos muito impacientes como espectadores do século XXI. Em boa parte nos acostumamos com um tipo de narrativa estilo MTV que é sustentado em edições rápidas e no ritmo veloz que são primordialmente para compensar a falta de conteúdo substancial. $\mathrm{O}$ atual zeitgeist do "irônico" está lentamente cansando e consigo ver a audiência procurando algo que tenha um foco mais sincero na condição humana. Rápido, engraçado e enérgico são divertidos, mas não satisfaz uma fome mais profunda que penso não poder ser apagado ou sublimado por via de marketing inteligente e gratificação instantânea. Como uma "droga" sintética, ela uma hora acaba e há um "crash". Eu acredito que estamos muito próximos do "crash" e muito perto de recuperarmos um entretenimento mais substantivo.
\end{abstract}

Rapunzel representa um pouco o sentimento desse "crash". A equipe criativa não sabia o que fazer e muito menos os executivos, ou, em outros aspectos, a equipe criativa não tinha espaço ou enfrentava um obstáculo, ou ainda enfrentava a discussão se o melhor era fazer um filme "2D ou 3D". Antes da equipe Pixar assumir a Disney, "Rapunzel” havia sido novamente cancelado. Lasseter e Catmull retomaram o projeto por acreditar que a personagem era forte. Porém, quem teve um "crash" pessoal foi o diretor do filme Glen Keane, que sofreu um infarto, necessitando se licenciar do cargo. Ele retornaria como consultor técnico, porém os jovens diretores Byron Howard e Nathan Greno

${ }^{44}$ Entrevista com o autor por e-mail, em 16 de novembro de 2005. 
assumiram as rédeas remodelando o projeto para uma comédia envolvendo Rapunzel e um criminoso fugitivo chamado Flynn Rider. Alan Menken, responsável pelas trilhas musicais dos anos 1990 estava na equipe.

Para não repetir o "erro" de "A Princesa e o Sapo", a Disney sucumbiu a uma decisão do departamento de marketing para que o título do filme tivesse gênero neutro. Desse modo "Rapunzel" se tornou "Tangled" ("Enrolados" no Brasil). A decisão foi controversa internamente, confirma Catmull (2014, p. 272), levando muitos no estúdio a se temer que as preocupações do departamento de marketing começassem a ditar decisões criativas. O filme, de fato, foi um sucesso, rendendo US\$ 590 milhões mundialmente. E os estúdios de animação Disney finalmente conseguiam se reerguer. As equipes criativas tiveram muita liberdade para abordar uma série novidades no campo do cinema de animação. Temas como inclusão do negro (“A Princesa e o Sapo”, 2009), gênero feminino ("Valente", 2012) e sustentabilidade ("Wall-E”, 2008) ganharam espaço. Tragédias externas também foram contornadas sem grandes obstáculos - por exemplo, os atentados de 11 de setembro de 2001 forçaram a mudança do clímax de "Lilo \& Stitch" (2002), que tinha um avião desviando de edifícios no Havaí, ou a tragédia do acidente nuclear em Fukushima, que alterou diálogos envolvendo radiação em "Carros 2" (2011).

A Disney e a Pixar combinaram os métodos específicos para reduzir divergências de produção em uma série de processos. Os filmes são revisados periodicamente com a revisão analítica nos comitês criativos, e viagens de pesquisa são feitas quando necessário, para evitar cópias, noções préconcebidas e clichês. É dada uma atenção especial aos limites impostos pelos criativos para evitar produzir algo complexo que não seja importante e evitar "miragens" - ações ou cenas específicas que tomam muitos meses de trabalho e na prática não são essenciais. Foi eliminado também o chamado “oversight group" com gerentes que controlam prazos e custos de produção. E há um processo contínuo de aprendizagem com a produção de curtas-metragens experimentais e a avaliação dos erros cometidos nos últimos filmes.

Ed Catmull, em seu livro "Creativity, Inc.” destaca a integração entre tecnologia e arte, afirmando que a "nova geração" enquanto estudava na CalArts, tinha preconceito em usar as novas tecnologias. Não queriam usar VHS/videotape porque os velhos mestres não usavam. O professor e animador Bob McCrea afirmou ao diretor da Pixar, Andrew Stanton: "Não seja idiota. Se tivéssemos essas ferramentas na época nós as usaríamos" (CATMULL, 2014, p. 204, tradução nossa). Walt Disney era inflexível em sua determinação para incorporar o novo e entender as tecnologias 
disponíveis, por isso mesmo experimentou com o som e a cor, desenvolveu a pintura matte ${ }^{45}$, a câmera multiplano ${ }^{46}$ e o sistema Xérox ${ }^{47}$. Mais recentemente, o filme híbrido "Dinossauro" (2000) ajudou a desenvolver o software Maya. Na Pixar, como já vimos, houve um esforço desde o início para que a tríade tecnologia, arte e negócios atuasse de forma equilibrada. John Lasseter popularizou a frase "A arte desafia a tecnologia, a tecnologia inspira a arte" (CATMULL, 2014, p. 204, tradução nossa).

O slogan articula justamente essa filosofia de integração. Quando o diretor Brad Bird, por exemplo, expressou dificuldade para explicar aos animadores como queria uma ação do personagem, uma decisão foi tomada e um software chamado Review Sketch foi criado - onde é possível desenhar no monitor como se fosse um lápis sobre uma folha de papel.

Embora a estrutura dos estúdios funcione bem, chamamos atenção para um outro fenômeno, este negativo, o do "artista anônimo". O progresso das novas tecnologias, somado à precariedade empregatícia do início do século XXI, resultou numa alta rotatividade e no empobrecimento da fama pública dos animadores. Se antes um estúdio como a Disney exaltava seus criativos, escalando-os para eventos, entrevistas na TV e making of nos DVDs, as novas estratégias de comunicação tornaram essa publicidade banal. Se era perfeitamente comum um fã conhecer "quem animou tais cenas" ou “quem supervisionou tal personagem”, atualmente uma nova geração passa incógnita.

Em primeiro lugar, o próprio cargo de supervisão de animação, em que um profissional é responsável pela atuação de um determinado personagem (função historicamente mais utilizada na Disney) tem sido substituída pelo padrão de "animador por cena”, ou seja, um animador é escalado para produzir algo em que seja especialista ou tenha mais habilidade. Na publicidade, os estúdios preferem a participação de animadores, preferindo destacar os dubladores, diretores, produtores, compositores e, com sorte, alguns membros da equipe criativa. O historiador Michael Barrier (2014) chamou atenção para uma questão que auxilia a entender um pouco essa questão. Um estudo multidisciplinar, publicado por professores das universidades de Yale e Swarthmore, analisou a relação entre motivos internos e instrumentais para a evolução profissional.

\footnotetext{
${ }^{45}$ Pintura matte é uma técnica em que cenários são pintados em lâminas de vidro com possibilidade de iluminação. $\mathrm{O}$ propósito é utilizá-la em casos em que seria muito caro construir o cenário real.

${ }^{46}$ A câmera multiplano foi usada pela primeira vez por Disney em 1937. O cenário é pintado em diversas camadas de vidro, e é filmado de forma a simular profundidade.

${ }^{47} \mathrm{O}$ sistema Xerox possibilitou a transferência automática dos desenhos dos animadores para a célula de animação. O efeito negativo é que os arte-finalistas se tornaram dispensáveis.
} 
Pesquisando cerca de 11 mil cadetes norte-americanos da Academia Militar de West Point, a pesquisa ranqueou quais motivos foram fundamentais para a decisão de entrar na academia. Os motivos eram diversos, mas eram divididos em duas categorias. A justificativa de desejar um bom emprego mais tarde é um motivo "instrumental”. Uma outra, aspirando ser treinado para ser um líder, é um motivo "interno". O senso comum leva a crer que as duas motivações juntas são melhores do que uma. Um médico pode desejar salvar vidas e almejar uma vida financeiramente melhor (aqui vemos os dois motivos ligados). No entanto, os resultados da pesquisa apontam que os cadetes, com motivos internos mais fortes, foram aqueles com maior tendência a se tornarem oficiais. Outro ponto é que cadetes, com motivos internos, também se deram melhor na carreira militar (evidenciado pelas promoções antecipadas de patente), e possuem propensão a permanecer na academia após os cinco anos obrigatórios, em relação aos colegas sem motivação interna. A exceção (e essa é a parte surpreendente) que os cadetes tivessem também motivos instrumentais (WRZESNIEWSKI, SCHWARTZ, 2014).

Levando em consideração essa pesquisa, Michael Barrier (2014) questiona o que acontece em situações em que uma indústria é povoada por pessoas que entram basicamente por motivos “internos”, porém essa mesma indústria é gerenciada por pessoas cujos motivos são esmagadoramente "instrumentais"? Em outras palavras, uma indústria cheia de pessoas que esperam se considerar como artistas, mas que é controlada por pessoas que só pensam em dinheiro. Barrier está refletindo o caso, que está na justiça norte-americana, de um suposto cartel entre os grandes estúdios de animação, incluíndo figuras criativas nas chefias, que teriam combinado limitar a movimentação e salários de seus funcionários (AMIDI, 2014). Na prática, um profissional não pode escolher onde ganhar mais, pois a estratégia serviu para evitar leilões entre os estúdios (como ocorreu nos anos 1990). O animador torna-se facilmente descartável, pois se estiver infeliz pode facilmente ser substituído por um novato com um salário semelhante.

Assim como Barrier, concordamos com o fato de que essas limitações contribuem para o entendimento do relativo anonimato dos animadores atualmente. A percepção de fora é que, ao contrário de uma década atrás, os animadores parecem ter sido rebaixados em relevância a níveis descartáveis, como os intervaladores (imbetweeners) e arte-finalistas dos velhos tempos. Sem a publicidade de antes, basicamente só os diretores representam a "criação" no filme. Na prática, os grandes estúdios passaram a tratar seus animadores como as antigas produtoras de animação para a TV. "É estranho pensar que Pixar e a DreamWorks como sendo fundamentalmente idênticas à HannaBarbera e Filmation, mas parece ser o caso" (BARRIER, 2014, tradução nossa). 
Apesar de toda a bela retórica da cultura Pixar e, em boa parte, ela é bem executada, evidentemente que os estúdios que se atrelam as grandes corporações de mídias estão a mercê das pressões naturais da busca por lucro. APixar idealista da época em que era basicamente uma start-up não é exatamente a mesma, agora que funciona dentro do mecanismo de uma corporação como a Disney. As pressões da tecnologia, do marketing e do mercado são fortes. Um bom exemplo foi Ed Catmull, ingenuamente, condenando um gênero na imprensa devido à percepção interna de que filmes como "Enrolados" (2010) e "A Princesa e o Sapo" (2009) estavam fora do gosto do público atual. "Filmes e gêneros seguem um curso [se referindo aos filmes de contos de fadas]. Eles poderão retornar futuramente porque alguém tem uma ideia nova... mas nós não temos qualquer outro musical ou contos de fadas em produção" (CHMIELEWSKI, ELLE, 2010, tradução nossa). O estúdio havia pouco tempo antes cancelado projetos como "A Rainha da Neve" e "João e o Pé de Feijão". Ironicamente, poucos anos depois a Disney produziu uma adaptação do primeiro - "Frozen - Uma Aventura Congelante" (Frozen, 2014), a maior bilheteria da história da animação, com US\$1,2 bilhão - e deve lançar "Gigantic" em 2018, uma adaptação do segundo projeto. Ambos os musicais são baseados em contos de fadas. Atente para o fato de "Frozen" e "Gigantic" possuírem títulos novamente neutros - o marketing realmente tem o seu peso.

Com Hollywood despejando tantos filmes parecidos, é fácil entender a dificuldade encontrada na hora de justificar projetos. E o conteúdo criativo original tem encontrado muita dificuldade para abrir espaço dentre as estratégias mais fáceis, como explorar remakes, reboots e continuações. Do resgate de filmes com décadas de história até releituras com inversão de gênero (o novo "CaçaFantasmas" da Sony é protagonizado por mulheres), calcula-se em 2016 que Hollywood esteja produzindo e desenvolvendo mais de 160 filmes derivados (BREW, 2016). E se atiçam os fãs, poucos realmente têm compensado o investimento fugindo da mediocridade. Animações entram na estratégia. Se a Disney está produzindo "Frozen 2", a Pixar espera capitalizar em cima de continuações de seus filmes mais populares até 2020. O público infantil está acostumado com o pêndulo entre "repetições" e "novidades". O que a Disney fez foi investir mais em qualidade em produtos que outrora seriam destinados aos supermercados (ou o antigo "home-video"). Ao contrário da Pixar, a Disney estrategicamente deve investir mais em animações originais nos próximos anos. Como veremos em seguida, a cultura digital e a cultura participativa têm importância fundamental nas ações da indústria do entretenimento. 


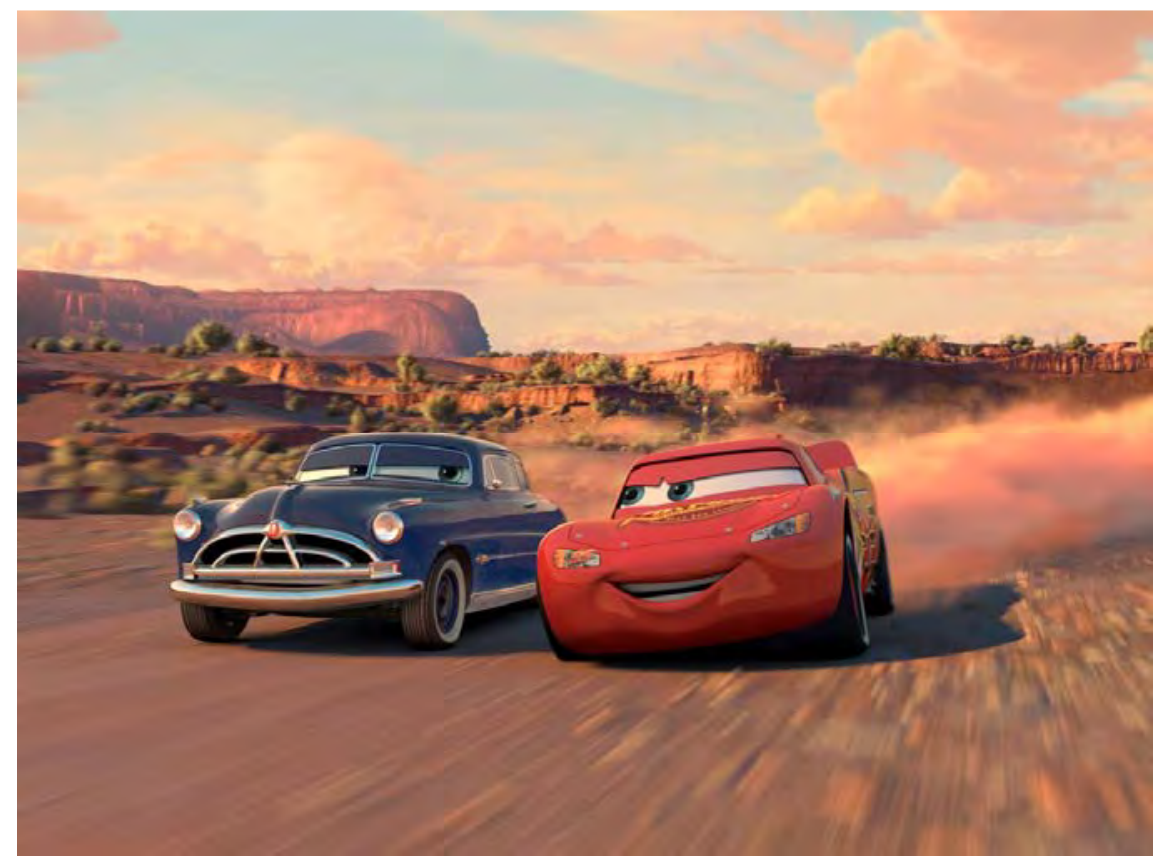

Figura 209 - "Carros” (2006), um sucesso comercial, mas nem tanto de crítica.

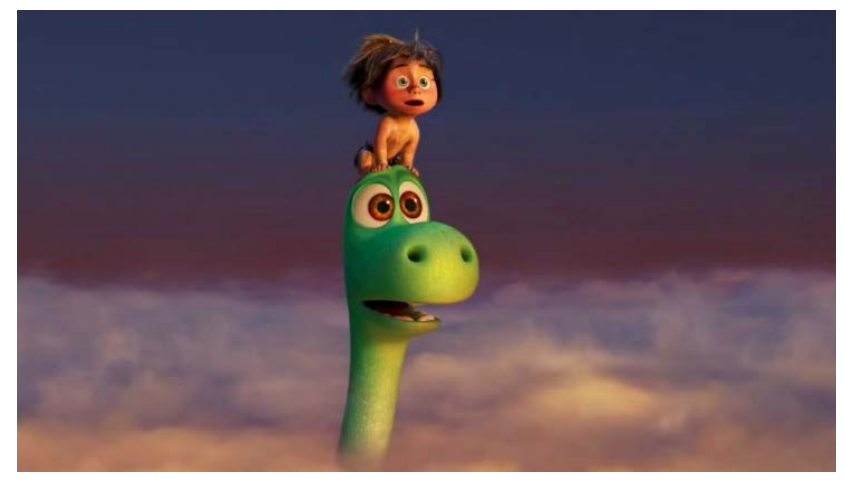

Figura 210 - “O Bom Dinossauro” (2015), a animação Pixar com a repercussão mais fria.

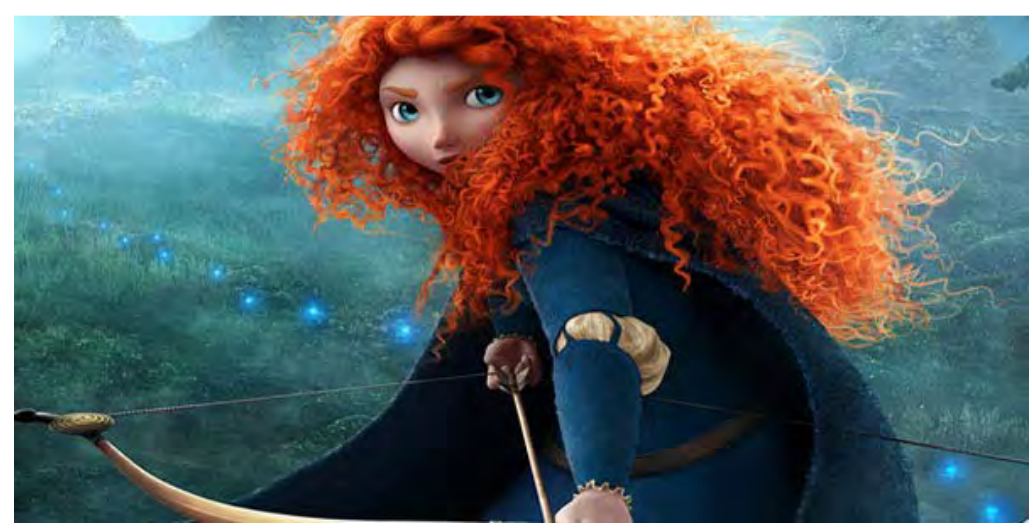

Figura 211 - "Valente" (2012), filme foi um do vários com troca de diretores no processo de produção. 


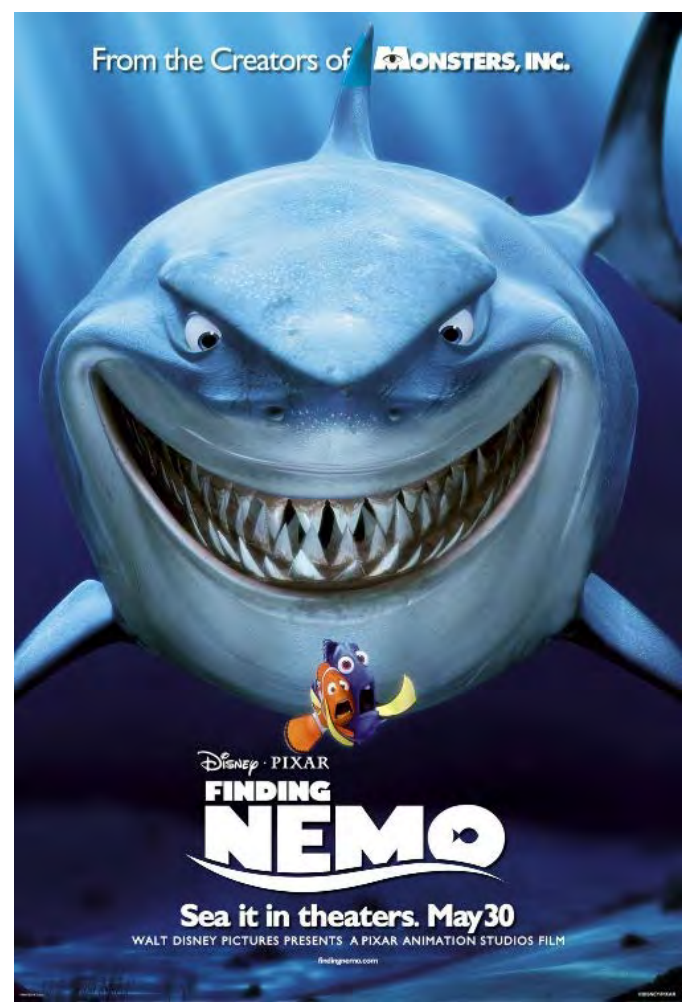

MEET THE LITTLE VOICES INSIDE YOUR HEAD.

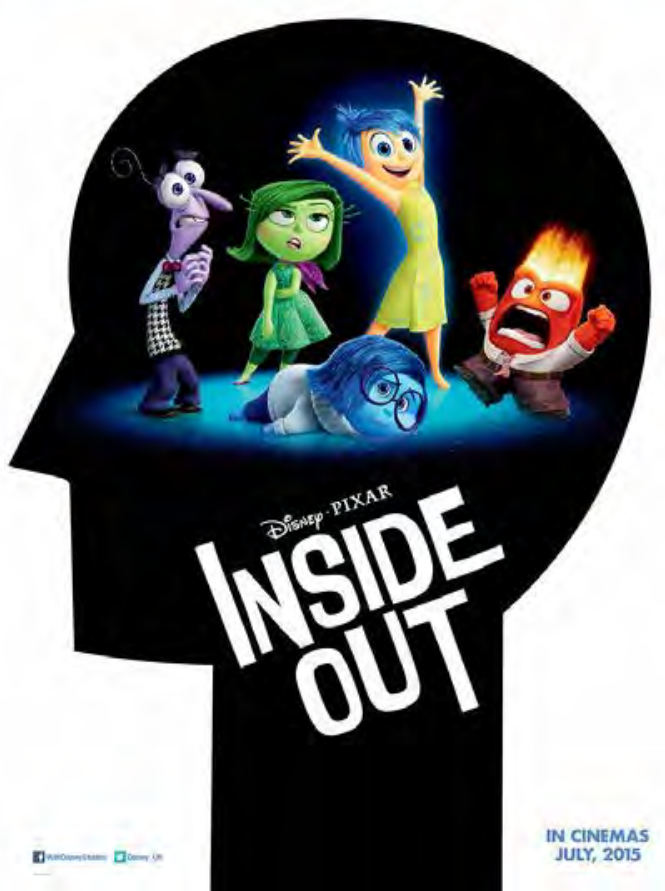

Figura 212 - "Procurando Nemo" (2003), terceira maior bilheteria da Pixar apenas superado por “Divertidamente" (2015) - Figura 213 e "Toy Story 3" - Figura 214.

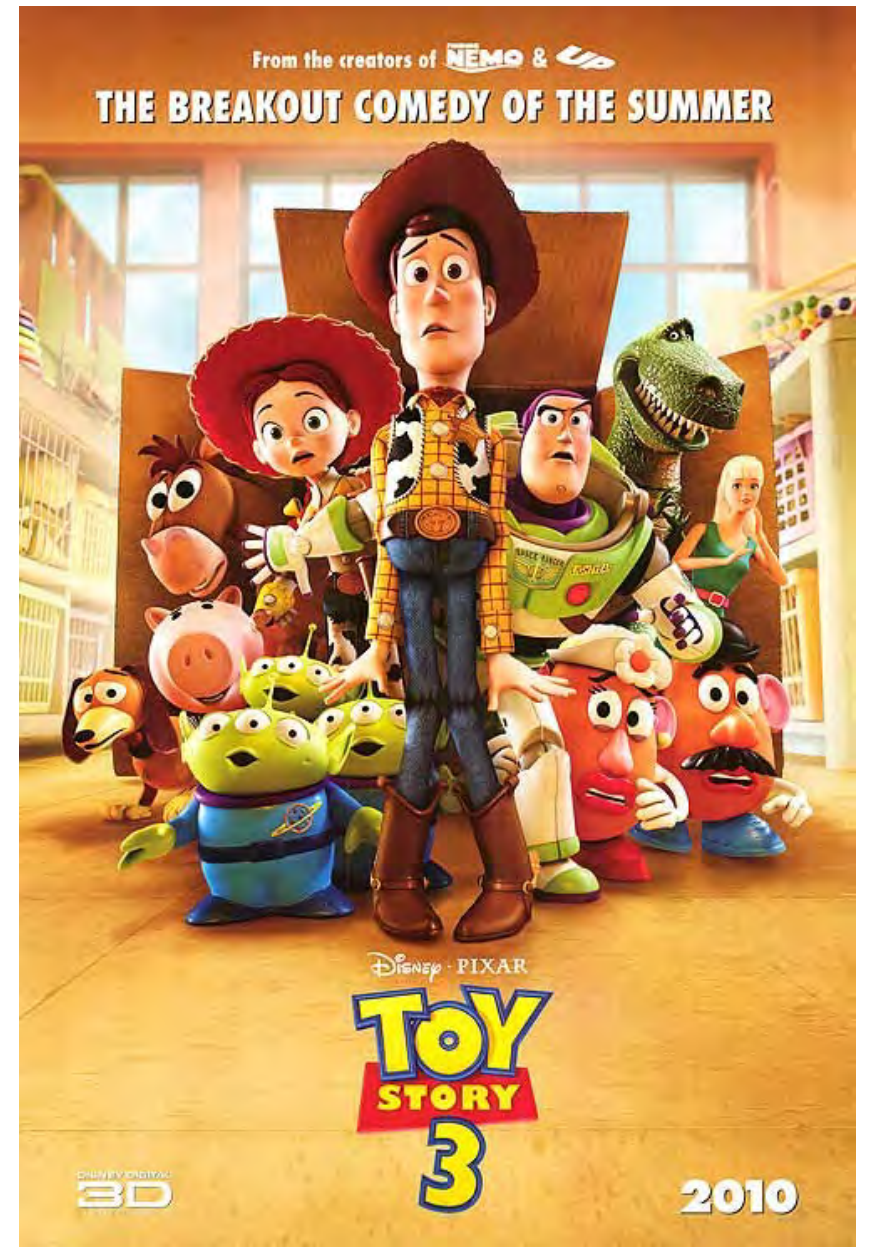




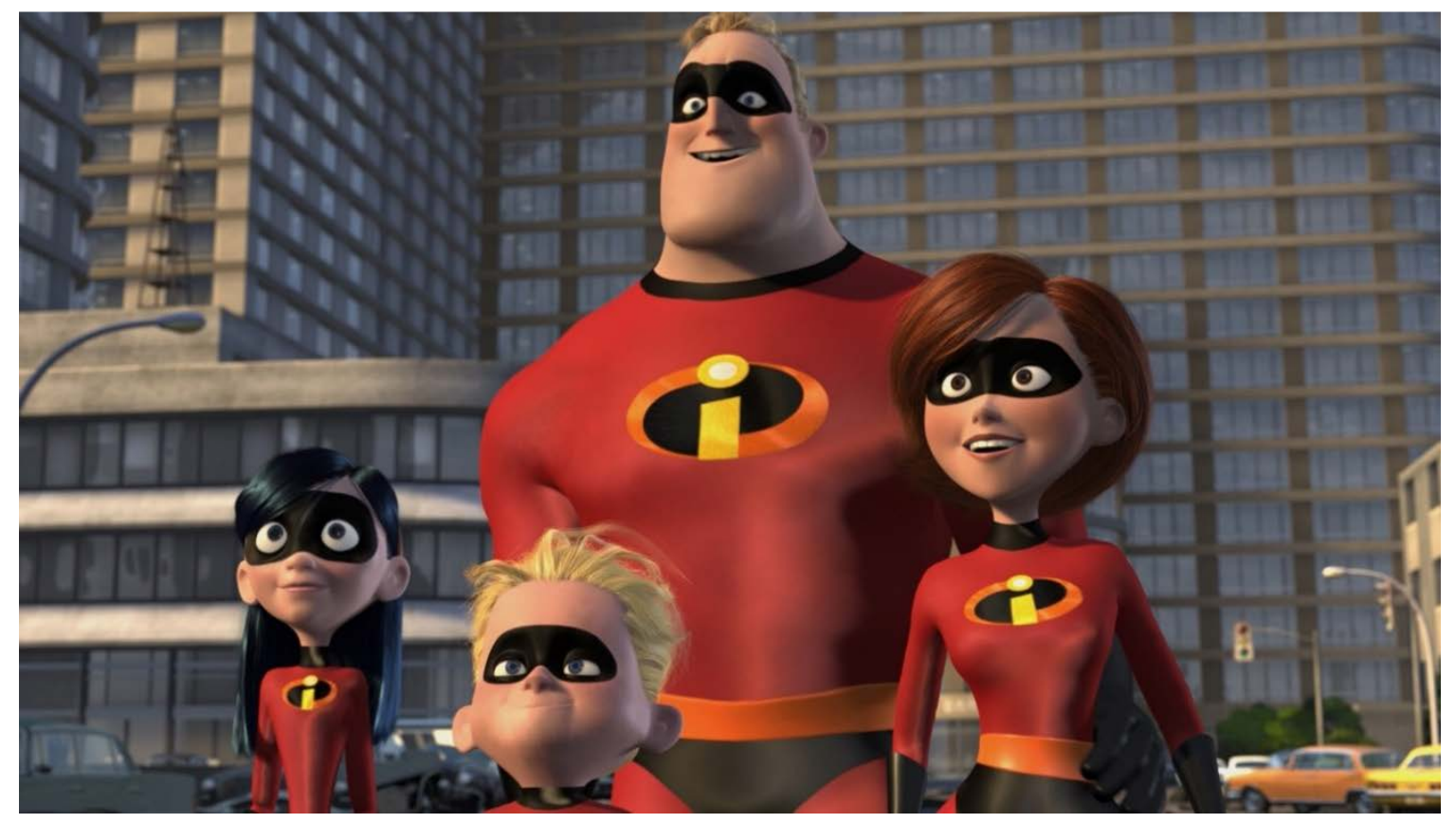

Figura 215 - “Os Incríveis” (2004), exemplo de animação de ação com situações de violência.
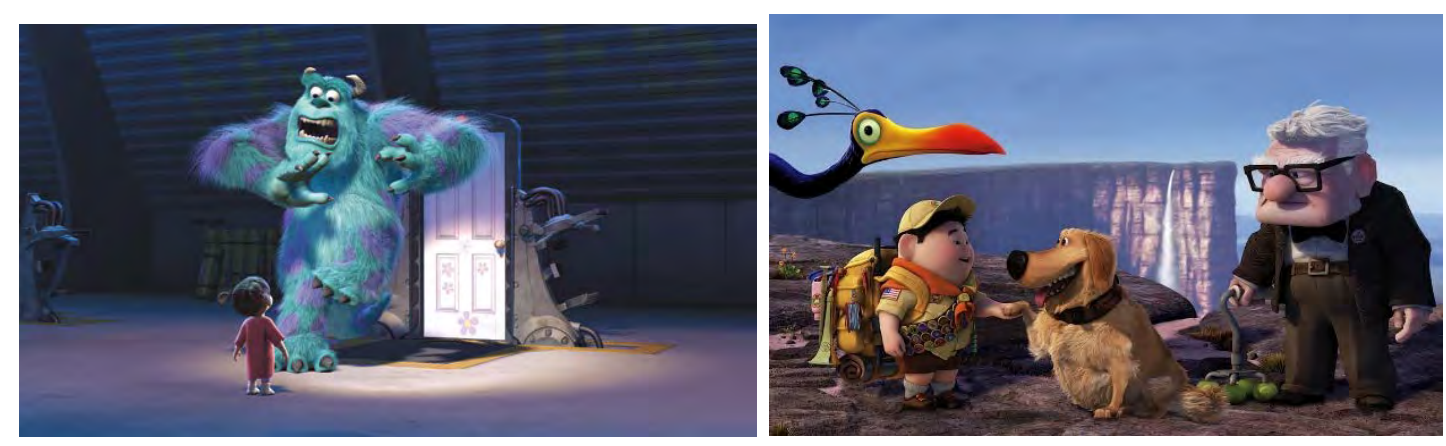

Figura 216 - "Monstros S.A" (2010). Figura 217 - “Up: Altas Aventuras" (2009).

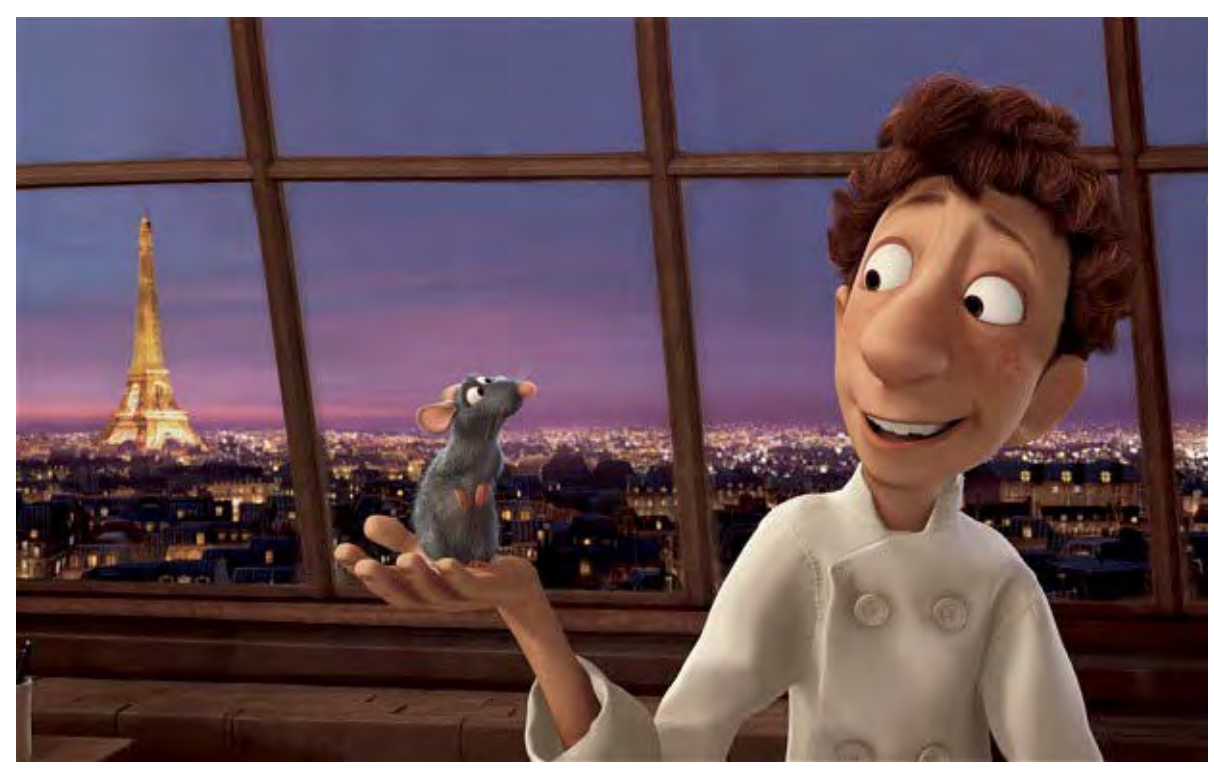

Figura 218 - "Ratatouille" (2007), um dos filmes mais sofisticados da Pixar. 


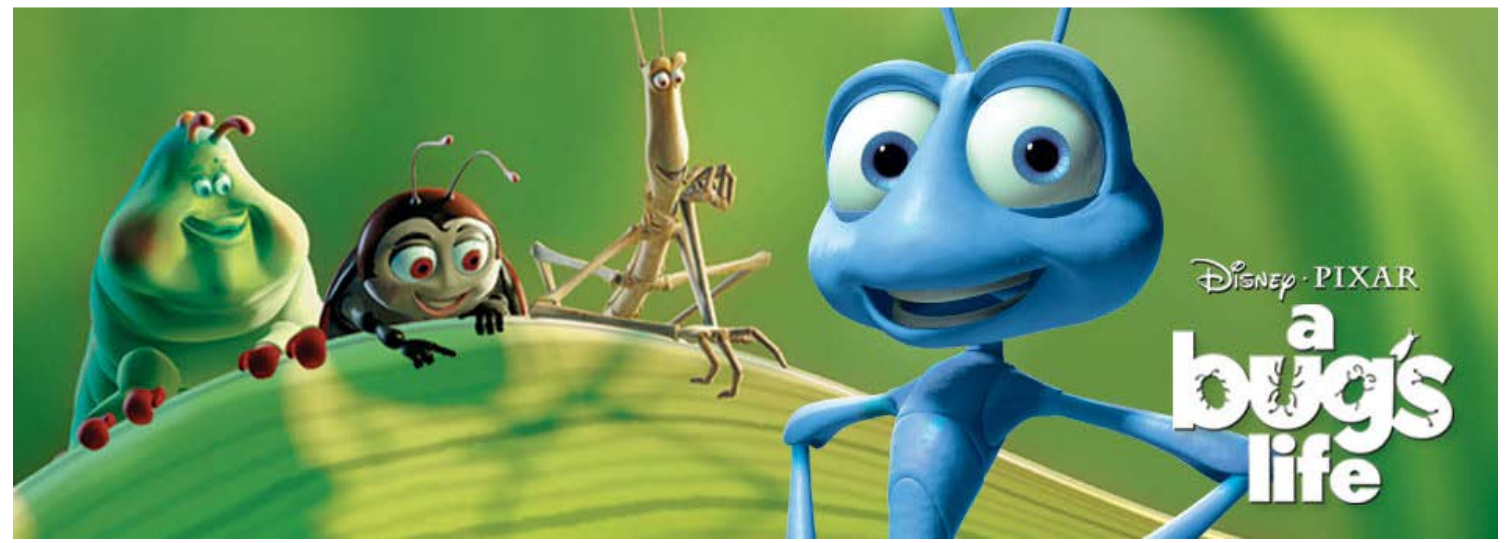

Figura 219 - "Vida de Inseto" (1998), sucesso na inércia do primeiro “Toy Story”.

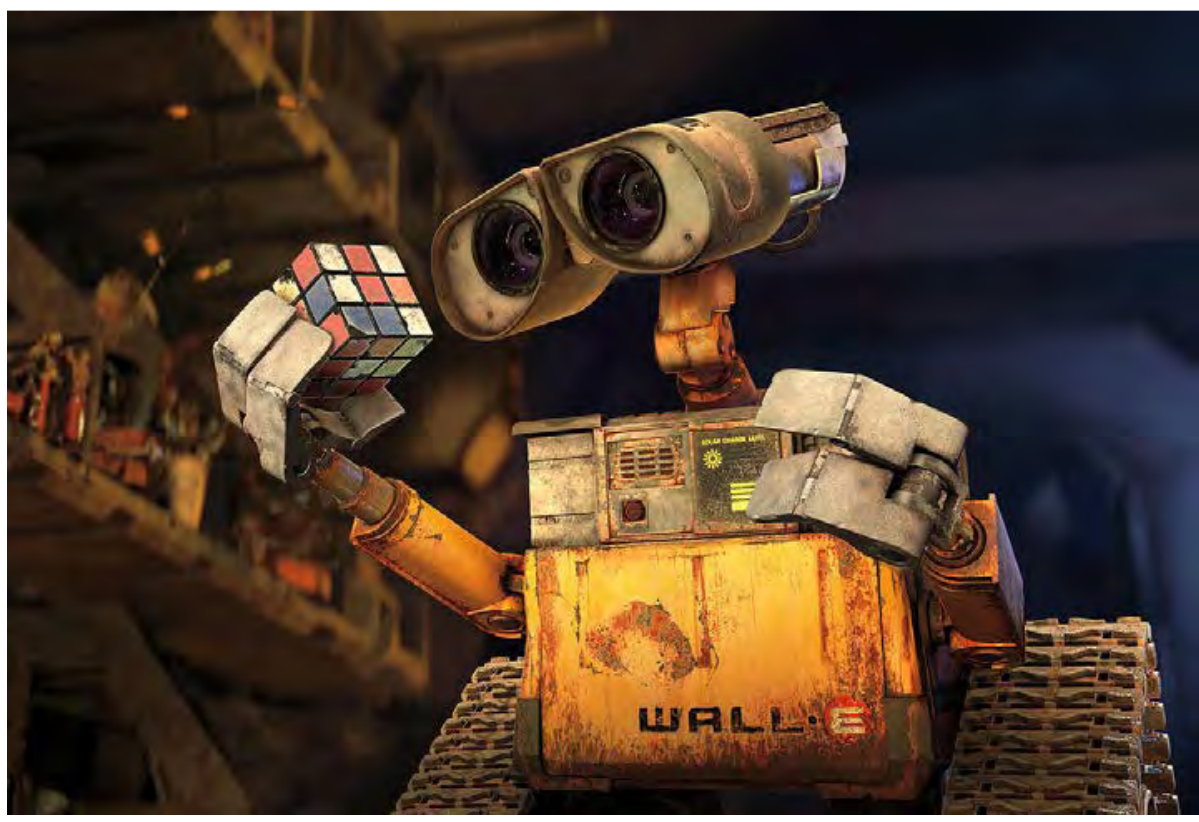

Figura 220 - "Wall-E", sucesso de crítica com seu tema ligado a sustentabilidade.
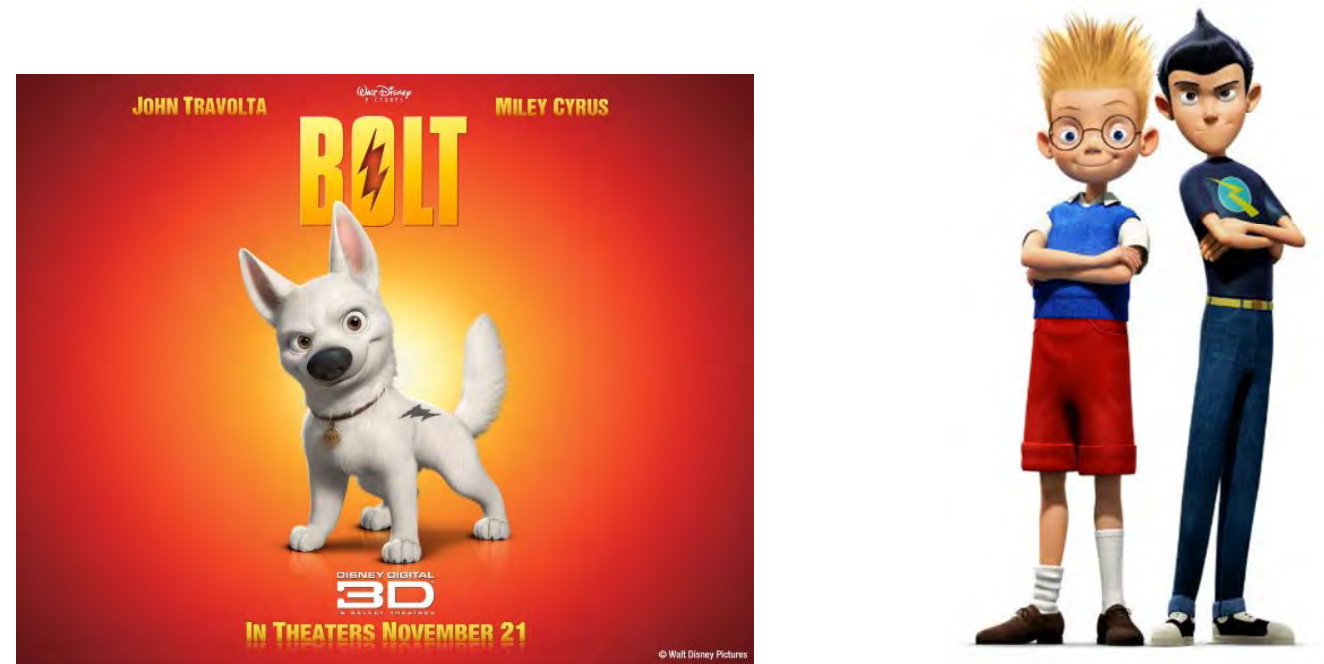

Figura 221 - A influência da Pixar altera produções da Disney como "Bolt: Supercão" (2008) e Figura 222 - "A Família do Futuro" (2009). 


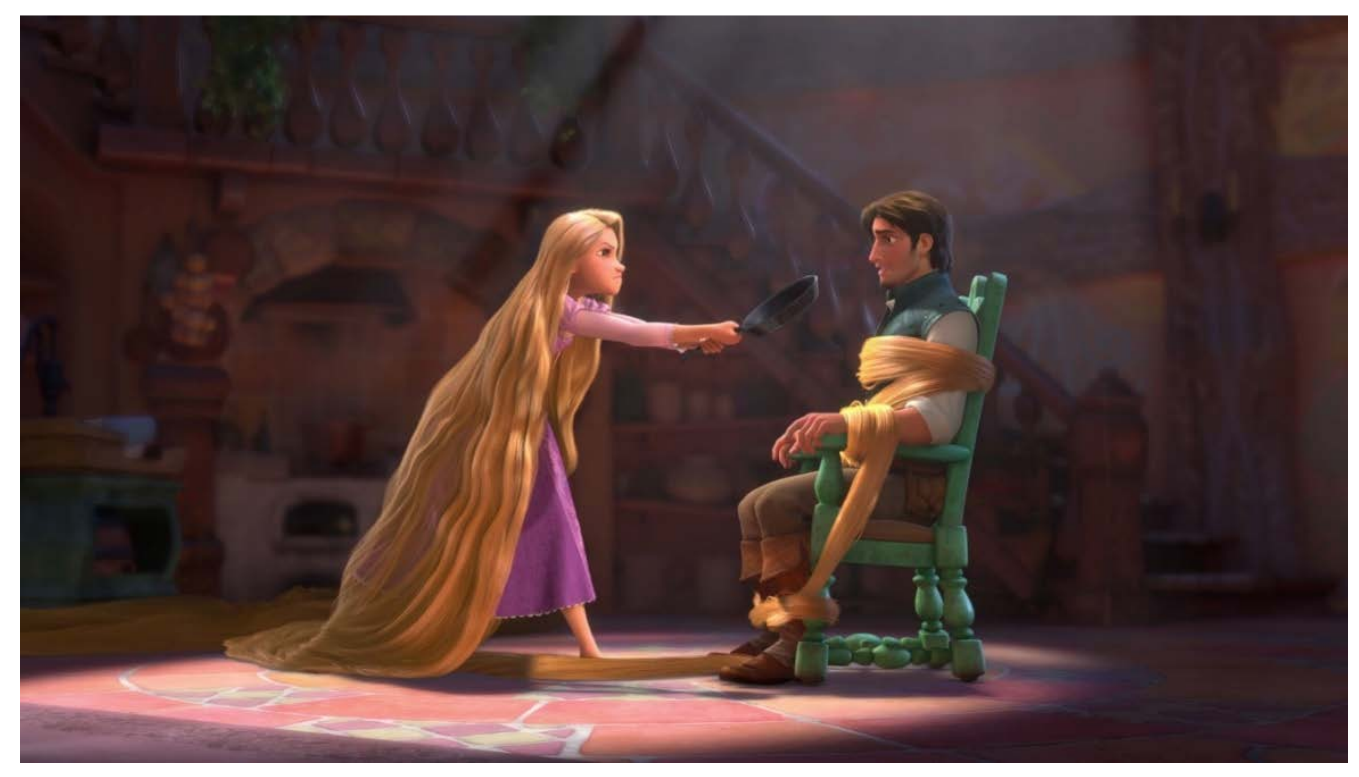

Figura 223 - "Enrolados" (2011) com a historia da Rapunzel é a primeira animação da nova gestão com resultado acima do esperado.

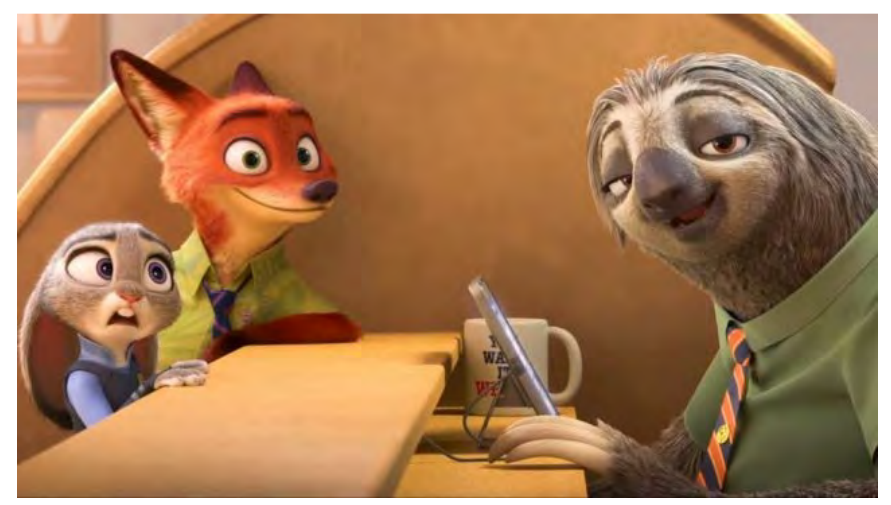

Figura 224 - "Zootopia: Essa Cidade é o Bicho" (2016).

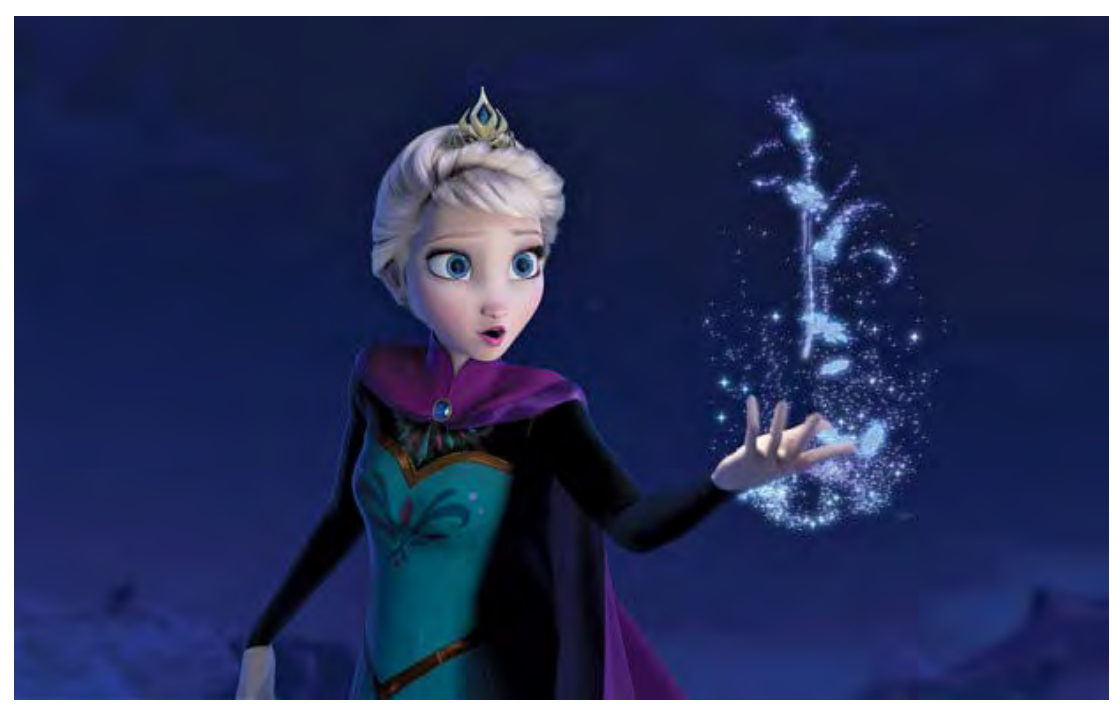

Figura 225 - "Frozen: Uma Aventura Congelante" (2014), o maior sucesso da animação Disney. 


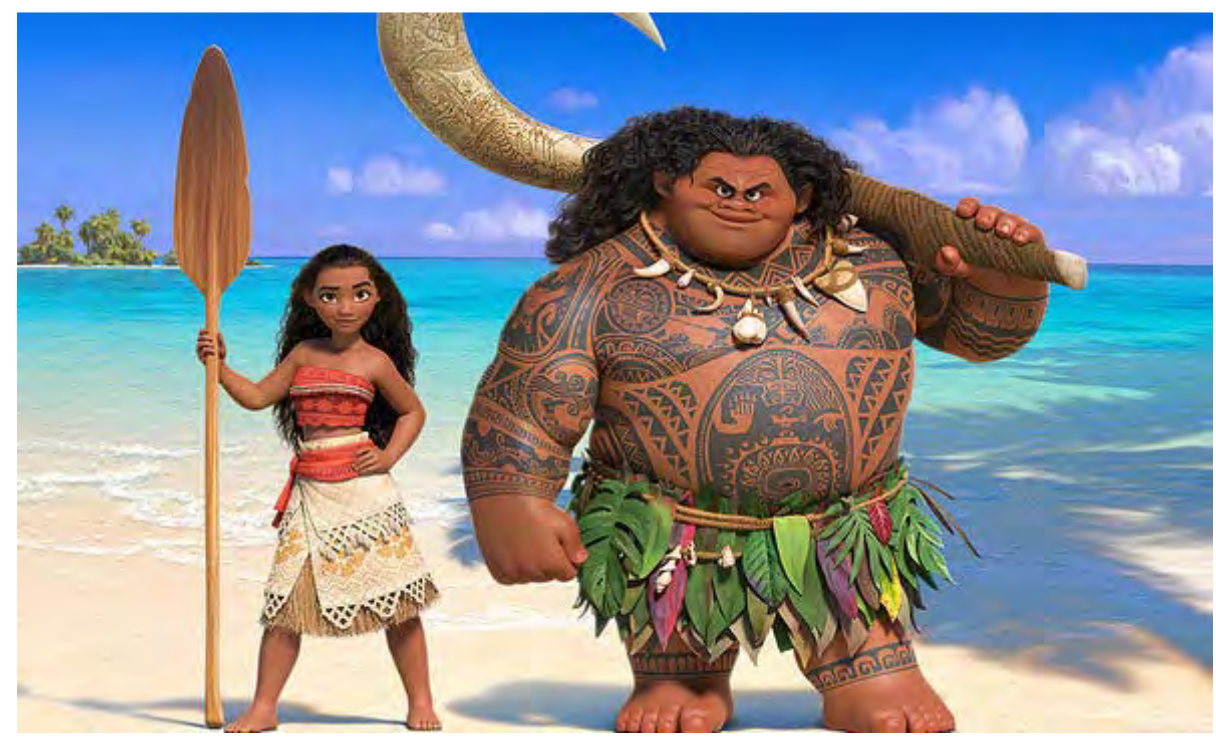

Figura 226 - "Moana” (2016), animação com tema polinésio.

\subsection{A Cultura Digital}

A Disney adquiriu a Marvel Entertaiment, detentora de super-heróis populares das histórias em quadrinhos, num claro empenho de possuir uma força criativa que pudesse, em primeiro lugar, preencher a lacuna do público jovem que a Disney arduamente lutava para agradar e, em segundo, produzir valor espalhando produções derivadas em suas mais diversas áreas.

A origem da busca por esse tipo de matéria-prima ou commodity tem origem na dificuldade encontrada pela indústria do entretenimento em produzir conteúdo original para consumo de massa. São poucos os casos a partir de 2010 em que uma produção original alcança um sucesso de nível global em relação a projetos que são claramente repetições ou baseados em material já muito popular, no caso dos quadrinhos e games. Uma saída para Hollywood foi observar o que ocorria com tecnologia ou, mais especificamente, com a cultura digital.

Há uma série de características que precisam ser compreendidas a partir da questão da percepção das coisas e de como o indivíduo se relaciona com o mundo. No âmbito do trabalho, por exemplo, não são poucas as pessoas que não percebem que a tecnologia proporcionou uma mudança que resulta na jornada de 24 horas de trabalho. O trabalho imaterial (GORZ, 2005) não se limita apenas ao do emprego normal de um indivíduo mas a tudo que ele produza de valor voluntariamente ou não quando se utiliza de aplicativos e mídias sociais. 
O livre arbítrio é um problema grave na sociedade atual, devido ao excesso de opções e possibilidades de escolhas. O que normalmente ocorre é o fato preconizado pelo sociólogo David Riesman (1995) em sua obra “A Multidão Solitária”. Quando analisa o tempo presente, no caso 1950, o autor afirma que não somos definimos pela tradição ou pela certeza de nossos projetos. A orientação viria do que os outros pensam de nós. O indivíduo faz parte de uma multidão solitária, pois dificilmente encontra algum sujeito que seja como ele. Normalmente encontra reflexos das identidades reconhecidas e legitimadas pela multidão. Isso sem dúvida acontece, especialmente no ambiente digital.

Um das características mais fortes da cultura digital é a efemeridade. Lipovetsky (2009) já chamou atenção para a questão de como o individualismo e o consumo ostentatório contribuíram para a moda frívola e efêmera no final do século XX. Porém, isso mudou no século XXI. Lipovetsky e Serroy afirmam que o modelo empresarial foi alterado para uma reorganização baseada no reinado do mix entre arte e mercado, e da fabricação industrial das emoções sensíveis. As empresas adotam um novo modelo econômico, rompendo com o capitalismo da era industrial. Rompe-se com o sistema fordista para um sistema de inovação capitalista baseado na sedução focalizada nos prazeres dos consumidores por meios das imagens e dos sonhos, das formas e dos relatos. A indústria passa a apostar numa estratégia focada nos gostos estético-afetivos dos consumidores, o que os autores nomearam “modelo pós-fordismo ou pós-industrial da economia liberal” (LIPOVETSKY, SERROY, 2015, p. 42).

Esse modelo não representaria a potencialização da preocupação criativa frente às questões comerciais e lucrativas, e sim que as dimensões criativas e imaginárias "se afirmam à medida que se intensificam a financeirização da vida econômica, a "ditadura" do mercado e de seus objetivos a curto prazo" (LIPOVETSKY, SERROY, 2015, p. 42). O capitalismo não é reduzido. Ele é ampliado como podemos observar na expansão da globalização dos mercados de consumo, moda, luxo e grandes empresas de cultura. Esse modelo trabalha com produtos pensados para gerar prazer, diversão e fazer sonhar. O "capitalismo artista", portanto, cria valor econômico por meio do valor estético e da experimentação. O capitalismo assumiria um papel da arte mexendo com o lúdico, com as sensações e os prazeres estéticos (LIPOVETSKY, SERROY, 2015, p. 43). Nesse sentido, os autores comentam que:

Se o casamento econômico com a estética criativa é hoje estrutural, os dispositivos institucionais que o encarnam, assim como o peso crescente do mundo das finanças, 
dão muitas vezes mais prioridades ao primeiro polo que ao segundo. Não sem consequências às vezes nefastas: foi por isso que, nos anos 1990 e 2000, uma major como a Disney, com a sua financeirização e sua pesada máquina burocrática, tornouse lenta em reagir; enquanto numerosos artistas deixavam a companhia, ela não soube antecipar a ascensão do digital e ficou atrasada no domínio dos desenhos animados. (LIPOVETSKY, SERROY, 2014, p. 44-45).

Esta aliança entre "arte" e "capitalismo" não torna o aspecto criativo superior. Como é o intuito desta tese descrever e analisar, os choques são inevitáveis. Temos, de um lado, gestores, marqueteiros e investidores em busca de rentabilidade e eficiência. E, do outro, temos artistas querendo autonomia e liberdade visando ambições artísticas.

O constante bombardeio de informações é responsável por causar uma saturação (CONTRERA, 2000) e o indivíduo tende a não absorver ou interpretar o que é relevante apenas dentro de parâmetros muito restritos. Do ponto de vista da comunicação, temos uma proliferação de textos e vídeos curtos, artigos e reportagens em formato de listas e tópicos, de modo que a leitura seja dinâmica. Isso não significa que as pessoas leiam menos e sim que elas leem uma quantidade maior de um modo diferente. O desafio é o aprofundamento dentro de um contexto quase infinito de informações e como produzir uma hierarquia de conteúdo relevante que extrapole o limite individual. A questão do efêmero transformou a percepção da História:

\footnotetext{
"A palavra "histórico" é agora usada mais em relação aos eventos esportivos do que para os econômicos, políticos e diplomáticos, pois a mídia se concentra no dia (hoje e amanhã) e na semana, muitas vezes sugerindo o que irá acontecer, e não relatando o que já aconteceu. A maior parte das coisas é efêmera" (BURKE, BRIGGS, 2006, p. 329).
}

As mídias sociais também mexem com o status pessoal. O psicólogo e sociólogo Erich Fromm (1976) apontou na década de 1970 para o início de uma mudança nos valores sociais. Até então o indivíduo era valorizado por "ser". Alcançar o status social de "ser" um professor, um empresário, um médico ou um advogado era certeza da obtenção de respeito e valor na sociedade. A partir de meados dos anos 1970, as pessoas passaram a dar prioridade ao ganho financeiro, a serem notadas pelo "ter". E esse prestígio podia ser relacionado tanto a uma posição profissional, ou ter sido um herdeiro ou não ter tido atitudes honestas. A profissão pouco importa em detrimento da possibilidade de adquirir um automóvel de luxo ou uma bolsa de grife. Não surpreendentemente, os salários de profissões antes prestigiosas, como a de professor, foram reduzidos. O que importa é ter dinheiro e posses materiais. 
Nas décadas de 1980 e 1990, o "ser" e o "ter" abriram espaço para o "parecer". Baudrillard (1991) é quem discute bem o simulacro nesta questão. As pessoas em busca de reconhecimento procuram se endividar consumindo bens luxuosos para chamar atenção de outras pessoas. Um indivíduo não precisa ser rico, desde que ele tenha conseguido acesso a certos bens luxuosos. Outra não precisa ser jovem, desde que faça uma cirurgia plástica para "parecer jovem". O consumo de bens de luxo é voltado para a aparência, então pouco importa "parecer que é" e sim "parecer que tem". Isso simboliza, neste contexto, uma determinada posição social para ser legitimado por seus pares (LIPPOVETSKY, 2009).

As décadas de 2000 e 2010 e as mídias sociais potencializaram o "parecer" ao "aparecer". Dada a dinâmica das mídias sociais e o isolacionismo físico onde as pessoas se comunicam mais virtualmente do que frente-a-frente, não basta simplesmente "parecer". Ao indivíduo interessa "aparecer aos olhos dos outros". As pessoas se tornam dependentes da exploração pessoal da própria imagem, publicando e esperando o compartilhamento e o "like" (de aprovação) de fotos com exposição corporal, viagens, participações em festas, encontros com ricos e famosos, etc. Essa preocupação superficial com a transmissão da exposição cria problemas nas relações interpessoais, com hostilidade, angústia, depressão, inveja, entre outros, dada a sensação muitas vezes falsa da felicidade alheia. Essas características comportamentais se fundem ao tipo de postura adotada para consumir bens de consumo digital.

\footnotetext{
Depois do automóvel, os utensílios de cozinha e de banheiro, as escovas de dente, a lingerie, os calçados esportivos, os óculos, os relógios não são mais apenas "produtos técnicos", mas artigos de grife, incessantemente renovados e apresentados em coleções. O iPod foi vestido com capas assinadas por Dior. Phillips e Svarovski colaboraram para coleções de pendrives engastados com cristais em forma de coração, cadeado ou animais. Prada, Armani, Dolce \& Gabbana assinaram celulares, respectivamente, para LG, Samsung e Motorola. É o tempo da mistura transestética entre moda e high-tech. (LIPOVETSKY, SERROY, 2014, p.80).
}

Os modismos e facilidades dos novos aplicativos criaram novas dinâmicas de entretenimento, como os vídeos curtos com canais com milhões de inscritos (YouTube), fenômenos culturais regionais não apreendidos pela mídia mainstream (caso do sertanejo universitário, no Brasil), a criação e popularidade de diferentes mídias sociais, a leitura em e-books, além de mudanças de comportamento no ato de se divertir. O público tem mais escolha. A redução percebida nos cinemas e na TV convencional é relacionada à forte competição no mercado de entretenimento e ao aproveitamento mais rápido do faturamento de DVDs, Blu-rays e atualmente do Video on Demmand, capitalizando os custos de marketing que eram direcionados quase totalmente ao cinema e à TV. 
O Netflix ajudou a modificar toda a dinâmica das janelas de lançamento. As janelas, as distâncias (mercados internacionais separados) e o intervalo temporal estão desaparecendo. O serviço de assinatura mensal para acessar seu acervo de filmes alterou a dinâmica da TV tradicional. Com os novos serviços de exibição (Tabela 14), diminui o sentido de reservar meses entre os lançamentos nos cinemas, mercado de vídeo, TV a cabo e TV aberta. As séries são disponibilizadas online com suas novas temporadas integrais (ULIN, 2014). O usuário pode assistir uma maratona de sua série favorita num único dia e sem intervalos comerciais. Nada impede que, no futuro, os filmes sejam lançados antes via aplicativos de streaming cheguem aos cinemas só depois.

A concorrência começa a crescer e a investir em conteúdo criativo original e não surpreende, portanto, que o Netflix tenha investido pesadamente em sua expansão para 130 países, conquistando território valioso. Estão correndo atrás serviços como o Now, o HBO Go, o ESPN Sync, GloboPlay, todos se utilizando das transmissões VoD (Video on Demand) em que o usuário escolhe o que deseja assistir e o streaming com transmissão em tempo real.

\begin{tabular}{|l|l|l|}
\hline \multicolumn{2}{|c|}{ Mudanças no Consumo e Aparição de Novas Empresas } \\
\cline { 2 - 3 } & \multicolumn{2}{|c|}{ EMPRESAS/PRODUTOS } \\
\hline \multicolumn{2}{|c|}{ Mercado } & \multicolumn{1}{|c|}{ Velha Mídia } \\
\hline Fotografia & \multicolumn{1}{|c|}{ Nova Mídia } \\
\hline Conhecimento & Polaroid, Kodak, Fuji & fotografia digital/telefone celular \\
\hline Música & Enciclopédias/Base de dados/Encarta & Google/Wikipedia/Bibliotecas digitais \\
\hline Jornalismo impresso & Gravadoras & Napster, Spotify, iTunes, etc. \\
\hline Rádio & Folha de S. Paulo, The New York Times & Blogs, Website, streaming, BuzzFeed \\
\hline Telefonia & CBN, Jovem Pan, Band News FM. & Podcasts, streaming \\
\hline Editorial & Telefônica, AT\&T & Facetime, Whatsapp, Snapchat, Periscope \\
\hline Leilão/Compras & Barnes \& Noble (livrarias), editoras & Kobo, Kindle, iPad (tablets), Amazon \\
\hline Cinema e TV & Sotheby's, Christies & Ebay, Mercado Livre, Alibaba \\
\hline Hospedagem & Disney, Warner, ABC, CNN, BBC, Globo & YouTube, Hulu, Vine, Vimeo, Amazon, Netflix \\
\hline Transporte & Hoteis & AirBnb* \\
\hline Games & Taxi & Uber, Lyft* \\
\hline Correspondência & Sega, Nintendo, (consoles) & Sony, Xbox, (streaming, crossmedia, ativistas) \\
\hline \multicolumn{2}{|l|}{} & E-mail, Messenger, Facebook, Twitter, Instagram \\
\hline *Empresas de tecnologia que oferecem serviços de viés sustentável da chamada "economia compartilhada". \\
\hline
\end{tabular}

Tabela 14 - Cultura Digital e a criação de novos modelos de negócio.

A Disney, mais focada em tecnologia, percebeu antes das concorrentes a transformação. A venda de DVDs foi a fonte primária dos lucros dos estúdios por mais de uma década. Porém, começaram a sofrer sucessivas quedas nas vendas (8,4\% em 2008, 13,3\% em 2009). Com faturamento de US\$ 8,5 bilhões, a venda de DVDs em 2009 igualou ao total de 2001. Esse valor deixou a venda 
de DVDs ficar abaixo do faturamento dos cinemas pela primeira vez desde o ano 2000. O declínio foi explicado pela ampliação do mercado de aluguel de filmes, revigorado por parcerias com grandes redes do varejo como McDonalds e Wal-Mart, e o vídeo on demand (VoD) de serviços como Netflix e Amazon, que cresceram 85\% entre 2006 e 2009 (HITT, IRELAND, HOSKISSON, 2014, p. 273). Nesse sentido,

[Bob Iger afirma que] a Disney foi a primeira companhia a distribuir filmes numa plataforma digital, o iTunes e via streaming investindo na plataforma de vídeo Hulu. [A primeira em] ampliar a capacidade de assinantes de TV a cabo para que possam assistir o conteúdo também via internet. As pessoas estão mais dispostas a pagar por qualidade, pela escolha e pela conveniência de uma plataforma de fácil navegação e também pagam pelo valor criativo do que consomem. As pessoas estão condicionadas a obter conteúdo gratuito, mas há o pensamento de que se você oferece um conteúdo com mais qualidade é possível monetizar essa distribuição para bancar a produção. Segundo estatísticas da própria Disney em 2009, um espectador investia US\$ 5 a hora para ver filmes numa sala de cinema. Gastam US\$ 0,75 a hora para ler livros, jornais e revistas. Se você assina um serviço de TV por assinatura, você investe US $\$ 0,50$ a hora. E se você assina um provedor de internet isso custa US $\$ 0,25$ a hora. Isso sem contar música, games e outros tipos de consumo na mídia. $\mathrm{O}$ resultado da pesquisa mostrou que as pessoas teriam maior capacidade de gastar mais em conteúdo nas plataformas online. Tudo graças a maior interconectividade e velocidade de conexão. Não existe somente uma forma de monetizar a internet. Existem múltiplos meios de fazer dinheiro. Primeiro pelo alto poder de interatividade e pela capacidade de observar o comportamento do consumo. Então isso ultrapassa a primeira forma de faturar que seria a propaganda, padrão básico da "velha mídia", há o micropagamento - a capacidade de pagar muito pouco pelo consumo de pequenas porções de conteúdo, o cruzamento desse conteúdo com as mídias sociais e os chamados mundos virtuais, o sistema "pay for content" - o sistema usado pelo iTunes para vender música e filmes e finalmente a assinatura - um modelo em que uma pessoa pode querer pagar um valor maior se considerar o conteúdo realmente muito bom. Por isso a Disney está atenta a todas as formas de monetização. Entretanto é importante frisar que a Disney se vê como produtora de conteúdo e não distribuidora (SIKLOS, 2009).

A Disney foi pioneira em compreender o movimento e anunciou em 2010 a redução das janelas de lançamento começando com “Alice no País das Maravilhas" (2010), filme de Tim Burton que seria o primeiro filme a surfar na onda da experiência do 3D estereoscópico nos cinemas. O plano de lançálo em DVD somente três meses após os cinemas enfureceu os donos de cadeias exibidoras (POMERANTZ, 2010). Porém, a estratégia era concentrar esforços na estreia sabendo que o grosso do faturamento nos cinemas geralmente é ganho nas primeiras três semanas, com especial atenção ao final de semana de lançamento.

O lançamento em VoD também é vantajoso se os estúdios eliminarem os intermediários e mantenham seus próprios aplicativos de distribuição de filmes. A Disney estava interessada em adquirir a 
BuzzFeed - uma rede multi-canal que produz conteúdo noticioso e de entretenimento para o YouTube - por sua capacidade de usar as novas tecnologias de produzir e distribuir conteúdo de curta duração e gostariam de usar em algumas áreas da companhia. O negócio, porém, não foi adiante. A Disney adquiriu a Maker por US\$ 500 milhões por sua estrutura de produção de conteúdo em curta-duração e sua capacidade de atrair produção, fazer boa distribuição e conseguir vender pelo uso de propaganda. De acordo com Bob Iger, a Disney chegou a conclusão que possuía a excelência para produzir, distribuir e vender conteúdo de longa-duração (Long-Form content), e faltava a expertise para os de curta (Short-Form content). O negócio pareceu promissor por ser uma área em que a Disney ainda não atua de forma profunda. Iger prossegue:

A Maker possui cerca de 12 bilhões de visualizações por mês e uma rede de 60 mil produtores de conteúdo para a produtora, e cerca de 10 mil candidatos por semana se inscrevem para que a Maker avalie e possa facilitar a distribuição. Destes, geralmente 100 são escolhidos. A fusão permite que os produtores da Maker tenham acesso ao material criativo protegido por direitos autorais da Disney, e a companhia, por sua vez, tem acesso a plataforma para promover seus lançamentos.

Por exemplo, canais com produtores mostravam ações como abertura de caixas exibindo novos brinquedos de Star Wars, deste modo lançaram os produtos relacionados a franquia mundialmente. É uma boa ferramenta para o marketing dos filmes. A decisão ou não comprar uma companhia como a Maker tem relação com os objetivos do planejamento estratégico da Disney. Iger afirma que a companhia realizou estudos para avaliar quanto tempo levaria para criar uma estrutura igual a do BuzzFeed. Os engenheiros levariam cerca de 5 anos, tempo considerado longo demais tamanha velocidade da evolução tecnológica. Decidiu-se, portanto, pela compra da empresa que tinha o domínio do modelo (SWISHER, 2015).

Na última década houve a popularização do formato de filme/vídeo de curta duração por conta das pequenas telas. Há alguns anos a Disney criou uma iniciativa para tornar Mickey Mouse relevante novamente para a geração mais jovem. E a primeira coisa que os executivos fizeram foi darem uma espiada em dezenas de curtas-metragens de animação produzidos pelo próprio Walt Disney a partir de 1928 até os anos 1950. E a partir daí pensaram em restaurá-los para um relançamento. Durante as exibições os executivos se deram conta de como as narrativas desses curtas de 8-9 minutos parecem arrastadas para a audiência de hoje, como se fossem minisséries. Houve uma grande discussão se o estúdio deveria cortar esses curtas clássicos (SWISHER, 2015). A decisão tomada foi editá-los para cerca de 3 minutos com uma nova trilha sonora e eles ficaram bons, mas não excelentes porque mesmo assim pareciam longos. Então uma nova série com traços estilizados foi produzida com uma 
duração entre um minuto e meio a 2 minutos. E se você olhar a nova geração que consome YouTube, BuzzFeed, Vine, Instagram, os conteúdos narrativos estão se tornando cada vez mais curtos.

[Iger analisa que] é necessário ter uma mão no presente e uma no futuro - as duas num lugar só podem lhe fazer fracassar. Não adiante pensar no futuro sempre pensar nas complexidades do presente. É preciso observar o mundo em mudança e o que o consumidor está fazendo. Quando o conteúdo de seriados e filmes foi colocado no iTunes, o chão se abriu embaixo de grandes parceiros como varejistas que vendiam os DVDs, serviços de TV a cabo, emissoras afiliadas e grandes redes de cinema. Foi necessário respeitar as preocupações de todas essas empresas, mas era mais importante respeitar as necessidades dos consumidores. A geração 2000 não difere online e off-line e está procurando cada vez mais entretenimento na plataforma online. Se a indústria do entretenimento da velha mídia não embarcar nessa mudança de paradigma corre o risco de se tornar marginalizada ou irrelevante. Talvez o maior trauma tenha sido sentido pelas gigantescas gravadoras que perderam muito dinheiro por não saber como dialogar com as novas mídias. Ficaram presas a um modelo de negócio antiquado de vender um CD de 12 músicas por um valor fechado. E quando o consumidor percebeu que as gravadoras e os varejistas não lhe traziam conveniência frente as inovações oferecidas, esse mercado foi corroído pela explosão da pirataria. Atualmente a indústria da música possui um faturamento considerável nas novas plataformas, mas talvez não as que fossem esperadas se erros não tivessem sido cometidos no passado com metas infladas (SIKLOS, 2009, tradução nossa).

A publicidade ainda continua forte na TV aberta e fechada (a cabo). Devido ao processo de infantilização do cinema americano para agradar ainda mais um público homogêneo, as TVs, especialmente a fechada, se tornaram celeiros de grandes produções, dando espaço para talentos criativos explorarem temas mais adultos, violência e sexo, temas épicos e fantasiosos. É o caso do seriado "Game of Thones" (2011) na HBO, que decidiu apostar em seriados originais quando viu seu acervo de filmes começar a ser acessado pelo público nos aplicativos VoD.

A Disney também produz para televisão. Sobre o tema, Bob Iger explica:

não há preocupação desde que sigam três fatores: $O$ conteúdo precisa ser muito bom (talvez utilizando o poder da marca para atrair audiência), é necessário ter navegação e interface muito boas de forma a permitir que o usuário encontre o conteúdo. E é necessário ter mobilidade. Em suma, bom conteúdo, boa navegação e boa mobilidade. E atualmente a maioria dos provedores de TV por assinatura ainda não conseguem fornecer mobilidade. Eles podem, mas ainda não possuem capacidade. E a navegação e interface são grandes problemas (SWISHER, 2015).

A concorrência ocorre quando o conteúdo produzido pelo BuzzFeed ou pela Maker se apresenta mais atrativo do que os oferecidos pelos serviços convencionais off-line. O último jogo de futebol americano na ESPN mostrou um dado interessante. O número de espectadores assistindo ao jogo em aplicativos de seus smartphones dobrou em um ano. E a nova geração tende a não consumir 
a programação de TV com a grade linear atual, e sim em partes, conforme sua conveniência e nos aparelhos como smartphones, tablets ou o que aparecer no futuro.

A rede de canais esportivos ESPN americana perdeu 3,2 milhões de assinantes em pouco mais de um ano. Trata-se de uma combinação de fatores. Uma parcela do público tem preferido fazer um downgrade dos pacotes de TV por assinatura, e isso elimina a ESPN. Outro fator é o alto preço pago para transmitir as competições. As concorrentes Fox Sports e NBC/Universal Sports estão "roubando" conteúdo da rival (SMITH, SHAW, 2015). A solução novamente foi investir em aplicativos que já representam uma audiência razoável para a ESPN. Não é coincidência que a Disney esteja testando seus próprios aplicativos explorando seu acervo - é o caso do DisneyLife que estreou em novembro de 2015, oferecendo seriados e longas-metragens da marca Disney por um preço fechado.

\subsection{A Aquisição e o impacto da MARVEL}

Com os suportes de comunicação em constante mudança, existem os desafios de acertar um sucesso nos cinemas que, em primeiro lugar, alcance grande sucesso, e, em segundo, tenha capacidade de desdobrar o sucesso em outras mídias. A Disney acertou a mão apostando em franquias que têm o poder de repetir o potencial de sucesso e tornar perene a força de publicidade para que os produtos derivados permaneçam por mais tempo à venda. Assim como fez com a Pixar, a decisão foi adquirir um conteúdo criativo popular e legitimado que pudesse ser potencializado pela estrutura de uma corporação de mídia. É nesse ponto que entram os super-heróis dos quadrinhos da Marvel Entertainment.

A crise de vendas nas histórias em quadrinhos da Marvel Comics nos anos 1990 foi um grande ponto de virada, pois representou uma série de abordagens para tentar salvar a editora, relacionando os super-heróis a diversas franquias cinematográficas. O antigo CEO, Ron Perelman, atraiu uma série de executivos competentes que tinham pouco espaço de manobra para revitalizar a editora.

A Marvel sob a gestão de Scott Sassa acumulava sucessivos prejuízos e injeções de investidores, que começaram a rarear ou perder o efeito por falta de uma boa estratégia. Um dos acordos foi com os bilionários Isaac "Ike" Perlmutter e Avi Arad envolvendo licenciamento sua empresa de brinquedos do primeiro, a Toy Biz. Em 1996, os prejuízos na Marvel estavam na casa dos US\$ 400 milhões. A briga entre 1996 e 1998 se resumia a uma completa disputa entre os dois titãs da 
Marvel, Ronald Perelman e Carl Icahn, e duas forças que estavam nos bastidores: os bancos aos quais a Marvel devia dinheiro e a empresa Toy Biz, de Ike Perlmutter, que tentava proteger sua licença exclusiva e vitalícia para produzir os brinquedos Marvel (HOWE, 2012, p. 405-407). As desavenças financeiras foram parar nos tribunais, incluindo até a criação de novos universos e personagens em 21 novos gibis, que os executivos da Marvel não conseguiam nomear ou detalhar.

Embora as diversas ações erráticas para levantar a editora, o executivo Joe Calamari obteve espaço para a exploração dos personagens Marvel nos cinemas. Porém, os projetos eram lentos "Blade", baseado no personagem da "Tumba de Drácula" de Marv Wolfman e Gene Colan, ficou uma década em desenvolvimento, mas estava prestes a ser produzido. Porém, todos os demais filmes baseados nos super-heróis permaneciam em pré-produção, caso de Surfista Prateado, Quarteto Fantástico, X-Men, Demolidor e Doutor Estranho. A situação irritava Avi Arad que controlava a Marvel Studios, e, pior ainda, pois a Toy Biz insistia em tentativas de controle acionário da Marvel em nome de sua segurança.

Durante uma discussão com os bancos para defender proposta de acordo com os investidores, Arad usou sua melhor retórica para convencê-los sobre o valor dos personagens:

Vivemos num dos países mais criativos do mundo. Mas olhem à sua volta e vejam como são poucos os personagens que duraram. Temos Star Wars, talvez Star Trek, e você fica em apuros para dar o nome de outros personagens que tenham sobrevivido tanto tempo. Eu tenho confiança de que o Homem-Aranha, só ele, vale sozinho um bilhão de dólares. Mas agora, neste momento calamitoso, nessa situação, vocês vão aceitar 380 milhões - ou que quer seja de Carl Ichahn - em troca de tudo? Uma das propriedades vale um bilhão! Temos X-Men. Temos Quarteto Fantástico. Todos podem virar filmes". (HOWE, 2012, p. 410).

A discussão rendeu outro resultado. A Toy Biz comprou parte das dívidas da Marvel para ter votos quando os bancos finalmente decidissem o plano de reestruturação. Calamari iniciou um processo de reforma da editora, trazendo Joe Quesada e Jimmy Palmiotti, quadrinistas com vasta experiência editorial e com bom trânsito na área. E havia um fator importante - os contatos com gente de Hollywood. Uma das primeiras ações foi convidar o cineasta e roteirista Kevin Smith para escrever a HQ do Demolidor, cuja revista estava prestes a ser cancelada.

Outros três títulos foram reformados - Inumanos, Pantera-Negra e Justiceiro - tudo com orçamento limitado da Marvel, mas o suficiente para atrair bons profissionais e equipamentos. E, no ano seguinte, a estratégia se repetiu com a criação da nova série "Heróis Renascem" com novos títulos 
de Capitão América, Vingadores, Quarteto Fantástico e Homem de Ferro (HOWE, 2012, p. 411-412). No entanto, a confusão entre os executivos sobre quem mandava em quê e as brigas no tribunal de falência tornavam a administração da editora muito complicada - os executivos que aprovaram os novos títulos não estavam mais lá quando eles foram lançados. Os novos, por sua vez, tentavam se virar com as decisões para os próximos passos. A produção de quadrinhos na redação era caótica.

Essa confusão só terminou quando a Toy Biz de Ike Perlmutter finalmente comprou a Marvel. $\mathrm{O}$ timing foi positivo, pois os primeiros resultados da Marvel nos cinemas começavam a aparecer. O lançamento de "Blade" pela New Line (braço da Warner Bros.) faturou US\$ 70 milhões. E isso porque Blade era considerado por Avi Arad o "patinho feio" da Marvel. De repente, Hollywood e Marvel abriram seus olhos para a possibilidade para uma franquia com os super-heróis dos quadrinhos. Na editora, Quesada e Palmiotti usavam suas melhores ferramentas de marketing para alavancar os quadrinhos e fazer pontes com diretores e produtores de Hollywood. Sucessos à parte, a Marvel permanecia financeiramente quebrada. Recebera somente US\$ 25 mil da New Line pelo sucesso de "Blade". A produção dos quadrinhos não era eficiente e a editora ainda sobrevivia graças a um empréstimo de US\$ 200 milhões.

O CEO da Marvel, Perlmutter iniciou um processo de cortes começando pelos executivos mais bem pagos (caso de Joe Calamari) até a revisão do contrato vitalício que dava a Stan Lee (o criador dos super-heróis, que era o rosto público da Marvel) US\$ 500 mil anuais. Chegou-se ao exagero de cobrar dinheiro de volta dos freelancers, com a justificativa de que os valores estavam superfaturados (HOWE, 2012, p. 418). A única ação positiva do período foi um acerto para vender os direitos do Homem-Aranha para que a Sony/Columbia finalmente o adaptasse para os cinemas. E mesmo esta vitória ganhou repercussão negativa com a quebra do silêncio do roteirista e desenhista Steve Dikto, que alegava não ser reconhecido como autor do Homem-Aranha. Lee teria dado apenas a ideia (SADOVSKI, 2014). Era mais um debate em meio aos processos jurídicos de artistas que tentavam obter reconhecimento e retorno financeiro de suas criações na Marvel Comics.

Peter Cuneo foi o terceiro executive escalado para dirigir a Marvel. Ele não acompanhava os quadrinhos assim como Perelman. Porém, o executivo tinha uma carta escondida no colete - a estratégia da criação de um vínculo emocional com o consumidor. Essa ideia funciona com quase todo tipo de produto, e ele enxergava na Marvel um grande futuro, não somente com filmes, mas em marketing cruzado de videogames, redes de fast-food, refrigerantes, guloseimas e o que fosse imaginável. Tentava copiar o que gigantes como a Disney fizeram, trabalhando a sinergia de suas 
criações. A solução foi usar a Marvel Characters Group para administrar os super-heróis como marcas (HOWE, 2012, p. 421).

As grandes majors sabiam muito gerenciar a sinergia de seus filmes. Entretanto, a Marvel tinha dificuldades na gestão de suas criações. Vendeu os direitos de exploração de seus super-heróis para os parques temáticos da Universal Studios, na costa leste dos Estados Unidos A Fox, por exemplo, antecipou o lançamento do primeiro filme da franquia "X-Men" e pegou a Marvel despreparada, sem nenhum produto no mercado - não havia graphic novel e nem anúncio na TV. Os produtos disponíveis eram para crianças e o filme focava num público na faixa dos 20 anos. O caso dos X-Men foi emblemático pois havia uma enorme batalha criativa e interferência editorial na produção de quadrinhos. Os editores começavam a levar a sério o que os fãs pediam (mais histórias de algum personagem, a retirada de outro, uma mudança de atitude) e isso era usado como estratégia para cobrar alterações aos artistas (GORDON et al, 2007).

Havia um aumento da burocracia interna e um descompasso entre o que era lançado nos cinemas e o que era produzido nos quadrinhos. Bill Jemas, executivo recrutado por Peter Cuneo para cuidar das operações diárias como presidente, reprovava o que acontecia aos X-Men. Reclamava que as histórias em quadrinhos não eram acessíveis e os personagens estavam envelhecendo, dizendo que eram "personagens projetados como adolescentes, andavam por aí de cavanhaque, barba e filhos" (HOWE, 2012, p. 423). A sugestão foi destruir o Universo Marvel e recomeçar do zero. Porém, a decisão final foi a criação de um universo paralelo, chamado "Ultimate", com versões jovens dos personagens da Marvel. Joe Quesada se tornou figura central em revigorar os super-heróis, trabalhando cada personagem em sua "metáfora central" e desenvolvendo melhor seus universos singulares. 


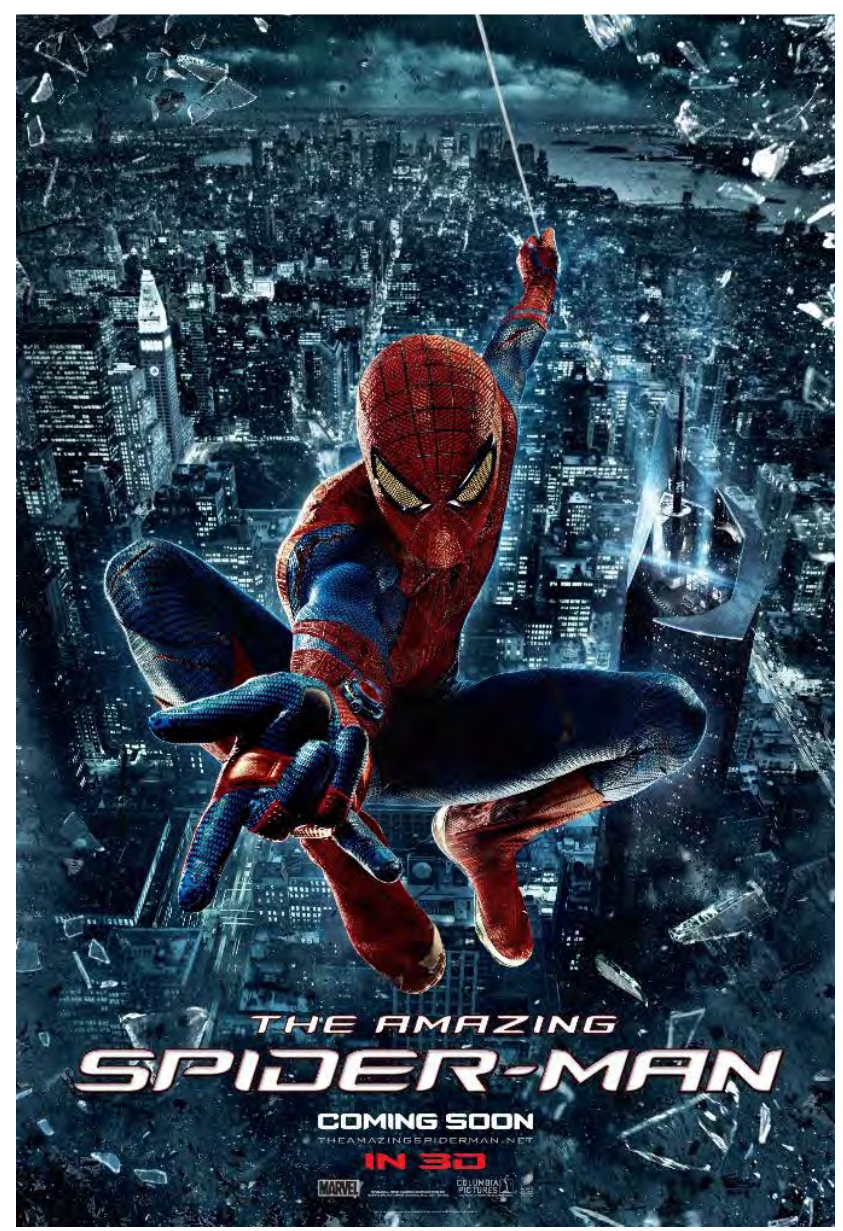

Figura 227 - "O Espetacular Homem-Aranha" - personagem licenciado para a Sony.

A estratégia de Bill Jemas era simplificar o Universo Marvel. Eram dele, por exemplo, ideias mirabolantes e consideradas blasfêmias, sobre como produzir histórias que revelassem situações que por anos eram vistas como misteriosas (a origem de Wolverine foi uma delas) e delimitar arcos de histórias, para que os quadrinhos pudessem ser facilmente relançados em volumes únicos, encadernados. Jemas e Quesada se tornaram os rostos públicos da Marvel na internet, ampliando o relacionamento com fãs, e o primeiro não era nada diplomático ao criticar publicamente gibis ruins e artistas/roteiristas que não eram escolhidos por seu talento.

A Marvel conseguiu negociar bons acordos com os estúdios de Hollywood, garantindo uma porcentagem do lucro bruto e não o liquido. Tratava-se de uma conquista marcante, pois enquanto "Homem-Aranha" (2002) estava nos cinemas, adaptações de grande orçamento estavam sendo preparadas para o "Hulk", "Demolidor" e "X-Men 2". Os super-heróis finalmente se tornaram uma mania em Hollywood e uma forma de atrair multidões aos cinemas. 
Do ponto de vista editorial, entretanto, a Marvel continuava patinando. Havia uma fraca recuperação do mercado de revistas em quadrinhos, porém, ele se resumia a apenas um quarto do que era nos anos 1990. 85\% das vendas se concentravam em lojas de quadrinhos e não se enxergava uma forma de renovar os leitores. O próprio Joe Quesada considera que "leitores de 8 anos" eram um mito (HOWE, 2012, p. 436). E a estratégia da Marvel não seguia uma política que atraísse crianças aos quadrinhos. Para Bill Jemas, o sucesso na TV de "Buffy: A Caça-Vampiro" (1997-2003) - Figura 228 - resumia tudo o que ele queria: "uma série prolongada com estrelas jovens e atraentes, esmerada na sua mitologia, que ainda era acessível ao novo público". Para o executivo, afugentar os nerds que formavam sua base de leitores era seu foco primário em prol de uma nova audiência mais abrangente:

Sempre existiu esse cabo de guerra ao tratar de um projeto, se ele devia almejar o mercado "central" e leal dos fãs dedicados (fanboys) ou o grande público de fãs da Marvel no "mercado de massa". [Após uma série de discussões públicas entre Joe Quesada e o roteirista Peter David sobre a decadência de "Capitão Marvel", Jemas provocou] "Peter é um roteirista que mostra o talento em duas ou três edições por ano, mas o resto é só piadinha interna para os fãs que leem o que ele faz há vinte anos. Ele só está retomando o que já foi feito. Eu acho que ele precisa fazer histórias mais acessíveis aos novos leitores. Senão, está condenado (HOWE, 2012, p. 437).

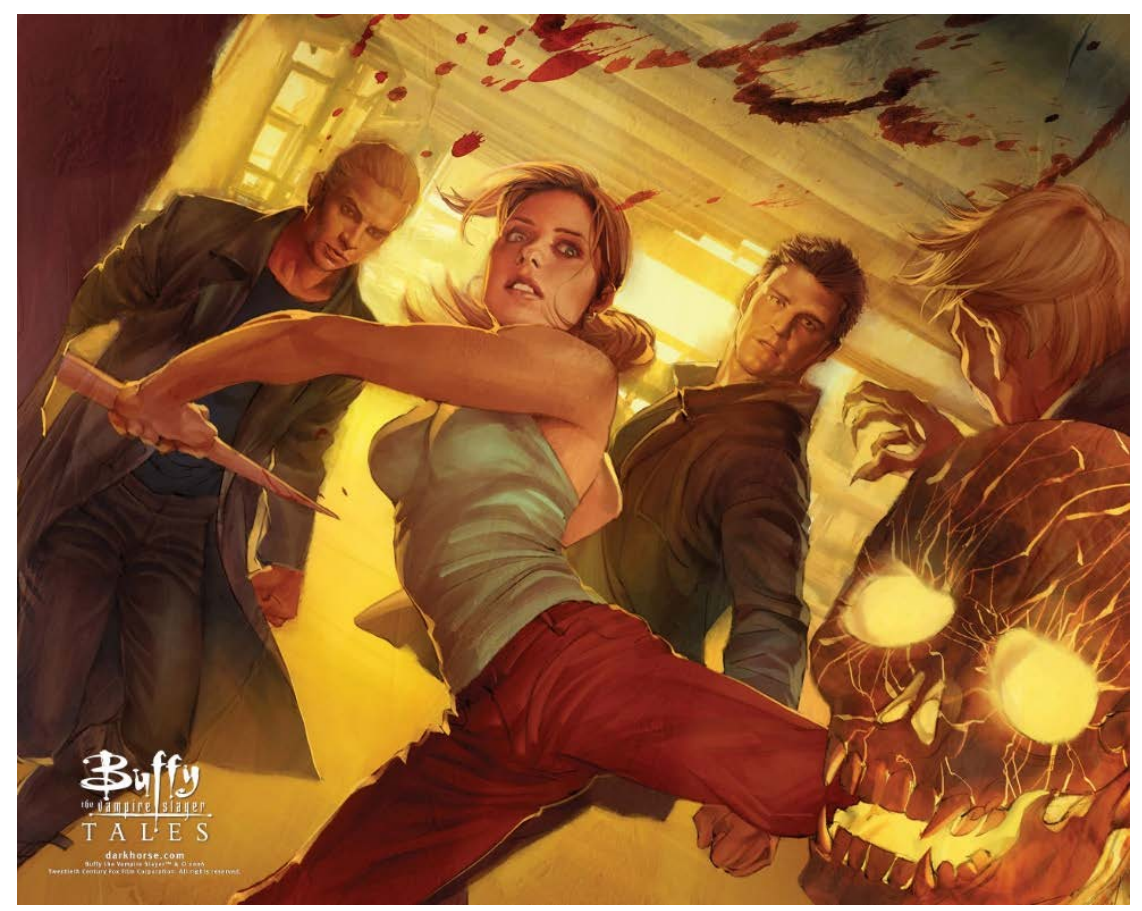

Figura 228 - "Buffy, a Caça-Vampiros", editora Dark Horse.

Enquanto Bill Jemas tinha relativa segurança pelo apoio que lhe era dado por Perlmutter, Avi Arad (o braço direito do dono) considerava as ações de Jemas problemáticas. Arad agia como mediador em conflitos com as estrelas de Hollywood. Atores como Michelle Pfeiffer e George Clooney criticavam o excesso de violência nos quadrinhos. A pressão de Hollywood resultou no 
aumento de atritos entre Arad e Jemas e um controle maior sobre a produção editorial. Os atritos se desdobravam na equipe criativa. Finalmente, em 2004, a Marvel passou por uma outra mudança, adotando definitivamente a estratégia dos universos para alacancar os super-heróis e ampliar o público leitor:

\begin{abstract}
A Marvel estava empregando análise estatística para alimentar informações sobre performance de autores e personagens em algoritmos que pudessem determinar lançamentos, cancelamentos e frequência de publicação. A editoria adotou o conceito de crossovers como nunca, com uma corrente incansável de tramas grandiosas que determinariam os rumos de diversos títulos. Por sua vez, cada um desses mega-arcos - que incluíam prólogos, epílogos e até séries mensais derivadas - alimentava o seguinte. Grandes personagens eram desmontados, morriam em explosões, sacrificavam-se, perdiam a memória, recuperavam a memória, perdiam os poderes ou revelavam-se aliens Skrulls transmorfos que há anos se passavam pelos personagens verdadeiros enquanto o original estava em cativeiro numa espaçonave (HOWE, 2012, p. 443).
\end{abstract}

Um fato importante da produção era que, a exemplo do que passou a ocorrer na Disney e na Pixar, as histórias eram concebidas por um comitê de "notáveis". As chamadas "cúpulas de escritores" funcionavam em conferências periódicas, nas quais um núcleo central de roteiristas (incluindo veteranos de Hollywood como Jeph Loeb e J. Michael Straczynski) reuniam-se com os editores e estrategicamente planejavam os próximos meses de produção. A criação funcionava da mesma forma com que séries de TV são desenvolvidas, pensando em próximas temporadas e produtos derivados. Os quadrinistas aqui não reclamavam publicamente da interferência editorial e da falta de visibilidade. Questionar sua fatia nos lucros bilionários da exploração é praticamente impossível, pois

Na indústria de quadrinhos do século XXI, quem se dava melhor era quem não tinha ilusão quanto à propriedade da viabilidade comercial em relação à expressão individual (Em troca das contribuições, eles eram recompensados com a oportunidade de publicar material autoral pela Marvel, por meio de uma nova linha chamada Icon. A divulgação desses títulos ficava a cargo deles) (HOWE, 2012, p. 443).

A última ação da Marvel antes da aquisição pela Disney foi o auto-gerenciamento dos filmes hollywoodianos e a aplicação da lógica do universo cinematográfico compartilhado nos cinemas. Desde o final dos anos 1990, a Marvel havia se transformado na maior fornecedora de matérias-prima na forma de seus super-heróis para a produção de franquias cinematográficas. A Fox tinha os direitos de X-Men, Demolidor e Elektra; a Sony/Columbia tinha o Homem-Aranha e o Motoqueiro Fantasma. A Universal produziu Hulk. E a New Line explorava Blade. Até 2005, os estúdios faturaram mundialmente US\$ 3,6 bilhões com os super-heróis. Porém, a Marvel continuava a receber pouco 
pelo material. Os dois primeiros filmes do Homem-Aranha renderam US\$ 1,6 bilhão aos estúdios Sony/Columbia - a parte da Marvel foi US\$ 75 milhões e nenhum centavo do mercado de DVDs.

O projeto de Avi Arad era tomar as rédeas do controle garantindo maior retorno financeiro. A ideia consistiu em retomar os direitos de Homem de Ferro da New Line e iniciar a produção de filmes dedicados a cada um dos personagens da marca/universo "Vingadores". Produziram um filme do Capitão América, um do Thor (ambos distribuídos pela Paramount Pictures), refizeram Hulk (2008) e, finalmente, combinaram todos os personagens num "mega filme" com todos eles juntos - "Os Vingadores" (2012), este já distribuído pela Disney, rendendo US\$ 1 bilhão. Uma briga interna em torno da velocidade das produções e a escolha dos personagens colocou os executivos Avi Arad e David Maisel em campos opostos. Desta vez o mercurial Perlmutter defendeu a estratégia de Maisel, forçando Arad a pedir demissão.

Em 31 de agosto de 2009, após meses de negociação, a Disney anunciou a compra da Marvel Entertainment. Ike Perlmutter recebeu US\$ 800 milhões em espécie, US\$ 589 milhões em ações, porém preferiu rejeitar uma cadeira no conselho de administração da Disney (FRITZ, 2009).

É interessante que a aquisição da Marvel pela Disney ocorreu num contexto em que um modismo tecnológico começava se mostrar saturado. A popularidade dos filmes 3D estereoscópicos nos cinemas entraram em decadência pelo fato da tecnologia em si ter mais protagonismo que o conteúdo dos diversos filmes mal produzidos ou com histórias ruins, que saturavam o mercado cinematográfico. A esperança de revolucionar com a TV 3D foi também um sobressalto, sem grandes avanços. Algumas produtoras especializadas sentiram o baque. Foi o caso da ImageMovers 3D, uma joint-venture entre a Disney e o cineasta Robert Zemeckis, criada em 2007 para produzir animações usando a tecnologia de motion-capture (consistindo de atores vestindo roupas com sensores, que informam os movimentos detalhados aos computadores). Zemeckis havia produzido uma série de filmes com a tecnologia para outros estúdios, como "A Casa Monstro" (Monster House, 2006) para a Columbia e "A Lenda de Beowulf" (Beowulf, 2007) para a Paramount. O primeiro filme para a Disney, "Um Conto de Natal” (A Christmas Carol, 2009), custou quase US\$ 200 milhões e retornou US\$ 325 milhões - um valor baixo em relação ao investimento, com a gravidade da produção não ter o potencial para se desdobrar nas demais mídias. Foi o suficiente para a Disney encerrar o acordo antes mesmo do lançamento do segundo e último filme da parceria, "Marte precisa de Mães" (Mars Need Moms, 2011) - o filme custou US\$ 150 milhões para ser produzido e faturou US\$ 39,5 milhões nas bilheterias - e ter projetos em desenvolvimento como os remakes de "Yellow Submarine" e uma 
continuação de "Uma Cilada para Roger Rabbit". Temos aqui mais um exemplo de saturação e meltdown (colapso) de uma companhia criativa:

[Robert Zemeckis] e a equipe inteira da ImageMovers construíram com sucesso um estúdio de última geração e produziram um filme incrível, "Um Conto de Natal", num período em que as dinâmicas da indústria estão mudando rapidamente. Porém, dado as realidades econômicas atuais, nós necessitamos encontrar caminhos alternativos de levar conteúdo criativo para o público e a ImageMovers não se encaixa mais em nosso modelo de negócio", afirmou Alan Bergman, então presidente do The Walt Disney Studios. (FINKE, 2010, tradução nossa).

A Marvel opera na Disney como um grande celeiro de personagens e universos cujo conteúdo é produzido cuidadosamente para se espalhar em vários suportes de mídia. Se a Pixar representou o preenchimento de uma lacuna na habilidade da Disney em produzir animações pretensamente com mais qualidade, o benefício trazido pela Marvel é a monetização dos personagens dos quadrinhos da Marvel usando as várias plataformas de entretenimento. A estratégia é lidar com o fato de que as novas tecnologias e a cultura digital implicaram na multiplicação de produtores e na dispersão da audiência, do tempo e dinheiro gastos para o entretenimento. Com tantos produtores de conteúdo disponíveis, uma gigante como a Disney precisa ter um conteúdo poderoso capaz de atrair um público de massa em nos mais diversos canais de distribuição.

A estratégia começa com a elaboração de um conjunto complexo de ideias e personagens dos muitos universos dos super-heróis em quadrinhos da Marvel para criar um universo único - chamado Universo Cinematográfico Marvel - de tal modo que seus universos possam ser compartilhados entre si e explorados em várias mídias. O primeiro passo partiu do comitê que, antes mesmo da aquisição pela Disney montou uma estratégia de produzir filmes, cada qual apresentando ao público um superherói: Homem de Ferro, Thor, Hulk, Capitão America, etc, de forma que as narrativas cruzassem entre si. O segundo passo foi a produção de filmes juntando todos os personagens. O terceiro passo foi o planejamento de diferentes fases com grupos de filmes que adicionam novos personagens que se inter-relacionam entre si de formas diferentes, caso de "Homem-Formiga" (Ant-Man, 2015), considerado um epílogo da fase dois, e "Guardiões da Galáxia" (Guardians of the Galaxy, 2014) baseados em personagens mais obscuros nos quadrinhos cujo filme se tornou um grande sucesso.

O quarto passo foi o aproveitamento do Universo Cinematográfico Marvel em revistas de histórias em quadrinhos inspiradas diretamente nos filmes; produção de curtas-metragens especiais com mais detalhes das histórias dos personagens (distribuído digitalmente e em Blu-ray); e produção 
de um novo conjunto de personagens a serem explorados na TV e nos aplicativos. A rede norteamericana $\mathrm{ABC}$ exibe "Agentes da S.H.I.E.L.D.", enquanto o Netflix exibe seriados originais dos chamados "heróis urbanos" da Marvel: "Jessica Jones" "Demolidor", "Luke Cage", "Punho de Ferro" e um seriado que una todos eles - "Os Defensores”. E, segundo a lógica expansiva e cruzada, esses personagens podem se unir aos personagens do Universo Cinematográfico nos cinemas. A Disney já confirmou a continuidade de produções originais para o Netflix.

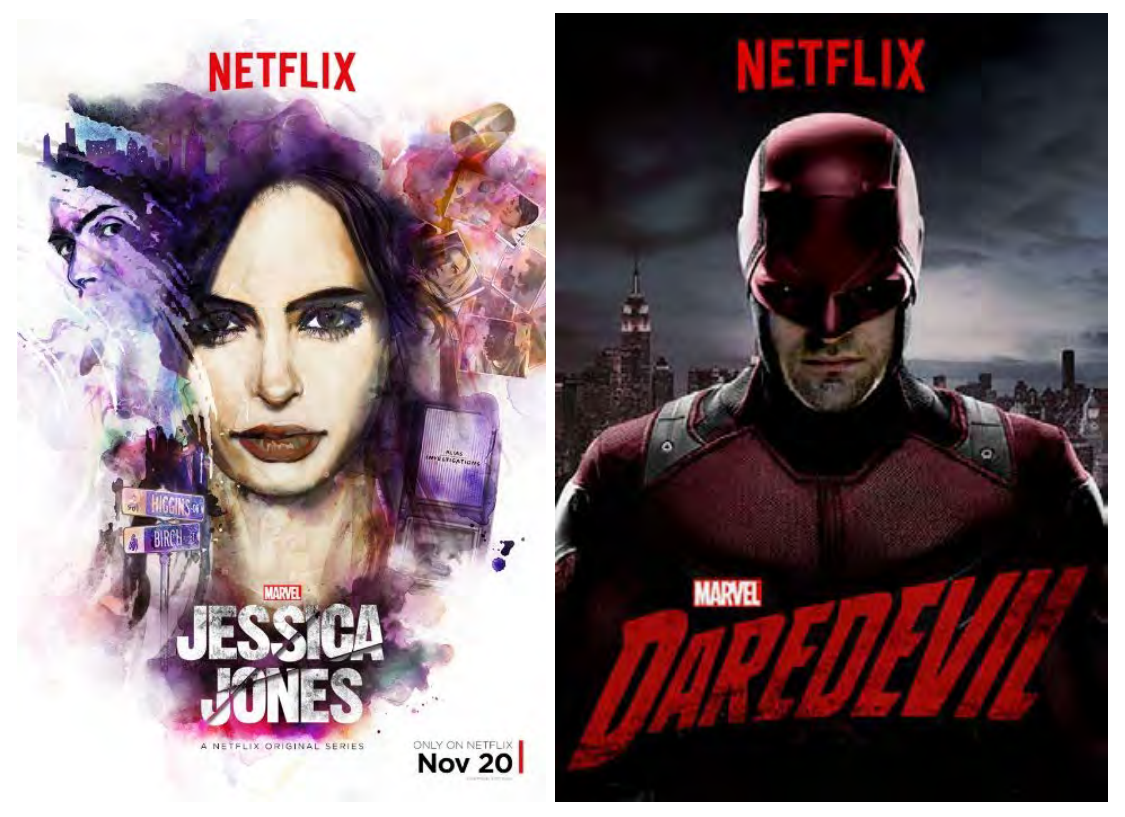

Figura 229 - "Jessica Jones". Figura 230 - "Demolidor"

O sucesso da estratégia ecoou até mesmo no comitê criativo da Marvel Studios. Kevin Feige, presidente da Marvel reportava ao CEO Ike Perlmutter. Porém, brigas envolvendo o orçamento de “Capitão América: Guerra Civil” (2016), forçaram a Disney a mudar o organograma e colocar o executivo reportando a Alan Horn, presidente dos estúdios Disney (BUSCH, LINCOLN, 2015). Perlmutter é obcecado por microgerenciamento e limitação de orçamentos, sendo responsável por pressionar o cancelamento dos quadrinhos do Quarteto Fantástico, escantear os X-Men, não acreditar em filmes de super-heroínas e tentar retirar Robert Downey Junior do papel de Homem de Ferro, por considerer que seu vínculo compromete uma fatia alta do orçamento. A consequência direta da mudança de Kevin Feige é o fim da influência do "comitê criativo" da Marvel Entertainment sobre a Marvel Studios. O comitê é formado por Perlmutter, seu braço direito Alan Fine (presidente da Marvel Entertainment), o Publisher Dan Buckley e o Chefe Criativo da Marvel Comics, Joe Quesada - responsável pela continuidade entre todos os ramos do negócio. Eles continuam no comando das produções da Marvel para TV e quadrinhos, merchandising e o licenciamento. A mudança dá mais 
autonomia para Feige (principal nome no gerenciamento dos filmes, cuja longa carreira data dos filmes X-Men quando trabalhou como produtor associado) e a Marvel Studios - o executivo está envolvido com o universo cinematográfico da Marvel desde Homem de Ferro, em 2008. O "Universo Cinematográfico Marvel” já rendeu mais de US\$ 8 bilhões até 2015 (BUSCH, LINCOLN, 2015). Horn tem no seu comando a Lucasfilm e a Marvel. Uma das ideias de Feige é cruzar as histórias dos personagens Marvel do cinema com as dos seriados da TV e Netflix:

Temos que continuar a inovar, fazer os negócios de forma diferente - quem cria, como criamos, como será distribuído, como será feito o marketing. Há uma demanda para observarmos as coisas de forma diferente. Temos a ideia de que é melhor nos perturbarmos do que sermos perturbados pelas novidades da mídia, porém tomar uma decisão sobre quando fazer isso requer tempo e cuidado. O Netflix é um comprador agressivo de conteúdos. Basicamente compram [da Disney] programação off-network (programas que já foram exibidos na rede $\mathrm{ABC}$, por exemplo), material original como os seriados da Marvel e há um acordo para um pacote de filmes. A tecnologia pode ajudar na criação de novas plataformas que consomem a produção criativa, [afirmou Bob Iger em entrevista ao canal Bloomberg em dezembro de 2015] (WESTIN, RUHLE, 2015, tradução nossa).

Ao contrário das histórias em quadrinhos de muitos desses heróis - e falamos aqui das histórias fora do universo cinematográfico -, o conteúdo dos filmes é menos violento, pretendendo atingir e conectar ao público mais diversificado possível. Esta estratégia complexa é uma evolução do processo que a própria Disney explora há décadas, por exemplo, quando cruzava horizontalmente seus produtos criativos nas áreas de cinema, teatro, parques temáticos e televisão, criando diferentes experiências para públicos muito diferentes:

A estratégia cultural da Disney é muito centrada no "cross-over". Na Disney Creative Entertainment, a arte e a cultura de massa são constantemente misturas. "Nosso objetivo é apagar a fronteira entre a arte e o entretenimento, e aqui nós concebemos ao mesmo tempo autênticas peças de teatro, espetáculos de marionetes, de fogos de artifício, eventos 'larger than life'. "Larger than life": adoro essa expressão, que resume muito bem o trabalho de Anne Hamburguer [presidente da Disney Creative Entertainment], consistindo em imaginar personagens que superam sua contingência, a idade e o país de origem, tornando-se universais e mainstream. "Ao mesmo tempo, precisamos ser muito "site specific", esclarece Hamburguer. "Cada espetáculo ocorrerá num país diferente, no Japão, na China, na França, e nós temos de nos adaptar a essas diferentes culturas. Em Hong Kong, nossos "guests" [visitantes] falam três línguas diferentes e assim, como as legendas não funcionam com as crianças, tentamos fazer espetáculos sem palavras". Na Disney, nunca se fala de clientes ou consumidores: fala-se de "guests" (convidados), como em "Be Our Guest”, a célebre canção do filme A Bela e a Fera (MARTEL, 2012, p. 63). 
Os resultados têm sido excelentes, porém não sem os seus riscos. Em primeiro lugar, a Marvel Entertainment boicota os personagens dos quadrinhos que não estão sob seu domínio no cinema. "O Quarteto Fantástico", por exemplo, teve sua revista cancelada porque os direitos cinematográficos permanecem com a Fox. Tanto o "Quarteto" e o "Homem-Aranha" estão sob contratos que não expiram enquanto a Fox ou a Sony/Columbia continuar a produzir filmes desses heróis. Isso explica porque vemos a cada 5 anos tantos reboots com filmes recontando a origem dos personagens ou explorando universos paralelos. A animação da Disney "Operação Big Hero" (Big Hero 6, 2014), apesar de inspirada nos quadrinhos Marvel, também é boicotada por não estar sob o controle do comitê da Marvel. A editora busca ganhar dinheiro explorando cada vez mais histórias em quadrinhos baseadas no Universo Cinematográfico (Figura 231) o que pode, em tese, levar a uma crise na produção de conteúdo original na mídia quadrinhos.

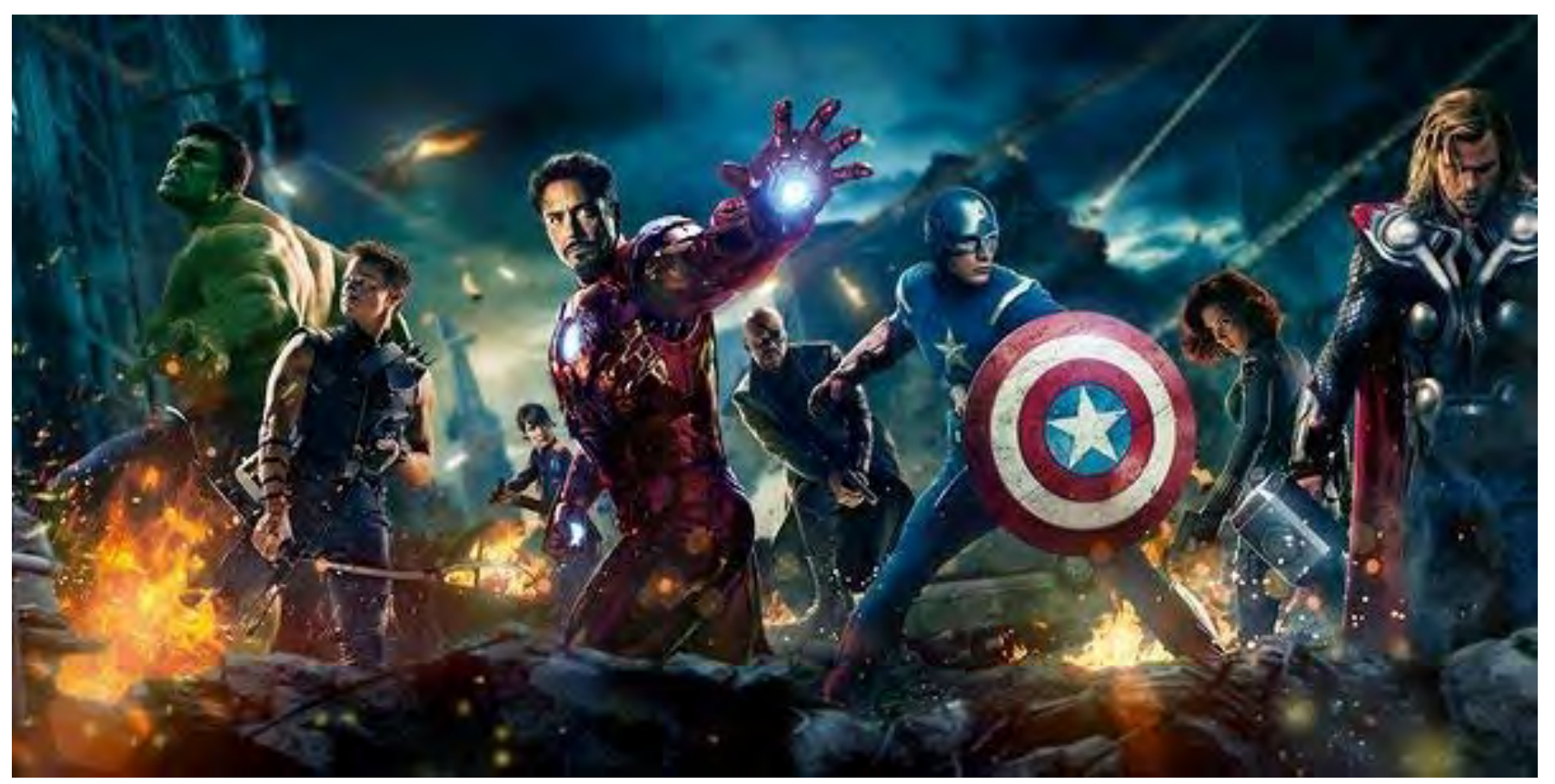

Figura 231 - "Vingadores", sucesso do universo compartilhado Marvel. 


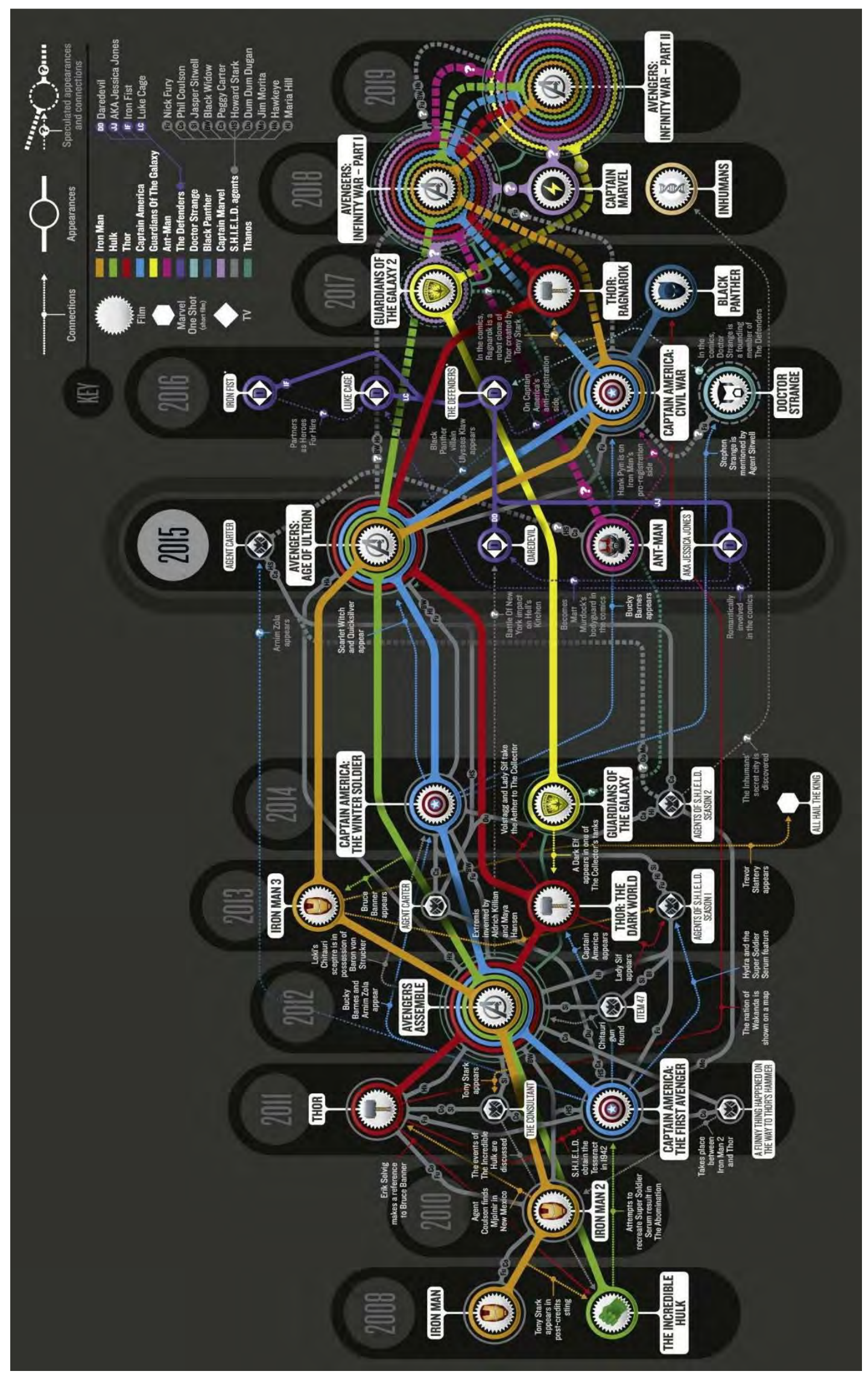

Figura 232 - Gráfico mostrando as conexões do Universo Cinematográfico Marvel. 


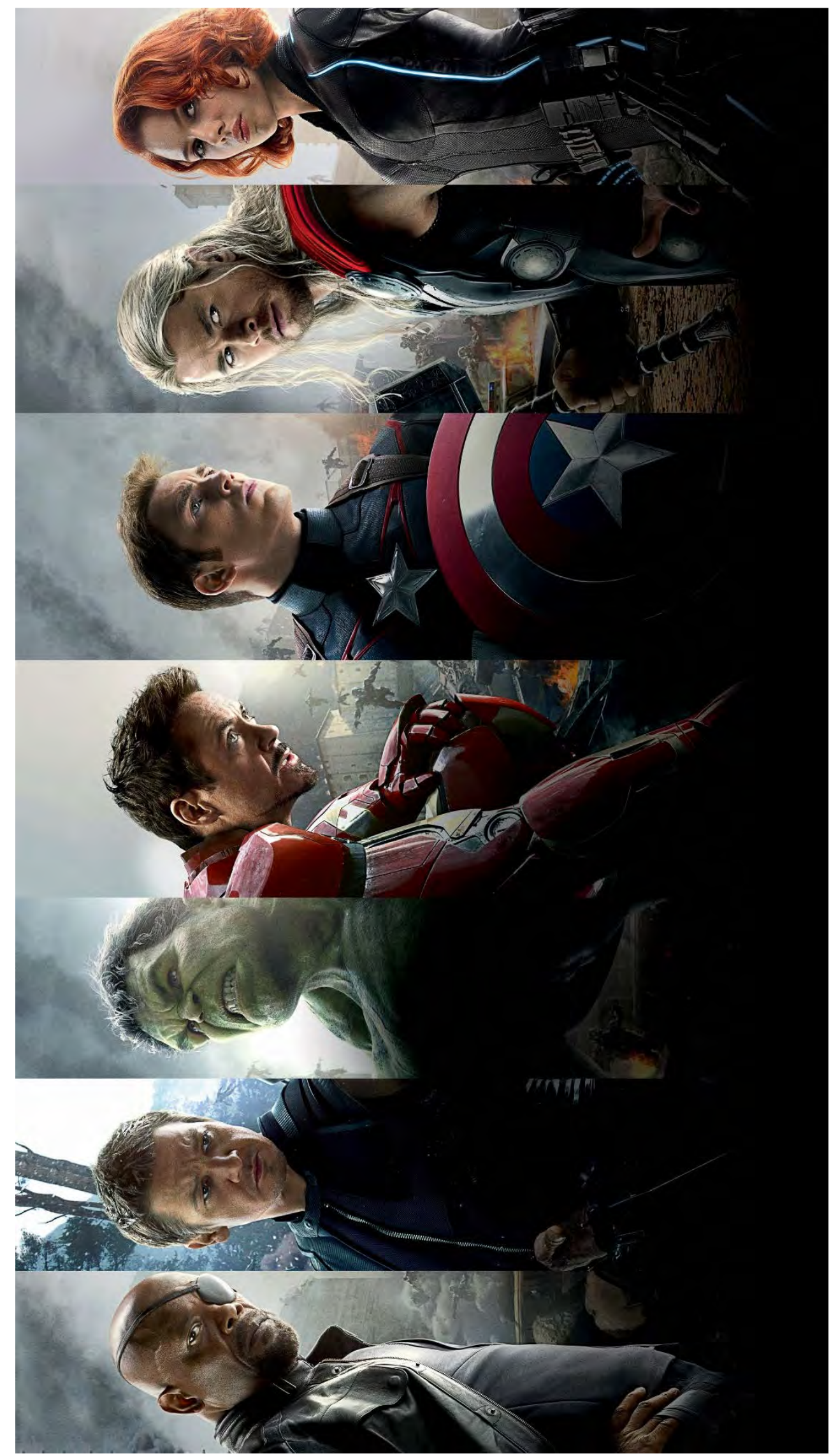

Figura 233 - "Vingadores: Era de Ultron" (2015) explorou narrativa compartilhada. 
Um segundo aspecto é que o mercado deve passar por um período de saturação de superheróis em todas as mídias. A Warner Bros., detentora dos direitos dos quadrinhos da DC Comics, sempre explorou mal o conceito de crossover nas produções de cinema e TV. As diversas versões cinematográficas de Superman e Batman não dialogam com produções televisivas com super-heróis. O controle de conteúdo é mais difícil pois os seriados estão espalhados em diversas redes de TV: "Gotham" na Fox, "Constantine" na NBC, "Arrow" e "Flash" na CW. Mas é justamente na televisão que a Warner começa a acertar no cruzamento de histórias e heróis. A partir de 2016, despejará no mercado sua primeira safra de filmes com a estratégia do universo compartilhado melhor planejada. É o caso de "Batman Vs Superman" e "Esquadrão Suicida", com diversos outros filmes previstos ao longo da década (ROGERS, FARINAS, 2015).

Há um risco plausível da saturação causar um colapso no mercado caso as empresas não atentem para o desenvolvimento de conteúdo original que surpreenda e renove esses universos. Os estúdios sabem disso e encontraram um elemento que pode lhes ajudar a indicar um caminho.

\subsection{LUCASFILM}

Em 30 de outubro de 2012 a Disney anunciou a aquisição da Lucasfilm por US\$ 4,05 bilhões, empresa criada por George Lucas formada por divisão de videogames, animação, efeitos especiais (Industrial Light \& Magic), som e pós-produção (Skywalker Sound) e a produtora cinematográfica (SMITH, 1987). A grande vantagem foi o acesso aos bens culturais legitimados pelo grande público representados pelas franquias Star Wars e Indiana Jones, além de toda a tecnologia de efeitos visuais de última geração (VELLA, 2012).

Novamente o CEO da Disney, Bob Iger, apostava em conteúdo pronto para ser explorado de imediato. Certamente um evento no passado contribuiu para o feito. Duas décadas antes, ainda quando trabalhava como executivo da rede $\mathrm{ABC}$, foi Iger quem aprovou a produção da série "O Jovem Indiana Jones" (Young Indiana Jones, 1994), que foi um fracasso de audiência. Quando se reencontraram em 2001 na primeira proposta de aquisição pela Disney, Lucas fez questão de relembrar a atenção dada ao antigo projeto dele. George Lucas cresceu sendo fã de Walt Disney e da Disneylândia. Contribuiu no desenvolvimento de várias atrações nos parques temáticos e recentemente se interessou pela produção de filmes de animação. Porém, não produziu nenhum 
grande sucesso desde a estreia em 2005 de "Star Wars - Episódio III - A Vingança dos Sith", a última parte da trilogia que concluía a saga de seis filmes iniciada em 1977.

Com intenção de se aposentar ou, como sempre repete, com intenção de produzir filmes mais autorais, considerou ser a hora certa para vender suas empresas e os direitos de duas das franquias mais populares e lucrativas de Hollywood. E a proposta da Disney previa uma boa autonomia para a equipe de Lucas explorar o que Iger caracteriza como "essência criativa", com a veterana produtora Kathleen Kennedy chefiando as novas criações. Juntamente com Pixar e Marvel, formavam o conjunto de empresas mais valiosas e com maior liberdade de criação e autonomia se comparado aos tempos de Michael Eisner. A exemplo do ocorrido com a Marvel, a ideia era produzir mais filmes, porém explorar a franquia Star Wars nos parques temáticos, brinquedos, televisão, etc.

A franquia Star Wars talvez explique melhor a estratégia adotada pela Disney e os demais players da indústria do entretenimento. A partir da cultura digital emergiu uma outra cultura complexa que está evoluindo paralelamente às novidades tecnologias. Trata-se da cultura do fã e todas as implicações de seu poder na produção cultural no início do século XXI.

\subsection{A Cultura de fã (Fandom)}

Há décadas a indústria cultural observa e tenta entender o comportamento e os gostos do público. Afinal, o "gosto" ou "não gosto" da audiência representa quais decisões a indústria fará sobre produzir e lançar determinado produto. Diversos estudos foram realizados para tentar entender o público, em geral com os pesquisadores se dividindo em dois campos. O primeiro estuda o espectador num aspecto mais psicológico, analisando o seu inconsciente. O segundo analisa a audiência, tentando entender as motivações para alguém sair de casa e ir ao cinema (OHMER, 2006).

Um dos mais famosos pesquisadores de audiência foi o norte-americano George Gallup. Após receber seu doutorado na Universidade do Arizona, trabalhou com pesquisas em revistas e jornais, porém ficou mais conhecido por sua atuação na área da propaganda. Suas pesquisas de opinião na política chamaram a atenção de Hollywood. A partir de sua metodologia, pesquisas nacionais foram feitas aferindo a popularidade de filmes. Na briga entre grandes e pequenos do cinema, a pesquisa nacional podia ser usada pelas majors para controlar os produtores independentes. A pesquisadora 
Susan Ohmer (2006) analisou a evolução das pesquisas, incluindo o contexto dos anos 1940, quando havia uma relação instável entre os estúdios Disney e a RKO, na época um grande estúdio responsável por distribuir as animações de Walt Disney.

Durante as duras negociações para renovar contrato, a RKO encomendou pesquisas para obter o feedback dos filmes "Fantasia" (1940) e "O Dragão Relutante" (1941). Os resultados mostravam, por exemplo, que o público em massa tinha conhecimento de "Fantasia", mas nem todos tinham interesse em vê-lo. Outros viram e não gostaram. Descobriram problemas de entendimento e pronúncia do título, outros não entendiam a ideia. Um jornal de Boston não sabia se enviava o crítico de cinema, de música ou de teatro - na dúvida enviou os três. O positivo é que o filme teve grande penetração junto ao público (OHMER, 2006, p. 200).

Após a Segunda Guerra Mundial, Walt Disney se tornou mais pragmático em relação a produção de filmes e curtas-metragens. Nesse período começou a pesquisa sistemática da Audience Research Institute (ARI) de Gullup, desenvolvendo métodos para produtores como Disney e David O. Selzick. O método era baseado na pesquisa do público crítico do estúdio (animadores e técnicos sêniors) e com público não-crítico (funcionários mais novos e público externo). Os atritos entre as avaliações eram inevitáveis. O executivo Card Walker considerava o método melhor por ser mensurável. Considerava que a avaliação das pessoas do desenvolvimento criativo não eram confiáveis. Logo, um departamento de pesquisa passou a fazer parte da estrutura do estúdio (THOMAS, 1958, p. 32).

Esse método consistia basicamente em avaliações com questões binárias (sim ou não) para ideias, gags, narrativas, ritmo e humor. Os dados compilados eram planificados e ganhavam notas para se saber o que havia agradado ou não, e para guiar o que o estúdio produziria depois. Alterações pontuais eram feitas nos curtas-metragens avaliados, mas o "cálculo do divertimento" influenciava as próximas produções. As notas planificadas foram com o tempo usadas em comparações entre filmes. Obviamente havia imprecisões neste método. Era comum uma avaliação de projeto dar positivo por algum detalhe, e numa pesquisa refeita meses depois dar negativo. Ohmer (2006) acredita que não somente aspectos econômicos acabaram com a produção de curtas-metragens nos anos 1950, e que a dificuldade na precisão do uso dos dados avaliados podem ter contribuído para a decisão. 
Nas décadas seguintes, o estúdio continuou a se utilizar de exibições-testes dos seus filmes em desenvolvimento. A despeito de executivos como Eisner e Iger afirmarem não confiar em pesquisas de mercado, as avaliações do público continuam tendo um grande poder no que é decidido de pequenas edições, a supressões e refilmagens de cenas inteiras.

Com a cultura digital observamos a emergência da cultura participativa. Ela é continua, criativa e desordenada. Sua propagação tem uma repercussão distribuída em rede. Implica na troca de conhecimento, em escrever com outros usuários e retomar ou reescrever o que escreveram outros. Para Pierre Lévy (2007), "a "inteligência coletiva" é distribuída por toda parte, incessantemente valorizada, coordenada em tempo real, que resulta em uma mobilização efetiva das competências".

O pesquisador Henry Jenkins (2009) produziu um trabalho marcante sobre a cultura da convergência analisando justamente o impacto da cultura participativa. A partir de dois programas de televisão populares nos EUA, "Survivor" (2000) e “American Idol” (2002), Jenkins analisou o comportamento do público trocando informações na Internet sobre spoilers (detalhes de cada programa), discussões com elogios, críticas e o suspense com as pessoas conjecturando o futuro dos participantes. Foi a partir deste momento que o modelo tradicional de propaganda na TV forçou as agências de publicidade a repensar sua interface com o público consumidor.

Uma das novidades foi o foco na "economia afetiva", incentivando as empresas a transformar as marcas naquilo que a indústria chama de "lovemarks" e a tornar imprecisa a fronteira entre conteúdos de entretenimento e mensagens publicitárias. Parte da lógica é que o consumidor é ativo, comprometido emocionalmente, ele parte de uma rede social. Não basta mais, portanto, "ver o anúncio" ou simplesmente "comprar o produto" (JENKINS, 2009, p. 49). O paradoxo é que, uma vez dentro da comunidade da marca, as barreiras entre produtores e consumidores estão sendo rompidas a medida que os consumidores procuram agir ao serem convidados a participar da história das franquias. Isso resultou em alterações em como o produto é produzido, divulgado e até mesmo refeito.

Diversos pesquisadores tentam compreender a lógica da cultura de fã (o fandom), pois os fãs se tornaram a nova moeda da indústria do entretenimento. Cada um com seus termos e hipóteses, o 
importante é a contribuição coletiva para impactar a produção. Em primeiro lugar temos a formação do fã.

De acordo com Chuck Tryon (2009), o DVD foi fundamental para a construção do "film geek". A tecnologia impôs a possibilidade de conteúdos que combinassem elementos do discurso da indústria, o discurso do jornalismo do entretenimento e o discurso do marketing e da propaganda. Esse aprendizado se dá pelas informações obtidas do material publicitário, do que é discutido na imprensa e do material disponível nos DVDs. Os chamados "materiais extras" ou bônus apresentam os bastidores (making of) com possibilidade de assistir ao filme com comentários do diretor e membros da produção, além do acesso a galerias de fotos e desenhos, entrevistas, materiais promocionais, cenas cortadas e alternativas e prévias. Trata-se de um conhecimento parcial, pois parte do material é usualmente destinado a imprensa, porém o mais importante é que essa "história de produção" não é totalmente real. O espectador está apreendendo a versão que o estúdio espera que ele tenha acesso. É necessário, por parte do fã, que ele se esmere para buscar outras informações - e nisso a Internet se tornou um grande aliado.

Além das mudanças que a cultura digital proporcionaram na forma do espectador acessar as produções audiovisuais, Tryon $(2009$, p. 125) afirma que os blogs inicialmente foram a grande força para impulsionar a multiplicação de produtores de conteúdo paralelamente a imprensa tradicional. As tecnologias que levaram à popularização das mídias sociais transformaram as práticas de recepção e, ao mesmo tempo, moldaram novas formas de produção e distribuição. Essas transformações incluem a apropriação pelos fãs das produções culturais do mainstream, que são retrabalhadas em forma de paródia, fan-fiction (histórias criadas por fãs) e os mash-ups (criações baseadas em misturas e customização de ideias), conteúdos informativos diversos em canais do YouTube, memes ${ }^{48}$, etc. $\mathrm{O}$ conteúdo resultante pode ser tanto complementar ou funcionar como contra-produto oferecendo um material paralelo ao oficial da indústria, o que representa um desafio aos criadores e proprietários dos direitos autorais.

A abertura dos direitos é importante por gerar divulgação, mas os limites são questionáveis. Jenkins (2009), nesse ponto, exalta a democracia do modelo. Porém, há diversos exemplos de censura

\footnotetext{
${ }^{48}$ Meme pode ser descrito como um conceito de imagem ou vídeo relacionado ao humor. O meme espalha-se pela rede de forma viral. Pode ser usado como uma forma de marketing para divulgar produtos.
} 
imposta pelas majors, desde proibir vídeos de fãs aos embargos aos jornalistas, que geralmente assistem as grandes produções antecipadamente e são submetidos a uma quarentena, só podendo expressar e publicar suas opiniões numa data específica - o propósito é proteger o lançamento de repercussões negativas.

Porém, há exemplos de uma "democracia participativa" se levarmos em conta a crise de legitimidade que vive o jornalismo com a expansão da cultura digital. Jenkins (2009) dedica um capítulo inteiro de sua pesquisa para falar das eleições presidenciais norte-americanas de 2004. Os cidadãos foram bem mais servidos pela cultura popular do que pelo noticiário ou pelo discurso político. A cultura popular assumiu novas responsabilidades ao instruir o público sobre o que estava em jogo nas eleições e o inspirou a participar plenamente do processo. Os cidadãos participaram ativamente das campanhas, além de debater e produzir informações sobre o tema. A imprensa, os candidatos e os partidos perderam parte do controle sobre o processo político. Todos os lados aceitam uma participação maior dos cidadãos e consumidores, mas ainda não concordam com os termos dessa participação (JENKINS, 2009, p. 51).

Os fãs também ganham conhecimento de forma passiva. É virtualmente impossível assistir a um filme ou programa de TV sem noções preconcebidas devido ao hype que os precede. Ao mesmo tempo, extensões da mídia garantem uma sobrevida aos produtos culturais para além de sua exibição de lançamento. Um bombardeio de informações da mídia impressa, trailers, discussões na internet (incluindo spoilers), merchandising, publicidade fazem com que o público saiba muitos detalhes em torno da experiência direta de assistir ao conteúdo desejado. Esses extras ou "paratextos" estão longe de serem algo periférico, moldando nossa percepção dos conteúdos e guiando nossas decisões sobre o que assistir e até mesmo como assistir.

O professor Jonathan Gray (2010) aponta que não é possível analisar adequadamente um produto cultural sem levar em conta suas proliferações. Cada uma delas são capazes de mudar o significado do texto, mesmo que levemente. No caso, o autor lista que trailers e reportagens direto do set de filmagem podem construir uma visão antecipada do que o público pode pensar sobre o gênero, tom e temas do texto. As discussões na internet (websites, listas de discussão, fóruns, mídias sociais) podem reforçar ou desafiar essa percepção. Videogames, quadrinhos e outras extensões narrativas 
contribuem para a amplificação do texto devido a sua imersão no universo narrativo. E há os produtos derivados como games, seriados de TV, livros, revistas e bônus de DVD/Blu-ray que, por exemplo, podem não ser considerados "o produto de verdade" (na origem), mas muitos espectadores ou leitores consideram seriamente o pacote com todos os produtos paralelos e derivados. Raramente temos a experiência exclusiva de um filme, livro ou história em quadrinhos. Somos bombardeados antecipadamente com prévias, entrevistas, promoções e produtos derivados.

A indústria percebeu isso com a evolução da tecnologia no início do século XXI. A interação entre os paratextos resultam numa hierarquização textual. A hierarquização funciona automaticamente quando estamos zapeando os canais na TV ou escolhendo aleatoriamente um filme num cinema multiplex - o público nessas circunstâncias tende a escolher conforme experiências anteriores do consumo do hype, da promoção e da sinergia. Gray (2010, p. 23) resume que a versão atual da frase "Não julgue um livro pela capa" é "Não acredite no hype". O hype não serve simplesmente para apontar o que devemos ou não acreditar, mas estabelece enquadramentos e filtros do que lemos, escutamos e assistimos. As narrativas mediadas são utilizadas há décadas como um filtro que torna o texto mais atrativo e poderoso - desde as reportagens cuidadosamente editadas até as propagandas que desafiam a semiótica para criar uma experiência que produza significado aos produtos e serviços. O hype, portanto, é a criação de significado pela publicidade excessiva para criar comoção por algo. Desse modo, nos força constantemente a julgar "livros" por suas capas reluzentes.

Um cuidado especial precisa ser dado aos termos "texto" e "paratexto" pretendidos aqui. Segundo Gray (2010, p. 6), um leitor facilmente poderia chamar um filme ou seriado de TV de "textos", no sentido de "fonte de origem do texto para os paratextos". O uso de texto neste sentido denota que o filme ou o programa é o texto completo, e/ou que ele seria a origem pura que se autocompleta. Na realidade, o filme ou o programa funcionam como parte do texto, sendo ele uma entidade contingente, estando num processo de formação e transformação ou vulnerável a formações e transformações posteriores. Não são o produto final mas a produtividade continuada (GRAY, 2010, p. 7). Neste caso, podemos tentar conformar o problema teórico considerando um filme como "produto principal” formado por um "texto". Lembrando Roland Barthes, "o texto está sempre em movimento, portanto impossível agarrar ou estudá-lo como um objeto cênico (...) [ele] distingue o texto (text) do trabalho (work). O trabalho pode ser feito pelas mãos. O texto é produzido pela linguagem, somente existindo no movimento de um discurso e é experimentado apenas em uma atividade de produção" (GRAY, 2010, p. 30). Temos acesso ao trabalho físico (seja um rolo de película, fita VHS, livro ou game) mas o indivíduo é livre para absorver sua própria interpretação do texto de seus conteúdos. 
"Promos e promoção envolvem vender a outra entidade. Ou, a um passo além de níveis "normais" de propaganda é o hype. O Dicionário de Inglês de Oxford define "hype" como "extravagante ou publicidade/promoção intensiva". Hype é etimologicamente derivada de "hyper" - significando "acima, além, sobre" ou "excessivamente acima do normal", o que por sua vez se origina do grego "huper", significando "excesso, além". O termo alude as relações públicas e a propaganda, se referindo ao exagero, circulação de massa e a venda frenética de algo. Hype é a propaganda que vai "além" e "acima" das normas aceitáveis, estabelecendo uma presença de peso, frequentemente por um breve ou insustentável período de tempo: assim como um indivíduo hiperventilando ou uma espaçonave em hipervelocidade - o o produto com hype necessitará desacelerar em algum ponto. Sua presença é mais forte no cinema e a na TV devido a atribuição dessas indústrias - ao menos em suas variedades de Hollywood - com suas redes de sinergia. Derivando do grego "sunergos", significa "trabalhando juntos", sinergia se refere de acordo com o Dicionário de Oxford a "uma interação ou cooperação de duas ou mais organizações, matérias, ou outros agentes que producem um efeito combinado maior do que a soma de seus diferentes efeitos". Dentro da industrias do entretenimento, refere-se a estratégia das plataformas multimídia, relacionar um produto midiático a uma mídia em outras "plataformas", como brinquedos, DVDs e/ou videogames, de modo que cada produto divulgue e enriqueça a experiência de outra. Enquanto o hype é frequentemente visto como ferramenta de propaganda e relações públicas, a mercadoria, produtos e games da sinergia são também chamados periféricos frequentemente destinados como plataformas diversificadas de geração de lucro". (GRAY, 2010, p. 4-5)

Tomamos como importantes esses produtos periféricos para a estratégia da indústria do entretenimento, e acreditamos que seja coerente tomar como ferramenta de análise a definição usada por Gray para "texto" e "paratexto". O autor trabalha com o conceito de paratextualidade inspirado nos termos usados por Gerard Genette, que o usou inicialmente para discutir uma variedade de materiais ao redor do texto literário. "O paratexto é formado por todos os elementos que normalmente são encarados como "fomentadores de lucro", de forma a analisá-los como produtores de textualidade, trazendo significado aos textos midiáticos. Mas não somente eles. Como já vimos, conteúdos culturais (gêneros narrativos, traços da sociedade, produtos culturais anteriores, etc." (GENNETE, 1997). Neste caso, o prefixo "para" de paratexto tem relação com algo adjacente, próximo e "distinto porém análogo a algo". A tese de Gray trabalha o paratexto como algo intrinsico ao texto.

Não se trata simplesmente de sequências ou produtos derivados: o paratexto também cria textos, ele gerencia e preenche o texto com significados que associamos a eles. Paratextos se encontram geralmente em formas tangíveis como cartazes, videogames, podcasts, críticas ou 
produtos, porém existem também formas intangíveis que funcionam como paratextos - um gênero, por exemplo, não é um paratexto em si, mas pode funcionar como um para influir na ação de enquadrar um texto. É muito comum a comparação feita pelos fãs entre produtos culturais, seja entre lançamentos que se assemelhem apenas pois os trailers e materiais promocionais sejam parecidos, como foi o caso de "O Senhor dos Anéis" (2002) e "Crônicas de Nárnia: O Leão, a Feiticeira e o Guarda-Roupa" (2005), comparações discutindo os livros em que se baseiam os filmes, a amizade entre os autores Tolkien e Lewis, como também entre produções de um mesmo cineasta - antes da estreia da refilmagem de "King Kong” (2005) os fãs especulavam projetando suas expectativas com a qualidade de sua produção anterior, justamente a saga “O Senhor dos Anéis” (GRAY, 2010, p. 127).

"Star Wars" é um exemplo curioso porque nos apresenta um desafio em caracterizar o que seria um paratexto "primário" ou "secundário/periférico". Para Gray (2010, p. 21) os brinquedos de "Star Wars" ajudaram no impacto e no entendimento dos filmes pelo público e pelos fãs. Enquanto críticos enxergam os brinquedos e demais produtos licenciados como elementos desimportantes ou ferramentas do consumismo manipulativo, o autor questiona que os brinquedos se tornaram uma fonte viável de texto, enquadrando e intensificando muitos dos temas do filme, ao mesmo tempo permitindo que o universo de Star Wars se tornasse habitável.

Há uma retroalimentação entre filmes, produtos e fãs que torna os universos acessíveis e exploráveis. E há uma imersão dos fãs nos paratextos interativos que reforçam diversos temas na inteligência coletiva. No caso de "Star Wars", dos super-heróis Marvel e DC Comics e das histórias em quadrinhos e animações Disney, esse processo ocorre de forma contínua por décadas. A indústria do entretenimento descobriu esse filão e o usa como commodities de suas novas produções. Como normalmente ocorre no mercado, o efeito manada gera produções originais com paratextos superficiais e de péssima qualidade. É por essa razão que para cada um "Harry Potter" (produção literária original dos anos 1990 que se desenvolveu em filmes e demais produtos) temos dezenas de produções derivadas de textos e paratextos já conhecidos, testados e aprovados cujo hype pode ser trabalhado de modo mais controlado e cujas perspectivas de investimento e lucro podem ser mais facilmente calculadas.

Há também os fenômenos amplificados pela tecnologia como o fan-fiction e os mash-ups são paratextos produzidos pela audiência. No caso da participação dos fãs, o conteúdo resultante pode 
ser tanto complementar ou funcionar como contra-produto oferecendo um conteúdo paralelo ao oficial da indústria.

Entrando no terreno da sinergia e do hype, a Disney se tornou um dos primeiros exemplos de corporação que soube dominar sua área com uso estratégico de seu conteúdo.

Pegue um filme de animação Disney médio, por exemplo. Antes de seu lançamento, o filme é normalmente precedido por um exército de brinquedos, livros para colorir, relógios, roupa de cama, e bonecos. Ele certamente terá sido divulgado durante a programação infantil, e o McDonalds ou alguma outra empresa de fast food terá lançado uma campanha especial temática de "Lanche Feliz". Assim, o filme sugere diversão e boas coisas para as crianças - ele é associado como bonecos fofos, brincadeiras, boa programação de TV e comida açucarada. Enquanto isso, é claro, a campanha de marketing Disney na média irá pesadamente popular o universo infantil com merchandise relacionado ao filme, tornando qualquer criança capaz de entender o sentimento de que "todos" estão assistindo ao filme. Finalmente, então, quando funciona, a paratextualidade Disney cria uma imagem bem formada de tudo o que o filme representa, e ele exorta a criança a ver o filme. Escrevendo sobre esses exemplos, Robert Allen declara que "um filme não é mais reduzido a sua experiência real de assistí-lo" - como se ele nunca tivesse sido assim! - dado que esta paratextualidade não somente precede o ato de assistir, mas o alimenta, fornece condições, e se torna parte daquele ato. Os brinquedos, hambúrgueres e tudo mais são agora parte do texto. Allen até mesmo sugere que em tal mercado sinérgico/paratextual os filmes não são mais o texto em primeiro lugar mas, ao contrário, "a parte não-comestível de um Lanche Feliz" e o "filme na lancheira"49. Quando Disney pode fazer muitas centenas de dólares com vendas de produtos a um consumidor individual jovem, comparado aos insignificantes 5 dólares que ele paga na bilheteria [para ver um filme] podemos no enganar em ver o filme como ipso facto (a evidência) do "texto primário". Allen é hiperbolicamente fatalista em declarar que o cinema morreu e que "esta é a hora de escrever o último capítulo da história do cinema de Hollywood e seu público", porém a máquina de hype e sinergia Disney não obstante ilustra a ampliação dos limites nebulosos entre a textualidade primária e secundária, ou entre texto e paratexto" (GRAY, 2010, p. 38 e 39).

Deste modo, o produto cultural deixa de ser simplesmente um filme e se torna uma grande franquia, uma grande série de filmes que podem ser dois, uma trilogia ou os atuais universos compartilhados. O conceito de franchising usado em Hollywood representa uma tensão entre a lógica racional econômica e o imaginário cultural, como afirma o pesquisador Derek Johnson (2009, p. 29). As franquias são como lojas de fast-food McDonalds funcionando como marcas - unitárias, compartilham expressões culturais cruzando mercados, permanecendo constituídos racionalmente por acordos de licenciamento e outras práticas de colaboração. Aliás, elas podem ter ou não relação

\footnotetext{
${ }^{49}$ Rober Allen chama de "movie on the lunchbox" todo o conjunto de produtos derivados como brinquedos, roupas, etc.
} 
com licenciamento. Grandes corporações de mídia como a Disney produzem uma série de franquias sem precisar contratar licenciamento de conteúdos externos - caso de "High School Musical" (2006) na TV ou de "Piratas do Caribe" (2003) no cinema. Paralelamente não é incomum esse mesmo tipo de produção se beneficiar de acordos com estúdios independentes e parceiras comerciais.

O primeiro filme a ser referido como franquia, segundo levantamento de Johnson (2012, p. 54-55) publicado numa crítica da revista Vanity Fair foi “Querida, Estiquei o Bebê" (1992), sequência de uma produção da própria Disney, "Querida, Encolhi as Crianças” (1989); e, no entanto, já havia modelos produção equivalentes a franquia muitos anos antes em Hollywood. O termo, como foi constatado, entrou em voga na década de 1990. De acordo com o autor, a chave para entender a conceito de franquia em Hollywood é compreender as forças econômicas e culturais que as têm moldado, imaginado e estruturado, assim como as estruturas industriais, relações sociais e imaginários culturais que ela facilitou (JOHNSON, 2012, p. 29).

Uma das análises de Johnson (2012, p. 67) utilizou os quadrinhos do X-Men para explicar a evolução das relações na indústria com base nas franquias: em um primeiro momento nos anos 1980, pequenas produtoras multiplicaram suas operações em resposta aos desafios do mercado; num segundo momento entre o fim dos anos 1980 e início dos 1990, conglomerados tentam mas falham em mobilizar franquias na tentativa de consolidar propriedades; e finalmente no final dos anos 1990 (processo de falência da Marvel e posterior oferta de licenciamento para adaptações cinematográficas) quando a franquia ofereceu relações mais flexíveis como alternativa aos conglomerados de mídia.

O que nos importa é que a franquia é uma estrutura poderosa para potencializar os fãs. Há franquias descentralizadas e não-seriais, ou seja, que possuem várias versões e narrativas ou são episódicas em diferentes tempos e contextos - é o caso do Batman, dos X-Men e de Star Trek (Jornada nas Estrelas).

Porém, as franquias seriais e que possuam uma origem central ou contínua se encaixam no que Jenkins (2009) analisa como sendo manifestações do storytelling transmídia, uma estética nova 
que surgiu com a cultura da convergência. Essa manifestação é mais restrita em relação as franquias não-seriais. Ela implica em colocar demandas nos consumidores e depende da participação ativa de uma comunidade do conhecimento (geeks) em mídias sociais. Esse mecanismo de troca de informações provoca a criação e manutenção de "mundos" como os que vemos em franquias como "Piratas do Caribe", "Os Vingadores" e nos exemplos mais trabalhados por Jenkins, "Harry Potter" e "Matrix", cujos "espectadores têm acesso a uma experiência coletiva a partir de peças narrativas espalhadas pelos produtores em diversas plataformas de mídia” (JOHNSON, 2012).

Podemos questionar o que provoca a atração dos fãs pelas franquias. Talvez seja uma relação direta com o ritmo frenético de lançamentos e opções de entretenimento. Zygmunt Bauman (2001) fala da ansiedade e a angústia causada por infinitas possibilidades de escolhas e de falta de modelos e durabilidade em um mundo dominado pelo consumo efêmero. Um bom motivo para a atração é o cult following. Trata-se do espaço de interação e experimentação, e seu resultado é absorvido pela mídia mainstream. A consequência é o conteúdo mainstream sendo apropriado pelos fãs em produções amadoras.

Os fenômenos culturais "Harry Potter" e "Star Wars", como analisa Jenkins (2009), são exemplos para explicar o cult following, porém foi a televisão que primeiramente experimentou os efeitos da pressão na relação entre fãs e produtores. A peça central é a figura do showrunner, o encarregado principalmente na televisão pelo trabalho diário de produção e dar coerência a evolução narrativa de um seriado ou programa de televisão. O conceito pode ser estendido ao cinema. Na prática é o "criador do programa", geralmente creditado como produtor executivo, pois tem poder superior ao dos diretores.

O seriado de TV "Lost" (2004) mudou o modo do "showrunning" devido ao seu status cult e do alto número de seguidores, mistérios expansivos, narrativa sci-fi subversiva e engajamento com a audiência via mídia sociais de forma inédita. O roteirista e produtor Jeff Melvoin afirma (BENNETT, 2014, p. 183) que o seriado caiu num turbilhão de sucesso onde de repente o público clamava por mais informações. A produção começou a criar todo tipo de merchandising da marca, não somente na internet. Havia uma questão relativa a própria jornada de trabalho. A produtora queria cenas extras, web-episódios e todo tipo de trabalho de criação que não estava incluído no trabalho originalmente contratado e pago aos criadores. E isso ainda tomava muito tempo e disposição. Houve uma 
dificuldade inicial para que os estúdios compreendessem que era necessário contratar uma equipe paralela para produzir esse tipo de conteúdo sem demandar mais trabalho da principal equipe criativa.

O showrunner como jargão do mainstream televisivo é algo novo. A ideia de um deles ser abraçado como uma "celebridade" por uma base de fãs é um conceito que os próprios roteiristas ainda estão se acostumando. Enquanto há muitos showrunners que amam serem os porta-vozes de seus shows -e dos elogios e adulações que acompanham a fama - há muitos outros que preferem o anonimato tradicional de um escritor criando suas histórias "off the radar" (incógnito) (BENNETT, 2014, p. 189).

Há também o gerenciamento do feedback na produção. Com a integração das mídias sociais se tornando uma enorme parte do marketing televisivo, do podcast, Twitter, Facebook e demais aplicativos que apareçam, espera-se que os showrunners ajudem a liderar o gerenciamento da percepção de seus shows e criar ações no cyber-verse com sua audiência. Hoje temos showrunners dialogando diretamente respondendo aos fãs nas diversas mídias sociais (BENNETT, 2014).

Desde o início do novo milênio, para as redes de televisão e os estúdios, conversar publicamente sobre o seu show é um requerimento de trabalho tão importante quanto escrevê-lo, esteja o showrunner gostando ou não disso. Até então, quando o anonimato era permitido para os showrunners e roteiristas, o feedback era limitado aos críticos de jornais e revistas, cartas de fãs enviadas aos escritórios ou ao uso de murais de mensagens sobre seus shows. Os fãs atualmente têm acesso aos showsrunners nas mídias sociais, festivais de televisão, convenções de fãs, onde seus questionamentos e críticas não possuem restrições ou filtragens (Figura 234). O grande risco é o showrunner cair na armadilha de se envolver demais no mundo do fandom e do diálogo da cultura pop. Os fãs desenvolvem uma relação tão forte com seus produtos cultuados, que não se sentem melindrados a expressar desapontamento ou raiva quando seus autores não produzem o esperado para a continuidade da produção. Dependendo de quão densa for esta relação, os showrunners podem ser pressionados por fãs infelizes que demandam mudanças, ameaçam parar de assistir/ler o produto ou fazer comentários críticos ou assustadores. Se há uma coisa que o showrunner tenta evitar a todo custo é ser forçado a ser criativo por comitê. E é necessário um equilíbrio entre o feedback dos consumidores e dos contratantes. (BENNETT, 2014, p. 190). 


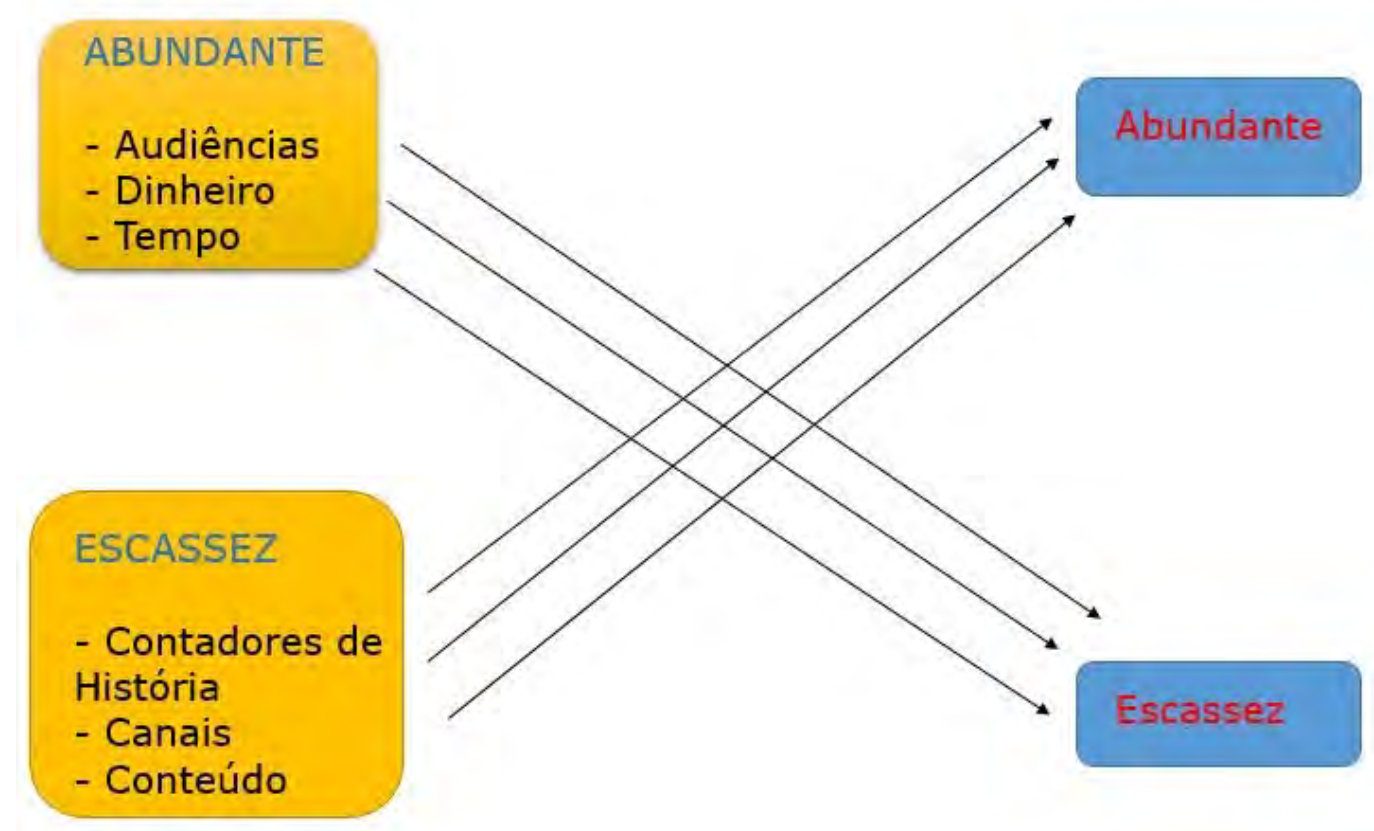

Figura 234 - As culturas digital e participativa inverteram os parâmetros de criação e consumo.

A mídia mainstream relaxa o controle dos personagens. As corporações de mídia têm lucro por volume, logo o relaxamento na proteção de suas criações pode ser comprometido com a apropriação pelos fãs. O que os estúdios têm feito é transformar todo tipo de criação em potencial em marcas (Figura 236). As histórias em quadrinhos de super-heróis funcionam como grandes marcas e não simplesmente como personagens marcantes em sua mídia original. Há diversos exemplos de filmes baseados em quadrinhos, mas que entram no processo. Se um filme como "Sin City - A Cidade do Pecado" (2005) deixa claro suas origens nos quadrinhos de Frank Miller, "A Estrada para a Perdição" (Road to Perdition, 2002) pouco diz sobre a origem nos quadrinhos de Max Allan Collins e Richard Piers Rayner. Nesta lógica, os quadrinhos mainstream podem vir a perder importância, pois o dinheiro está nos filmes e nos produtos. Embora as editoras invistam na criação de quadrinhos inspirados nos filmes, os resultados ainda são tímidos. 


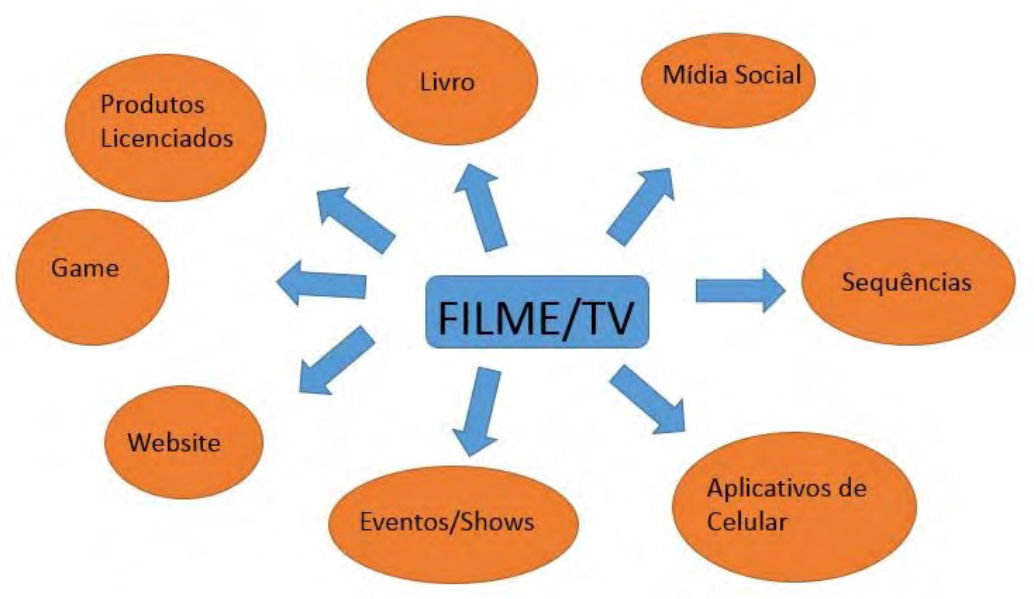

Figura 235 - Hierarquização da indústria do entretenimento até os anos 1990.

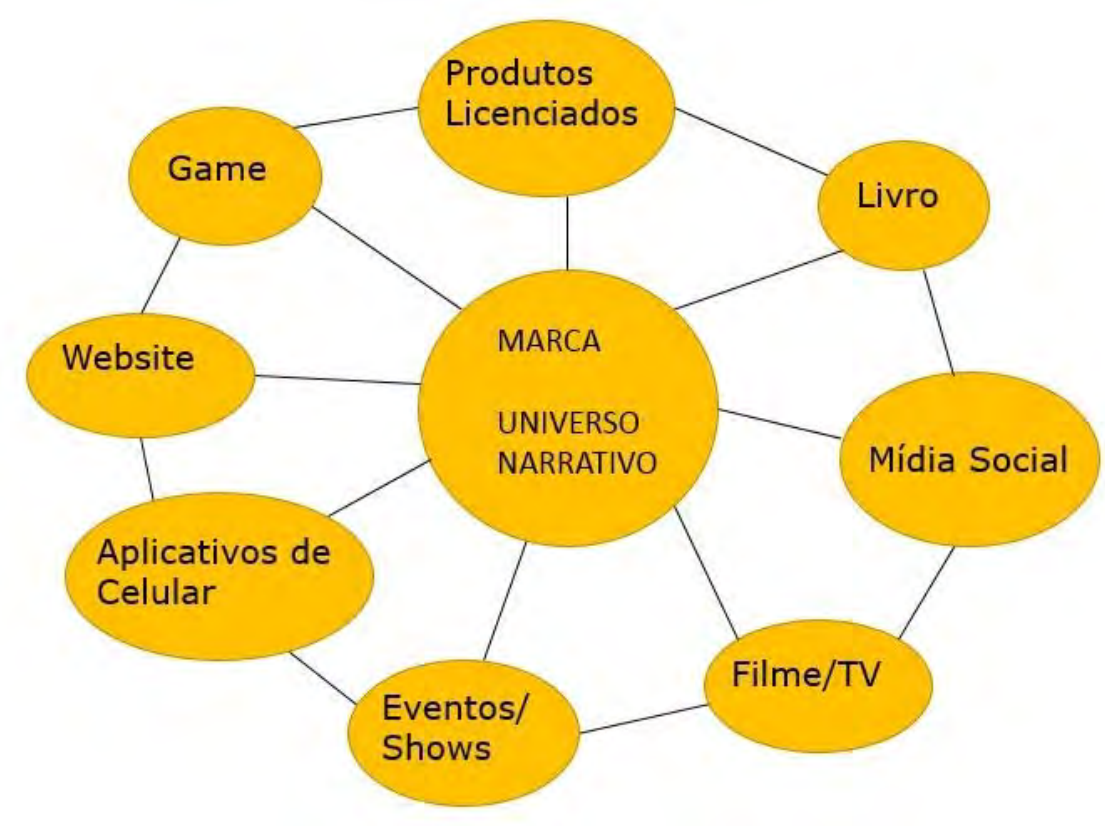

Figura 236 - Hierarquização da indústria do entretenimento a partir dos anos 2000.

As franquias de mais sucesso em Hollywood seguem a lógica do "world building", a criação de mundos ou universos atrelados ao storytelling transmídia. A lógica da criação na era de ouro de Hollywood era um filme ser baseado simplesmente em uma boa história como "E o Vento Levou" (1939). A partir da segunda metade do século XX muitos dos sucessos partiram da criação de um excelente personagem que poderia render posteriormente uma franquia (Indiana Jones, Freddy Krueger, James Bond, etc). No início do século XXI, o contexto pede a criação de mundos ou universos que sejam a origem de múltiplas histórias e personagens, de modo que possam ser explorados em várias mídias. É o caso de filmes como “Alice no País das Maravilhas" (2010) ou do 
seriado "Game of Thrones" (2011), que possuem mapas expansivos de seus mundos e que podem ser explorados de diversas formas indefinidamente (Figura 237).

O conceito de World Building descreve o início da construção de um processo em que se desenha e projeta um mundo ficcional além de sua necessidade, de modo que esses espaços extras sejam utilizados por especulação ou necessidade criativa num determinado tempo futuro - da mesma forma que se constrói um edifício e aos poucos se ocupam os apartamentos. Isso cria uma ânsia de curiosidade no espectador ou leitor como também nos produtores, que ganham uma chance de explorar esse conceito na forma de projetos grandiosos como as franquias e derivados (BERNARDO, 2014).

Isso não impede problemas. Se o quadrinista Don Rosa consegue elaborar seu próprio universo "Disney-Barksiano" de modo satisfatório, Tim Burton é um diretor conhecido por ser um construtor de mundos com uma forte qualidade estetética de inspiração pessoal. Porém, com exceção de seus primeiros filmes, Burton não consegue elaborar estruturas narrativas que forneçam um casamento com sua arte. Seus mundos, entretanto, são cativantes o suficiente para atrair multidões às exposições de sua arte.

Walt Disney é um exemplo importante porque a Disneylândia foi criada não como um simples parques de diversões, mas uma experiência em que o público pode adentrar ambientes e espaços de modo absorver e experimentar pessoalmente o que até então só havia assistido nos cinemas. E o mais curioso é que apesar da existência de divisões do parque em áreas temáticas, há uma queda de barreiras em que você observa diferentes universos convivendo juntos num tipo diferente de intertextualidade - isso muitas décadas antes de um executivo sugerir que "todas as princesas dos filmes Disney vivessem no mesmo universo para que pudessem se tornar uma marca" (STEWART, 2006). Os quadrinhos foram incrivelmente eficientes com isso. Carl Barks basicamente criou a estrutura para a cidade de Patópolis no estado americano fictício da Calisota (junção de Califórnia e Minnesota) em 1944. Na década seguinte, os quadrinistas italianos foram além e criaram uma cidade própria para o Mickey Mouse chamada Topolinia (Mouseton em inglês) (BECATTINI. e BOSCHI, 2012). E há diversos exemplos de antigos filmes explorando mundos como “O Mágico de Oz” (1939) e "20 Mil Léguas Submarinas" (1954). O que é novo no século XXI é o processo de criação já pensando em desdobramentos em outras plataformas. 


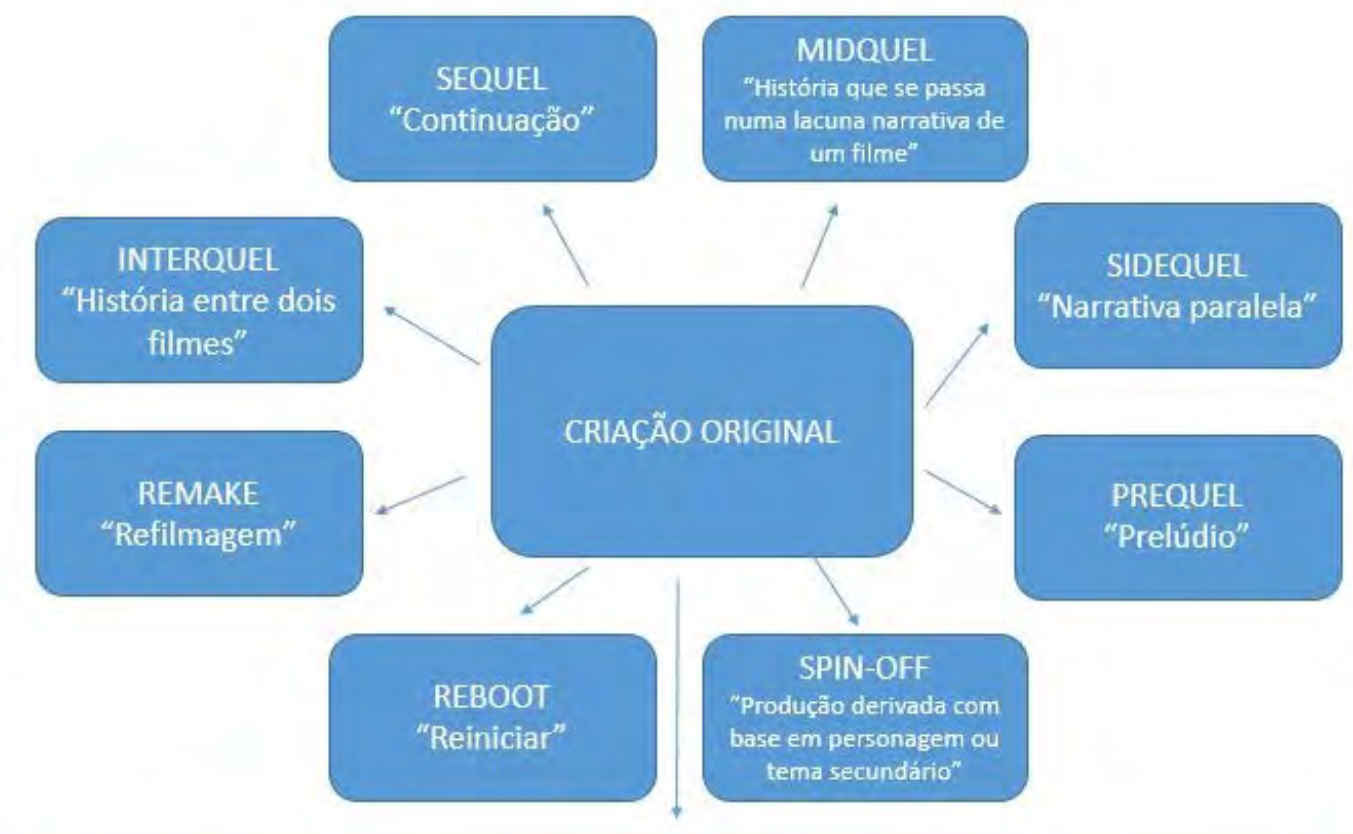

Relançamento - "Ativismo digital dos fãs pode promover o retorno de velhas produçốes"

Figura 237 - Gráfico ilustra o desdobramento possível de uma criação original.

Estes universos seriados explorados por Hollywood via Storytelling Transmídia, podem ser definidos como "representação de um processo onde elementos integrais de uma ficção se tornam dispersos sistematicamente através de múltiplos canais de distribuição pelo propósito de criar uma experiência unificada e coordenada de entretenimento". (JENKINS, 2009). Esse conceito desafia um problema comum da indústria cultural em produzir criações derivadas que não respeitam ou simplesmente ignoram suas fontes de origem. Quando uma continuação de filme, história em quadrinhos ou mesmo de videogame não obtém sucesso, muitas vezes isso tem relação com seu desvio do material que o precedeu. Quando a produção é bem pensada, o resultado é primoroso, seja em um seriado como "Game of Thrones" ou um game como "Epic Mickey". Os personagens secundários desses mundos expandidos são ideais para a criação de narrativas derivadas. É por essa razão que o cinema, os games, os quadrinhos e demais mídias investem tanto em produções derivadas, que podem ser prelúdios, continuações e todo tipo de artifício para se aprofundar nos mundos. Não é de se espantar que outras corporações adotem o storytelling em suas estratégias de marketing para contar histórias de suas marcas com narrativas emocionais, perenes e que envolvam o consumidor (BERNARDO, 2014). A marca e os "mundos construídos" dominaram o centro do processo criativo mainstream. 
Os melhores universos também bebem da fonte de antigos textos e procuram atrair seu público com histórias que estabeleçam ligações de caráter social e psicológico. Das antigas fábulas e contos de fadas até clássicas obras como "Sherlock Holmes" e "O Senhor dos Anéis", uma das qualidades mais fortes é sua mitologia. Autores como Umberto Eco (1998), Peter Coogan (2006) e Bem Saunders (2011) trabalharam o mito na indústria cultural. Vejamos nas palavras do mestre Tolkien:

"Esse aspecto de "mitologia" - a subcriação, não a representação ou interpretação simbólica das belezas e dos terrores do mundo - é muito pouco considerado, penso eu. Será porque é mais visto no Reino Encantado ou no Olimpo? Por que se pensa que pertence à "mitologia inferior", não à "superior"? Tem havido muita discussão a respeito das relações entre essas coisas, o conto popular e o mito, mas mesmo que não houvesse discussão, a questão exigiria atenção em qualquer exame de origens, por breve que fosse. Houve uma época em que era opinião dominante que todos esses elementos derivavam de "mitos da natureza". Os Olímpicos eram personificações do Sol, da aurora, da noite e assim por diante, e todas as histórias contadas sobre eles eram originalmente mitos (alegorias seria uma palavra melhor) das grandes mudanças elementais e processos da natureza. O épico, a lenda heroica, a saga então localizavam essas histórias em lugares reais e as humanizavam atribuindo-as a heróis ancestrais, mais poderosos que homens e no entanto já homens. E finalmente essas lendas se reduziram, transformando-se em contos populares, Märchen, contos de fadas - histórias infantis" (TOLKIEN, 2014, p. 22-23).

"Star Wars" é um universo constituído de mitologia. Embora seja alvo de debates interpretativos envolto ao tema de uma força totalitária e um grupo rebelde, George Lucas tem uma versão mais abrangente da construção desse mundo. Lucas estava olhando para o que ele chama de "velha propaganda" que permeou várias sociedades - mitologias, o que eles todos acreditam, relacionamento com seu pai, relacionamento com a sociedade, com sua história, com os deuses. Tudo isso é antigo, mas psicologicamente são motivos que criam motivos que através da narrativa explicam ao público no que eles acreditam.

George Lucas explica que

a primeira coisa foi encontrar o motivo psicológico que permeia a narrativa storytelling, torná-la mais popular e mostrar que não todos, mas a maioria dos garotos tem um certo relacionamento psicológico com seus pais [aqui no caso a figura paterna] e isso permeia toda a História. E a narrativa tenta explicar 
que "nós sabemos qual é o seu segredo sombrio e você faz parte do nosso grupo por sabermos as mesmas coisas. Sabemos o que pensa da sua mãe, o que pensa do seu irmão, sabemos o que pensa do seu pai.... e de sabemos realmente! E isso é o que faz as pessoas pensarem "Ei, é por isso que acredito nisso!". A parte mais brutal do ponto de vista religioso/espiritual é que as pessoas pegam essas ideias e a distorcem e você as usa para criar um herói para proteger toda a sociedade. E isso também permeia sociedades por toda a história (ROSE, 2015, tradução nossa).

Star Wars é um projeto experimental que se tornou um universo que mistura elementos conhecidos de mitologia e do próprio entretenimento, no caso dos quadrinhos e dos filmes de "Flash Gordon" e dos antigos filmes-seriados de faroeste e mistério da Republic Pictures. Foi vendido como ópera espacial e não como ficção-científica, embora tenha sido visto como filme para crianças pelos executivos de Hollywood). Lucas afirma que foi

um modo de informar garotos de 12 anos sobre mitos e situações que enfrentarão quando atingirem a idade adulta e na sociedade. E na época não havia mitologias nacionais nos EUA. O que mais se produzia e divulgava eram filmes de faroeste cujo ápice ocorrera nos anos 1950. A ideia central da saga era aproveitar as ideias psicológicas dos problemas sociais, políticos e espirituais e condensá-los numa história de fácil compreensão. A "Força" [dos Jedi] tem origem em todos os tipos de credo em várias sociedades e tempos, uma espécie de metáfora para o que é a religião. O nome vem de "Life force" usada em várias religiões. Se você acredita ou não em religião ou Deus, há alguma coisa e não temos ideia do que seja. Então forças psicológicas humanas trabalham para tentar buscar essas explicações (ROSE, 2015, tradução nossa).

A constatação é que sendo esta mitologia realmente uma explicação racional para explicar a atratividade, a despeito dos aspectos comerciais, a saga Star Wars se tornou um grande sucesso comercial em toda a cadeia de valor (Figura 241). No potente conjunto entre cultura digital e cultura de fã, os produtos fortemente ligados a mitologias atraem seguidores tão fieis que induzem a uma aura - aquela mesma discutida por Walter Benjamin (1994) - os produtos culturais passam a serem tratados como sacrossantos (exemplo na Figura 239).

Esta questão do tempo do "art business" é resumida por Lipovetsky e Serroy em quatro lógicas principais: 
1. A integração e generalização da ordem do estilo, da sedução e da emoção nos bens destinados ao consumo mercantil.

2. A generalização da dimensão empresarial das industriais culturais e criativas - constituindo cada vez menos um "mundo à parte" ou "uma economia às avessas", sendo regidos pelas economias de mercado.

3. Uma nova superfície econômica de grupos empenhados nas produções dotadas de um componente estético - o que era marginal se tornou um setor fundamental da atividade econômica.

4. O capitalismo artista é o sistema em que são desestabilizadas as antigas hierarquias artísticas e culturais, ao mesmo tempo que as esferas artísticas, econômicas e financeiras se interpenetram. Universos diferentes se desenvolvem em processos de hibridização misturando de maneira inédita estética e indústria, arte e marketing, magia e negócios, design e cool, arte e moda, arte pura e divertimento. (LIPOVETSKY, SERROY, 2014, p. 47-48).

Para além dos seis filmes dirigidos ou supervisionados por Lucas, um universo expandido foi elaborado. Tornou-se tão grande que a Lucasfilm se viu obrigada a catalogar o material num banco de dados. A ideia de um banco de dados chamado Holocron partiu do setor de licenciamento editorial. A Lucasfilm pretendia criar um jogo de RPG (Role Playing Game) em parceria com a Wizards of the Coast. Decidiram que seria necessário um banco de dados interno com todo o novo e antigo material criado para Star Wars. Até então, a Lucasfilm mantinha a mitologia oficial em grandes blocos encadernados pretos chamados "Bíblias" contendo as sinopses da história e os glossários (CHEE, 2012). O material não se restringe aos filmes. Ao contrário de outras franquias que promovem um reboot a cada versão cinematográfica, "Star Wars" amadureceu sendo um universo único. E tudo o que existe externamente aos filmes é conhecido como "universo expandido".

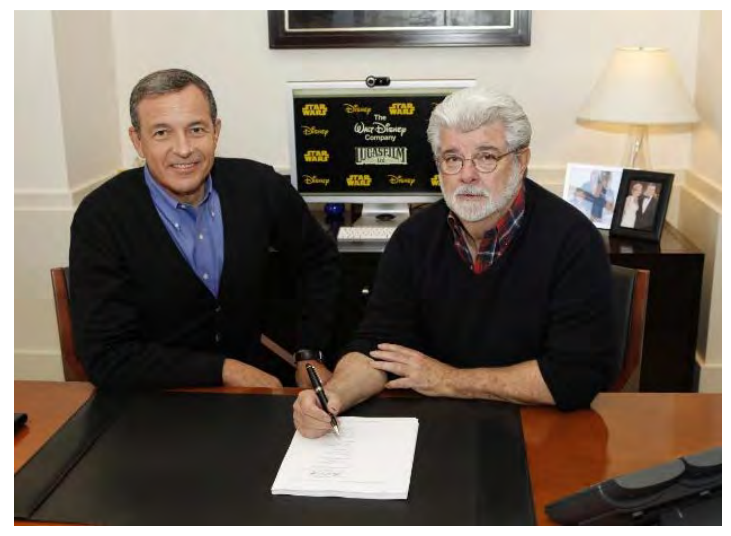

Figura 238 - Bob Iger e George Lucas na divulgação da aquisição da Lucasfilm. 


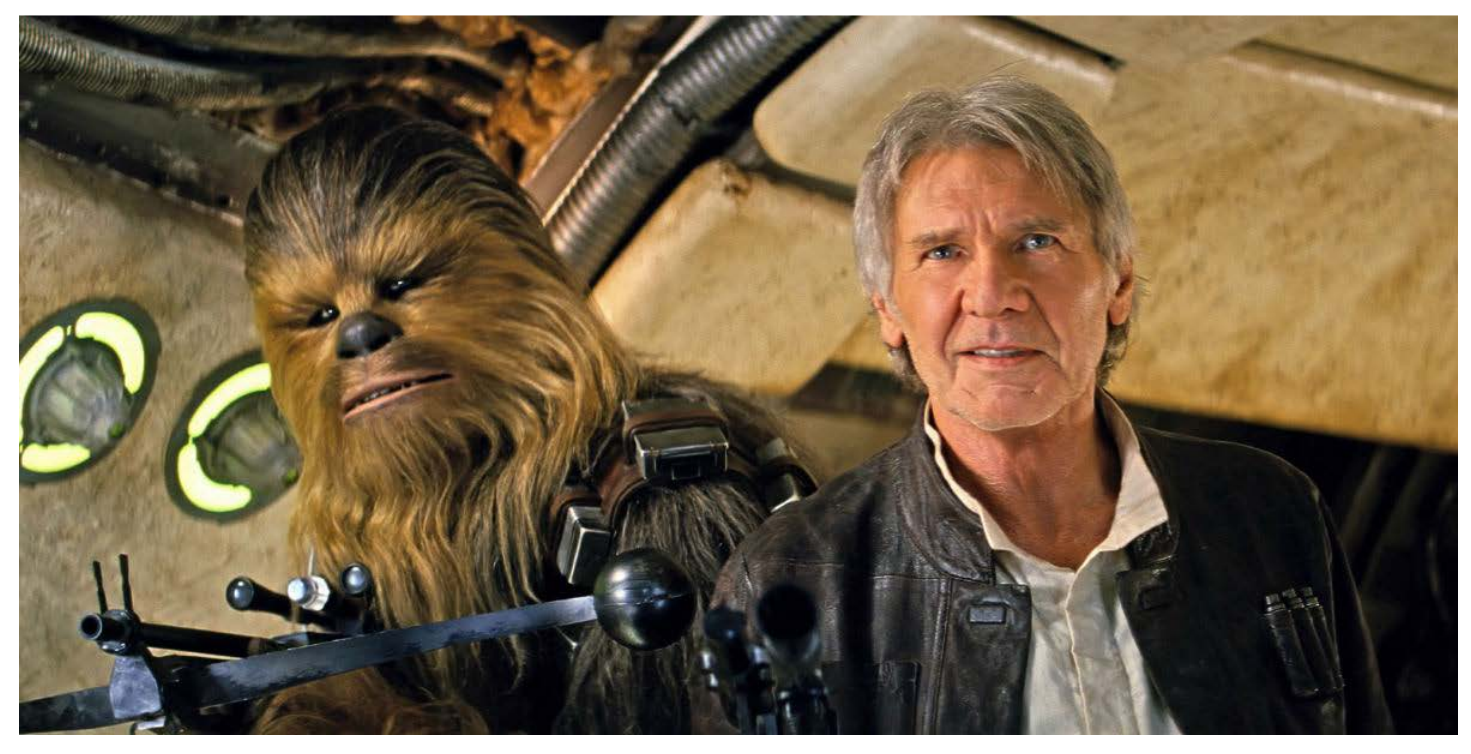

Figura 239 - O retorno de Chewbacca e Han Solo. Ligação afetiva com os fãs foi o elemento essencial para atrair os fãs em "Star Wars - Episódio VII: O Despertar da Força" (2015).

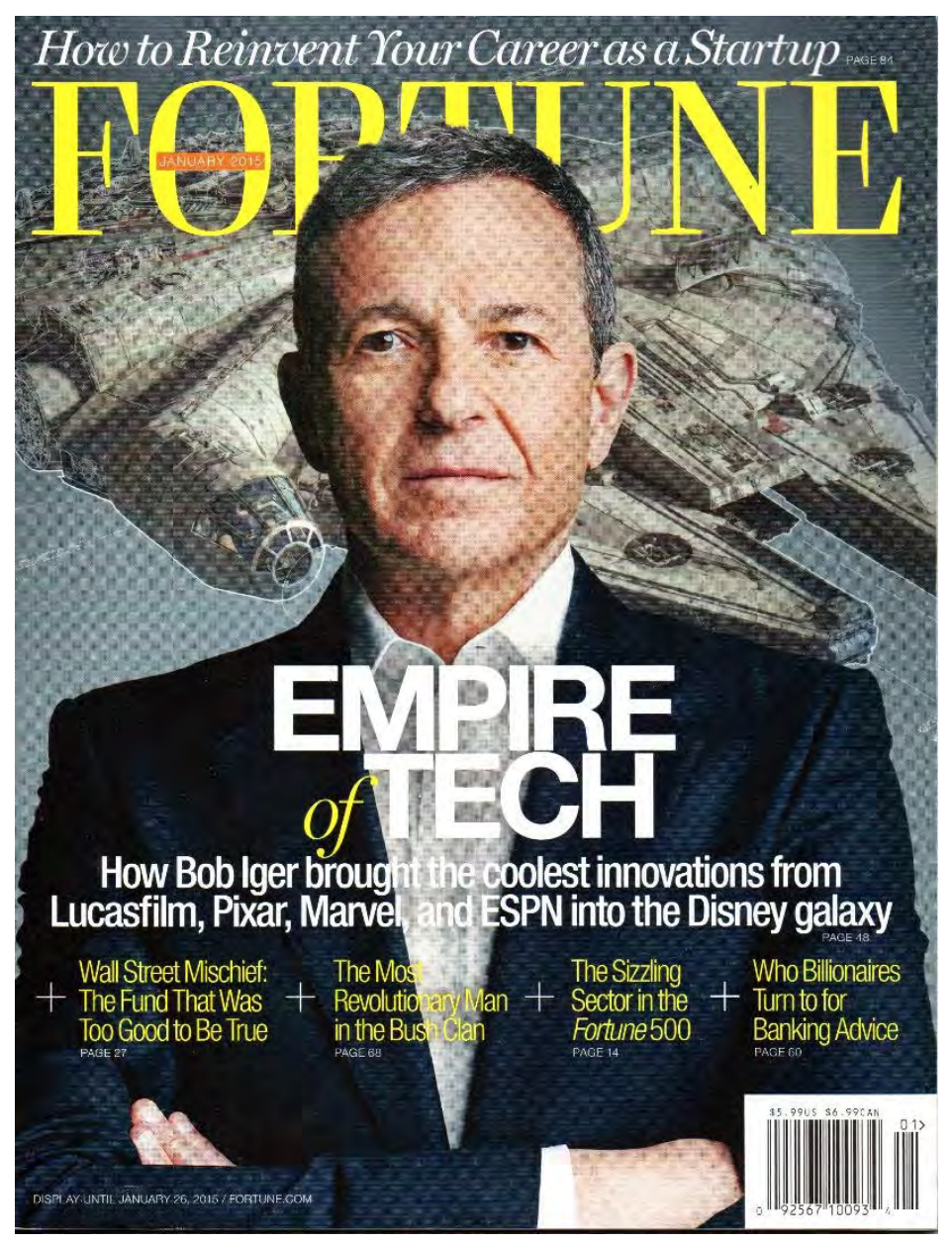

Figura 240 - O CEO Bob Iger promoveu "Star Wars" ao discutir sua doutrina tecnológica com a revista Fortune. 


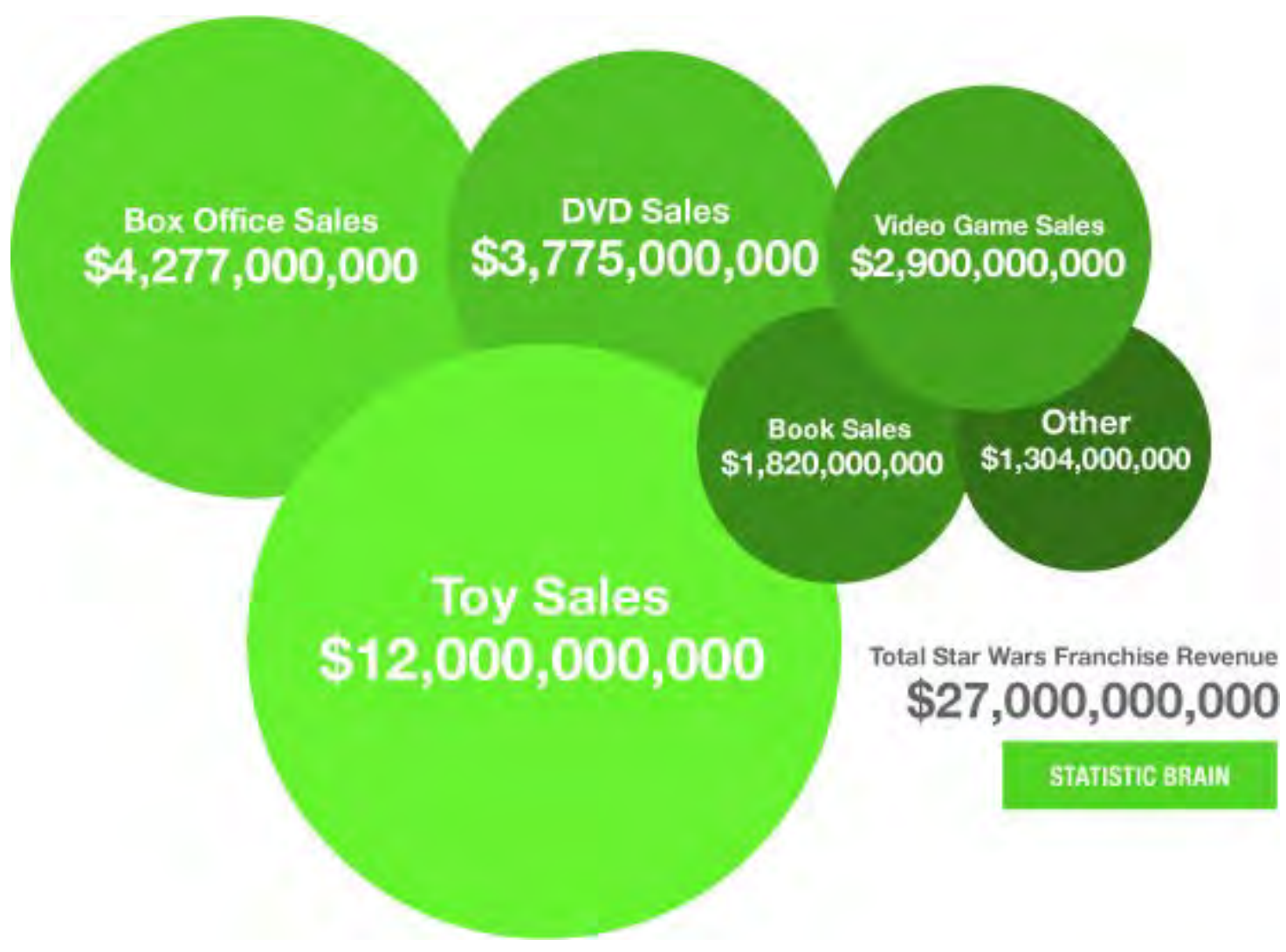

Figura 241 - Cadeia de valor (em dólares) da saga "Star Wars" até janeiro de 2015. (StatisticBrain.com)

O curador do banco de dados Holocron é Leland Chee, cuja tarefa é catalogar os mais de 35 anos de história para estabelecer a continuidade representando um cânone e evitando um reinício. O banco de dados foi dividido em níveis: (G) o mundo representado pelos seis filmes criados por George Lucas; (T) cânone da televisão com filmes e séries, incluindo o desenho "Guerras Clônicas"; (C) cânone com materiais que incluam materiais do universo expandido não superados pelos níveis anteriores; (S) materiais secundários como livros e projetos ruins como o sofrível especial de TV Star Wars Holiday Special" (1978); (SW) com finais alternativos de videogames, por exemplo; e (D) desvios como paródias em "Star Wars Detours" (BAKER, 2008). Há, deste modo, uma continuidade cruzando os produtos criados em todos os suportes de mídia: filmes, seriados, romances, graphic novels, games, merchandising, etc.

Com a aquisição da Lucasfilm pela Disney, a primeira decisão foi produzir um novo filme descartando o "universo expandido". A exemplo do que a Marvel Entertainment estruturou, seria mais prático e vantajoso criar um novo universo cinematográfico se baseando no núcleo central da criação - no caso os seis primeiros filmes. O novo "Star Wars: O Despertar da Força" (2015) foi desenvolvido em torno de muito mistério e com uma estratégia de marketing que dialogava com fãs, 
restringia vazamento de informações de forma draconiana e agendava datas para grandes revelações. Um grande evento fechado para fãs foi montado só para a prévia com o elenco e outro só para a estreia mundial (Figura 242). O lançamento do trailer foi cercado de enorme expectativa e sua publicação gerou um recorde de visualizações (112 milhões) com direito a apropriação do material e produção de outros materiais pelos fãs (WESTIN, RUHLE, 2015), como afirma a declaração da equipe da Lucasfilm no website de Star Wars:

A excitação. A alegria. O poder dos fãs de Star Wars.

Eles são reais.

Depois de dois teasers quebrando recordes, o trailer completo de Star Wars Episódio VII estreou no início desta semana, e estamos sensibilizados pela resposta. A prévia exibida durante o Monday Night Football da ESPN foi visto por uma audiência televisiva de mais de 16 milhões de pessoas, seguido por uma liberação imediata no YouTube, Facebook e plataformas em todo o mundo. Em apenas 24 horas, o trailer foi visto mais de 112 milhões de vezes online. Isso é 128 milhões de vezes no mundo todo em um único dia! Porém, mais do que números, houve discussão, havia vídeos de reação, havia memes divertidos. Houve aplausos e havia lágrimas de fãs jovens e antigos. Vimos e adoramos tudo, e isso significa o mundo para os criadores do filme. E nós estamos espantados com as vendas antecipadas de ingressos.

Websites ficaram lentos, caíram, e tornaram-se um só com a Força. (Provavelmente não foi um congestionamento tão grande de rede em uma galáxia muito, muito distante, desde a armadilha do Imperador na Batalha de Endor.) Incrivelmente - mas não surpreendentemente - vocês estabeleceram vários recordes, incluindo a maior venda antecipada de ingressos em vários países. No Reino Unido, mais de 200.000 ingressos foram vendidos no primeiro dia. Na Noruega, vocês enfrentaram temperaturas abaixo de zero durante a noite para se certificar de que estavam entre os primeiros a ver o filme. Felizmente, ainda há muitos ingressos disponíveis para o fim de semana de estreia e além.

Todos nós da Lucasfilm estamos totalmente dominados pelo entusiasmo que vimos dos fãs esta semana e durante a antecipação por este filme. E ainda temos 56 dias até o lançamento oficial em 18 de dezembro!

Obrigado a todos por tornar o universo de Star Wars o que ele é, e por mantê-lo vivo, crescente e significativo. Star Wars está de volta e começando uma nova jornada emocionante, e é por causa de vocês.

A força. Ela está chamando vocês. Nós não podemos esperar para que vocês embarquem, novamente, em dezembro". (Declaração no website oficial de Star Wars - www.starwars.com, tradução nossa) 


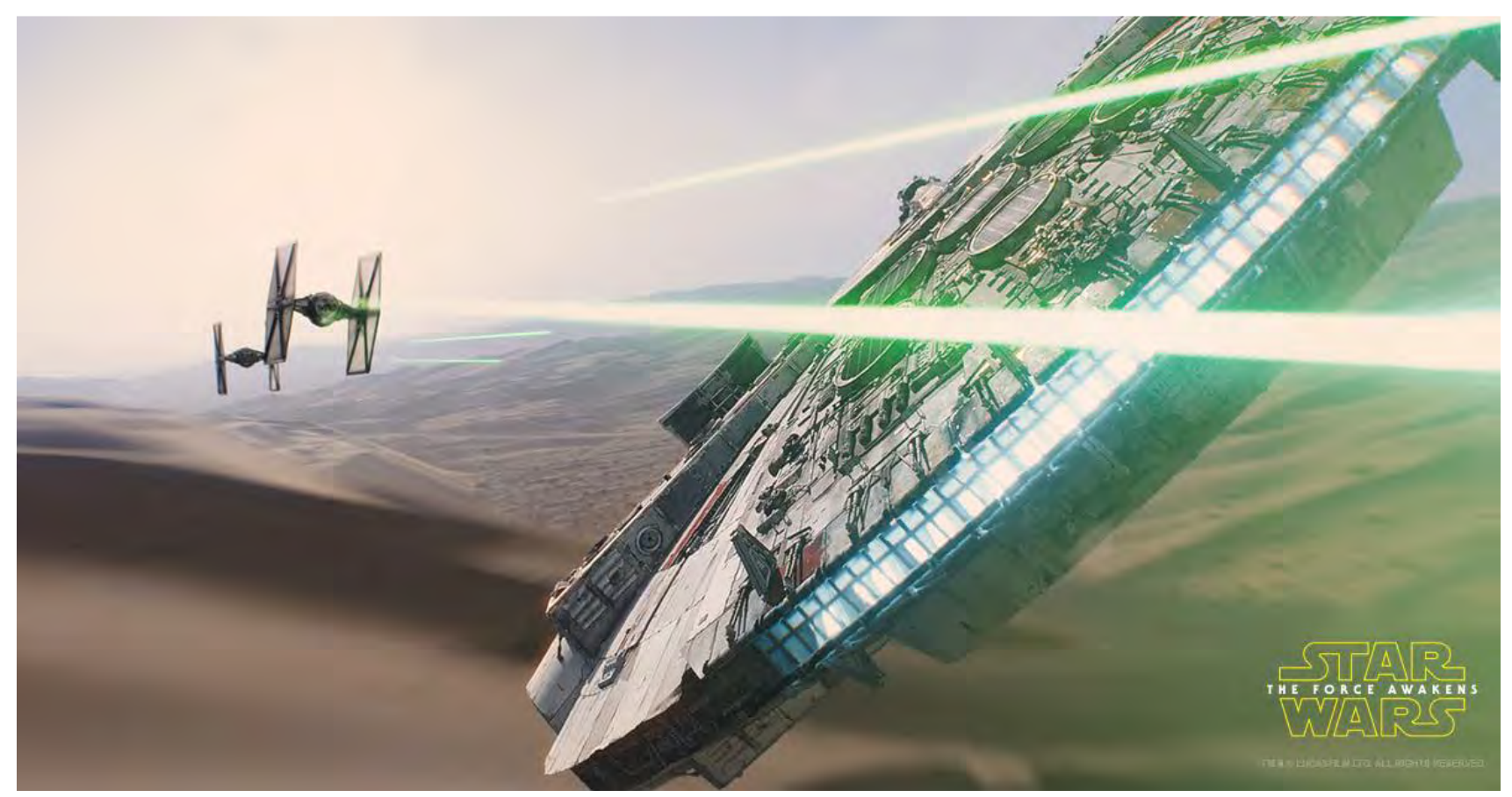

Figura 242 - O hype e as discussões entre fãs ajudaram na divulgação do filme.

Não é surpresa, portanto, que os fãs se tornaram uma grande força para a indústria cultural. A convenção de fãs de quadrinhos - San Diego Comic Con, já havia se transformado no maior evento de entretenimento dos EUA com lançamentos de quadrinhos, games, seriados e filmes, resultou em desdobramentos e exportação de eventos similares em muitos países, inclusive no Brasil.

A própria Disney percebeu o potencial e lançou em 2009 o seu próprio programa para fãs - o D23 (O Clube Oficial para Fãs) - com portal na internet, brindes, revista, visitas guiadas e gigantescos eventos para divulgar os lançamentos em todas as suas áreas de atuação. Com o volume de pessoas atraídas para um evento exclusivo como Star Wars, não resta dúvida que é perfeitamente possível acreditar que a D23 Expo (um herdeiro da San Diego Comic Con) produza outros eventos gigantescos para Star Wars e Marvel. Confira abaixo as maiores bilheterias da Disney. 
2 Marvel's The Avengers

$\$ 623.357 .910$

3 Avengers: Age of Ultron

$\$ 459.005 .868$

$4 \quad$ Pirates of the Caribbean: Dead Man's

Chest

$\$ 423.315 .812$

$5 \quad$ Toy Story 3

$\$ 415.004 .880$

$6 \underline{\text { Iron Man } 3}$

$\$ 409.013 .994$

$7 \quad$ Frozen

$\$ 400.738 .009$

$8 \quad \underline{\text { Inside Out }}$

$\$ 356.461 .711$

$9 \quad$ Finding Nemo

$\$ 339.714 .978$

10 Alice in Wonderland (2010)

11 Guardians of the Galaxy

$\$ 333.176 .600$

12 The Lion King

$\$ 312,855.561$

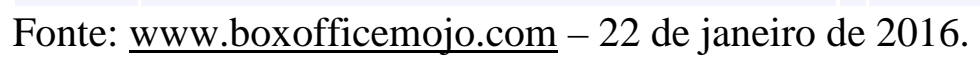

Tabela 15 - Lista com as maiores bilheterias da Disney, incluindo animações e as produções de recentes aquisições, caso da Marvel e Lucasfilm.

Neste processo de retroalimentação, são anunciados uma série de novos filmes em produção - continuações, além de outros filmes isolados baseados em personagens secundários - em lançamentos previstos em periodicidade, em média, anual. Além de possíveis seriados, games, novas áreas temáticas nos parques temáticos, numa sucessão de produções que levam ao risco da saturação. 


\section{EPIC MICKEY}

O caso do game Epic Mickey ajuda a explicar, de forma resumida, a dinâmica e os riscos desse processo criativo analisado até o momento. Em 2013 a indústria do videogame superou a do cinema em faturamento mundial (US\$ 53 bilhões X US\$ 50 bilhões) e continua sua trajetória ascendente podendo chegar aos US\$ 100 bilhões no biênio 2016-2017 (COX, 2014).

Em 2011, o mercado de histórias em quadrinhos foi pego de surpresa com uma notícia surpreendente. A graphic novel baseada no game Epic Mickey (2011) havia vendido mais de 1,2 milhão de cópias e a tendência do sucesso era continuar enquanto seria lançado em outros países. A surpresa vem do fato de que não era um lançamento comum ou baseado numa franquia do cinema. Era um título oriundo do mundo dos videogames. A história com roteiro de Peter David (roteirista de filmes como "Homem Aranha") e arte da escola italiana dos quadrinhos como Paolo Mottura e Fabio Celoni, é basicamente uma metanarrativa onde os mais diversos elementos das origens mais diversas são apresentadas ao leitor, com o cuidado gráfico de resgatar o visual do design de produção do videogame, que por si só se inspirara em curtas-metragens clássicos de animação Disney. Uma continuação, também baseada na sequência do game - Disney Epic Mickey 2: Poder em Dobro (2013) - também teria Peter David no roteiro e Fabrizio Petrossi na arte.

A graphic novel (Figura 243) é destacada aqui por ser um produto derivado, comprovando a tentativa da Disney em criar uma nova marca ou franquia inspirada no game. Algo inédito até então. Sua criação constatou que seguiu todo o aparato de sinergia já elaborada pela Disney. E uma dos mais caros investimentos. Porém, é necessário entendermos a lógica por trás desse lançamento que possui um contexto complexo. A ideia da Disney em produzir um game usando Mickey Mouse aprisionado em um mundo de personagens rejeitados é de 2005, quando Warren Spector, um desenvolvedor de games, foi convidado a produzi-lo. A Disney também tinha um grande potencial em mãos - o personagem Osvaldo - O Coelho Sortudo (Oswald - the Lucky Rabbit). Criado em 1927 por Walt Disney e Ub Iwerks, o personagem estrelou uma série de curtas-metragens na era do cinema mudo (GROSSMAN, 2011, p. 46). Por causa de uma renegociação de contrato, o produtor Charles Mintz se aproveitou de brechas e contratou toda a equipe de Disney e ainda lhe roubou os direitos do personagem, que posteriormente faria parte do catálogo da Universal Pictures sob o estúdio de Walter Lantz. Osvaldo foi somente recuperado em 2006 quando o CEO da Disney, Bob Iger, em uma negociação peculiar conseguiu negociar com a NBC Universal a troca de um narrador esportivo da rede de TV ABC (de propriedade Disney), Al Michaels, que desejava trocar de emissora, por uma série de contrapartidas que incluíam os direitos de utilização do coelho Osvaldo. 
Havia diversos modos de reintroduzir o velho-novo personagem na Disney atual, mas todos os projetos, incluindo uma história em quadrinhos no estilo dos velhos curtas-metragens, foram adiados em nome de um "grande projeto" que viria na forma do game Epic Mickey, que teria Osvaldo como principal nome no mundo dos personagens rejeitados e esquecidos. Ao contrário de lançamentos singulares dos anos 1980 como Castle of Illusion ou da popular série de games e quadrinhos Disney japoneses Kingdom Hearts, Epic Mickey fazia parte de uma estratégia de renovar o interesse no Mickey, tendo como proposta reintroduzir os personagens a uma nova geração com uma nova roupagem mas apostando, ao mesmo tempo, em uma abordagem retrô. O projeto foi desenvolvido pela Junction Point Studios, empresa de Warren Spector, adquirida pela Disney Interative para a produção de games. Spector, um fã assumido do universo Disney, dirigiu a equipe que montou a criação mais sinérgica das últimas décadas.

O universo paralelo onde se passa o game/história foi criado pelo feiticeiro Yensid - Disney escrito ao contrário - mais conhecido do segmento "O Aprendiz de Feiticeiro" do filme "Fantasia" (1940). O cenário da história é nada mais do que uma versão pós-apocalíptica do parque Disneylândia chamada "Refugolândia" (Wasteland), cujas atrações também seriam aproveitadas. Neste mundo construído por Osvaldo e o Médico Louco (personagem criado nos anos 1930) vivem todos os personagens e elementos rejeitados e esquecidos do mundo Disney. Um exemplo são os gremlins, personagens de um filme cuja colaboração entre Walt Disney e o escritor Roald Dahl nunca foi a adiante. O vilão tem origem nas histórias em quadrinhos: o Mancha Negra, criado em 1939. E toda uma narrativa precisa ser elaborada para que fosse coerente por mais de 10 horas de ação. Um grande desafio tendo em vista que Mickey Mouse não é um personagem complexo e sofisticado, tendo mais um senso de humor e travessura, e também um senso de que precisa superar obstáculos para atingir seus objetivos, basicamente um instinto de ser prestativo e heroico (GROSSMAN, 2011, p. 20-21). E até mais importante do que isso - seu design não pode alienar o público (as pessoas se conectam com uma figura já conhecida). Novamente os quadrinhos influenciaram - o quadrinhista Carson Van Osten foi um dos responsáveis pelo design de personagens. Quem jogou o game e leu a graphic novel, teve a chance de assimilar um conteúdo complementar, com maior penetração nos sentimentos dos personagens envolvidos.

O padrão de desenvolvimento que vemos no game e no seu produto derivado - a graphic novel - não segue a ordem comum de seus correlatos. Trata-se de uma estratégia maior de aliar produto e potencial para criar uma marca e franquia - storytelling transmídia. Vejamos em seguida as duas estratégias que influem na produção e os obstáculos enfrentados num caso como do Epic Mickey, pertencente a estratégia do Blockbuster. 
Warren Spector, desenvolvedor do game e atualmente professor da University of Texas em Austin, ministrou uma master class em 2007 onde elencou as características da produção de games. O primeiro ponto é que não havia diálogo entre a produção de games e a universidade há cerca de uma década atrás. O segundo ponto é se a produção de games está se tornando um negócio mainstream (MARTEL, 2012). Não chega a ter mais que o volume de negócios de Hollywood, porém com alguns títulos de games custando o equivalente a dezenas de milhões de dólares (superior a muitos filmes) a produção já atingiu um padrão para se tornar relevante. Há também a questão de convergência de mídias, a expansão do universo de jogadores/consumidores (milhões), audiência diversificada (a faixa etária consumidora aumenta, o público feminino tornando-se uma parcela relevante no consumo), e o fato de ter atraído atenção para discussão até no Congresso dos Estados Unidos. Um debate que poderia ser aproveitado pela universidade, tendo em vista a "janela de cultura" que se abre com discussões sobre temas como a liberdade de expressão e a violência, o gênero do consumidor, a economia, a faixa etária, entre outros (SPECTOR, 2007).

Muitos desenvolvedores são jovens e não são altamente escolarizados, pois as universidades ainda estão atrasadas em relação a alta capacitação informal nessa área. Os games também possibilitam novas abordagens no design. E na questão dos recursos, os desenvolvedores não têm os mesmos fundamentos dos profissionais oriundos da formação em outras áreas, como o cinema. Entretanto, esses profissionais estão altamente capacitados para trabalhar na TV, cinema e noutras mídias.

O processo de gerenciamento de projetos é novo. Conhecido como método SCRUM, ele é interativo e incremental para a administração de projetos e desenvolvimento de software ágil, sendo usado para antecipar uma decisão num projeto complexo no qual há enorme imprevisibilidade (CARVALHO e MELLO, 2009). Nele, há reuniões diárias com a equipe, transparência no planejamento, problemas não são ignorados, "horas extras" nem sempre são sinônimo de "produção extra". E finalmente, a questão da credibilidade. O pesquisador Henry Jenkins (2009) é um dos expoentes na questão da discussão acadêmica dos games, convergência e fandom (a cultura dos fãs). 

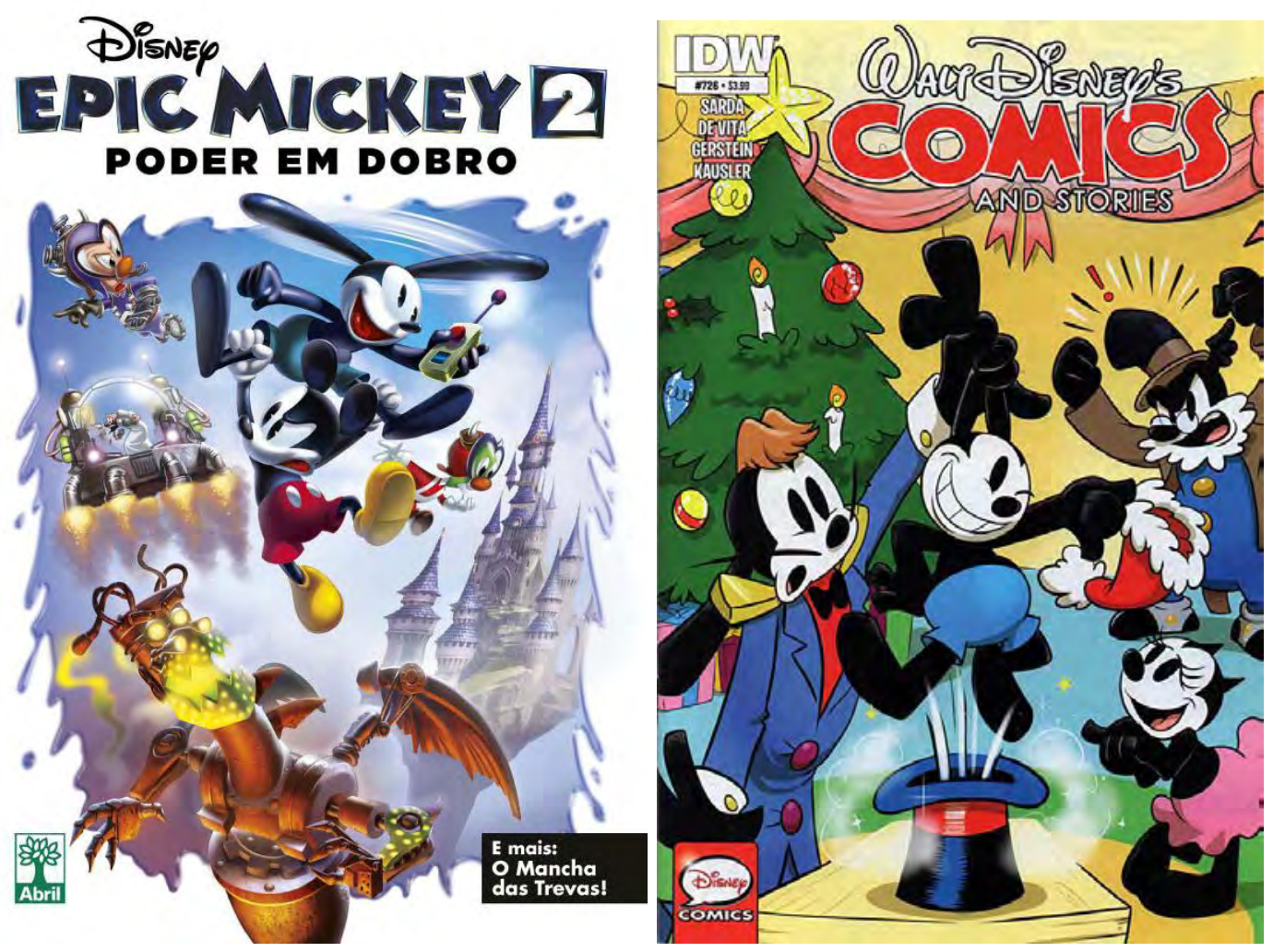

Figura 243 - Capa da graphic novel "Epic Mickey 2 - Poder em Dobro".

Figura 244 - Gibi com história em quadrinhos inédita do Osvaldo em 2015.

Percebemos até aqui que a cultura do game é algo ainda relativamente novo na universidade. Um de seus atributos está no potencial de reciclagem de suas criações. Um game/marca criado há três décadas pode ser refeito e lançado com sucesso por diversas vezes, atingindo não só as velhas gerações, mas as novas. Essa cultura do game aliada a cultura de fã tem sido estrategicamente utilizada pela indústria do cinema quando relançam franquias cinematográficas do zero após poucos anos do último lançamento de uma série ("Homem Aranha” é um exemplo). E um fator igualmente importante e atrelado a esse modelo é a "cultura do fã" (JENKINS, 2006), já familiarizado com o conteúdo ou seus personagens, que consumirá mais facilmente um produto com apelo já reconhecido e legitimado. Estas novidades geralmente passam por testes e consultas do mesmo grupo consumidor. Não é coincidência, portanto, que os desenvolvedores de Epic Mickey se preocupam em não alienar o público de Mickey Mouse nem o dos games e, no desdobramento, o dos quadrinhos.

Se o Epic Mickey foi produzido seguindo a estratégia Blockbuster dentro do esquema atual de storytelling transmídia, e tudo caminhou nesse sentido, seus desenvolvedores e a própria Disney 
cometeram falhas. Se do ponto de vista criativo o produto era certeiro, do técnico havia limitações que desapontaram os jogadores - a imprecisão da "câmera" com o ponto de visão dos personagens e algumas ações importantes dos personagens foram criticados. Um segundo problema é que, apesar de sombrio, o game não estabelece se foi feito para crianças ou para o público adulto já familiarizado com os personagens e a forma de jogo. Aliás, esse problema da lacuna etária se repete mesmo no mundo do cinema (GASI, 2012). E um terceiro problema: o game foi desenvolvido para somente uma plataforma - o Nintendo Wii. A estratégia transmídia tem como pressuposto atingir o maior número de pessoas, o que demonstra até aqui que a faixa etária e a limitação de plataforma são provas concretas do problema com o título. Mesmo assim, o Epic Mickey vendeu entre 30 de novembro de 2010 e o fim do mesmo ano mais de 1,3 milhão de cópias (que depois teria algum efeito nos quadrinhos), um número respeitável.

A solução encontrada com o moderado sucesso foi produzir uma sequência que ouvisse os fãs e respeitasse integralmente a estratégia transmídia. Desta vez, os problemas de "câmera" e jogabilidade foram resolvidos, os personagens passaram a falar e momentos musicais foram inseridos. Do ponto de vista do fã consumidor, o game-continuação Epic Mickey 2: Poder em Dobro (Power of Two) é a antítese de seu antecessor. A premissa reduz a complexidade narrativa e o tom se torna mais infantil e simplista (GASI, 2012). Estas características, somadas as críticas ao primeiro jogo, alienaram o público do novo lançamento. Do ponto de vista da produção, a estratégia seguiu a visão de que era necessário alcançar o maior público possível. A saída foi levar o novo Epic Mickey 2 ao máximo de plataformas disponíveis (console, online e smartphone), tornando o desafio muito mais técnico do que narrativo. O estúdio Junction Point precisou coordenar o trabalho de 800 pessoas em 10 locais diferentes para que o game fosse desenvolvido para 8 plataformas que incluíam o Mac OSX, o Microsoft Windows, o Wii, o Wii U e o Xbox 360.

A Disney não confirma, mas extraoficialmente calcula-se que o orçamento ficou entre US\$ 20 e 30 milhões. Planejando vender 2 milhões de unidades (US\$ 50 milhões em faturamento), as vendas de Epic Mickey 2 amargaram um fracasso de 270 mil cópias vendidas no mesmo período em que o primeiro superou 1 milhão. A longo prazo, o game vendeu mais de 700 mil cópias mundialmente, porém o dano para a contabilidade do estúdio foi desastroso. O efeito foi a estagnação e o resultado o meltdown (colapso) da "equipe de produção". A Disney foi obrigada a assumir os prejuízos, fechando a Junction Point e demitindo seus funcionários (FRITZ, 2013). Quaisquer que tenham sido os motivos do fracasso nas vendas, temos a prova de que nem a mais poderosa corporação 
de mídia está imune aos efeitos humanos da cultura digital e do fandom. A Disney deixou de investir pesadamente em produção de games para consoles e migrou para projetos que tenham um foco maior nas mídias sociais ou em projetos transmídia como o Disney Infinity, que tem obtido sucesso devido ao mix de venda de produto físico, games e kits com expansão dos jogos.

O final feliz da história do coelho Osvaldo é que o game pode não ter prosseguido, porém a história em quadrinhos do seu retorno foi finalmente publicado na revista Walt Disney Comics \& Stories (2015) - Figura 244. A velha mídia das histórias em quadrinhos permanece sendo um canal ativo para novidades. 


\section{CONSIDERAÇÕES FINAIS}

A primeira constatação é como as transformações tecnológicas ocorrem em velocidade tão acelerada nas duas primeiras décadas do século XXI. São transformações que alteram os hábitos e as percepções e transformam também indústrias como a do entretenimento. Esta tese explicou as mudanças ocorridas no período de transição entre uma era basicamente formada pelas décadas de 1980 e 1990 e uma pós anos 2000 em diferentes terrenos e áreas de atuação. Lembramos que quando esta tese foi iniciada em 2011 pouco se discutia no Brasil o papel dos universos narrativos nas estratégias de produção de quadrinhos e no cinema e os efeitos de saturação e meltdown (colapso). Nos anos seguintes, alguns dos mais respeitáveis pesquisadores da comunicação começaram a tratar do tema. Muitos são citados neste trabalho, com especial atenção para Henry Jenkins (2009), que proferiu palestras em 2015 usando exemplos Disney que foram analisados na pesquisa.

Emprestando um conceito da economia, este processo de estagnação e meltdown (colapso) é equivalente ao conceito da "destruição criativa" como formulada por Joseph Schumpeter (1961) um processo dinâmico de nascimento, envelhecimento e morte de tecnologias, identificado como essência do capitalismo. Uma espécie de caos perene em que o capitalismo tem a capacidade de inventar e reinventar de forma constante. Isso ocorre basicamente por quatro elementos: o estoque de conhecimento, de capital ou investimento, de empreendedorismo e da "cultura do âmbito da atividade" (aqui no caso a "cultura do estúdio"). A interação destes quatro elementos contribuem na busca por mais quantidade e qualidade gerando a "destruição criativa", que nada mais é do que o processo de inovação

Em outras palavras, um processo que ocorre em busca do lucro, de novos conhecimentos, da conquista de novos territórios. Cria-se, assim, um novo paradigma. A tese sistematiza o processo ocorrido nos anos 2000 com a transição da animação tradicional para a computadorizada e posteriormente, tenta obter respostas para as mudanças que ocorrem com as transformações conjuntas da cultura digital e cultura de fã na indústria cultural. 
Do ponto de vista da produção, destacamos o trabalho de dois quadrinistas (Don Rosa e Casty) e pontuamos os trabalhos de alguns animadores tradicionais da Disney da era 1980-1990. Durante minha visita técnica aos estúdios Disney, meu anfitrião me guiou por um corredor interno no campus criativo de Glendale, que exibia belos esboços a lápis do animador Andreas Deja com muitos de seus personagens emoldurados à vista de quem quisesse ver. Em outra parede fui apresentado a um outro conjunto de quadros com esboços rústicos e rápidos. O nome do artista estava lá, mas eu não reconhecia. Tratava-se de Ricky Nierva, diretor de arte e designer de produção da Pixar, com vasta contribuição ao estúdio desde que foi admitido em 1997. Não era um desconhecido e nem um novato. Foi aí que comecei a discutir com meu anfitrião a questão do anonimato dos artistas. Ambos concordamos que esse é um problema na atualidade. Embora não seja o normal um entusiasta não conhecer todas as figuras na produção (aliás, historicamente, somente algumas dezenas de artistas tiveram reconhecimento público), os artistas da geração anterior tinham muito mais visibilidade. Hoje, estão limitados praticamente no âmbito de seus pares nas convenções específicas.

Meu guia na visita aos estúdios Disney, Floyd Norman comentou e depois até publicou em seu blog (NORMAN, 2015b) que hoje há muito mais produção de animação ocorrendo nos Estados Unidos e em outros países em relação aos anos 1950 quando a Disney operava com 600 artistas. A estreia de "Toy Story" em 1995 e a posterior redução de preços e popularização dos softwares de animação e design proporcionaram uma enxurrada de novas produtoras independentes e um número maior de lançamentos - muitos deles brigando de igual para igual com os filmes dos grandes estúdios. Porém, como afirma Norman (2005b) “artistas da animação e uma legião de talentos habilidosos permanecem invisíveis. Embora seus belos trabalhos possam ser vistos na tela, o público continua tendo pouco interesse em quem fez o filme que ele assistiu”. A crítica dele é em comparação à fama dada às celebridades que dão vozes aos personagens, que ganham muito mais holofotes.

Pode não ser um problema somente do público. É possível encontrar um enorme grupo de entusiastas espalhados pela Internet, que conhecem bem muitos nomes na criação. O problema certamente tem relação com a discussão levantada na tese sobre a redução na importância dada pelo estúdio aos criadores. Talvez nem seja importante solucionar a questão da motivação "interna" ou "instrumental" de quem tem o poder decisório, mas é fato que o espaço dado aos criadores foi muito reduzido, seja nos eventos, ou em extras de DVDs e Blu-rays (produtos em extinção), em livros e na própria divulgação dos filmes. Em um momento em que as grandes produtoras instauram comitês 
para discutir e decidir rumos criativos, é razoável constatar que este mecanismo de potencializar filmes, produtos comerciais em si, em marcas ainda mais poderosas, tenham reduzido o status dos animadores a meros operários fabris com pouquíssima visibilidade. Neste quesito, os quadrinistas levam vantagem, pois a produção autoral tem sido muito valorizada.

Da mesma forma, foi impossível para a Pixar manter o idealismo da época em que era apenas um estúdio independente nos anos 1990, produzindo filmes que eram distribuídos pela Disney. Como lembrou Floyd Norman (2005b), “a Pixar nos anos 1990 era uma start-up com no máximo 300 funcionários", um estúdio "boutique" com um grupo de amigos criativos, bancados por um investidor abnegado. Passados todos esses anos, a Pixar está tão corporativa quanto a Disney, já experimentou um pequeno tropeço com o lançamento abaixo do esperado de "O Bom Dinossauro" (The Good Dinosaur, 2015), e na busca do lucro aparentemente fácil em continuações como "Carros 3” (2017), “Procurando Dory” (2016), “Toy Story 4” (2018) e “Os Incríveis 2” (2019).

O que constatamos nos capítulos 5 e 6 é que mesmo em uma nítida expansão do mercado de animação, a produção sofreu o processo de saturação, estagnação e finalmente o "meltdown”, com a consequente demissão e redução de um tipo de produção em detrimento de outro. O rápido processo de transição, instituído pela corporação, resultou numa quebra da passagem natural entre as gerações de artistas e criou obstáculos no processo criativo dos estúdios. A técnica tradicional não desapareceu, porém ficou mais limitada aos estúdios independentes e aos projetos publicitários. A técnica da animação computadorizada rapidamente foi impulsionada e, num período mais curto, chegou próxima a uma nova saturação, somente evitada pelo desvio de atenção dos grandes estúdios aos grandes projetos com universos compartilhados.

Não significa o "fim da História", como disse o economista Francis Fukuyama (1992). Visitando os estúdios, é perceptível a ânsia da criação em muitos desenhistas e o trabalho é de excelente qualidade. Não raramente, os animadores e designers têm suas obras expostas em galerias de arte e eventos especiais. Como no caso do Tim Burton, em que sua obra já foi apreendida por seus fãs e convertida ao status de arte, a indústria cultural tem esse poder de valorizar e derrubar significações. A cultura digital e a cultura de fã tem sua contribuição na valorização dessa arte. 
Nos capítulos 6 e 7, somado ao estudo de caso do capitulo 8, constatamos que não apenas a transição ocorre do ponto de vista do estúdio e sua equipe produtora, mas que atualmente envolve fortemente os efeitos da cultura digital e da cultura de fã. Do ponto de vista macro da produção de filmes, os estúdios e também as editoras de quadrinhos continuam em sua saga de tentar compreender seu público para produzir conteúdo. E o público, graças a cultura digital, se tornou uma ferramenta útil quando grupos de fãs passaram a interagir, produzir e cobrar os criadores. A cultura fandom é o principal motor para a produção das grandes franquias, e ela é quem decidirá o destino em caso de saturação e estagnação técnica ou criativa. Quando usamos esses termos, não se trata de indicar uma explicação única e sim constatar tendências envolvendo a ambição de alguns projetos e o posterior fechamento de empresas produtoras.

Estamos vivendo uma época da intensificação. O professor Jeffrey Nealon (2012) revisou o trabalho de Fredric Jameson sobre o pós-modernismo. Jameson analisava os anos 1980, e podemos ampliar para os 1990, como período de fragmentação na cultura. Nealon aponta que atualmente vivemos justamente a intensificação. Há um capitulo tratando das commodities culturais em que observa as novas apropriações dos jovens em relação aos produtos culturais antigos. Por exemplo, uma música transgressora dos anos 1960 é usada hoje em contextos diferentes, seja em comerciais de TV até uma academia de musculação. Essa relação não é tão nova, porém o importante é como esse material atrai o jovem atual que não possui investimento pessoal na "autenticidade", não conhece e muitas vezes não entende a motivação original do produto. A resposta de Nealon é que não é mais o gosto musical que conta ou define um ouvinte, e sim um novo ecletismo. Seria o triunfo do pósmoderno superado a obrigação residual modernista com o estilo pessoal.

Uma das reflexões possíveis é que o ponto final não é enxergar esses produtos culturais analisados simplesmente como commodities ou comprovação de popularidade, e justamente como "intensificações” que definem as combinações econômicas, sociais e históricas atuais. A novidade aqui é que analisamos que a força da evolução tecnológica traz muito mais impacto do que se pensava nesse conjunto de fatores. Se retirarmos os aspectos econômicos da análise, veremos que o conceito de universo compartilhado representa uma nova ideia para os estúdios de Hollywood. Ela envolve técnicas narrativas diferentes do usual, com elementos mais proeminentes nas histórias em quadrinhos e na TV. Ela necessita de profissionais especialistas neste tipo de storytelling, o que justifica a presença nos créditos de nomes ligados a essas áreas. Seriados como "Jornadas nas Estrelas" (Star 
Trek) e "Arquivo X" (X-Files) são exemplos de que os produtores de TV sabiam, muito antes do cinema, como trabalhar com episódios singulares, arcos narrativos que duram uma temporada e uma linha geral que permeia todo o seriado. Os fãs, por sua vez, contribuem via ativismo digital, resultando em alterações, retorno de séries canceladas e continuações com seus personagens favoritos. Seriados de TV são criados coletivamente a partir de um showrunner. Como analisamos, a Pixar, Marvel e a Lucasfilm, todas trabalham com comitês criativos elaborando as produções com a supervisão de um executivo criativo: John Lasseter (Disney e Pixar), Kevin Feige (Marvel), John Knoll e Kathleen Kennedy (Lucasfilm).

Temos também a questão dos limites da exploração pela indústria cultural com as variáveis econômicas globais e o fluxo global da produção, em que a Disney busca atingir novos mercados e públicos - "o capitalismo atual busca primeiramente saturar e aprofundar, intensificando seu domínio sobre os mercados existentes, na medida em que o capitalismo global do século XXI está sem novos territórios para conquistar" (NEALON, 2012, p.26). É uma boa resolução para entender o ponto central que permeia esta tese. O modelo de produção após sua expansão se torna saturado, pois passa a dominar todo o mercado em suas diferentes mídias, inclusive o instável mundo dos quadrinhos. Esta estagnação, que resulta da conquista do mercado, não é o suficiente para agradar investidores e acionistas; logo, a saída estratégica é intensificar o mercado para aproveitar os bons frutos que vem dele. E os estúdios se utilizam dos fãs consumidores para retroalimentar a produção, com novidades que muitas vezes são "mais do mesmo", por vezes piorados.

O próprio CEO Bob Iger corrobora que as pesquisas de mercado não conseguem aferir o que os fãs desejam. Embora os comitês criativos esbocem projetos para uma década, os executivos financeiros estão mesmo preocupados é com o resultado anual. Não é incomum que a especulação em torno do desejo do fã resulte em lixo - produções medíocres, mal elaboradas ou modificadas a tal ponto de serem criticadas ou boicotadas. Quando acertam a narrativa, entretanto, seja com o auxílio de algoritmos de consumo ou pela troca de informações em mídias sociais, o resultado pode ser um novo fenômeno popular - caso do seriado da Netflix, "Stranger Things", uma homenagem aos filmes e a cultura pop dos anos 1980 que alcançou mais audiência que seriados de super-heróis como "Demolidor" e "Jessica Jones"50.

${ }^{50}$ Informação sobre "Stranger Things" incluída na versão corrigida da tese. 
Os estúdios de Hollywood têm intensificado essa estratégia para intensificar a produção e dar continuidade ao modelo de expansão. Um dos modos seria intensificar o espetáculo - geralmente as continuações dos filmes de super-heróis possuem cenas de ação mais exageradas e não estranhamente vemos múltiplos vilões. Na animação ocorre o mesmo com a inserção de mais personagens, mais ação e mais cenas mirabolantes. Um dos fatores que contribuem para um certo tipo de estética é o mercado chinês. Cientes do que agrada a clientela asiática, os estúdios de Hollywood se submetem a produções pensadas com o tipo de ação que agrada a esse público. Mais explosões, menos filosofia ocidental - muito complicado para o público médio nesse mercado e mais fácil de ultrapassar o mercurial sistema de censura chinês, sempre zeloso com a "propaganda americana". No plano político a Disney teve muito sucesso na China. Tanto que, em 2010, o presidente Barack Obama escalou o CEO da Disney para o President's Export Council, conselho de exportação que aconselha o presidente na promoção de exportações, empregos e crescimento nos EUA. Bob Iger, em ação diplomática, liderou uma negociação delicada para expandir as relações comerciais com a China. Sua aproximação com o presidente Xi Jiping lhe valeu encontros com o mandatário em Washington e Pequim (Figura 246), e destravou a autorização para a construção da Disneylândia de Xangai. Não sem antes abrir generosas exceções no negócio - o parque foi visibilizado pela formação de duas empresas: uma proprietária (43\% Disney e 57\% Shendi Group chinês) e outra operacional gerenciando o dia-a-dia do parque (com controle majoritário chinês).

Um segundo tipo de estratégia dos estúdios é a intensificação narrativa criando conexões entre os filmes, resultando em um mundo compartilhado que faz os filmes individuais mais ambiciosos e obrigatórios para o consumo dos fãs. Há vantagens e desvantagens neste modelo de produção. Um dos obstáculos nas produções audiovisuais é a questão do tempo. Os universos dos super-heróis sobrevivem nos quadrinhos em parte pelo efeito que o quadrinista Stan Lee chama de "ilusão da mudança" (DAVID, 1998). Os eventos nas histórias em quadrinhos aparentam estar sempre em desenvolvimento a cada derrota de um vilão pelo herói, porém as características básicas do protagonista são sempre reiniciadas ao fim. O Peter Parker de "Homem-Aranha" pode derrotar o vilão mais tecnologicamente dotado, porém ele permanece sendo um estudante com todas as qualidades que transmitem empatia ao leitor. No cinema e na TV, o tempo já se torna um problema quando percebemos o envelhecimento dos atores e quando uma equipe inteira precisa ser substituída. Por mais que haja liberdade criativa, neste modelo não é possível matar ou alterar personagens importantes sem atenção ao universo expandido e compartilhado. 
"Star Wars", como analisamos, é um universo singular se comparado aos múltiplos heróis e universos que a Marvel necessita para se perpetuar. Entretanto, a franquia possui uma grande vantagem - justamente o espaço temporal da narrativa. Não é preciso reiniciar características básicas de personagens. Os criadores podem avançar ou retroceder no tempo com novos personagens, situações e ambientes, com o cuidado do entrelaçamento com o material existente. Semelhante ao que a Disney fazia ou tentava fazer em suas continuações nos anos 1990. "Star Wars: O Despertar da Força” (Star Wars: The Force Awakens, 2015) não é uma continuação stricto sensu das duas antigas trilogias. É uma espécie de ponte que serve para fechar o antigo arco e iniciar um novo.

Os próximos filmes da saga seguirão as determinantes do filme de 2015, mesmo que ele repita muitas das características básicas dos antigos filmes. Outros projetos, como "Rogue One: A Star Wars Story" $(2016)^{51}$, são produções autônomas que expandem o universo narrativo. Neste caso, a premissa do filme se baseia numa frase informada no prólogo de "Star Wars: Uma Nova Esperança" (Star Wars: A New Hope) de 1977, envolvendo o roubo dos planos do Império por espiões rebeldes, que nunca são mostrados ou citados durante o filme. Portanto, temos o início de uma antologia de filmes relacionados a saga. A Disney se apropriou de um método "patenteado" pela Marvel e que é aprimorado pela Lucasfilm.

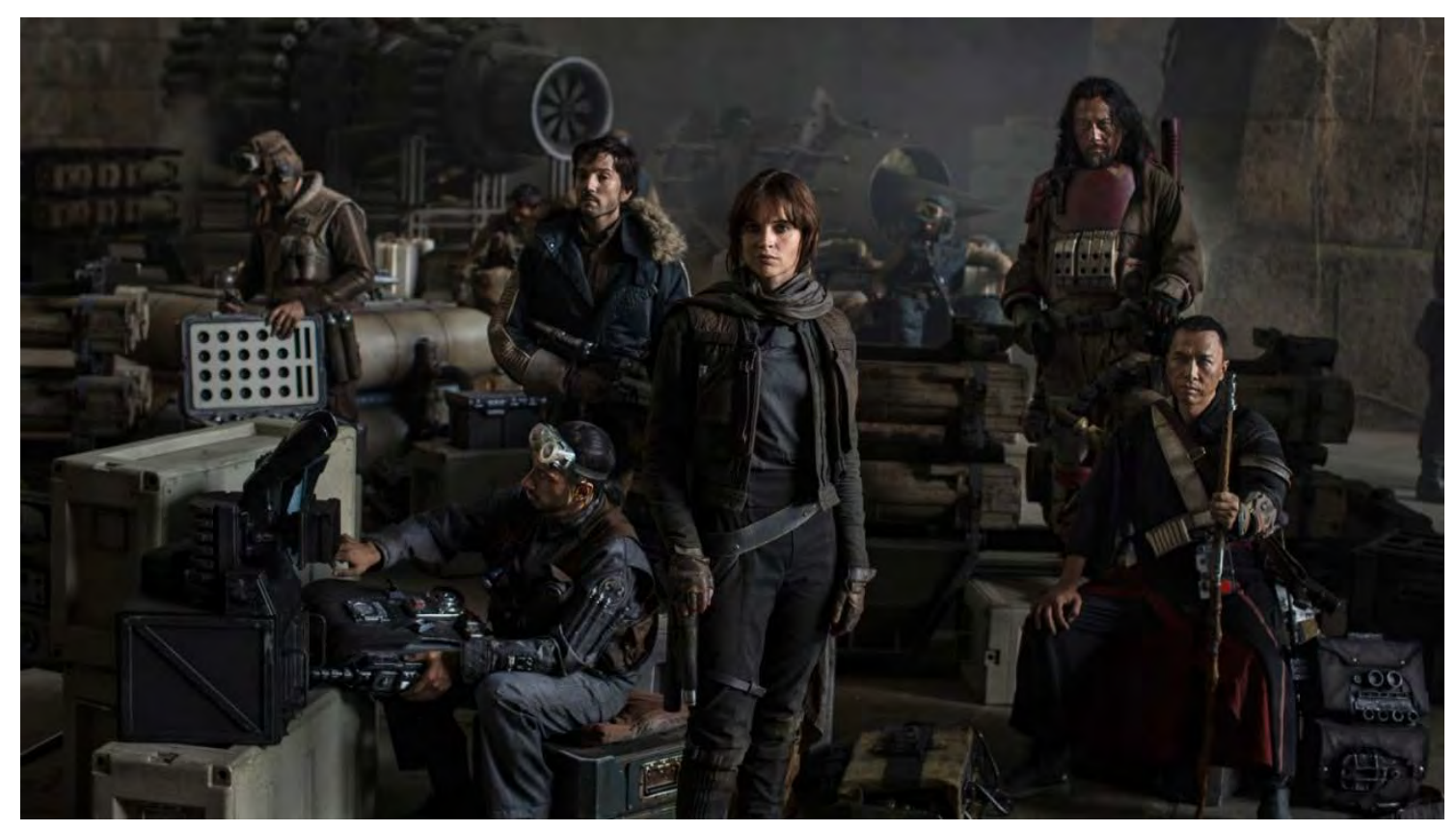

Figura 245 - Personagens de "Rogue One”, filme autônomo na saga “Star Wars”

\footnotetext{
${ }^{51}$ O Líder dos Rogues, ou Rogue 1, é o piloto mais habilidoso do Esquadrão Rogue, a equipe de elite da Aliança Rebelde. Na primeira trilogia Luke Skywalker foi um Rogue. 
Os filmes em franquias como Marvel e Star Wars não são encarados como meras continuações. As sequências finitas do passado se tornaram séries teoricamente infinitas. Não se produz mais filme como sinônimo de "terceiro ato" (como nas antigas trilogias cinematográficas). O conceito é investir em filmes que não tenham fim, sejam eternos "segundos atos" em busca de conclusão. Se os filmes com protagonistas-solo se esgotarem, basta combiná-los em outra série de filmes. Outra solução é justamente o compartilhamento de universos. O "Homem-Formiga" abre espaço para o mundo místico do Dr. Estranho, a natureza alien de Asgard em "Thor" serve de ponte para os "Guardiões da Galáxia”. É uma intensificação lucrativa. A Marvel tem 17 produções planejadas a partir de 2016. A Lucasfilm pelo menos 7 filmes (ROGERS, FARINAS, 2015) E o modelo foi incorporado pelas concorrentes Fox ("X-Men: Apocalipse”, "Deadpool", "Gambit”), Warner ("Esquadrão Suicida", "Superman vs Batman") 52, Paramount (“Trasnformers", 2017) e Universal (filmes que utilizem seu acervo de monstros como Lobisomem, Múmia, Drácula, etc). O reconhecimento de personagens legitimados pelo público os potencializa como marca. E o processo é cada vez mais potencializado.

A ideia da expansão de universos pode ser constatada com o investimento em franquias baseadas nas animações de sucesso. A Disney continua produzindo filmes live-action e animações originais, porém aprovou a produção de "Frozen 2", não só expandindo o filme original quanto também abre novas frentes construindo atrações e áreas temáticas nos parques temáticos e um musical na Broadway. A Pixar, sempre crítica em relação a continuações gratuitas, produz nesse momento continuações de "Procurando Nemo", "Carros 2", "Os Incríveis" e "Toy Story 3". No âmbito dos quadrinhos específicos Disney, o investimento das editoras é muito mais humilde, porém, cada vez mais se investe em marcas para tentar impulsionar os títulos. A animação Disney começa a introduzir o modelo de universo compartilhado de forma mais intensa. Do ponto de vista das marcas adquiridas pela Disney, o tempo dirá se conseguirão domar os efeitos da saturação e principalmente do ativismo digital dos fãs. O Episódio VII de "Star Wars" teve a vantagem de ser lançado em um clima de hype positivo, baseado na experiência negativa que muitos tiveram com os últimos filmes da franquia. Com o sucesso conquistado, em parte pela estratégia inteligente de satisfazer os fãs repetindo

\footnotetext{
${ }^{52}$ Os filmes da Warner e Fox todos com previsão de estreia nos cinemas em 2016.
} 
elementos narrativos do filme de 1977, a Disney tem o desafio de surpreender nas próximas produções com um nível de hype muito maior.

Podemos concluir que, embora os elementos da estratégia transmídia, com investimentos muito altos em produção, marketing e acesso a múltiplas plataformas tenha seus riscos e não seja infalível, é possível afirmar que a Disney reforça a tendência do abandono do velho modelo de criação para o desenvolvimento de seus maiores produtos culturais, adotando uma estratégia central pelo uso de marcas baseadas em personagens ou universos conhecidos ou estrategicamente construídos e compartilhados. No caso específico do cinema, a lógica se inverte quando temos as marcas ditando as produções. Um filme de super-herói Marvel ou os personagens da franquia Star Wars servem de núcleo central para todo tipo de produto (filmes, livros, mídia social, games, aplicativos, etc). Temos, portanto, a confluência das culturas de produção, a digital, a de fã e as grandes corporações. O desafio é acompanhar como as novas formas de consumo digitais afetarão essa dinâmica nas próximas décadas. Quem viver, verá!

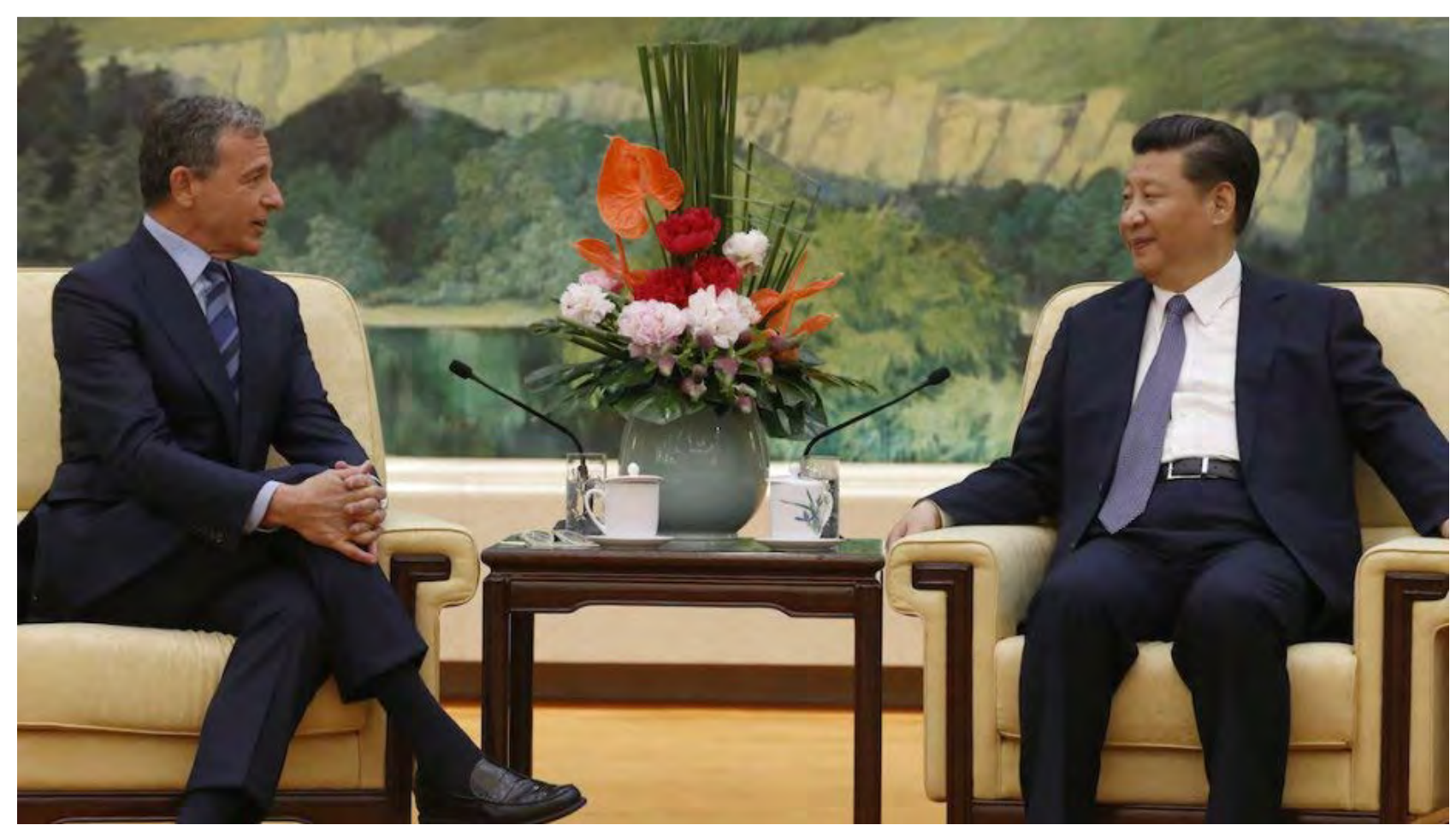

Figura 246 - Bob Iger e o presidente chinês Xi Jinping no Grande Salão do Povo em Pequim em 5 de maio de 2016. (Getty Images) 


\section{REFERÊNCIAS 53}

A Grande Família Pato. Planeta Gibi, 2009. Disponível em: <http://www.planetagibi.net/2009/05/grande-familia-pato-tomas-reco.html > Acesso em: 19 de nov. 2011.

A PATADA (suplemento). Tio Patinhas n 195, p. 4. São Paulo: Editora Abril, 4 de outubro de 1981. A SAgA DO TIO PATINHAS. Volumes 1, 2 e 3. Editora Abril: São Paulo, 2007.

ADORNO, Theodor W. “A Indústria Cultural”. In: COHN, Gabriel (org.). Comunicação e Indústria Cultural. São Paulo: T.A. Queiroz, 1989.

. “O fetichismo na música e a regressão da audição” In: Textos Escolhidos: Benjamin, Horkheimer, Adorno, Habermas (Coleção Os Pensadores). 2aed. Tradução de Luiz João Baraúna. São Paulo: Abril Cultural, 1983, pp.165-191.

ALLAN, Robin. Walt Disney and Europe. Indiana: Ed. Indiana; 1999

ALENCAR, Marcelo. Tio Patinhas e sobrinhos no Espaço (reportagem). O Estado de S. Paulo. Caderno 2, p. 55.01 de maio de 1991.

AMIDI, Amid. Disney, DreamWorks, Pixar, Lucasfilm, Sony Are Sued in Wage Theft Scandal.

Blog Cartoon Brew, 2014. Disponível em: <http://www.cartoonbrew.com/disney/disneydreamworks-pixar-lucasfilm-sony-are-sued-in-wage-theft-scandal-103501.html > Acesso em: 09 de set. 2014.

Chart: A Guide to Every Disney Animation Sequel, Remake \& Spinoff. Website Cartoon

Brew, 2015. Disponível em: < http://www.cartoonbrew.com/business/chart-a-guide-to-everydisney-animation-sequel-remake-spinoff-116256.html>. Acesso em: 17 de jul. 2015.

ANDERSON, Cris. A Cauda Longa - A nova dinâmica de marketing e vendas: como lucrar com a fragmentação dos mercados. Rio de Janeiro: Elsevier, 2006.

${ }^{53}$ De acordo com a Associação Brasileira de Normas Técnicas. NBR 6023. 
ANDRAE, Thomas. Carl Barks and the Disney Comic Book: Unmasking the Myth of Modernity. University of Mississippi Press; 2006.

ASIMOV, Isaac. Eu, Robô. São Paulo: Editora Aleph, 2014.

BAKER, Chris. "Meet Leland Chee, the Star Wars Franchise Continuity Cop" (Artigo). Wired, 2008. Disponível em: <http://www.wired.com/2008/08/ff-starwarscanon/?currentPage=all $>$ Acesso em 8 nov. 2014.

BAITELLO Jr., Norval. O Animal que parou os relógios. São Paulo: Annablume, 1999.

A era da Iconofagia. São Paulo: Hacker Editores, 2005.BAUDRILLARD, Jean. Para uma econômica política do signo. São Paulo: Martins Fontes, 1983.

BARKS, Carl. O Ouro e o Repolho. O Pato Donald n 222. Editora Abril: São Paulo, 1956 (HQ original de 1954).

Paraíso Perdido. Mickey no 30. Editora Abril: São Paulo, 1955 (HQ original de 1954).

BARRIER, Michael J. Hollywood Cartoons - American Animation in Its Golden Age. New York: Oxford University; 1999.

The Animated Man: A Life of Walt Disney. Los Angeles: University of California Press, 2007.

Disneyisme. Michael Barrier.com (artigo sobre a exposição de arte Disney em Paris)., 2007.

Disponível em:

<http://www.michaelbarrier.com/Commentary/Disney\%20at\%20Paris/Disney_at_Paris.htm> Acesso em : 8 de jan. 2007b.

_. "I don't think we can continue", 2012. Disponível em <http://michaelbarrier.com/Home\%20Page/WhatsNewArchivesJan12.html\#idontthink>. Acesso em: 22 de jan. de 2012.

_."Internal" vs. "Instrumental". (Artigo em website), 2014. Disponível em: $<$ http://www.michaelbarrier.com/Home\%20Page/WhatsNewArchivesJuly14.html\#internalvsinstru mental> Acesso em: 13 de jul. de 2014. 
BAUDrillard, Jean. Para uma Crítica da Economia Política do Signo. Rio de Janeiro: Elfos Ed.; Lisboa, Edições 70, 1995.

. Simulacros e Simulação. Lisboa: Relógio D’Água, 1991.

O Sistema dos Objetos. São Paulo: Perspectiva, 2009.

A Disney World ilimitada. In Folha de São Paulo (original para o "Libération). Caderno Mais. < http://www1.folha.uol.com.br/fsp/1997/2/09/mais!/3.html > 9 de fev. de 1997.

Banalidade mortífera. In Folha de São Paulo. caderno Mais!, 2001. Disponível em: <http://www1.folha.uol.com.br/fsp/mais/fs 1006200108.htm > Acesso em: 09 de abr. de 2011.

BAUMAN, Zygmunt. Vidas Desperdiçadas. Rio de Janeiro: Editora Zahar, 2005.

. Vida para Consumo: A Transformação das Pessoas e Mercadoria. Rio de Janeiro: Jorge Zahar Ed., 2008.

BAUMAN, Zygmunt e LYON, David . Vigilância Liquida. Rio de Janeiro: Ed. Zahar, 2014.

BAZIN, André. O que é o cinema?. São Paulo: Cosac Naify, 2015.

BECATTINI, A. e BOSCHI, L. I Disney Italiani. Battipaglia: Nicola Pesce Editore, 2012.

BENDAZZI, Giannalberto. Animation: A World History: Volume I: Foundations - The Golden Age. New York, 2015, p. 86

BENJAMIN, Walter. “A Obra de Arte na era de sua Reprodutibilidade Técnica”. In Magia e Técnica, Arte e Política. $7^{\mathrm{a}}$ edição. São Paulo: Brasiliense (Obras Escolhidas, v.1), 1994.

Mickey Mouse. (Fragmento escrito pelo autor em discussão com Glück e Weill), 1931. Disponível em: <http://culturaebarbarie.org/sopro/verbetes/mickeymouse.html> Acesso em: 14 de mai. 2013.

BENKLER, Yochai. The Wealth of Networks: how social production transforms markets and freedom. Londres: Yale University Press, 2006.

BENNETT, Tara. Showrunners: The Art of Running a TV Show. Londres: Titan Books, 2014. 
BERNARDO, Nuno. Transmedia 2.0: How to Create an Entertainment Brand Using a Transmedial Approach to Storytelling. Londres: beActive Books, 2014.

BOGDAVICH, Peter. Afinal, quem faz os filmes?. Cia das Letras, São Paulo, 1997.

BOOTH, Cathy. Home of the Toys - Jobs' um-Hollywood studio has become the hottest place on the planet for computer-savvy filmmakers. Time (magazine). Nova York, Vol. 154, Vol. 16. Science and Society, p. 41-44. 18 de outubro de 1999.

BOURDIEU, Pierre. “Gostos de Classe e Estilos de Vida”. In Sociologia [da coletânea] Renato Ortiz (org.). São Paulo: Ática, 1983.

BOX OFFICE MOJO. Pesquisa para as tabelas de bilheterias. Disponível em: $<$ http://www.boxofficemojo.com/>.

BREW, Simon. 163 movie sequels currently in the works. Disponível em: <http://www.denofgeek.com/uk/movies/movie-sequels/35837/163-movie-sequels-currently-in-theworks>. Acesso em 12 de ago. 2016 (versão atualizada).

BRODE, Douglas. From Walt to Woodstock: How Disney Created the Counterculture. Austin: University of Texas Press, 2004.

“BROTHER BEAR” - Entertainment Weekly, 2013. Disponível em:

<http://www.ew.com/article/2003/08/14/brother-bear> Acesso em: 15 de agosto de 2013.

BURKE, Peter e BRIGGS, Asa (tradução Maria Carmelita Pádua Dias). Uma História Social da Mídia: de Gutenberg à Internet. 2.ed. rev. e ampl. Rio de Janeiro: Jorge Zahar Ed., 2006.

BUSCH, Anita e LINCOLN, Rose A. Marvel Studios Reporting Directly To Alan Horn, Separate From Other Marvel Projects. Deadline (website), 2015. Disponível em: <http://deadline.com/2015/08/marvel-studios-disney-alan-horn-1201511245/> Acesso em: 31 de agosto de 2015 .

CALDWELL, John Thornton. Production Culture: Industrial Reflexity and Critical Practice in Film and Television. Duke University Press, 2008.

CANEMAKER, John. Paper Dreams - The Art and Artists of Disney Storyboards. New York : Hyperion, 1999 
. Treasures of Disney Animation Art. New York: Harry N. Abrams, 1982.

. Walt Disney's Nine Old Men \& The Art of Animation. New York : Disney Editions, 2001

. Before the Animation Begins - The Art and Lives of Disney Inspirational Sketch Artists.

New York: Hyperion, 1996

CARVAlHO, Bernardo Vasconcelos de, MELlO, Carlos Henrique. Revisão, Análise e

Classificação da Literatura sobre o método de desenvolvimento de produtos ágil Scrum. Anais do Simpósio de Administração da Produção, Logística e Operações Internacionais - SIMPOI. 2009.

Disponível em:

<http://www.simpoi.fgvsp.br/arquivo/2009/artigos/E2009_T00109_PCN92031.pdf> Acesso em: 11 de nov. de 2014.

CASTY. A Ilha de Quandomai. Mickey nº 815. Editora Abril: São Paulo, 2010.

_. O Mancha das Trecas: O Futuro já Chegou (3 partes). Epic Mickey 2: Poder em Dobro. Editora Abril: São Paulo, 2013 (HQ original de 2012).

_. Mickey e o Mundo do Amanhã. Mickey nº 791. Editora Abril: São Paulo, 2008.

. Os Sombronautas (1 $1^{\mathrm{a}}$ parte). Mega Disney n³. Editora Abril: São Paulo, 2013b (HQ original de 2012).

CATMULL, Ed. Creativity, Inc. Overcoming the Unseen Forces that stand in the way of true inspiration. Random House. New York, 2014.

CHEE, Leland. "What is the Holocron?", 2012. Disponível em: <http://www.starwars.com/news/what-is-the-holocron> Acesso em: 10 de out. 2014.

CERVO, Amado 1.; BERVIAN, Pedro A. Metodologia científica: para uso dos estudantes universitários. $3^{\text {a }}$ ed. São Paulo: McGraw-Hill do Brasil, 1983.

CERVO, Amado; BERVIAN, Pedro; SILVA, Roberto da. Metodologia Científica. São Paulo: Pearson Prentice Hall, 2007.

CHMIELEWSKI, Dawn C. e ELLER, Claudia. Disney animation is closing the book on fairy tales. Los Angeles Times , 2010. Disponível em:

<http://articles.latimes.com/2010/nov/21/entertainment/la-et-1121-tangled-20101121> Acesso em:

17 de novembro de 2013. 
CHRISTENSEN, Jerome. America's Corporate Art: The Studio Authorship of Hollywood Motion Pictures. Stanford University Press. Stanford, 2012.

COHEN, David. Disney exec: Studios should lean on tentpoles. Variety, 2011. Disponível em: <http://www.variety.com/article/VR1118041020?nstrack=sid:302126|met:102300|cat:0|order:3] Acesso em 10 de ago. 2011.

CONSTANZO, Gennaro. Topolino 3000: Intervista a Casty., 2013. Disponível em: < http://www.comicus.it/index.php/component/k2/item/55252-topolino-3000-intervista-acasty/55252-topolino-3000-intervista-a-casty> Acesso em: 15 de maio de 2014.

CONTRERA, Malena. Mídia e Pânico - Saturação da Informação, Violência e Crise Cultural na Mídia. São Paulo: Ed. Annablume, 2000.

George Lucas \& Steven Spielberg: Studios will Implode; VOD is the Future. Variey online, 2013. Disponível em < http://variety.com/2013/digital/news/lucas-spielberg-on-future-ofentertainment-1200496241/>. Acesso em 13 de jun. 2013.

COOGAN, Peter. Superhero: The Secret Origin of a Genre. Austin, TX: MonkeyBrain, 2006.

COTTER, Bill: The Wonderful World of Disney Television - A Complete History. New York: Hyperion, 1997

CORLIS, Richard. "Enough is enough" - After five years full of rancor and embaressments, Disney and Jeffrey Katzenberg settle their lawsuit. Time (magazine). Nova York: vol. 154, $\mathrm{n}^{\circ} 3$. The Arts, p. 44.19 de julho de 1999.

COX, Kate. It's Time To Start Treating Video Game Industry Like The \$21 Billion Business It Is. Consumerist, 2014. Disponível em: < http://consumerist.com/2014/06/09/its-time-to-starttreating-video-game-industry-like-the-21-billion-business-it-is/> Acesso em: 15 de set. 2014.

CRETON, Laurent. Cinéma et marché. Paris: Armand Colin/Masson, 1997.

. Économie du Cinéma: Perspectives stratégiques. Paris: Armand Colin, 2014.

DARNTON, Robert. O Grande Massacre de Gatos e outros episódios da história cultura francesa. Ed. Graal: Rio de Janeiro, 1986

Entrevista no programa Roda Viva (TV Cultura). São Paulo, 24 de setembro de 2012. 
DAVID, Peter. "The Illusion of Change". Comics Buyer's Guide $\mathrm{n}^{\circ}$ 1285, 1998. Disponível online em: <http://www.peterdavid.net/2012/12/24/the-illusion-of-change/> Acesso em: 14 de ago. 2015.

DCML (The Disney Comics Mailing List) - lista de discussões online: http://stp.lingfil.uu.se/ starback/dcml/list.html e http://nafsk.se/pipermail/dcml/

DEBORD, Guy. A Sociedade do Espetáculo. Rio de Janeiro: Contraponto, 1997.

DENIS, Sébastien. O Cinema de Animação. Lisboa: Edições Texto \& Grafia, 2010.

DER HAMBURGUER DONALDIST. $\mathrm{n}^{\circ}$ 77, 1991.

DIAS, Luis. Casty in Italiano. Entrevista disponível no blog Chutinosaco..

$<$ http://chutinosaco.blogspot.com.br/2015/10/casty-in-italiano.html> 14 de outubro de 2015 .

DISNEY CORPORATE WEBSITE. <http://thewaltdisneycompany.com/about-disney/companyoverview>

ROSA, Don. Rosa's First Steps, traduzido do artigo original em grego da Komix magazine \#172, setembro de 2002, traduzido para o inglês por Kriton Kyrimis. Disponível em:

<http://nafsk.se/pipermail/dcml/2002-October/014539.html> Acesso em: 14 de abr. 2011.

DON ROSA (mensagem em lista de discussão online), 1994. Disponível em: <http://nafsk.se/pipermail/dcml/1994-August/002657.html> Acesso em: 20 de abr. 2011.

DORFMAN, Ariel; MATTELART, Armand. Para Ler o Pato Donald - comunicação de massa e colonialismo. São Paulo: Ed. Paz e Terra, 1980

DUNCAN, Randy; SMITH, Matthew J. The Power of Comics - History, Form \& Culture. New York: Continuum, 2009.

ECO, Umberto. Apocalípticos e Integrados. São Paulo: Perspectiva, 1998.

. Viagem na Irrealidade Cotidiana. Rio de Janeiro: Nova Fronteira, 1984.

ELBERSE, Anita. Should you invest in the long tail?. Harvard Business Review website. Julho de 2008. 
Blockbusters: Hit-making, risk-taking, and the big business of entertainment. New York: Henry Holt, 2013.

EMPIRE MAGAZINE. Gráfico do Universo Cinematográfico Marvel. Março 2015.

EPIC MICKEY (graphic novel). São Paulo: Editora Abril, 2011.

EPIC MICKEY 2: PODER EM DOBRO (graphic novel). São Paulo: Editora Abril, 2013.

FEILD, Robert D. The Art of Walt Disney. Londres: Collins, 1947.

FINCH, Christopher. The Art of Walt Disney. New York: Crown, 1995.

FINKE, Nikki. "Disney Closing Zemeckis' Digital Studio". Deadline, 2010. Disponível em: <http://deadline.com/2010/03/disney-closing-zemeckis-digital-studio-in-2011-28214/> Acesso em: 15 de março de 2014.

FRANK, Robert; COOK, Phillip. The Winner-Take-All Society. New York: Penguin Books, 1995. FRITZ, Ben. "Disney tells details of Marvel Entertainment acquisition in a regulatory filing". Los Angeles Times, 2009. Disponível em: <http://articles.latimes.com/2009/sep/23/business/fi-ctmarvel23> Acesso em: 12 de abr. 2014.

. Disney unveils plans to revive its video game business. Los Angeles Times, 2013.

Disponível em: <http://articles.latimes.com/2013/jan/15/entertainment/la-et-ct-disney-infinity20130115> Acesso em: 15 de nov. 2014.

FROMM, Erich. Ter ou Ser?. Rio de Janeiro: Zahar, 1976.

FUKUYAMA, F. O fim da História e o último homem. Rio de Janeiro: Rocco, 1992.

GABLER, Neal. Walt Disney: The Triumph of the American Imagination. New York: Knopf, 2006

GADASSIK, Alla. Animation and critical theory [resenha do livro de Esther Leslie, "Hollywood Flatlands: Animation, Critical Theory and the Avant-Garde". In Jump Cut - A Review of Contemporary Media. $\mathrm{n}^{\mathrm{o}}$ 52, verão de 2010. Disponível em: <http://www.ejumpcut.org/currentissue/gadassikFlatlands/index.html>. Acesso em 19 de fev. de 2012. 
GENNETE, Gerard. Paratexts, The Threshold of Interpretation, tran. Jane E. Lewin. Cambridge: Cambridge University Press, 1997.

GEERTZ, Clifford. A Interpretação das Culturas. Rio de Janeiro: LTC, 2011.

GIRVEAU, Bruno. Once Upon a Time: Walt Disney: The Sources of Inspiration for the Disney Studios. Londres: Prestel, 2007.

GLINTENKAMP, Pamela. Industrial Light \& Magic: The Art of Innovation. New York: Harry N. Abrams, 2011.

GORDON, Ian, JANCOVICH, Mark, MCALLISTER, Matthew P. (Ed.). Film and Comic Books. Jackson: The University Press of Mississipi, 2007.

GORZ, André. O Imaterial - Conhecimento, Valor e Capital. São Paulo: Annablume, 2005.

GRANT, John: Encyclopedia of Walt Disney's Animated Characters - From Mickey Mouse to Hercules. New York: Hyperion, 1998

GRASER, Marc. How TV has Replaced Animated Films as Disney's Biggest Brand Ambassador. Variety, 2013. Disponível em: <http://variety.com/2013/biz/features/how-tv-hasreplaced-animated-films-as-disneys-biggest-brand-ambassador-1200324380/> Acesso em: 06 de março de 2014.

GRAY, Jonathan. Show sold separately - Promo, Spoilers and other Media Paratexts. New York: New York University Press, 2010.

GREEN, Howard e GREEN, Amy: Remembering Walt - Favorite Memories of Walt Disney. New York: Disney. Hyperion, 1999.

GREENE, Doyle. Critical Theory and Wile E. Coyote, 2012. Disponível em: <http://www.kiddiematinee.com/greene.html >. Acesso em: 03 de mai. 2012.

GREENFELD, Karl Taro. A Media Giant. Time (magazine). Nova York, Latin American Edition:. Vol. 154 n 12. Business, p. 28-34. 20 de setembro de 1999

GROVER, Ron: The Disney Touch - Disney, ABC \& the Quest for the World's Greatest Media Empire. Ed. Irwin, Chicago: 1997. 
GASI, Flávia. Epic Mickey: Power of Two - crítica. website Omelete, 2012. Disponível em: 〈http://omelete.uol.com.br/games/critica/epic-mickey-power-two-critica〉. Acesso em: 29 de nov. 2014.

GONÇALO JÚNIOR. O Homem Abril - Cláudio de Souza e a história da maior editora brasileira de revistas. São Paulo: Opera Graphica Editora, 2005.

GROSSMAN, Austin. The Art of Epic Mickey. New York: Disney Editions, 2011.

HAHN, Don. O Despertar da Bela Adormecida (Waking Sleeping Beauty). Documentário. Stone Circle Pictures. 85 minutos, 2009.

HARVEY, David. Condição Pós- Moderna. São Paulo: Edições Loyola, 1992.

HITT, Michaell A., IRELAND, R. Duane, HOSKISSON, Robert. Strategic Management: Concepts: Competitiveness and Globalization. Cincinatti: South-Western College Pub; 11ed, 2014.

HOGGART, Richard. As utilizações da cultura 1: aspectos da vida cultural da classe trabalhadora. Lisboa, Portugal: Editorial Presença, 1973

As utilizações da cultura 2: aspectos da vida cultural da classe trabalhadora. Lisboa, Portugal: Editorial Presença, 1973

HOLLISS, Richard e SIBLEY, Brian. The Disney Studio Story. New York: Crown; 1988.

HOWE, Sean. Marvel Comics - A História Secreta. São Paulo: Editora Leya, 2012.

HULETT, Steve. Mouse in Transition: An Insider's Look at Disney Feature Animation. Theme Park Press, 2014.

IGER, Bob. Bob Iger and Graydon Carter discuss managing media in the digital age. Entrevista realizada na University of Southern California no início de 2015. Disponível em: < https://www.youtube.com/watch?v=ljqH60v4EzI> Acesso em: 19 de fev. 2015.

ISAACSON, Walter. Steve Jobs: a biografia. São Paulo: Companhia das Letras, 2011.

INDUCKS $-<\underline{\text { http://coa.inducks.org/> }}$ 
IWERKS, Leslie. The Hand Behind the Mouse: An Intimate Biography of Ub Iwerks. New York: Disney Editions, 2001.

The Hand Behinf the Mouse: The Ub Iwerks Story. Documentário. Leslie Iwerks Productions, 90 minutos, 1999.

A História da Pixar (The Pixar Story). Documentário. Leslie Iwerks Productions. 87 minutos, 2007.

JAMESON, Fredric. Pós-Modernismo - A lógica cultural do capitalismo tardio. São Paulo: Editora Ática, 1996.

A Virada Cultural - Reflexões dobre o pós-modernismo. Rio de Janeiro: Editora Civilização Brasileira, 1998.

JENKINS, Henry. The Wow Climax: Tracing the Emotional Impact of Popular Culture. New York: NYU Press, 2006.

Fans, Bloggers and Gamers: Media Consumers in a Digital Age. New York: NYU Press, 2006.

. Cultura da Convergência. São Paulo: Aleph, 2009.

JOHNSON, Derek. Media Franchising - Creative License and Collaboration in the Culture

Industries. New York: New York University Press, 2012.

JONES, Brian Jay. Jim Henson: The Biography. New York, Ballantine Books, 2013.

. Pais da TV. São Paulo: Editora Conrad, 2001.

KALlAY, William. The Making of Tron: How Tron Changed Visual Effects and Disney Forever. William Kallay (publisher), 2011.

KASHNER, Sam (foto de Annie Leibovitz). The Class that Roared. Revista Vanity Fair, 2014. Disponível em: < http://www.vanityfair.com/culture/2014/03/calarts-animation-1970s-tim-burton> Acesso em: 02 de mar. de 2014.

KATZENBERG, Jeffrey. The World is Changing: Some thoughts on our business (memorando interno na Disney). 11 de janeiro de 1991. 
KELLER, Morton; KELLER, Phyllis. Making Harvard Modern: The Rise of America's University. EUA, Oxford University Press, 2001

KIMMEL, Daniel M. The Dream Team: The Rise and Fall of DreamWorks: Lessons from the New Hollywood. Chicago: Ivan R. Dee, 2006.

KORTEN, David. Quando as Corporações Regem o Mundo. Editora Futura: São Paulo,1995.

KRANTZ, Michael. Animators, Sharpen your Pixels. Time (magazine). Nova York, Vol. 152, $\mathrm{n}^{\circ}$ 22. The Arts, p. 74-76. 30 de novembro de 1998.

_. Jobs's Golden Apple. Time (magazine). Nova York, Vol. 154, nº 5. Technology, p. 40-42. 2 de agosto de 1999.

. . Steve's Two Jobs - Apple uses art to creat technology. Pixar uses technology to creat art. You have to be a bit crazy to be both. Time (magazine). Nova York, Vol. 154, ${ }^{\circ} 16$. Science and Society, p. 34-38. 18 de outubro de 1999.

LANG, Brent. 'Star Wars: The Force Awakens' Passes 'The Avengers' at Domestic Box Office. Variety, 2015. Disponível em: < http://variety.com/2015/film/box-office/star-wars-forceawakens-box-office-avengers-1201670337/> - Acesso em: 31 de dez. de 2015.

LAPORTE, Nicole. The Men who would be king - An almost epic tale of moguls, movies and a company called DreamWorks. Boston/New York: Houghton Mifflin Harcourt, 2010.

LARAIA, Roque de Barros. Cultura: um conceito antropológico. Zahar. Rio de Janeiro, 1986

LAZZARATO, Maurízio; NEGRI, Antonio. Trabalho Imaterial - formas de vida e produção de subjetividade. Rio de Janeiro: DP\&A Editora, 2001.

LÉVY, Pierre. A Inteligência Coletiva. 5a ed. São Paulo: Loyola, 2007.

LEPPERT, Richard. Essays on Music. University of California Press: Los Angeles. 2002.

LESLIE, Esther. Hollywood Flatlands - Animation, Critical Theory and the Avant-Garde. Verso Books, 2003.

LEV-RAM, Michael. Empire of Tech: How Bob Iger brought the coolest innovations from Lucasfilm, Marvel, and ESPN into the Disney galaxy. Revista Fortune. 1 de janeiro de 2015. 
CORDES, Sebastian. LIFE AND TIMES OF DON ROSA. (documentário). 75 min. 2010

LINDQUIST, Jack e COMBS, Melinda J. In Service to the Mouse: My Unexpected Journey to Becoming Disneyland's First President. Orange, California: Chapman University Press/Neverland Media, 2010.

LIPOVETSKY, G. O império do efêmero: a moda e seu destino nas sociedades modernas. São Paulo: Cia das Letras, 2009.

LIPOVETSKY, Gilles e SERROY, Jean. A Estetização do Mundo - Viver na Era do Capitalismo Artista. São Paulo: Cia das Letras, 2015.

LISOTTI, Veronica. Andrea Castellan, in arte Casty: conservate la fantasia ed imparate ad applicarla, 2012. Disponível em: <http://www.cartoonmag.it/news/andrea-castellan-in-arte-castyconservate-la-fantasia-ed-imparate-ad-applicarla.html> Acesso em: 15 de mai. 2014.

LITTLETON, Cynthia. 'Jessica Jones', 'Narcos', 'Master of None’ Vierwership Revealed as NBC Asks for Netflix 'Pespective'. Variery, 2016. Disponível em:

<http://variety.com/2016/tv/news/jessica-jones-narcos-master-of-none-narcos-ratings-netflix$\underline{1201679334 />}$ Acesso em: 13 de jan. 2016.

LUND, Dan. Dream on Silly Dreamer. Documentário. WestLund Productions. 40 minutos, 2005.

MACALLISTER, Matthew P., SEWELL JR, Edward; GORDON, Ian. Introducing Comics and Ideology. in Comics and Ideology. New York: Peter Land. 2001.

MALONEY, Janice (photo illustrations for Time Digital by Aaron Goodman). A New Magic Kingdom. Time (magazine), Nova York, Vol. 152, nº13, p. TD4 (6 páginas).28 de setembro de 1998.

MALTIN, Leonard: Of Mice and Magic - A History of American Animated Cartoons. New York: Plume, 1980.

. The Disney Films. New York: Ed. Disney Editions, 2000.

MAIR, George. The Barry Diller Story: The Life and Times of America's Greatest Entertainment Mogul. New York: Wiley, 1998. 
MATHUROS, Fon. Who's coming to Davos 2016?. World Economic Forum website, 2016. Disponível em: < http://www.weforum.org/agenda/2016/01/who-s-coming-to-davos-2016> Acesso em: 13 de jan. 2016.

McGONIGAL, Jane. A Realidade em Jogo - Por que os games nos tornam melhores e como eles podem mudar o mundo. Rio de Janeiro: BestSeller, 2012.

MCLUHAN, Marshall. Os Meios de Comunicação como Extensões do Homem. $4^{\mathrm{a} e d . ~ S a ̃ o ~ P a u l o: ~}$ Cultrix, 1974.

MANNHEIM, Karl. Sociologia da Cultura. São Paulo: Perspectiva, 2008

MARCIANÒ, Luigi. Il giardino di Topolino. Fumetto Anno XVIII n. 70 maio de 2009. Disponível em: < http://www.papersera.net/papersera/IntervistaCasty2.php> Acesso em: 15 de set. 2015.

MARTEL, Frédéric. Mainstream: A guerra global das mídias e das culturas. Rio de Janeiro: Ed. Civilização Brasileira, 2012.

MARTINS, José de Souza. "Tio Patinhas e o Centro do Universo" in Ciência e Cultura, vol. 27 n 9, p. 8-9. Sociedade Brasileira para o Progresso da Ciência, Setembro de 1975.

MASCARELLO, Fernando. História do Cinema Mundial. Campinas, SP: Papirus, 2006.

MASTERS, Kim. Keys to the Kingdom: The Rise of Michael Eisner and the Fall of Everybody Else. New York: Harper Collins, 2001.

Battle of the Bugs. Nova York, Time (magazine), Vol. 152, $\mathrm{n}^{\circ} 13$. Arts, p. 46.28 de setembro de 1998.

_. The Prince and the Promoter - For DreamWorks' Jeffrey Katzenberg, the Promissed Land is an epic animated version of the moses sage... and an audience to appreciate it. Time (magazine). Nova York, Vol. 153, nº 24. The Arts, p. 38-40. 21 de junho de 1999.

MAYER-SCHÖNBERGER, Viktor e CUKIER, Kenneth. BIG DATA - Como extrair volume, variedade, velocidade e valor da avalanche de informação cotidiana. Rio de Janeiro: Campus, 2013

MERGERS: DISNEY'S WORLD. Newsweek (magazine), Nova York, Vol. CXXVI, nº 7. Business, p. 20-31. 14 de agosto de 1995. 
MIÉGE, Bernard. As Indústrias Culturais e mediáticas: uma abordagem sócio-econômica. In Revista Matrizes. Ano 1, nº 1. ECA-USP: São Paulo, 2007.

MINTZBERG, Henry. Mintzberg on Management: Inside our Strange World of Organization. The Free Press, New York, 1989.

MIRANDA, Orlando. Tio Patinhas e os Mitos da Comunicação. São Paulo: Summus, 1978.

MONTORI, Carlo A. 40 Anni di Lupo Alberto: Badcomics.it intervista Casty. Entrevista com Casty, 2014. Disponível em: <http://www.badcomics.it/2014/02/40-anni-lupo-alberto-badcomics-itintervista-casty/10705/> Acesso em: 17 de set. 2015.

MOOG, Vianna. Bandeirantes e Pioneiros - Paralelo entre Duas Culturas. 22a edição. Rio de Janeiro: José Olympio Editora, 2011.

MORIN, Edgar. Cultura de Massas no Século XX: Neurose. 9a Ed. Rio de Janeiro: Forense Universitária, 1997.

MOTTA, Carlos M. Filmes na TV e Programação. O Estado de S. Paulo (jornal), Caderno 2, 27 de novembro de 1988

MOYA, Álvaro de: O Mundo de Disney. São Paulo: Ed. Geração Editorial, 1996.

NEALON, Jeffrey T. Post-Postmodernism: Or, the Cultural Logic of Just-In-Time Capitalism. Stanford, CA: Stanford University Press, 2012.

NORMAN, Floyd. Pixar's Early Days. Blog pessoal, 2015a. Disponível em:

<http://floydnormancom.squarespace.com/blog/2015/11/10/pixars-early-days> Acesso em: 10 de nov. 2015.

. Where Credit is Due. Blog pessoal, 2015b. Disponível em:

<http://floydnormancom.squarespace.com/blog/2015/11/30/where-credit-is-due > Acesso em: 30 de nov. 2015.

. NORMAN, Floyd. Son of Faster Cheaper: A Sharp Look Inside the Animation Business. Theme Park Press, 2015c.

O PATO DONALD, 662, Editora Abril, 1964.

OHMER, Susan. George Gallup in Hollywood. Columbia University Press, New York, 2006. 
OKRENT, Daniel. Happily Ever After? The “most transformational event" turns Wall Street on its ear, two giants into one and the future into na alluring promisse. Time (magazine). Nova York, Vol. 155, n³, Business, p. 30-35. 24 de janeiro de 2000.

ORSON WELLES FAZ A SUA DECLARAÇÃO DE PRINCÍPIOS. Jornal Diretrizes - 12 de março de 1941.

ORWELL, George. "Boys Weeklies”, in Collect Essays. Veja também N. Tucker, "A new look at the British Comic", Where, dez. 1976.

A Revolução dos Bichos. São Paulo: Companhia das Letras, 2007.

O TICO-TICO, Rio de Janeiro, Editora O Malho, n. 1507, 1934.

PAIK, Karen. To Infinity and Beyond!: The story of Pixar Animation Studios. Londres: Virgin Books, 2007.

PALMIERI, Christoper. Why Disney Won't Be Taking Magic Wristbands to Its Chinese Park. Bloomberg Business, 2016. Disponível em: <http://www.bloomberg.com/news/articles/2016-0110/why-disney-won-t-be-taking-magic-wristbands-to-its-chinese-park> Acesso em: 10 de jan. 2016

PAIXÃO POR FAZER. [documentário]. Editora Abril, 2007. 60 min.

PEGORARO, Celbi. Disney no Brasil: Como tudo Começou. Monografia de TCC do curso de jornalismo. São Paulo: Universidade Mackenzie, 2007.

Comunicação e velocidade: uma análise da aceleração no cinema de animação. Revista do Programa de Pós-graduação em Comunicação - Universidade Federal de Juiz de Fora: Vol.5 • nº 1 , junho 2011

A Fabricação de Valor no Imaginário: Problemáticas no deslocamento da imagem da produção Disney. Estudos em Comunicação - Communication Studies (Universidade da Beira Interior - Portugal. Online) No 11, p. 228-249, 2012.

Fantasia e uma Nova Dimensão Sonora: convergência de linguagens musical, artística e cinematográfica. Anagrama (USP. Online), Vol. 5, No 4, 2012. 
PEGORARO, Celbi; VENTURA, Fernando. Inducks e créditos nos quadrinhos Disney brasileiros. In VERGUEIRO, Waldomiro (et al.). Intersecções Acadêmicas: panorama das primeiras jornadas internacionais de histórias em quadrinhos. São Paulo: Criativo, 2013.

PEPPER, Mark D. Post-Postmodernism and the Market Popularity of Superhero Movies. Enculturation - a journal of rhetoric, writing and culture. Issue 18, 2015. Disponível em: < http://enculturation.net/post-postmodern-superheroes> Acesso em: 14 de ago. 2015.

PETERS, Tom. The Circle of Innovation: You Can't Shrink Your Way to Greatness. New York: Random House, 1997.

POMERANTZ, Dorothy. Disney to Keep Pushing Movie Release Windows. Forbes, 2010. Disponível em: <http://www.forbes.com/sites/dorothypomerantz/2010/08/10/disney-to-keeppushing-movie-release-windows/\#357520f2115e4097a4172115> Acesso em: 20 de out. 2013.

PRICE, David. The Pixar Touch: The making of a Company. Knopf, New York, 2008.

PROGRAMA DE HOJE (seção). Jornal do Brasil, Rio de Janeiro, p. 14, 3 de jan de 1930. PROSS, Harry. Estrutura Simbólica do Poder. Barcelona: G. Gili, 1980

PUSTZ, Matthew. Comic Book Culture: Fanboys and True Believers.University Press of Mississippi, 1999.

RADFAHRER, Luli. Enciclopédia da Nuvem - 100 Oportunidades e 550 Ferramentas para Inspirar e Expandir. Rio de Janeiro: Ed. Campus, 2012.

RAMO, Joshua Cooper. A Two-Man Network. Time (magazine). Nova York: Vol. 155, n³, Business, p.36-39. 24 de janeiro de 2000.

RESTEL, Christoph e ALBERT, Florian (com perguntas adicionais de Daniel Jacob e Stefan Pfister). Entrevista com Andrea Castellan, 2007. Disponível em: <http://www.lustigetaschenbuecher.de/casty.php> Acesso em: 18 de ago. 2015.

RIESMAN, David. A Multidão Solitária. São Paulo: Ed. Perspectiva, 1995.

ROGERS, Adam e FARINAS, Ulises. The Force will be - Star Wars and the Quest for the Forever Franchise. Wired, 2015. Disponível em: <http://www.wired.com/2015/11/building-thestar-wars-universe/>. Acesso em: 05 de dez. 2015. 
ROLLASON, Christopher. 'All was to play for'. Resenha do livro de Esther Leslie, "Hollywood Flatlands: Animation, Critical Theory and the Avant-Garde". [Data de publicação indisponível] Disponível em: <http://www.wbenjamin.org/hollywood.html>. Acesso em: 12 de mar.2012.

ROMANO, Vicente. Presente e Futuro Imediato das Telecomunicações São Paulo em Perspectiva, v. $13, \mathrm{n}^{\circ} 3,1998$.

_. Ordem Cultural e ordem natural do Tempo. CISC, 2002.

ROMEDER, Stephan. Dez aplicações possíveis do conceito de Internet das Coisas em PMEs. Computer World, 2015. Disponível em: <http://computerworld.com.br/dez-aplicacoes-possiveis-doconceito-de-internet-das-coisas-em-pmes> Acesso em: 09 de set. 2015.

ROSA, Keno Don. Fortuna Deslizante. Tio Patinhas nº 291. Editora Abril: São Paulo, 1989 (HQ original de 1987)

. De Volta a Xanadu. Almanaque Disney nº 252. Editora Abril: São Paulo, 1992 (HQ original de 1991).

. O Retorno dos Três Cavaleiros. Revista Zé Carioca nº 2182. São Paulo: Editora Abril, junho de 2001

ROSE, Charlie. Entrevista com George Lucas. Programa Charlie Rose. Rede PBS, 24 de dez. 2015. Disponível em: 〈http://www.charlierose.com/watch/60665244> Acesso em: 28 de dez. 2015. ROTTEN TOMATOES. Pesquisa de dados da crítica especializada. Disponível em: $<$ https://www.rottentomatoes.com/>

SADOVSKI, Roberto. Stan Lee e Steve Ditko: afinal, quem criou o Homem-Aranha?. UOL, 2014. Disponível em: <http://entretenimento.uol.com.br/noticias/redacao/2014/04/24/stan-lee-esteve-ditko-afinal-quem-criou-o-homem-aranha.htm> Acesso em: 26 de abril de 2014.

SANTOLI, Lorraine. Inside the Disney Marketing Machine: In The Era of Michael Eisner and Frank Wells. Theme Park Press, 2015.

SANTOS, Roberto Elísio dos. Introdução à teoria da comunicação. São Bernardo do Campo: EDIMS, 1992.

Para Reler os Quadrinhos Disney: Linguagem, análise e evolução de HQs. São Paulo: Paulinas, 2002. 
_. Quadrinhos Disney no Brasil. Site Omelete, 2003. Disponível em: <http://omelete.uol.com.br/quadrinhos/quadrinhos-disney-no-brasil/> Acesso de: 25 de mai. de 2011. _. Disney Comics in Brazil in the '30s and 440s, 2011a. Disponível em: <http://pizarro.net/didier/_private/tomart/Comics_BrazilI.htm>. Acesso em: 18 de abr. de 2011.

80 anos de quadrinhos Disney, 2011b (publicado em 13 de jan. 2010). Disponível em: <http://omelete.uol.com.br/quadrinhos/80-anos-de-quadrinhos-disney/>. Acesso em: 12 de mai. de $2011 b$.

SAUNDERS, Ben. Do The Gods Wear Capes?. Spirituality, Fantasy, and Superheroes. New York: Bloomsbury Academic, 2011.

SCARZANELLA, Eugenia. Entre Dos Exílios: Cesare Civita, um Editor Italiano em Buenos Aires, Desde La Guerra Mundial Hasta la Dictadura Militar (1941-1976). Revista de Indias, Espanha, vol. LXIX, n. 245, 2009.

SCHATZ, Thomas. O Gênio do Sistema: A Era dos Estúdios em Hollywood. Cia das Letras, São Paulo, 1991.

SCHUMPETER, Joseph. A. Capitalismo, Socialismo e Democracia. Rio de Janeiro: Editora Fundo de Cultura, 1961.

SCHWARTZ, Tony e EISNER, Michael. Work in Progress. New York: Random House, 1998.

SCHUMPETER, Joseph. A. Capitalismo, Socialismo e Democracia. Rio de Janeiro: Editora Fundo de Cultura, 1961.

SENNETT, Richard. A Cultura do Novo Capitalismo. Rio de Janeiro: Editora Record, 2006.

SHALE, Richard. Donald Duck Joins Up - The Walt Disney Studio during World War II: In Funnyword no 17. 1976.

SIKLOS, Richard. Bob Iger of Walt Disney on Digital Business Models. Fortune Brainstorm. Tech, 22 de jun. 2009. Disponível em: <https://www.youtube.com/watch?v=6DNYeeqBnos $>$ Acesso em: 10 de jul. 2014.

SILVA, Bruno Adriano. Resenha do livro:"CEVASCO, Maria Eliza. As Dez Lições Sobre os Estudos Culturais. São Paulo: Boitempo Editorial, 2003". in Revista HISTEDBR On-line, Campinas, n.30, p.322-324, jun.2008 
SITO, Tom. Drawing the Line: The Untold Story of the Animation Unions from Bosko to Bart Simpson. Lexington: The University Press of Kentucky, 2006.

_. Moving Innovation: A History of Computer Animation. Cambridge: MIT Press, 2015.

SMITH, Gerry e SHAW, Lucas. ESPN's Dilemma in Mobile Age Where Fans See Clips All Day. Bloomberg Business, 2015. Disponível em: <http://www.bloomberg.com/news/articles/2015-1216/espn-s-dilemma-in-mobile-age-where-fans-can-watch-clips-all-day > Acesso em: 16 de dez. 2015.

SMITH, Thomas. G. Industrial Light \& Magic: The Art of Special Effects. Del Rey, 1986.

SNIDER, Mike. USA TODAY CEO Forum. Entrevista pública com Jeffrey Katzenberg realizada na Newhouse School em 17 de outubro de 2012.

SODRÉ, Muniz. A Comunicação do Grotesco: Introdução à Cultura de Massa no Brasil. Rio de Janeiro: Vozes, 1983.

SOLOMON, Charles. Enchanted Drawings: The History of Animation. New York: Random House, 1994.

The Disney That Never Was - The Stories and Art from Five decades of Unproduced Animation. New York: Hyperion,1995.

SPECTOR, Warren. Palestra (lecture) na University of Texas - Austin. 10 de setembro de 2007. Disponível em: <https://www.youtube.com/watch?v=3JK3uWPtbv4> Acesso em: 20 de out. 2014. STEWART, James B. Disney War. Londres: Simon \& Schuster, 2005.

STYLER, Trudie. The Sweatbox. Documentário. 95 minutos. [Não foi oficialmente distribuído], 2000.

SWISHER, Kara. Entrevista com Bob Iger e Marc Andreessen. Vanity Fair Establishment Summit, 8 de out. 2015. Disponível em: 〈https://www.youtube.com/watch?v=FtsBBKAJgFQ> Acesso em: 13 de out. 2015.

SWINGEWOOD, Alan. O Mito da Cultura de Massa. Rio de Janeiro: Interciência, 1978. 
SYLT, Christian. Revealed: The \$307 Million Cost of Disney's John Carter. Forbes, 2014. Disponível em: <http://www.forbes.com/sites/csylt/2014/10/22/revealed-the-307-million-cost-ofdisneys-john-carter/\#13d9acf841eb> Acesso em: 23 de out. 2015.

THOMAS, Bob. Walt Disney: An American Original. New York: Disney Editions, 1994.

Building a Company - Roy O. Disney and the Creation of an Entertainment Empire. New York: Hyperion,1998.

. Walt Disney: The Art of Animation. New York. Golden Press, 1958.

. Disney's Art of Animation - From Mickey Mouse to Hercules. New York: Hyperion, 1997.

THOMAS, Frank; JOHNSTON Ollie: The Illusion of Life - Disney Animation. New York: Disney Editions, 1981

TOLKIEN, J.R.R.. "Sobre contos de fadas" in Árvore e Folha. São Paulo: WMF Marins Fontes, 2014, p.1.

TOFFLER, Alvin. Future Shock. New York: Bantam Books, 1971.

TOPOLINO. revista nº 2772. Modena: Panini, 13 de janeiro de 2009.

TRYON, Chuck. Reiventing Cinema - Movies in the Age of Media Convergence. New Jersey:

Rutgers University Press, 2009.

ULIN, Jeff. The Business of Media Distribution: Monetizing Film, TV and Video Content in an Online World. Burlington: Focal Press, 2014.

VAZ, Mark Cotta. Industrial Light \& Magic: Into the Digital Realm. Del Rey, 1996.

VENTURA, Fernando: Zé Carioca no Traço do Canini - As Histórias em Quadrinhos Disney de Renato Canini. Monografia de pós-graduação em Design Gráfico. São Paulo: Universidade de Belas Artes, 2003.

VELLA, Matt. What Disney is really buying. Fortune, 2012. Disponível em:

<http://fortune.com/2012/10/31/what-disney-is-really-buying/> Acesso em 13 de jun. 2013. 
VERGUEIRO, Waldomiro; RAMA, Angela (org.). Como usar as histórias em quadrinhos na sala de aula. São Paulo: Contexto, 2010.

VERGUEIRO, Waldomiro; SANTOS, Roberto Elísio dos. O Tico-Tico: Centenário da Primeira Revista de Quadrinhos do Brasil. São Paulo: Opera Graphica Editora, 2005

VIRILIO, Paul. Velocidade e Política. São Paulo: Estação Liberdade, 1996.

WALT DISNEY's COMIC AND STORIES. No 614, Don Rosa, 1997.

WALT DISNEY COMICS \& STORIES. (história em quadrinhos do coelho Osvaldo). $\mathrm{n}^{\circ} 726$.

San Diego: IDW Publishing, 2015.

WATTS, Steven. The Magic Kingdom: Walt Disney and the American Way of Life. (Columbia: University of Missouri Press, 2001) orig. Boston: Houghton Mifflin, 1997.

WESTIN, David e RUHLE, Stephanie. “Disney's Bob Iger on 'Star Wars', ESPN and China”. Entrevista canal Bloomberg, 21 de dez. 2015. Disponível em:

<https://www.youtube.com/watch?v=Emx_3y4sR7g> Acesso em: 22 de dez. de 2015.

WEIRDO. no. 4, Robert Crumb, 1981.

WILlIAMS, Raymond. Cultura e Materialismo. São Paulo: Editora Unesp, 2005.

Cultura. São Paulo: Paz e Terra, 2011.

WOLK, Douglas. Reading Comics: how graphic novels work and what they mean. Cambridge:

Da Capo Press, 2007.

WRZESNIEWSKI, Amy e SCHWARTZ, Barry (et al.). Multiple types of motives don't multiply the motivation of West Point cadets. PNAS Journal. vol. 111 no. 30. julho de 2014. 